
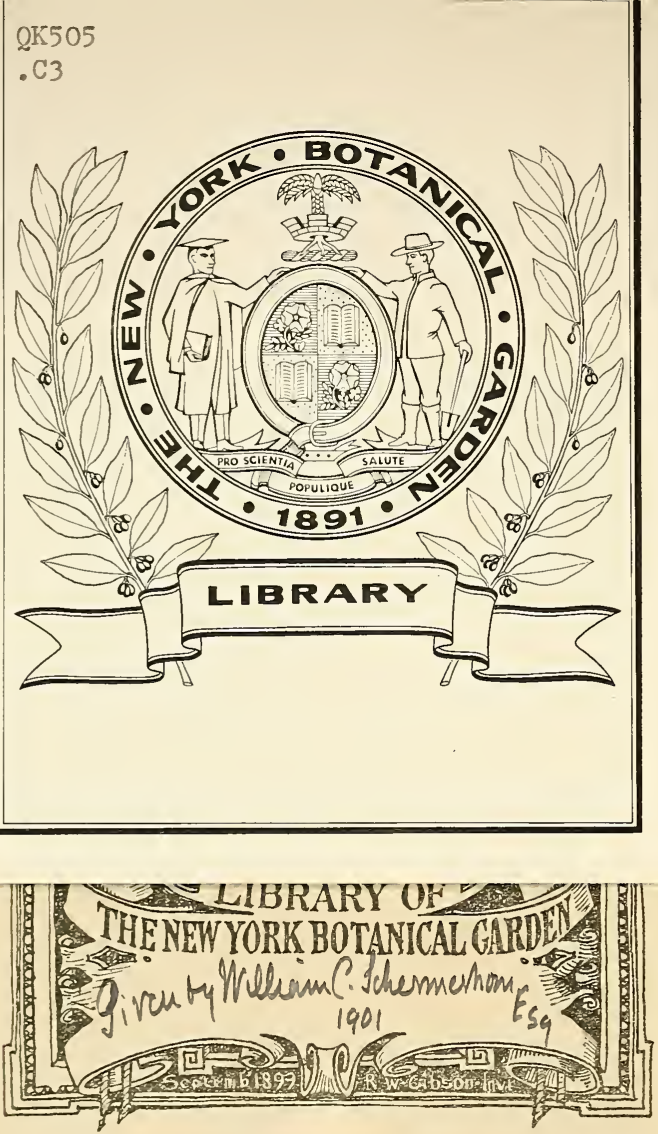



\section{MOSSES AND FERNS}




$$
\text { SAX }
$$


THE

\section{STRUCTURE \& DEVELOPMENT OF THE}

\section{MOSSES \& FERNS (ARCHEGONIATAE)}

DOUGLAS HOUGHTON CAMPBELL, Ph.D.

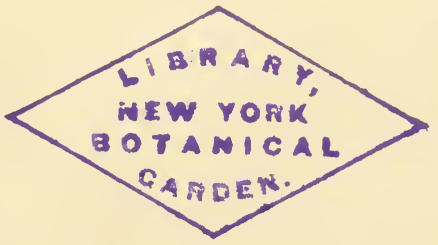

Zlonoon

MACMILLAN AND CO.

AND NEW YORK

I 895 
.13 


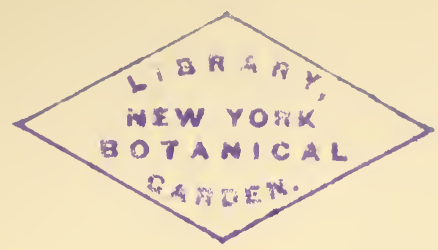

PREFACE

EVER since the appearance of Hofmeister's remarkable investigations upon the Archegoniatæ, the ever-increasing list of works upon these plants has borne witness to the interest felt by botanists in their structure and development. From time to time the results of these investigations have been collected, but for the most part this has been done in general text-books, where want of space has naturally made it impossible, often, to give much more than a mere summary of results.

The last ten years have been especially noteworthy, not only for the number of investigations upon the Archegoniates, but for the extension of our knowledge to many forms which were hitherto but very imperfectly known. These results have come from two sources: first, the extension of the field of research to the Tropics, through the establishment there of experiment-stations and properly equipped laboratories in connection with botanical gardens; second, the advances in histological methods, especially the use of the microtome in embryological studies, which have made possible the accurate determination of many important structural details hitherto but very unsatisfactorily made out. The application of these more exact methods of research have made necessary, also, a careful is review of the results of earlier investigations, and the correction of mistakes due to imperfect manipulations.

The results of these later researches have only begun to find their way into the text-books, and the present work was undertaken mainly for the purpose of presenting, in somewhat detailed form, a résumé of the substance of the great mass of literature upon the subject which has accumulated, and much of 
which is necessarily out of reach of the many botanical workers who have not access to the great libraries.

Various papers, published by the author from time to time, have served as the basis of the work, and these have been supplemented by a somewhat extended series of observations upon representatives of most of the groups of the Archegoniates, the results of which are now published for the first time. It is hoped that the result is a fairly comprehensive statement of our present knowledge of the comparative morphology of the Muscineæ and Pteridophyta.

Except where otherwise stated, the drawings were made by the author from his own preparations, and the majority were prepared expressly for this work.

In view of the extremely unsettled state of botanical nomenclature at the present time, it was thought best to adopt a somewhat conservative attitude, and for the most part the names employed in the text are those which have long been familiar to the botanical student. Various departures from the generally accepted arrangement of the orders and families have been made, the reasons for which are set forth at sufficient length in the text.

The author wishes to express his thanks to the many botanists both at home and abroad to whom he is indebted for assistance, both in the form of materials and information, without which the work would have been impossible. Especial thanks are due Professor W. Carruthers, through whose courtesy the great botanical collections and libraries of the British Museum at South Kensington were placed at his disposal. $\mathrm{He}$ is also under great obligation to Professor F. O. Bower for the advance sheets of recent important papers, which made it possible to complete the latter chapters much more satisfactorily than otherwise could have been done.

DOUGLAS HOUGHTON CAMPBELL.

Staxford University, California, Warch 1895 . 


\section{CONTENTS}

\section{CHAPTER I}

PAGE

INTRODUCTION

\section{CHAPTER II}

MUSCINEÆ (BRYOPHYTA)-HEPATICÆ-MARCHANTIACEE

\section{CHAPTER III}

\section{MARCHANTIEA}

CHAPTER IV

The JungermanNiaCER.

CHAPTER V

THE ANTHOCEROTEE

\section{CHAPTER VI}

The Mosses (Musci): SPhagnace£-AndreÆaceÆ

\section{CHAPTER VII}




\section{CHAPTER VIII}

The Pteridophyta-Ophioglossacee .

CHAPTER IX

MaRatTIACEE-ISOETACEE

CHAPTER X

FILICINEE LEPTOSPORANGIATE

\section{CHAPTER XI}

Classification of the Homosporous leptosporangiate • 338

CHAPTER XII

Leptosporangiatæ Heterosporeæ (Hydropterides) . . 378

\section{CHAPTER XIII}

EQUISETINEE

\section{CHAPTER XIV}

LYCOPODINEÆ

CHAPTER XV

SUMmary AND CONClusions 


\section{CHAPTER I}

\section{INTRODUCTION}

UNDER the name Archegoniatæ are included a large number of plants which, while differing a good deal in many structural details, still agree so closely in their essential points of structure and development as to leave no room for doubting their close relationship. Besides the Bryophytes and Pteridophytes, which are ordinarily included under this head, the Gymnospermæ or Archespermæ might very properly be also embraced here, but we shall use the term in its more restricted meaning.

The term Archegoniatæ has been applied to these plants because the female reproductive organ or archegonium is closely alike, both in origin and structure, in all of them. This is a multicellular body, commonly flask-shaped, and either entirely free or more or less coherent with the tissues of the plant. In all cases there is an axial row of cells developed, of which the lowest forms the egg. The others become more or less completely disorganised and are discharged from the archegonium at maturity. Among the Algx there is no form at present known in which the female organ can be certainly compared to the archegonium, although the oogonium of the Characeæ recalls it in some respects.

The antheridium or male organ of the Archegoniatæ, while it shows a good deal of similarity in all of them, still exhibits much more variation than does the archegonium, and is more easily comparable with the same organ in the Algx, especially the Characeæ. Like the archegonium it may be 
entirely free, or even raised on a long pedicel; or it may be completely sunk in the tissue of the plant, or even be formed endogenously. It usually consists of a single outer layer of cells containing chlorophyll, and these enclose a mass of small colourless cells, the sperm cells, each of which gives rise to a single ciliated spermatozoid. The development of the latter is very uniform throughout the Archegoniatæ, and differs mainly from the same process in the higher green Algæ, especially the Characeæ, in the larger amount of nuclear substance in the spermatozoids of the former.

Fertilisation is only effected when the plants with ripe sexual organs are covered with water. The absorption of water by the mature sexual organs causes them to open, and then, as the spermatozoids are set free, they make their way through the water by means of their cilia and enter the open archegonium, into which they penetrate to the egg. The sexual cells do not differ essentially from those of the higher Algæ, and point unmistakably to. the origin of the Archegoniatæ from similar aquatic forms. Indeed all of the Archegoniatæ must still be considered amphibious, inasmuch as the gametophyte or sexual plant is only functional when partially or completely submerged.

Non-sexual gonidia are known certainly only in Aneura, one of the lower Liverworts, but special reproductive buds or gemmæ, both unicellular and multicellular, are common in many forms.

A very marked characteristic of the whole group is the sharply-marked alternation of sexual and non-sexual stages. The sexual plant or gametophyte varies much in size and complexity. It may be a simple flat thallus comparable in structure to some Algæ, and not superior to these in complexity so far as the vegetative parts are concerned. In others it becomes larger and shows a high degree of differentiation. Thus among the Liverworts the Marchantiaceæ, while the gametophyte still retains a distinctly thalloid form, still show a good deal of variety in the tissues of which the thallus is composed. In others, e.g. the true Mosses, the gametophyte has a distinct axis and leaves, and in the higher ones the tissues are well differentiated for special functions. The gametophyte itself may show two well-marked phases, the protonema and the gametophore. The former is usually 
filamentous, and arises directly from the germinating spore; and upon the protonema, as a special branch or bud, the much more complex gametophore is borne. Often, however, as in many thallose Liverworts and Pteridophytes, the protonema is not clearly distinguishable from the gametophore, or may be completely suppressed. In the Pteridophytes the gametophyte is, as a rule, much simpler than in the Bryophytes, resembling most nearly the less specialised forms of the latter. In the socalled heterosporous Pteridophytes the gametophyte becomes extremely reduced and the vegetative part almost entirely suppressed, and its whole cycle of development may, in extreme cases, be completed within twenty-four hours or even less.

The non-sexual generation, or " sporophyte," arises normally from the fertilised egg, but may in exceptional cases develop as a bud from the gametophyte. In its simplest form all the cells of the sporophyte, except a single layer upon the outside, give rise to spores, but in all the others there is developed a certain amount of vegetative tissue as well, and the sporophyte becomes to a limited extent self-supporting. In the higher Bryophytes the sporophyte sometimes exceeds in size the gametophyte, and develops an elaborate assimilative system of tissues, abundantly supplied with chlorophyll and having an epidermis with perfect stomata; but even the most complex moss-sporogonium is to a certain extent dependent upon the gametophyte, with which it remains in close connection by means of a special absorbent organ, the foot. In these highly developed sporogonia the sporogenous tissue occupies but a small space, by far the greater part of the tissue being purely vegetative.

In the Pteridophytes a great advance is made in the sporophyte beyond the most complex forms found among the Bryophytes. This advance is twofold, and consists both in an external differentiation and a more perfect development of the tissues. The earliest divisions of the embryo resemble very closely those of the Bryophyte sporogonium, but at an early stage four distinct organs are usually plainly distinguishable, viz. stem, leaf, root, and foot. The last corresponds in some degree to the same organ in the moss-sporogonium, and like it serves as an absorbent organ by which the young sporophyte is supplied with nourishment from the gametophyte. In short, 
the young sporophyte of the Pteridophyte, like that of the Bryophyte, lives for a time parasitically upon the gametophyte. Sooner or later, however, the sporophyte becomes entirely independent. This is effected by the further growth of the primary root, which brings the young sporophyte into direct communication with the earth. The primary leaf, or cotyledon, enlarges and becomes functional, and new ones arise from the stem apex. Usually by the time this stage is reached the gametophyte dies and all trace of it soon disappears. In some of the lower forms, however, the gametophyte is large and may live for many months, or even years, when not fecundated, and even when the sporophyte is formed, the prothallium (gametophyte) does not always die immediately, but may remain alive for several months. The spore-forming nature of the sporophyte does not manifest itself for a long time, sometimes many years, so that spore-formation is much more subordinate than in the highest Bryophytes. With few exceptions the spores are developed from the leaves and in special organs, sporangia. In the simplest cases, i.e. Ophioglossum, the sporangia are little more than cavities in the tissue of the sporiferous leaf, and project but little above its surface. Usually, however, the sporangia are quite free from the leaf and attached only by a stalk. These sporangia are in the more specialised forms of very peculiar and characteristic structure, and are of great importance in classification.

Corresponding to the large size and development of special organs in the sporophyte of the Pteridophytes, there is a great advance in the specialisation of the tissues. All of the forms of tissue found in the Spermaphytes occur also among the Pteridophytes, which indeed, so far as the character of the tissues of the sporophyte is concerned, come much nearer to the former than they do to the Bryophytes. This is especially true of the vascular bundles, which in their complete form are met with first in the sporophyte of the Pteridophyta. In size, too, the sporophyte far exceeds that of the highest Mosses ; while in these the sporogonium never exceeds a few centimetres in extreme height, in some Ferns it assumes tree-like proportions with a massive trunk Io to I 5 metres in height, with leaves 5 to 6 metres in length.

In the formation of the spores all of the Archegoniatx show great uniformity, and this extends, at least as regards 
the pollen spores, to the Spermaphytes as well. In all cases the spores arise from cells which at first form a solid tissue arising from the division of a single primary cell, or group of cells (Archesporium). These cells later become more or less completely separated, and each one of these so-called "spore mother cells," by division into four daughter cells, forms the spores. The young spores are thin walled, but later the wall becomes thicker and shows a division into two parts, one inner larger, which generally shows the cellulose reaction and is called the endospore (intine), and an outer more or less cuticularised coat, the exospore (exine). In addition a third outer coat (perinium, epispore) is very generally present. As the spore ripens there is developed within it reserve food materials in the form of starch, oil, and albuminous matter, and quite frequently chlorophyll is present in large quantity. Some spores retain their vitality but a short time, those of most species of Equisetum and Osmunda, for example, germinating with difficulty if kept more than a few days after they are shed, and very soon losing their power of germination completely. On the other hand, some species of Marsilia have spores so tenacious of life that they germinate perfectly after being kept for several years.

From the germinating spore arises the gametophyte bearing the sexual organs. Both archegonia and antheridia may be borne upon the same plant, or they may be upon separate ones. From the fertilised egg within the archegonium is produced the sporophyte or non-sexual generation, and from the spores which it produces arise the sexual individuals again, thus completing the cycle of development.

On comparing the lower Archegoniates with the higher ones, it is at once evident that the advance in structure consists mainly in the very much greater development of the sporophyte. In the Bryophytes, as a class, the gametophyte is more important than the sporophyte, the latter being, physiologically, merely a spore-fruit, which in many forms, i.e. Sphagnum, is of relatively rare occurrence. The gametophyte in such forms is perennial, and the same plant may produce a large number of sporogonia, and at long intervals. The sporophyte in such forms is small and simple in structure, and its main function is spore formation, as it has but little power of independent growth. In the Pteridophytes, on the other hand, the gameto- 
phyte (prothallium) rarely produces more than one sporophyte, and as soon as this, by the formation of a root and leaf, becomes self-supporting, the gametophyte dies. In short, the sole function of the latter in most of them is to support the sporophyte until it can take care of itself.

When the lower Pteridophytes are compared with the more specialised ones, a similar difference is found. In the lower forms, like the Marattiaceæ and Equisetaceæ, the gametophyte is relatively large and long-lived, and closely resembles certain Liverworts. In these forms a considerable time elapses before sexual organs are produced, and in artificial cultures of the Marattiaceæ a year or more sometimes passes before archegonia are formed. These prothallia, too, multiply by budding, much as the Liverworts do. In case no archegonia are fecundated the prothallium may grow until it reaches a length of three or four centimetres, and resembles in a most striking manner a thalloid Liverwort. In such large prothallia it is not unusual for more than one archegonium to be fecundated, although usually only one of the embryos comes to maturity, and the prothallium may continue to live for some time after the sporophyte has become independent. Usually, however, as soon as an archegonium is fertilised, the formation of new ones ceases, and as soon as the sporophyte is fairly rooted in the ground the prothallium dies.

In most of the lower Pteridophytes the prothallia are monœcious, but in the more specialised ones are markedly diøcious. When this is least marked the males and females differ mainly in size, the latter being decidedly larger; in the more extreme cases the difference is much more pronounced and is correlated with a great reduction in the vegetative part of the gametophyte in both males and females. This reaches its extreme phase in the so-called heterosporous forms. In these the sex of the gametophyte is already indicated by the character of the spore. Two sorts of spores are produced, large and small, which produce respectively females and males. In all of the heterosporic Pteridophytes the reduction of the vegetative part of the gametophyte is very great, especially in the male plants. Here this may be reduced to a single quite functionless cell, and all the rest of the plant is devoted to the formation of the single antheridium. In the female plants the reduction is not so great; and although sometimes but one 
archegonium is formed, there may be in some cases a considerable number, and owing to the large amount of nutritive material in the spore, in case an archegonium is not fertilised, the prothallium, even if it does not form chlorophyll, may grow for a long time at the expense of the food materials that normally are used by the developing embryo. In strong contrast to the slow growth and late development of the reproductive organs in the homosporous forms, most of the heterosporous Pteridophytes germinate very quickly. The Marsiliacex, in which the female prothallium is extremely reduced, show the opposite extreme. Here the whole time necessary for the germination of the spores and the maturing of the sexual organs may be less than twenty-four hours, and within three or four days more the embryo is completely developed.

That heterospory has arisen independently in several widely separated groups of Pteridophytes is plain. The few genera that still exist are readily separable into groups that have comparatively little in common beyond possessing two sorts of spores; but each of these same forms shows much nearer affinities to certain widely separated homosporous groups.

In some of the heterosporous forms the first divisions in the germinating spore take place while it is still within the sporangium, and may begin before the spore is nearly fully developed. In other cases the sporangia become detached when ripe, and the spore (or spores), still surrounded by the sporangium, falls away from the sporophyte before germination begins. In these respects the heterosporous Pteridophytes show the closest analogy with the similar processes among the lower Spermaphytes, where it has been shown in the most conclusive manner that the ovule with its enclosed embryo-sac is the exact morphological equivalent of the macrosporangium of Selaginella or Azolla, for example, and that the seed is simply a further development of the same structure. 


\section{CHAPTER II}

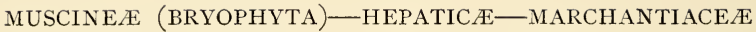

THE first division of the Archegoniatæ, the Muscineæ or Bryophyta, comprises the two classes, Hepaticæ or Liverworts, and the Musci or Mosses. In these as a rule the gametophyte is much more developed than the sporophyte, and indeed in many forms the latter is very rarely met with. They are plants of small size, ranging in size from about a millimetre in length to 30 centimetres or more. A few of them are strictly aquatic, i.e. Riella and Ricciocarpus among the Hepaticæ, and Fontinalis of the Mosses; but most of them grow upon a solid substratum. A favourite position for many is the trunks of trees or rocks. Many others grow upon the earth. They vegetate only when supplied with abundant moisture, and some forms are very quickly killed if allowed to become dry; but those species which grow in exposed places may be completely dried up without suffering, and some of those that inhabit countries where there are long dry periods may remain in this condition for months without losing their vitality, reviving immediately and resuming growth as soon as they are supplied with the requisite moisture.

The germinating spores usually produce a more or less well-marked "protonema," from which the gametophore arises secondarily. The protonema sometimes is persistent and forms a dense conferva-like growth, but more commonly it is transient and disappears more or less completely after the gametophore is formed. No absolute line, however, can be drawn between protonema and gametophore, as the former may arise secondarily from the latter, or even from the sporophyte. With very few exceptions, i.e. Buxbaumia, the 
gametophyte of the Muscince is abundantly supplied with chlorophyll, and therefore capable of cntirely independent growth. No true roots are found, but root-hairs are generally present in great numbers, and these serve both to fasten the plant to the substratum and also to supply it with nutriment.

The form of the gametophyte varies much. In the simplest Hepaticx, like Aneura and Pellia, it is a flat, usually dichotomously branched thallus composed of nearly or quite uniform cells, without traces of leaves or other special organs. From this simplest type, which is quite like certain Algæ, differentiation seems to have proceeded in two dircctions; in the first instance the plant has retaincd its thalloid character, but there has been a specialisation of the tissues, as we see in the higher Marchantiacex. In the second case the differentiation has been an external one, the thalloid form giving place to a distinct leafy axis. This latter form reaches its completest expression in the higher Mosses, where it is accompanied by a high degree of specialisation of the tissues as well. The growth is usually from a single apical cell, which varies a good deal in form among the thalloid Hepaticæ, but in the foliose Hepaticæ and Mosses is with few exceptions a threesided pyramid.

The gametophyte of the Muscinex frequently is capable of rapid multiplication, which may occur in several ways. Where a filamentous protonema is present this branches extensively, and large numbers of leafy axes may be produced as buds from it. Sometimes these buds are arrested in their development and enter a dormant condition, and only germinate after a period of rest. Another very common method of multiplication is for the growing ends of the branches of a plant to become isolated by the dying away of the tissues behind them, so that each growing tip becomes the apex of a new plant. Very common in the Hepaticæ, but less so in the Mosses, is the formation of gemmæ or special reproductive buds. These are produced in various ways, the simplest being the separation of single cells, or small groups of cells, from the margins of the leaves. In the case of Aneura multifida they are formed within the cells and discharged in a manner that seems to be identical with that of the zoospores of many Algx. Again, multicellular gemmæ of peculiar form occur in several of the Hepaticæ, e.g. Blasia, Marchantia, where they occur in 
special receptacles, and among the Mosses similar ones are common in Tetraphis and some other genera.

The archegonia of all the. Muscineæ agree closely in their earlier stages, but differ more or less in the different groups at maturity. In all cases the archegonium arises from a single superficial cell, in which three vertical walls are formed that intersect so as to form an axial cell and three peripheral ones. From the axial cell develop the egg, canal cells, and cover cells of the neck, and from the peripheral cells the wall of the venter and the outer neck cells. In all Muscineæ except the Anthoceroteæ the archegonium mother cell projects above the surrounding cells, but in the latter the mother cell does not project at all, and the archegonium remains completely sunken in the thallus. In all other forms the archegonium is nearly or quite free, and usually provided with a short pedicel. This is especially marked in the Mosses, where the lower part of the archegonium is as a rule much more massive than in the Hepaticæ.

The most marked difference, however, between the archegonium of the Hepaticæ and Mosses is in the history of the cover cell or uppermost of the axial row of cells of the young archegonium. This in the former divides at an early period into four nearly equal cells by vertical walls, the resulting cells either remaining undivided, or undergoing one or two more divisions; but in the Mosses this cell functions as an apical cell, and to its further growth and division the whole growth of the neck is due.

The antheridia, except in the Anthoceroteæ, also arise from single superficial cells, and while they differ much in size and form, are alike in regard to their general structure. The antheridium always consists of two parts: a stalk or pedicel, which varies much in length, and the antheridium proper, made up of a single layer of superficial cells and a central mass of small sperm cells. The former always contain chloroplasts, which often become red or yellow at maturity. The sperm cells have no chlorophyll, but abundant protoplasm and a large nucleus, which latter forms the bulk of the body of the spermatozoid found in each sperm cell of the ripe antheridium. The spermatozoids are extremely minute filiform bodies, thicker behind and provided with two fine cilia attached to the forward end. Adhering to the thicker posterior end there may usually be seen a delicate vesicle, which represents the 
remains of the cell contents not used up in the formation of the spermatozoid.

When the ripe sexual organs are placed in water their outer cells absorb water rapidly and become strongly distended, while the central cells, i.e. the canal cells of the archegonium, and the sperm cells, whose walls have become mucilaginous, have their walls dissolved. The swelling of the mucilage derived from the walls of the central cells, combined with the pressure of the strongly distended outer cells, finally results in the bursting open of both archegonium and antheridium. In the former, by the forcing out of the remains of the canal cells an open channel is left down to the egg, which has been formed by the contracting of the contents of the lowest of the axial cells. In the antheridium the walls of the sperm cells are not usually completely dissolved at the time the antheridium opens, so that the spermatozoids are still surrounded by a thin cell wall when they are first discharged. This soon is completely dissolved, and the spermatozoid then swims away. The substance discharged by the archegonium exercises a strong attraction upon the spermatozoids, which are thus directed to the open mouth of the archegonium, which they enter. Only a single one actually enters the egg, where it fuses with the egg-nucleus, and thus effects fertilisation. The egg immediately secretes a cellulose wall about itself, and shortly after the fusion of the nuclei is complete the first segmentation of the young embryo takes place.

The origin of the sexual organs is from a single cell, but the position of this cell varies much. In the thalloid Hepaticæ it is a superficial cell, formed from a segment of the apical cell either of a main axis or of a special branch. In most of the foliose Hepaticæ and the Mosses, the apical cell of the shoot becomes itself the mother cell of an archegonium, and of course with this the further growth of the axis is stopped. The antheridia in the foliose Hepaticx are usually placed singly in the axils of more or less modified leaves, but in most Mosses the antheridia form a terminal group. Mixed with the sexual organs are usually found sterile hair-like organs, paraphyses, often of very characteristic forms. In the foliose Hepaticæ and most Mosses, the archegonia are often surrounded by specially modified leaves, and in the former there is also an inner cup-like perichatium formed from the tissue surrounding 
the archegonia. In the thallose Hepaticæ, both antheridia and archegonia are generally enclosed by a sort of capsule, similar to the perichrtium of the foliose forms formed by the growth of the tissue of the thallus immediately surrounding them.

\section{The Asexual Generation}

\section{(Sporophyte, Sporophore, Sporogonium)}

The sporophyte of the Muscineæ is usually known as the "sporogonium," and, as already stated, never becomes entirely independent of the gametophyte. After the first divisions are completed there is at an early period, especially in the Hepaticæ, a separation of the spore-producing tissue or archesporium, all the cells of which may produce spores, as in Riccia and the Mosses, or a certain number form special sterile cells which either undergo little change and serve simply as nourishment for the growing Spharocarpus, or more commonly assume the form of elongated cells,-elaters, which assist in scattering the ripe spores.

\section{CLASSIFICATION}

\section{Class I. Hepatica (Liverworts)}

The protonema is either rudimentary or wanting, and not sharply differentiated from the gametophore. The gametophore is, with the exception of Riella Haplomitrium and Calobryum, strongly dorsiventral, and may be either a (usually dichotomously) branched thallus or a stem with two or three rows of leaves. Non-sexual multiplication of the gametophyte by the separation of ordinary branches, or by special reproductive bodies, gonidia (Aneura multifida) or gemmæ-(many foliose Jungermanniacea, Blasia, Marchantia, etc.). The sporogonium (except in Anthoceroteæ) remains within the enlarged venter (Calyptra) of the archegonium until the spores are ripe. Before the spores are shed the sporogonium generally breaks through the calyptra by the elongation of the cells of the stalk or seta. All the cells of the archesporium may produce spores, or part of them may produce sterile cells or elaters. 


\section{Class II. Musci (Mosses)}

The gametophyte shows a sharp separation into protonema and gametophore. The protonema arises primarily from the germinating spore, and may be either a flat thallus or more commonly an extensively branching confervoid growth. Upon this as a bud the gametophore arises. This has always a more or less developed axis about which the leaves are arranged in two, three, or more rows. A bilateral arrangement of the leaves is rare, and the stems branch monopodially. The asexual multiplication is by the separation of branches through the dying away of the older tissues, or less commonly by special buds or gemmæ. Both stem and leaves have the tissues more highly differentiated than is the case in the Hepaticæ. The archesporium is developed as a rule later than is the case in the Hepaticæ, and within is a large central mass of tissue, the columella, which persists until the capsule is ripe. In most cases there is a large amount of assimilative tissue in the outer part of the capsule, and the epidermis at its base is provided with stomata. The growing embryo breaks through the calyptra at an early stage, and the upper part is in most cases carried up on top of the elongating sporogonium. In very much the greater number of forms the top of the capsule comes away as a lid (operculum).

\section{The Hepatice}

The Hepaticæ show many evidences of being a primitive group of plants, and for this reason a thorough knowledge of their structure is of especial importance in studying the origin of the higher plants, as it seems probable that all of these are derived from Liverwort-like forms. On comparing the Hepaticæ with the Mosses one is at once struck with the very much greater diversity of structure shown by the former group, although the number of species is several times greater in the latter. On the one hand, the Hepaticæ approach the Algæ, the thallus of the simpler forms being but little more complicated than that of many of the higher green Algæ. On the other hand, these same simpler Liverworts resemble in a most striking manner the gametophyte of the Ferns. The same 
difference is observed in the sporophyte. This in the simplest Liverworts, e.g. Riccia, is very much like the spore-fruit of Coleochate, one of the confervoid green Algæ; on the other hand, the sporogonium of Anthoceros shows some most significant structural affinities with the lower Pteridophytes. The simplest form of the gametophyte among the Hepaticæ is found in the thallose Jungermanniaceæ and Anthoceroteæ. In such forms as Aneura (Fig. 38) and Anthoceros (Fig. 55) the thallus is made up of almost perfectly uniform chlorophyllbearing tissue, fastened to the earth by means of simple root-hairs. In forms a little more advanced, i.e. Metzgeria, Pallavicinia (Fig. 38), there is a definite midrib present. From this stage there has been a divergence in two directions. In one series, the Marchantiaceæ, there has been a specialisation of the tissues, with a retention of the thalloid form of the plant. In Riccia (Figs. I-9) we find two clearly marked regions, a dorsal green tissue, with numerous air-spaces, and a ventral compact colourless tissue. In the higher Marchantiaceæ (Fig. I6) this is carried still further, and the air-chambers often assume a definite form, and a distinct epidermis with characteristic pores is formed. In the Marchantiaceæ also, ventral scales or leaf-like lamellæ are developed, and root-hairs of two kinds are present. Starting again from the flat, simple thallus of Aneura (Riccardia), two other characteristic types are met with, the peculiar spiral thallus of Riella, and the leafy axis of the more specialised Jungermanniaceæ. Between the latter and the strictly thallose forms are a number of interesting intermediate forms, like Blasia and Fossombronia, where the first indication of the two dorsal rows of leaves is met with; and in Blasia at least the rudiments of the ventral row of small leaves (Amphigastria) usually found in the foliose forms are present.

The tissues of the Liverworts are very simple, and consist for the most part of but slightly modified parenchyma. Occasionally (Preissia) thickened sclerenchyma-like fibres occur, but these are not common. Mucilage cells of various kinds are common. The secreting cells may be hairs on the ventral surface, and especially developed near the apex, where the mucilaginous secretion serves to protect against drying up; or they may be isolated (Marchantia) or rows of cells (Conocephalus) within the tissue of the thallus. In the Anthoceroteæ 
stoma-like slits upon the ventral surface lead to cavities where great quantities of mucilaginous matter are secreted.

The growth of the gametophore is usually due to the division of a single apical cell. In some of the thallose forms, e.g. Marchantiaceæ, Anthoceroteæ, a single initial cell is not always to be recognised in the older thallus, but in these forms a single initial always appears to be present in the earlier stages. In the Jungermanniaceæ, however, a single apical cell is always distinguishable, but varies a good deal in form in different genera, at least among the thalloid forms, or even in the same genus. Among the foliose Jungermanniacex it always has the form of a three-sided pyramid. From the apical cell segments are cut off in regular succession, and the first divisions of the segments also show much regularity, and often bear a definite relation to the tissues of the older parts.

\section{The Sexual Organs}

The archegonium is always traceable to a single cell, but the position of the mother cell is very different in different genera. In the simplest cases, e.g. Riccia, Spharocarpus (Figs. $2,29)$, the mother cell is formed from a superficial cell of one of the youngest dorsal segments of the apical cell, close to the growing point of an ordinary branch of the thallus, whose growth is in no way affected by the formation of archegonia. In such forms the archegonia stand alone, and about each is developed a sort of involucre by the growth of a ring of cells immediately surrounding the archegonium rudiment. In other cases the archegonia are found in groups, e.g. Pallavicinia (Fig. 38 ), separated by spaces where no archegonia are found. Here each group of archegonia has a common involucre. In Aneura and most of the higher Marchantiaceæ the archegonia are found in the same way, but upon special modified branches. In the foliose Jungermanniaceæ the origin of the archegonia is somewhat different. Here they are formed upon short branches, where, after a small number of perichætial leaves have been formed, the subsequent segments of the apical cell develop archegonia at once, and finally the apical cell itself becomes the mother cell of the last-formed archegonium, and, of course, with this the growth in length of the branch ceases. With the exception of the Anthoceroteæ, where the arche- 
gonium mother cell does not project at all, it quickly assumes a papillate form and is divided by a transverse wall into a basal cell, and an outer one from which the archegonium itself develops. The divisions in this outer cell are remarkably uniform. Three vertical walls are first formed, intersecting so as to enclose a central cell (Fig. 2, G). In this central cell a transverse wall next cuts off a smaller, upper cell (cover cell) from a lower one. Subsequently the three (or in the Jungermanniaceæ usually but two) first-formed peripheral cells divide again vertically, and by transverse walls in all of the peripheral cells, and somewhat later in the central one also, the young archegonium is divided into two tiers, a lower one or venter, and an upper one, the neck (Fig. 2, F). The middle cell of the axial row, by a series of transverse walls, gives rise to the row of neck canal cells, and the lowermost cell divides into two an upper one, the ventral canal cell, and a larger lower one, the egg.

The antheridium shows very much greater diversity in its structure, and equally great difference in its position. The origin in the thallose forms is usually the same as that of the archegonium, and indeed where the two grow mixed together, as in many species of Riccia, it is sometimes difficult to distinguish them in their earliest stages. Usually, however, the antheridia are borne together, either on special branches (Marchantia, species of Aneura), or they are produced in a special part of the ordinary thallus, which usually presents a papillate appearance (e.g. Fimbriaria). In the foliose Jungermanniaceæ the antheridia are often borne singly in the axils of slightly modified leaves, but in no case does the apical cell of the shoot become transformed into an antheridium. With the exception of the Anthoceroteæ, where the antheridia are of endogenous origin, the antheridium, like the archegonium, arises from a single superficial cell. The first division usually divides the primary cell into a stalk cell and the body of the antheridium. The first may remain very short and undergo but few divisions, or it may develop into a stalk of considerable length. The first division in the upper cell may be either transverse (Marchantiaceæ, Sphcrocarpus) or vertical (Jungermanniaceæ). Later, by a series of periclinal walls, a central group of cells is separated from an outer single layer of cells. The latter divide only a few times, and develop chlorophyll, 
which sometimes changes into a red or yellow pigment at maturity. The inner cells give rise to a very large number of sperm cells, which in most Hepaticæ are extremely small, and consequently not well adapted to studying the development of the spermatozoids. In a few forms, however, they are larger; and in Pellia especially, where the sperm cells are relatively large, the development has been carefully studied by Guignard, ${ }^{1}$ Buchtien, ${ }^{2}$ and others of late years, as well as by many of the earlier observers, and a comparison with other Hepaticæ shows great uniformity in regard to the origin and development of the spermatozoid. After the last division of the central cells the nuclei retain their flattened form, and thus the sperm cells remain in pairs, an appearance very common in the ripe antheridium of most Liverworts. Just before the differentiation of the body of the spermatozoid begins, the nucleus has the appearance of an ordinary resting nucleus, but no nucleolus can be seen. The first change is an indentation in the edge of the discoid nucleus, and this deepens rapidly until the nucleus assumes a crescent form. One of the ends is somewhat sharper and more slender than the other, and this constitutes the anterior end. As the body of the spermatozoid grows in length it becomes more and more homogeneous, the separate chromosomes apparently fusing together as the body develops. The body of the spermatozoid increases in length until it forms a slender spiral band coiled in a single plane, lying parallel with the one in its sister cell.

The full-grown spermatozoid in Pellia epiphylla has, according to Guignard, ${ }^{3}$ from three to four complete coils. Most Hepaticæ have much smaller spermatozoids, and they have fewer coils than in Pellia. In all the Hepaticæ the spermatozoid is provided with two cilia, which sometimes exceed in length the body. There is still some disagreement as to their exact method of formation, but from the latest researches of Strasburger ${ }^{4}$ it seems probable that they arise as direct outgrowths of the forward end of the body of the spermatozoid, this pointed anterior portion not being nuclear in nature, but composed of what Strasburger calls "kinoplasm." They begin to form at an early stage in the development of the spermatozoid, and reach their full length

1 Guignard (I).

3 Guignard (I), p. 67.
2 Buchtien (I).

4 Strasburger (8), pt. iv. p. I25. 
before the body of the spermatozoid is complete. Usually when the spermatozoid escapes, it has attached to the coil a small vesicle which swells up more or less by the absorption of water. This vesicle is the remains of the cytoplasm of the cell, and may, perhaps, contain also some of the central part of the nucleus. Guignard ${ }^{1}$ asserts that sometimes the cytoplasm is all used up during the growth of the spermatozoid, and that the free spermatozoid shows no trace of a vesicle.

In the Ricciaceæ and in Spharocarpus new archegonia continue to form even after several have been fertilised, so that numerous sporogonia develop upon the same branch of the thallus; but in most Liverworts the fertilisation of an archegonium checks the further formation of archegonia in the same group, and only those that are near maturity at the time reach their full development; and even if more than one archegonium of a group is fecundated, as a rule but one embryo comes to maturity.

Unquestionably the lowest type of sporogonium is found in Riccia (Fig. 6). Here the result of the first divisions in the embryo is a globular mass of cells, which a little later shows a single layer of peripheral cells and a central mass of spore mother cells, all of which produce spores in the usual way. The sporogonium remains covered by the venter of the archegonium until the spores are ripe, and never projects above the surface of the thallus. The spores only escape after the thallus (or at least that part of it containing the sporogonia) dies and sets them free as it decays. In the genus Spharocarpus (Fig. 30), which may be taken to represent the next stage of development, we notice two points in which it differs from Riccia. In the first place there is a basal portion (foot), which is simply an absorbent organ, and takes no part in the production of spores. Secondly, only a part of the archesporium develops perfect spores. A number of the spore mother cells remain undivided, and serve simply to nourish the growing spores. In the majority of the Hepaticæ the sporogonium shows, besides the foot and the capsule, an intermediate portion, the stalk or seta, which remains short until the spores are ripe, when, by a rapid elongation of its cells, the capsule is forced through the calyptra and the spores are discharged outside. In these forms, too, some of the cells of the archesporium remain undivided, and

1 Guignard (I), p. 66. 
very early are distinguished by their elongated shape from the young spore mother cells. These elongated cells later develop upon the inner surface of the cell wall peculiar spiral thickened bands, which are strongly hygroscopic. These peculiar fusiform cells, the elaters, are found more or less developed in all the Hepaticæ except the lowest ones. The Anthocerotex differ very much from the other Hepaticre in the structure of the sporogonium, as they do in other respects. Here alone among Bryophytes the sporogonium may have unlimited growth, the development continuing as long as the gametophyte remains alive. While in the lowest genus, Notothylas, the growth is limited, and the spores and elaters occupy the greater part of the sporogonium, in Anthoceros the archesporium consists of but a single layer of cells surrounding a central cylindrical mass of tissue, the columella, and is separated from the outside of the capsule by several layers of cells. The outer tissue is rich in chlorophyll, and there is a well-developed epidermis with large stomata differing neither in origin nor structure from those of vascular plants. The foot is very large, and just above it is a zone of actively dividing cells which cause the growth in length of the sporogonium.

The dehiscence of the sporogonium is different in the different orders. In the Ricciaceæ and some Marchantiaceæ the ripe sporogonium opens irregularly; in a few cases (species of Fimbriaria) the top of the capsule comes off as a lid; in most Jungermanniacex the wall of the capsule splits vertically into four valves, and in the Anthocerotex the sporogonium divides into two valves like a bean-pod.

The spores are always of the tetrahedral type, i.e. the nucleus of the spore mother cell divides twice before there is any division of the cytoplasm, although this division may be indicated by ridges projecting into the cell cavity, and partially dividing it before any nuclear division takes place. The four nuclei are arranged at equal distances from each other near the periphery of the mother cell, and then between them are formed simultaneously cell walls dividing the globular mother cell into four equal cells having a nearly tetrahedral form. These tetrads of spores remain together until nearly full grown, or in a few cases until they are quite ripe. In the ripe spore two, sometimes three, distinct coats can be seen, the inner one (endospore, intine) of unchanged cellulose, the outer one 
(exospore, exine) strongly cutinised and usually having upon the outside characteristic thickenings, ridges, folds, spines, etc. Where these thickenings are formed from the outside they constitute the third coat (perinium, epispore). The exospore is especially well developed in species where the spores are exposed to great heat or dryness, and which do not germinate at once. In those species that are found in cooler and moister situations, especially where the spores germinate at once, the exospore is frequently thin. The nucleus of the ripe spore is usually small. The cytoplasm is filled with granules, mostly albuminous in nature, with some starch and generally a great deal of fatty oil that renders the contents of the fresh spore very turbid. Some forms, especially the foliose Jungermanniaceæ, have also numerous chloroplasts, but this is lacking usually in those forms that require a period of rest before germination. In Pellia and Conocephalus the first divisions in the germinating spore take place while the spores are still within the sporogonium.

The germination of the spores begins usually by the formation of a long tube (germ-tube, "Keimschlauch" of German authors), into which pass the granular contents of the spore. At the same time there may be formed a root-hair growing in a direction opposite to that of the germinal tube, although quite as often the formation of the first root-hair does not take place until a later period. If the spore does not contain chlorophyll before germination, it is developed at an early stage, before any cell-divisions occur. Often the formation of a germ-tube is suppressed and a cell surface or cell mass is formed at once, and all these forms may occur in the same species. The germination only takes place when the light is of sufficient intensity, and the amount of light is a very important factor in determining the form of the young plant. Thus if the light is deficient, the germ-tube becomes excessively long and slender, and divisions may be entirely suppressed. An excess of light tends to the development at once of a cell surface or cell mass. In the simpler thalloid forms the first few divisions in the young plant establish the apical cell, and we cannot properly speak of the gametophore as arising secondarily from a protonema ; in other cases, however, the young plant does arise as an outgrowth or bud from a protonema, which only rarely has the branching filamentous character of the Moss protonema. 


\section{Classification OF THE HEPATICA}

The Hepaticæ are readily separated into the three following well-marked groups.

Group I. Marchantiaceæ.

Group II. Jungermanniaceæ.

Group III. Anthoceroteæ.

The following diagnoses are taken, with some modifications, from Schiffner. ${ }^{1}$

\section{GROUP I. MARCHANTIACEA:}

Gametophyte always strictly thallose, composed of several distinct layers of tissue, the uppermost or chlorophyll-bearing cells usually containing large air-spaces. The dorsal epidermis usually provided with pores, ventral surface with scales arranged in one or two longitudinal rows. Rhizoids of two kinds, with smooth walls, and papillate ; sexual organs, except in the lowest forms, united in groups which are often borne on special stalked receptacles. The first divisions of the embryo are arranged like the quadrants of a sphere. Sporogonium either with or without a stalk, and all the inner cells forming spores, or some of them producing elaters. No columella present.

\section{Fam. I. Ricciacere}

Chlorophyll-bearing tissue with or without air-chambers, and, where these are present, they never contain a special assimilative tissue. Epidermal pores wanting or rudimentary. Sexual organs immersed in open cavities upon the dorsal surface. Sporogonium without foot or stalk, and remaining permanently within the venter of the archegonium. All the cells of the archesporium producing spores.

\section{Fan. 2. Corsiniea}

Air-chambers well developed; epidermis with distinct pores; sexual organs in distinct groups, but the receptacles 
always sessile; sporogonium with a short stalk, producing besides the spores sterile cells, which may have the form of very simple elaters.

\section{Fam. 3. Marchantiece}

Air-chambers (with exception of Dumortiera) highly developed, and the chambers in most cases containing a loose filamentous assimilative tissue. Pores upon the dorsal surface always present (except in Dumortiera) and highly developed, ring-shaped or cylindrical. Sexual organs always in groups, usually upon special long-stalked receptacles. Sporogonium stalked and when ripe breaking through the calyptra, opening by teeth or a circular cleft, more seldom by four or eight valves. The archesporium develops sterile cells, usually in the form of elaters, as well as spores.

\section{The Marchantiacee}

The Marchantiaceæ constitute a very natural order of plants, all of whose members agree very closely in their fundamental structure. The separation of the Ricciaceæ as a group coordinate with the Jungermanniaceæ and Anthoceroteæ is not warranted, as more recent investigations, especially those of Leitgeb, ${ }^{1}$ have shown that the two groups of the Marchantiaceæ and Ricciaceæ merge almost insensibly into each other.

They are all of them strictly thallose forms, the thallus being unusually thick and fleshy, and range in size from a few millimetres in some of the smaller species of Riccia, to Io to 20 centimetres in some of the larger species of Dumortiera and Conocephalus. In most of them branching is prevailingly dichotomous, and as this is rapidly repeated, it often causes the thallus to assume an orbicular outline. Some forms, however, e.g. Targionia (Fig. I, E), fork comparatively seldom, and the new branches are for the most part lateral. The thallus is fastened to the substratum by rhizoids, which are unicellular and usually of two kinds, those with smooth walls and those with peculiar papillate thickenings or teeth that project inward (Fig. I I). The cells of the lower layers of tissue are usually nearly or quite destitute of chloroplasts, which, however, occur

\footnotetext{
I Leitgeb (7), vol. iv.
} 
in large numbers in the so-called chlorophyll-bearing layer, just below the dorsal epidermis. This chlorophyll-bearing layer
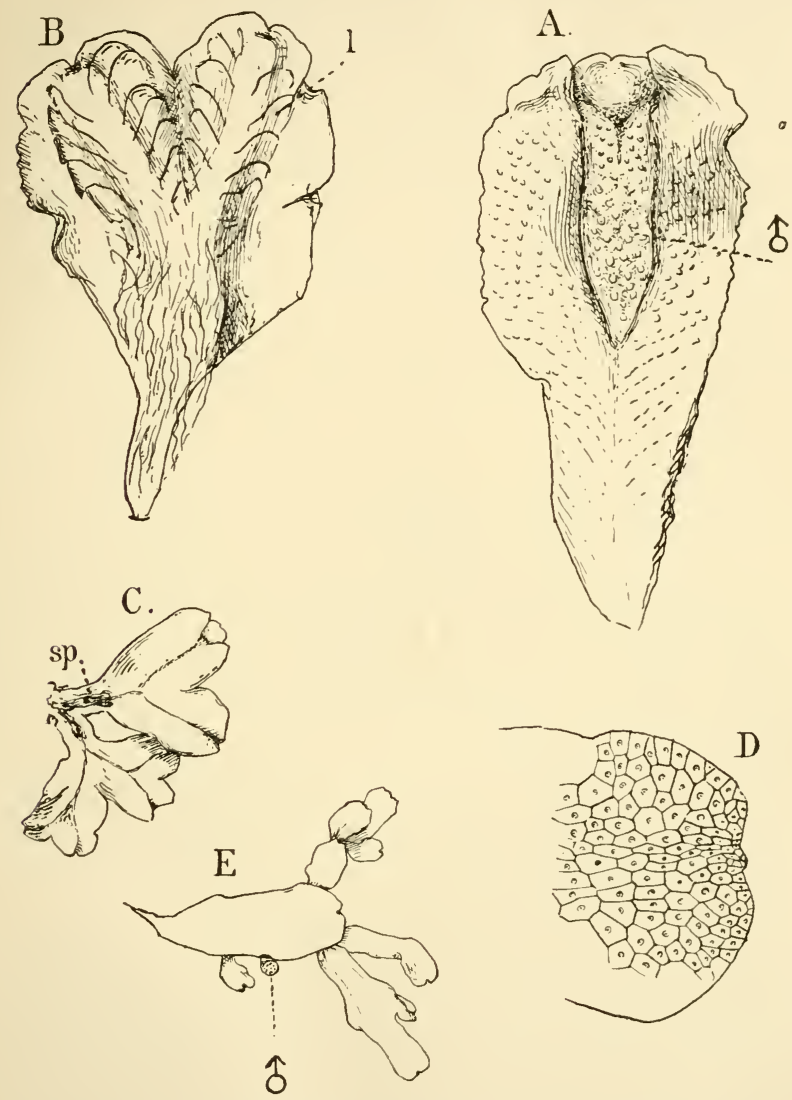

Fıg. I.-Marchantiaceæ. A, B, Male plants of Fimbriaria Californica (Hampe). A, from above : B, from below ; $\delta$, antheridial receptacle ; l, ventral lamellæ, $\times_{4} ;$ C, Riccia glauca (L.), $\times 6$; sp, sporogonia; D, Conocephalus conicus (Corda), $\times_{4} ; \mathrm{E}$, Targionia hypophy,lla (L.), $\times 2 ; \delta$. antheridial branch.

contains air-spaces in all forms except some species of Dumortiera, and these spaces are either simple narrow canals, 
as in Riccia glauca, or they may be large chambers separated by a single layer of cells from their neighbours. Such forms occur in most of the higher Marchantiaceæ.

The growth of the thallus is due to the division of a small group of cells occupying the bottom of the heart-shaped indentation in the forward part of the thallus. Sections parallel to the surface, cutting through this group, show a row of marginal cells that appear very much alike, and it is impossible always to tell certainly whether or not there is a single definite initial cell. Such a single initial is unquestionably present in the earlier stages, and it is quite possible that it may persist, but owing to its small size and its close resemblance to the adjoining cells, this cannot be positively asserted. In vertical sections the initial cell (or cells) appears nearly triangular, with the free outer wall somewhat convex. From this cell two sets of segments are cut off, the dorsal segments giving rise to the green tissue, and the lower segments producing the ventral lamellæ and colourless lower layers of cells of the thallus.

The plants multiply asexually either by the older parts of the thallus dying away and leaving the growing points isolated, or lateral branches, which are often produced in great numbers from the lower surface of the midrib, become detached and each branch forms a separate plant. The well-known gemmæ of Marchantia and Lumularia are the most striking examples of special asexual reproductive bodies.

The sexual organs are always derived from the dorsal segments of the apical cell, either of the ordinary branches or of special shoots. The archegonium is of the regular form, and the antheridium always shows a series of transverse divisions before any longitudinal walls are formed in it.

While the gametophyte may reach a very considerable degree of specialisation, the sporophyte is relatively insignificant even in the higher forms, and has the foot and stalk poorly developed. While the Marchantiacex grow for the most part in moist situations, and some of them, e.g. Marchantia polymorpha, are very quickly killed by drying, some species, e.g. Riccia hirta, a common Californian species, grows by preference in exposed rocky places exposed to the full force of the sun. This latter species as well as several others of the same region, e.g. Fimbriaria Californica, Targionia hypophylla, do not die at the end of the rainy season, but become completely dried up, in 
which condition they remain dormant until the autumn rains begin, when they absorb water and begin to grow again at once. In these cases usually only the ends of the branches remain alive, so that each growing tip becomes the beginning of a new plant.

\section{The Riciacee}

As a type of the simplest of the Marchantiacer, we may take the genus Riccia, represented, according to Schiffner, ${ }^{1}$ by I 07 species, distributed over the whole earth. Most of them are small terrestrial plants forming rosettes upon clay soil, or sometimes on drier and more exposed places. A few species, e.g. R. fluitans, are in their sterile condition submersed aquatics, but only fruit when by the evaporation of the water they come in contact with the mud at the bottom.

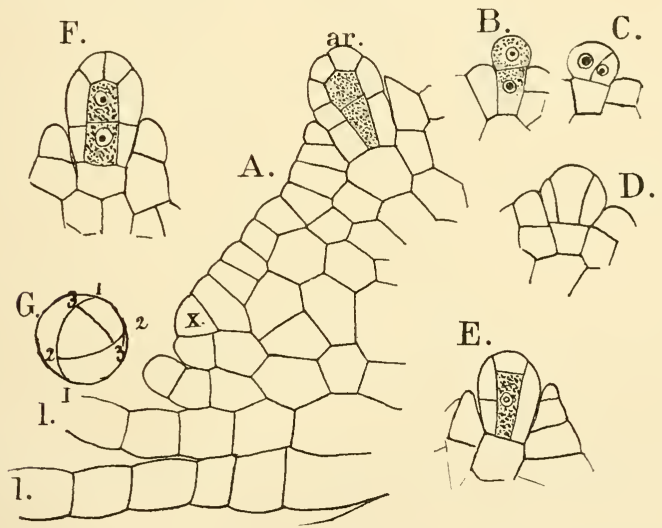

Fig. 2. - Riccia glauca (L.). Development of the archegonium, $\times 525$. A, Vertical section through the growing point ; $x$, apical cell; ar, young archegonium; $l$, ventral lamell $x ; \mathrm{B}-\mathrm{F}$, successive stages in the development of the archegonium, seen in longitudinal section; G, cross-section of young archegonium (diagrammatic).

The dichotomously branched thallus shows a thickened midrib, which is traversed upon the dorsal surface by a longitudinal furrow which in front becomes very deep. At the bottom of this furrow, at the apex of the thallus, lies the growing point. A vertical section through this shows a nearly triangular

\footnotetext{
1 Schiffner (I), p. 14 .
} 
apical cell which lies much nearer the ventral than the dorsal surface (Fig. 2, $x$ ). From this are cut off successively dorsal and ventral segments. Each segment next divides into an inner and an outer cell. From the outer cells of the dorsal segments the sexual organs arise, and from those of the ventral segments the overlapping lamellæ upon the lower surface of the thallus, and also the root-hairs. The rapid division of the inner cells of the segments, especially those of the dorsal ones, causes the thallus to become rapidly thicker back of the apex.
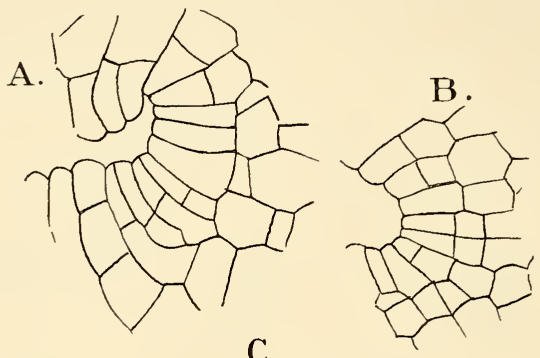

C.

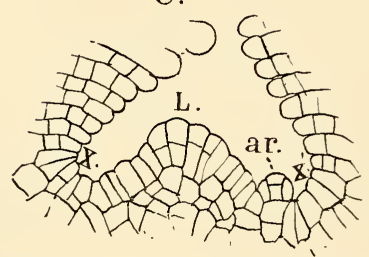

FIG. 3.-Riccia glauca (L.). Horizontal sections of the growing point. A, B, $\times 525 ;$ C, $\times$ about 260 . C shows the dichotomy of the growing point; $x, x^{\prime}$, the two new growing points; $\mathrm{L}$, the lobe between them; ar, a young archegonium.

Sections made parallel to the surface of the thallus, and passing through the growing point (Fig. 3), show that the margin is occupied by a group of cells that look very much alike. Sometimes one of these cells is somewhat larger than the others, but more commonly it is impossible to decide with certainty that a single initial is present. From a comparison of the two sections it is at once evident that the initial cells have nearly the form of the segment of a disc, and that in addition to the dorsal and ventral segments lateral ones are cut off as well. In the region just back of the apex the tissue of the thallus is 
compact, but in the older parts a modification is observable both on the dorsal and ventral surfaces. In the former, a short distance from the growing point, the superficial cells project in a papillate manner above the surface. This causes little depressions or pits to be formed between the adjacent cells (Fig. 3, C). The subsequent divisions in the papille are all transverse, and this transforms each papillatc surface cell into a row of cells which, as it elongates, causes the pits between it and the adjacent ones to become deep but narrow air-channels, so that in the older parts of the thallus the upper portion is composed of closely-set vertical rows of chlorophyllbearing cells separated by narrow clefts opening at the surface. In Riccia glauca, as well as other species, the uppermost cell of each row often enlarges very much, and with its fellows in the other rows constitutes the epidermis. According to Leitgeb's researches this epidermal cell is formed by the first division in the outer cell of the segment, and either undergoes no further division, or by dividing once by a transverse wall forms a twolayered epidermis (R. Bischoffii). On the ventral side the outer cells of the segments project in much the same way, but they remain in close contact laterally with the neighbouring cells, so that instead of forming isolated rows of cells, transverse plates or lamellæ, occupying the median part of the lower surface of the thallus, are formed. These remain but one cell thick, and grow very rapidly, and bend up so as to completely protect the growing point. With the rapid widening of the thallus in the older parts these scales are torn asunder, and the two halves being forced apart constitute the two rows of ventral scales found in the older parts. Later these scales dry up and are often scarcely to be detected except close to the growing point.

In the case of Ricciocarpus natans, ${ }^{1}$ instead of a single scale being formed, each cell of the horizontal row, which ordinarily gives rise to a single scale, grows out independently, much as do the dorsal surface cells in the other species, and the result is a horizontal series of narrow scales, each one corresponding to a single cell of the original row. These later are displaced by the subsequent growth of the thallus, and their arrangement in transverse series can only be seen in the younger parts. The very rapid increase in length of the dorsal rows of cells as they recede from the growing point soon causes them to overarch

1 Leitgeb (7), vol. iv. p. 29. 
the latter, which thus comes to lie in a deep groove; indeed not infrequently the end cells of the rows on opposite sides of the groove actually meet, so that the groove becomes a closed tube.

$R$. fuitans ${ }^{1}$ and $R$. crystallina differ in some respects from the other forms. In these, owing to a greater expansion of the tissues of the older parts of the thallus, the air-spaces are very much enlarged. In the former they are almost completely closed above, as the epidermai cells, by repeated vertical divisions, keep pace with the growth of the thallus and form a continuous epidermis, with only a small central pore over each of the large air-chambers. In $R$. crystallina, however, there is no such secondary growth of the epidermal cells, and in consequence the cavities are completely open above, so that the surface of the thallus presents a series of wide depressions separated by thin lamellæ. These two species also show some difference as to the ventral scales. Those in $R$. fuitans are small and do not become separated into two, and in $R$. crystallina they are wanting entirely.

Most of the Ricciaceæ multiply by special adventive shoots that arise from the ventral surface of the midrib. These become detached and form new individuals. According to Fellner ${ }^{2}$ the rhizoids develop at the apex a young plant in a manner entirely similar to that by which the young plant arises from the germtube of the germinating spore.

By far the commonest method of branching in most species of Riccia is a true dichotomy. The first indication of this process is a widening of the growing point and a corresponding increase in the number of the marginal cells. The central cells of the marginal group now begin to grow more vigorously than the others and to project as a sort of lobe (Fig. 3, C, L), and this lobe divides the initial cells into two groups lying on either side of it. As soon as this is accomplished each new group of initials continues to grow in the same manner as the original group, and two new growing points are established, each of which develops a separate branch. The growth of the middle lobe is limited, and it remains sunk in the fork between the two new branches.

The thallus is attached to the substratum by root-hairs of two kinds. The first are smooth-walled elongated cells, with colourless contents, the others much like those of the higher

I Leitgeb (7), vol. iv. p. II.

2 Fellner (I). 
Marchantiaceæ. Their walls are undulating, and projecting inward are numerous more or less developed spike-like protuberances. The root-hairs arise from large superficial cells of the ventral part of the midrib. They are readily distinguished from the adjacent cells by their much denser contents, even before they have begun to project.

The arrangement of the tissues of the fully-developed thallus is best seen in vertical cross-sections. In $R$. glauca and allied forms four well-marked tissue zones can be readily recognised in such a section. The lowest consists of a few layers of colourless rather loose parenchyma, from which the root-hairs arise, and to which the ventral lamellæ are attached. Above this a more compact, but not very clearly limited region, the midrib. The elongated form of the midrib cells, which contain abundant starch but no chlorophyll, is, of course, not evident in cross-section. Radiating from the midrib are closely-set rows of chlorophyll-bearing cells with the characteristic narrow air-spaces between. The median furrow is very conspicuous in such a section, and extends for about half the depth of the thallus. Terminating each row of green cells is the enlarged colourless epidermal cells, often extended into a beak-like appendage. In some species, e.g. R. hirta, some of the surface cells grow out into stout thick-walled pointed hairs.

\section{The Sexual Organs}

In Riccia the sexual organs are formed in acropetal succession from the younger segments of the initial cells, and continue to form for a long time, so that all stages may be met with upon the same thallus. While both antheridia and archegonia may be found together, in the two species $R$. glauca and $R$. hirta, mainly studied by myself, I found that as a rule several of one sort or the other would be formed in succession, and that not infrequently antheridia were quite wanting from plants that had borne numerous archegonia. Both archegonia and antheridia arise from single superficial cells of the younger dorsal segments of the initial cells. In their earliest stages they are much alike, the mother cell of the antheridium being, however, usually somewhat larger than that of the archegonium. The cell enlarges and projects as a papilla above the surface, when it is divided by a transverse wall into an outer cell and 
an inner one. The latter divides but a few times and forms the short stalk; the outer cell, which has dense granular contents, develops into the archegonium or antheridium as the case may be. In the former case the divisions follow the order already indicated for the typical Liverwort archegonium. In the outer cell, which continues to enlarge rapidly, a nearly vertical wall is formed (Fig. 2, C), which divides the cell into two very unequal parts. This wall is curved and strikes the periphery of the mother cell at about opposite points (Fig. 2, G, I). A second wall of similar form is next formed in the larger cell $(\mathrm{G}, 2)$, one end of which intersects the first wall, and finally a third wall (3) intersecting both of the others is formed. The young archegonium seen in vertical section at this stage (Fig. 2, D) shows a large central cell bounded by two smaller lateral ones; in cross-section the central one appears triangular. Each of the four cells of which the archegonium rudiment is now composed divides into two. The outer ones each divide by radial walls into equal parts, and the central one divides into an upper smaller cell (cover cell) and a lower larger one (Fig. 3, E). The next divisions are horizontal and divide the young archegonium into two tiers of cells. The lower one forms the venter, and the upper one the neck, and next the cover cell divides into four nearly equal cells by intersecting vertical walls. The archegonium at this stage (Fig. 2, F) is somewhat pear-shaped, being smaller at the bottom than at the top, and the basal cell is still undivided. It now rapidly increases in length by the transverse division and growth of all its cells, and there is at the same time a marked increase in diameter in the venter, which finally becomes almost globular (Fig. 4). The axial cell of the neck, the neck canal cell, divicies, according to Janczewski, ${ }^{1}$ always into four in $R$. Bischoffii, and the same seems to be true for $R$. lirta (Fig. 4, A), and probably is the same in other species. The number of divisions in the outer neck cells is various, but is most active in the lower part, but in the central cell of the venter there is always but a single transverse division which separates the ventral canal cell from the egg. The four primary cover cells enlarge a good deal as the archegonium approaches maturity, and divide by radial walls usually once, so that the complete number is normally eight- 
Janczewski gives ten in $R$. Bischoffic. The basal cell finally divides into a single lower cell which remains undivided, completely sunk in the thallus, and an upper cell which divides into a single layer of cells forming part of the venter, and continuous with the other peripheral cells. The mature archegonium (Fig. 4) has the form of a long-necked flask with a much enlarged base. The canal cells are completely indistinguishable, their walls having become absorbed and the
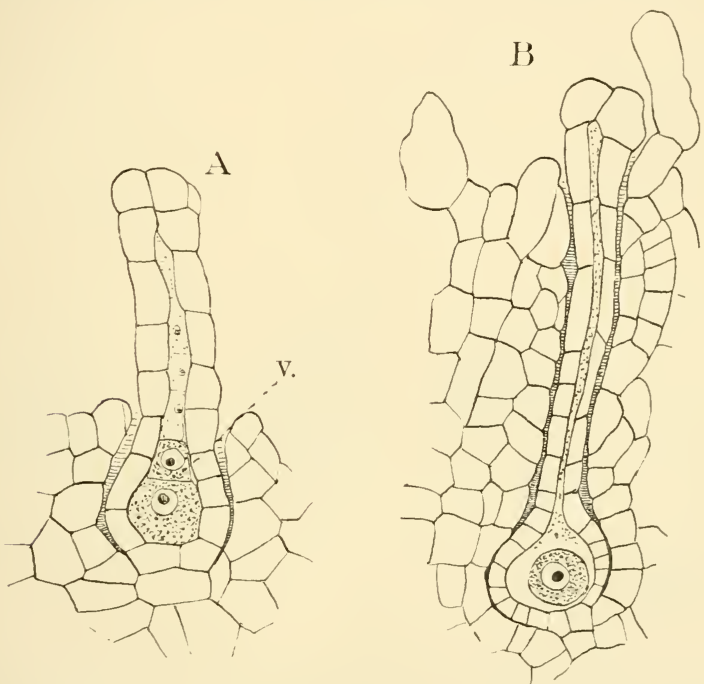

FIG. 4.-A, Archegonium of Riccia hirta (Aust.), showing the ventral canal cell $(v), \times 525$; $\mathrm{B}$, ripe archegonium of $R$. glauca, longitudinal section, $\times 260$.

contents run together into a granular mass. The nuclei of the neck-canal cells are small and not readily recognisable after the breaking down of the cell walls, but from analogy with the higher forms it is not likely that they completely disappear in the ripe archegonium. The cytoplasm of the central cell contracts to form the naked globular egg. The cytoplasm is filled with granules, and the nucleus, which is of moderate size, shows a distinct nucleolus, but very little chromatin. A special receptive spot was not certainly to be seen. 
Almost coincident with the first cell division in the archegonium rudiment there is a rapid growth of the cells immediately surrounding it. These grow up as a sort of ring or ridge about the archegonium, which is thus gradually immersed in a cup-shaped cavity, and the growth of the cells about this keeps pace with the increase in length of the archegonium, so that even when fully grown only the very extremity of the neck projects above the level of the thallus. The whole process is undoubtedly but a modification of the
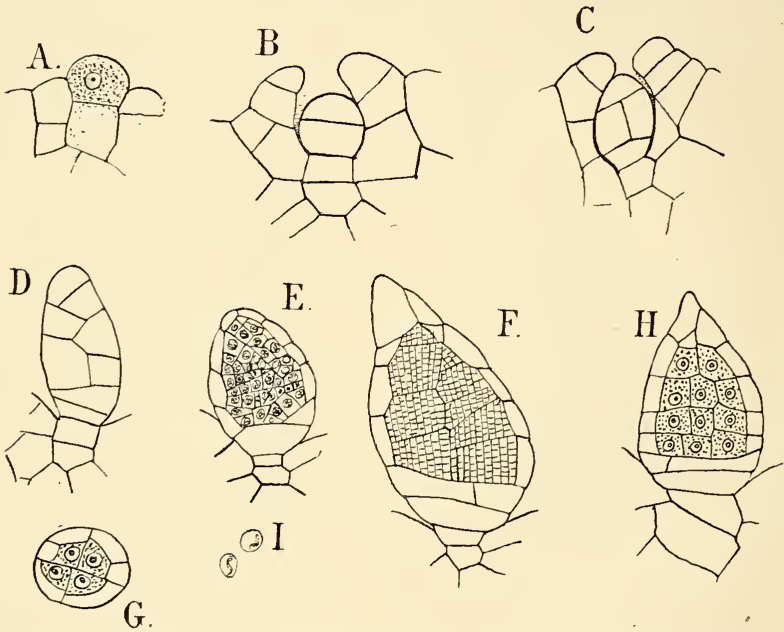

FIG. 5.-A-F, Development of the antheridium of $R$. glauca, seen in longitudinal section; G, crosssection of a young antheridium of the same; H, antheridium of $R$. hirta; $\mathrm{I}$, sperm cells of $R$. glauca. Figs. E, F, $\times 150 ; \mathrm{I}, \times 600$, the others $\times 300$.

ordinary growth of the dorsal part of the thallus, and the space about the archegonium is the direct equivalent of the ordinary air-spaces.

The first division in the primary antheridial cell is the same as in the archegonium, but the later divisions differ much and do not show such absolute uniformity. The first division wall in the upper cell (Fig. 5, B) is always transverse, and this is followed by a second similar wall, but the subsequent divisions show considerable variation even in the same species. After a varying number of transverse walls have been formed, 
in most cases the next divisions, which are formed only in the middle segments, are vertical, and divide the segments into quadrants of a circle when seen in transverse section. Occasionally a case is met with where the division walls are inclined alternately right and left, and the divisions strongly recall those of the typical Moss antheridium (Fig. 5, D).

The separation of the sperm cells is brought about by a series of periclinal walls in a number of the middle segments, by which four central cells in each segment (Fig. 5, G) are separated from as many peripheral cells. These central cells have, as usual in such cases, decidedly denser contents than the peripheral ones.

The lower one or two segments and the terminal ones do not take part in the formation of sperm cells, but simply form part of the wall of the antheridium. The central cells now divide with great rapidity, the division walls being formed nearly at right angles to each other, so that the central part of the antheridium becomes filled with a very large number of nearly cubical cells. The divisions are formed with such regularity that the boundaries of the original central cells remain very clearly marked until the antheridium is nearly mature. The basal cell of the antheridium rudiment in $R$. glauca divides once by a horizontal wall (Fig. 5, B, D) and forms the short stalk of the antheridium, which, however, is almost completely sunk in the thallus. Between this stalk and the central group of cells there are usually two layers of cells, so that the wall of the antheridium is double at the base, while it has but a single layer of cells in the other parts. The uppermost cells are often, although not always, extended into a beak. The spermatozoids do not seem to differ either in their method of development or structure from those of other Hepaticæ, but their excessively small size makes it extremely difficult to follow through the details of their development. When ripe the wall cells are much compressed, but are always to be distinguished.

Like the archegonia, the antheridia are sunk separately in deep cavities, which are formed in exactly the same way. Unlike the archegonia, however, the antheridium does not nearly reach to the top of the cavity, whose upper walls are in many species very much extended into a tubular neck, which projects above the general level of the thallus, and through which the spermatozoids are discharged. 


\section{The Embryo}

After fertilisation is effected the egg develops at once a cell-membrane and enlarges until it completely fills the cavity of the venter. The first division wall is more or less inclined to the axis of the archegonium, but approaches usually the horizontal. The lower of the two cells thus formed divides first by a wall at right angles to the first formed, but this is followed in the upper half of the embryo by a similar division, so that the embryo is divided into nearly equal quadrants. In
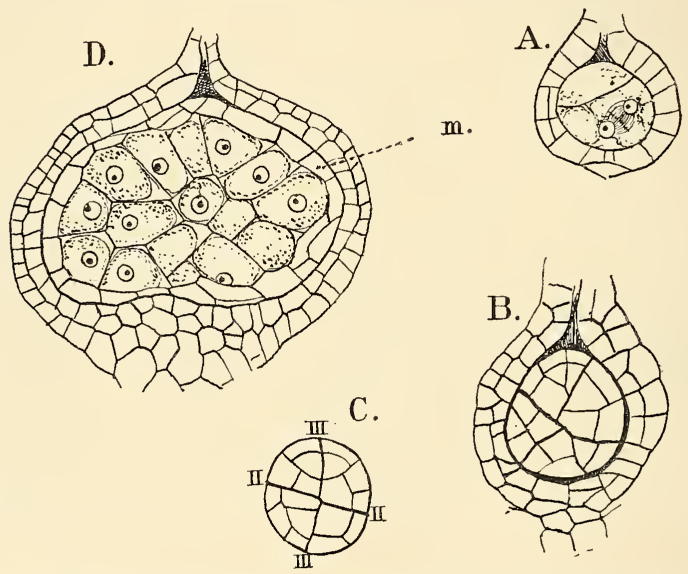

Fig. 6.-A, B, Young embryos of $R$. glauca in longitudinal section, showing the venter of the archegoniun, $\times_{2} 60$; C, transverse section of a similar embryo, $x_{260} ; \mathrm{D}$, longitudinal section of the archegonium and enclosed embryo of $R$. hirta at a later stage, $\times 220 ; m$, the sterile cells of the sporogonium.

each of the quadrants a wall meeting both of the others at right angles next appears (Fig. 6, C, III), and the embryo at this stage consists of eight nearly equal cells. The next walls are not exactly alike, but the commonest form is a curved wall (Fig. 6, C) striking two of the others, usually walls II and III, and intersecting the surface of the embryo. This wall divides the octants into two cells, which appear respectively triangular and quadrilateral in section. By the next division the archesporium is separated from the wall of the sporogonium. These walls 
are periclinal, and by them a single layer of outer cells is separated from the central mass of cells which constitutes the archesporium (Fig. 6, B, D).

At first the cells of the embryo are much alike, but as it grows the inner cells increase in size and their contents become densely granular, while the outer cells grow only in breadth, and not at all in depth, assuming more and more a tabular form, and for the most part undergo divisions only in a radial direction, so that the walls remain but one cell thick in most places. As the sporogonium increases in diameter the central cells begin to separate and round off. Their walls become partially mucilaginous, and in microtome sections stain strongly with Bismarck-brown or other reagents that stain mucilaginous membranes. With this disintegration of the division walls the cells separate more and more until they lie free within the cavity of the sporogonium. Each of these spore mother cells is a large gobular cell with thin membrane and densely granular contents. The nucleus is not so large as is usually the case in cells of similar character, and, except the nucleolus, stains but slightly with the ordinary nuclear stains. In the fresh state these spore mother cells are absolutely opaque, owing to the great amount of granular matter, largely drops of oil, that they contain. In embedding these in paraffine, however, the oil is dissolved and removed, and microtome sections show the fine granules of the cytoplasm arranged in a net-like pattern, the spaces between probably being occupied by oil in the living cells.

Fig. 7, A shows the nucleus of the mother cell undergoing the first division. The small size of the nuclei, and the small amount of chromation in them, make the study of the details of the nuclear division difficult here, and as there was nothing to indicate any special peculiarities these were not followed out. After the first nuclear division the daughter nuclei divide again, after which the four nuclei arrange themselves at equal distances from each other, the division walls form simultaneously between them, dividing the spore mother cell into the four tetrahedral spores. A section through such a young spore-tetrad is shown in Fig. $7, \mathrm{~B}$, where one of the cells is somewhat shrunken in the process of embedding. The cell walls at this stage are very delicate and of unchanged cellulose; but as they grow older 
the wall soon shows a separation into endospore and exospore. The latter in $R$. hirta, which was especially studied, is very thick, at first yellowish in colour, but deepening until when ripe it is black. Sections parallel to the surface show in this species what appear to be regular rounded pits, but vertical sections of the spore-coat show that this appearance is due to a peculiar folding of the exospore, which also shows a distinct striation, the outer layer being much thicker and denser than the inner ones. The nucleus of the ripe spore is remarkably

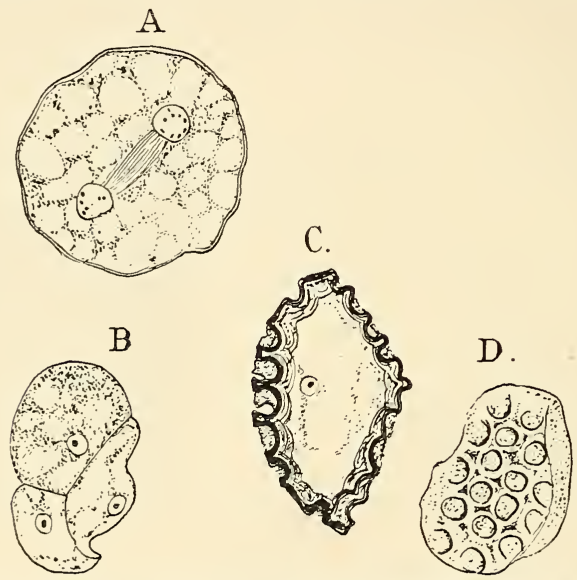

FIG. 7.--Riccia hirta (Aust.). A, Section of a spore mother cell undergoing its first division, $\times 600$; $\mathrm{B}$, section of young spore tetrad, $\times_{300} ; \mathrm{C}$, section of ripe spore, $\times_{300} ; \mathrm{D}$, surface view of the exospore of a similar stage, $\times 300$.

small, and it is evident that the dense contents of the ripe spore is largely oil or some similar soluble matter, as in microtome sections there is very little granular matter visible.

At the same time that the first division wall forms in the embryo, the outer cells of the venter begin to divide by periclinal walls, so that the single layer of cells in the wall of the unfertilised archegonium becomes changed into two, and the basal portion becomes still thicker; the neck takes no part in this later growth. The cells of the venter develop a great deal of chlorophyll, which is quite absent from the sporogonium itself, and before the spores are ripe the inner layer of cells of 
the calyptra (venter) becomes almost entirely absorbed, so that only traces of these cells are visible when the spores are ripe. The wall of the sporogonium also disappears almost completely as the latter matures, but usually in microtome sections traces of this can be made out in the ripe capsule, although the cells are very much compressed and partially disorganised. The contents of these cells, as well as the inner calyptra cells, no doubt are used up to supply the growing spores with nourishment. Thus, when ripe, the spores practically lie free in the cavity surrounded only by the outer layer of calyptra cells. The neck of the archegonium persists and is made conspicuous by the dark brown colour of the inner walls of the cells.

Hitherto the germination of the Ricciacex was only known in $R$. glauca. ${ }^{1}$ The account here given is based upon observations made upon $R$. hirta - a very common Californian species. It fruits in winter and early spring, and the spores remain dormant during the dry summer months. If the spores are sown in the autumn they germinate within a few days by bursting the massive black exospore, through which the colourless endospore enclosing the spore contents projects in the form of a blunt papilla. This rapidly grows out into a long club-shaped filament (Fig. 8, A), much less in diameter than the spore, and into this the spore contents pass. These now contain albuminous granules and great numbers of oil-globules, and among these chlorophyll bodies, which at first are small and not very numerous. They, however, increase rapidly in size, and divide also, so that before the first cell division takes place the chloroplasts are abundant and conspicuous. The formation of the first root-hair does not take place usually until a number of divisions have been formed in the young thallus. The first root-hair (Fig. 9, R) arises at the base of the germinal tube, and is almost free from granular contents. It, usually at least, is separated by a septum from the germ-tube. The first wall in the latter is usually transverse, although in exceptional cases it is oblique (Fig. 8, B), and this is followed by a second one parallel to the first (Fig. 8, C). In each of these cells a vertical wall is formed, and then a second at right angles to this, so that the nearly globular mass of cells at the end of the germ-tube is composed of eight nearly equal cells or octants. As these divisions proceed the

1 Fellner (1). 
oil drops which are so abundant in the undivided germ-tube disappear almost completely, and are doubtless used up by the growing cells.

According to Leitgeb's view, and that of other authors, the eight-celled body at the end of the germ-tube is a sort of protonema, from which the gametophore arises as a lateral outgrowth. I have seen nothing in the species under consideration which supports such a view. Here the axis of growth is continuous with that of the germ-tube, and in some cases at least, and probably always, a single apical cell is developed

A.

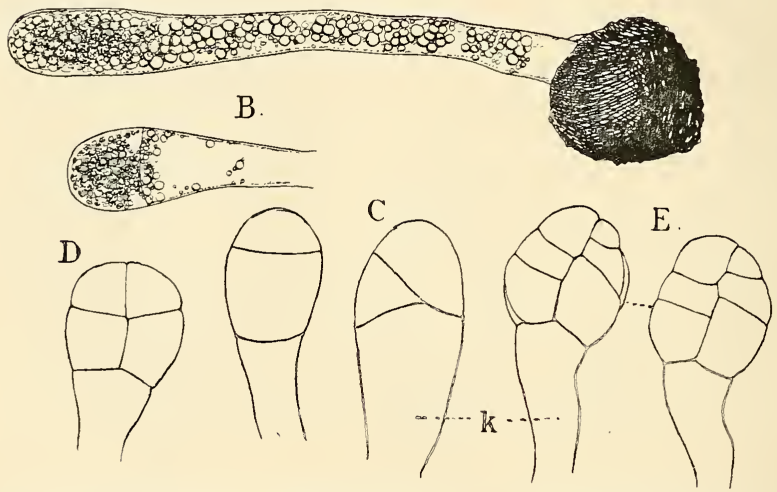

FIG. 8.-Riccia firta (Aust.). Germination of the spores, $\times$ Igo. In $E$ the figure at the left represents a surface view, the one at the right an optical section; $\mathrm{K}$, germinal tube.

at the apex at a very early stage. Probably this initial cell is one of the four terminal octant cells resulting from the first divisions. This cell sometimes has but two sets of segments cut off from it at first, alternately right and left, but whether this form is constant in the young plant I cannot now say.

The four lower quadrants also divide, at first only by transverse walls, and these cells lengthening give rise to a cylindrical body composed of four rows of cells, terminated by the more actively dividing group of cells at the summit. The single apical cell is soon replaced by the group of initials found in the full-grown gametophyte, and the method of growth from 
now on is essentially the same. The growth of the cells in the forward part of the dorsal surface of the young thallus is more active than that of the ventral side, so that they project over the growing point (Fig. 9), and as the outer cells of the lateral segments of the apical cell (or cells) also increase rapidly in size as they recede from the growing point, the forward margin

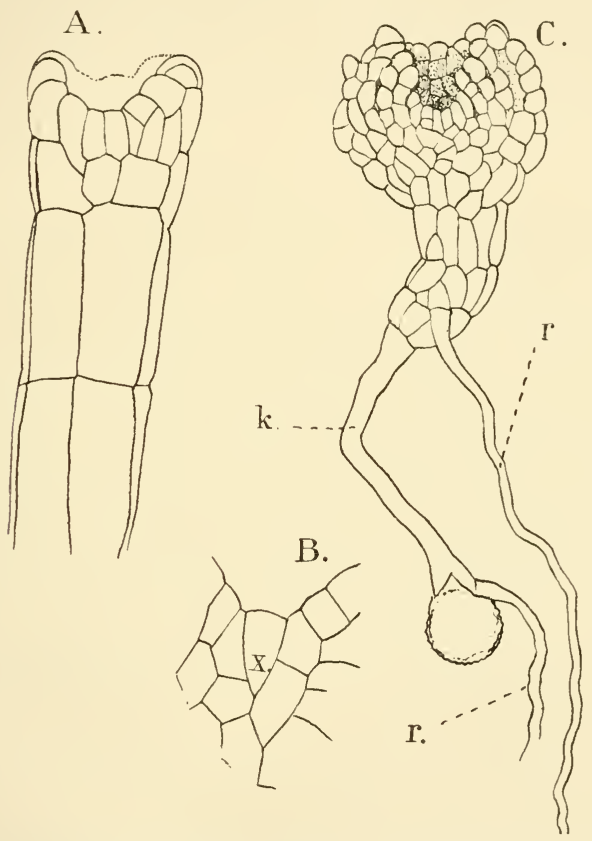

FIG. 9. - Riccia hirta (Aust.). Later stages of germination. A, from below, $\times 260 ; \mathrm{B}$, optical section of $\mathrm{A}$, showing apical cell $x, \times 520 ; \mathrm{C}, \times 85 ; r$, root-hairs.

of the thallus, seen from below, is deeply indented, and the forward part of the thallus is thus occupied by a deep cavity, at the bottom of which, toward the ventral side, lies the growing point. This cavity is the beginning of the groove or furrow found in the older thallus.

At first the cells of the young thallus are without intercellular spaces, but at an early period (Fig. 9, C) the outer cells 
of the young segments separate and form the beginnings of the characteristic air-spaces. In $R$. hirta some of the dorsal cells about the same time form short pointed papillæ, the first indication of the pointed hairs characteristic of this species. As the plant grows, new root-hairs are formed by the growing out of ventral cells into papillæ, which are cut off by a partition from the mother cell. These first-formed root-hairs are always smooth-walled, and it is only at a much later stage that the other form develops, as well as the ventral lamellæ, which are quite absent from the young plant.

\section{Classification of the Ricciaced}

Besides the genus Riccia, which includes all but three species of the family, there are two other genera, each represented by a single species, which undoubtedly belong here. Of these Ricciocarpus natans is of almost world-wide distribution. It is a floating form which, like Riccia fluitans, only fruits when growing upon the earth. Leitgeb ${ }^{1}$ has made a very careful study of the structure and development of the thallus, which differs a good deal from that of Riccia, in which genus this plant was formerly placed. The apical growth is essentially the same, and the differentiation of the tissues begins in the same way, but the chlorophyll-bearing tissue is extraordinarily developed. The air-spaces are formed in the same way as in Riccia, but they become very deep, and at an early stage, while still very narrow, are divided by cellular diaphragms into several overlying chambers, which, narrow at first, later become very wide, so that the dorsal part of the thallus is composed of a series of large polyhedral air-chambers arranged in several layers, and separated by walls but one cell thick. The upper chambers communicate with the outside by pores, quite like those of the Marchantieæ. The ventral tissue and midrib are rudimentary, and the very long pendent ventral lamellæ are produced separately in transverse rows, which however become displaced by the later growth of the thallus, so that their original arrangement can no longer be made out. Oil-bodies like those found in the Marchantiex occur. The fruiting plant, which grows on the margins of ponds, etc. where the floating form is found, is much more richly branched and more vigorous than

1 Leitgeb (7), vol. iv. 
the floating form. The ventral scales become shorter, and numerous wide but unthickened root-hairs are formed, which are almost completely lacking in the floating form. The structure of the reproductive organs and sporogonium are essentially the same as in Riccia, except that the plants are strictly diocious.

The third genus, Tesselina (Oxymitra), represented by the single species, T.pyramidata, is much less widely distributed, belonging mainly to Southern Europe, but also found in Paraguay. This interesting form has also been carefully examined by Leitgeb, ${ }^{1}$ who calls attention to its intermediate position between the Ricciaceae and the Marchantieæ. The thallus has all the characters of the latter : air-chambers opening by regular pores, usually surrounded by six guard-cells; two rows of ventral scales, independent from the beginning; and the sexual organs united into groups upon special parts of the thallus. The sporogonium, however, is entirely like that of Riccia, so that it may properly be placed in the same family. The plants are diœeious and strictly terrestrial.

A third genus, Cronisia, represented also by a single species, C. paradoxa, is placed provisionally with the Ricciacea by Schiffner, ${ }^{2}$ but the structure and development have not been investigated with sufficient completeness to make this certain. It has been found only in Brazil. Schiffner says of this form : "It belongs perhaps to the Corsinieæ, and forms a direct transition from the Ricciacea to that family."

1 Leitgeb (7), vol. iv. p. 34 .

2 Schiffner (I), P. I5. 


\section{CHAPTER III}

MARCHANTIE

COMPARIng the Marchantieæ with the Ricciaceæ, the close similarity in the structure and development of the thallus is at once apparent, but the former are more highly developed in all respects. The development of definite air-chambers in the green tissue, and a continuous epidermis with the characteristic pores, is common to all of them with the exception of the peculiar genus Dumortiera, where the development of the airchambers is partially or completely suppressed. The genera Ricciocarpus and Tessalina on the one hand, and Corsinia and Boschia on the other, connect perfectly Riccia with the higher Marchantiaceæ as regards the structure of air-spaces and epidermis, as they do in other respects. The epidermal pores in the Marchanticæ are sometimes simple pores surrounded by more or less symmetrically arranged guard cells (Fig. IO, D), or they are, especially upon the female receptacles, of a most peculiar cylindrical form, which arises by a series of transverse walls in the primary guard cells (Fig. IO, C). There is a good deal of difference in the character of the air-chambers in different genera. In Reboulia and Fimbriaria, for instance, they resemble a good deal those of Ricciocarpus, or more or less complete division of the primary chambers being produced by the formation of diaphragms or laminæ, which give the green tissue an irregular honey-combed appearance, and in these forms there is not a sharp separation of the green tissue from the central colourless tissue. In other genera, Marchantia, Targionia (Fig. I6), Conocephalus, the dorsal part of the thallus is occupied by a single layer of very definite air-chambers, each opening at the surface by a single central pore. Seen from the 
surface the boundaries of these spaces form a definite nctwork which in Conocephalus (Fig. I, D) is especially conspicuous. The bottom of these chambers is sharply defined by the colourless cells that lie below, and the space within the chamber is filled by a mass of short, branching, conferva-like filaments, which in the centre of the chamber have free terminal cells, but toward the sides are attached to the epidermal cells and are more or less confluent with the adjacent filaments.

As in Riccia root-hairs of two kinds are present, but the thickenings in the tuberculate rhizoids (Fig. I I) are much more pronounced, and these are not infrequently branched,

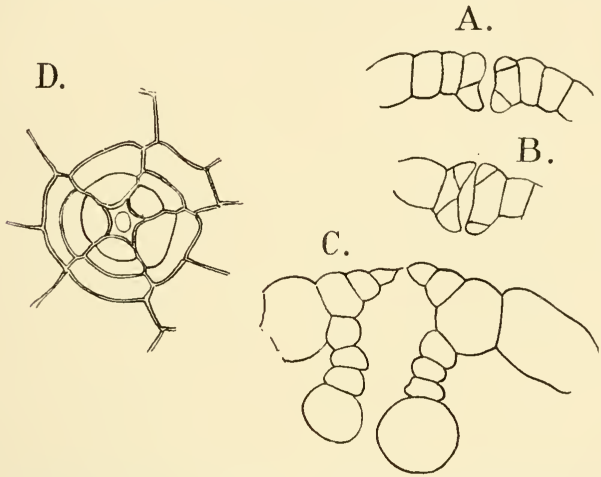

FIG. 10.-Fimbriaria Califorica (Hampe). Development of the pores upon the archegonial receptacle, $\mathrm{X}_{26} 6 \mathrm{~A}$ A, B, C, in longitudinal section; $\mathrm{D}$, view from above.

and may extend nearly across the cavity of the hair. The ventral scales are not produced by the splitting of a single lamella, as in Riccia, but are separate from the first and usually arranged in two rows. Leitgeb ${ }^{1}$ recognises two types of these organs. In their earliest stages they are alike, and both arise from papilla close to the growing point. In both cases this papilla is cut off from a basal cell, but in the first type (Sauteria, Targionia, Dumortiera) it remains terminal, usually forming the tip of a leaf-like terminal appendage of the scale. In the second type, represented by most of the other genera, this originally terminal papilla is forced to one side by the development of a lateral appendage to the scale, 
which, arising at first from a single cell, rapidly increases in size, and forms the overlapping dark purple marginal part of the scale so conspicuous in many species.

In different parts of the thallus are found large

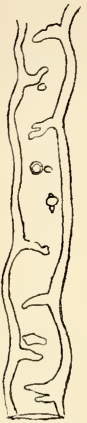
mucilage cells, which are usually isolated, or in Conocephalus, according to Goebel's ${ }^{1}$ investigations, they may form rows of cells which become confluent so as to form mucilage ducts. In the earlier stages these cells have walls not differing from those of the adjacent cells, but as they grow older the whole cell wall is dissolved, and the space occupied by the row of young cells becomes an elongated cavity filled with apparently structureless mucilage. These cells are recognisable at an early period, as their contents are much denser and more finely granular than those of the adjacent cells. Small cells, each containing a peculiar oil body, are found abundantly in

FIG. II.-Marchantia poly. morpha (L.) Part of a tuberculate rhizoid, $\times 525$.

most species, both in the body of the thallus and in the ventral scales. The structure and development of these curious bodies, which are found also in many other Hepaticæ, have been carefully studied by Pfeffer. $^{2}$ The oil body has a round or oval form usually, and in the Marchantieæ usually is found in a special cell which it nearly fills. It is brown or yellowish in colour, and has a turbid granular appearance. The extremely careful and exhaustive study of these bodies by Pfeffer has shown that the oil exists in the form of an emulsion in water, and that in addition to the oil and water more or less albuminous matter is present, and tannic acid. The latter is especially abundant in the oil bodies of Lunularia, less so in Marchantia and Preissia.

The thallus of the Marchantiaceæ is made up almost entirely of parenchyma, but Goebel ${ }^{3}$ states that in Preissia commutata there are elongated sclerenchyma-like cells in the midrib. The walls of the large colourless cells of the lower layers of the thallus are often marked with reticulate thickenings, which are especially conspicuous in Marchantia.

Most of the Marchantieæ have no special non-sexual reproductive organs, but in the genera Marchantia and Lunularia special gemmæ are produced in enormous numbers ;

1 Goebel (5), p. 53 I.

2 Pfeffer (2).

3 Goebel. 
and in the latter form, which is extremely common in greenhouses, the plant multiplies only by gemmre, as the plants are apparently all female. These gemmæ, as is well known, are produced in special receptacles upon the dorsal side of the thallus. The receptacles are cup-shaped in Marchantia, and crescent-shaped in Lumularia, where the forward part of the margin of the cup is absent. These cups are apparently

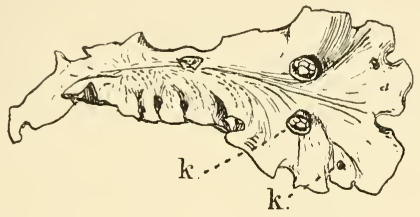

A.
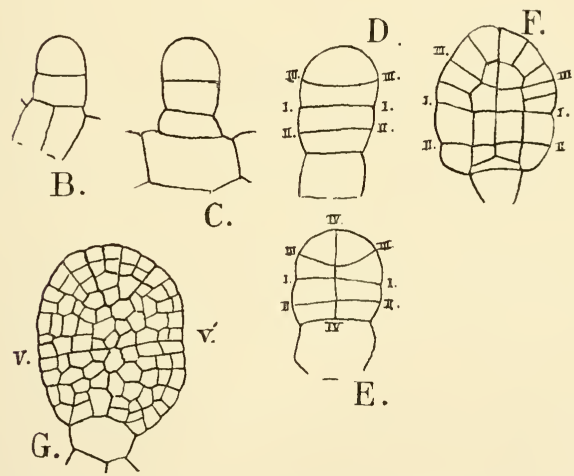

FIG. 12.-MIarchantia polynorpha (L.). A, Plant with gemma cups $(k, k), x_{2}$; B-F, development of the gemmæ, $\times_{525} ; \mathrm{G}$, an older gemma, $\times_{260} ; v, v^{\prime}$, the two growing points.

specially developed air-chambers, which, closed at first, except for the central pore, finally become completely open. The edge of the fully-developed receptacle is fringed. The gemmæ arise from the bottom of the receptacle as papillate hairs, and their development is the same in the two genera where they occur. Fig. I 2 shows their development in $M$. polymorpha.

One of the surface cells of the bottom of the receptacle projects as a papilla above the surface, and is cut off by a transverse wall from the cell below. The outer cell next 
divides again by a transverse wall into a lower cell, which develops no further, and a terminal cell from which the gemma is formed. This terminal cell first divides into two equal cells by a cross-wall (Fig. I 2, B), and in each of these cells a similar wall arises, so that the young gemma consists of four nearly equal superimposed cells (Fig. I 2, D). The wall III in Fig. I $2, \mathrm{D}$, arises a little later than wall II, and is always more or less decidedly concave upward. Each of the four primary cells of the gemma is divided into two by a central vertical wall, and this is followed by periclinal walls in each of the resulting cells. At first the gemma is but one cell in thickness, but later walls are formed in the central cells parallel to the surface, so that it becomes lenticular. As it grows older there is established on opposite sides (Fig. I 2, G, v, $v^{\prime}$ ) two growing points, which soon begin to develop in the manner found in the older thallus, and come to lie in a depression, so that the older gemmæ are fiddle-shaped. The gemma stands vertically, and there is no distinction of dorsal and ventral surfaces. The cells contain chlorophyll, except here and there the cells with oil bodies, and an occasional large colourless superficial cell. Among them are small club-shaped hairs, which secrete a mucilage that swells up when wet, and finally tears away the gemmæ from their single-celled pedicels.

The further development of the gemmæ depends upon their position as to the light. Whichever side happens to fall downward becomes the ventral surface of the young plant, and the colourless cells upon this surface grow out into the first rhizoids. The two growing points persist, and the young plant has two branches from the first, growing in exactly opposite directions. As soon as it becomes fastened to the ground the dorsiventrality is established, and upon the dorsal surface the special green lacunar tissue and the epidermis with its characteristic pores are soon developed, while the ventral tissue loses its chlorophyll, and soon assumes all the characters found in the mature thallus.

The branching of the thallus is in most cases dichotomous, as in Riccia, but occasionally, as in Targionia (Fig. I, E), the growth is largely due to the formation of lateral adventitious branches produced from the ventral surface.

In structure and development the sexual organs correspond closely to those of the Ricciaceæ, but they are always formed 
in more or less distinct groups or "inflorescences." As might be expected, this is least marked in the lower forms, especially the Corsinieæ, ${ }^{1}$ where the main distinction between them and the lower Ricciacex is that in Corsinia the formation of sexual organs is confined to a special region, and that the archegonia do not have an individual envelope as in Riccia, but the whole group of archegonia is sunk in a common cavity, which is of exactly the same nature as that in which each archegonium is placed in the latter. In most of the Marchantieæ, however, both antheridia and archegonia are borne in special receptacles, which in the case of the latter are for the most part specially modified branches or systems of branches, raised at maturity upon long stalks (Fig. I9). The antheridial receptacles are sometimes stalked, but more commonly are sessile, and often differ but little from those of the higher Ricciacex.

The sporogonium shows an advance upon that of the Ricciaceæ by the development of a lower sterile portion, or foot, in addition to the spore-bearing portion or capsule, and in the latter there are always sterile cells, which in all but the lowest Corsinieæ have the form of elaters. At maturity, also, the ripe capsule breaks through the calyptra, except in the Corsiniex, where, too, the sterile cells do not develop into elaters, but seem to serve simply as nourishing cells for the growing spores. The stalk of the capsule is always short compared with that of most Jungermanniacea, and the wall of the capsule remains intact until the spores are ripe.

The spores vary much in size, and in the development of the outer wall. In Marchantia polymorpha and other species where the spores germinate promptly, the ripe spore contains chlorophyll, and the exospore is thin and slightly developed. In such cases there is no distinct rupture of the exospore, but the whole spore elongates directly into the germ-tube. In Conocephalus, where the spores are very large, the first divisions occur in the spores before they are scattered. In species where the spores do not germinate at once the process is much like that of Riccia, and the thick exospore is ruptured and remains attached to the base of the germ-tube.

The apical growth of the Marchantiex is very much like that of Riccia. In Fimbriaria Californica (Fig. I 3) the apical cells seen in vertical section show the same form as those of 
Riccia, and the succession of dorsal and ventral segments is the same; but here the development of the ventral segments is much greater, and there is not the formation of the median ventral lamellæ as in Riccia, but the two rows of ventral scales arise independently on either side of the midrib, very near the growing point, and closely overlap and completely protect the apex. The formation of the lacunæ in the dorsal part of the thallus begins earlier than in Riccia, and corresponds

A.

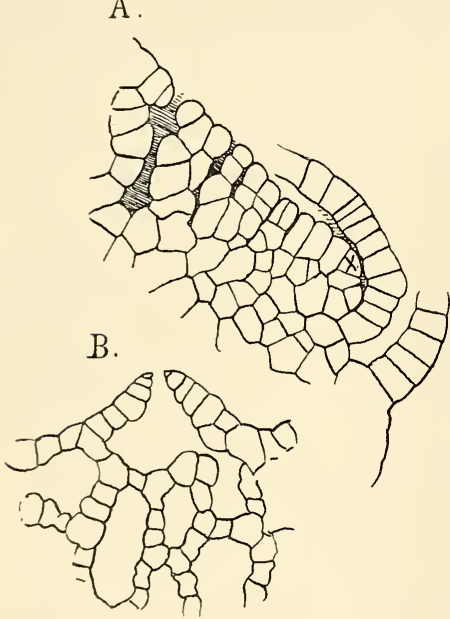

F1G. 13.-Fimbriaria Californica (Hampe). A, Vertical section through the apex of a sterile shoot, showing the formation of the air-chambers ; $x$, the apical cell, $\times 300 ; \mathrm{B}$, similar section through an older part of the thallus, cutting through a pore, $\times$ roo. very closely to what obtains in Ricciocarpus. The pits are at first very narrow, but widen rapidly as they recede from the apex. In the epidermal cells surrounding the opening of the cavity, there are rapid divisions, so that the opening remains small and forms the simple pore found in this species. As in Ricciocarpus, the original airchambers become divided by the development of partial diaphragms into secondary chambers, which are not, however, arranged in any regular order, and communicate more or less with one another.

In Targionia (Figs. I6, I7), where the archegonia are borne upon the ordinary shoots, the growth of the dorsal segments is so much greater than that of the ventral ones that the upper part of the thallus projects far beyond the growing point, which is pushed under toward the ventral side. A similar condition is found in the archegonial receptacles of other forms, where this includes the growing point of the shoot (Fig. I9). In Targionia the lacunx are formed much as in Fimbriaria, but they are shallower and much wider, and the pores correspondingly few. The assimilative tissue here resembles that 
of Marchantia and others of the higher forms. It is sharply separated from the compact colourless tissue lying below it, and the cells form short confervoid filaments more or less branched and anastomosing, and except in the central part of the chamber united with the epidermal cells. Under the pore, however, the ends are free and enlarged with less chlorophyll than is found in the other cells.

All of the Marchantieæ except the aberrant genus Dumortiera correspond closely to one or the other of the above types in the structure of the thallus, but in the latter the airchambers are either rudimentary or completely absent, and the ventral scales are also wanting. Leitgeb ${ }^{1}$ investigated $D$. irrigua, whose thallus is characterised by a peculiar areolation composed of projecting cell plates, and came to the conclusion that these were the remains of the walls of the air-chambers, whose upper parts, with the epidermis, were thrown off while still very young. He had only herbarium material to work with, but in this he detected traces of the epidermis and pores in the younger parts. I examined with some care fresh material of $D$. trichocephala, from the Hawaiian Islands, and find that in this species, which has a perfectly smooth thallus without areolations, that no trace of air-chambers can be detected at any time. Vertical sections through the apex show the initial cells to be like those of other Marchantiaceæ, and the succession of segments the same, but no indications of lacunæe can be seen either near the apex or farther back, the whole thallus being composed of a perfectly continuous tissue without any intercellular spaces, and no distinct limit between the chlorophyll-bearing and the colourless tissue. As Dumortiera corresponds in its fructification with the higher Marchantiex, the peculiarities of the thallus are probably to be regarded as secondary characters, perhaps produced from the environment of the plant, and species like $D$. irrigua would form transitional stages between the typical Marchantiaceous thallus and the other extreme found in D. trichocephala.

The structure and development of the sexual organs are very uniform among the Marchantiex. In Fimbriaria Californica, which is dicecious, the antheridial receptacle forms a thickened oval disc just back of the apex. Not infrequently (Fig. I, A), when the formation of antheridia begins not long

\footnotetext{
1 Leitgeb (7), vol.'vi. p. 124.
} 
before the forking of the thallus, both of the new-growing points continue to develop antheridia for a time, and the receptacle has two branches in front corresponding to these. The receptacle is covered with conspicuous papillæ which mark the cavities in which the antheridia are situated. Vertical longitudinal sections through the young receptacle show antheridia in all stages of development, as their formation, like those of Riccia, is strictly acropetal. The first stages are exactly like those of Riccia, and the primary cell divides into two cells, a pedicel and the antheridium proper. The divisions in the lower cell are somewhat irregular, but more numerous than in Riccia, so that the stalk of the ripe antheridium is more massive (Fig. I4). In the upper cell a series
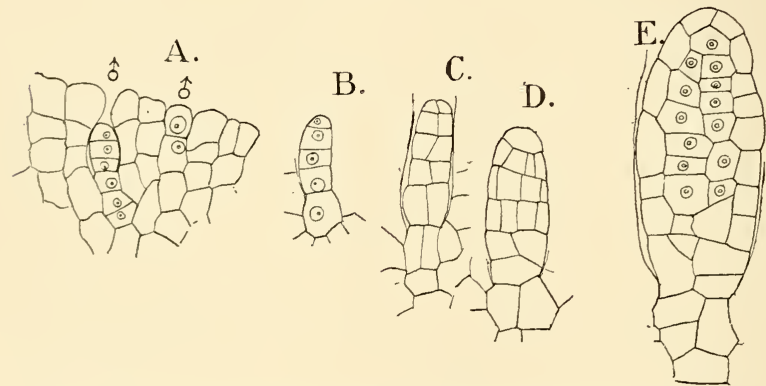

FiG. 14.-Fimbriaria sp. (?). A, Part of a vertical section of a young antheridial receptacle, showing two very young antheridia $(\delta), \times_{420}$; B-E, older stages.

of transverse walls is formed, varying in different species in number, but more than in Riccia, and apparently always perfectly horizontal. In Marchantia polymorpha Strasburger ${ }^{1}$ found as a rule but three cells, before the first vertical walls were formed. In an undetermined species of Fimbriaria (Fig. I 4), much like F. Californica, the antheridia were unusually slender, and here frequently four, and sometimes five transverse divisions are formed before the first vertical walls appear. Sometimes all the cells divide into equal quadrants by intersecting vertical walls, but quite as often this division does not take place in the uppermost and lowest cell of the body of the antheridium, or the divisions in these parts are more 
irregular. The separation of the central cells from the wall is exactly as in Riccia, and the lower segments do not take any part in the formation of the sperm cells, but remain as the basal part of the wall. In Fimbriaria the top of the antheridium is prolonged as in Riccia, but in Marchantia this is not the case. The wall cells, as the antheridium approaches maturity, are often much compressed, but in Targionia hypophylla,
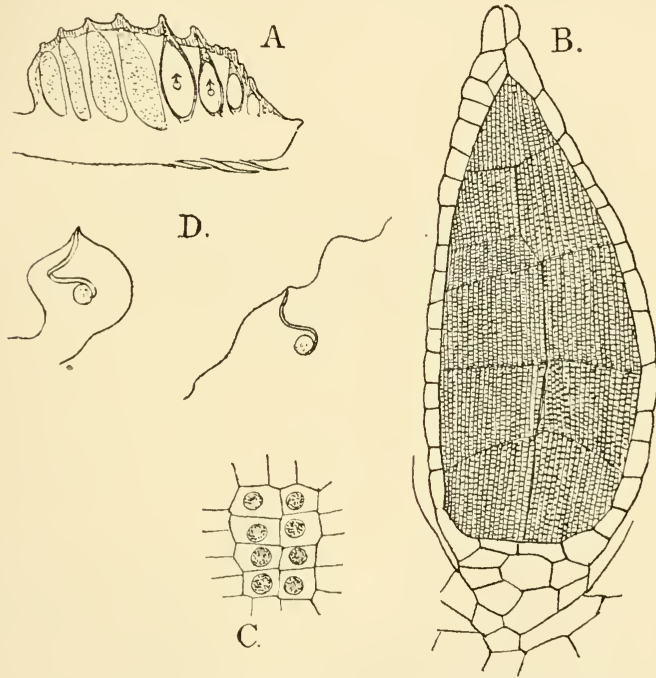

FIG. 15.-Finbriaria Californica (Hampe). A, Longitndinal section of a fully-developed male receptacle $\times 8$; B, longitudinal section of a nearly ripe antheridium, $\times 100 ; \mathrm{C}$, young sperm cells, $\times 600 ; \mathrm{D}$, spermatozoids, $\mathrm{XI200}$

where Leitgeb ${ }^{1}$ states that this compression is so great that the cells appear like a simple membrane, I found that, so far from this being the case, the cells were extraordinarily large and distinct, and filled the whole space between the body of the antheridium and the wall of the cavity, which in Leitgeb's figures ${ }^{2}$ is represented as empty. The antheridium becomes sunk in the thallus precisely as in Riccia. The sperm cells are nearly cubical and the spermatozoid is formed in the

1 Leitgeb (7), vol. vi. Pl. X. Fig. 12.

2 Leitgeb, l.c. 
usual way. The free spermatozoid (Fig. I 5, D) shows about one and a half complete turns of a spiral. The cilia are very long, and the vesicle usually plainly evident.

When the antheridia are borne directly upon the thallus, the apical growth continues after antheridia cease to be formed, and the receptacle is thus left far back of the growing-in point. In forms like Targionia, however, where there are special antheridial branches, the growth of these is limited, and generally ceases with the formation of the last antheridia. The most specialised forms are found in the genus Marchantia and its allies, where the antheridial receptacle is borne upon a long stalk, which is a continuation of the branch from which it grows, and the receptacle is a branch-system. The growing point of the young antheridial branch forks while still very young, and this is repeated in quick succession, so that there results a round disc with a scalloped margin, each indentation marking a growing point, and the whole structure being equivalent to such a branch system as is found in Riccia or Anthoceros, where the whole thallus has a similar rosette-like form. The antheridia are arranged in radiating rows, the youngest one nearest the margin and the eldest in the centre. In some tropical species, e.g. $M$. geminata, the branches of the receptacle are extended and its compound character is evident.

The archegonia are never sunk in separate cavities, but stand free above the surface of the thallus. The simplest form may be represented by Targionia. Here the archegonia arise in acropetal succession from the dorsal segments of the initial cells of the ordinary branches. A superficial cell enlarges and is divided as in Riccia into an outer and an inner cell. The latter undergoes irregular divisions and its limits are soon lost. In the outer cell the divisions occur in the same order as in Riccia, but from the first the base of the archegonium is broad and not tapering. Strasburger ${ }^{1}$ states that in Marchantia there is a division of the outer of the two primary cells by a wall parallel to the first, and that the lower one forms the foot of the archegonium, and Janczewski ${ }^{2}$ gives the same account of the young archegonium of Preissia commutata. This certainly does not occur in Targionia, and to judge from the later stages of Fimbriaria Californica, this species too lacks

1 Strasburger (2), p. 4 I6.

2 Janczewski (I), p. 386 . 
this division. The full-grown archegonium is of more nearly uniform thickness than in Riccia, as the venter does not become so much enlarged. The neck canal cells are more numerous, about eight being the common number, but in Targionia the formation of division walls between these is sometimes sup-

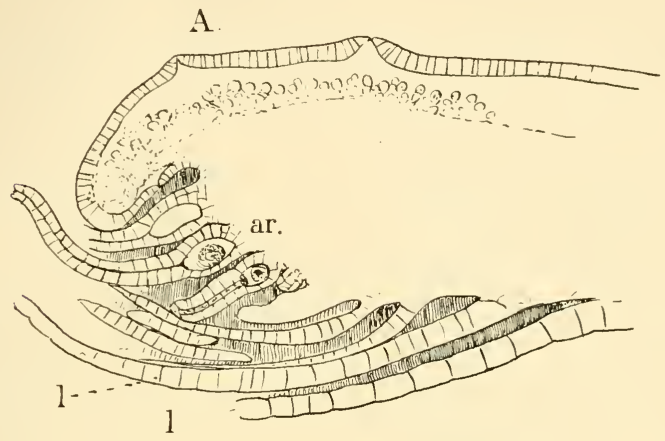

B.

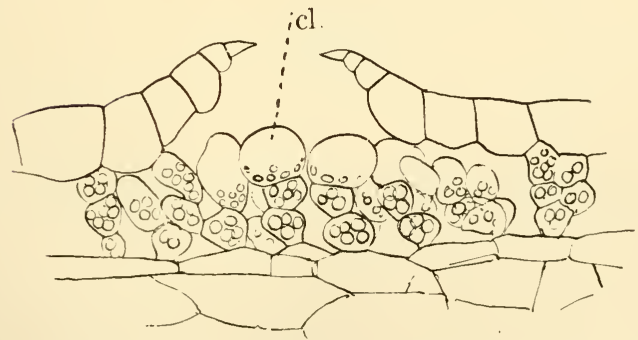

FIG. 16. - Targionia hypophylla (L.). A, Longitudinal section of the thallus, $\times 100$; ar, archegonia ; $l l$, ventral scales; $\mathrm{B}$, median section through a pore, showing the assimilating cells $(\mathrm{cl})$ below, $\times 300$.

pressed (Fig. I 7, C), so that this may account for Janczewski's ${ }^{1}$ error in stating that the number was always four, as the nuclei in unstained sections might be very easily overlooked. The cover cells are somewhat smaller than in Riccia and do not usually undergo as many divisions, there being seldom more 
than six in all. In Targionia (Fig. 2 I, A), and Strasburger ${ }^{1}$ observed the same in Marchantia, the ripe egg shows a distinct "receptive spot," that is, the upper part of the unfertilised egg is comparatively free from granular cytoplasm, while the lower part, about two-thirds in Targionia, is much more densely granular. The nucleus is not very large and has very little chromatin. The nucleolus is large and distinct and stains very intensely. As the archegonium of Targionia matures, its neck elongates rapidly and bends forward and upward, no
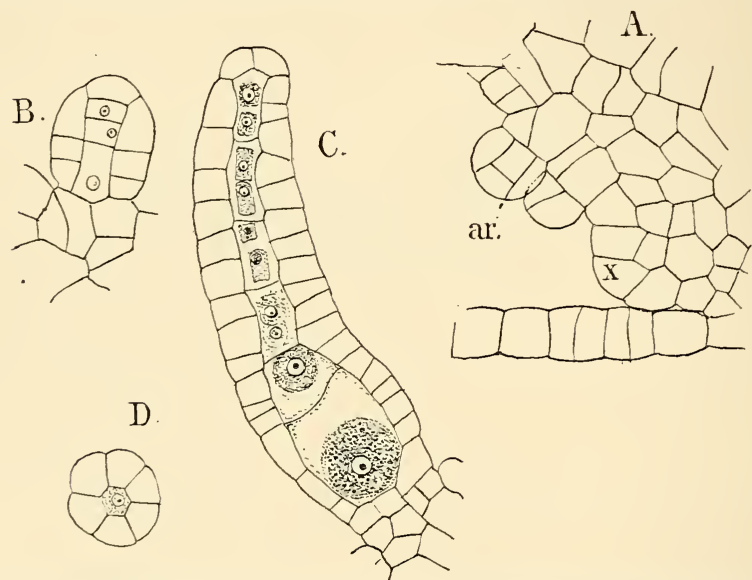

FIG. I7.-Targionia hypophylla (L.). A, Longitudinal section of the apex of the thallus, with young archegonia (ar), $\times 525 ; x$, the apical cell; $\mathrm{B}$, young; $\mathrm{C}$, older archegonium in longitudinal section; D, cross-section of the archegonium neck, $\times 525$.

doubt an adaptation to facilitate the entrance of the spermatozoid. A similar curving of the archegonium neck is observed in other forms where the archegonium is upon the lower side of the receptacle.

After an archegonium (or sometimes several of nearly equal age) is fertilised, the growth in length of the thallus stops, but there is a rapid lateral growth with results in the formation of two valves, which meet in front much like the two parts of a bivalve shell, and this involucre completely encloses the young growing sporogonium. 
In the simplest cases, where the archegonia are borne upon a receptacle ${ }^{1}$ which is raised upon a stalk, e.g. Plagiochasma, Clevea (Fig. I 8, A), the receptacle does not represent, according to Leitgeb, ${ }^{2}$ a complete branch, but is only a dorsal outgrowth of the latter, which may grow out beyond it, or even form several receptacles in succession. The first indication of the receptacle is a dorsal prominence which soon becomes almost hemispherical, and near the hinder margin the first archegonium arises, without, apparently, any special relation to the growing point. On the lateral margins are then formed two other archegonia, not, however, simultaneously ; and finally a fourth may be formed in front: three or four archegonia in all seem to be the ordinary number. The stalk of the receptacle is also a dorsal appendage of the thallus, and not a direct continuation of it.
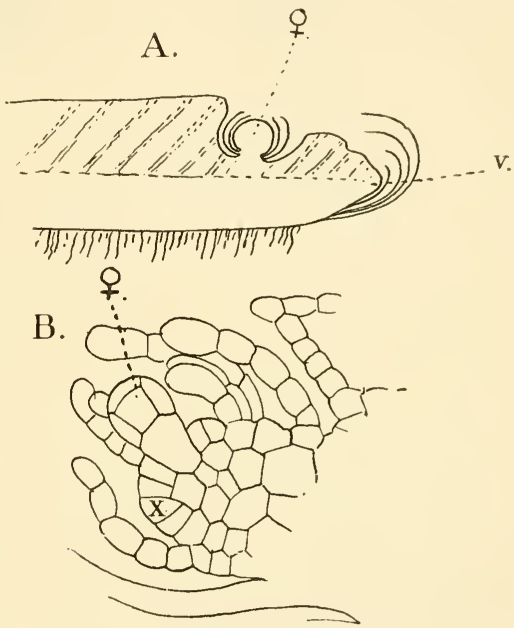

FiG. 18. - A. Clevea st. A, longitudinal section of the thallus showing the dorsal origin of the female receptacle $(q) ; v$, the growing point (diagram after Leitgeb); B, Reboulia hemispharica (Radd.), longitudinal section of very young receptacle with the first archegonium $(q) ; x$, the apical cell, $\times 300$ (after Leitgeb).

\section{The next type}

is that which Leitgeb ${ }^{3}$ attributes to Grimaldia, Reboulia, Fimbriaria, and some others, but it is not the type found in Fimbriaria Californica. In this type the structure of the receptacle and the origin of the archegonia are the same as in that just described; but here the growing point of the branch forms the forward margin of the receptacle, and the stalk is a direct continuation of the axis of the

1 The sporogonial receptacle of the Marchantiex is sometimes known as the Carpocephalum.

2 Leitgeb (7), vol. vi. p. 29.

3 Leitgeb, l.c. p. 3 . 
CHAP.

branch. Upon its ventral surface it shows a furrow in which root-hairs are produced in great numbers, and this furrow

A.

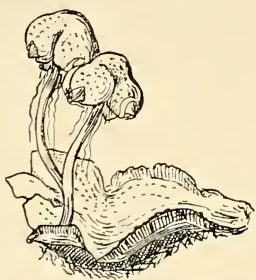

B.
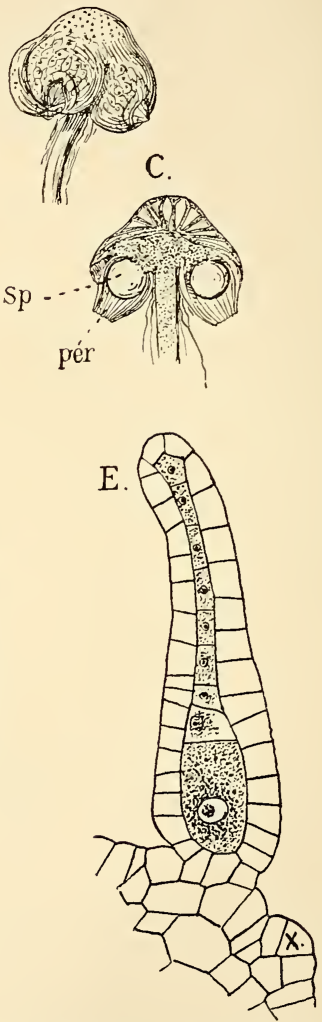

Fig. 19.-Fimbriaria Californica (Hampe). A, Plant with two fully-grown sporogonial receptacles, natural size; $\mathrm{B}$, a single receptacle, $\mathrm{X}_{4} ; \mathrm{C}$, the same cut longitudinally, showing the sporogonium $(s p)$, enclosed in the perianth (per); D, nearly median section of a young receptacle showing one growing point $(x)$ and an archegonium $(a r)$; $\mathrm{L}$, air-spaces; st, a pore; $r$, rhizoids, $\times_{40}$; $\mathrm{E}$, the growing point of the same with an archegonium, $\times_{300} ; x$, the apical cell.

passes over into the ventral surface of the thallus (Fig. I $9, \mathrm{~B})$. 
The highest type is that of Leitgeb's 1 "Compositæ." Here the female receptacle is a branch system similar to that of the male receptacle of Marchantia. The branching is usually completed at a very early period, while the receptacle is almost concealed in the furrow in the front of the thallus. A simple case of this kind is seen in Fimbriaria Californica (Fig. I9). Here there are four growing points that have arisen from the repeated dichotomy of the primary growing point of the branch, and each of these gives rise to archegonia in acropetal succession, much as in Targionia, but the number of archegonia is small, not more than two or three being as a rule formed from each apex. The development of the dorsal tissue is excessive and the ventral growth reduced to almost nothing, and the growing apices are forced under and upward and lie close to the stalk, and the archegonia have the appearance of being formed on the ventral side of the shoot, although morphologically they are dorsal structures. In the common Marchantia polymorpha the branched character of the receptacle is emphasised by the development of the "middle lobe" between the branches. These lobes grow out into long cylindrical appendages between the groups of archegonia, and give the receptacle a stellate form. Usually in $M$. polymorpha there are eight growing points in the receptacle, and of course as many groups of archegonia, which are much more numerous than in any other genus, amounting to a hundred or more in one receptacle. In Marchantia, as well as some other genera with compound receptacles, there are two channels in the stalk, showing that this is here influenced by the first dichotomy. While the archegonia, before fertilisation, are quite free, the whole group of archegonia, and indeed the whole receptacle, is invested with hairs or scales of various forms that originate either from the epidermis of the dorsal side, or as modifications of the ventral scales.

The lacunar tissue is very much developed upon the receptacles, as are to an especial degree the peculiar cylindrical breathing pores. The formation of these begins in the same way as the simple ones, being merely the original opening to the air-space. This seen from the surface shows an opening with usually five or six cells surrounding it. Vertical sections show that very soon the cells surrounding the pore become 
deeper than their neighbours and project both above and below them. In these cells next arise (Fig. IO, A, B) a series of inclined walls by which each of the original cells is transformed into a row of several cells, and these rows together form a curious barrel-shaped body surrounding the pore. The upper cells converge and almost close the space above, and this is still further diminished by the cuticle of the outer cell wall of the uppermost cells growing beyond the cells and leaving simply a very small central opening. The rows of cells also converge below, and in Fimbriaria Californica the lowermost cells are very much enlarged, and probably serve to close the cavity completely at times, and act very much like the guard cell of the stomata of vascular plants. In Leitgeb's group of the Astroporæ, the simple pores of the thallus have the radial walls of the surrounding cells strongly thickened, so that the pores seen from the surface appear star-shaped. The most specialised of the Marchantiea, i.e. Marchantia, Lumularia, etc., have the cylindrical pores upon the vegetative part of the thallus as well as upon the receptacle, but in the others they occur only upon the latter.

\section{The Sporogonium}

The first divisions in the embryo of the Marchantiee are the same as in the Ricciacex, but only the upper part (capsule) of the sporogonium develops spores, while the rest becomes the stalk. The simplest form of capsule is found in the genera Corsinia and Boschia, which have been carefully studied by Leitgeb. ${ }^{1}$ In these the embryo, instead of remaining globular as it does in Riccia, elongates and very early becomes differentiated into a nearly globular upper part, or capsule, and a usually narrower basal portion, the stalk (Fig. 20). In the capsule at a very early period a single distinct layer of outer cells is separated from the central group of cells, and forms the wall of the capsule, which in Boschia at maturity develops upon the inner cell walls thickened bars. Only a portion of the cells of the central part produce spores; the remainder do not divide after the spore mother cells are formed, but remain either as simple slightly elongated nourishing cells (Corsinia) or elaters (Boschia).

${ }^{1}$ Leitgeb (7), vol. iv. pp. 45-47. 
The other Marchantiex are much alike, and as Targionia was found to be an especially. satisfactory form for study, on account of the readiness with which straight sections of the embryo could be made, it was taken as a type of the higher Marchantieæ. The first division wall (basal wall) is transverse, and divides the embryo into two nearly equal parts. This is followed in both halves by nearly vertical walls (quadrant walls), and these and the basal wall are then bisected by the octant walls, so that as in Riccia the young embryo is formed of eight nearly equal cells. In Targionia, even at this period, the embryo is always somewhat elongated instead of globular. The next division walls vary a good deal in different individuals. Fig. 2 I, C shows a very regular arrangement of cells, where the first divisions were much the same in all the quadrants. Here all the secondary walls were nearly parallel with the basal wall, and intersected the quadrant and octant walls; but quite as often, especially in the upper half of the eribryo, these secondary walls may intersect the basal wall. In no cases seen was there any indication of a two-sided apical cell such as Hofmeister ${ }^{1}$ figures for Targionia, and probably his error arose from a study of forms where the quadrant walls were somewhat inclined, in which

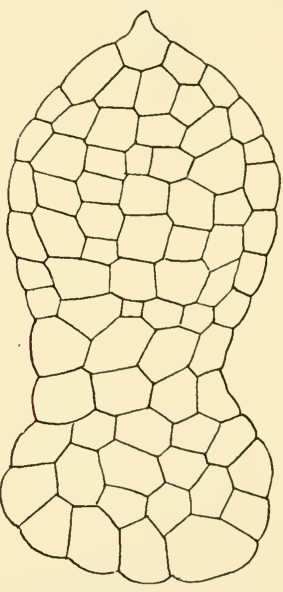

FIG. 20.-Corsinia marchantioids (Radd). Young sporogonium, optical section, $\times 300$ (Leitgeb). case the intersection of one of the secondary walls with it might cause the apex of the embryo to be occupied by a cell that, in section, would appear like the two-sided apical cell of the Moss embryo. The regular formation of octants was observed by me in Fimbriaria Californica, and by Kienitz-Gerloff ${ }^{2}$ and others in Marchantia, Grimaldia, and Preissia, and probably occurs normally in all Marchantiaceæ.

After the first anticlinal walls are formed in the octants, no definite order could be observed in the succeeding cell divisions,

1 Hofmeister (I), Pl. XV. Figs. 24, 25.

${ }^{2}$ Kienitz-Gerloff $(\mathbf{1}, 2)$. 
especially in the lower half of the embryo. In the upper part periclinal walls appear, but not at any stated time, so far as could be made out, and the first ones do not, as Leitgeb asserts,
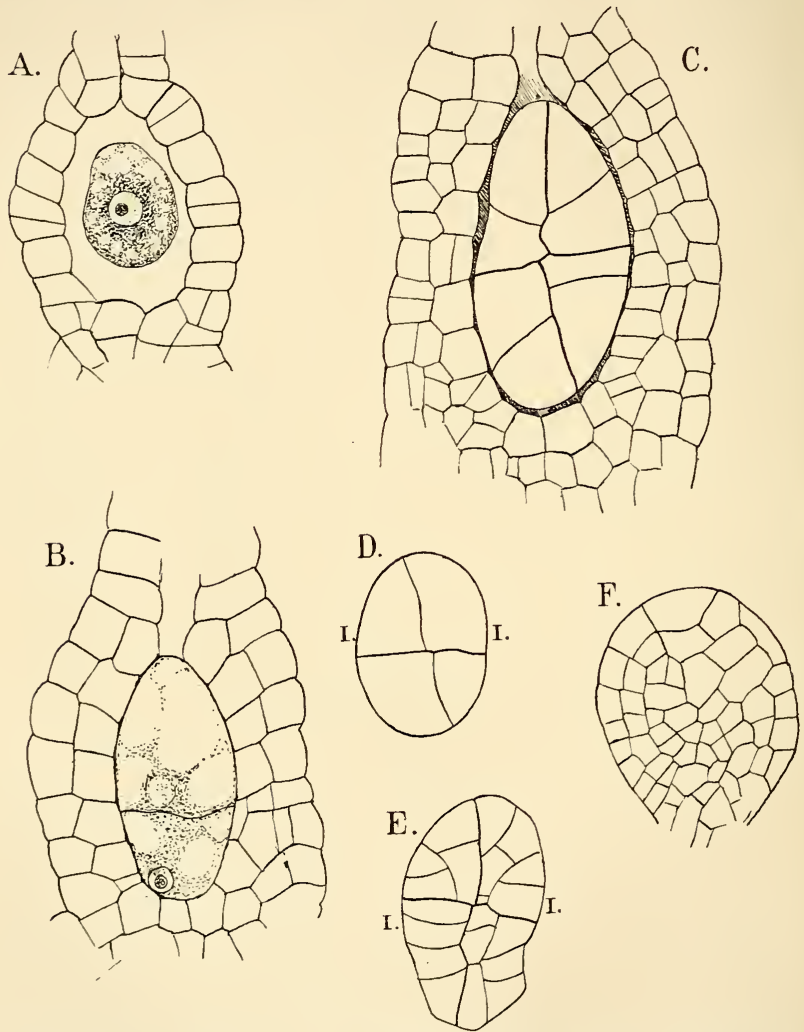

FIG. 21.-Targionia hypophylla (L.). A, Longitudinal section of the venter of a ripe archegonium, $\times 500 ; \mathrm{B}-\mathrm{E}$, development of the embryo, seen in longitudinal median section-B, two-celled, $\mathrm{D}$, four-celled stages, $\times_{500}$, except $\mathrm{E}$, which is magnified $\mathrm{r}_{5} 0$ times ; F, nearly median section of the upper part of an older embryo, $\times 250$.

necessarily determine the separation of the archesporium, as in the Corsinieæ. The growth now becomes unequal, the cells in the central zone not dividing so actively, a marked constriction 
is formed, and the young sporogonium becomes dumb-bell shaped. By this time a pretty definite layer of cells (Fig. $2 \mathrm{I}, \mathrm{F}$ ) is evident upon the outside of the capsule, but the cells of the globular lower part, or foot, are nearly or quite uniform. They are larger than those of the capsule, and more transparent. In the latter the wall becomes later more definite, and remains but one cell thick until maturity. The arrangement of the cells of the archesporium is very irregular, and until the full number of these is formed they are all much alike.
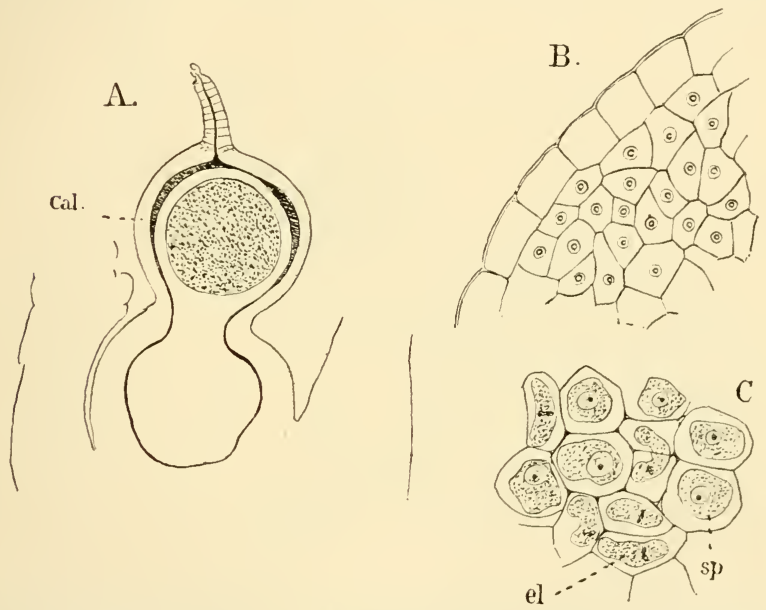

FIG, 22.-Targionia hypophylla (L.). A, Median Iongitudinal section of older embryo enclosed in the calyptra (cal), $\times 80 ; \mathrm{B}$, a portion of the upper part of the same embryo, $\times{ }_{4} \mathrm{SO}_{0}$; the nucleated cells represent the archesporium; C, part of the archesporium of a still later stage; $e l$, elaters; $s p$, sporogenous cells, $\times_{4} 80$.

Just before they separate, however, careful observation shows that two well-marked sorts of cells are present, but intermingled in a perfectly irregular way. A part of these cells are nearly isodiametric, the others slightly elongated, and the nuclei of the former cells are larger and more definite than those of the latter. At this stage the cells begin to separate by a partial deliquescence of their cell walls, and when stained with Bismarck-brown these mucilaginous walls colour very deeply, and the cells are very distinct in sections so treated. They finally separate completely, and the much-enlarged globular 
capsule now contains a mass of isolated cells of two kinds, globular sporogenous cells and elongated elaters. The former now. divide into four spores, but before the nucleus divides the division of the spores is indicated by ridges which project inward and divide the cavity of the mother cell almost completely.

With the first divisions in the embryo the venter of the archegonium, which before was only one cell thick, divides by a series of periclinal walls into two layers of cells, which later undergo further divisions, so that the calyptra surrounding the

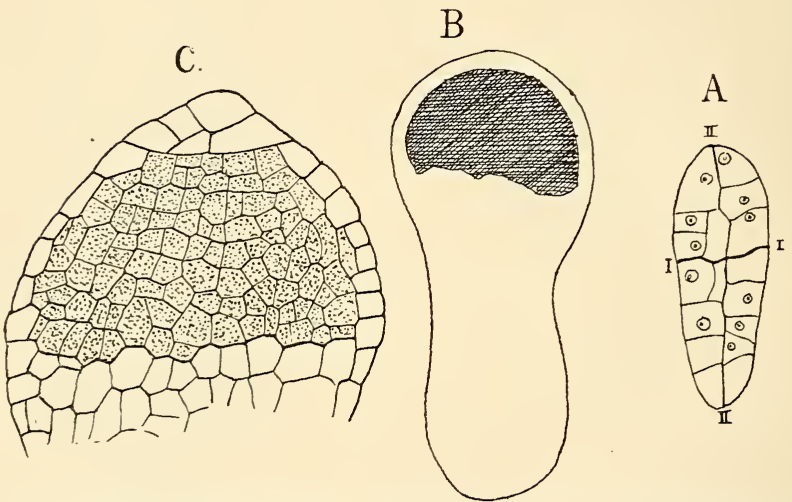

FIG. 23.-Finzbriaria Californica (Hampe). A, Young, B, older embryo in median section. A, $\times 300 ; \mathrm{B}, \times 100 ; \mathrm{C}$, upper part of a sporogonium, after the differentiation of the archesporium, $\times 200$.

older capsule may consist of four or more layers of cells. The neck of the archegonium remains unchanged, but the tissue of the thallus below the archegonium grows actively, and surrounds the globular foot, which has grown down into the thallus for some distance, and only the capsule remains within the calyptra. This large growth of the foot is at the expense of the surrounding cells of the thallus, which are destroyed by its growth, and through the foot nourishment is conveyed from the thallus to the developing capsule. That is, the sporogonium is here a strictly parasitic organism, growing entirely at the expense of the thallus. 
The further growth of the spores and elaters was studied in Fimbriaria Californica. The spores remain together in tetrads, until nearly ripe. In sections parallel to the surface of the younger spores (Fig. 24, C) the outer surface of the exospore is covered with very irregular sinuous thickenings, at first projecting but little above the surface, but afterward becoming in this species extraordinarily developed. In sections of the ripe spore (Fig. 24, D) three distinct layers are evident, the cellulose endospore, the thick exospore, and this outer thickened
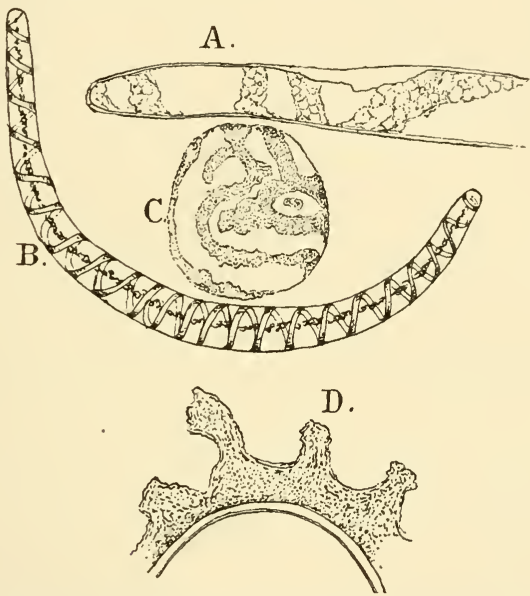

Fig. 24.-Fimbriaria Californica (Hampe). A, Young elater $\times 600 ; \mathrm{B}$, a fully-grown elater, $\times 300$; $\mathrm{C}$, surface view of the wall of a young spore, showing the developing episporic ridges, $\times 600$; D, section of the wall of a ripe spore, $\times 300$.

mass of projecting ridges which has every appearance of being deposited from without, and must therefore be characterised as epispore (perinium); Leitgeb ${ }^{1}$ distinctly states that thickenings of this character do not occur in the Marchantieæ, but that the thickenings are always of the character of those in Riccia.

The elaters are at first elongated thin-walled cells with a distinct although small nucleus, and nearly uniformly granular cytoplasm. As they grow the cytoplasm loses this uniform appearance, and a careful examination, especially of sections, shows that the granular part of the cytoplasm begins to form 
a spiral band, recalling somewhat the chlorophyll band of Spirogyra. This is the beginning of the characteristic spiral thickening of the cell wall, and while at first irregular, the arrangement of the granular matter becomes more definite, and following the line of this spiral band of granules in the cytoplasm, there is formed upon the inner surface of the wall the regular spiral band of the complete elater. This band, which is nearly colourless at first, becomes yellow in the mature elater, and in Targionia, where there are generally two, they are almost black. Not infrequently branched elaters are found, but these are unicellular, and no doubt owe their peculiar form to their position between the spore mother cells in the young archesporium. An axial row of granules, which seem to be of albuminous nature, remains in the elaters of Fimbriaria until maturity.

The differences in the structure of the sporogonium in different genera of the Marchantieæ are slight. In Marchantia polymorpha, the young sporogonium is nearly globular, and even when full grown it is ellipsoid with the stalk and foot quite rudimentary. Most forms, however, have the foot large, but the stalk, compared with that of most Jungermanniaceæ, is short. In most of them the whole of the upper half of the young embryo develops into the capsule, but in Fimbriaria Californica I found that the archesporium was smaller than in other forms described, and that sometimes the apical part of the sporogonium was occupied by a sort of cap of sterile cells. (Fig. 23).

The dehiscence of the capsule is either irregular, e.g. Targionia, or by a sort of lid, e.g. Grimaldia, or by a number of teeth or lobes, e.g. Lunularia, Marchantia. In some forms after fertilisation there grows up about the archegonium a cupshaped envelope, " perianth, pseudoperianth," which in Fimbriaria especially is very much developed, and projects far beyond the ripe capsule (Fig. I9).

The germination of the spores corresponds in the main with that of Riccia. Except in cases where the exospore is very thin, in which case it is not ruptured regularly, the exospore either splits along the line of the three converging ridges upon the ventral surface, and through this split the endospore protrudes in the form of a papilla, as in Riccia; or in Targionia (Fig. 25) the exospore is usually ruptured in two places on 
opposite sides of the spore, and through each of these a filament protrudes, one thicker and containing chlorophyll, the other more slender and nearly colourless. The first is the germ tube,
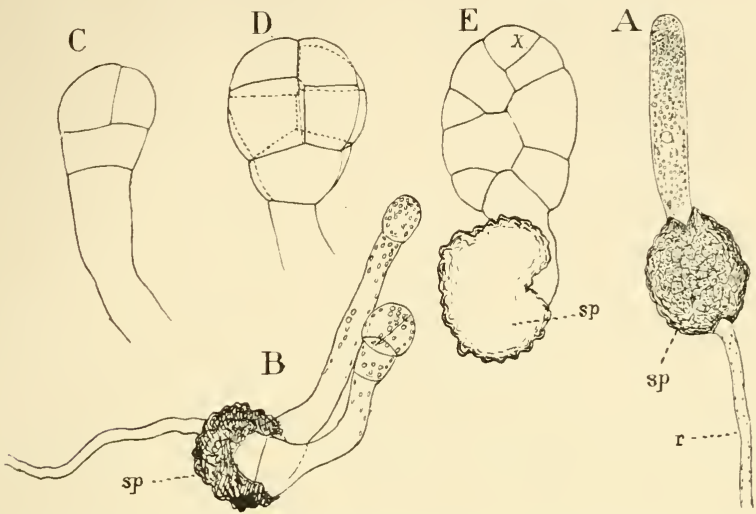

FIG. 25.--Targionia hypophylla (L.). Germination of the spores, $x$ about 200. In $\mathrm{B}$ two germ tubes have been formed; $\mathrm{C}$ and $\mathrm{E}$ are optical sections; $x$, apical cell; $r$, primary rhizoid; sp, spore membrane.

the second the first rhizoid. In Fimbriaria Californica the first root-hair does not usually form until a later period. In Targionia a curious modification of the ordinary process is quite often met with (Fig. 25, B). Here, by a vertical division in the very young germ tube, it is divided into two similar cells, which both grow out into germ tubes. Whether both of these ever produce perfect plants was not determined, but the first divisions in both were perfectly normal. The first divisions in the germ tube are not quite so uniform as in Riccia hirta, but resemble them very closely in the

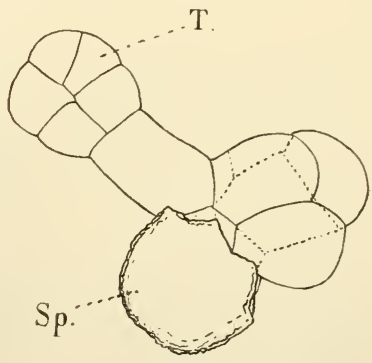

FIG. 26.-Targionia hypophylla (L.). Germ plant in which the thallus ( $\mathrm{T}$ ) has been formed secondarily; $\times 260$. commoner forms.

In Fimbriaria especially, and this has also been observed in 

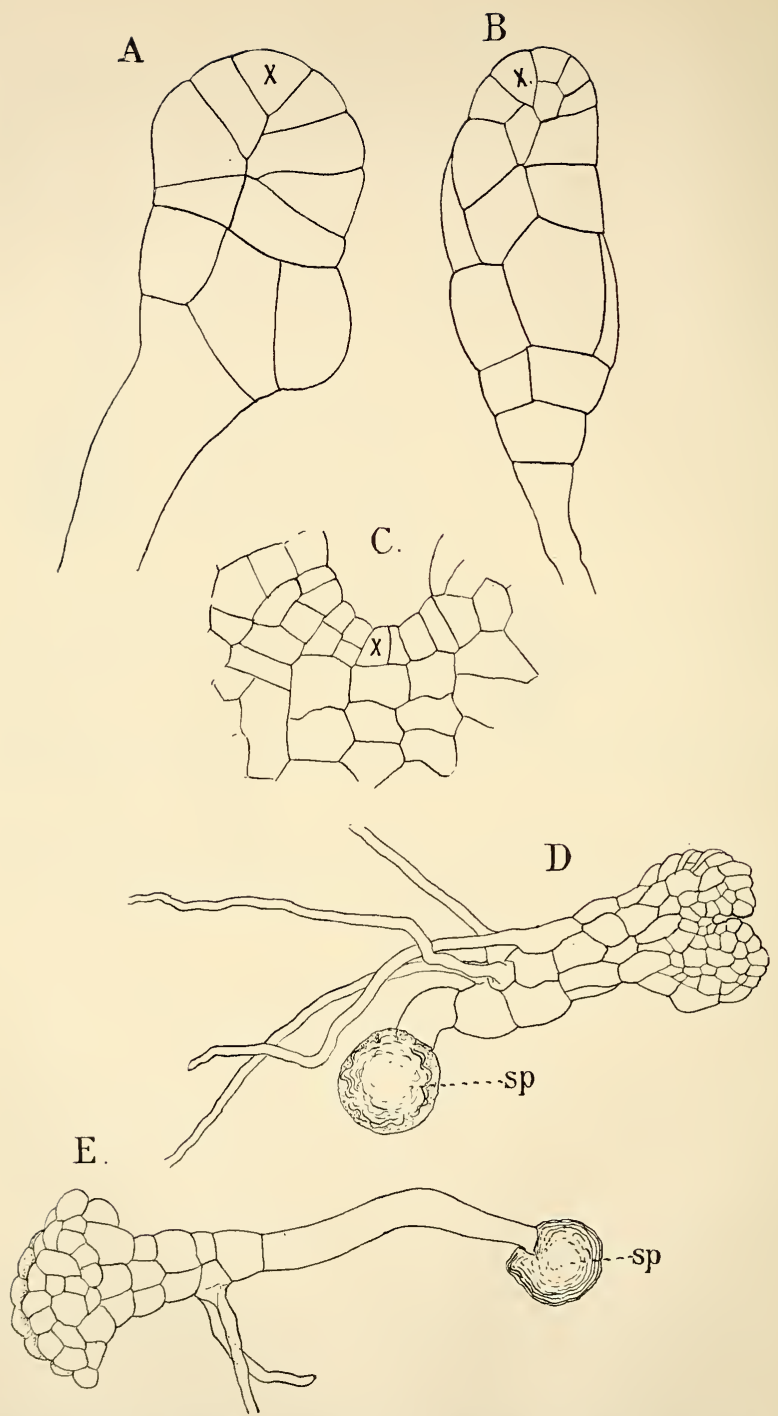

F1G. 27.-Fimbriaria Californica (Hampe). A, B, Young plants in optical section, showing the single two-sided apical cell $(x), \times_{26} 6$; C, horizontal section of an older plant with a single foursided initial $(x), \times_{425} ; \mathrm{D}, \mathrm{E}$, two young plants, $\mathrm{D}$ from below, $\mathrm{E}$ from the side, $\times 85$. 
Marchantia ${ }^{1}$ and other genera, a distinct two-sided apical cell is usually developed at an early period, and for a time the growth of the young plant is due to the segmentation of this single cell. Finally this is replaced by a single four-sided cell (Fig. $27, \mathrm{C}$ ), very much like the initial cell of the mature thallus. The young plant, composed at first of homogeneous chlorophyll-bearing cells, grows rapidly and develops the characteristic tissues of the older thallus. The first rhizoids are always of the simple form, and the papillate ones only arise later, as do the ventral scales. Targionia shows a number of peculiarities, being much less uniform in its development than Fimbriaria. While it often forms the characteristic germ tube, and the divisions there are the same as in Riccia and Fimbriaria, the formation of a germ tube may be completely suppressed, and the first result of germination is often a cell mass, from which later a secondary germ tube may be formed with the young plant at the apex (Fig. 26). Such cases as these are the only ones where it seems really proper to speak of the plant arising secondarily from a protonema, for in other cases, as in Riccia, the growth is perfectly continuous, and the axis of the young thallus is coincident with that of the germ tube, and in no cases observed by me could it in any sense be looked upon as a secondary lateral growth.

\section{Classification of the Marchantiea}

The higher Marchantieæ are readily separable into three families, the Corsinieæ, Targionieæ, and the true Marchantieæ. Leitgeb has made a further division of the latter family, but some of the characters given are not sufficiently constant to warrant his division, and for that reason it has been thought best not to accept them. ${ }^{2}$ Thus Fimbriaria Californica, which is, in regard to its fructification, typical, has the female receptacle of the composite type, a character which, according to Leitgeb, not only does not belong to the genus Fimbriaria, but is not found in any genus of the group (Operculatæ) to which he assigns it. This species too does not have the capsule operculate, but opens irregularly. The Corsinieæ, as we have

2 Leitgeb (7) and Schiffner (I), p. 24. 
already seen, are exactly intermediate in character between the highest Ricciaceæ, such as Tessalina, and the lower Marchantieæ, and this is true both of the structure of the thallus and the sporogonium. Corsinia differs from all the higher Marchantieæ in the character of the ventral scales, which are formed in more than two rows, like those of Ricciocarpus. Boschia, the other genus, has two rows of scales of the ordinary form. The archegonia are borne in a group in a depression upon the dorsal surface of the thallus, but are not formed upon a special receptacle, although after fertilisation the cells at the bottom of the cavity multiply actively and form a small prominence upon which the young sporogonia are raised, and this may perhaps be the first indication of the archegonial receptacle in the other forms,

The Targioniea include the two genera Targionia, which has been already described at length, and Cyathodium, ${ }^{1}$ a genus whose development is not sufficiently known to make its systematic position quite certain. In the position of the sexual organs, and the formation of the two-valved involucre about the fruit, as well as the position of the latter, it corresponds closely to Targionia, but the structure of the thallus is extraordinarily simple, there being practically but two layers of cells with large irregular air-chambers between. While two sorts of rhizoids are present, those that represent the papillate type of the other Marchantiaceæ, while thicker walled than the others, do not develop the projecting prominences. Indeed the whole structure of the plant is curiously reduced, and Leitgeb describes it as resembling the young plants of Marchantia or Preissia. The development of the sexual organs is but imperfectly known, and the suggestion of Leitgeb's, that possibly the antheridium is reduced to a single cell, seems hardly probable in view of the structure of the rest of the plant. The sporogonium has the stalk and foot exceedingly rudimentary, but the upper part of the capsule shows a zone of cells whose walls are marked by peculiar ring-shaped thickenings, and opens regularly by a number of teeth, which on account of the thickened bars upon the cell wall offer a superficial resemblance to the peristome of the Bryineæ. As in Targionia the archegonia arise near the apex of the ordinary shoots, and no proper receptacle is formed.

${ }^{1}$ Leitgeb (7), vol. vi. p. 136. 
All of the other forms have the archegonia borne upon a special receptacle, which, as the sporogonia develop, is raised upon a stalk. Here belong, according to Schiffner, ${ }^{1}$ sixteen genera with about I 50 species. The receptacle may be, as we have seen, strictly dorsal in origin, or it may include the growing point of the archegonial branch, or finally it may be a branch system arising from the repeated dichotomy of the original growing point.

\section{Résumé of the Marchantiacee}

Comparing the different members of this order, one is struck by the almost imperceptible gradations in structure between the different families, and this accounts for the difference of opinion as to where certain genera belong. That the Ricciacex cannot be looked upon as a distinct order is plain, and they may perhaps be best regarded as simply a family co-ordinate with the Corsinieæ and Targioniex, and not a special group opposed to all the other Marchantiaceæ. The gradual increase in complexity of structure is evident in all directions. First the thallus passes by all gradations from Riccia-with its poorly defined airchambers with no true pores and single ventral lamellæ, through Ricciocarpus and Tessalina, where definite air-chambers are present, opening by pores of the same form as those of the lower Marchantieæ, and separate ventral scales occur-to forms like Marchantia, where the air-chambers are very definite and contain a special assimilating tissue, and the pores are of the cylindrical type. With this differentiation of the thallus is connected the segregation of the sexual organs and the development of special receptacles upon which they are borne. Finally, in the development of the sporogonium, while there is almost absolute uniformity in the earlier stages, we find a complete series of forms, beginning with Riccia, where no stalk is developed and all the cells of the archesporium develop spores, ascending through Tessalina, with a similar absence of a stalk, but the first indication of sterile cells, through the Corsiniece, to forms with a massive foot and elaters fully developed. It may be said, however, that there is no 
CHAP. III

absolute parallelism between the development of the gametophyte and that of the sporophyte, for in Marchantia, the most specialised genus as to the gametophyte, the sporogonium is less developed than in the otherwise simpler Targionia and Fimbriaria. 


\section{CHAPTER IV}

THE JUNGERMANNIACEE

A VERY large majority of the Hepaticæ belong to the Jungermanniaceæ, which show a greater range of external differentiation than is met with in the Marchantiaceæ, but less variety in their tissues, the whole plant usually consisting of almost uniform green parenchyma. In the lowest forms, e.g. Aneura and Metzgeria, the gametophyte is an extremely simple thallus, in the former composed of almost perfectly similar cells, in the latter showing a definite midrib. Starting with these simplest types, there is a most interesting series of transitional forms to the more specialised leafy ones, where, however, the tissues retain their primitive simplicity. All of the Jungermanniaceæ grow from a definite apical cell, which differs in form, however, in different genera, or even in different species of the same genus. Root-hairs are usually present, but always of the simple thin-walled type.

The gametophyte, with the exception of the genera Haplomitrium, Calobryum, and Riella, is distinctly dorsiventral, and even when three rows of leaves are present, as in most of the foliose forms, two of these are dorsal and lie in the same plane, while the third is ventral. In the thallose forms, while the bilaterality is strongly marked, there is not the difference between the tissues of the dorsal and ventral parts which is so marked in the Marchantiaceæ. In the lowest forms the gametophyte is a simple flat thallus fastened to the substratum by simple root-hairs, and develops no special organs except simple glandular hairs which arise on the ventral side near the apex, and whose mucilaginous secretion serves to protect the growing point. In Blasia and Fossombronia we have genera 
that, while still retaining the flattened thalloid character, yet show the first formation of lateral appendages which represent the leaves of the true foliose forms. In the latter the axis is slender, and the leaves usually in three rows and relatively large.

The archegonia correspond closely in their development to those of the Marchantiaceæ, and in the lower (anacrogynous) forms arise in much the same way from surface cells of the dorsal part of the younger segments, and the apical cell is not directly concerned in their formation. The archegonia in these thus come to stand singly or in groups upon the dorsal surface of the thallus, whose growth is not interrupted by their development. In the higher leafy forms (Jungermanniaceæ acrogynæ) they occur in groups at the end of special branches, whose apical cell finally itself becomes the mother cell of an archegonium, and with this the growth in length of the branch ceases.

The antheridia differ essentially in their first divisions from those of the Marchantiaceæ. After the first division in the mother cell, by which the stalk is cut off from the antheridium itself, the first wall in the latter, in all forms investigated except Sphcerocarpus and Riella, is vertical, instead of horizontal, and the next formed walls are also nearly vertical. The ripe antheridium is usually oval in outline and either nearly sessile or provided with a long pedicel. The spermatozoids are as a rule larger than in the Marchantiaceæ, and show more numerous coils, but like them are always biciliate.

The embryo differs in its earliest divisions from that of the Marchantiaceæ. The first transverse wall divides the embryo into an upper and lower cell, but of these the lower one, except in Spharocarpus and Riella, takes no further part in the development of the sporogonium, but either remains undivided or divides once or twice to form a small appendage to the base of the sporogonium. In the upper cell the first wall may be either vertical (i.e. Pellia and most anacrogynous forms), or it may be transverse. From the upper of the two primary cells not only the capsule but the stalk and foot as well are formed. The development of these different parts varies in different forms, and will be taken up when considering these.

All of the Jungermanniaceæ, except the Rielleæ, possess perfect elaters, but in the latter these are represented merely by sterile cells that probably serve simply for nourishing the 
growing spores. The sporogonium remains within the calyptra until the spores are ripe, when by a rapid elongation of the cells of the seta it breaks through the calyptra, which is left at its base, and the capsule then opens. The opening of the capsule is usually effected by its walls splitting into four valves along lines coincident with the first formed vertical cell walls in the young embryo. These valves, as well as the elaters, are strongly hygroscopic, and by their movements help to scatter the ripe spores. The latter show much the same differences observed in the Marchantiacex. When the spores germinate at once they have abundant chlorophyll and a thin exospore, but where they are exposed to drying up, they have no chlorophyll and the exospore is thick and usually with characteristic thickenings upon it. From the germinating spore the young gametophyte may develop directly, or there may be a well-marked protonemal stage. This latter is always found in the foliose forms, and is either a flat thallus, like the permanent condition of the lower thallose genera, or sometimes (Protocephalozia) it is a branched filamentous protonema, very much like that of the Mosses, and sometimes long-lived and producing numerous gametophores.

Non-sexual reproductive bodies in the form of unicellular gemmæe are found in many species, and in Blasia special receptacles with multicellular gemme something like those of Marchantia occur.

The Jungermanniacexe naturally fall into two well-marked series, ${ }^{1} \mathrm{~J}$. anacrogynæ and J. acrogynæ, based upon the position of the archegonia. These in the former are never produced directly from the apical cell of a branch, in the latter group the apical cell of the archegonial branch always sooner or later becomes transformed into an archegonium. The Haplomitrieæ show some interesting intermediate forms between the two groups, but all the other Jungermanniaceæ examined belong decidedly to one or the other. As a rule the Anacrogynæ are thallose (the "frondose" forms of the older botanists), but a few genera, especially Fossombronia, show a genuine formation of leaves. All the Acrogynxe have a distinct slender stem with large and perfectly developed leaves.

1 Prof. L. M. Underwood proposes the name Netzgeriaceæ for the J. anacrogynæ, reserving the name Jungermanniacex for the $J$. acrogynz. These two groups he considers co-ordinate with the Marchantiaceæ and Anthocerotex. 


\section{Jungermanniacece Anacrogyne}

The simplest form belonging here is Sphcerocarpus, a plant that shows certain affinities with the Ricciaceæ, but on the whole seems to be more properly placed at the bottom of the series of the Jungermanniaceæ. S.terrestris is a small plant growing upon the earth, usually in crowded patches, where, if abundant,

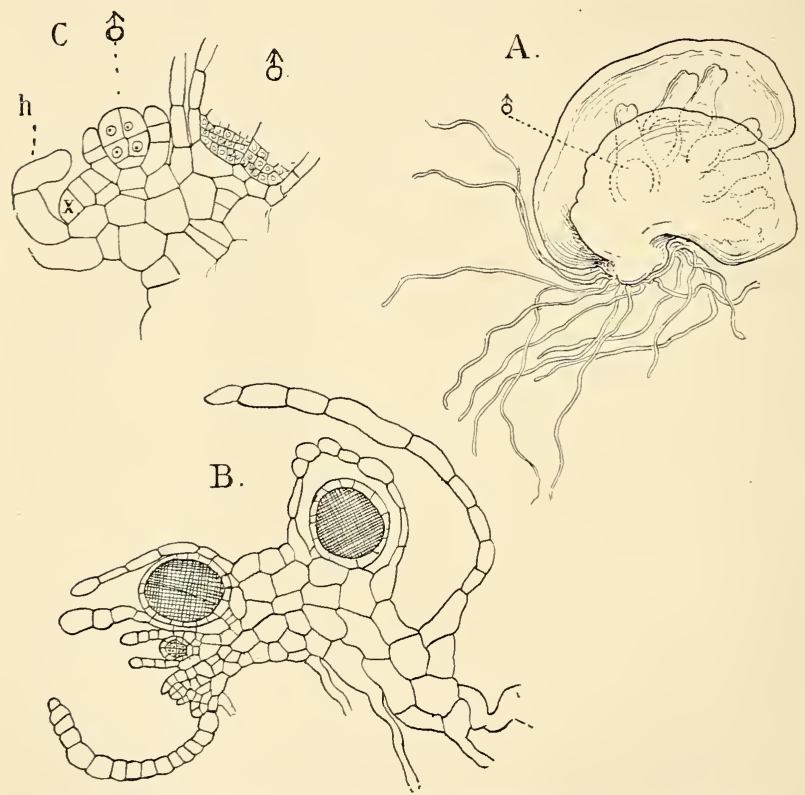

FIG. 28.-Spharocarpus terrestris var. Californicus (Aust.). A, Male plant, $\times 40 ; \delta$, antheridia ; B, median section of a similar plant, $\times 80$; $\mathrm{C}$, the apex of the same section, $\times 240 ; h$, ventral hair.

it is conspicuous by the bright green colour of the female plants. The males are very much smaller, often less than a millimetre in diameter, and purplish in colour, so that they are easily overlooked. The thallus is broad and passes from an indefinite broad midrib into lateral wings but one cell in thickness (Fig. 28). The forward margin is occupied by a 
number of growing points formed by the rapid dichotomy of the original apex, and separated only by a few rows of cells. From the lower side of the thallus grow numerous root-hairs of the thin-walled form. The whole upper surface is covered with the sexual organs, each of which is surrounded by its own very completely developed envelope.

A vertical section passing through one of the growing points (Fig. 28, C) shows a structure closely like a similar section of Riccia. The apical cell $(x)$ produces dorsal and ventral segments, and from the outer cells of the former the sexual organs arise exactly as in Riccia. On the ventral surface the characteristic scales of Riccia are absent, and are replaced by the glandular hairs found in most of the anacrogynous Jungermanniaceæ.

The development of the archegonium shows one or two peculiarities in which it differs from other Hepaticæ. The mother cell is much elongated, and the first division wall, by which the archegonium itself is separated from the stalk, is some distance above the level of the adjacent cells of the thallus, so that the upper cell is very much smaller than the lower one. The upper cell has much denser contents than the lower one, which instead of remaining undivided as in Riccia, divides into two nearly equal superimposed cells, this division taking place about the same time as the first division in the archegonial cell (Fig. 29, B). The divisions in the latter are the same as in Riccia, and the general structure of the archegonium offers no noteworthy peculiarities. The number of neck canal cells is small, probably never exceeding four, and in this respect recalls again Riccia. The central cell is relatively large, and the ventral canal cell often nearly as large as the egg. As the archegonium develops, its growth is stronger on the posterior side, and it thus curves forward. At first the young archegonium projects free above the surface, but presently an envelope is formed about it exactly as in Riccia, but arising at a later stage. After this has begun to form, its growth is very rapid, and it soon overtakes the archegonium and grows beyond it, and finally forms a vesicular body, plainly visible to the naked eye, at the bottom of which the archegonium lies. The formation of this involucre is quite independent of the fertilisation of the archegonium, and as these peculiar vesicles cover completely the whole dorsal 
surface of the plant, they give it a most characteristic appearance. Usually each archegonium has its own envelope, but Leitgeb ${ }^{1}$ states that two or even more may be surrounded by a common envelope. When ripe, the venter of the archegonium is somewhat enlarged, but not so much as in Riccia. The egg-cell is very large, oval in form, and nearly fills the cavity of the single-layered venter.

The first wall in the embryo is transverse, and divides the egg cell, which before division becomes decidedly elongated, into two nearly equal cells. Ordinarily in each of these cells

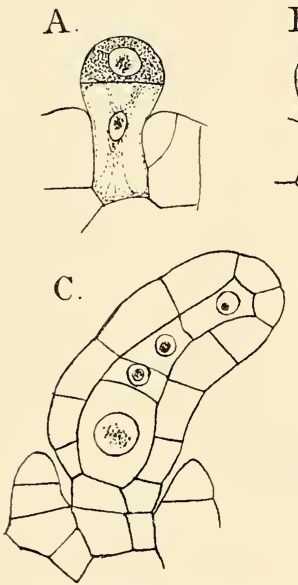

$\mathrm{B}$.
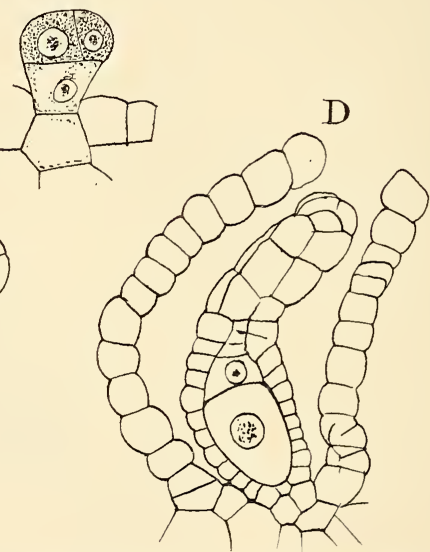

FIG. 29.-Spharocarpus terrestris var. Californicus (Aust.). Development of the archegonium. A-C, Longitudinal sections, $\times 600 ; \mathrm{D}, \times 300$.

similar transverse walls are formed before any vertical walls appear, so that the embryo consists of a simple row of cells. As in the Marchantiaceæ the first wall separates the future capsule from the stalk, and in this respect Spharocarpus approaches the Marchantiaceæ rather than the Jungermanniaceæ. Following the transverse walls there are formed in all the upper cells nearly median vertical ones, which are intersected by similar ones at right angles to them, so that in most cases (although this is not absolutely constant) the upper 
half of the young sporogonium at this stage (Fig. 30, A) consists of two tiers, each consisting of four cells. The lower part of the embryo is pointed, and the basal cell either under-
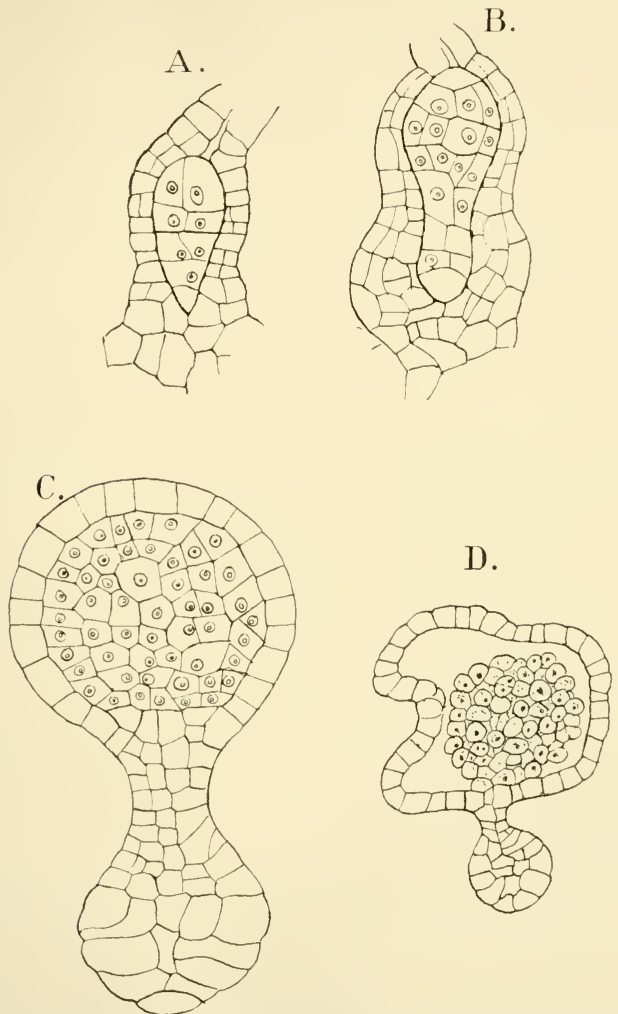

FIG. 30.-Spharocarpus terrestris var. Califomicus. A, B, Median longitudinal sections of the archegonium venter, with encloserl embryos, $\times_{260} ; \mathrm{C}$, an older sporogonium in median section, $\times 260$; D, a still later stage, showing the large space between the archesporial cells and the wall, $\times 85$.

goes no further division or divides but once by a transverse wall, and remains perfectly recognisable in the later stages (Fig. 30, B, C). The other cells of the lower half divide much 
like those of the upper half, but the divisions are somewhat less regular.

There next arise in all the cells of the upper half periclinal walls, which at once separate the wall of the capsule from the archesporium. This wall in the later stages (Fig. 30, C, D) is very definite, and remains but one cell thick up to the time the sporogonium is mature. The further divisions in the capsule are without any apparent order, and result in a perfectly globular body composed of an outer layer of cells enclosing the archesporium, which consists of entirely similar cells with rather small nuclei and dense contents. While these changes are going on in the capsule, the lower part of the embryo loses its originally pointed form, and the bottom swells out into a bulb (the foot), which shows plainly at its base the original basal cell of the young embryo. This bulb is characterised by the size of the cells, which are also more transparent than those of the other parts of the embryo.

Owing to the development of the stalk of the archegonium, after fertilisation the whole embryo remains raised above the level of the thallus, instead of penetrating into it, as is usually the case. The stalk or portion between the capsule and foot remains short, and in longitudinal section shows about four rows of cells. As the calyptra grows the upper part becomes divided into two layers, the part surrounding the foot into three. Instead of breaking through the calyptra at maturity, the capsule grows faster than the calyptra long before it is mature, and the upper part of the calyptra is first compressed very much and finally completely broken through by the enlarging capsule.

Leitgeb $^{1}$ calls attention to the fact that soon after the cells of the archesporium begin to separate, the whole mass of cells becomes completely separated from the wall of the capsule, which grows rapidly until the cavity within is much larger than the group of archesporial cells, which thus float free in the large cavity: Fig. 30, D shows a section through a sporogonium at this stage. The cells making up the central mass are apparently alike, but Leitgeb ${ }^{2}$ says that in the living sporogonium part of the cells have abundant starch and chlorophyll, while in the others these are wanting or present in much less quantity, while their place is taken by

$$
1 \text { Leitgeb (7), vol. iv. p. 7o. } 2 \text { Leitgeb, l.c. }
$$


oil, but that no rule could be made out as to the distribution of the two sorts of cells. The latter are the spore mother cells, while the others are gradually used up by the developing spores. The latter remain united in tetrads, and escape from the capsule by the gradual decay of its wall and of the surrounding tissue of the gametophyte.

The male plants are very much smaller than the females, with which they grow and under which they are at times almost completely hidden. The cell walls of the antheridial envelopes are often a dark purple-red colour, and this makes them much harder to see than the vivid green of the female plant. The apical growth and origin of the antheridium is

A

B

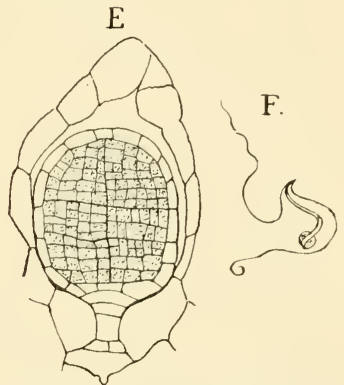

Fig. 3I.-Spharocarpus terrestris var. Californicus. Development of the antheridium. A.D, Median longitudinal sections, $\times_{450} ; \mathrm{E}$, an older one, $\times_{225} ; \mathrm{F}$, a spermatozoid, killed with osmic acid, $\times$ goo.

the same as in Riccia. The first division in the primary antheridial cell is the same as in that of the archegonium, but the basal cell is smaller, and does not divide again transversely, and takes but little part in the formation of the stalk. In the antheridium mother cell are next formed two transverse walls, dividing it into three superimposed cells. The two uppermost divide, as in the Marchantiaceæ, by vertical median walls into regular octants, the lower by a series of transverse walls into the stalk, which consists of a single row of cells sunk below the level of the thallus. After the division of the body of the antheridium into the octant cells, periclinal walls are formed in each of these, so that the body of the antheridium consists of eight central cells and eight peripheral ones, and the stalk 
of two cells, of which the upper one forms the base of the antheridium body (Fig. 3 I, D). At this stage and the one preceding it Spharocarpus recalls very forcibly the structure of the antheridium of the Characeæ, although the succession of walls is not exactly the same. The divisions of the central cells are extremely regular, walls being formed at right angles, so that the sperm cells are almost perfectly cubical, and the limits of the primary central cells are recognisable for a long time.

The development of the antheridial envelope begins much earlier than that about the archegonium, but in exactly the same way. By the time that the wall of the antheridium is formed the envelope has already grown up above its summit, and as the antheridium develops it extends far beyond it like a flask, at the bottom of which the antheridium is placed, and through whose neck the spermatozoids escape. These are very much like those of the other Hepaticæ, and in size exceed those of most of the Marchantiaceæ, but are smaller than is usual among the Jungermanniaceæ.

Leitgeb ${ }^{1}$ studied the germination of the spores, which remain united in tetrads permanently. He found that all the spores of a tetrad were capable of normal development, which does not differ from that of Riccia or other thallose Liverworts. A more or less conspicuous germ tube is found at the end of which the young plant develops, one of the octants of the original terminal group of cells becoming, apparently, the apical cell for the young plant. The latter rapidly grows in breadth and soon assumes all the characters of the older plant. Leitgeb (Fig. r 7, P1. IX.) shows a condition that looks as if at an earlier stage a two-sided apical cell had been present, but he says nothing in regard to this. The sexual organs appear while the plant is extremely small. Leitgeb says he observed the first indications of them on individuals only one millimetre in diameter, and before the first papillate hair on the ventral surface had been formed.

Corresponding closely in the origin and structure of the sexual organs to Sphcerocarpus, but differing much in habit, is the peculiar genus Riella, containing seven species, all submersed aquatics, and, so far as is yet known, confined to Northern Africa and Southern Europe. The plant (Fig. 32,

1 Leitgeb (7), vol. iv. PI. IX. Fig. I7. 
A) grows upright in the water, and consists of a central axis, about which a membranous expansion winds like the thread of a screw. Leitgeb ${ }^{1}$ has carefully investigated the develop-
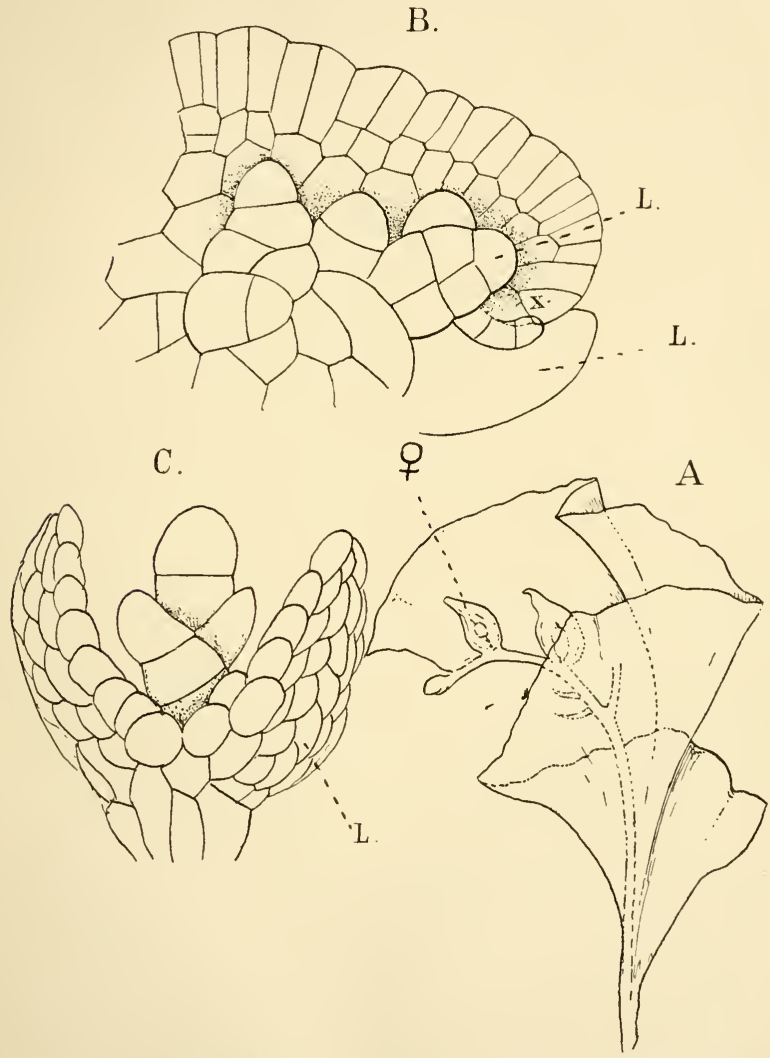

FIG. 32.-Kiella helicophylla (Mont.). A, A female plant enlarged; $q$, sporogonia; B, lateral, $\mathrm{C}$, ventral view of the growing point, $\times 600 ; x$, the apical cell; $\mathrm{L}$, leaves (after Leitgeb).

ment of the thallus in R. helicoplyylla and R. Parisii, and found that the apical growth is like that of Spharocarpus, and that 
the peculiar wing is a dorsal growth (Fig. 32, B, C). Lateral leaf-like appendages are developed on either side of the growing point (Fig. 32, B, C). Both archegonia and antheridia resemble those of Sphcerocarpus very closely, and the structure of the capsule is also the same, no true elaters being developed, but instead these are simply sterile cells. Goebel ${ }^{1}$ has recently made some further investigations upon the development of Riella, and believes that the origin of the growing point is secondary. His view is, however, based upon a study of secondary growths from the young thallus, as he was unable to procure very young germ plants. ${ }^{2}$

Aneura (Riccardia) and Metzgeria represent the simplest of the typical anacrogynous Jungermanniaceæ. In the former the thallus is composed of absolutely similar cells, all chlorophyll-bearing, and in each cell one or more oil bodies, like those of the Marchantiaceæ. In Metzgeria (Fig. 33) the wings of the thallus are but one cell thick, and there is a very definite midrib, usually four cells thick. The apical growth in both genera is the same, and is effected by the growth of a "twosided " apical cell. ${ }^{3}$ The segmentation is very regular, especially in Metzgeria (Fig. 33), where each of the segments divides first into an inner and an outer cell, the former by subsequent divisions parallel to the surface of the thallus producing the thickened midrib, the outer cells dividing only by perpendicular walls, forming the wings. From the ventral surface of the young midrib papillæ project, which curve up over the growing point, in the form of short two-celled hairs, whose end cells secrete mucilage for its protection. In Aneura the growth is very similar, but all of the cells divide by walls parallel to the surface of the thallus, and no midrib is formed, and the thallus is several cells thick in all parts. In both genera numerous delicate colourless root-hairs are developed from the ventral surface, especially of the midrib, when that is present. Aneura is of interest as showing the only case among the Bryophytes of structures that may be compared to the zoospores of the green Algæ. In $A$. multifida Goebel ${ }^{4}$ dis-

1 Goebel (14).

2 On the fertilisation of the archegonium of Riella, see Kruch (1).

3 "Two-sided" is hardly a strict equivalent for the German "zweischneidig," but will be used here in the same sense, i.e. an apical cell from which two sets of lateral segments are cut off.

${ }^{4}$ Goebel (8), p. 337. 
covered that the two-celled gemme which had been described as formed simply by a separation of the cells of the thallus, were really formed within the cells and expelled from them through an opening, after which they divided into two cells and ultimately developed a young plant, much as an ordinary spore would do. The absence of cilia from these cells, which probably are the last reminiscences of the ciliated gonidia of
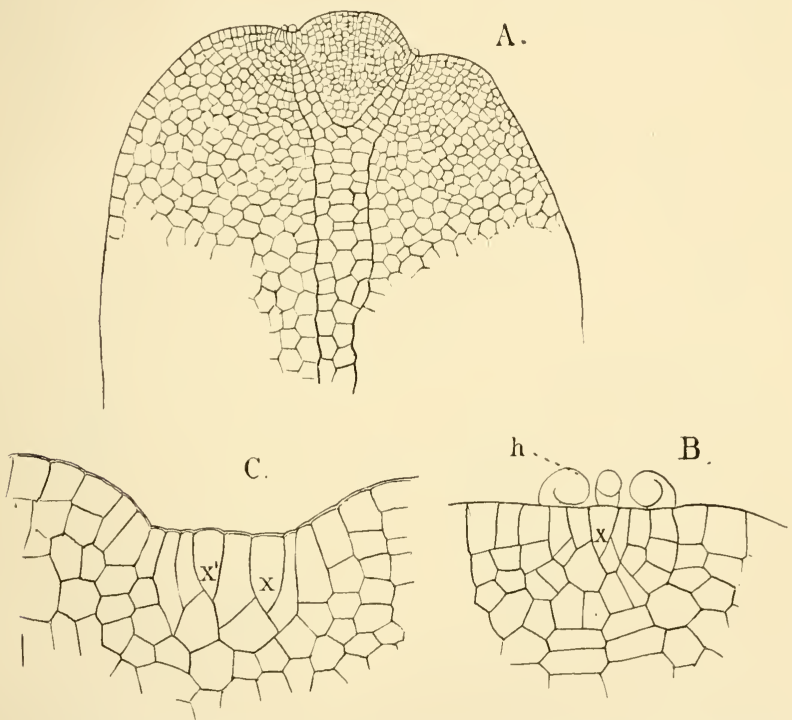

FIG. 33.- Metsgeria pubescens (Radd.). A, Surface view of the thallus in process of division, $\times 80$; growing point of a branch showing the two-sided apical cell $(x)$ and the ventral hairs $(h), \times 240$; $\mathrm{C}$, the growing point in process of division, $x, x^{\prime}$, the apical cells of the two branches, $\times_{4} 8$.

the aquatic ancestral forms, is to be accounted for by the terrestrial habit of Aneura.

The branching is dichotomous, and is brought about by the formation of a second apical cell in one of the youngest segments. This apical cell is formed by a curved wall, which strikes the outer wall of the segment (Fig. 33, C). Thus two apical cells arise close together, and as segments are cut off from each, they are forced farther and farther apart, and 
serve as the growing point of two shoots, which may continue to grow equally, when the thallus shows a marked forking ( $M$. furcata), or one of the branches grows more strongly than the other, which is thus forced to one side and appears like a lateral branch (A. pinnatifida, Fig. 38, B).

The sexual organs in both Aneura and Metzgeria are borne on short branches, which in the latter arise as ventral structures,

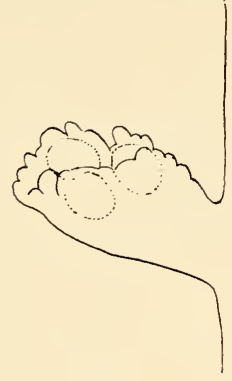

B.

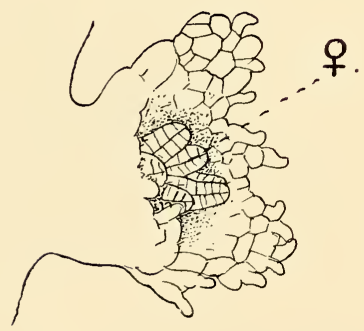

A

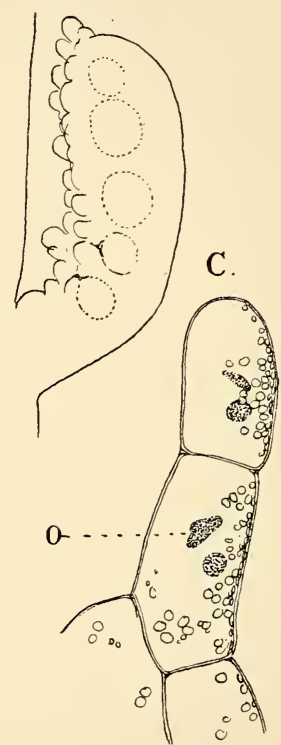

FIG. 34.-Aneura pinnatifida (Nees).' A, Part of a thallus with two antheridial branches, slightly magnified; $\mathrm{B}$, an archegonial branch, $\times_{40} ; \mathrm{C}$, cells from the margin of the archegonial branch showing the oil bodies $(0), \times 300$.

but in Aneura are simply ordinary branches that are checked in their growth by the production of the sexual organs, and not infrequently may grow out into ordinary branches after the formation of the sexual organs has ceased. In $A$. pinnatifida (Fig 34, B) archegonia and antheridia are usually produced upon separate branches, but may occur together.

The origin of the antheridia can be readily followed in sections 
made parallel to the surface of a male branch. The apex is occupied by an apical cell of the usual form, and the cell divisions in the young segment are extremely regular. The segment first divides into an inner and an outer cell, and the former probably next into a dorsal and a ventral one. The dorsal cell divides by a longitudinal wall into two nearly equal cells, of which the inner one, dividing by a wall perpendicular to the first, gives rise to the primary cell of the antheridium (Fig. 35, A 0 ). This cell now projects above the surface of the thallus, and

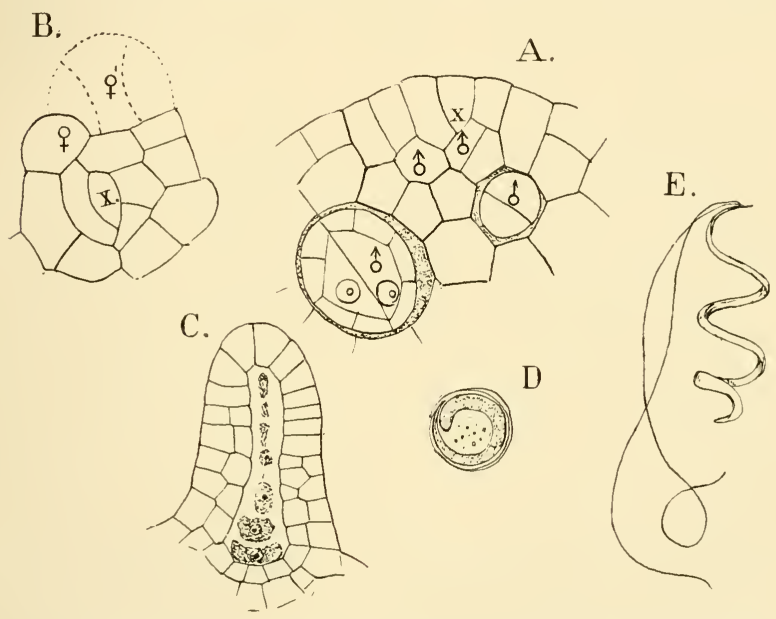

FIG. 35.-Aneura pinnatifida (Nees). A, Horizontal section of the apex of a young antheridial branch, $\times 56_{5} ; x$, the apical cell; $\delta$, antheridia; $\mathrm{B}$, transverse section of a young archegonial branch, passing through the apical cell $(x)$; $\$$, young archegonia, $\times_{525} ; \mathrm{C}$, longitudinal section of a nearly ripe archegonium, $\times_{262} ; \mathrm{D}, \mathrm{E}$, spermatozoids of Pellia calycina, $\times_{1225}(\mathrm{D}, \mathrm{E}$, after Guignard).

divides into a single stalk cell, which undergoes no further divisions, and the antheridium mother cell. The divisions in the latter correspond to those in the other Jungermanniaceæ. First a vertical wall is formed, dividing the young antheridium into two equal parts. Next, in each of these, two walls arise, intersecting each other as well as the median wall, and dividing each half of the antheridium into three cells, two peripheral ones and a central one. (A somewhat later stage than this is shown in Fig. 35 , A.) The peripheral cells do not reach to 
the top of the antheridium, and next a periclinal wall is formed near the top of the central cells, by which a third peripheral cell is formed in each half of the antheridium, which now consists of two central cells and six peripheral ones. The further divisions were not followed in detail, but seem to correspond with those in the higher forms.

Of the two first cells into which the dorsal cell divides, the one which does not produce the antheridium, together with the inner of the two into which that cell first divides, form a partition which rapidly increases in height with the growth of the antheridia, and separates each from its neighbour by a single layer of cells, so that the antheridia are sunk in chambers, arranged in two rows, corresponding to the two series of segments of the apical cell.

The archegonia are borne upon similar but shorter branches, and here too the development is very regular. In Fig. 35, B, a vertical section through the end of a young female branch is shown with the apical cell $(x)$. Segments are here, too, cut off alternately right and left, and from each segment an archegonium develops. The segment is first divided, probably, as in the male branch and the vegetative ones, into an inner and an outer cell, but I did not succeed in getting satisfactory longitudinal sections parallel to the surface, so cannot speak positively on this point. The youngest segment, in which the archegonium mother cell is recognisable, shows in vertical section three cells, a small ventral one, a middle larger one, and a dorsal one-the archegonium mother cell. The latter does not form any stalk, but divides at once by the three intersecting walls, as in other Hepaticæ, and the further development corresponds with these, except that the base of the archegonium is not free, and the central cell is below the level of the superficial cells of the thallus. The archegonium neck is short, and the basal part as well as that part of the venter which is free, two cells thick (Fig. 35, C). The number of neck cells is small (apparently about four), but whether the number is constant cannot be stated positively. The female branch remains very short, and the archegonia, which are only produced in small numbers (usually not more than six to eight), are close together and surrounded by an irregular sort of envelope formed by the more or less incurved and very much laciniated margins of the branch. Secondary hair-like growths are also 
formed, so that to the naked eye the archegonial receptacles appear as densely fringed and flattened tufts upon the sides of the larger branches.

The earliest stages in the embryo are not perfectly known. Kienitz-Gerloff ${ }^{1}$ investigated Metzgeria furcata and Leitgeb ${ }^{2}$ species of Aneura. In both of these the first division in the embryo separates an upper cell, from which capsule and seta develop, from a lower cell, which forms a more or less conspicuous appendage at the base of the foot. The earliest divisions in the upper part are not known, but it soon becomes a cylindrical body consisting of several tiers of cells, each composed of

A

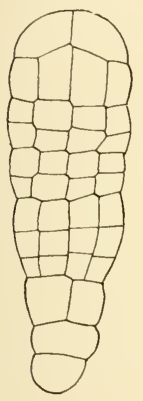

B

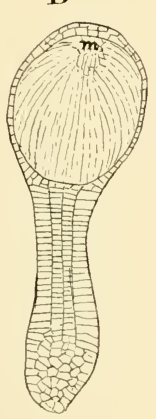

C

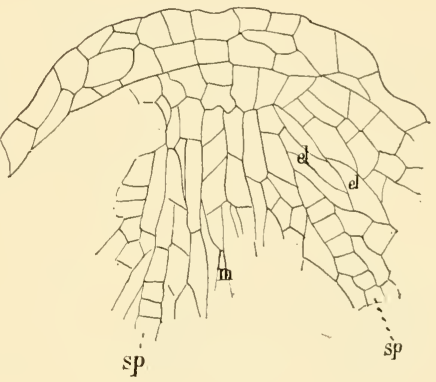

FIG. 36.-A, Young embryo of Anevra multifida (Dum.), optical section, $\times 235$ (after Leitgeb) ; B, median longitudinal section of an older sporogonium of $A$. pingzis (Dum.), $\times_{35}$; C, upper part of $\mathrm{B}, \times 200 ; s p$, sporogenous cells; $e l$, young elaters; $m$, apical group of sterile cells.

four equal quadrant cells. According to Leitgeb, ${ }^{3}$ the upper tier, from which the capsule develops, is formed by the first transverse wall in the upper part of the embryo. This upper tier is next divided by nearly transverse walls into four terminal cover cells, and four larger ones below, and these latter are again divided each into three cells, an inner one and two outer ones, so that the capsule consists of four central cells, the archesporium, and twelve wall cells (Fig. 36, A). A similar division in the lower tiers results in the formation of four axial rows and a single outside layer of cells in the stalk. In the lowest tiers the divisions are much less regular, and the first,

1 Kienitz-Gerloff (I).

${ }^{2}$ Leitgeb (7), vol. iii. p. 47.

${ }^{3}$ Leitgeb, l.c. 
which is not very largely developed, shows no definite arrangement of the cells. The part of the wall of the capsule formed from the four cover cells later become two-layered, but the rest remains but one cell thick. In Metzgeria ${ }^{1}$ the wall becomes

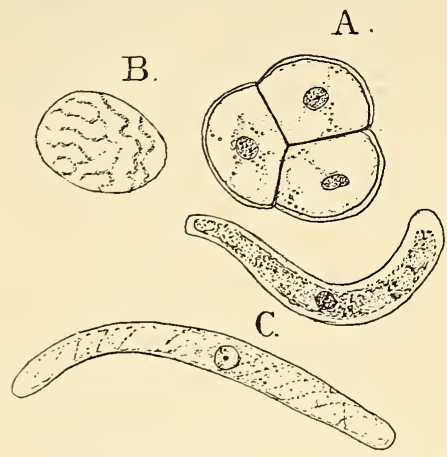

D.
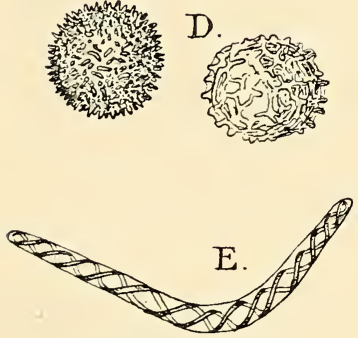

FIG. 37.-Fossombronia longiseta (Aust.). A, Section through a young tetrad of spores; $\mathrm{B}$, surface view of the wall of a young spore ; $\mathrm{C}$, two young elaters, $\times 600$; $\mathrm{D}$, two ripe spores; $\mathrm{E}$, elater, $\times 300$.

later two-layered. The archesporium divides first into two layers. In the upper cells the divisions are more regular than in the lower one, and later the archesporium is made up of cells arranged in more or less regular lines, starting from just below the apex and radiating from this point, extending to the base of the capsule. These cells are at first of similar form, and with the growth of the capsule become elongated with pointed ends that fit together without any spaces between. Some of these cells, however, divide rapidly by transverse walls and give rise to rows of isodiametric cells (Fig. 36, $s p$ ), wedged in between others that have remained undivided $(e l)$. The former are the young sporogenous cells, the latter the elaters. A mass of cells lying just below the apex, and be-

longing to the archesporium, remains but little changed, and forms the point of attachment for the elaters after the capsule opens (Fig. 36, B, C, m).

The further development of spores and elaters is similar to that in the higher Marchantiaceæ, and when the capsule is 
mature it opens by four valves which extend its whole length.

The germination of the spores of Aneura has been studied by $\mathrm{Kny}^{1}$ in $A$. palmata, and by Leitgeb ${ }^{2}$ in $A$. pinguis, which agrees in all respects with the former. The spores, as is usual in the Jungermanniacex, have a poorly-developed exospore, and contain chlorophyll when ripe. Before any divisions take place, the spore enlarges to two or three times its original volume, and then elongates and by repeated cross-walls forms a filament of varying length. In the end cell next an inclined wall arises, which is met by another nearly at right angles to it, and thus the two-sided apical cell is established, and the thallus gradually assumes its complete form (Fig. 40, A).

In the other thallose anacrogynous forms, i.e. Pallavicinia (Fig. 38, A), the sexual organs are borne upon the dorsal surface of the ordinary shoots, usually surrounded by a sort of involucre. In most of these forms the apical cell is of a different type from that of Aneura, but is variable even in the same species. Thus in Pallavicinia cylindrica, while the commoner form is nearly wedge-shaped, appearing four-sided seen from the surface, and triangular in vertical section, it may approach very nearly the two-sided type (Fig. 39, C). In the ordinary form four sets of segments are cut off,-dorsal and ventral, as in Riccia or Spherocarpus, and two sets of lateral ones. In Pellia calycina the apical cell shows a similar form, but in $P$. epiphylla (Fig. 39, D, E) another type is seen. Here, while the surface view is the same as in $P$. calycina, in vertical section the cell is nearly semicircular, i.e. here there are but three sets of segments, two lateral ones and a basal one extending the whole depth of the thallus, and only later showing a division into ventral and dorsal cells. Probably this type has been derived from the former by a gradual increase in the size of the angle formed by the dorsal and ventral walls of the apical cell, which finally became so great as to practically form one plane.

Janczewski ${ }^{3}$ followed very carefully the development of the archegonium in Pellia epiplyylla, which differs a good deal from that of Aneura. The archegonia are formed in groups just back of the apex, but he does not seem to have been able to detect any relation between them and the segments of the

1 Kny (I).

${ }^{2}$ Leitgeb (7), vol. iii. p. 48 .

${ }^{3}$ Janczewski (1), p. 389 . 
apical cell such as obtains in Aneura, but it seems probable that such a relation does exist. After the archegonium mother cell is cut off, it does not at once divide by vertical walls, but there is first cut off a pedicel, after which the upper cell under-

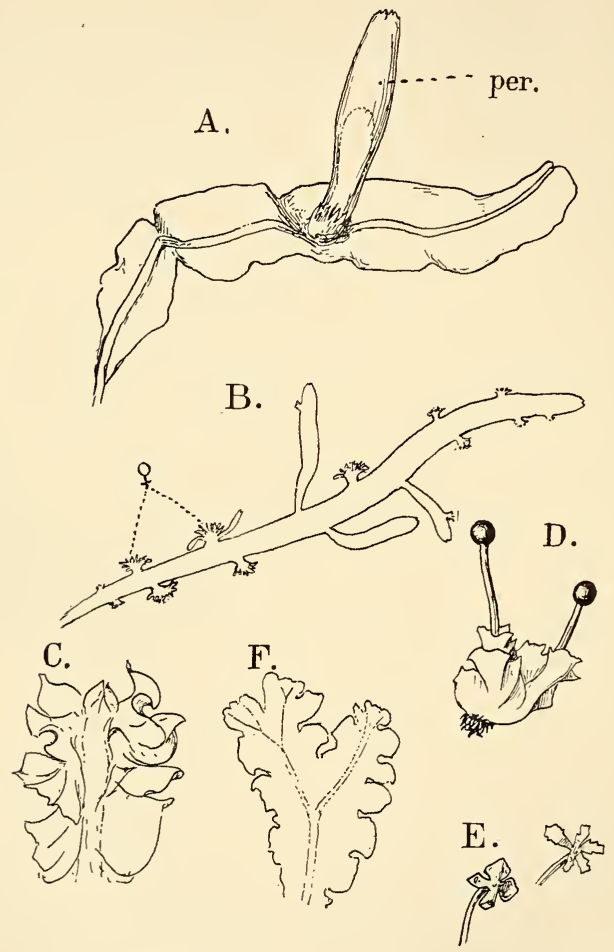

FIG. 38.-A, Pallavicinia cylindrica (Aust.), $\times_{4}$; per, the elongated perianth; $\mathrm{B}$, Aneura pinnatifida (L.), $\times 6$; $\&$, archegonial branches; C-E, Fossombronia longiseta (Aust.), $\times_{4} ; \mathrm{F}$, Blasia pusilla (L.), $\times 4$.

goes the usual divisions. Of the three peripheral cells one is much smaller and does not as a rule divide longitudinally, so that the neck has normally but five rows of cells instead of six, as in the Marchantiaceæ. Owing to the formation of the pedicel, 


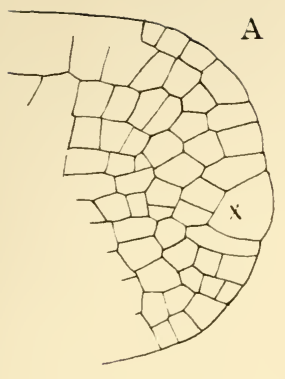

C.
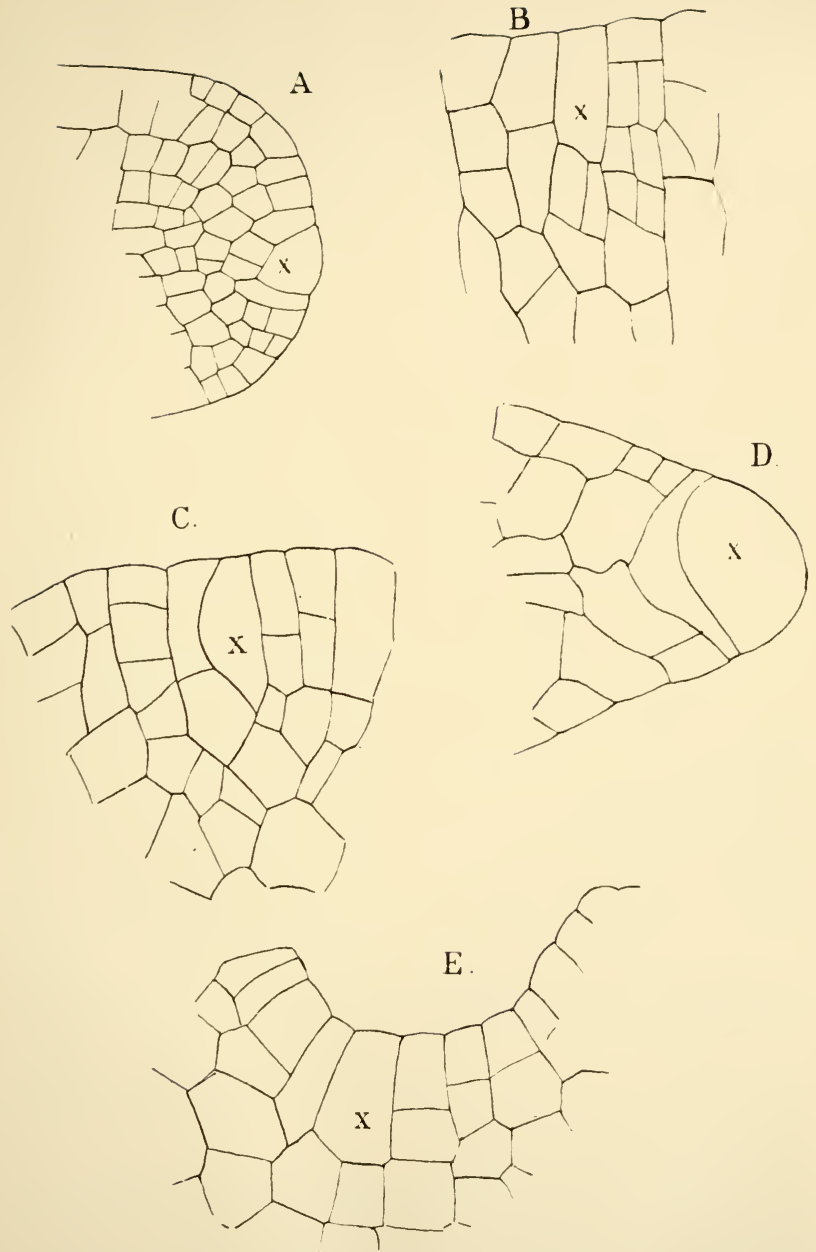

Fig. 39.-A, Vertical, B, C, horizontal sections through the apex of Pallazicinia cylindrica (Aust.), $x$, apical cell, $\mathrm{A}, \times_{225} ; \mathrm{B}, \mathrm{C}, \mathrm{\times}_{450} ; \mathrm{D}, \mathrm{E}$, Pellia epipliylla (Nees); D, vertical section: E, horizontal (optical) section, $\times 450$. 
the archegonium is quite free at the base, and like that of Aneura the wall of the venter is two-layered. The neck becomes very long, and, according to Janczewski, the number of neck canal cells may reach sixteen or even eighteen.

The antheridia of Pellia are larger than in Aneura, but in their development are similar except that the stalk is multicellular. The spermatozoids

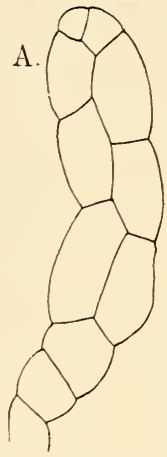

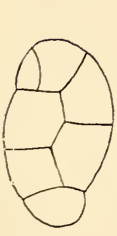

1

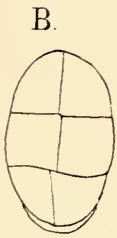

2

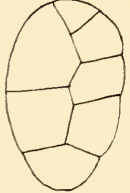

3
Fig. 40.-A, Young plant of Aneura palnata (Nees), $\times{ }_{26} 6_{5}$ (after Leitgeb); B, three views of a young plant of Pellia calycina, $\times_{420}$ (Leitgeb). are the largest known among the Hepaticæ (Fig. 35, D, E). In some species of Pallavicinia the very strongly developed midrib is made up in part of thick-walled elongated cells; but usually such cells are absent. The development of the sporogonium is best known in Pellia epiphylla. ${ }^{1}$ Here the first wall, as in Aneura, separates a lower cell, which simply forms an appendage, from the upper cell, from which the stalk and capsule develop. In the latter the first wall is vertical, and is followed in each of the resulting cells by horizontal walls, by which the separation of the capsule from the seta is effected. These four cells are now divided by vertical walls, so that two layers of four cells each are present. The first periclinal walls in the apical group of cells separate the archesporium from the wall of the capsule.

The differentiation of the capsule and seta follows as in Aneura, and the arrangement of the cells of the archesporium is much the same except that the rows of cells radiate from the base of the capsule and not from the summit. The foot is very distirict and forms a pointed conical cap, whose edges

1 Kienitz-Gerloff (I); Hofmeister (I). 
overlap the base of the seta. As in Targionia, and this is true for the other Jungermanniaceæ, the spore mother cells become deeply four-lobed before the division of the nucleus takes place. Farmer ${ }^{1}$ has recently studied this carefully in Pallavicinia decipiens and also in species of Aneura. In the former, previous to the division of the nucleus, there is formed a "quadri-polar nuclear spindle," which extends into each of the four divisions or lobes of the cell. Then follows a division of the chromosomes into four groups, apparently without the daughter nuclei first assuming the resting stage, and these four groups of chromosomes travel to the four poles of the spindle and gradually assume the form of resting nuclei, after which the division walls are formed, completely dividing the cavity of the cell. The division of the nucleus occurs very late here, sometimes the thickenings upon the outside of the spores being indicated before the primary nucleus divides. In Aneura multifida, the formation of the quadri-polar spindle occurs, but there is afterward a formation of two distinct nuclear figures of the ordinary type.

The growth of the seta after the spores are ripe is extremely rapid, but consists entirely in a simple elongation of the cells. Askenasi ${ }^{2}$ has investigated this in Pellia epiphylla, and states that in three to four days the seta increases in length from about I $\mathrm{mm}$. to in some cases as much as $80 \mathrm{~mm}$., and that this extraordinary extension is at the expense of the starch which the outer cells of the young seta contain in great abundance, but which disappears completely during the elongation of the seta. The growing sporogonium here as well as in other species is strongly heliotropic.

The calyptra in the thallose Anacrogynæ is usually massive, and in addition there is formed about the growing sporogonium a special envelope inside the involucre, which in Pallavicinia especially (Fig. 38 , A) becomes prolonged into a tube which completely encloses the sporogonium until just before its dehiscence.

The further development of the spores and elaters corresponds with that of the Marchantiaceæ (Fig. 37), and here there is the same method of the development of the thickenings upon the walls of the elaters and the spores. In cases where the spores germinate immediately, chlorophyll is developed and

$$
1 \text { Farmer (4). }
$$

2 Askenasi ( $\mathrm{I})$. 
no proper exospore is formed, although the outer layer of the cell wall is more or less cuticularised.

In the germination of the spores Pellia offers an exception to the other Jungermanniacex, in that the spores divide into a multicellular body before they are discharged from the capsule. The presence of centrospheres in the dividing nuclei has been recently demonstrated by Farmer. ${ }^{1}$ The ripe spore here is an oval body which consists of several tiers of cells, the end cells being usually undivided, and the middle ones each consisting of four equal quadrant cells. There is some disagreement as to the earliest stages in the germination and the establishment of the apical growth. Hofmeister ${ }^{2}$ states that in P. epiphylla one end cell of the spore grows out into the first rhizoid, while the other develops into the growing point of the young plant. Muiller, ${ }^{3}$ on the other hand, states that in $P$. calycina both ends of the spore develop root-hairs while the growing point, which at first has a two-sided apical cell, like that of Metzgeria, arises laterally.

Connecting the strictly thallose anacrogynous Hepaticæ with the foliose acrogynous ones, are a number of most instructive intermediate forms. Of these Blasia (Fig. 38, F) is perhaps the simplest. Here the margin of the thallus is lobed, and these lobes, according to Leitgeb's ${ }^{4}$ view, are very simple leaves. In Fossombronia (Fig. 38, C, D), while the general thallose form is more or less evident, the leaves are unmistakable, and as their development shows, morphologically the same as the leaves of the acrogynous forms. The most remarkable form, however, is Treubia insignis, a very large foliose Liverwort discovered by Goebel in Java. This has all the appearance of a very large acrogynous form, and also the typical threesided apical cell; but in regard to the position of the sexual organs it is typically anacrogynous. These and the Haplomitrieæ form a perfect transition from the Anacrogynæ to the Acrogynæ.

The multicellular gemmæ of Blasia ${ }^{5}$ have been alluded to. These are produced in long flask-shaped receptacles, and when mature form nearly globular brownish bodies whose cells contain much oil, and whose stalk consists of a simple row of cells. Among these are glandular hairs, which secrete mucilage, by the

1 Farmer (5). 2 Hofmeister (I), p. 21. ${ }_{4}$ Leitgeb (7), vol. i. p. 5 .
3 Müller, N. J. C. (I), p. 257.

5 Leitgeb, l.c. p. $5^{8}$. 
swelling of which the gemmæ are loosened from their pedicels, as in Marchantia. Similar but simpler gemmæ having usually three cells occur in Treubia. ${ }^{1}$ Blasia is also characterised by the presence of colonies of Nostoc within the thallus. These occupy cavities in the bases of the leaves and are normally always present.

\section{The Haplomitriea}

The two genera, Haplomitrium and Calobryum, which constitute this family, differ from all other Hepaticæ in having the leaves radially arranged, and not showing the dorsiventral form that characterises all the others. The plants are completely destitute of rhizoids but possess a rhizome-like basal part, from which the leafy axes arise. The latter have well-developed leaves arranged more or less distinctly in three rows. The stem grows from a tetrahedral apical cell, as in the acrogynous forms, but in Haplomitrium at least the apical cell does not develop into an archegonium. The archegonia are in this genus borne at the end of ordinary shoots, but in Calobryum the end of the female branch becomes much broadened and the numerous archegonia stand crowded together. In this case it is possible that the apical cell of the stem may finally produce an archegonium. Much the same difference is observable in the arrangement of the antheridia.

\section{Classification}

Jungermanniaceæ Anacrogynæ. Apical cell of female axis never becoming transformed into an archegonium.

A. Anelaterea. No true elaters, but sterile cells representing these. Capsule cleistocarpous. Here belong the three genera, Thallocarpus, Spharocarpus, Riella.

B. Elatereæ. Capsule opening either by four valves or irregularly. Elaters always developed.

a. Gametophore always dorsiventral, either strictly thallose or with more or less developed leaves. Families,Metzgerieæ, Leptotheceæ, Codonieæ.

b. Gametophore upright with three rows of radially arranged leaves. Fam. I., Haplomitrieæ.

1 Goebel (13). 


\section{The Hepatice Acrogyne}

Treubia and Haplomitrium, as we have seen, connect almost insensibly the anacrogynous with the acrogynous Hepaticæ. The latter are much more numerous than the former, but much more constant in form, and are doubtless a later specialised group derived from the former. While differing in the form and arrangement of the leaves and other minor details, they are remarkably constant in their method of growth and in the position of the sexual organs, especially the archegonia. These are always formed upon special branches, where, after a varying

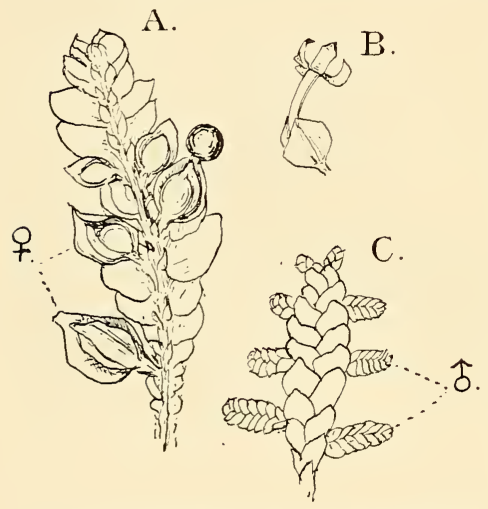

FIG. 4I.-Porella Bolanderi (Aust.). A, Female plant, $\times_{4}$; $\$$, archegonial branches: $\mathrm{B}$, an open sporogonium, $\times_{4}$; C, a male plant, $\times_{4} ; \delta$, the antheridial branches.

mats closely covering the substratum. number of segments are cut off, the apical cell becomes the mother cell of an archegonium. The study of any typical form will illustrate the principal characters of the group. The species selected, Porella (Madotheca) Bolanderi, is very like the common and widely distributed $P$. platyphylla, which corresponds with it in all structural points.

The plant grows upon rocks, especially, but also upon the trunks of trees, and forms dense It branches extensively, but always monopodially, dichotomous branching never occurring in the acrogynous Jungermanniaceæ. The slender stem is completely hidden above by the two rows of closely-set, overlapping, scale-like leaves. Upon the ventral side, which is fastened by scattering rhizoids to the substratum, there is a row of much smaller leaves (Amphigastria), more or less irregularly disposed. The dorsal leaves are nearly oval in outline, but the twolobed form, that is very conspicuous in many species, is not so noticeable here. The amphigastria are much smaller, and more elongated than the dorsal leaves. The structure of the leaf is 
of the simplest character, consisting of a single layer of polygonal cells containing numerous chloroplasts.

The plants grow where they are exposed to alternate wetting and drying up. They may at any stage become completely dried up, and on being moistened will resume at once their activity. In the dried condition, the species under consideration often remains for several months without
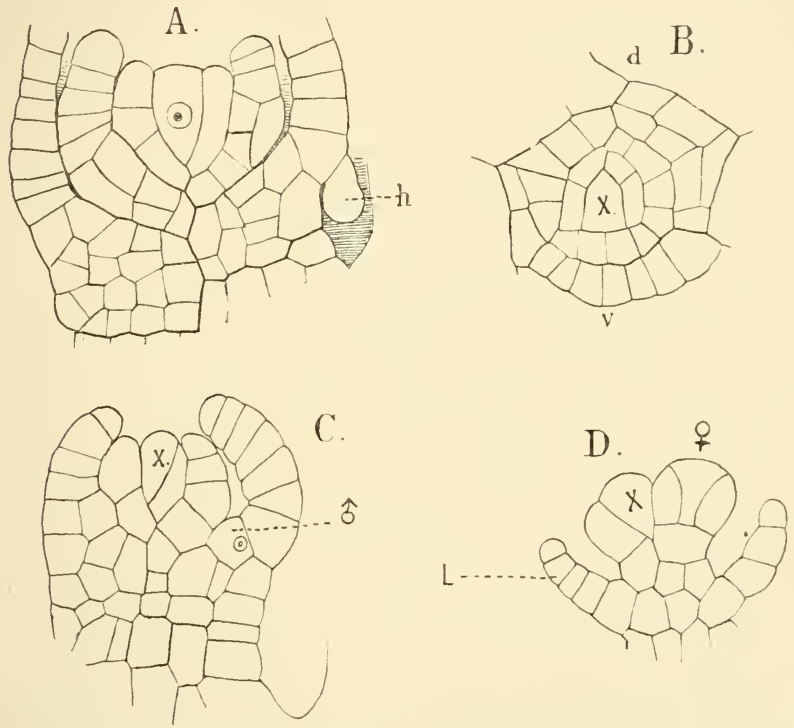

Fig. 42.--Porella Bolanderi (Aust.). A, Median longitudinal section of a vegetative axis; $\mathrm{B}$; a cross-section of the apex of a similar one, $\times 500 ; x$, the apical cell; $h$, hair; $d$, dorsal surface; ', ventral surface.

apparently being injured in the least, and this power is shared to a considerable degree by most of the acrogynous forms, whose favourite habitat is the trunks of trees.

The apical growth of the stem is extremely regular, and as in all the other acrogynous Hepaticæ, the apical cell is a three-sided pyramid (Fig. 42, A). In longitudinal section it is much deeper than broad, and its outer face is almost flat. In cross-sections (Fig. 42, B) it has the form of an isosceles triangle, the shorter 
side turned toward the ventral surface of the plant. From this cell three sets of lateral segments are cut off, two dorsal and one ventral, and each of these gives rise to a row of leaves, a leaf corresponding to each segment of the apical cell. The first division wall in each segment is at right angles to its broad faces and divides it into two cells of somewhat unequal size. The next wall formed divides the larger of the two primary cells into an inner and an outer cell (Fig. 42, A), so that the young segment now consists of three cells, an inner one and two outer; the latter in the dorsal segments correspond to the two lobes usually found in the dorsal leaves. The two outer cells now divide by walls in two planes, and rapidly grow out above the level of the apical cell and form lamellæ which remain single-layered, and undergo but little further modification beyond an increase in size. From the base of the young leaves simple hairs develop, but remain small and inconspicuous. The inner of the three first formed cells of the segment, by further division and growth in all directions, produces the axis of the plant. This in cross or longitudinal section shows almost perfectly uniform tissue. No distinct epidermis, or central strand, like that found in most Mosses, can be seen.

The branching is monopodial and the branch represents the ventral lobe of a leaf. After the first division by which the two lobes of the leaf are separated, only the dorsal one develops into the lamina of the leaf, which is thus in the segment from which a branch is to form, only one-lobed. In the ventral cell three walls arise (Fig. 43), intersecting so as to cut out a pyramidal cell of the same form as the apical cell of the main axis, and the cell so formed at once begins to divide in the same way, and forms a lateral axis of precisely the same structure as the main one.

The plants are strictly diøecious and the two sexes are at once recognisable. The males are smaller, and bear special lateral branches which project nearly at right angles from the main axis, and whose closely imbricated light green leaves make them conspicuous. At the base of each of the leaves is a long-stalked antheridium, large enough to be readily seen with the naked eye.

The development of the antheridium may be easily traced by means of sections made parallel to the surface of the branch. At the apex (Fig. 42, C) is an apical cell much 
like that in the sterile branches, but with the outer face more convex. The divisions in the segments are the same as there, but the whole branch remains more slender, and the hairs at the base of the leaves are absent. The antheridia arise singly from the bases of the leaves, close to where they join the stem, and are recognisable in the fourth or fifth youngest leaf (Fig. 42, C, of ). The antheridial cell assumes a papillate form, and divides by a transverse wall into an outer and inner cell, and the former divides by a similar wall into two cells, of which the upper one is the mother cell

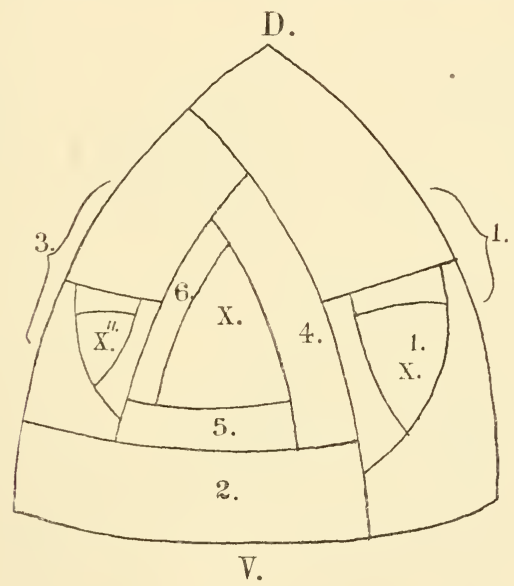

FIG. 43.-Diagram showing the ordinary method of branching in the acrogynous Jungermanniacere (after Leitgeb), D, Dorsal; V, ventral part of stem; $\mathrm{X}^{\prime} \mathrm{X}^{\prime \prime}$, apical cells of the branches. The segments are numbered.

of the antheridium, and the other the stalk. The first wall in the antheridium itself is vertical (Fig. 44, B), and divides it into two equal parts. Each of these is now divided by two other intersecting walls, best seen in cross-section (Fig. 45, A), which separate a central cell, nearly tetrahedral in form, from two outer cells. In the complete separation of the central cell by these first two walls, Porella appears to differ from the other Jungermanniaceæ examined, ${ }^{1}$ where these first two peripheral cells do not reach to the top of the antheridium, 
and a third cell is cut off before the separation of the central part of the antheridium from the wall is complete. It is possible, too, that in Porella this may be sometimes the case. The antheridium in cross-section at this stage shows two perfectly symmetrical halves (Fig. 45, A). The two central cells form a rhomboid surrounded by six cells, the first of the primary peripheral cells being in each case divided into two. The divisions proceed rapidly in both the central cells and in the peripheral ones. In the latter they are for a long time

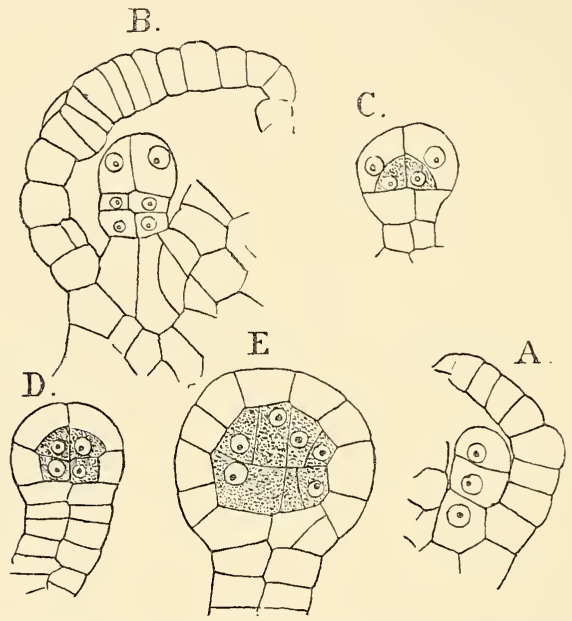

Fig. 44.-Porella Bolanderi (Aust.). Successive stages of the young antheridium in median longitudinal section, $\times 60 c$.

always radial, so that the wall remains but one cell thick; but as the antheridium approaches maturity periclinal walls also form in the lower part, which thus becomes double, and at points even three cells thick. After the division of each primary central cell into equal quadrants, a series of curved walls intersecting the inner walls of the peripheral cells arise, and then periclinal walls (Fig. 45, C), but beyond this no definite succession of walls could be traced.

The development of the spermatozoids is the same as in other Liverworts. The slender body shows about two complete coils; 
the vesicle is small, but always present, and the cilia somewhat longer than the body (Fig. 45, F). The stalk of the antheridium is long and at maturity composed of two rows of cells. Before the central cells of the antheridium are separated from the peripheral ones, the stalk shows a division into two tiers of two cells each (Fig. 44, B), but it is only the lower one that forms the real stalk; the other forms the base of the antheridium itself. The cells of the wall have numerous chloroplasts, but the great mass of colourless sperm cells within make the ripe

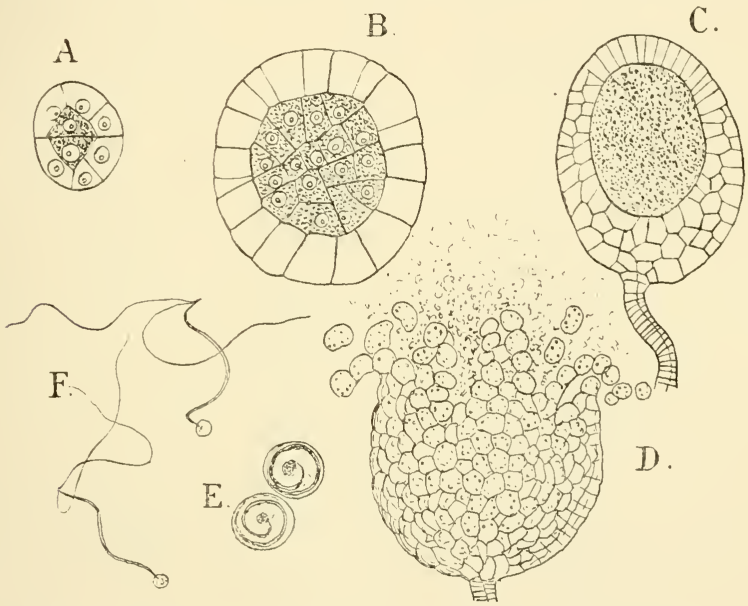

FIG. 45.-Porella Bolanderi (Aust.). A, B, Cross-sections of young antheridia, $\times 600$; C, longitudinal section of nearly ripe antheridium, $\times 100 ; D$, ripe antheridium in the act of opening, $\times 50 ;$ E, F, spermatozoids, $\times 1200$.

antheridium look almost pure white. If one of these is brought into water it soon opens in a very characteristic way. The cells of the wall absorb water with great avidity, and finally the upper part bursts open by a number of irregular lobes which curl back so strongly that many of the marginal cells become completely detached. The whole mass of sperm cells, with the included spermatozoids, is forced out into the water, and if they are perfectly mature, the spermatozoids are quickly liberated and swim away (Fig. 45, D).

The female plants are decidedly larger than the males, but 
the archegonial branches are much less conspicuous than the antheridial ones. The older ones, which either contain a young sporogonium or abortive archegonia, are readily distinguished on account of the large perianth (Fig. 4I, A), but those that contain the young archegonia are situated very near the apex of the main shoot, and are scarcely to be distinguished from the very young vegetative branches. However, a plant with the older perichætia, or very young sporogonia, will usually show young archegonial branches as well.

The archegonial branch originates in the same way as the vegetative branches, and the first divisions of its apical cell are the same; but only two or three segments develop leaves, after which each young segment divides into an inner and an outer cell; the latter becomes at once the mother cell of the young archegonium. The inner cell divides further by a transverse wall, and the outer of the two cells thus formed gives rise to the short but evident pedicel of the archegonium. The latter is very like that of the anacrogynous Liverworts. Of the three first walls (Fig. 46, C), the last formed one is much shorter, so that one of the three peripheral cells is much smaller, and does not divide by a vertical wall, and the neck has but five rows of cells, as in Pellia. This appears to be universal among the Jungermanniaceæ examined. ${ }^{1}$ Often in Porella the three primary walls converge at the bottom so as to almost meet, in which case the central row of cells is narrower at the base (Fig. 46, D). The rest of the development is exactly as in the other Hepaticæ. The number of neck canal cells in the full-grown archegonium is normally eight. The archegonium (Fig. 46, L) at maturity is nearly cylindrical, with the venter but little enlarged. The canal cells are broad, but the egg small. The venter has a two-layered wall.

The first-formed archegonia arise in strictly acropetal succession, and finally the apical cell divides by a transverse wall, and the outer cell so formed becomes transformed into an archegonium. In a number of cases observed, young archegonia were noticed among the older ones, apparently formed secondarily from superficial cells between them, and not from the younger segments of the apical cells.

A perianth is formed about the group of archegonia, much as in the anacrogynous forms.

1 Janczewski (I), p. 393. 
The early divisions in the embryo of Porella are less regular than those in some others of the foliose Liverworts. The embryo at first is composed of a row of cells, of which the lowest, cut off by the first transverse wall, undergoes here no further development. In Jungermania bicuspidata ${ }^{1}$ this lower cell undergoes further divisions to form the filamentous appendage at the base of the sporogonium. The next divisions
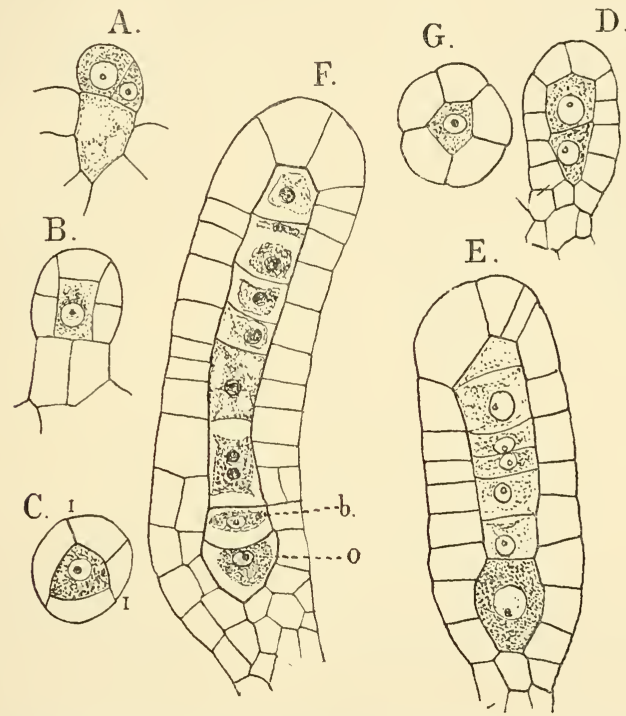

Fig. 46.-Porella Bolanderi (Aust.). Development of the archegonium, $\times 600$; C, cross-section of young archegonium; G, cross-section of the neck of an older one. The others are longitudinal sections; $b$, ventral canal cell ; $o$, the egg. .

in the upper part of the embryo correspond closely to those described in Pellia and Aneura, but the succession of the walls is more variable and the limits of the primary cells more difficult to follow. The number of the cells, too, that contribute to the formation of the capsule, cannot be determined exactly, and there is evidently some variation in this respect, as there is in the time of the separation of the capsule wall from the 
archesporium. Both longitudinal and transverse sections of the sporogonium at this stage (Fig. 47) show a good deal of irregularity in the arrangement of the cells, and the first periclinal walls form at very different distances from the surface, so that it is clear that the wall cannot be established, as in Radula for instance, by the first periclinals.

The cells of the older archesporium are arranged in more or less evident rows radiating from the base (Fig. 48, A). No definite relation of spores and elaters can be made out, the two sorts of cells being mingled apparently without any regular order. Some of the cells cease dividing and grow regularly in all direc-
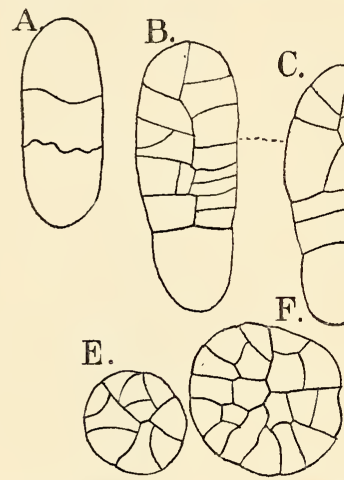

C.

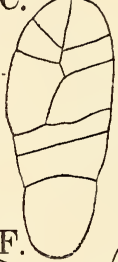

G.

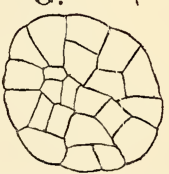

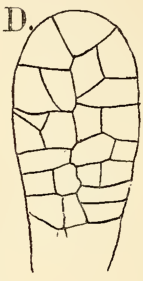

FIG. 47.-Poreila Bolanderi (Anst.). Development of the embryo. A-D, in longitudinal section; E-G, transverse sections. $\mathbf{B}$ and $\mathrm{C}$ are sections of the same embryo, and E, F, G are successive sections of a single embryo, $\times 525$.

tions, while others may divide further and grow mainly in the plane of division, so that they become elongated. The former are the young spore mother cells, the latter the elaters (Fig. 48 , C). The division of the spores begins while the cells of the archesporium are still united, although at this time the swollen and strongly striated cell walls of the mother cells (Fig. 48, C) show that they are becoming mucilaginous. At this stage sections through the archesporium show the deeply-lobed spore mother cells with the elongated elaters packed in between them, the pointed ends of the latter fitting into the interstices between the spore mother cells. The latter are somewhat angular and the wall distinctly striated. It is the inner layer 
only of the wall that projects into the cavity of the cell and forms the characteristic lobes marking the position of the
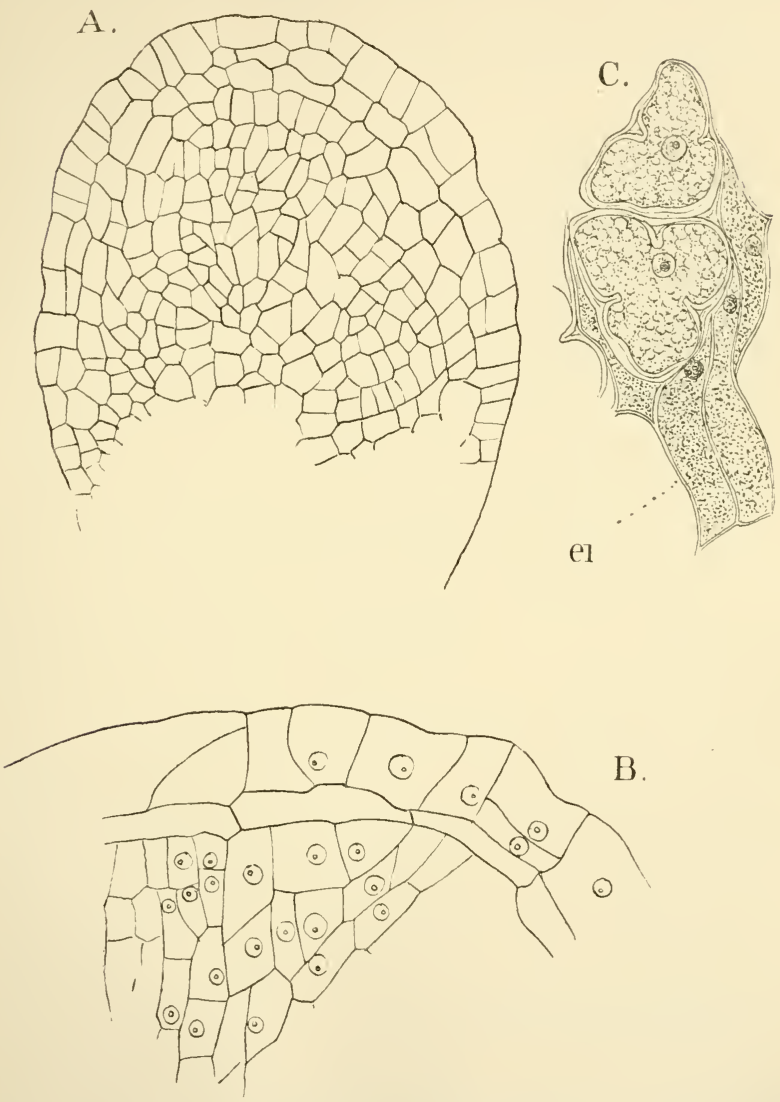

FIG. 48.-Porella Bolanderi (Aust.). A, Nearly median longitudinal section of an advanced embryo, $\mathrm{X}_{260}$; B, the upper part of a similar embryo, $\times_{525}$; $\mathrm{C}$, sporogenous cells and elaters from a still older sporogonium, $\times 525$.

four spores. The cell cavity is filled with crowded granules, some of which are chloroplasts. The nucleus, which is of 
moderate size, and rich in chromatin, has a distinct nucleolus. The elaters have thinner walls than the spore mother cells, and the contents are more finely granular. A distinct nucleus staining strongly with the usual reagents is present. The further history of spores and elaters corresponds closely with that of the forms already described.

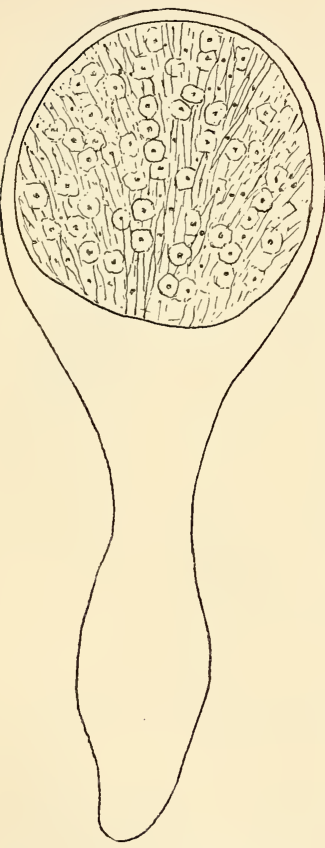

Fig. 49.-Porella Bolanderi (Aust.). Longitudinal section of a sporogonium after the final division of the sporogenous cells, $\times 85$. The ripe spores have only a thin wall, which is coloured brown, and has delicate granular thickenings.

In a paper by Le Clerc du Sablon ${ }^{1}$ the statement is made, and figures are given, showing that at an early stage in the development of the spores and elaters of a number of Hepaticæ the walls of the cells are completely destroyed, so that the young spore mother cells and elaters are primordial cells. A great many carefully stained microtome sections of a large number of Liverworts belonging to all the principal groups have been examined by me, and invariably the presence of a definite cell wall can be demonstrated at all stages.

Many of the foliose Hepaticæ show much greater regularity in the early divisions of the embryo, and in the establishment of the archesporium and the arrangement of its cells. This is especially marked in Frullania. $^{2}$ Here, after the upper part of the embryo has divided into three tiers of cells, these undergo the usual quadrant divisions, and the four terminal cells only, form the capsule, in which the archesporium is established by the first periclinal walls (Fig. 50). The divisions in the archesporium are also extremely regular, so that the spores and elaters form regularly alternating vertical rows. In

$$
1 \text { Le Clerc du Sablon (3). }
$$


Frullania the lower cell of the embryo, instead of remaining undivided, or forming simply a row of cells, divides repeatedly, and the cells grow out into papillæ, so that it probably is functional as an absorbent organ, like the foot of the Anthoceroteæ. Radula ${ }^{1}$ and Jungermannia, while more regular in the divisions than Porella, still are less so than Frullania, and in these more than the upper tier of cells take part in the growth of the capsule. The degree to which the seta and foot are developed varies. In Porella there is not a distinctly marked foot, the lower part of the seta being simply somewhat enlarged, but in others, like Jungermannia bicuspidata, there is a large heart-shaped foot, very distinct from the seta. In Porella the seta is short, projecting but little beyond the perianth; but in others it may reach a length of several centimetres.

The development of the perianth is quite independent of
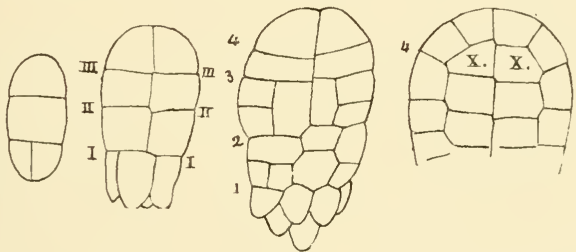

Fig. 50.-Frullania dilatata (Nees). Development of the embryo, $\mathrm{x}_{300}$ (after Leitgeb); $x, x$, the archesporial cells. The numbers indicate the primary transverse divisions.

fertilisation, and not infrequently it contains, although fully developed, only abortive archegonia. It is not always formed, but when present, according to Leitgeb, ${ }^{2}$ it is the product of the older segments of the apical cell from which archegonia are formed, and arises as a sort of wall about the whole group of archegonia. In Porella, as well as most of the foliose Hepaticæ, the capsule opens by four equal valves, the lines of splitting corresponding, according to Leitgeb, to the first quadrant walls in the young embryo.

The germination of the spores shows a great deal of variation, and has been studied in a large number of forms by several observers. Recently a number of tropical species have been investigated, especially by Spruce ${ }^{3}$ and Goebel, ${ }^{+}$and some extremely interesting variations have been discovered. In these
1 Hofmeister (I).
${ }^{2}$ Leitgeb (I), vol. ii. p. 47 .
3 Spruce (2).
4 Goebel (I2). 
forms when the exospore is not strongly developed, it is simply stretched by the expanding endospore, and finally becomes no longer discernible; but when it is clearly differentiated, it splits with the swelling of the endospore and then remains unchanged at the base of the young plant. The germinating spore may give rise to a cell mass immediately, which develops insensibly into the leafy axis, or it may form a simple or branched protonema of very different form, which sometimes reaches a large size and upon which the leafy axis arises as a bud.

The simplest form may be illustrated by Lophocolea. Here the germinating spore divides by a transverse wall into two equal cells, one of which continues to grow and divide until a short filament is formed. After a varying number of transverse divisions an oblique wall is formed in the terminal cell, and a second one nearly at right angles to it. By these divisions the dorsiventral character is established, the first-formed segment being ventral. A third oblique wall now arises; intersecting both of the others, and the three include a tetrahedral cell which is the permanent apical cell of the young plant. The ventral segments do not at first form any trace of leaf-like structures, and in the dorsal segments the leaves are at first simple rows of cells; but a little later the leaves show plainly their two-lobed character, each being made up of two rows of cells united at the base. From the ventral segments the amphigastria develop gradually, being quite absent in the earlier ones. Chiloscyphus closely resembles Lophocolea, but the filamentous protonema is longer, and is often branched. A similar filamentous protonema is present in Cephalozia (Jungermannia) bicuspidata and cther species.

Lejeunia $^{1}$ shows a most striking resemblance in its early stages to the simple thalloid Jungermanniaceæ. The germinating spore forms either a short filament or a cell surface (Fig. $5 \mathrm{I}, \mathrm{A})$. In either case, at a very early stage, a two-sided apical cell is established, and for a time the young plant has all the appearance of a young Metzgeria or Aneura. This two-sided apical cell gives place to the three-sided one found in the older gametophyte, and the leaves and stem are gradually developed as in Lophocolea.

In Radula, ${ }^{2}$ and according to Goebel, much the same condition occurs in Porella, the first divisions of the spore give rise

1 Goebel (12).

2 Goebel (I 2); Hofmeister (I), p. 55. 
to a disc, and the formation of a filament is completely suppressed. This disc is nearly circular in outline, and at its edge a single large cell appears (Fig. 5 I, B), whose relation to the primary divisions of the spore is not quite clear. This cell forms the starting-point for the growing apex of the gamctophore. As in the other forms, the first leaves are extremely rudimentary, and only gradually is the complete gametophyte developed.

How far this variation in the form of the protonema is of morphological importance is a question, as the same specics may show both a filamentous protonema and the discoid form. According to Leitgeb this is the case in several species of Jungemannia, and he suggests that the conditions under
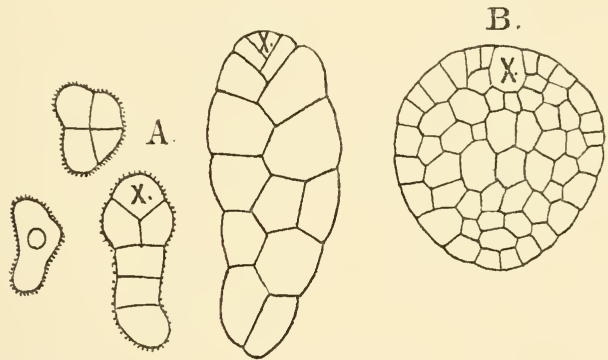

FIG. 51.-A, Germination of Lejenna serpyllifolia; B, young plant of Raduia complanata (Dum.); $x$, the apical cell (all the figures after Goebel).

which germination takes place probably affect to a considerable extent the form of the protonema. This is well known to be the case in Ferns.

The very peculiar modifications observed in certain tropical Hepaticæ, especially by Spruce and Goebel, should be mentioned in this connection. In these forms the protonema is permanent and the leafy gametophore only an appendage to it. In Protocephalozia ephemeroides, a species discovered by Spruce in Venezuela, the plant forms a dense branching filamentous protonema much like that of the true Mosses, which it further resembles by having a subterranean and an aerial portion. Upon this confervoid protonema are borne the leafy gametophores, which are small and appear simply as buds. 
Among the other remarkable forms is Lejeunia metageriopsis, a Javanese species discovered by Goebel growing upon the leaves of various epiphytic Ferns. It has a thallus much like that of Metzgeria, and like it has a two-sided apical cell. This thallus branches extensively (Fig. 52, A), and propagates itself by

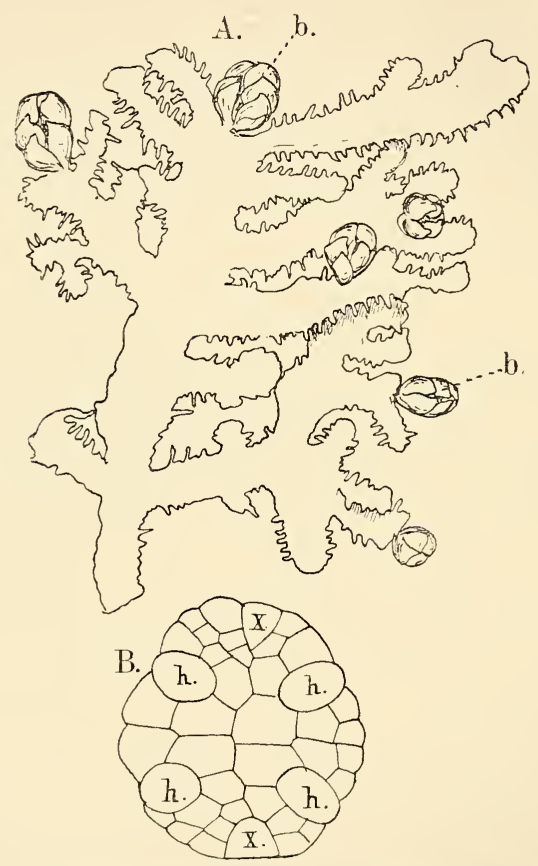

FIG. 52.-A, Lejeunia metzgeriopsis (Goebel), showing the thalloid protonema with terminal leafy buds (b), $\times$ I $_{4}$ (after Goebel). B, Gemma of Cololejennia Goebelii.

numerous multicellular gemmæ. This thallose condition is, however, only maintained during its vegetative existence. Previous to the formation of the sexual organs, the two-sided apical cell of a branch becomes three-sided, as in the young plant of other species of Lejeunia, and from this three-sided 
apical cell a short leafy branch, bearing the sexual organs, is produced. ${ }^{1}$

Considerable variety is exhibited by the leaves of the Acrogynæ as to their form and position, but all agree in their essential structure and carly growth. The two lobes may be either equal in size or unequal. In the latter case either the dorsal or ventral lobe may be the larger, when the leaves are overlapping, as occurs in most genera. Where the dorsal half is the larger it covers the ventral lobe of the leaf in front of it, and the leaves are said to be "incubous"; where the reverse is the case, the leaves are "succubous." These differences are of some importance in classification.

In many species, especially the tropical epiphytic forms, one lobe of the leaf frequently forms a sac-like organ, which appears to serve as a reservoir for moisture. These tubular structures sometimes have the opening provided with valves, which open readily inward, but not from the inside, and thus securely entrap small insects and crustaceans which find their way into them. Schiffner ${ }^{2}$ compares them to the pitchers of a Sarracenia or Darlingtonia,

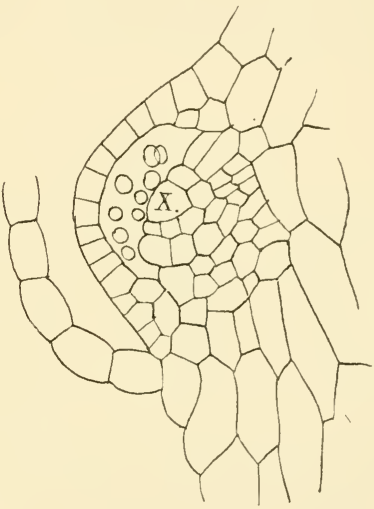

FIG. 53. - Mastigobryum trilobatum (Nees). Longitudinal section of the stem, showing the endogenous origin of the branches; $x$, the apical cell of the branch, $\times 245$ (after Leitgeb). and suggests that they may serve the same purpose.

The branching of the foliose Jungermanniacex has been carefully investigated by Leitgeb, and will briefly be stated here. Two distinct forms are present, terminal branching and intercalary. The former has already been referred to, but it shows some variations that may be noted. In most cases the whole of the ventral part of a segment, which ordinarily would produce the ventral lobe of a leaf, forms the rudiment of the branch, so

1 For a complete account of these forms as well as others, see Goebel's papers in the Annals of the Buitensorg Botanical Garden, vols. vii. and ix., and in Flora, 1889 and 1893 .

2 Schiffner (1), p. 65. 
that the leaf, in whose axil the branch stands, has only the dorsal lobe developed. In the other case, only a part of the cell is devoted to forming the branch, and the rest forms a diminished but evident ventral leaf-lobe, in whose axil the young branch is situated. The formation of the intercalary branches, which are for the most part of endogenous origin, may be illustrated by Mastigobryum, where the characteristic flagellate branches arise in this manner. Here the apical cell of the future branch (the branches in this case arise in strictly acropetal order) springs from the ventral segment, and exactly in the middle. It is distinguished by its large size, and is covered by a single layer of cells (Fig. 53). In this cell the first divisions establish the apical cell, which then grows in the

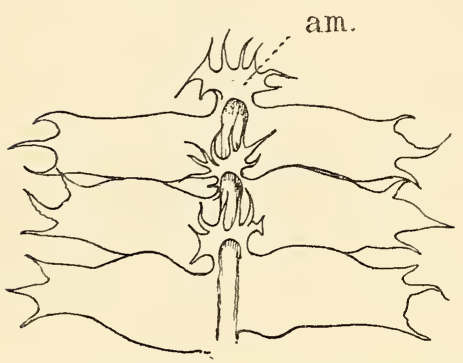

Fig. 54.--Ventral surface of the stem of Chiloscyphus combinatus (N. von E.), showing amphigastria $(a m), \times_{I_{4}}$ (after Schiffner). usual way. The young bud early separates at the apex from the overlying cells, which rapidly grow, and form a dome-shaped sheath, between which and the bud there is a space of some size. Later the young branch grows more rapidly than the sheath and breaks through it.

The non-sexual

reproduction of the acrogynous Hepaticæ may be brought about either by the separation of ordinary branches through the dying away of the older parts of the stem, or in a few cases observed ${ }^{1}$ new plants may arise directly from almost any point of a leaf or stem. Gemmæ are known in a large number of species. These in most of the better known cases are very simple unicellular or bicellular buds arising often in great numbers, especially from the margins and apices of leaves. Curious discoid multicellular gemmæ have been discovered in a number of species, especially in several tropical ones investigated by Goebel. ${ }^{2}$ The gemmæ upon the thallus of Lejeunia metzgeriopsis are of this character, and similar ones are found in Cololejennia Goebelii. In the 
latter (Fig. 52, B) the gemma is a nearly circular cell plate attached to the surface of the leaf by a stalk composed of a single cell. The first wall in the young gemma divides it into two nearly equal cells, in each of which a two-sided apical cell is formed, so that like the gemma of Marchantia there are two growing points. There are usually four cells that differ from the others in their thicker walls and projecting on either side of the gemma above the level of the other cells. These serve as organs of attachment, perhaps by the secretion of mucilage, and by them the young plant adheres to the surface of the fern leaf upon which it grows. The development of the gemmæ, whether unicellular or multicellular, follows very closely that of the germinating spores.

\section{Classification of the Jungermanniacea Acrogyna}

In attempting to classify this immense family, great difficulties are encountered. While they show a considerable amount of variation, the differences are not constant, and the forms merge so one into another that a satisfactory subdivision of the group seems almost hopeless. In regard to essential characters, such as the growth of the stem, origin and structure of the sexual organs and sporogonium, they show remarkable uniformity, and evidently constitute a most natural group, allied very closely to the anacrogynous forms, as we have already attempted to show. The latest attempt to classify them is that of Schiffner, ${ }^{1}$ who confesses how difficult, perhaps impossible, a satisfactory arrangement is. He proposes eight subdivisions, as follows: I. Epigoniantheæ; II. Trigonantheæ; III. Ptilidioideæ; IV. Scapanioideæ; V. Stephaninoidex ; VI. Pleurozioideæ ; VII. Bellincinioideæ ; VIII. Jubuloideæ.

1 Schiffner (1), p. 22. 


\section{CHAPTER V}

\section{THE ANTHOCEROTEÆ}

THIs order contains but three genera, Anthoceros, Dendroceros, and Notothylas, and differs in so many essential particulars from the other Hepaticæ that it may be questioned whether it should not be taken out of the Hepaticæ entirely and given a place intermediate between them and the Pteridophytes. All the members of the order correspond closely in the structure of the gametophyte, and while showing a considerable variation in the complexity of the sporophyte, there is a perfect series from the lowest to the highest in regard to the degree of development of the latter, so that the limits of the genera, which depend almost entirely upon the sporophyte, are difficult to determine. The Anthocerotex are of extraordinary interest morphologically, as they connect the lower Hepaticæ on the one hand with the Mosses, and on the other with the vascular plants. Leitgeb ${ }^{1}$ has endeavoured to show that they are sufficiently near to the Jungermanniaceæ to warrant placing them in a series with that order opposed to the Marchantiaceæ, but a careful study of both the gametophyte and the sporophyte has convinced me that this view cannot be maintained; and that while probably the affinities of the Anthocerotex are with the anacrogynous Jungermanniaceæ rather than with the Marchantiacex, nevertheless the two latter orders are much nearer each other than the former is to either of them.

The gametophyte in all the forms is a very simple thallus, either with or without a definite midrib. Of the three genera Dendroceros is confined to the tropical regions, while the other

1 Leitgeb (7), vol, v. p. 9. 
genera occur in the temperate zones, but are more abundant in the warmer regions, where they also reach a greater size. The species of Anthoceros and Notothylas grow principally upon the ground in shady and moist places, and are not well adapted to resist dryness.

A marked peculiarity of their structure is the character of the chloroplasts. There is as a rule but a single large flattened chloroplast in each cell, such as occurs in a good many confervoid Algx, e.g. Coleochate, Stigeoclonium, and others, but, so far as I know, is found elsewhere among the Archegoniatx only in certain cells of Selaginella. Simple thin-walled rhizoids are formed abundantly upon the ventral surface, where there are in many species curious stoma-like clefts which open into cavities filled with a mucilaginous secretion, and in some of which, in all species yet examined, are found colonies of Nostoc which form dark blue-green roundish masses, often large enough to be readily detected with the naked eye, and which were formerly ${ }^{1}$ supposed to be gemmæ.

The sexual organs are very different from those of the other Hepaticæ, and are more or less completely sunk in the thallus from the first. While the first divisions in the archegonium are much like those in the other Hepatica, the subsequent ones are much less regular except in the axial row of cells, and the limits of the outer neck-cells are in the subsequent stages difficult to determine, and the archegonium projects very little above the surface of the thallus, even when full grown. The divisions in the axial row of cells correspond to those in the other Archegoniatæ.

The origin of the antheridium is entirely different from that of all other Bryophytes, but shows, as will be seen later, certain suggestive resemblances to that of the lower Pteridophytes. Instead of arising from a superficial cell, as in all of the former, the antheridium, or in most cases the group of antheridia, is formed from the inner of two cells arising by the division of a superficial one. The outer one takes no part in the formation of the antheridia, but simply constitutes part of the outer wall of the cavity in which they develop.

While the gametophyte is extremely simple in structure, being no more complicated than that of Aneura or Metzgeria, the sporophyte reaches a degree of complexity not equalled by

1 Hofmeister (I), p. I8. 
any of the other Bryophytes. Here, instead of the greater part of the sporogonium being devoted to spore formation, and the sporogonium dying as soon as the spores are scattered, the archesporium, especially in the higher forms, constitutes but a small part of the sporogonium, which develops a highly differentiated system of assimilating tissue, with complete stomata of the same type as those found in vascular plants; and in addition a central columella is present whose origin and structure point to it as possibly a rudimentary vascular bundle. In all of them this growth of the sporogonium is not concluded with the ripening of the first spores, but for a longer or shorter time it continues to grow and produce new spores. This reaches its maximum in some species of Anthoceros, where the sporogonium may reach a length of several centimetres, and continues to grow as long as the gametophyte remains alive. In these forms the foot is provided with root-like processes, which are closely connected with the cells of the gametophyte, from which nourishment is supplied to the growing sporophyte.

The archesporium produces spores and elaters, but the latter are not so perfect as in most of the Hepaticæ. They often show a definite position with regard to the spore mother cells; this is especially marked in Notothylas. The archesporium in all forms that have been completely investigated arises secondarily from the outer cells of the capsule. Leitgeb's ${ }^{1}$ conjecture that in Notothylas the whole central part of the capsule is to be looked upon as the archesporium, is not confirmed by my observations on $N$. valvata (orbicularis), where the formation of a columella and the secondary development of the archesporium are exactly as in Anthoceros. ${ }^{2}$ It is hardly likely that in the other species there should be so essential a difference as would be implied by such an assumption. The development of the spores and their germination show some peculiarities which will be considered when treating of these specially. The sporogonium shows no clear separation into seta and capsule, all except the foot and a very narrow zone above it producing spores. At maturity it opens longitudinally by two equal valves, between which the columella persists. The splitting is gradual and progresses with the ripening of the spores. 
The type of the order, Anthoceros, includes fifteen to twenty species distributed over the world, but especially luxuriant in the tropics. The species that has been most studied is the cosmopolitan A. lavis, which has been the subject of repeated investigations by numerous botanists. This species was carefully examined by the writer, as well as the larger $A$. fusiformis, a common Californian species allied to $A$. punctatus. The gametophyte is a fleshy dark-green or sometimes yellowish green thallus, which branches dichotomously, so that it often forms orbicular discs like those of the Marchantiacex, but owing to the very rapid division of the growing points, and the irregular form of the margin, the individual apices are not usually recognisable. The thallus is either smooth, as in A. levis, or it is very much crisped and roughened by ridges and spines upon the upper surface. On cutting into the plant great quantities of colourless mucilage escape. Here and there, scattered through it, are dark blue-green specks, the Nostoc colonies always found in the thallus. Colourless root-hairs fasten it to the ground. No indications of the sexual organs can be seen from the outside, and it is sometimes difficult to procure them for study, as in both species their formation ceases very soon after the sporogonia begin to develop, and when these are large enough to be seen with the naked eye it is too late to procure the young sexual organs.

The sporogonia are produced in great numbers, especially in A. fusiformis (Fig. 55, A), where they reach a length of 5 to 6 centimetres, or even more, and stand so closely together that a patch of fruiting plants has the appearance of a tuft of fine grass. In California the plants are annual. The spores germinate in the autumn with the commencement of the winter rains, and the sexual organs are mature by about the middle of January. As soon as fertilisation is effected the development of sexual organs ceases, and the regular apical growth stops, the margin of the thallus growing out irregularly beyond the young sporogonia, which are thus left some distance from the margin. After they are once formed they grow as long as the thallus remains alive, and this, in California, usually continues until about the Ist of May, when with the cessation of rain the thallus gradually dries up. I saw no evidences of the thallus surviving the dry season, as is the case with Riccia and Targionia. 


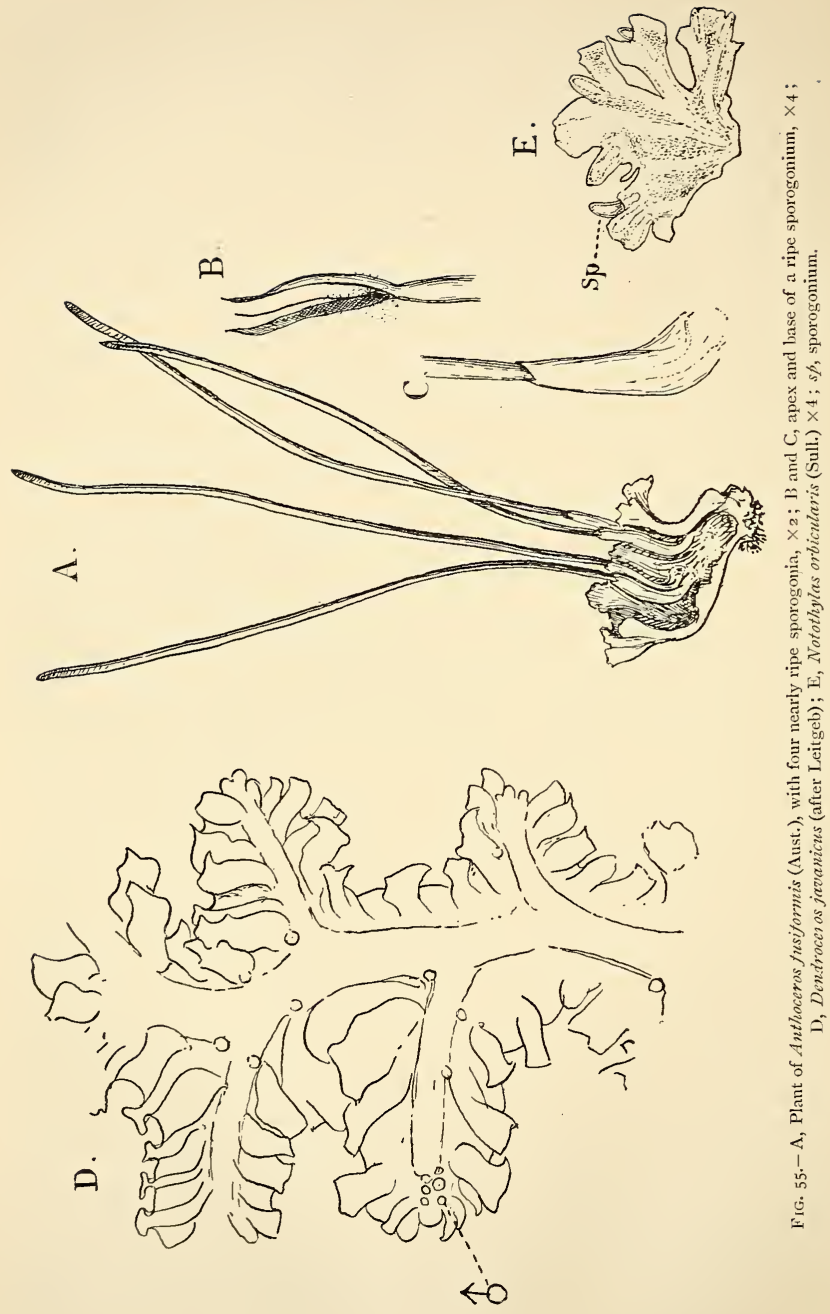


In order to study the apical growth satisfactorily, young plants that show no signs of the sporogonia should be selected. In $A$. fusiformis such a plant will show the margin of the thallus occupied by numerous growing points separated by a greater or smaller number of intervening cells. It is somewhat difficult to determine positively whether one or more apical cells are present. In sections parallel to the surface the initial cells are seen to occupy the bottom of a shallow depression (Fig. $56, \mathrm{C})$. In the case figured, $x$ probably is the single apical cell, and it seems likely that this is usually the case, although Leitgeb ${ }^{1}$ was inclined to think that there were several marginal cells of equal rank. The outer wall of the cells shows a very marked cuticle. A vertical section passing through one of the growing points (Fig. 57) shows that the apical cell is much larger than appears from the transverse section. On comparing the two sections it is evident that its form is the same as in the Marchantiaceæ or Pallavicinia. Two sets of lateral segments, and two sets of inner ones, alternately ventral and dorsal, are cut off, and the further divisions of these show great regularity, this being especially the case in the dorsal and ventral segments. Each of these first divides into an inner and an outer cell. The former divides repeatedly and in both segments forms the central part of the thallus. It is these cells that, according to Leitgeb, ${ }^{2}$ later show thickenings upon their walls somewhat like those met with in many Marchantiaceæ. From the outer cells are developed the special superficial organs both on the ventral and dorsal sides. From the former arise the colourless delicate root-hairs and peculiar stoma-like organs, the mucilage clefts, first described by Janczewski, ${ }^{3}$ who also pointed out the true nature of the Nostoc colonies found within the thallus. These mucilage clefts, especially in their earlier stages, resemble closely the stomata of the higher plants. They arise by the partial separation of two adjacent surface cells close to the growing point, and often at least the two cells bounding the cleft are sister cells. However, the same division of the neighbouring cells frequently occurs without the formation of a cleft, and there is nothing to distinguish the two cells bounding the cleft from the adjacent ones, and a homology with the real stomata on the sporogonia is not to be assumed. The mucilage slit becomes

${ }^{1}$ Leitgeb (7), vol. v. p. 13.

2 Leitgeb, l.c.

3 Janczewski (I). 
wider, and beneath it an intercellular space is formed which widens into a cavity whose cells secrete the abundant mucilage filling it. This mucilage escapes through the clefts and covers

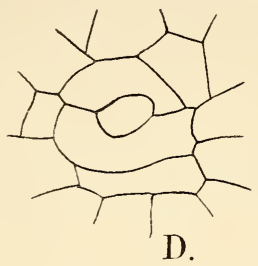

C.
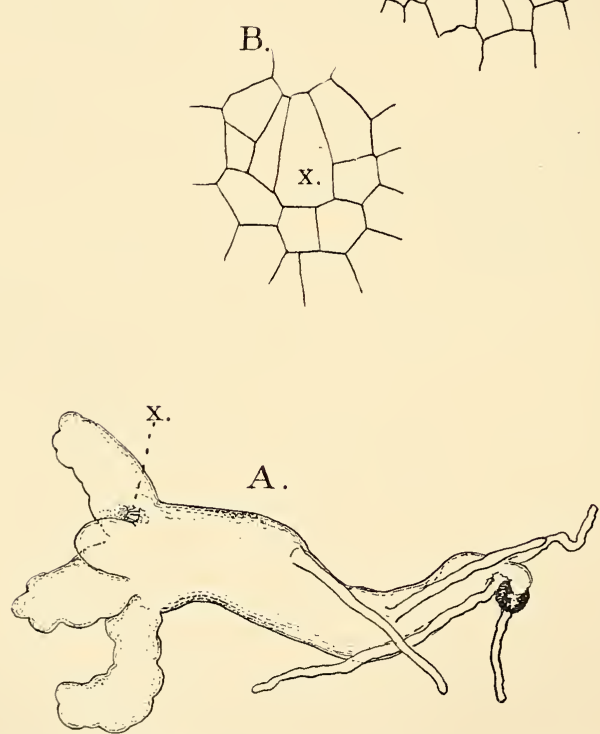

FIG. 56.-Anthoceros fusiformis (Aust.). A, Young plant with single growing point $(x), \times 85 ; \mathrm{B}$, horizontal section of the growing point of a similar plant, $\times_{525} ; x$, the single apical cell; $\mathrm{C}$, similar section of a growing point from an older plant, with possibly more than one initial cell, $\times 260 ; \mathrm{D}$, a mucilage slit from the ventral side of the thallus, $\times 525$.

the growing point in the same way as that secreted by the glandular hairs in the Jungermanniaceæ.

Each cell of the thallus contains a single chloroplast which may be either globular or spindle-shaped, or more or less 


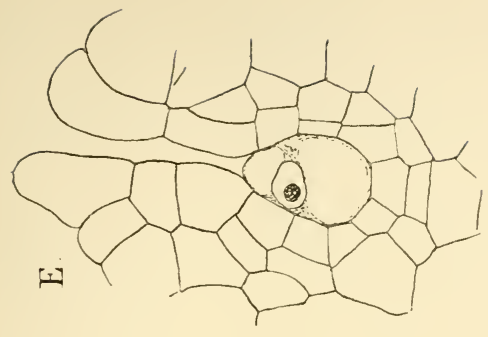

尊

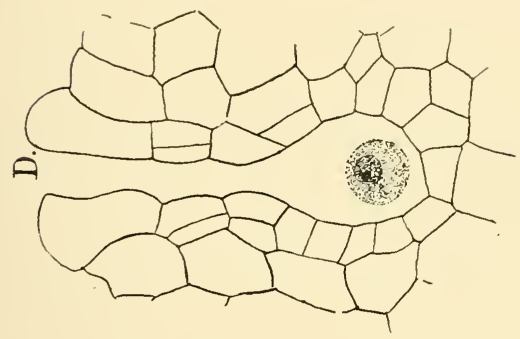

$\because \bar{\Xi}$

先

을

ํ.

$\Xi$

․ㅡㄹ

동

bo

气

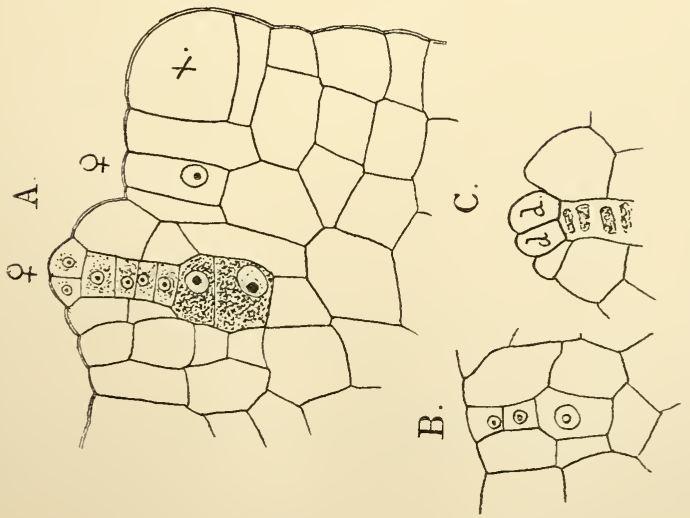

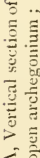

$<0$

窇 
flattened. The nucleus of the cell lies in close contact with the chloroplast, and usually partly or completely surrounded by it. There is no separation of the tissues into assimilative and chlorophylless, as in the Marchantiaceæ, and in this respect Anthoceros approaches the simplest Jungermanniaceæ, as it does in the complete absence of ventral scales or appendages of any kind, except the rhizoids.

The infection of the plant with the Nostoc has been carefully studied by Janczewski ${ }^{1}$ and Leitgeb. ${ }^{2}$ The infection takes place while the plant is young, and is usually brought about by a free active filament of Nostoc making its way into the intercellular space below the mucilage slit, through whose opening it creeps. Once established, the filament quickly multiplies until it forms a globular colony. The presence of the parasite causes an increased growth in the cells about the cavity in which it lies, and these cells grow out into tubular filaments which ramify through the mass of filaments, and become so interwoven and grown together that sections through the mass present the appearance of a loose parenchyma, with the Nostoc filaments occupying the interstices. Other organisms, especially diatoms and Oscillarea, often make their way into the slime cavities, but according to Leitgeb's investigations their presence has no effect upon the growth of the thallus.

The plants are monœcious in $A$. fusiformis, and this is true of other species observed. In the former, however, the antheridia appear a good deal earlier than the archegonia. I observed them first on young plants grown from the spores, that were not more than $3 \mathrm{~mm}$. in length. The exact origin of the cell from which the antheridia develop could not be made out, as none of my sections showed the youngest stages. Waldner's ${ }^{3}$ observations upon $A$. lavis, however, and my own on Notothylas valvata, as well as a study of the older stages in $A$. fusiformis, leave no doubt that in this species as in the others the antheridia are endogenous, and the whole group of them can be traced back to a single cell. They arise close to the growing point, and the cell from which they arise is the inner of two cells formed by a transverse wall in a surface cell. The outer cell (see figure of Notothylas) divides

I Janczewski (I).

${ }^{2}$ Leitgeb (7), vol. v. p. 15.

3 Waldner (2); see also Leitgeb (7), vol. v. p. 15. 
almost immediately by another wall parallel with the first, so that the group of antheridia is separated by two layers of cclls from the surface of the thallus. The inner cell does not at once develop into an antheridium, at least in most spccies, although in the case of a doubtful species, probably $A$. Vincentianus from New Zealand, Leitgeb ${ }^{1}$ found normally but one antheridium in each cavity. The cell divides first by a longitudinal wall into two, each of which generally divides again, so that there are four antheridium mother cells, all, however, unmistakably the product of a single cell, and if a comparison is to be made with the antheridium of any other Liverwort, the antheridium in the latter is homologous, not with the single one of Anthoceros, but with the whole group, plus the twolayered upper wall of the cavity in which they lie.

The first divisions in the antheridium are the same as those in the original cell, i.e. the young antheridium is divided longitudinally by two intersecting walls, and the separation of the stalk from the upper part is secondary; indeed in the earliest stages it is difficult to tell whether these longitudinal divisions will result in four separate antheridia or are the first division walls in a single one. Secondary antheridia arise later by budding from the base of the older ones, so that in the more advanced conditions the antheridial group consists of a varying number, in very different stages of development (Fig. 58). After the first transverse walls by which the stalk is separated, the next division in each of the upper cells is parallel to it, so that the body of the antheridium is composed of nearly equal octant cells. Then by a periclinal wall each of these eight cells is divided into an inner and an outer cell, and the eight central ones then give rise to the sperm cells, and the outer ones to the wall. The four stalk cells by repeated transverse divisions form the four-rowed stalk found in the ripe antheridium. The uppermost tier of the stalk has its cells also divided by vertical walls and forms the basal part of the antheridium wall. The transverse and vertical division walls in the central cells alternate with great regularity, so that there is little displacement of the cells, and up to the time of the separation of the sperm cells the four primary divisions are still plainly discernible, and the individual sperm cells are cubical in form. In the peripheral cells hardly less regularity is observable. Except near

1 Leitgeb (7), vol. v. p. I7. 
the apex none but radial walls are formed after the first transverse wall has divided the body of the antheridium into two tiers, and when complete the wall consists of three well-marked transverse rows of cells, the lower being derived from the uppermost tier of stalk cells. At the apex the cells are not quite so regular (Figs. D, E). In its younger stages the antheridium is very transparent and perfectly colourless. In each peripheral cell a chloroplast is evident, but at this stage it is quite colourless and the nucleus is very easily seen in close contact with it.

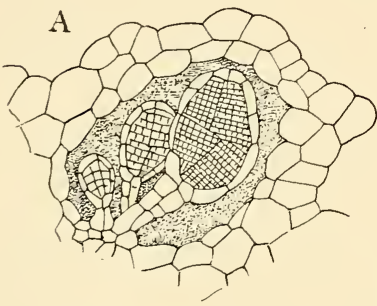

B.
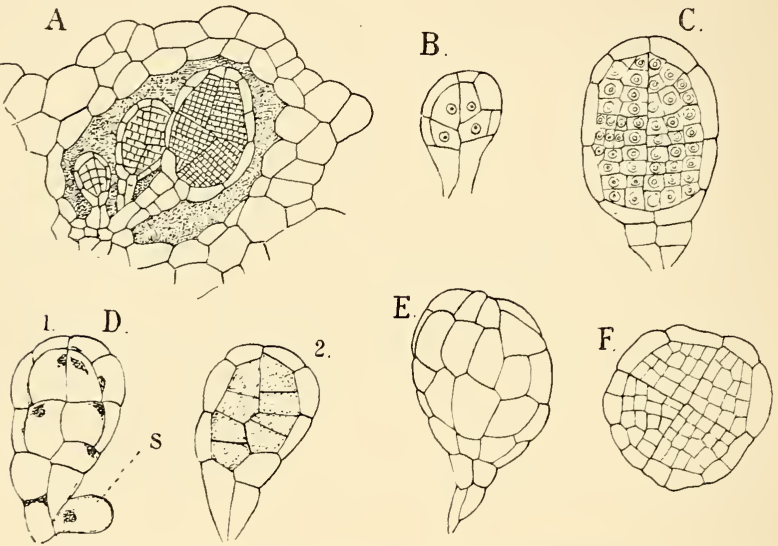

FIG. 58.-Anthoceros fusiformis (Aust.). Development of the antheridium; D, E, drawn from living specimens, the others microtome sections; D, I, shows the single chloroplast in each of the wall cells $s_{2}$ and the secondary antheridium $(s)$ budding out from its base; 2 is an optical section of the same; E, surface view of full-grown antheridium; F, cross-section of a younger one. Figs. A, $\mathrm{E} \times 225$, the others $\times 450$.

As the antheridium grows the chloroplasts develop with it, becoming much larger and elongated in shape, and at the same time develop chlorophyll. The mature chloroplast is a flattened plate that nearly covers one side of the cell, and its colour has changed from green to a bright orange as in the antheridium of many Mosses. The sperm cells are discharged through an opening formed by the separation of the apical cells of the antheridium. These cells do not become detached, and return to their original position, so that the empty antheridium has its 
wall apparently intact. The spermatozoids are small and entirely like those of the other Hepatice.

Leitgeb ${ }^{1}$ found in abnormal cases that the antheridia might arise superficially, as in the other Hepatica. Whether this is a reversion to the primitive condition would be hard to say, but it is at any rate possible.

At first the cell from which the antheridial complex arises is not separated from its neighbours by any space. About the time that the first divisions in it are formed, the young antheridial cells begin to round off and separate from the cells above them. With the growth of the surrounding cells this is increased, so that before the divisions in the separate cells begin, the group of papillate cells is surrounded by a cavity of considerable size. To judge by the readiness with which the walls of the cavity stain, it is probable that the separation of the cells is accompanied by a mucilaginous change in their outer layers.

The first account of the archegonium was given by Hofmeister, who, however, overlooked the peripheral cells and only saw the axial row. Later Janczewski ${ }^{2}$ showed that Anthoceros did not differ essentially in the development of the archegonium from the other Hepaticæ, and his observations were confirmed by the later researches of Leitgeb ${ }^{3}$ and Waldner. ${ }^{4}$ The formation of archegonia does not begin until the older antheridia are mature, and very often, especially in $A$. lavis, few or no antheridia were found on the plants with well-developed archegonia. After the formation begins, each dorsal segment gives rise to an archegonium, so that they are arranged in quite regular rows, in acropetal order. After the transverse wall by which the segment is divided into an inner and an outer cell is formed, the outer cell becomes at once the mother cell of the archegonium, much as in Aneura. In this cell next arise three vertical intersecting walls, by which a triangular (in crosssection) cell is cut out as in the other Hepaticæ. Sometimes it looks as if one of these walls was suppressed, but even in such cases the triangular form of the central cell is evident. The main difference between the archegonium at this stage in Anthoceros and the other Hepaticæ lies in the complete submersion of the archegonium rudiment in the former. In this 
respect Aneura, where the base of the archegonium is confluent with the cells of the thallus, offers an interesting transition between the other Hepaticæ, where the base of the archegonium is entirely free, and Anthoceros.

The archegonium rudiment divides into two tiers as in the other Liverworts, and the peripheral cells divide longitudinally, and here too the neck shows the six vertical peripheral rows although it is completely sunk. Later, the limits of the neck become often hard to determine, although by later divisions the central cell is surrounded by a pretty definite layer of cells. The axial cell divides into two of nearly equal size, but the inner one soon increases in breadth more than the upper one. The latter divides again by a transverse wall into an outer cell corresponding to the cover cell of the ordinary hepatic archegonium, the other to the primary neck canal cell. The cells of this central row soon become clearly different from the other through their more granular contents. The lower cell grows much faster than the others and divides into the egg cell and the ventral canal cell. The cover cell divides by a vertical wall into two nearly equal cells, and these usually, but not always, divide again, so that four cells arranged cross-wise form the apex of the archegonium. In $A$. fusiformis in nearly ripe archegonia I have sometimes been able to see but two of these cover cells, but ordinarily four are present. The neck canal cell divides first into two, and these then divide again, so that four cells are formed. This was the ordinary number in $A$. fusiformis. In a nearly ripe archegonium of $A$. levis five neck canal cells were seen, but in no cases so many as Janczewski ${ }^{1}$ describes for this species, where he says as many as twelve may be present.

If the earlier divisions in the archegonium of Anthoceros are compared with those of the other Hepaticæ, the most striking difference noticed is the separation of the cover cell. In the latter the first division of the axial cell separates the cover cell from an inner one, and by the division of the latter the primary neck canal cell is cut off from the central cell. In Anthoceros the neck canal cell is cut off from the outer, and not from the inner cell.

As the archegonium approaches maturity the cover cells become very much distended and project strongly above the surrounding cells. In stained microtome sections their walls

1 Janczewski (2), p. 415. 
colour very strongly, showing that they have become partially mucilaginous. This causes them to separate readily, and they are finally thrown off, so that in the open archegonium no trace of them is to be scen. The walls of the canal cells and the central cell undergo the same mucilaginous change, but here it is complete, and before the archegonium opens the partition walls of the canal cells completely disappear, and the neck contains a row of isolated granular masses corresponding in number to the canal cells. The ventral canal cell is quite as large as the egg, which consequently does not nearly fill the cavity at

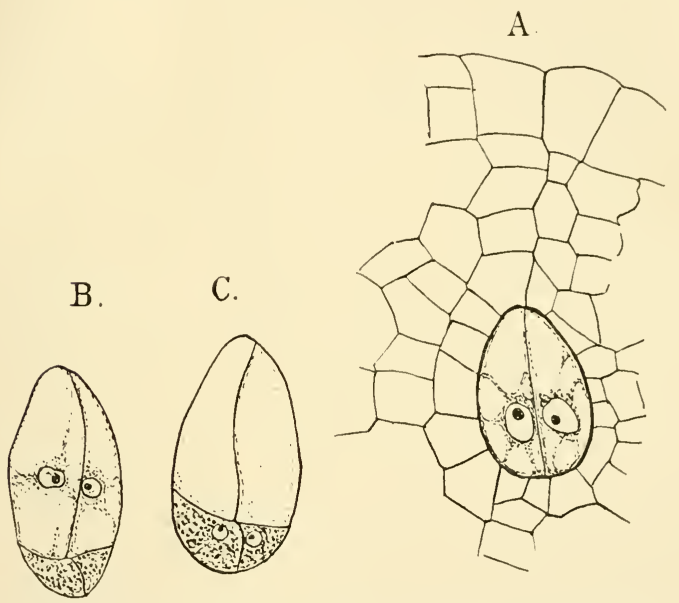

FiG. 59.-Anthoceros fusiformis (Aust.). A, two-celled embryo within the archegonium venter, $\times 600 ; \mathrm{B}, \mathrm{C}$, two longitudinal sections of a four-celled embryo, $\times 600$.

the base of the open archegonium (Fig. 57, D) after the canal cells have been expelled. The egg did not, in any sections studied, show clearly a definite receptive spot, but appeared to consist of uniformly granular cytoplasm with a nucleus of moderate size. The upper neck cells in the open archegonium become a good deal distended, and the canal leading to the egg is unusually wide. Surrounding the central cavity the cells are arranged in a pretty definite layer.

Hofmeister was the first to study the development of the embryo in Anthoceros, and described and figured correctly the 
first divisions, but his account of the apical growth, which he supposed was due to a single apical cell, and the differentiation of the archesporium, was shown by the careful investigation of Leitgeb ${ }^{1}$ to be erroneous. The following account is based upon a large series of preparations of $A$. levis and $A$. fusiformis, which seem to agree in all respects. After fecundation the egg at once develops a cellulose wall and begins to grow until it completely fills the centre cavity of the archegonium. As it grows the uniformly granular appearance of the cytoplasm disappears, and large vacuoles are formed, so that the whole cell appears much more transparent. The granular cytoplasm is now mainly aggregated about the nucleus, which has also increased in size (Fig. 57, E). The first division wall is parallel with the axis of the archegonium and divides the embryo into two equal parts, in which the character of the cells remains much as in the undivided egg. Here too the granules are most abundant about the nucleus, from which radiate plates that separate the vacuoles. The next divisions are transverse and divide the embryo into two upper large cells and two lower smaller ones. The embryo at this stage is oval and more or less pointed above. In each of the four primary cells vertical walls arise that divide the embryo into octants, but the upper octants are decidedly larger than the lower. Next, in the upper cells, transverse walls are formed and the embryo then consists of three tiers of four cells each. Of these the cells of the upper tier are decidedly the larger. At this stage, in neither species examined by me, were any traces present of the projection of the basal cells figured by Leitgeb. ${ }^{2}$ As his drawings were made from embryos that had been freed from the thallus, probably with the aid of caustic potash, it is quite possible that this appearance was due in part at least to the swelling of the cell walls through the action of the potash. At any rate in microtome sections of both species in these early stages, the basal cells do not project in the least (Fig. 6o, A). The next divisions are very uniform in the upper tier of cells, from which the capsule develops, but less so for the two lower ones. In the upper tier, seen in cross-section (Fig. 60, B I), a slightly curved wall running from the median wall to the periphery forms in each quadrant, which thus viewed is divided into an inner four-sided and an outer three-sided cell. In the former a

1 Leitgeb (7), vol. v.

${ }^{2}$ Leitgeb (7), vol. v. PI. I. 
periclinal wall next forms, which cuts off an inner square cell (Fig. 6o, D). In longitudinal section these periclinal walls are seen to be concentric with the outer walls of the cells, and to strike the median and quadrant walls at some distance below the apex of the sporogonium so as to completely enclose the central cells (Fig. 6o, C). By the formation of these first periclinal walls the separation of the columella from the wall of
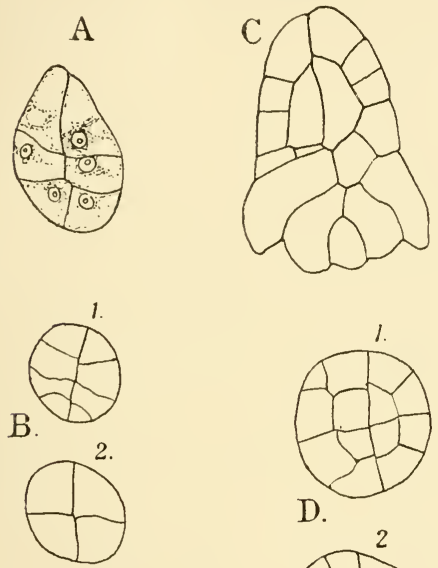

D.

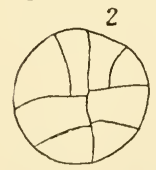

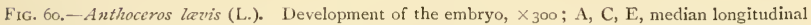
sections; $\mathrm{B}$ and $\mathrm{D}$, successive cross-sections of embryos of about the age of $\mathrm{A}$ and $\mathrm{C}$ respectively. In $\mathbf{E}$ the archesporium is differentiated.

the capsule is completed, and this is not unlike what obtains in the sporogonium of many other Hepaticæ; but an essential difference must be observed. In the latter the central group of cells forms the archesporium; here these cells, as we shall see, take no part in spore formation. In the lower tiers of cells similar but less regular divisions occur (Fig. 60, D 2), and the outer cells begin to grow out into root-like processes which push down among the cells of the thallus and obviously serve 
the purposes of haustoria. Leitgeb ${ }^{1}$ states that the foot arises only from the lowest of the primary tiers of cells, but in most of my sections of the earlier stages the fact that the foot was composed of two distinct layers of cells, corresponding in position to the two lower tiers of cells in the embryo, was very obvious (Fig. 60, E).

The origin of the archesporium in Anthoceros was in the main correctly shown by Leitgeb, ${ }^{2}$ but I find that the extent of the archesporium is less than he represents. In Pl. I. Figs. 3 and Io of his monograph on the Anthocerotex, he figures the archesporium as extending completely to the base of the columella. A large number of sections were examined, and in no case was this found to be so. Instead, it was only from the cells surrounding the upper half of the columella that the archesporium was formed. Previous to the differentiation of the archesporium the four primary cells of the columella divide by a series of transverse walls until there are about four cells in each row. Radial walls also form in the outer cells so that their number also increases, and the young capsule consists of the central columella composed of four rows of cells and a single layer of cells outside. The archesporium now arises by a series of periclinal walls in the peripheral cells of the upper half only of the capsule, and is thus seen to arise from the peripheral cells of the capsule, and not from the central ones. Fig. 6o, E shows a longitudinal section of the sporogonium at this stage. Three parts may be distinguished-the foot, the capsule, and an intermediate zone between. This latter is important, as it is from this that the meristematic part of the older sporogonium is formed. With the separation of the archesporium the apical growth ceases, and the future growth is intercalary.

In the capsule cell, divisions proceed rapidly in all its parts. The original four rows of cells forming the columella increase to sixteen, which is the normal number in the fully-developed sporogonium. The archesporium, by the formation of a second series of periclinal walls, becomes two-layered, and the wall outside the archesporium becomes about four cells thick, the outermost layer forming a distinct and well-developed epidermis.

The foot grows rapidly in size, but the divisions are very irregular, and finally it forms a large bulbous ap-

1 Leitgeb (7), vol. v.

${ }^{2}$ Leitgeb, l.c. 
pendage to the base of the sporogonium. The cells are large and the outer ones develop still further the root-like character of those in the young foot. The tissues of the thallus about the base of the sporogonium grow rapidly with it, and the connection between the surface cells of the sporogonium foot and the adjacent cells of the thallus is very intimate.

The subsequent growth of the capsule is entirely dependent upon the activity of the zone of meristem at its base. This divides very actively, and the divisions correspond exactly with the primary ones in the young embryo, so that the completed portions of the older parts of the capsule are continuous with the forming tissues at the base. A series of cross-sections at different points, compared with a median longitudinal section, shows in a most instructive way the gradual development of the different parts of the mature capsule (Fig. 62). The centre of the sporogonium is occupied by a columella composed of sixteen rows of cells, which in cross-section form a nearly perfect square. At the base these cells are thin-walled and show no intercellular spaces, but farther up their walls begin to thicken and the rows gradually separate until in the upper part the columella has somewhat the appearance of a bundle of isolated fibres. The archesporium is constantly growing from below, and the new cells are cut off

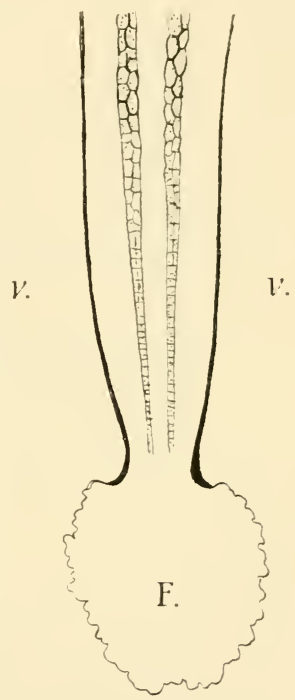

Fig. 6I.-Antroceros lavis (L.). Median longitudinal section through the base of the sporogonium. The archesporium is shaded. F, Foot; $v^{\prime}$, $\imath$, basal sheath, $\times$ ioo. from those surrounding the columella in the same way as at first. The archesporium, as well as the columella, can be traced down nearly to the base of the capsule, and its cells are very early recognisable both by their position and by their contents. At first but one cell thick, the archesporium soon becomes double, but does not advance beyond this condition. As the archesporium is followed from the base towards the apex of the capsule the cells begin to show a differentiation. 


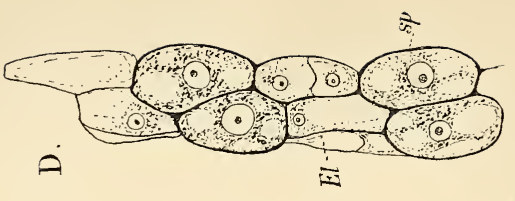

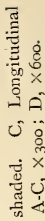

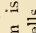

ह

눙

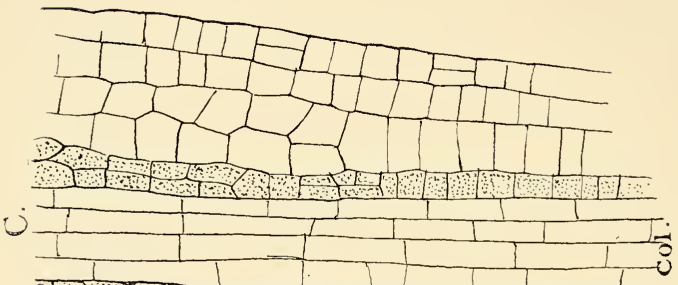

E

官

할

플

政

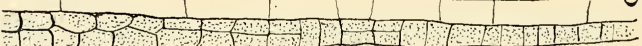
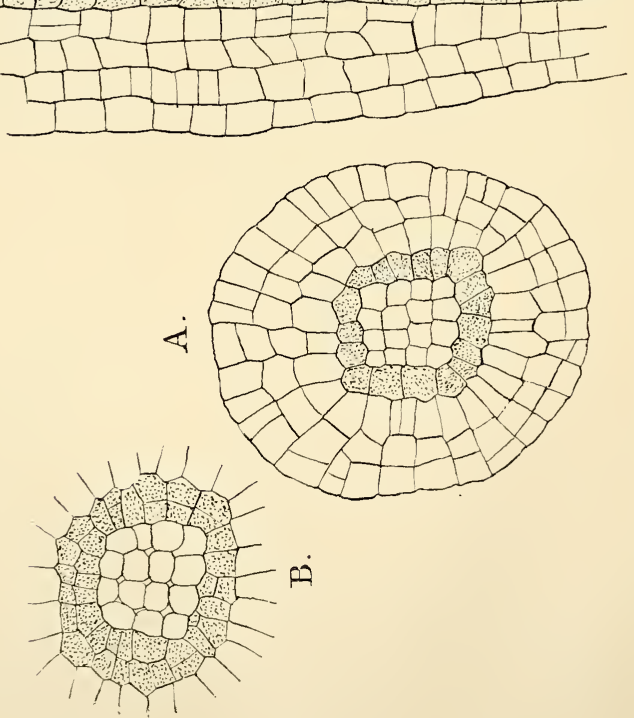

की 
Up to the point where the archesporium becomes divided into two layers the cells appear alike; but shortly after this their walls begin to separate, and two distinct forms are recognisable, arranged with much regularity in many cases, although this arrangement is not invariable. Pretty regularly alternating are groups of oval, swollen cells, with large nuclei and abundant granular cytoplasm, and much more slender ones, that may undergo secondary longitudinal divisions. The latter have smaller nuclei and more transparent contents. Examination higher up shows that the former are the spore mother cells, the others the elaters, which here have the character of groups of cells, and do not develop the spiral thickenings found in most Hepatice. As these two sorts of cells grow older they separate completely, and the spore mother cells become perfectly globular. The sterile cells remain more or less united, and form a sort of network in whose interstices the spores lie.

The development of the spores can be easily followed, at least in most of the details, in fresh material, and on this account it was among the first plants in which cell division was studied. ${ }^{1} \quad$ The mother cells in all stages can be found in the same sporogonium, and on account of their great transparency show the process of cell division very satisfactorily. The nucleus, however, is small, and its behaviour during the cell division is not so easy to follow. Strasburger ${ }^{2}$ has described this at length, and I can confirm his account. The mother cell, just before division, is filled with colourless cell sap, and the cytoplasm is confined to a thin film lining the cell wall. This cytoplasmic layer is somewhat thicker on one side, and here the nucleus is situated (Fig. 63, A). Lying close to the nucleus is a roundish body, of granular consistence and yellowish green in colour. This is a chloroplast, which at this stage is less deeply coloured than later. The chloroplast contains a number of granules, some of which are starch. The cell increases rapidly in size, and the nucleus, together with the chloroplast, moves away from the wall of the cell toward the centre, where they are suspended by cytoplasmic threads. The chloroplast next divides into two equal portions, which move apart (Fig. $63, \mathrm{~B})$, but remain connected by the cytoplasmic filaments. They approach again, and each dividing once more, the four 
resulting chloroplasts remain close together with the nucleus, in the centre of the cell.

Owing to the small amount of chromatin in the nucleus, the karyokinetic figures are small and the changes difficult to follow satisfactorily. Enough can be easily made out, however, to show that the process is in no way peculiar. There is first a nuclear spindle of the ordinary form, and the resulting nuclei assume the resting stage before dividing again. Each then divides again, and the four nuclei move to points equidistant from each other, and which are already occupied by the four chloroplasts. After this
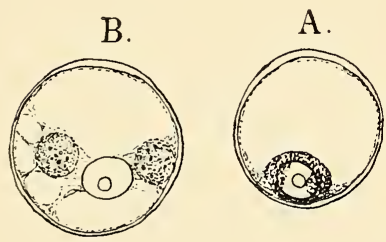

C.
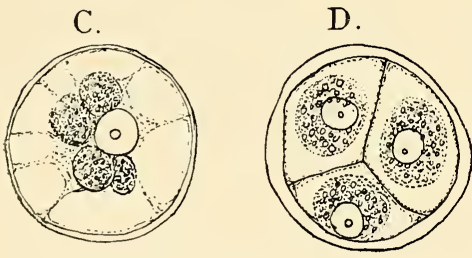

FIG. 63.-Spore division in A. fusiformis, optical sections of living cells, $\times 600$. is accomplished, cell walls arise simultaneously between the four nuclei, dividing the mother cell into four tetrahedral cells,--the young spores. The wall of the mother cell becomes thicker, and in the later stages swells up on being placed in water, so that it interferes a good deal with the study of the spores in the fresh condition. As the spores ripen they develop a thick exospore, which is yellow in colour and irregularly thickened in $A$. lavis, and in $A$. fusiformis black and covered with small tubercles. The chlorophyll disappears and the spore becomes filled with oil and other food materials. The spores remain together until nearly ripe. The elaters, if this name can properly be applied to the sterile cells, at maturity consist of simple or branching rows. of cells, which in some cases arise from the division of a single one; but more commonly, at least in A. lavis, where they branch, it is probable that they are to be looked upon as merely fragments of the more or less continuous network of sterile cells. The contents mainly disappear from the older elaters, and their walls become thick and in colour like the wall of the spores. 
In $A$. fusiformis they are longer and more symmetrical than in A. lavis, and in one group of the genus, according to Gottsche, ${ }^{1}$ the claters, which consist of a row of five to six cells, have a distinct spiral band as in Dendroceros. Leitgeb ${ }^{2}$ thinks, however, that this group is more nearly related to the latter genus than to Anthoceros proper, inasmuch as in addition to the peculiar elaters the epidermis of the capsule has no stomata, which are always present in typical species of Anthoceros.

If the epidermis from the young capsule is examined it is seen to be composed of elongated narrow cells much like those in the epidermis of elongated leaves of Monocotyledons. In the older parts some of these cells cease to elongate, and become

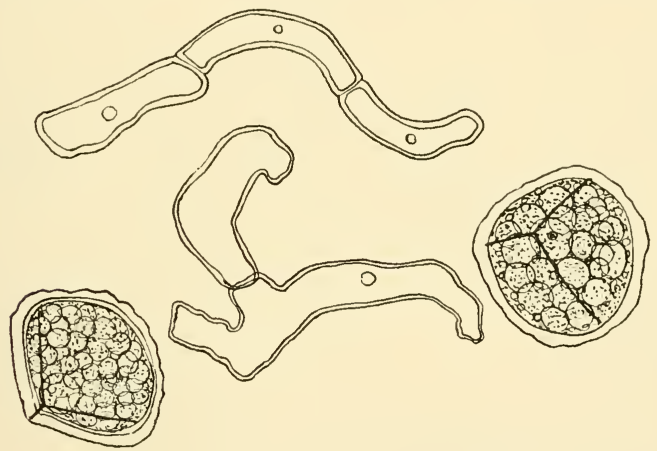

FIG. 64.-Ripe spores and elaters of -1 . Lavis, $\times 600$.

more nearly oval (Fig. 65, A). These are the young stomata, and exactly as in the vascular plants, each divides longitudinally by a septum which later separates in the middle and forms the pore surrounded by its two guard cells. The walls of the other epidermal cells become much thickened and distinctly striated. Each epidermal cell contains a single large chloroplast like that in the cells of the gametophyte, and between the cells are welldeveloped air-chambers communicating with the stomata, so that there is here a typical assimilative system of tissues.

About the base of the growing sporogonium is a thick tubular sheath representing in part the calyptra of the other Hepaticæ, but involving, besides the archegonium venter, also

1 Gottsche (2).

2 Leitgeb (7), vol. v. p. 27. 
the surrounding tissue of the gametophyte. This sheath keeps pace with the growth of the sporophyte for a long time, but finally the sporogonium grows more rapidly and projects far beyond it, and this remains as a tube surrounding its base. The growth of the sporogonium continues as long as the gametophyte remains alive, and in $A$. fusiformis is often 6 centimetres or more in length, and reaches nearly this length before the first spores are ripe and the capsule opens. This it does by splitting at the top into two equal valves between which the dried-up columella protrudes. The split deepens as the younger spores ripen, and may finally extend nearly to the base. It is quite possible, although this point was not

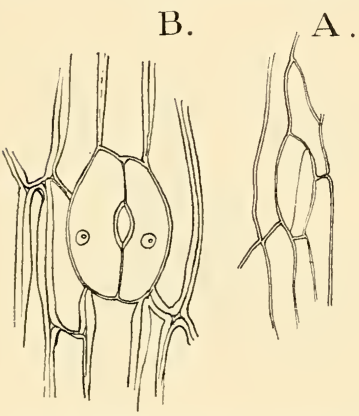

FiG. 65.-A, young; B, fully developed stoma from the epidermis of the sporogonium of $A$. lcevis, $\times 250$. investigated, that the line of dehiscence corresponds to the primary vertical wall in the embryo, as is the case in the Jungermanniaceæ.

The germination of the spores $^{1}$ has hitherto been observed only in A.lavis. A study of the germination in $A$. fusiformis shows a general correspondence with the results of other observers, but certain points were brought out that do not seem to have been observed in A. lavis. The spores of $A$. fusiformis are protected by a perfectly opaque black exospore, which is covered with small spines or tubercles. These spores will not germinate readily when fresh, but after resting for a few months grow freely. As in other similar spores, the exospore is ruptured along the three ridges upon the ventral side (i.e. that with which it was in contact with the other spores of the tetrad), and through this cleft the endospore protrudes as a papilla which sometimes grows into a very long germ tube, or more commonly divides before it reaches a great length. Into this tube passes the single chromatophore which, during the early period of germination, has resumed its green colour, and with it the oil drops and other contents of the spore. A good deal of variation was observed here in the

I Hofmeister (I); Grönland (I); Leitgeb (7), vol. v. p. 29. 
first divisions, as is the case in A. lavis. The first division wall is, in most cases at least, transverse, and is usually followed by a second similar one, before any longitudinal walls appear. Then in the end cell two intersecting walls and the formation of four terminal quadrant cells are often seen (Fig. 66, D), as in other Hepaticæ. Variations from this type are often met with, and some of these are shown in the figures. Very commonly a second cell is cut off by an oblique wall from the germ tube subsequent to the first transierse wall, but this does not, at least in the early stages, devclop into a root-hair, the

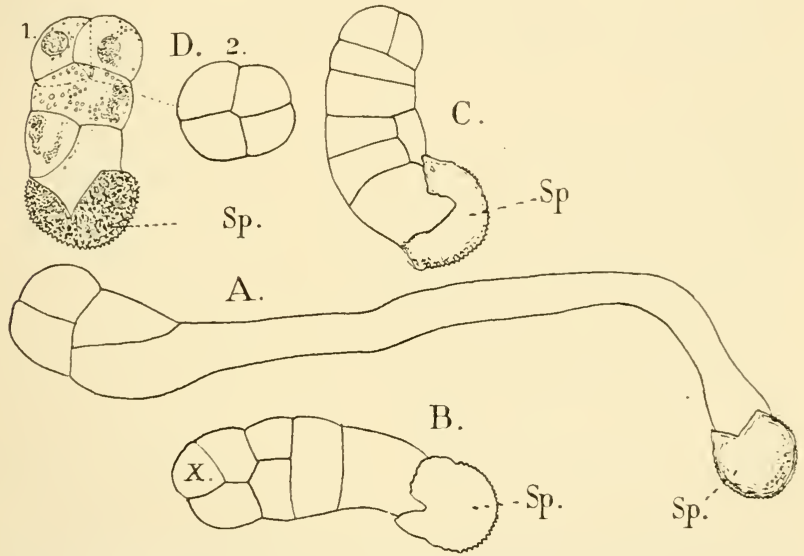

Fig. 66.-Anthoceros fusiformis (Aust.). Germination of the spores, $\times 250$. A shows a form with very long germ tube; in $\mathrm{B}$ there seems to be a definite apical cell. Fig. D, 2, is an apical view of $\mathrm{D}, \mathrm{I}$.

first root-hair being met with only after the young plant has become a cell body of considerable size (Fig. 67).

Whether the young plant regularly grows from a single apical cell is difficult to say, but it seems probable, and numerous forms like Fig. 66, B were encountered where there certainly seemed to be a two-sided apical cell, such as occurs so often in other Hepaticæ. At a later stage (Fig. 67, B) a single apical cell of the form found in the mature thallus is unmistakably present. By this time the marginal lobes that give this species its peculiar crimped appearance begin to develop. They arise close to the growing point, and grow rapidly beyond it, but do 
not show any definite apical growth. The plant at this stage has a striking resemblance to the prothallium of Equisetum. With the appearance of the marginal lobes, the first of the mucilage slits appears upon the ventral surface (Fig. 67), and from time to time surface cells grow out into the delicate rhizoids, and a little later the first dichotomy of the growing point takes place. Up to this time the young plants appeared entirely free from Nostoc, but soon after they were found to be infected, which no doubt was connected with the formation of the mucilage slits through which the Nostoc enters the thallus.

Dendroceros includes about a dozen species of tropical Liver-
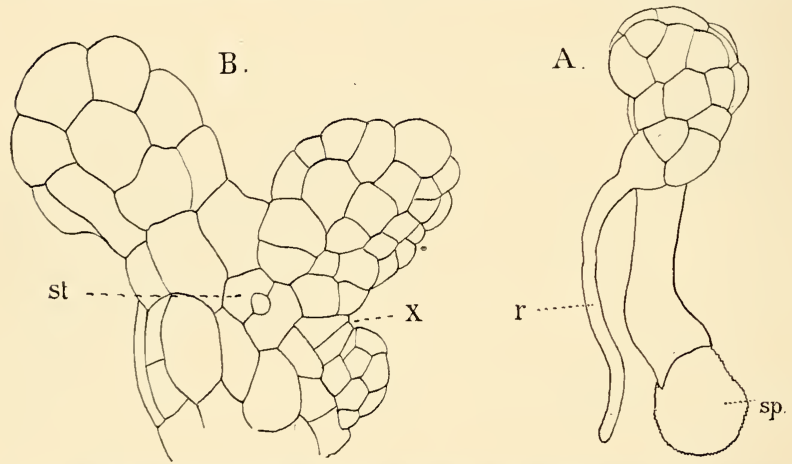

FiG. 67.-Anthoceros fusiformis (Aust.). A, Young plant showing the first rhizoid ( $r) ; \mathrm{B}$, upper part of an older one with the first mucilage cleft $(s t) ; x$, the growing point, $\times_{215}$.

worts, which are distinguished at once from Anthoceros by the very characteristic form of the thallus. This has a massive midrib, projecting below, but the rest of the thallus is but one cell thick and forms lateral wings which are much folded and lobed, so that the aspect of the plant is somewhat like a Fossombronia. As in Anthoceros, some species have a perfectly compact thallus without intercellular spaces (D. cichoraceus), while in others these are very much developed and the thallus has a more or less spongy texture, i.e. D. Javanicus. This development of the thallus and sporogonium has been studied only by Leitgeb, ${ }^{1}$ and in the main seems to correspond very 
closely to Anthoceros. A difference may be noted, however, in some details. Thus the form of the apical cell is like that of Pellia epiphylla, where the inner segments extend the whole depth of the thallus, and the division into dorsal and ventral segments is secondary. The formation of the wings begins near the apex and is the result of the growth of the marginal cells, which project strongly and divide rapidly by vertical walls only. The walls of the cells are thickened at the angles, and the surface view is curiously like a cross-section of the collenchyma of many vascular plants. As in Anthoceros mucilage slits are formed, sometimes on both surfaces of the thallus, and through these the plant is infected with Nostoc, as in the other Anthoceroteæ. In Dendroceros the Nostoc colonies are very large and cause conspicuous swellings upon the thallus.

All the species of Dendroceros, according to Leitgeb, are monocious, and the development of the sexual organs appears to be the same as in Anthoceros. The antheridia are very large and borne singly in cavities whose upper wall projects above the surface of the midrib. So far as is known the origin and development correspond closely to those of Anthoceros, except that the stalk is much longer and has but two rows of cells, which probably indicates that but one longitudinal wall is formed in the antheridial cell before the transverse walls that separate stalk and capsule. Gemma occur in some species (D. cichoraceus, D. Javanicus), and are roundish cell masses developed from single cells of the lamina. So far as could be determined from incomplete material, the conclusion was reached by Leitgeb that Dendroceros approaches Anthoceros very closely in the development of the sporogonium. The origin of the columella, which usually in the later stages is composed of more than sixteen rows of cells, and the differentiation of the archesporium, seem to be exactly the same, and the further development of the large bulb-like foot and the formation of the spores and elaters are the same. The spores are larger, and the elaters (Fig. 74, B) provided with distinct spiral bands. In none of the species examined by Leitgeb did he find any traces of stomata upon the capsule, and concludes that they are entirely wanting in this genus, which in this respect, as well as in the character of the elaters, approaches closely one section of the genus Anthoceros. The spores, as in Pellia and Conocephalus, germinate within the capsule, and at the time of 
dispersal are already multicellular. Apparently no germ tube is formed, but the spores develop at once into a cell mass upon which, while still very young, the mucilage clefts are developed, and at an early stage the infection by the Nostoc cells is effected. The growth of the older capsule and gradual development of the spores are the same as in Anthoceros.

The third genus, Notothylas, is of especial interest, because it was largely upon the results of his investigations upon this plant that Leitgeb ${ }^{1}$ based his theory of the close relationship of the Anthoceroteæ and Jungermanniaceæ. All of Leitgeb's observations on the young capsule were made from herbarium material, and, as he himself admits, were in all cases embryos that had not fully developed. The writer has made a very complete examination of the commonest American species, $N$. orbicularis (valvata), and the results of the study of the development of the sporogonium differ so much from those of Leitgeb that they will be given somewhat in detail.

The thallus much resembles a small Anthoceros, and sections through it show that in its growth and the development and structure of the sexual organs there is close correspondence. The thallus contains very large lacunæ, which are formed in pretty regular acropetal order, and vertical sections show these large cavities increasing regularly in size as they recede from the apex. Similar but less regular lacunæ occur in $A$. fusiformis. The antheridia arise as in Anthoceros, endogenously. The youngest stage found is shown in Fig. 68, A. Here evidently the young antheridia ( $\hat{o}$ ) have been formed by the longitudinal division of a single hypodermal cell, whose sister epidermal cell has divided again by a transverse wall to form the outer wall of the antheridial cavity (Figs. A, B). The commonest number of antheridia formed is four.

Less regularity is found in the next divisions than in Anthoceros, although in the main they are the same. This is observable both in longitudinal and cross-sections (see Fig. 68, D). The full-grown antheridium is more flattened than in either species of Anthoceros examined by me, and the stalk shorter and thicker, but otherwise closely resembles it, although the extremely symmetrical arrangement of the cells, especially of the wall, is much less noticeable.

The archegonia correspond very closely, both in position 
and structure, with those of the other genera, the most marked peculiarity being the more nearly equal diameter of the cover cell and central cell, and a corresponding increase in the breadth of the neck canal cell. Subsequently the central cell becomes much enlarged and the appearance of the fully-developed archegonium is very much like that of Anthoceros (Fig. 69, A). As in $A$. fusiformis, the usual number of neck canal cells seems to be four, and in no case did the number exceed five. The cover cells were four in number in all the archegonia studied, and are
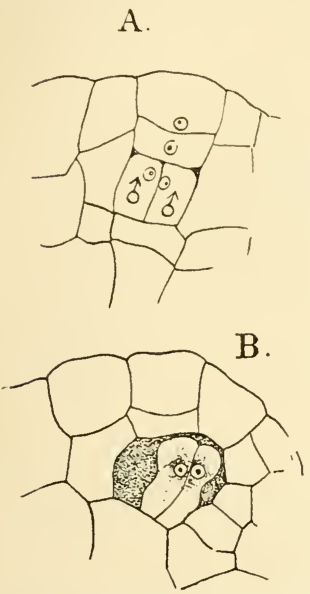

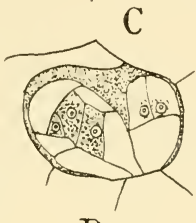

D.
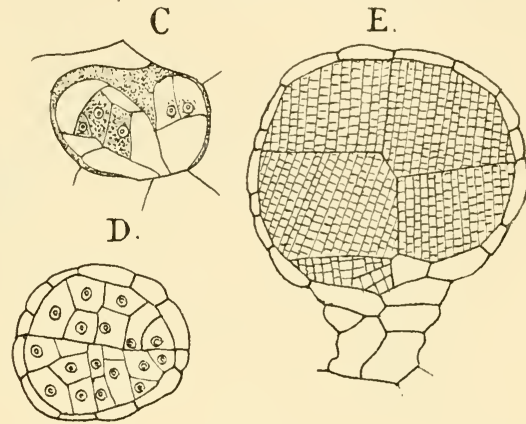

FiG. 68.-Notothylas orbicularis (Sull.). Development of the antheridium. D, cross-section, the others longitudinal sections; E, nearly ripe antheridium, $\times 300$, the other figures $\times 600$; $\delta$, A, the primary antheridial cells.

larger than in Anthoceros. As in that genus, they are thrown off when the archegonium opens.

The youngest embryo found was composed of four cells, and presented quite a different appearance from the corresponding stage in Anthoceros. It is impossible from this stage to tell whether the first wall in the embryo is vertical or transverse. This embryo consisted of four nearly equal quadrants, instead of having the two upper cells larger than the lower ones. By comparison with the older stages there is little doubt that here the first transverse wall separates the foot from the capsule, as in Spharocarpus, and that the upper cell 
develops directly into the capsule instead of the latter being determined by the second transverse walls. In the next youngest stages found (Fig. 7I, B) the archesporium was already differentiated. A comparison of this with the corresponding stage of Anthoceros shows conclusively that the two are practically identical in structure. The columella, evidently formed as in Anthoceros, and as there made up of four rows of cells, is surrounded by the archesporium cut off from the peri-

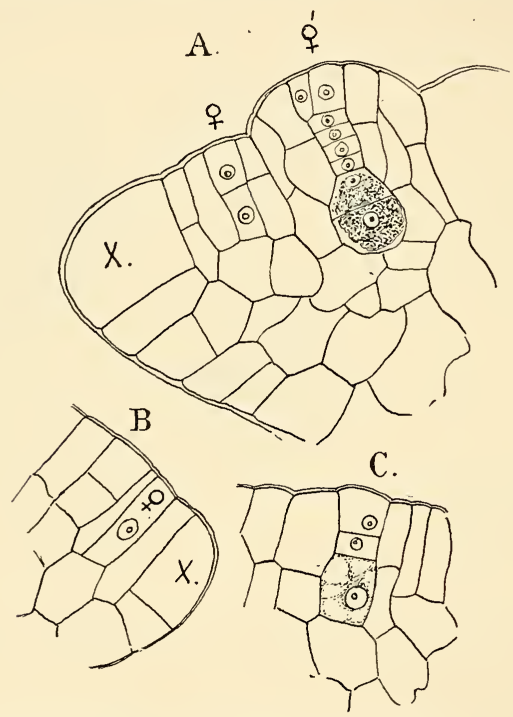

FIG. 69.-Notothylas orbicularis (Sull.). Development of the archegonium, $\mathrm{x} 600 ; x$, the apical cell.

pheral cells. Leitgeb's surmise that the columella is a secondary formation is, therefore, for $N$. orbicularis at least, entirely erroneous, and it is extremely likely that when normal specimens of the other species are examined from microtome sections, in the young stages at least, a similar columella will be found. The single embryo that Leitgeb ${ }^{1}$ figures of $N$. orbicularis (valvata) is at once seen to be abnormal, and as his conclusions were drawn from a study of similar dead embryos 
in the other species, they cannot be accepted without more satisfactory evidence. While in the main corresponding to the embryo of Anthoceros there are some interesting differences which are closely associated with the structure of the older sporogonium. The foot is smaller than in Anthoceros and derived only from the lowest tier of cells. The columella is decidedly smaller, and the archesporium, as well as the young sporogonium wall, relatively much thicker. As in Anthoceros, the archesporium does not extend to the foot, but is separated by the zone of cells which there give rise to the meristem at the
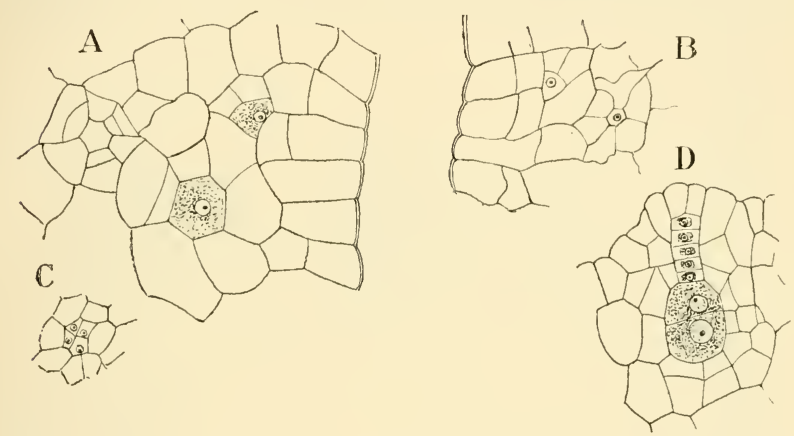

Fig. 70.-Notothylas orbicularis (Sull.). A, B, Horizontal sections of the growing point with young archegonia; $\mathrm{C}$, cross-section of the apex of an archegonium, showing the arrangement of the cover cells; $\mathrm{D}$, longitudinal section of a nearly ripe archegonium, $\times_{4} 00$.

base of the capsule. The form of the embryo is different too. It is pear-shaped and more elongated than in Anthoceros.

As the embryo develops these differences become more apparent and others arise. Fig. 7 I, C shows a stage where the division of the archesporial cells has begun, and it is at once apparent how much more conspicuous they are. It is seen too that the outer cells of the upper part of the capsule are also dividing actively, and that, compared with Anthoceros, the apical part of the capsule retains its meristematic character for a much longer period. Corresponding with this, the growth at the base of the capsule is much less marked. The divisions in the archesporium are much more active than in Anthoceros, and also less regular. At first divisions occur in the upper portion in all directions, so that above the columella there is 
a mass of archesporial tissue much thicker than that below, and occupying very much more space than the corresponding tissue in Anthoceros. Longitudinal sections through the basal part of the older sporogonium show an arrangement of tissues similar to those in Anthoceros, but there are differences corresponding to those in the young stages. The foot (Fig. 72, A) is much smaller and flatter, and sometimes shows a very regular structure. The central part is composed of a compact mass of rather large cells, between which and the base of the capsule is a narrow zone of meristematic tissue. The superficial cells do not always grow out into the root-like processes found in Anthoceros
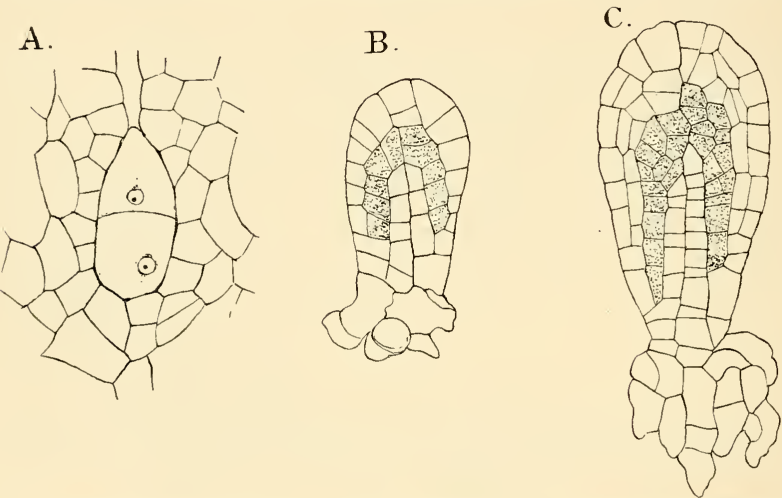

FiG. 71.-Notothylas orbicularis (Sull.). A, Four-celled embryo; B, C, older embryos, in longitudinal section. The archesporial cells are shaded. A, $\times 450 ; \mathrm{B}, \mathrm{C}, \times_{225}$.

and Dendroceros, but may remain short and project but slightly. The cells are characterised by abundant granular cytoplasm and conspicuous nuclei, showing that they are probably not only absorbent cells, but also elaborate the food materials taken in from the gametophyte. The gradual transition of the differentiated tissues above into the meristem at the base, is precisely as in Anthoceros, and sections at that point in the two genera can scarcely be distinguished from one another. The columella (in longitudinal section) in both shows four parallel rows of cells, outside of which lies the single row of archesporial cells, and four rows of cells belonging to the wall of the capsule.

As the section is examined higher up, however, there are 
marked differences, especially in the divisions of the arche-

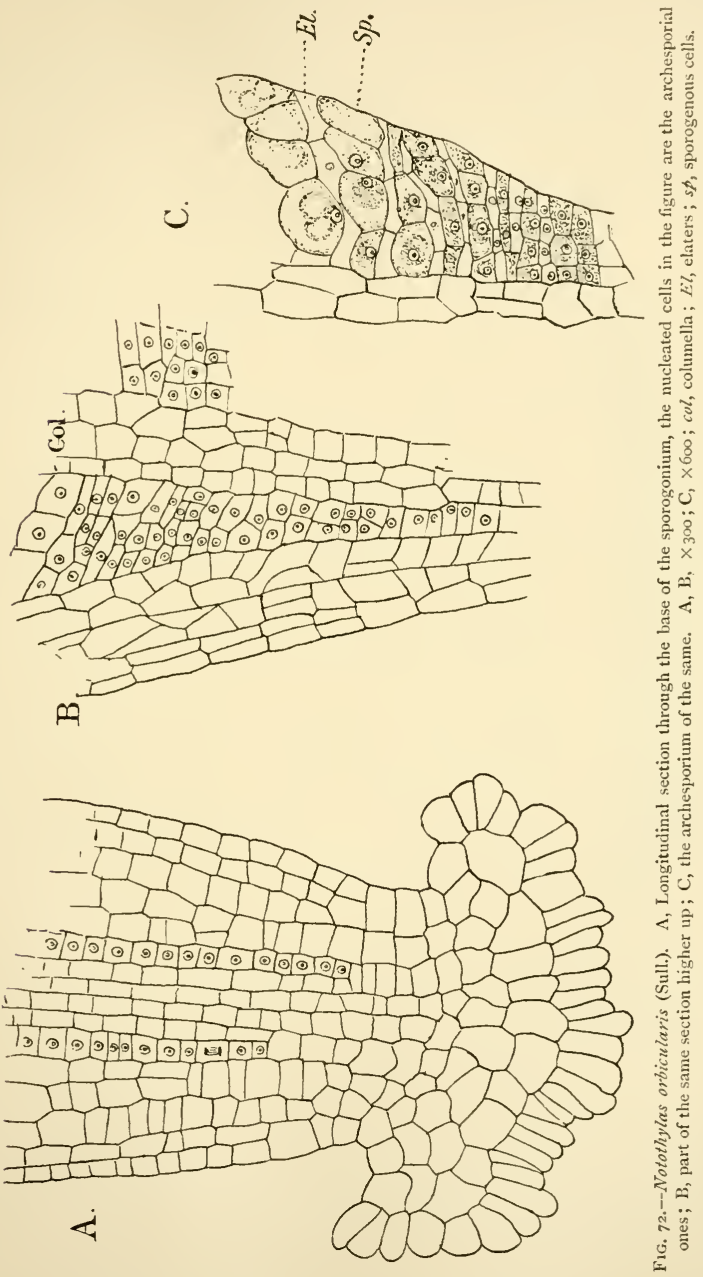

sporium. The first divisions in the archesporium of Notothylas 
are periclinal, and for a short distance it is two-layered, as it is permanently in Anthoceros; but still further up it widens very rapidly by the formation of repeated periclinal walls, and soon comes to be much thicker than either the columella or the capsule wall. A further study of the developing archesporium shows that the divisions occur with a good deal of regularity. The archesporial cells are divided by alternating vertical and transverse walls into four layers of cells instead of two, as in Anthoceros, and these cells are arranged in regularly placed

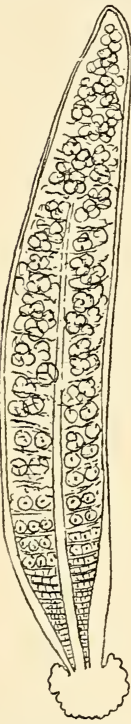

Fig. 73.--LongitudinaI section of a nearly ripe sporogonium of N.orbicularis, $\times 50$. transverse rows. At first the cells appear alike, but later there is a separation into sporogenous and sterile cells as in Anthoceros. Each primary transverse row of cells becomes divided into two. The upper row grows much faster, and its cells become swollen and the cytoplasm more granular, while the lower row has its cells remaining flattened and more transparent, i.e. there is a separation of the archesporium into alternate layers of sporogenous and sterile cells as in Anthoceros, but here the number of cells is double that in the latter, and the longer axis of the cells is transverse instead of vertical. In the portion of the archesporium above the columella these alternate layers of spore mother cells and sterile cells extend completely across the cavity, and Leitgeb ${ }^{1}$ has correctly figured this, although he probably was mistaken in assuming that this arrangement extended to the base of the capsule.

The further development of the capsule is much like that of Anthoceros, but the division of the chloroplast takes place before the spore mother cells are isolated, and the primary chloroplast is evident almost as soon as the sporogenous cells are recognisable as such. The cells of the columella do not become as elongated as in Anthoceros, and develop thickenings much like those of the sterile cells of the archesporium, and it was this partly that led Leitgeb ${ }^{2}$ to the conclusion that even where a definite columella was present it probably arose as a secondary formation in the archesporium, similar 
to the formation of the axial bundle of elaters in Pellic, and that in Notothylas as in the Jungermanniacex, the archesporium arose from the inner of the cells formed by the first periclinal walls, and not from the outer ones. That this is not true for $N$. orbicularis is shown beyond question from sections of both the older and younger sporogonium, and it would be extremely strange if the other species should differ so radically from this one as would be the case were Leitgeb's surmise correct.

The wall of the capsule does not develop the assimilative apparatus of the Anthoceros capsule, and stomata are completely absent from the epidermis. The inner layers of cells are more or less completely disorganised, and they probably serve to nourish the growing spores, which here, of course, are correspondingly more numerous than in Anthoceros. As there, the sterile cells form a series of irregular chambers in which the spores lie. At maturity these sterile cells separate into irregular groups (Fig. 74, C). Their walls are marked with short curved thickened bands, yellowish in colour like the wall of the ripe spores. At maturity the capsule projects but little beyond its sheath, and opens by two valves. In some species, e.g. $N$. melanospora, the capsule often opens irregularly.

The Anthocerotex form a most interesting series of forms among themselves, but are also of the greatest importance in the study of the origin of the higher plants. Unquestionably Notothylas represents the form which comes nearest to the other Liverworts, but until the other species are investigated further we shall have to assume that the type of the sporogonium is essentially different from that of the lower Hepaticæ, and corresponds to that of the other Anthocerotex. The primary formation of the columella and the subsequent differentiation of the archesporium occur elsewhere only in the Sphagnacex. From Notothylas, where the archesporium constitutes the greater part of the older sporogonium, and the columella and wall are relatively small, there is a transition through the forms with a relatively large columella to Dendroceros, where the spore formation is much more subordinated and a massive assimilative tissue developed. In Notothylas the secondary growth of the capsule at the base, while it continues for some time, is checked before the capsule projects much beyond its sheath. In Dendroceros the growth continues much 
longer, although it does not continue so long as in Anthoceros.

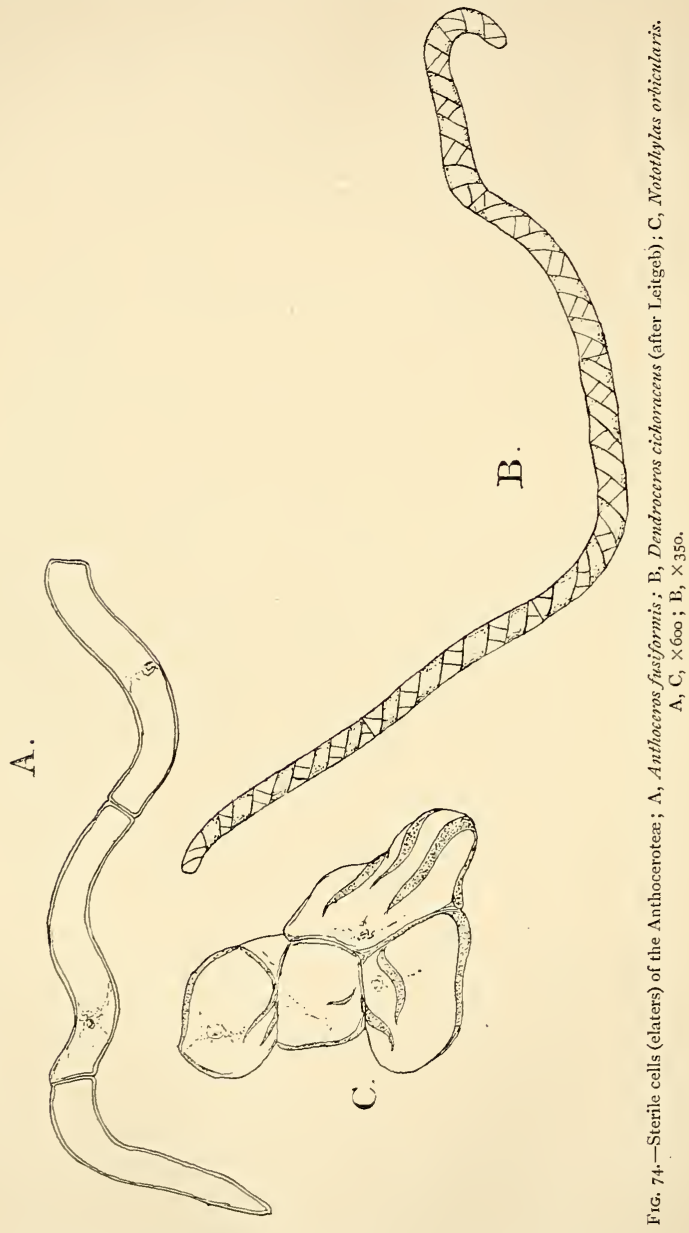

The assimilative system of tissue in the latter is finally completed by the development of perfect stomata, and the growth 
of the capsule is unlimited. All that is needed to make the sporophyte entirely independent is a root connecting it with the earth.

\section{The Inter-relationships of the Hepatice}

From a review of the preceding account of the Liverworts, it will be apparent that these plants, especially the thallose forms, constitute a very ill-defined group of organisms, one set of forms merging into another by almost insensible gradations, and this is not only true among themselves, but applies also to some extent to their connection with the Mosses and Pteridophytes. The fact that the degree of development of gametophyte and sporophyte does not always correspond makes it very difficult to determine which forms are to be regarded as the most primitive. Thus while Riccia is unquestionably the simplest as regards the sporophyte, the gametophyte is very much more specialised than that of Aneura or Spharocarpus. The latter is, perhaps, on the whole the simplest form we know, and we can easily see how from similar forms all of the other groups may have developed. The frequent recurrence of the two-sided apical cell, either as a temporary or permanent condition in so many forms, makes it probable that the primitive form had this type of apical cell. From this hypothetical form, in which the thallus was either a single layer of cells or with an imperfect midrib like Spharocarpus, three lines of development may be assumed to have arisen. In one of these the differentiation was mainly in the tissues of the gametophyte, and the sporophyte remained comparatively simple, although showing an advance in the more specialised forms. The evolution of this type is illustrated in the germinating spores of the Marchantiaceæ, where there is a transition from the simple thallus with its single apical cell and smooth rhizoids to the complex thallus of the mature gametophyte. In its earlier phases it resembles closely the condition which is permanent in the simpler anacrogynous Jungermanniaceæ, and it seems more probable that forms like these are primitive than that they have been derived by a reduction of the tissues from the more specialised thallus of the Marchantiacex. Spharocarpus, showing as it does points of affinity with both the lower Marchantiaceæ and the anacrogynous Jungermanniaceæ, probably represents more nearly than any other known form 
this hypothetical type. Its sporogonium, however, simple as it is, is more perfect than that of Riccia, and if our hypothesis is correct, the Marchantiaceæ must have been derived from Spharocarpus-like forms in which the sporophyte was still simpler than that of existing species. Assuming that this is correct, the further evolution of the Marchantiaceæ is simple enough, and the series of forms from the lowest to the highest very complete.

In the second series, the Jungermanniacex, starting with Spharocarpus, the line leads through Aneura, Pellia, and similar simple thallose forms, to several types with more or less perfect leaves-i.e. Blasia, Fossombronia, Treubia, Haplomitrium. These do not constitute a single series, but have evidently developed independently, and it is quite probable that the typical foliose Jungermanniaceæ are not all to be traced back to common ancestors, but have originated at different points from several anacrogynous prototypes.

The systematic position of the Anthocerotex is more difficult to determine, and their connection with any other existing forms known must be remote. While the structure of the thallus and sporogonium in Notothylas shows a not very remote resemblance to the corresponding structures in Spharocarpus, it must be remembered that the peculiar chloroplasts of the Anthoceroteæ, as well as the development of the sexual organs, are peculiar to the group, and quite different from other Liverworts. To find chloroplasts of similar character, one must go to the green Algæ, where in many Confervaceæ very similar ones occur. It is quite conceivable that the peculiarities of the sexual organs may be explained by supposing that those of such a form as Spharocarpus, for example, should become coherent with the surrounding envelope at a very early stage, and remain so until maturity. In Aneura we have seen that the base of the archegonium is confluent with the thallus, in which respect it offers an approach to the condition found in the Anthocerotex; but that this is anything more than an analogy is improbable. The origin of the endogenous antheridium must at present remain conjectural, but that it is secondary rather than primary is extremely likely, as we know that occasionally the antheridium may originate superficially. In regard to the sporogonium, until further evidence is brought forward to show that Notothylas may have the columella absent 
in the carly stages, it must be assumed that its structure in the Anthocerotex is radically different from that of the other Liverworts. Of the lower Hepatica Spherocarpus perhaps offers again the nearest analogy to Notothylas, but it would not be safe at present to assume any close connection between the two. Of course the very close relationships of the three genera of the Anthocerotex among themselves are obvious.

On the whole, then, the evidence before us seems to indicate that the simplest of the existing Hepaticx are the lower thallose Jungermanniacex, and of these Spharocarpus is probably the most primitive. The two lines of the Marchantiacex and Jungermanniaceæ have diverged from this common ancestral form and developed along different lines. The Anthocerotex cannot certainly be referred to this common stock, and differ much more radically from either of the other two lines than these do from each other, so that at present the group must be looked upon as at best but remotely connected with the other Hepaticæ, and both in regard to the thallus and sporophyte has its nearest affinities among certain Pteridophytes. The possibility of a separate origin of the Anthoceroteæ from Coleochatelike ancestors is conceivable, but it seems more probable that they have a common origin, very remote, it is true, with the other Liverworts. 


\section{CHAPTER VI}

THE MOSSES (MUSCI): SPHAGNACEÆ-ANDREÆACE $Æ$

THE Mosses offer a marked contrast to the Hepaticæ, for while the latter are pre-eminently a generalised group, the Mosses with a very few exceptions are one of the most sharply-defined and specialised groups of plants known to us. Although much outnumbering the Liverworts in number of species, as well as individuals, the differences in structure between the most extreme forms are far less than obtain among the Liverworts. While the latter occur as a rule in limited numbers, and for the most part where there is abundant moisture, the Mosses often cover very large tracts almost to the exclusion of other vegetation, especially in northern countries. In more temperate regions, the familiar peat-bogs are the best known examples of this gregarious habit. Mosses are for the most part terrestrial, and are found in almost all localities. Some grow upon organic substrata, especially decaying wood, and are to a greater or less extent saprophytic. Haberlandt ${ }^{1}$ first called attention to this, and investigated a number of forms, among them Rhynchostegium murale, Eurynchium pralongum, Webera nutans, and others, and in these found that the rhizoids had the power of penetrating the tissue of the substratum, much as a fungus would do. The most remarkable case, however, is Buxbaumia, where the leaves are almost completely absent and the saprophytic habit very strongly pronounced. Most of the Mosses, however, are abundantly provided with assimilative tissue, and grow upon almost every substratum, although most of them are pretty constant in their habitat. A number of species are typically aquatic, i.e. Fontinalis and many species of Sphagnum and

1 Haberlandt (4). 
Hypnum; others grow regularly in very exposed situations on rocks, e.g. Andreac. Very many, like Funaria hygrometrica and Atrichum undulatum, grow upon the earth; and others again, like species of Mnium and Thuidium, seem to grow exclusively upon the decaying trunks of trees. Indeed Mosses are hardly absent from any locality except salt water. With the exception of the Sphagnacer and Andrexacex, and possibly Archidium, the type of structure found among the Mosses is extraordinarily constant, and they may all be unhesitatingly referred to a single order, the Bryaceæ, which includes within it an overwhelming majority of the species.

The gametophyte of the Musci always shows a well-marked protonema, which in most cases has the form of an extensively branching alga-like filamentous structure, from which later a distinct leafy axis arises as a lateral bud. In Sphagmum this protonema is a flat thallus, and the same is true of Tetraphis and a few other forms, but the filamentous protonema is very much more common. The gametophore arises from this protonema as a lateral bud, which develops a pyramidal apical cell, from which three sets of segments are cut off, each segment developing a leaf. The only exception to this, so far as is known at present, is the genus Fissidens, ${ }^{1}$ where the apical cell is wedge-shaped, and only two sets of segments are formed. Upon these leafy branches the sexual organs are borne. The relative degree of development of the protonema and the gametophore differ much in different forms. Thus in the Phascaceæ the protonema is permanent, and the gametophore small and poorly developed. In the higher ones, the protonema disappears more or less completely, and the assimilative functions are entirely assumed by the large highly developed gametophore, which is capable of reproducing itself by direct branching without the intervention of the protonema. The commonest form of gametophore is the upright stem with the leaves arranged radially about it, but in many creeping forms, such as some species of Mnium, Hypmum, etc., the gametophore is more or less dorsiventral; but in these the apical cell is pyramidal, and produces three rows of leaves. Growing out from the base of the stem in most Mosses, and fastening it to the substratum, are numerous brown rhizoids which are not, however, morphologically distinct from the protonema. Thus if a turf of growing 
Moss is turned upside down, the rhizoids thus exposed to the light very soon develop chlorophyll, and grow out into normal protonemal filaments.

In most of the Mosses the leaves show a one-layered lamina traversed by a midrib, which may be quite small or very massive. This midrib is made up in part of elongated thickwalled sclerenchyma, and is obviously a conducting tissue. The highest grade of development of the leaf is met with in Polytrichum, where the midrib is very massive and peculiar vertical laminæ of chlorophyll-bearing cells grow out from the surface of the leaf. In Buxbaumia the leaves are almost entirely abortive. The peculiar leaves of Sphagnum will be referred to later, as well as the details of structure of the leaves of other forms.

The stem, except in the lowest forms, is traversed by a well-defined central strand of conductive tissue, and in a few of the highest ones, e.g. Polytrichum, there are in addition smaller bundles, continuations of the midribs of the leaves, recalling the "leaf-traces" found in the stems of Spermaphytes.

The forms of non-sexual reproduction among the Musci are extraordinarily various, and a careful study of them shows that the morphological connection between the protonema and gametophore is a very intimate one, as they may arise reciprocally one from the other. With the exception of certain resting buds developed from the protonema it appears ${ }^{1}$ that the formation of the leafy stem is always preceded by the protonema. The latter arises primarily from the germinating spores, but may develop secondarily from almost any part of the gametophore or even in exceptional cases from the cells of the sporophyte. ${ }^{2}$ From these protonemal filaments new gametophores arise in the usual way. The gametophore itself, especially where it is large and long lived, by the separation of its branches rapidly increases the number of new individuals. This is especially marked in Sphagmum, where this is the principal method of propagating the plants. Special organs of propagation in the form of gemmæ also occur, and these may develop from the protonema or from the gametophore. Tetraphis pellucida (Fig. I O5) is a good example, showing these specialised gemmæ which after a time germinate by giving rise to a protonema upon which, as usual, the gametophore arises

\footnotetext{
1 Goebel (10), p. 170.
}

2 Pringsheim (2); Stahl (I). 
as a bud. In size the gametophore of the Mosses ranges from a millimetre or less in height in Buxbaumia and Ephemerum to 30 to $50 \mathrm{~cm}$. in the large Polytrichacea and Fontinalis. The branching of the gametophore is never dichotomous, and so far as is known the lateral branches arise, not in the axils of the leaves, but below them. Underground stems or stolons,

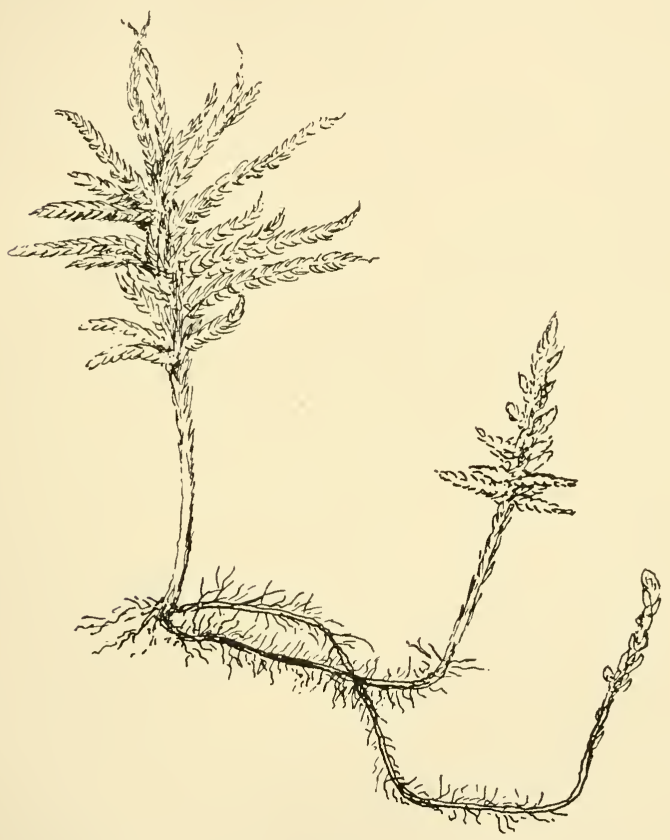

FIG. 75.-Climacinm Americanum (Brid.), showing the formation of stolons, $\times 2$.

which afterwards develop into normal leafy axes, are common in many forms, e.g. Climacium (Fig. 75).

The sexual organs are borne either separately or together at the summit of the gametophoric branches. Where the plants are diœcious, it sometimes happens that the two sexes do not grow near together, in which case, although archegonia may be plentiful, they fail to be fecundated and thus no cap- 
sules are developed. This no doubt accounts for the extreme rarity of the sporogonium in many Mosses, although in other cases, e.g. Sphagnum, it would appear that the formation of the sexual organs is a rare occurrence. These resemble in general those of the Hepaticæ, but differ in some of their details. The leaves surrounding them are often somewhat modified, and in the case of the male plants (Atrichum, Polytrichum) different in form and colour from the other leaves, so that the whole structure looks strikingly like a flower. As a rule, the archegonial receptacles are not so conspicuous. The early divisions of the archegonium correspond closely with those of the Liverworts, but after the "cover cell" is formed, instead of dividing by cross walls into four cells, it functions for some time as an apical cell, and to its activity is due the entire development of the neck. The venter is usually very much more massive than in the Hepaticæ, and the egg small.

The antheridia, except in Sphagnum, are borne also at the apex of the stem, whose apical cell does not always, at any rate, become transformed into an antheridium, as we sometimes find, especially in species of Atrichum and Polytrichum, that the axis grows through the antheridial group and develops a leafy axis, which later may form other antheridia at its apex. Where the plants are diœcious the males are usually noticeably smaller than the females. The antheridia, except in Sphagnum, are very uniform in structure, and like the archegonium exhibit a very definite apical growth (Fig. 90). The wall remains onelayered, as in the Liverworts, and often the chloroplasts in its cells become red at maturity, as in some Liverworts, e.g. Anthoceros. The ripe antheridium is in most Mosses clubshaped, and the sperm cells are discharged while still in connection, the complete isolation of the sperm cells only taking place some time after the mass has lain in water. In Sphagnum the antheridia are much like those of certain leafy Liverworts, and stand singly in the axils of the leaves of the male branches.

The sporogonium of the Mosses reaches a high degree of development in the typical forms, and shows great uniformity, both in its development and in the essential structure of the full-grown sporophyte. With the exception of Sphagnum, which will be referred to more specially later, the early growth of the sporogonium is due to the segmentation of a two-sided apical cell. The separation of the archesporium takes place. at a late 
period, and like that of Anthoceros it occupies but a very small part of the sporogonium, which in all the higher forms attains a considerable size and complexity. All the archesporial cells form spores, and no trace of elaters can be found.

In all but the lower forms, the sporogonium becomes differentiated into a stalk (seta) and a capsule. This differentiation is gradual, and the elongation of the seta is not a rapid process, due simply to an elongation of the cells, but is caused by actual growth and cell division. In Sphagmum and Andreac, where no seta is present, the axis of the gametophore elongates and forms a sort of stalk (pseudopodium), which carries up the capsule above the leaves.

The separation of the capsule and seta takes place by a rapid enlargement of the upper part of the very much elongated embryo about the same time that the archesporium becomes recognisable. This enlargement is accompanied by a separation of the cells of two layers of the wall, by which an intercellular space is formed which later may become very large (Figs. 97-100). A second similar space may be formed inside the archesporium, but this is found only in the Polytrichacex. In the Sphagnaceæ and Andreæaceæ this space is not found. These spaces are traversed by protonema-like filaments of chlorophyll-bearing cells, and the cells of the massive wall of the capsule also contain much chlorophyll, so that there is no question that the sporogonium is capable of assimilation. Stomata, much like those of Anthoceros or the vascular plants, occur upon the basal part of the capsule in many species, but are not always present.

In Sphagmum and all the higher Bryaceæ the capsule opens regularly by means of a circular lid or operculum. This in the latter group is a most characteristic structure, and with its accompanying structures, the "annulus" or ring of thickened cells surrounding the opening of the rim, and the "peristome,"the fringe of teeth inside the annulus,- - form some of the most important distinguishing marks of different genera and species. When ripe, the operculum falls off and the ripe spores are set free. The teeth of the peristome, by their hygroscopic movements, play an important part in scattering the spores, and physiologically take the place of the elaters of the Hepaticæ.

Some Mosses live but a few months, and after ripening their spores, die. This is the case with Funaria hygrometrica, 
at least in California. Other Mosses are perennial, and some species of peat or tufa-forming Mosses seem to have an unlimited growth, the lower portions dying and the apices growing on until layers of peat or tufa of great thickness result, covered over with the still living plants whose apices are the direct continuation of the stems which form the basis of the mass.

IVith the exception of a very few forms all the Mosses are readily referable to three orders. The first two, the Sphagnaceæ and the Andreæaceæ, are represented each by a single genus, and are in several respects the forms that come nearest the Liverworts. All the other Mosses, except perhaps Archidium and Buxbaumia, conform to a very well-marked type of development, and may be referred to a common order, the Bryineæ. The Phascaceæ or cleistocarpous forms are sometimes separated from the higher Bryineæ as a distinct order, but a study of their development shows that they belong to the same series, and only differ in the degree of development from the more specialised stegocarpous forms.

\section{ORDER I. SPHAGNACEEE}

The Sphagnaceæ, or Peat-Mosses, are represented by the single genus Sphagnum. They are Mosses of large size, which, as is well known, often cover large tracts of swampy land and about the borders of lakes, forming the familiar peat-bogs of northern countries. Owing to the empty cells in the leaves and outer layers of the stem, they suck up water like a sponge, and the plants when growing are completely saturated with water. The colour is usually pale green, but varies much in depth of colour, and in many species is red or yellow. When dry the colour is much duller, largely owing to the opacity of the dry, empty cells which conceal to a great extent the colour of the underlying tissues. They branch extensively, and, according to Schimper, a branch is always formed corresponding to every fourth leaf; but Leitgeb has shown that although this is the rule numerous exceptions to it occur. In sterile plants the branches are of two kinds, long flagellate branches which hang down almost vertically and are applied to the stem, and much shorter ones that are crowded together at the apex and have only a limited growth. The leaves are inserted on the stem by a broad base, and taper to a more or less well-marked point. 
According to Schimper, the divergence of the leaves of the main axis is always two-fifths, but on the smaller branches variations from this sometimes occur. The leaves show no trace of a midrib. As the axis elongates the leaves become separated, as

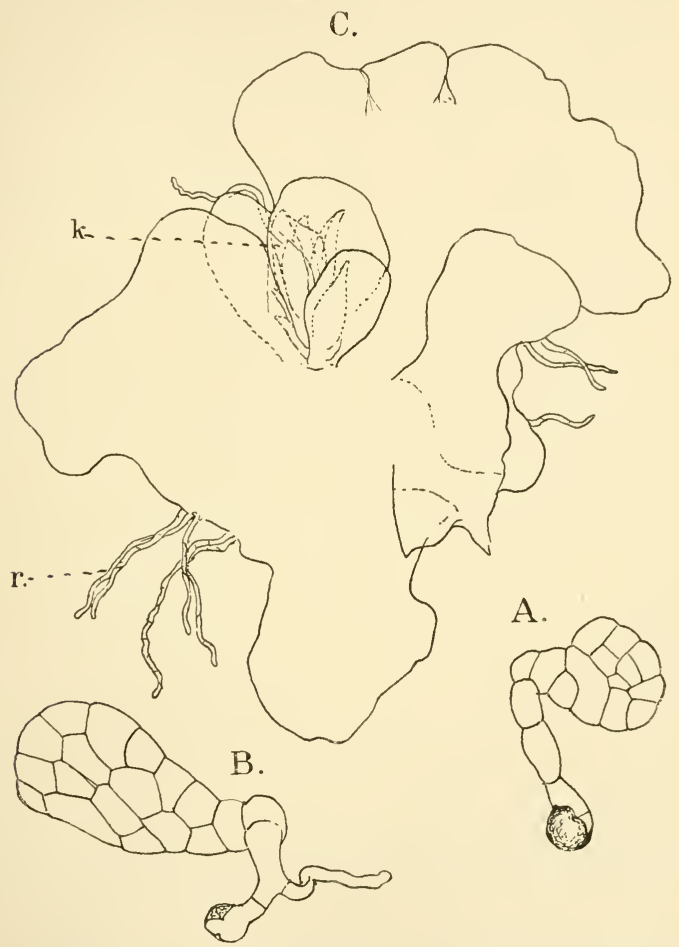

FIG. 76.-Sphagnum $(s p)$; A, B, Young protonemata, $\times_{262}$; C, an older protonema with a Ieafy bud $(k), \times$ about $40 ; r$, marginal rhizoids.

well as the lower branches, but upon the smaller branches they remain closely imbricated. Root-hairs are present only in the earlier stages of the plant's growth, and are only occasionally found in a very rudimentary condition in the older ones.

The spores of Sphagnum on germination form first a very 
short filament, which soon, at least when grown upon a solid substratum, forms a flat thallus, which at first sometimes grows by a definite apical cell. ${ }^{1}$ It first has a spatulate form (Fig. $76, \mathrm{~A}, \mathrm{~B})$, which later becomes broadly heart-shaped, and closely resembles in this condition a young Fern prothallium, for which it is readily mistaken. The older ones become more irregular and may attain a diameter of several millimetres. The thallus is but one cell thick throughout its whole extent, and is fastened to the earth by colourless rhizoids. Later similar filaments grow out from the marginal cells of the thallus, and a careful examination shows that they are septate, and closely resemble the protonemal filaments of other Mosses. Like those, the septa, especially in the colourless ones, are strongly oblique. These marginal protonemal threads may, according to Hofmeister ${ }^{2}$ and Schimper, ${ }^{3}$ produce a flattened thallus at their extremity, and thus the number of flat thalli may be increased. Schimper states that if the germination takes place in water, the formation of a flat thallus is suppressed and the protonema remains filamentous, but Goebel disputes this.

In the few cases observed by me, only one leafy axis arose from each thalloid protonema, and although this is not expressly stated by Hofmeister and Schimper, their figures would indicate it. At a point, usually near the base, a protuberance is formed by the active division of the cells, in a manner probably entirely similar to that in other Mosses, and this rapidly assumes the form of the young stem. The first leaves are very simple in structure, and are composed of perfectly uniform elongated quadrilateral cells, all of which contain more or less chlorophyll. Like the older ones, however, they show the characteristic twofifth divergence. Schimper states that the fifth leaf, at the latest, shows the differentiation into chlorophyll-bearing and hyaline cells, found in the perfect leaves. The first leaves in which this appears only show it in the lower part, the cells of the apex remaining uniform.

At the base of the young plant very delicate colourless rhizoids are developed, and these show the oblique septa so general in the rhizoids of other Mosses. As the plant grows older these almost completely disappear.

The apex of the stem and branches is occupied by a pyramidal apical cell with a very strongly convex outer free

1 Goebel (12), p. II.

${ }^{2}$ Hofmeister (I).

3 Schimper (I). 
base. From the lateral faces of the apical cell, as in the acrogynous Liverworts, three sets of segments are formed. The whole vegetative cone is slender, especially in the smaller branches. The first division in the young segment is parallel to its outer face, and separates it into an inner cell, from which

A.

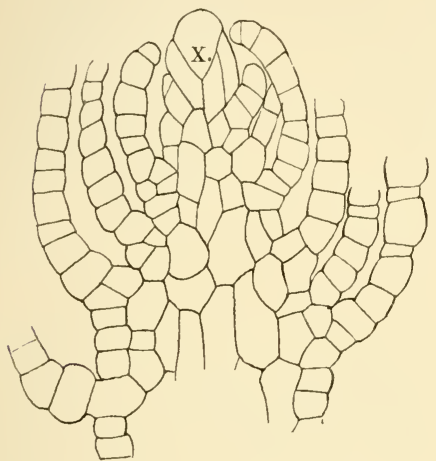

C.

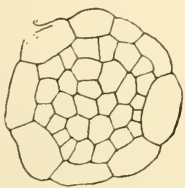

B.

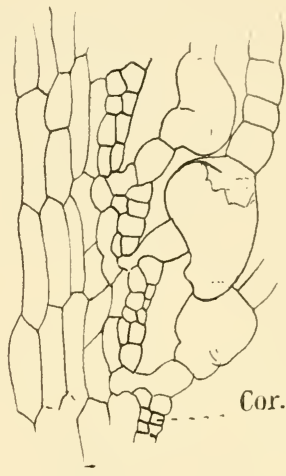

D.

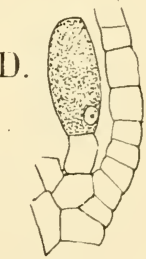

Fig. 77.- Sphagnum cymbifolium (Ehrh.). A, Median longitudinal section of a slender branch; $x$, the apical cell ; B, part of a section of the same farther down, showing the enlarged cells at the bases of the leaves, and the double cortex $(c o r)$; $\mathrm{C}$, cross-section near the apex of a slender branch; D, glandular hair at the base of a young leaf - all $\times 525$.

the central part of the axis is formed, and an outer cell which produces the leaves and cortex.

The second wall, which is nearly horizontal, divides the outer cells of the segment into an upper and a lower cell, the former being much broader than the latter, which is mainly formed from the kathodic half of the segment, which is higher than the anodic half. ${ }^{1} \quad$ The next wall divides the upper cell 
into an upper and a lower one, the former being the mother cell of the leaf, the lower, with the other basal cell, giving rise to the cortex. Growth proceeds actively in the young leaf, which soon projects beyond the surface of the stem, and by the formation of cell walls perpendicular to its surface forms a laminar projection. The position of the cell walls in the young leaf is such that at a very early period a two-sided apical cell is established, which continues to function for a long time, and to whose regular growth the symmetrical rhomboidal form of the cells of the young leaf is largely due (Fig. 78). The leaves do not retain their original three-ranked arrangement, but from the first extend more than one-third of the circumference of the stem, so that their bases overlap, and the leaves become very crowded, and the two-fifth arrangement is established. The degree to which the central tissue of the stem is developed varies with the thickness of the branch. In the main stem it is large, but in the small terminal branches it is much less developed, as well as the cortex, which in these small branches is but one cell thick. Later the cortex of the large branches becomes two-layered (Fig. 77, B), and is clearly separated from the central tissue, whose cells in longitudinal section are very much larger. In such sections through the base of very young leaves characteristic glandular hairs are met with. They consist of a short basal cell and an enlarged terminal cell containing a densely granular matter, which from its behaviour with stains seems to be mucilaginous. The form of the secreting cell is elongated oval (Fig. 77, D), and the hair is inserted close to the base of the leaf, upon its inner surface.

The young leaf consists of perfectly uniform cells of a nearly rhomboidal form (Fig. $78, \mathrm{~A}$ ), and this continues until the apical growth ceases. Then there begins to appear the separation into the chlorophyll-bearing and hyaline cells of the mature leaf. This can be easily followed in the young leaf, where its base is still composed of similar cells, but where toward the apex the two sorts of cells become gradually differentiated. The future hyaline cells grow almost equally in length and breadth, although the longitudinal growth somewhat exceeds the lateral. These alternate regularly with the green cells, which grow almost exclusively in length, and form a network with rhomboidal meshes, whose interstices are occupied by the hyaline cells. The latter at first contain chlorophyll, which 
soon, however, disappears; and finally, as is well known, they lose their contents completely, and in most cases round openings
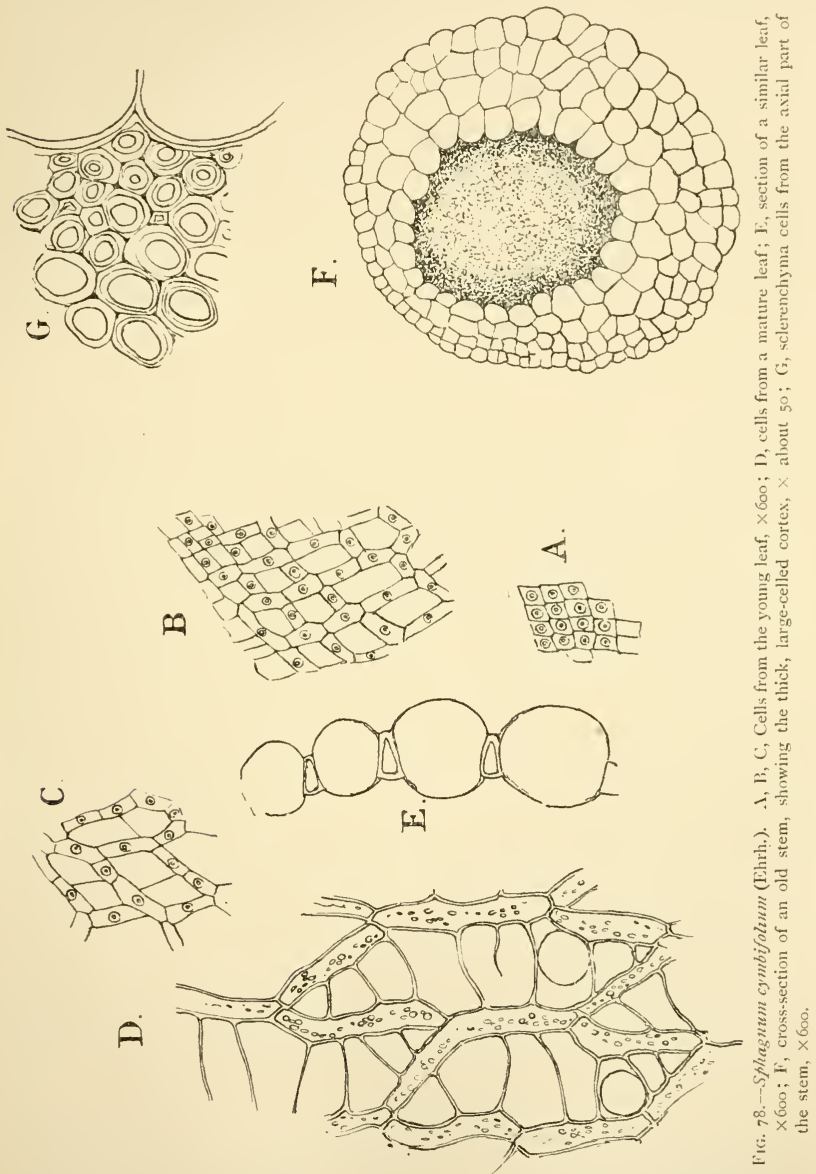

are formed in their walls. The protoplasm is mainly used up in the formation of the spiral and ring-shaped thickenings upon the inner surface of the wall, so characteristic of these cells 
(Fig. 78, D). The chlorophyll cells are sometimes so crowded and overarched by the hyaline ones that they are scarcely perceptible, and of course in such leaves the green colour is very faint. Cross-sections of the leaves show a characteristic beaded appearance, the large swollen hyaline cells regularly alternating with the small wedge-shaped sections of the green cells (Fig. 78, E). Russow ${ }^{1}$ has shown that the leaves of the sporogonial branch retain more or less their primitive character, and the division into the two sorts of cells of the normal leaves is much less marked. He connects this with the necessity for greater assimilative activity in these leaves for the support of the growing sporogonium. From his account too it seems that the stem leaves lose their activity very early.

The degree of development of the thickenings upon the walls of the hyaline cells varies in different species, and in different parts of the leaf. It is, according to Russow, ${ }^{2}$ best developed in the upper half of the leaf, where these thickenings have the form of thin ridges projecting far into the cell cavity.

The development of the central tissue of the stem varies. The central portion usually remains but little altered and constitutes a sort of pith composed of thin-walled colourless parenchyma, which merges into the outer prosenchymatous tissue of the central region. The cells of the latter are very thick walled, and elongated, and their walls are usually deeply stained with a brown or reddish pigment. In their earlier stages, according to Schimper, ${ }^{3}$ the prosenchyma cells have regularly arranged and characteristic pitted markings on their walls, but as they grow older and the walls thicken, these become largely obliterated. Cross-sections of these prosenchyma cells show very distinct striation of the wall (Fig. 78 , $\mathrm{G}$ ), which becomes less evident as they approach the thinnerwalled parenchyma of the central part of the stem. No trace of a central cylinder of conducting tissue, such as is found in most of the Mosses, can be found in Sphagmum, and this is correlated with the absence of a midrib in the leaves.

The cortex at first forms a layer but one cell thick, but is from the first clearly separated from the axial stem tissue. In the smallest branches it remains one-layered (Fig. 77, C), but in the larger ones it early divides by tangential walls into two layers, which at this stage are very conspicuous (Fig. $77, \mathrm{~B}$ ).
1 Russow (4).
${ }^{2}$ Russow, l.c. p. 8.
${ }^{3}$ Schimper (I), p. 36. 
Later there may be a further division, so that the cortex of the main axes frequently is four-layered. While the cells of the young cortex are small, and the tissue compact, later there is an enormous increase in size of the cells, which finally lose their protoplasmic contents and resemble closely the hyaline cells of the leaves. Like the latter, the cortical cells are perfectly colourless, and usually have similar circular perforations in their walls. The resemblance is still more marked in S. cymbifolium, where there are spiral thickened bands, quite like those of the hyaline leaf cells. On the smaller branches the cortical cells ${ }^{1}$ have been found to be of two kinds-the ordinary form and curious retort-shaped cells with smooth walls and a single terminal pore.

\section{The Branches}

Leitgeb $^{2}$ has studied carefully the branching of Sphagnum, which corresponds closely to the other Mosses investigated. The branch arises from the lower of the two cells into which the outer of the two primary cells of the segment is divided. In this cell, which ordinarily constitutes part of the cortex, walls are formed in such a way that an apical cell of the ordinary form is produced. These lateral branches themselves branch at a very early period, and form tufts of secondary ones. Schimper was unable to make out clearly what the nature of this branching was, but suggested a possible dichotomy. Leitgeb, however, concludes that it is monopodial, and that each branch corresponds to a leaf, as do the primary branches. The growth of all the lateral branches, both the descending flagellate ones and the short upright ones at the top of the stem, is limited, and lasts through one vegetative period only. This, however, is not true of the branches that are destined to contain the axis. These are apparently morphologically the same as those whose growth is limited, but they continue to grow in the same manner as the main axis.

\section{The Sexual Organs}

The sexual organs in Sphagnum are produced on branches that do not differ essentially from the sterile ones. The leaves of the antheridial branches are usually brightly coloured,-red,

$$
1 \text { schimper (I), p. } 39 .
$$

2 Leitgeb (I). 
yellow, or dark green, and are closely and very regularly set, so that the branch has the form of a small catkin (Fig. 79, A).
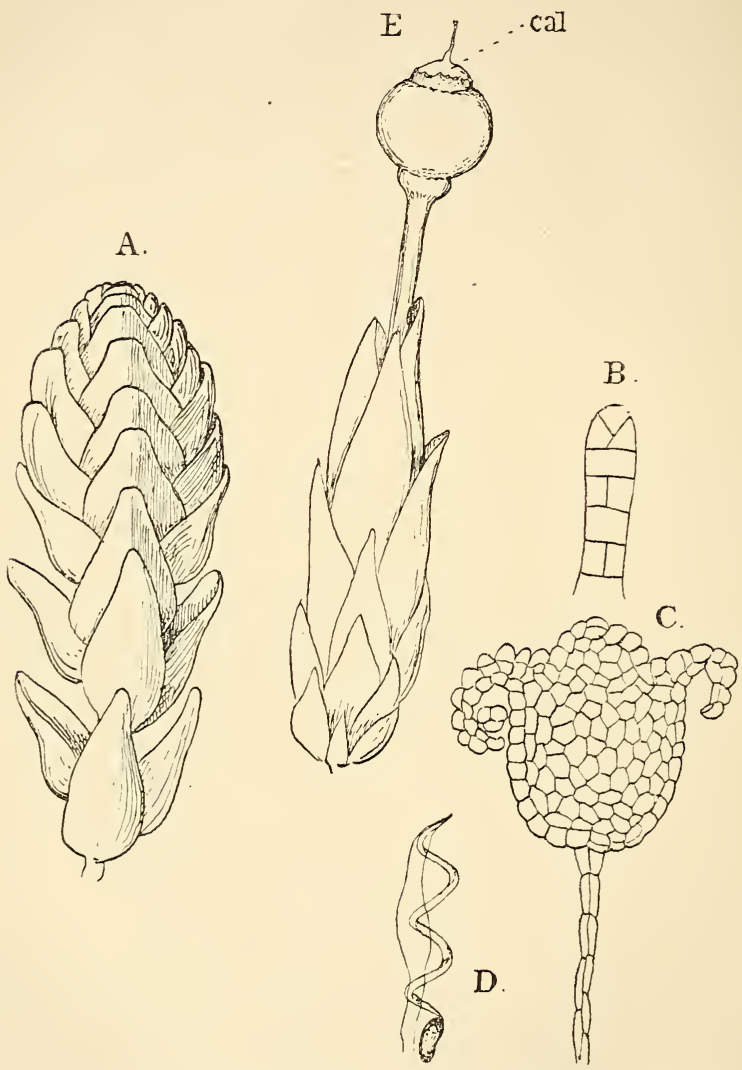

FIG. 79.-A, Male catkin of Sphagnum cymbifolium, $\times 50 ;$ B, young antheridium of $S$. acutifolium, $\times 350 ; C$, opened antheridium of the same species; D, spermatozoid, $\times$ roco (about); E, female branch with sporogonium of $S$. acutifolium, slightly magnified; cal, calyptra. A, C, E, after Schimper; B, after Leitgeb.

The antheridia stand singly in the axils of the leaves, and Leitgeb ${ }^{1}$ states that their position corresponds with that of 
branches, with which he regards them as homologous, having observed in some cases a bud occupying the place of an antheridium. He studied in detail their development, which differs considerably from that of the other Mosses. The antheridium arises from a single cell whose position corresponds to that of a lateral bud on an ordinary branch. This cell grows out into a papilla and becomes cut off by a transverse wall. The outer cell continues to elongate without any noticeable increase in diameter, and a series of segments are cut off from the terminal cell by walls parallel to its base, so that the young antheridium consists of simply a row of cells, comparable to the very young antheridium of the Marchantiacex. Intercalary transverse divisions may also arise, and later some or all of the cells, except the terminal one, divide by longitudinal walls, usually two intersecting ones in each cell, so that the antheridium rudiment at this stage is composed of a long stalk composed of several rows of cells, usually four, and a terminal cell which later gives rise to the body of the antheridium. The first divisions in the body of the antheridium only take place after the stalk has become many times longer than the terminal cell, and is divided into many cells.

The account of the development of the antheridium given by Hofmeister and Schimper is incomplete, and differs in some respects from that of Leitgeb. Neither of the former observers seems to have clearly recognised the presence of a definite apical cell from the first. Schimper ${ }^{1}$ states that after the stalk has been formed four rows of segments arise from the terminal cell ; to judge from the somewhat vague statements of Hofmeister $^{2}$ it appears that he regarded the terminal growth as taking place by the activity of a two-sided apical cell, as in other Mosses. Leitgeb states that, while this form of growth does frequently occur, usually the divergence of the segments is not exactly half, and the segments do not stand in two straight rows, but some of them are intercalated between these, forming an imperfect third row. Each segment is first divided by a radial wall into nearly equal parts, and these are then divided into an outer and an inner cell, and from the latter by repeated divisions the sperm cells are formed. The body of the full-grown antheridium is broadly oval, and 
both in its position and shape recalls strongly that of such a foliose Liverwort as Porella.

The development of the spermatozoids has been carefully followed by Guignard, ${ }^{1}$ and corresponds in the main with that of the Hepaticæ. A peculiar feature is the presence of a pearshaped amylaceous mass, firmly attached to the posterior coil. This becomes evident at a very early stage in the development and remains unchanged up to the time the spermatozoids are liberated (Fig. 79, D). The vesicle in which it is enclosed collapses, leaving only the large starch granule, which finally becomes detached. The free spermatozoid has about two complete coils, and in form recalls that of Chara. The cilia are two and somewhat exceed in length the body.

The ripe antheridium is surrounded by a weft of fine branching hairs, which Schimper suggests serve to supply it with moisture. ${ }^{2}$ It opens by a number of irregular lobes (Fig. 79, C), precisely as in Porella, and, like that, the swelling of the cells is often so great that some of them become entirely detached. Schimper states that antheridia may be formed at any time, but they are more abundant in the late autumn and winter.

The archegonia are found at the apex of some of the short branches at the summit of the plant, and externally are indistinguishable from the sterile branches. The development of the archegonia has not been followed completely, but to judge from the stages that have been observed and the mature archegonium, its structure and development correspond closely to that of the other Mosses. As in these, and the acrogynous Hepaticæ, the apical cell of the branch becomes an archegonium, and a varying number of secondary archegonia arise from its last-formed segments. The mature archegonium has a massive basal part and long somewhat twisted neck, consisting of six rows of cells. As in the other Mosses, the growth of the young archegonium is apical, and probably as there the neck canal cells are formed as basal segments of the apical cell, and the ventral canal cell is cut off from the central cell in the usual way. The venter merges gradually into the neck above and the pedicel below, and at maturity its wall is two or three cells thick. The $\operatorname{egg}^{3}$ is ovoid, and

1 Guignard (1), p. 69.
2 These are probably the hyphæ of a fungus.

: Waldner (2). 
the nucleus shows a distinct nucleolus. Whether a receptive spot is present is not stated. Mixed with the archegonia are numerous fine hairs like those about the antheridium. The leaves immediately surrounding the group of archegonia later
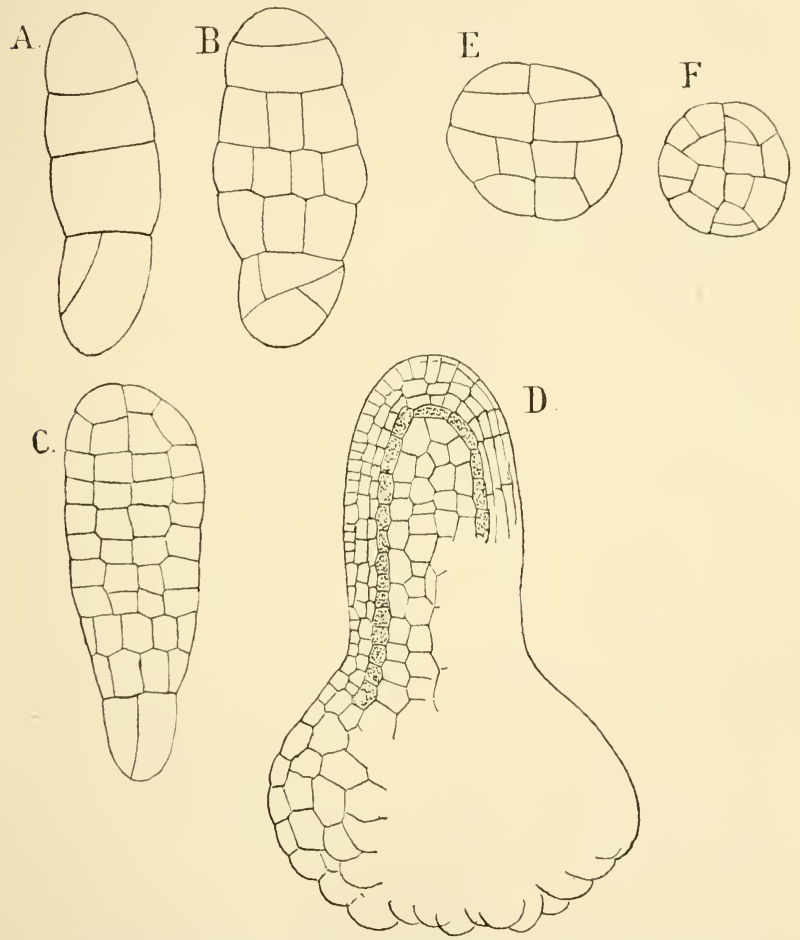

FIG. 8o.--Sphagnum acutifolium (Ehrh.). Development of the embryo (after Waldner). A.D, Median sptical section; E, F, cross-sections. A, D, E, F, $\times_{3} 60 ; \mathrm{C}, \times_{315} ; \mathrm{D}, \times_{153}$.

enlarge much and form a perichætium. By the subsequent elongation of the main axis both archegonial and antheridial branches are often separated by the growth of the axis between them, although at first they are always crowded together at the top of the main stem. 


\section{The Sporogonium}

Waldner $^{1}$ has recently studied carefully the development of the embryo of Sphagnum, which differs essentially from all the other Mosses, and has its nearest affinity in the Anthoceroteæ. In the species $S$. acutifolium, mainly studied by Waldner, the sexual organs are usually mature in the late autumn and winter, and fertilisation occurs early in the spring. The ripe sexual organs are found in a perfectly normal condition in mid-winter, under the snow, and apparently remain in this condition until the first warm days, when they open and fertilisation is effected. The first embryos were found late in February, and development proceeded from that time.

The first division in the embryo is horizontal and divides it into two cells. In the lower of these the divisions are irregular, but in the upper one the cell walls are arranged with much regularity. The upper cell is the apical cell of the young embryo, and from it, by walls parallel to the base, a series of segments is formed (Fig. 80, A). These are usually about seven in number, and each of these segments undergoes regular divisions, these beginning in the lower ones and proceeding towards the apical cell, which finally ceases to form basal segments and itself divides in much the same way as the segments. The latter first divide by two vertical divisions into quadrants, and in each quadrant either directly by periclinal walls, or by an anticlinal wall followed by a periclinal wall in the inner of the two cells (Fig. 8o, E), four central cells in each segment are separated from four or eight peripheral ones. The terms endothecium and amphithecium have been given respectively to these two primary parts of the young Moss-sporogonium. By the time that the separation of endothecium and amphithecium is completed, a division of the embryo into two regions becomes manifest (Fig. 8o, C). Only the three upper segments, including the apical one, give rise to spores; the lower segments together with the original basal cell of the embryo form the foot, which in Sphagmum is very large. The cells of the foot enlarge rapidly and form a bulbous body very similar in appearance and function to that of Notothylas or Anthoceros. The next divisions too in the upper part of the sporogonium 
find their nearest analogies in these forms. The central mass of cells, both in position and origin, corresponds to the columella in these genera, and the archesporium arises by the division of the amphithecium into two layers by tangential walls, and the inner of these two layers, in contact with the columella, becomes at once the archesporium. By rapid cell division the upper part of the sporogonium becomes globular, and is joined to the foot by a narrow neck, much as in Notothylas (Fig. 8 I). The single-layered wall of the young sporogonium becomes six or seven cells thick, and the columella very massive. The one-layered archesporium also divides twice by tangential walls, and thus is four-layered at the time the spore mother cells separate. All the cells of the archesporium produce spores of the ordinary tetrahedral form. The so-called "microspores" have been shown conclusively to be the spores of a parasitic fungus. ${ }^{1} \quad$ The layer of cells in immediate contact with the archesporium on both inner and outer sides has more chlorophyll than the neighbouring cells, and forms the "spore-sac."

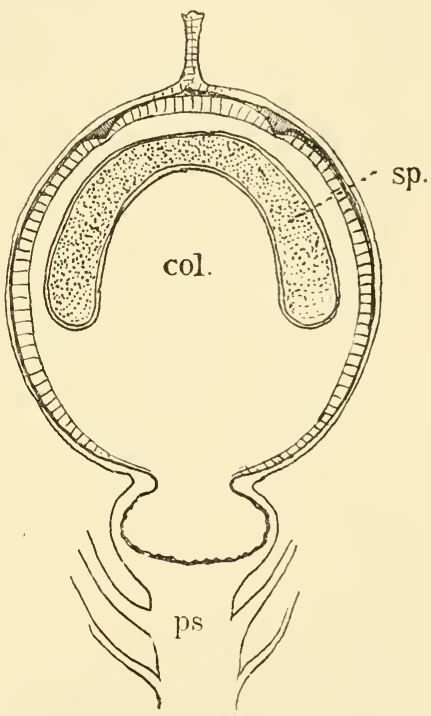

FIG. 8r,-Median longitudinal section of a nearly ripe sporogonium of $S$, acutifolium, $\times_{24} ; p s$, pseudopodium ; $s p$, spores ; col, columella (after Waldner).

The ripe capsule opens by a circular lid which is indicated long before it is mature. The epidermal cells where the opening is to occur grow less actively than their neighbours, and thus a groove is formed which is the first indication of the operculum. The cells at the bottom of the groove have thinner walls than the other cells of the capsule wall, and when it ripens these dry up and are very readily broken, so that the operculum 
is very easily separated from the dry capsule. Stomata, according to Schimper, ${ }^{1}$ always are present, sometimes in great numbers; but Haberlandt ${ }^{2}$ states that these are always rudimentary, and he regards them as reduced forms. No seta is formed, but its place is taken physiologically by the upper part of the axis of the archegonial branch, which grows up beyond the perichætium, carrying the ripe sporogonium at its top (Fig. 79, E). The upper part of this "pseudopodium" is much enlarged, and a section through it shows the bulbous foot of the capsule occupying nearly the whole space inside it. The ripe capsule breaks through the overlying calyptra, the upper part of which is carried up somewhat as in the higher Mosses, while the basal part together with the upper part of the pseudopodium forms the "vaginula."

The disorganised contents of the canal cells, which are usually ejected from the archegonium, in Sphagnum remain in a large measure in the central cavity, and on removing the young embryo from the venter of the archegonium, this mucilaginous mass adheres to it and forms a more or less complete envelope about it, in which are often found the remains of spermatozoids.

The species of Sphagnum are either monøecious or diøecious, but in no cases do archegonia and antheridia occur upon the same branch.

\section{The Andreacea}

The second order of the Mosses includes only the small genus Andreaa, rock-inhabiting Mosses of small size and dark brown or blackish colour. In structure they are intermediate in several respects between the Sphagnaceæ and the Bryineæ, as has been shown by the researches of Kühn ${ }^{3}$ and Waldner, ${ }^{4}$ to whom we owe our knowledge of the life-history of Andread. They all grow in dense tufts upon silicious rocks, and are at once distinguished from other Mosses by the dehiscence of their small capsules. These, like those of Sphagnum, are raised upon a pseudopodium, but are destitute of a true seta. The capsule opens by four vertical slits, which do not, however, extend entirely to the summit (Fig. 82). This peculiar form of dehiscence recalls the Jungermanniaceæ, but is probably only

1 Schimper (I), P. 55 .
2 Haberlandt (4), p. 475.

+ Waldner (2).

3 Kïhn (I). 
an accidental resemblance. The closely-set stems branch frcely ; the leaves, with three-eighth divergence, are either with a midrib (A. rupestris) or without one ( $A$.petrophila).

The growth of the stem is from a pyramidal apical cell, as in Sphagmum, and probably the origin of the branches is also the same as in that genus. The growth of the young leaves is usually from a two-sided apical cell, but another type of growth

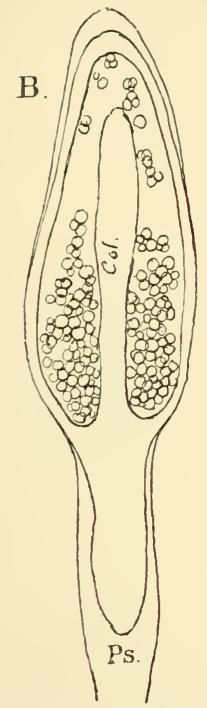

A.

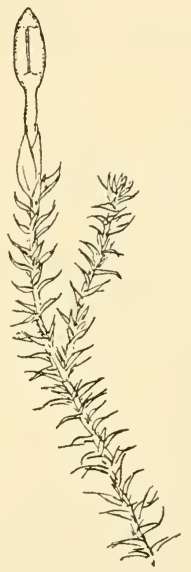

Fig. 32,-Andrea petrophila (Ehrh.). A, Plant with rife sporogonium, x 10; 1, median section of nearly ripe capsule, $\times 80 ; p s$, pseudopodium; col, columella.

is found where the apical cell is nearly semicircular in outline, and segments are cut off from the base only. These two forms of apical growth apparently alternate in some instances in the same leaf. The originally thin walls of the leaf cells later become thick and dark-coloured, whence the characteristic dark colour of the plant.

The stem in cross-section shows an almost uniform structure, and no trace of the central conducting tissue of the higher Mosses can be found. The outer cells are somewhat thickerwalled and darker-coloured, but otherwise not different from 
the central ones. Numerous rhizoids of a peculiar structure grow from the basal part of the stem, and from these, new branches arise which replace the older ones as they die away. These rhizoids are not simple rows of cells as in the Bryineæ, but are either cylindrical masses of cells or flattened plates. These penetrate into the crevices of the rocks, or apply themselves very closely to the surface, so that the plants adhere tenaciously to the substratum.

\section{Spores and Protonema}

The germination of the spores and the development of the protonema show numerous peculiarities. The spores may
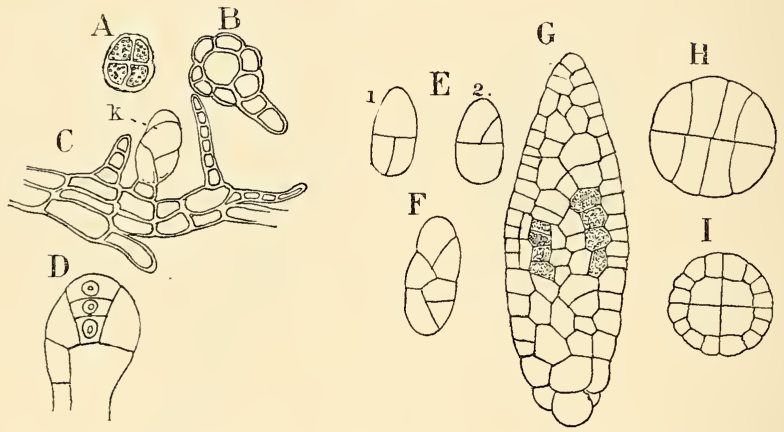

FIG. 83.-A, B, Germinating spores of A. petrophila, $\times 200 ; C$, protonema with bud $(k)$; D, young archegonium in optical section; $\mathrm{E}, \mathrm{x}, 2$, two views of a very young embryo of $A$. crassinerva, $\times 266 ; \mathrm{F}$, somewhat older embryo of $A$. petrophila; $\mathrm{G}$, older embryo showing the first archesporial cells; H, 1, cross-sections of young embryos, $\times 200$. A-D, after Kühn ; E-1, after Waldner.

germinate within a week, or sometimes remain unchanged for months. They have a thick dark-brown exospore and contain chlorophyll and oil. The first divisions take place before the exospore is ruptured, and may be in three planes, so that the young protonema then has the form of a globular cell mass (Fig. 83, A). This stage recalls the corresponding one in many of the thallose Hepaticæ, e.g. Pellia, Radula, and is entirely different from the direct formation of the filamentous protonema of most Mosses. Some of the superficial cells of this primary tubercle grow out into slender filaments, either with straight or oblique septa, and these later ramify exten- 
sively. Where there are crevices in the rock, some of these branches grow into them as colourless rhizoids, but here, as in the Bryinex, there is no real morphological distinction between rhizoid and protonema. Most of the filamentous protoncmal branches do not remain in this condition, but become transformed into cell plates or cylindrical cell masses, like the stemrhizoids. The flat protonema recalls strongly that of Splagmum, and is probably genetically connected with it. All of the different protonemal forms, except what Kiihn calls the "leaflike structures," vertical cell surfaces of definite form, can give rise to the leafy axes. The development of these seems to correspond exactly with that of the other Mosses, and will not be further considered here.

\section{The Sexual Organs}

The species of Andrecea may be either monoecious or diocious. Archegonia and antheridia occur on separate branches, but their origin and arrangement are identical. The first-formed antheridium derelops directly from the apical cell of the shoot, and the next older ones from its last-formed segments, but beyond this no regularity can be made out. In the first one the apical cell projects, and its outer part is separted from the pointed inner part by a transverse wall. This is followed by a second wall parallel to the first, so that the antheridium rudiment is composed of three cells. Of these the lower one takes little part in the future development. Of the two upper cells the terminal one becomes the body of the antheridium, the other the stalk. In the former, by two inclined walls, a two-sided apical cell is developed, and the subsequent growth is the same as in the Bryineæ. The middle cell of the antheridium rudiment divides repeatedly by alternating transverse and longitudinal walls, and forms the long two-rowed stalk of the mature antheridium. On comparing the antheridium with that of the other Mosses, we find that it approaches Sphagnum in the long stalk, but in its origin and the growth of the antheridium itself, it rescmbles closely the higher Mosses.

The first archegonium also is derived immediately from the apical cell of the female branch, and the first divisions are the same as in the first antheridium. Here, too, the subsequent development corresponds exactly with that of the higher 
Mosses, and will be passed over for the present. The ripe archegonium shows no noteworthy peculiarities, and closely resembles in all respects that of the other Mosses.

\section{The Sporogonium}

The more recent researches of Waldner $^{1}$ on the development of the sporogonium of Andreaa have shown clearly that here, too, the latter stands between the Sphagnaceæ and the Bryineæ. The first division in the fertilised ovum is transverse and divides it into two nearly equal parts. The lower of these divides irregularly and much more slowly than the upper one. In the latter (Fig. $8_{3}, \mathrm{E}$ ) the first division wall is inclined, and is followed by a second one which meets it nearly at right angles, and by walls inclined alternately right and left-in short, has the character of the familiar "two-sided" apical cell. The number of segments thus formed ranges from eleven to thirteen. Each segment is first divided by a vertical median wall into equal parts, so that a cross-section of the young embryo at this stage shows four equal quadrant cells. The next divisions correspond to those in Sphagnum, and result in the separation of the endothecium and amphithecium. The formation of the archesporium, however, differs from Sphagnum, and is entirely similar to that of the higher Mosses. Instead of arising from the amphithecium as in the former, the archesporium here is formed by the separation of a single layer of cells from the outside of the endothecium. All of the segments do not form spores, but only three or four, beginning with the third from the base. The two primary segments of the upper part of the embryo, like the corresponding ones in Sphagnum, go to form the foot, which is not so well developed, however, as in the latter. The originally one-layered archesporium later becomes double, and as in Sphagnum extends completely over the columella, which is thus not continuous with the tissue of the upper part of the sporogonium. As in Sphagnum also, no trace of the intercellular space formed in the amphithecium of the Bryinex can be detected. A section of the nearly ripe capsule shows the club-shaped columella extending nearly to the top of the cavity. With the growth of the capsule the 
space between the inner and outer spore-sacs becomes very large to accommodate the growth of the numerous spores. The pseudopodium is exactly the same as in Sphagmum, and the vaginula and calyptra are present. The latter is much firmer than in Sphagnum, and like that of the Bryinex.

\section{Archidium}

The genus Archidium is one whose systematic position has been long a subject of controversy. It has usually been associated

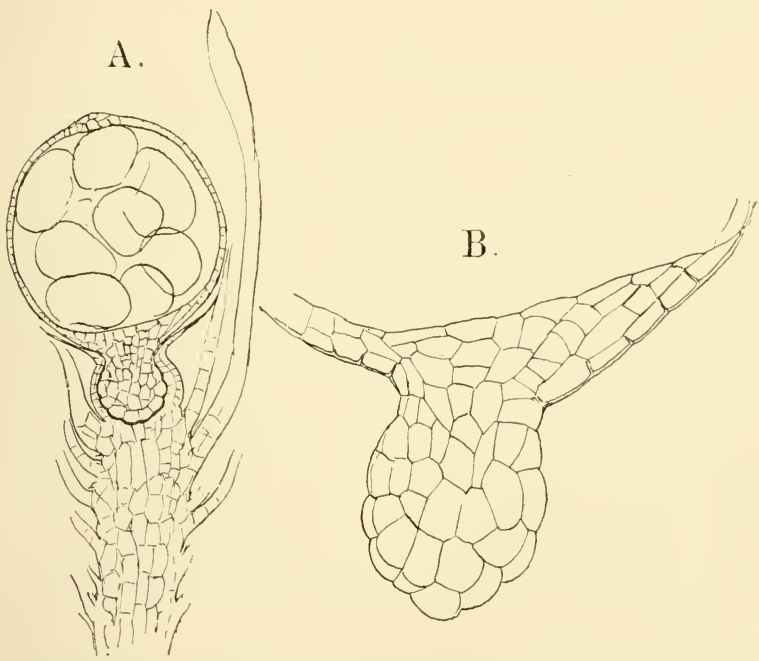

Fig. 84.-Archidium Razenclii (Aust.). A, Median section through a nearly ripe sporogonium, $\times 90 ; \mathrm{B}$, base of the sporogoniun, $\times 270$.

with the so-called cleistocarpous Bryineæ, but the researches of Leitgeb seem to point to a nearer affinity with Andread.

The species of Archidium are small Mosses growing on the earth, and especially characterised by the small number, but very large size, of the spores contained in the sessile globular sporogonium. Hofmeister ${ }^{1}$ was the first to study the develop-

1 Hofmeister (I), P. 160. 
ment, and his account agrees in the main with Leitgeb's, except as to the relation of the columella and outer spore-sac. The first divisions in the embryo correspond exactly to those in Andrecea and the Bryinex, and for a time the young embryo grows from a two-sided apical cell. The secondary divisions in the segments, however, are quite different from that observed in any other Moss, and are like those in the antheridium. Instead of the first wall dividing the segment into equal parts, it divides very unequally. The second wall strikes this so as to enclose a central cell, triangular in cross-section, which with the corresponding cell of the adjacent segment forms a square. This square, the endothecium, does not therefore at first show the characteristic four-celled stage found in all other Mosses. The amphithecium becomes ultimately three-layered, and between the second and third layers an intercellular space is formed, as in the Bryineæ, but this extends completely over the top of the columella. The most remarkable feature, however, is that no archesporium is differentiated, but any cell of the endothecium may apparently become a spore mother cell. The number of the latter is very small, seldom exceeding five or six. They become rounded off, and gradually displace the other endothecial cells, which doubtless serve as a sort of tapetum for the nourishment of the growing spores. Each spore mother cell as usual gives rise to four spores, which are here very much larger than in any other Moss. A section of the ripe sporogonium (Fig. 8I) shows that only one of the primary three layers of amphithecial cells can be recognised except at the extreme apex and base. The seta is present, and a foot, much like that of Andreaa, and penetrating into the tissue of the stem apex, is seen.

Leitgeb is inclined to look upon Archidium as a primitive form allied on the one hand to Andreae and on the other to the Hepaticæ, possibly Notothylas. However, as his assumption that the latter has no primary columella has been shown to be erroneous, his comparison of the whole endothecium of Archidium with that of Notothylas cannot be maintained, as we have shown that in the latter, as in Anthoceros, the archesporium arises from the amphithecium, and not from the endothecium, as is the case in Archidium. Inasmuch as the gametophyte and sexual organs of Archidium are those of the typical Mosses, it seems 
quite as likely that the older view that Archidium is a degenerate form is correct. At any rate, until more convincing evidence can be brought forward in support of a direct connection between it and the Hepaticæ than the formation of the spores directly from the central tissue of the sporogonium, it cannot be said that the question of its real affinities is settled. 


\section{CHAPTER VII}

THE BRYINEA

UNDER the name Bryinea may be included all the other Mosses; for although the so-called cleistocarpous forms are sometimes separated from the stegocarpous Mosses as a special order, the Phascaceæ, the exact correspondence in the development of both the gametophyte and sporophyte shows that the two groups are most closely allied, the former being either rudimentary or degraded forms of the others.

With few exceptions the protonema is filamentous and shows branches of two kinds, the ordinary green ones with straight transverse septa, and the brown-walled rhizoids with strongly oblique ones, but the two forms merge insensibly into one another, and are mutually convertible. In a few forms, notably the genus Tetraphis, the protonema is thalloid, and as in Sphagmum these flat thalli give rise to filamentous protonemal threads, which in turn may produce secondary thalloid protonemata. In some of the simpler forms, e.g. Ephemerum, the protonema is permanent, and the leafy buds appear as appendages of it; but in most of the larger Mosses the primary protonema only lives long enough to produce the first leafy axes, which later give rise to others by branching, or else by secondary protonemal filaments growing from the basal rhizoids. The early stages of development of the primary protonema are easily traced, as the spores of most Mosses germinate readily when placed upon a moist substratum. The ripe spores usually contain abundant chlorophyll and oil, and the thin exospore is brown in colour. The spore absorbs water and begins to enlarge until the exospore is burst, when the endospore protrudes as a papilla which grows out into a filament; or the 
endospore sometimes grows out in two dircetions, and one of the papille remains nearly destitute of chlorophyll and forms the first rhizoid. The growth of the protonemal filaments is strictly apical, no intercalary divisions taking place except those by which lateral branches arise. If abundant moisture is prescnt, the protonema grows with great rapidity and may form a dense branching alga-like growth of considerable extent. Sooner or later upon this arise the leafy gametophores. The development of the latter, as we have seen, also takes place

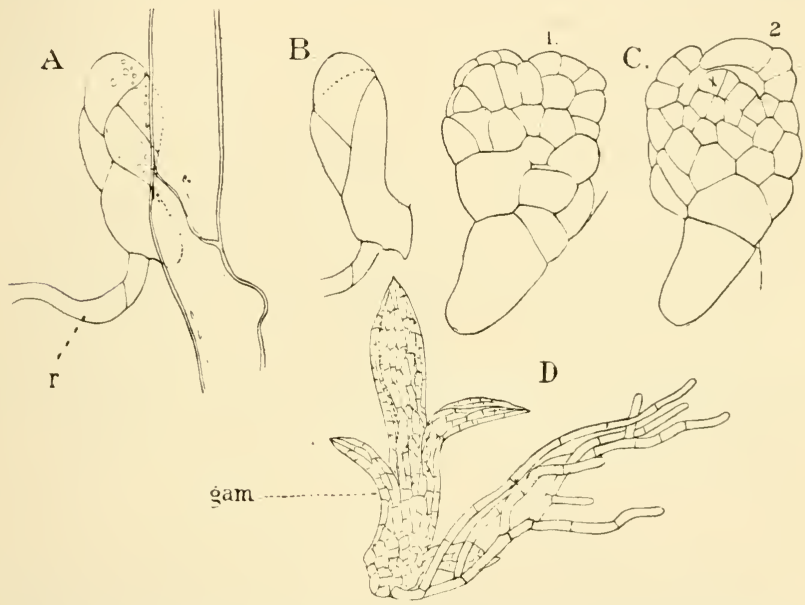

FiG. 85.-Funaria liygrometrica (Sibth.). A, Fragment of a protonemal branch with a young gametophoric bud; $r$, rhizoid; B, median optical section of the bud; C, older bud-I, surface view ; 2, optical section; $x$, apical cell ; D, protonema with a still older gametophore $(\mathrm{g} a n)$ attached. A.C, $\times 225 ; \mathrm{D}, \times_{3} 6$.

abundantly from the secondary protonemal filaments which may be made to grow from almost any part of the gametophore.

The development of the bud is as follows. From a cell of the protonema a protuberance grows out near the upper end. This is at first not distinguishable from a young protonemal branch, but it very soon becomes somewhat pear-shaped, and instead of elongating and dividing simply by transverse walls, the division walls intersect so as to transform it into a cell mass. After the cell is separated it is usually divided at once by a 
strongly oblique wall, which is then intersected by two others successively formed and meeting each other and the first-formed one at nearly equal angles, so that the terminal cell of the young bud (Fig. 85, A) has the form of an inverted pyramid; that is, by the first divisions in the bud the characteristic tetrahedral apical cell of the gametophore is established. From now on the apical cell divides with perfect regularity, cutting off three sets of lateral segments. From the base of the young gametophore the first rhizoid (Fig. 85, A, $r$ ) is formed at a very early period. The first two or three segments do not give rise to leaves, and the leaves formed from the next younger segments remain imperfect. Thus in Funaria hygrometrica these earliest formed leaves show no midrib. The young leaves rapidly elongate and completely cover up the growing point of the young bud, and' are at first closely imbricated. Later, by the elongation of the axis, the leaves become more or less completely separated (Fig. 85, C, D). In Funaria, as well as in many other Mosses, buds are often met with that have become arrested in their development, lost their chlorophyll, and assumed a darkbrown colour. This arrest often seems to be the result of unfavourable conditions of growth, and under proper conditions these buds probably always will develop either directly or by the formation of a secondary protonema into perfect plants.

\section{Apical Growth of the Stem}

The growth of the stem of the fully-developed gametophore is better studied in one of the larger Mosses. The growth of the gametophore is so limited in length in Funaria that it is not so well adapted for this. Perhaps the best species for this purpose is the well-known Fontinalis antipyretica, which has already been carefully studied by Leitgeb. ${ }^{1}$ Amblystegium riparium, var. fluitans, was examined by me and differed in some points from Leitgeb's figures of Fontinalis. Fig. 86, A shows an exactly median longitudinal section through a strong growing point. Compared with Leitgeb's figures the apical cell is much deeper than in Fontinalis, and in consequence the young segments more nearly vertical. Here, as in Sphagnum, the first wall in the young segment divides it into an inner and an outer 
cell, from the latter of which alone are formed the lateral appendages of the stem. The inner cells of the segments by repeated longitudinal and transverse divisions form all the tissues of the axis. The second division wall in the segment, like that in Sphagnum, is at right angles to the first, but in Amblystegium it extends the whole breadth of the segment. By this division the outer of the two primary cells of the segment is divided into an upper cell, from which the leaf develops, and a lower one, from which the outer part of the stem and the buds are
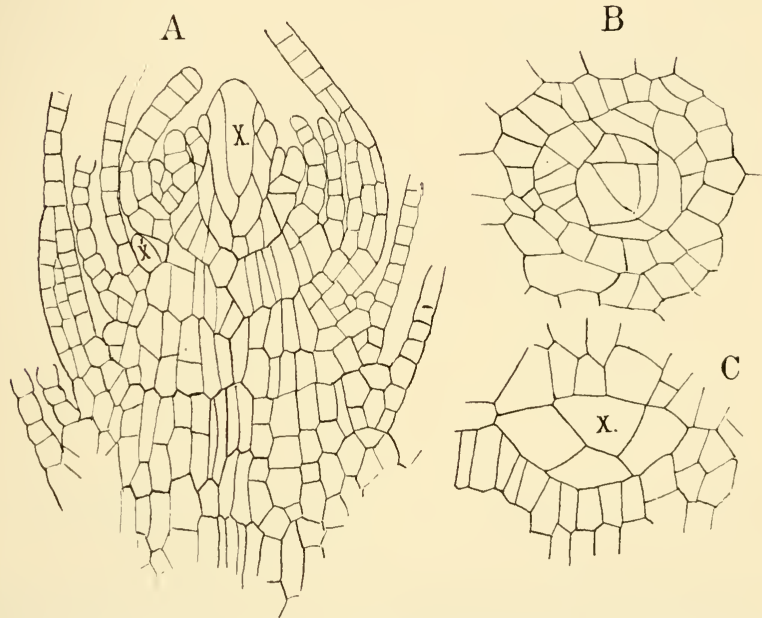

FIG. 86. - Amblystegium riparium, var. fuıtans (Bruch and Schimp). A, Median longitudinal section of a strong shoot ; $x$, apical cell ; $x^{\prime}$, initial of a lateral branch, $\times 250 ; \mathrm{P}$, transverse section through the apex, $\times 250 ; C$, similar section through a young branch, $\times 500$.

formed. The leaves grow from a two-sided apical cell (Fig. 87), as indeed they seem to do in all Mosses, and the divisions proceed with great rapidity and the young leaves quickly grow beyond and surround the growing point. In Amblystegium, as in all the typical Bryineæ, the leaf has a well-developed midrib. The formation of this begins while the leaf is very young and proceeds from the base. In the middle row of cells (Fig. 87, C) a wall first arises parallel to the surface of the leaf, and this is followed by a wall in the cell on the lower side of the leaf 
(Fig. 87, D). By further divisions in all the cells of this central strand the broad midrib found in the mature leaf is developed. In Amblystegium all the cells of the midrib are alike and have thickened walls. The midrib projects on both sides of the leaf, but rather more strongly upon the lower side. In Funaria (Fig. 88) the structure of the midrib is more definite. Here two rows of cells take part in the formation of the midrib. Each of these first divides as in Amblystegium by a wall parallel to the surface of the leaf, so that in cross-section the central
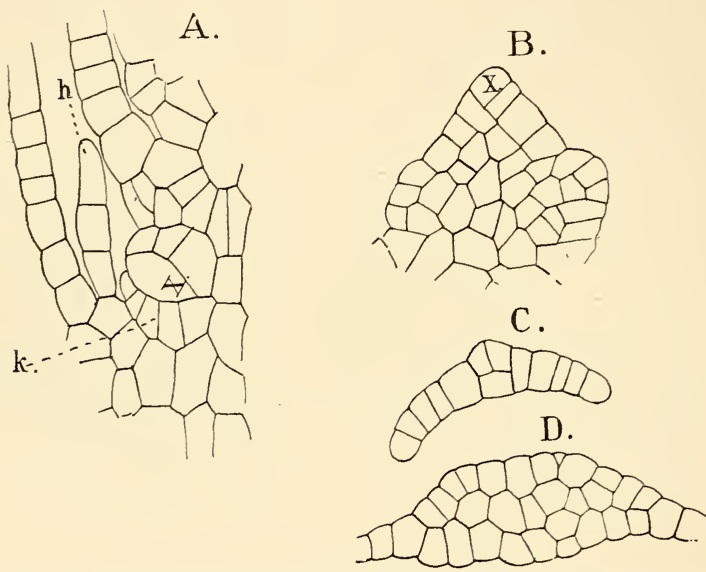

F1G. 87.-Amblystegizm riparium, var. fultans (Br. and Sch.). A, Longitudinal section of the stem passing through a young lateral branch $(k)$; $h$, hair at the base of the subtruding leaf ; $\mathrm{B}$, horizontal section of a very young leaf, showing the apical cell $(x)$; C, D, transverse sections of young leaves, showing the development of the midrib. All the figures $\times 525$.

part of the leaf shows a group of four cells, those on the outer side being larger than the others. In the former the next wall is a periclinal one and divides the cell into an inner and an outer one. From the two inner cells by further division is formed the group of small conducting cells that traverse the centre of the midrib, while the outside cells together with those on the inner side of the midrib become much thickened and serve for strengthening the leaf. Here as in Amblystegium the lamina of the leaf remains single-layered, and its cells contain numerous large chloroplasts which, as is well known, continue 
to multiply by division after the cells are fully grown. The marginal cells in the leaf of Funaria are much narrower than those between them and the midrib, and their forward ends
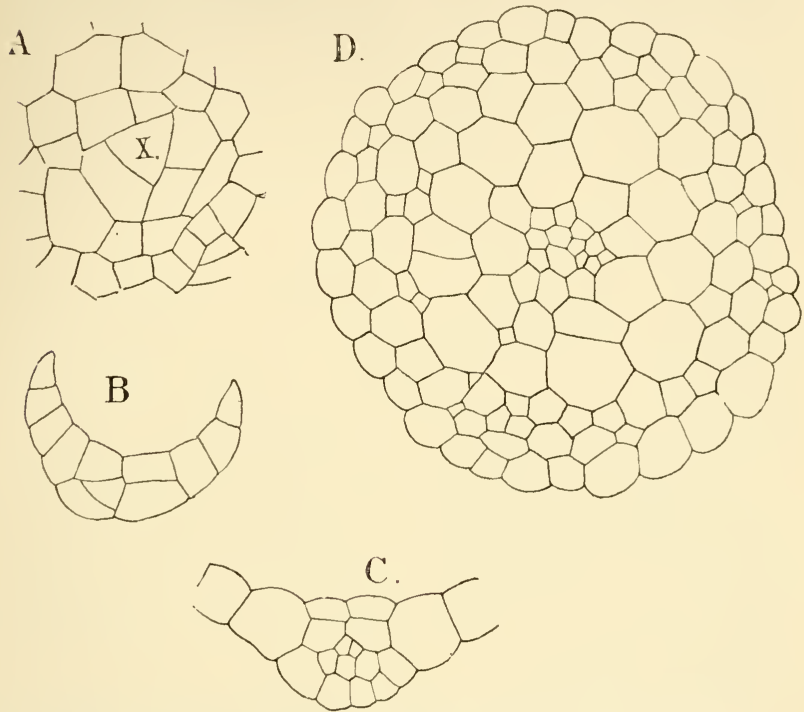

FIG. 88. - Funaria hygrometrica (Sibth.). 1, Transverse section of the apex of a young shoot, $\times 515$; $\mathrm{E}, \mathrm{C}$, cross-sections of young leaves, $\mathrm{X}_{5} \mathrm{r}_{5} ; \mathrm{D}$, cross-section of the stem, $\times 257$.

often project somewhat, giving the margin of the leaf a serrate outline, which is also common in many other Mosses.

\section{The Branches}

For the study of the branching of the stem, Amblystegium again is much better than Funaria, whose short stem and infrequent branching make it difficult to find the different stages. In Amblystegium, however, every median section will show some of the stages, and it is easy to follow out all the details, as has already been done in Fontinalis by Leitgeb. ${ }^{1}$ The lateral shoots originate from a basal cell of the segment below the middle of the leaf. It is very easily seen that it 
belongs to the same segment as the leaf standing above it, and therefore is not axillary in its origin. The mother cell of the young branch projects above the surrounding cells, and in it are formed in succession three oblique intersecting walls which enclose the narrow pyramidal apical cell (Figs. 86, 87). The secondary divisions in the first set of segments are not so regular as in the later ones, but the bud rapidly grows, and very soon the perfectly regular divisions of the young segments are established. So far as investigations have been made upon other genera, they follow the same line of development as Amblystegium, Fontinalis, and Sphagnum.

Where the growth of the main axis is stopped by the formation of sexual organs, a lateral branch frequently grows out beyond the apex of the main axis, as in Sphagnum, and thus sympodia arise. In other cases, where the growth of the lateral branches is limited, characteristic branch systems arise, such as we find in Thuidium or Climacium (Fig. 75).

Compared with Amblystegium, the growing point of Funaria and other Mosses of similar habit is much broader, and the apical cell not so deep. The arrangement of the segments is much the same, except that the original three-ranked arrangement of the segments which is retained in Fontinalis ${ }^{1}$ is replaced in most Mosses by a larger divergence, owing to a displacement like that in Sphagnum.

A cross-section of the older stem (Fig. 88, D) shows in most Bryineæ a central cylinder of small thin-walled cells surrounded by a large-celled cortical tissue, which in the older parts of the stem often has its walls strongly thickened and reddish brown in colour. An epidermis, clearly recognisable as such, cannot usually be detected. The outer cells contain chlorophyll, which is wanting in the central cylinder.

The rhizoids in Funaria grow mainly from the base of the stem, and the first ones arise very soon after the young bud is formed. Their growth, like that of the protonemal branches, is strictly apical, and they branch extensively. The young ends are colourless, but as they grow older the walls assume a deep brown colour. Usually the division walls in the rhizoids are strongly oblique. Their contents include more or less oil, and where they are exposed to the light, chlorophyll.

1 This is only strictly true in the smaller branches. 


\section{The Sexual Organs}

Funaria is strictly dicecious. The male plants (Fig. 89, A) are easily distinguished by their form. They are about $\mathrm{I} \mathrm{cm}$.
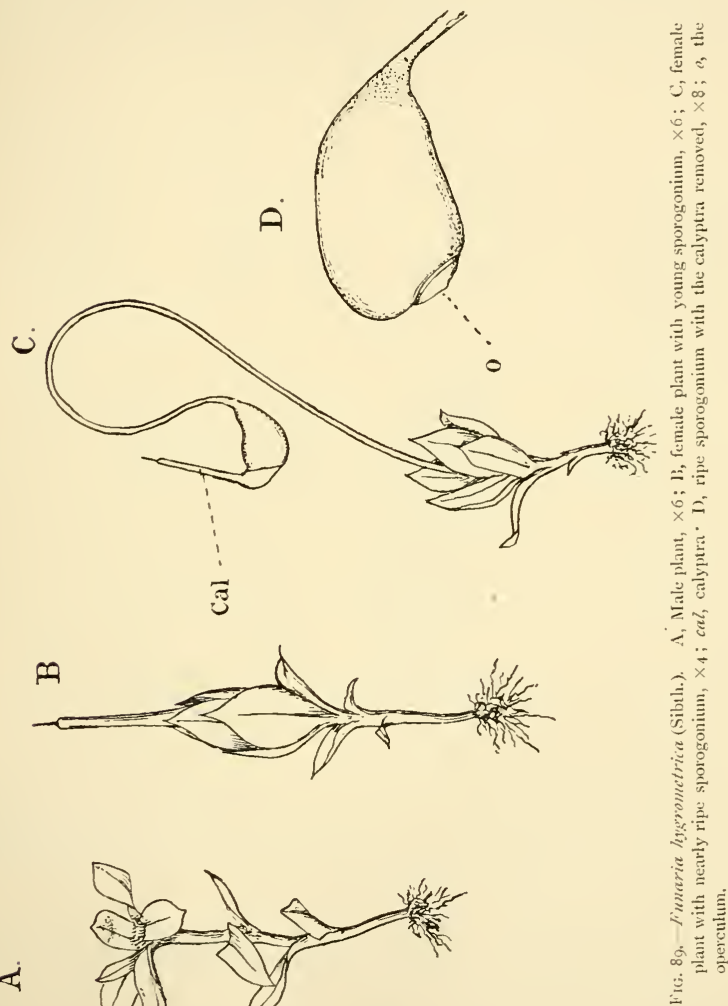

in height, with the lower leaves scattered, but the upper ones crowded so as to present much the appearance of a flower whose centre forms a small reddish disc. These male plants either grow separately or more or less mixed with the females. 
Whether the first antheridium, as in Andreaa and Fontinalis, arises from the apical cell is doubtful, and it is impossible to trace any regularity in the order of formation of the very numerous antheridia. Except in very old plants, all stages of development are found together, and the history of the antheridium may be easily followed. A superficial cell projects above its neighbours, and this papilla is cut off by a transverse

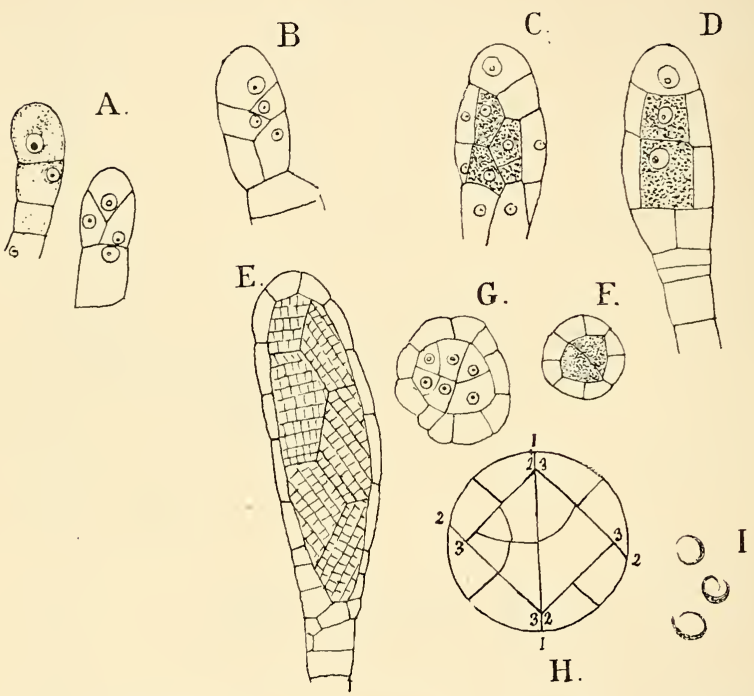

FIG. 9o.-Funaria hygrometrica (Sibth.). Development of the antheridium. A-D, LongitudinaI sections of young stages, $\times 600 ; \mathrm{D}$ is cut in a plane at right angles to $\mathrm{C}$; $\mathrm{E}$, optical section of an oIder stage, $\times 300 ; \mathrm{G}, \mathrm{F}$, cross-sections of young antheridia, $\times 600 ; \mathrm{H}$, diagram showing the first divisions in the antheridium; I, young spermatozoids, $\times$ I200.

wall. The outer cell either becomes at once the mother cell of the antheridium, or other transverse walls may occur, so that a short pedicel is first formed (Fig. 90, A). Finally in the terminal cell, as in Andrecea, two intersecting walls are formed enclosing a two-sided apical cell, from which two ranks of segments are cut off in regular succession (Figs. A, B, C). The number of these segments is limited, in Funaria not often exceeding seven, and after the full number has been formed, the 
apical cell is divided by a septum parallel with its outer face into an inner cell, which with the inner cells of the segments forms the mass of sperm cells, and an outer cell which produces the upper part of the wall. Before the full number is completed, the secondary divisions begin, proceeding from the base upward. These are very regular, and correspond closely to those in the antheridium of the Jungermanniacex, and can only be clearly made out by comparing transverse and vertical sections of the young antheridium. Fig. 90, $\mathrm{H}$ shows a diagram illustrating this: $I$ is the wall separating two adjacent segments, and 2 the first wall formed in the segment itself. The wall 2 , it will be seen, starts near the middle of the periphery of the segment and strikes the wall I far to one side of the centre, so that the segment is thus divided into two cells of very unequal size, although their peripheral extent is nearly equal. The next wall (3) strikes both the wall $\mathrm{I}$ and 2 at about equal distances from the periphery, and thus each segment is divided into an inner cell which in cross-section has the form of a triangle, and two peripheral cells. The latter divide only by radial walls, and give rise to the single-layered wall of the antheridium. The inner cells of the segments by further division in all directions form the mass of sperm cells. The first division wall in the central cell starts from near the middle of the segment wall and curves slightly, so that the two resulting cells are unequal in size. From this first division wall usually two others having a similar form extend to the peripheral cells, and these are next followed by others nearly at right angles to them. After this transverse and longitudinal walls succeed with such regularity that the limits of the primary segments remain perfectly evident until the antheridium is nearly full grown.

The central cells in the fresh antheridium are strongly refringent, and in stained sections show a much more granular consistence than the outer ones. The nucleus, as in other cases studied, uses its nucleolus before the formation of the spermatozoids begins. The latter in their structure and development correspond with those of Sphagmum, but owing to their smaller size are not favourable for studying the minute details of development.

In the peripheral cells are numerous chloroplasts which lie close to the inner wall of the cell in the ripe antheridium. 
As the antheridium ripens, these gradually assume a bright orange-red colour. The development of the stalk varies in different cases. Sometimes it consists of a row of several cells, sometimes the antheridium is almost sessile. The
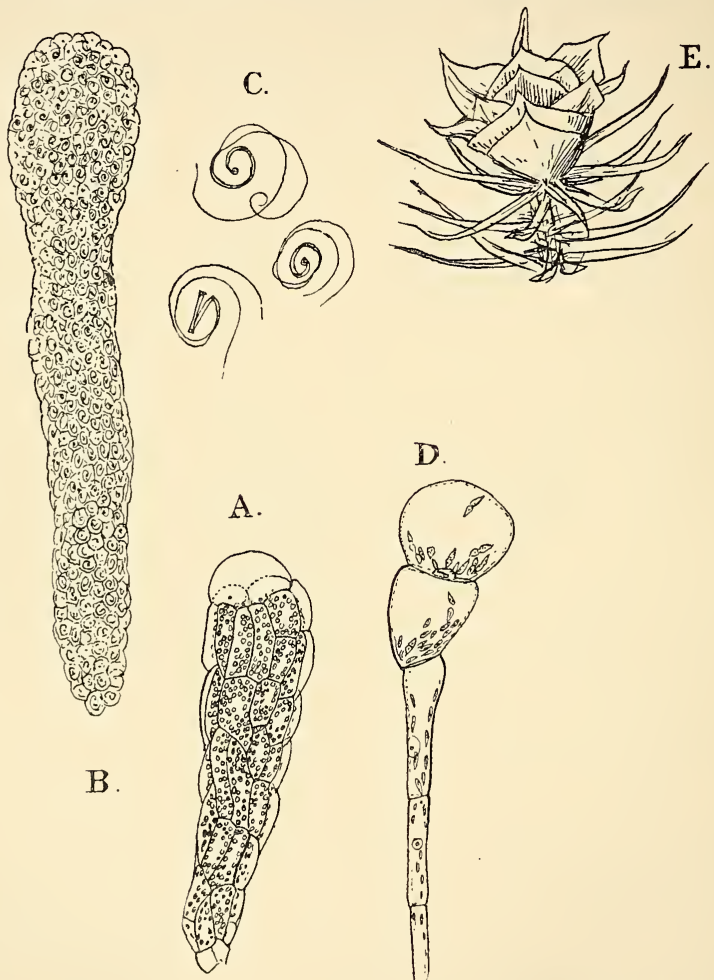

D.

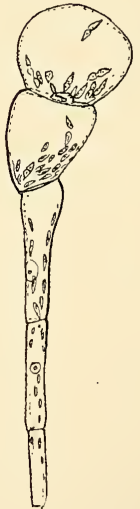

FIG. 91.-Funaria hygrometrica (Sibth.). A, Antheridium that has just discharged the mass of sperm cells $(\mathrm{B}), \times_{300} ; \mathrm{C}$, spermatozoids, $\times_{1300} ; \mathrm{D}$, paraphysis, $\times_{300}$; $\mathrm{E}$, male "flower" of Atrichum undulatum, $\times 6$

lowermost segments of the apical cell help to form the upper part of the stalk, and sometimes the two lowest seem to take no part in the formation of the sperm cells. There is no absolute uniformity in the cell divisions of the stalk, which 
varies in the arrangement of the cells in different individuals in the same inflorescence.

If ripe antheridia are placed in water, they open within a few minutes. The peripheral cells become much distended, especially the terminal ones; and the chromatophores being entirely confined to the inner part of the cells, the antheridium seems to be surrounded by a layer of perfectly hyaline cells. The dehiscence takes place at the summit between the terminal cells, which are simply separated without rupturing their walls. As soon as the mass of sperm cells is ejected, the opening closes completely and the empty antheridium looks very much as it did before, except that it is slightly contracted below. The whole mass of sperm cells is thrown out without separating the cells, and in this stage the walls of the sperm cells are still very evident. It sometimes happens that the mass is thrown out before the spermatozoids are complete, in which case they never escape. If, however, the spermatozoids are mature, they show active motion within the sperm cells while these are still in connection, and are set free by the gradual dissolution of the mucilaginous walls. The free spermatozoid is much like that of Sphagnum, but the body is somewhat shorter. The cilia are relatively very long and thick, and as in all Bryophytes but two in number. A small vesicle can usually be seen attached to the posterior end.

Growing among the antheridia are found peculiar sterile hairs, or paraphyses. These in Funaria are very conspicuous, and consist of a row of cells tapering to the base, and very much larger at the apex. The terminal cell, or sometimes two or three of them, are almost globular in form and very much distended. All the cells of the paraphyses contain large chloroplasts which in the globular end cells are especially conspicuous and often elongated with pointed ends.

The archegonia are formed while the female plant is still very small, and it is much more difficult to recognise the female plants than the males. The archegonia are ripe at a time when the female plant is still but a few millimetres in height. In this case there is no doubt that the apical cell forms an archegonium directly, but not necessarily the first one, which arises usually from one of the last-formed segments. The elongation of the axis of the female branch is but slight, even in the later stages, and the plant remains bud-like even after the sporogonium is 
developed. In regard to the development of the leafy axis, or gametophore, therefore, Funaria offers a very marked contrast to Fontinalis or Sphagnum, where the gametophore reaches such a large size and has practically unlimited growth.

The young archegonia are quite colourless, and the details

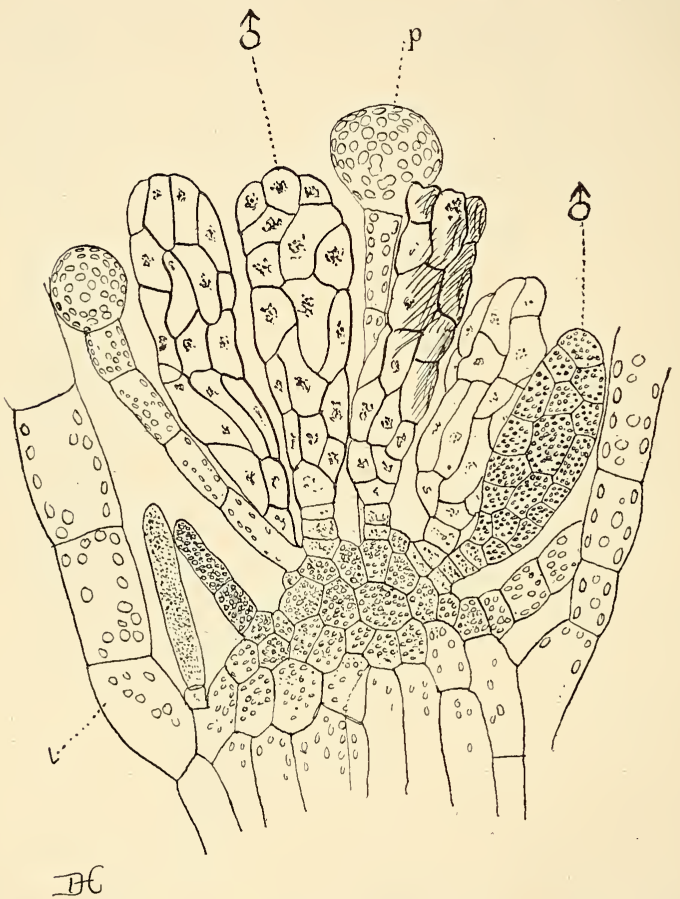

Fig. 92.-Longitudinal section through the apex of a male plant of F. liygrometrica, $\times 300$; L, leaf; $\delta$, antheridia ; $p$, paraphyses.

of their structure may be made out without difficulty. The first division separates a basal cell from a terminal cell, which is the mother cell of the archegonium. In the latter three walls now arise, as in the Hepaticæ and Andreaa, but in Funaria these do not all reach to the basal wall, but intersect at some distance above it, so that they enclose a tetrahedral cell, pointed below instead 
of truncate. This tetrahedral cell now divides by a transverse wall into an upper cell, corresponding to the "cover cell" of the Liverwort archegonium, and an inner one (Fig. 93, A),
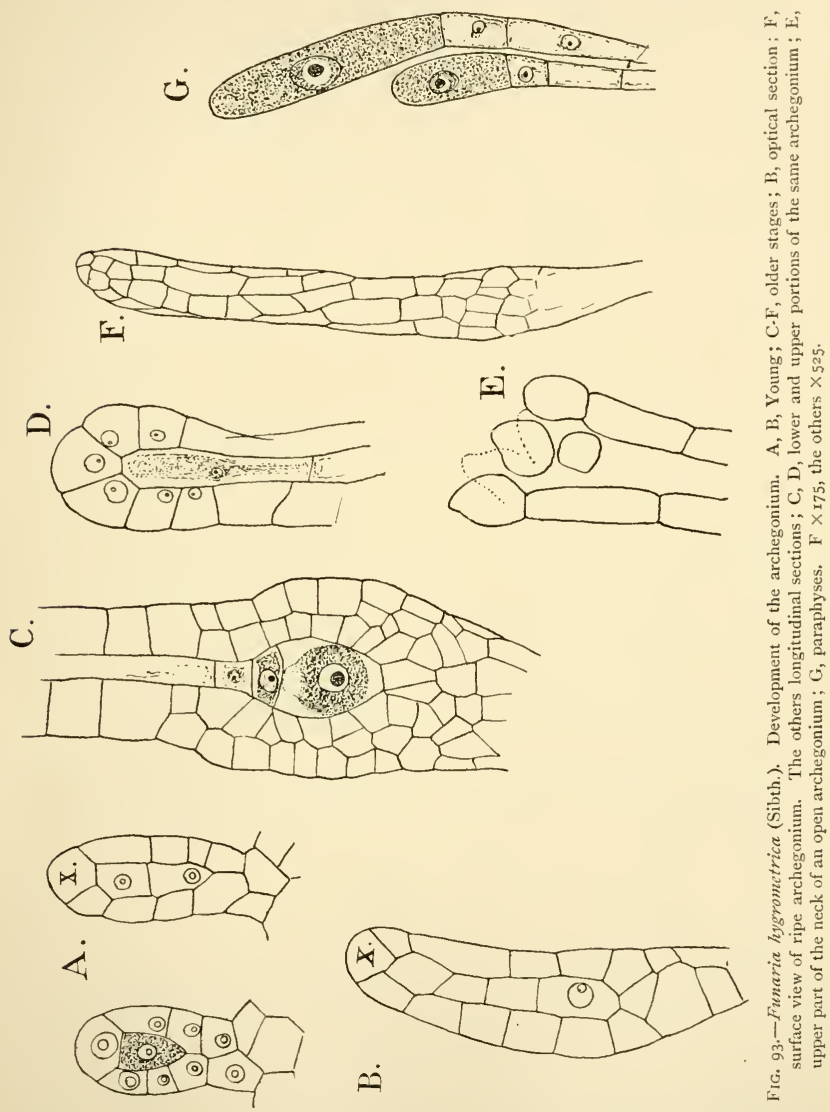

which gives rise, as in the Hepaticæ, to the egg and ventral canal cell. From this point, however, the development proceeds in another way, and follows the method observed in Andreaa. 
The cover cell, instead of dividing by quadrant walls, has a regular series of segments cut off from it, and acts as an apical cell. These segments are cut off parallel both to its lateral faces and base, and thus form four rows of segments, the three derived from the lateral forces forming the outer neck cells, and the row of segments cut off from the base constituting the axial row of neck canal cells. Each row of lateral segments is divided by vertical walls, and forms six rows, which later divide by transverse walls as well, so that the number of cells in each row exceeds the original number of segments. This is not the case with the canal cells, which, so far as could be determined, do not divide after they are first formed. The wall of the venter owes its origin entirely to the three peripheral cells formed by the other primary walls in the archegonium mother cell. This becomes two-layered before the archegonium is mature, and is merged gradually into the massive pedicel, which in the Mosses generally is much more developed than in the Hepaticæ, In the older archegonia the neck cells do not stand in vertical rows, but are somewhat obliquely placed, owing to a torsion of the neck during its elongation. From the central cell the ventral canal cell is cut off, as usual, but is relatively smaller than is usual among the Hepaticæ. The egg shows a distinct receptive spot, which is not, however, very large. The rest of the egg shows a densely granular appearance, and the moderately large nucleus shows very little colourable contents, beyond the large central nucleolus. ${ }^{1}$ The terminal cells of the open archegonium diverge widely, giving the neck of the archegonium a trumpet shape (Fig. 93, F). Usually some of the cells become detached and thrown off.

\section{The Embryo}

The first (basal) wall in the fertilised ovum divides it into an upper and lower cell, as in Sphagnum and Andreaa, and the next divisions correspond closely to those in the latter. In both cells a wall is formed intersecting the basal wall, but not at right angles. This is especially the case in the upper cell, where a second wall strikes the first one nearly at right angles, and establishes the two-sided apical cell by which the

${ }^{1}$ It is perhaps questionable whether this mass is really the nucleolus. It may be composed in part of closely aggregated chromosomes. 
embryo grows for a long time. In the lower cell the divisions

A.

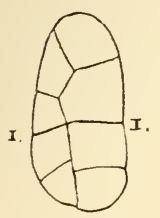

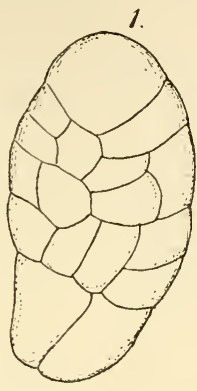
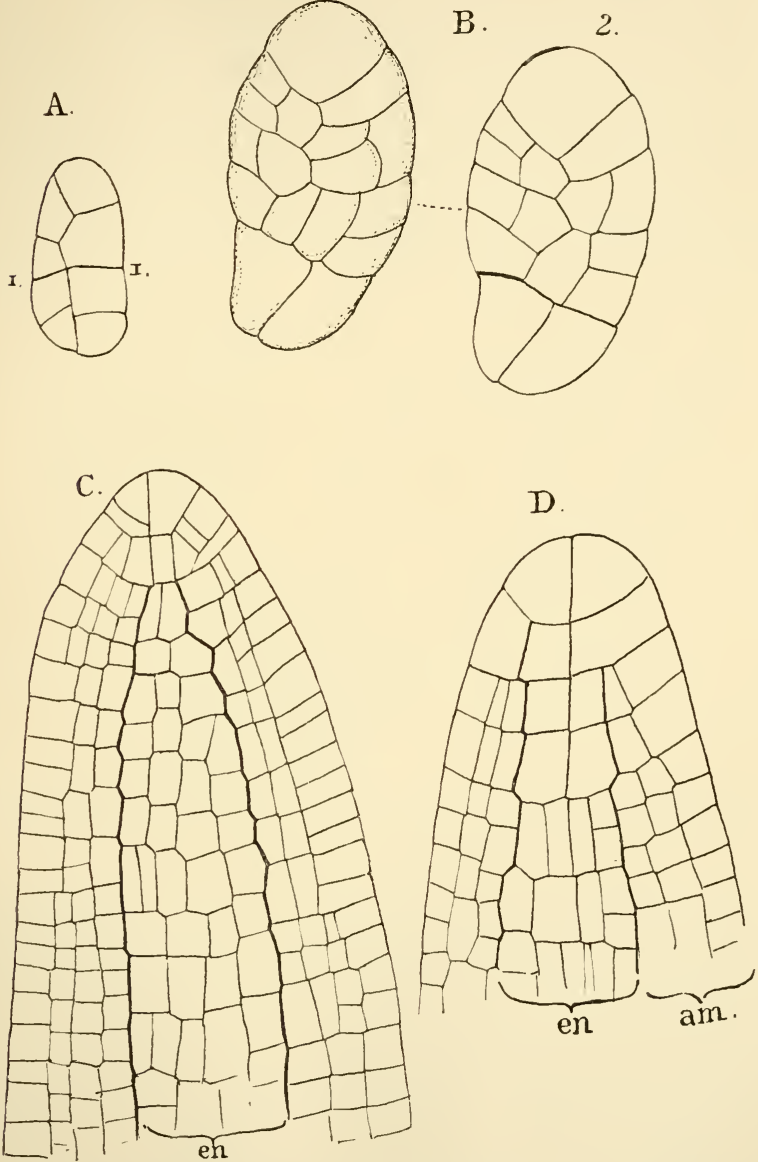

FIG. 94--Funaria hygrometrica (Sibth.). Development of the embryo. A, Optical section of a very young embryo; $\mathrm{B}, \mathrm{C}$, surface view and optical section of an older one, $\times 600 ; \mathrm{C}, \mathrm{D}$, longitudinal sections of the apex of older embryos, $\times 600 ; e n$, endothecium; $a m$, amphithecium.

are somewhat less regular, but here also it is not uncommon 
to find a somewhat similar state of affairs, so that the embryo may be said to have two growing points, although the lower end shows neither such regular nor so active growth as the upper one. In the latter the divisions follow each other with almost mathematical precision. There seems to be no rule as to how many segments are cut off from the apical cell before it ceases to function as such, but it is very much larger than in Andreaa, and the embryo soon becomes extremely elongated. A series of transverse sections of the young sporogonium shows very beautifully the succession of the first walls in the young segments. In a section just below the apex (Fig. 95, A), each
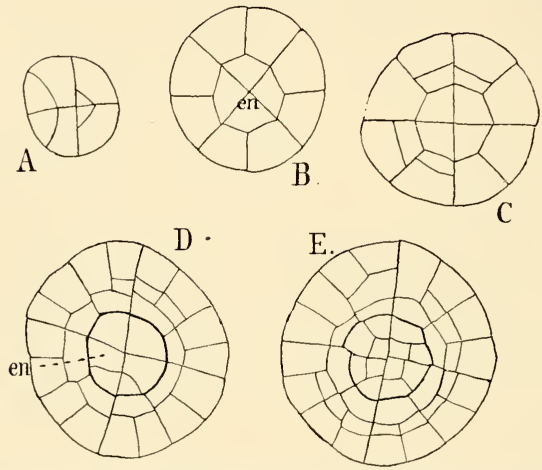

FIG. 95.-Five transverse sections of a young embryo of F. hygrometrica. A, Just below the apex, the others successively lower down; $e n$, endothecium, $\times{ }_{45}$.

segment is seen to be first divided by a median wall into two equal cells. In Funaria usually the next division wall is periclinal, and at once separates endothecium and amphithecium. In most other Bryineæ that have been examined, however, and this may also occur in Funaria (see Fig. 95, A), the second walls formed in the young segments are anticlinal, and it is not until the third set of walls is formed that the separation of endothecium and amphithecium is complete. The next divisions (Fig. 95, C) are in the amphithecium, and separate it into two layers. In the endothecium now a series of walls is formed, almost exactly repeating the first divisions in the original segment (Figs. D, E), and transforming it into a group 
of four central cells and eight peripheral ones. Each of the latter divides twice by intersecting walls, so that a group of about sixteen cells (Fig. 96, A) occupies the middle of the endothecium. The eight peripheral cclls divide by radial walls, after which each of these cells is divided by a periclinal wall into an outer and an inner cell (Fig. 96, B), and the outer cells divide rapidly by radial walls and form the archesporium. The single layer of cells immediately within, and therefore sister cells of the primary archesporial ones, is the inner spore-sac.

The account of the development of the endothecium here
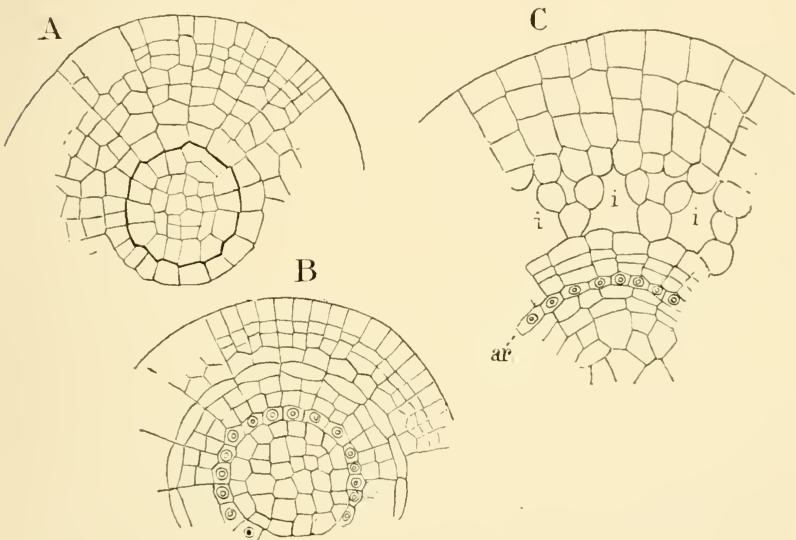

FIG. 96.- Three transverse sections of an older sporogonium of $F$. hygrometrica, $\times 400$; ar, archesporium; $i$, intercellular spaces.

given differs slightly from the account of Kienitz-Gerloff. ${ }^{1}$ It was found first that there was not the absolute constancy in the number of cells given by him; thus in Fig. 96, A there are only fourteen cells in the inner part of the endothecium, and although there are sixteen cells in the outer row their position is not perfectly symmetrical. Again the periclinal division of the cells of the inner spore-sac takes place later than he states is the case.

In the eight primary cells of the amphithecium there first arise periclinal walls that divide each cell into an inner small

1 Kienitz-Gerloff (2). 
cell in contact with the endothecium, and an outer larger one. This first division separates the wall of the capsule from the outer spore-sac. The latter next divides by radial and transverse walls, and later by periclinal walls into two layers (Fig. 96). Almost coincident with the latter, the rows of cells lying immediately outside it show a very characteristic appearance. They cease to divide, and with the rapid growth in diameter of the capsule become much extended both vertically and laterally, but are compressed radially. It is between these cells and the spore-sac that the characteristic air-space found in the capsule is formed. This is first evident shortly after the enlargement of the base of the capsule begins. The development can be very easily followed in longitudinal sections made at this stage. The formation of the space begins at the base of the capsule and proceeds toward the top. The line of cells bordering on the spore-sac is very easily followed, owing to their being so much larger than the neighbouring ones. As this is followed down, it is found that at the base of the capsule the cells are separated by large intercellular spaces, which become less marked toward the apex. With the rapid enlargement of the capsule these spaces become very large, and sections made a little later show that during this process the cells remain in contact at certain points, and form short filaments that extend across the space and unite the wall of the capsule with the outer spore-sac. At the base of the capsule the formation of intercellular spaces is not confined to the single layer of cells but involves the whole central mass of tissue, which becomes thus transformed into a bundle of filaments connecting the columella with the basal part (apophysis) of the capsule. The innermost of the two layers of cells between the archesporium and the air-space finally undergoes a second periclinal division, and in the fullgrown sporogonium the archesporium is bounded on the outside by three layers of cells.

The differentiation into seta and capsule takes place late in Funaria, and the first indication of this is the enlargement of a zone between the two, forming the apophysis, which at this stage (Fig. 97) is much greater in diameter than the upper part of the capsule. Sections through the apophysis and seta show a less regular arrangement of the cells than the sporiferous part of the capsule, but the general order of cell- 


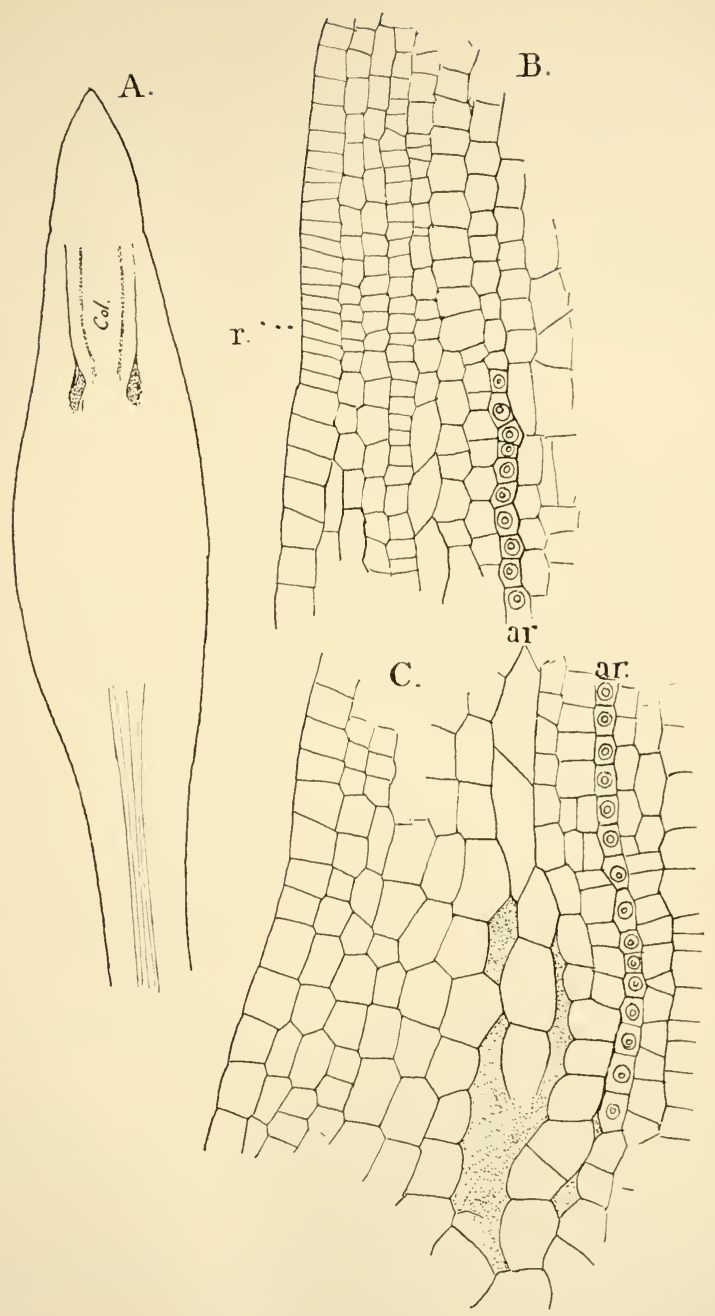

FiG. 97.-Funaria hygrometrica (Sibth.). A, Longitudinal section of a sporogonium showing the first differentiation of its parts, $\times$ about $96 ; \mathrm{B}$, the upper part of the same, $\times 600 ; r$ marks the limits of the theca and operculum; $C$, basal part of the capsule of the same, $\times 600$. The intercellular spaces are beginning to form; ar, archesporium; col, columella. 
succession is the same, except for the formation of the archesporium. Almost as soon as the capsule is recognisable, the first indication of the operculum or lid becomes evident. About half-way between the extreme apex of the sporogonium and the top of the apophysis, a shallow depression is noticed extending completely round the capsule and separating the sharply conical apex from the part below. An examination of a longitudinal section at this point shows that at the point of separation the epidermal cells of the opercular portion are

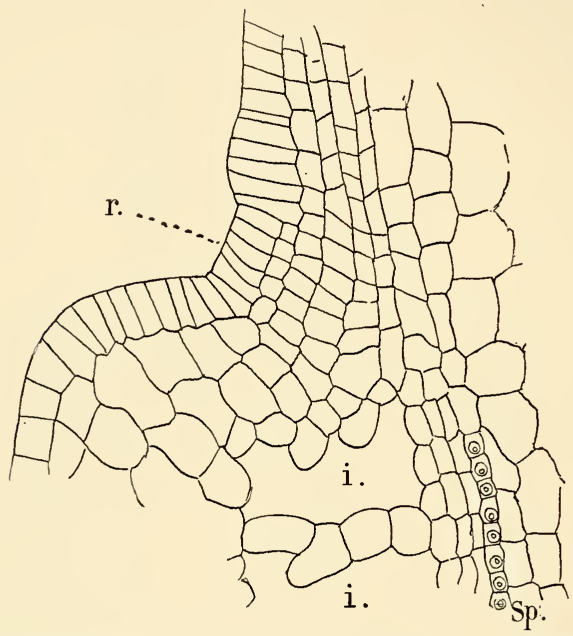

FIG. 98.-Longitudinal section of an older capsule of $F$. hygrometrica; $i$, intercellular spaces; $s p$, archesporium ; $r$, cells between operculum and theca, $\times 525$.

much narrower than those immediately below. Examining the tissues farther in, the archesporium is seen to extend only to a point opposite the base of the operculum, and the same is true of the row of large cells where the air-space is formed. If a similar section is made through an older capsule (Fig. 98) it is evident at once that the enlargement takes place mainly below the junction of the operculum, and there is also a similar but less pronounced increase in diameter in the operculum itself; but there is a narrow zone at the junction of the operculum and capsule, where the epidermal cells increase but 
little in depth, while those above this point become very much larger and project beyond them. This narrow zone of cells marks the point where when ripe the operculum becomes detached. The latter, up to the time the sporogonium is ripe, is composed of a close tissue without any intercellular spaces. The epidermal cells, seen from the surface, are seen to be arranged in spiral rows running from the base to the apex. Its central part is made up of large thin-walled parenchyma, continuous with the tissue of the columella. The archesporium, therefore, is not continuous over the top of the columella, as in Sphagmum and Andreae, but is cylindrical. The archesporium forms simply a single layer of small cells, and occupies a very small part of the sporogonium, much less, relatively, than in any of the forms hitherto described. Before the final division of the spores it divides more or less completely into two layers. The cells resulting from this last division are the spore mother cells, which separate soon after their formation and lie free in the space between the inner and outer spore-sacs, where each one divides into four tetrahedral spores.

In the operculum, as the capsule approaches maturity, the differentiation of annulus and peristome takes place. The former consists of about four rows of cells (Fig. 98) that occupy the periphery of the broadest part of the operculum. These cells are very much compressed vertically, but are deep and have their walls thicker than their neighbours. Just below them are about two rows of similar cells, but somewhat less compressed and with very thin walls. These latter cells mark where the separation takes place, the annulus forming the rim of the loosened operculum.

The peristome arises from the fifth layer of cells from the outside of the operculum. If a median longitudinal section of a nearly ripe capsule is examined, the row of cells belonging to this layer (Fig. 99, per) is at once seen to have the outer walls strongly thickened, and this thickening extends for a short distance along the transverse walls. The inner walls of the cells also show a slight increase in thickness, but much less marked than the outer ones. A similar thickening of the cell walls occurs also in about three rows of cells which run from the outside of the capsule to the base of the peristome, and form the rim of the "theca" or urn.

The epidermis of the whole capsule has its outer walls 
very much thickened, and upon the apophysis are found stomata quite similar to those found upon the sporogonium of Anthoceros or the leaves of vascular plants. Haberlandt ${ }^{1}$ showed that while the form of the fully-developed stoma in Funaria differs from that of most vascular plants, this difference is secondary, and that in its earlier stages no difference exists. This can be easily verified, and with little difficulty all the different stages found. The young stoma
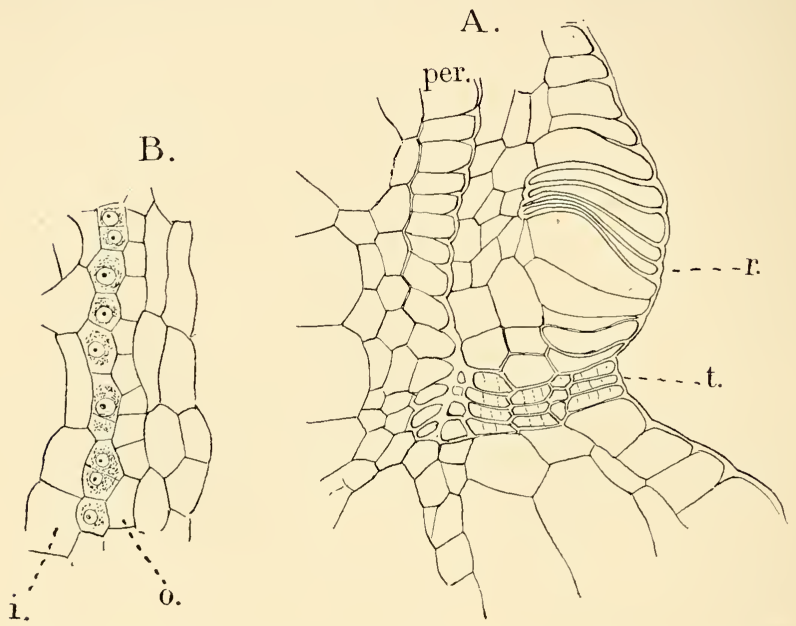

FIG. 99.-A, Longitudinal sections of a nearly ripe capsule of $F$. hygrometrica, $\times_{2} 60$; per, peristome ; $r$, annulus; $t$, thickened cells forming the margin of the theca; $\mathrm{B}$, the sporogenous cells shortly before the final divisions; $i$, inner; $o$, outer spore-sac, $\times 525$.

(Fig. IOI) has the division wall extending its whole length, as is the case in stomata of the ordinary form. As the stoma grows larger, however, the median wall does not grow as fast as the lateral walls, and a space is left between its extremities, so that the two guard cells have their cavities thrown into communication, and the division wall forms a cellulose plate extending from the lower to the upper surface of the stoma, but with its ends quite free. The formation of the pore by the splitting of the middle lamella of the division wall takes 
place in the ordinary way. Later the walls of the epidermal cells become very thick and show a distinct striation (Fig. IOI). By the formation of the stomata the green assimilating tissue of the apophysis and central part of the capsule are put into direct communication with the external atmosphere.

The lower part of the seta grows downward and penetrates the top of the stem of the gametophyte, from which, of course, it derives a portion of its sustenance. The centre of the seta is traversed by a well-marked central cylinder, whose inner cells are small and thin-walled, and are mainly concerned in conducting water; immediately outside of this is a circle of

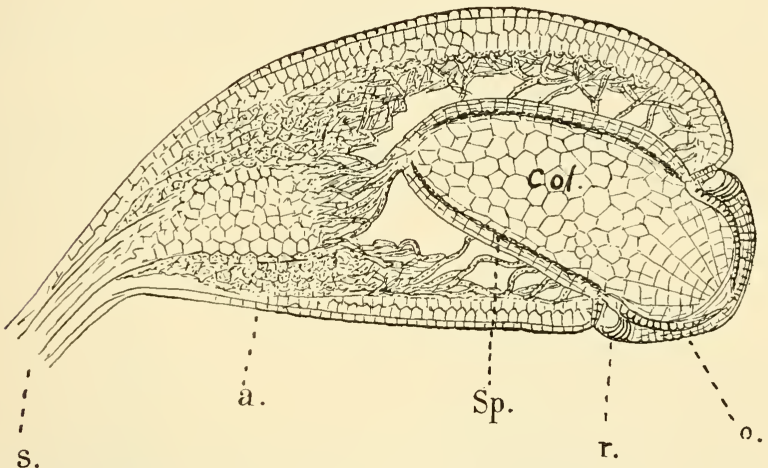

F1G. I0o.-Longitudinal section of a fully-developed sporogonium of Funaria hygrometrica, $x$ about $40 ; s$, seta ; $a$, apophysis ; sp, spores ; col, columella ; $r$, annulus ; $o$, operculum.

thick-walled brown cells (Leptome of Haberlandt), and the rest of the seta is made up of nearly similar thick-walled cells which grow smaller towards the periphery.

At maturity, as the supply of water is cut off from below, the capsule dries up, and all the delicate parenchyma composing the columella and inner part of the operculum, as well as that between the spore-sac and the epidermis of the theca, completely collapses, leaving little except the spores themselves, and the firm cell walls of the peristome, and the cells connecting the latter with the wall of the capsule. By the breaking down of the unthickened lateral and transverse walls of the peristomial cells, the outer and inner thickened walls are separated and 
form the two rows of membranaceous teeth that surround the
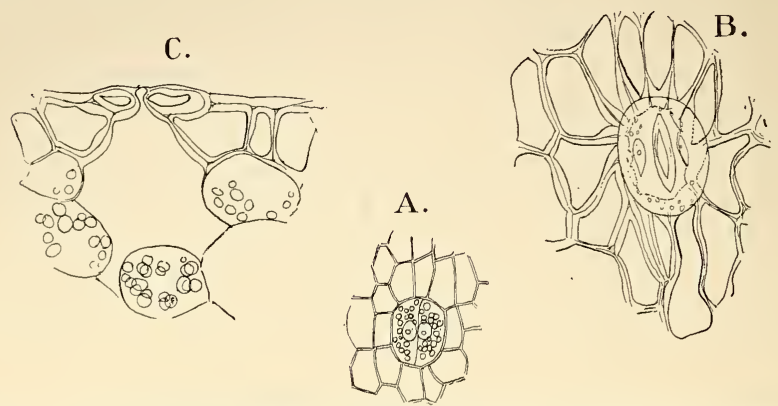

FIG. IoI.-Funaria hygrometrica (Sibth.). A, Young; B, older stoma, from the base of the capsule ; C, vertical section, $\times 360$.

mouth of the urn (Fig. IO2). By the drying up of the thinwalled cells between the annulus and the margin of the theca the operculum is loosened and is very easily separated. The

B.

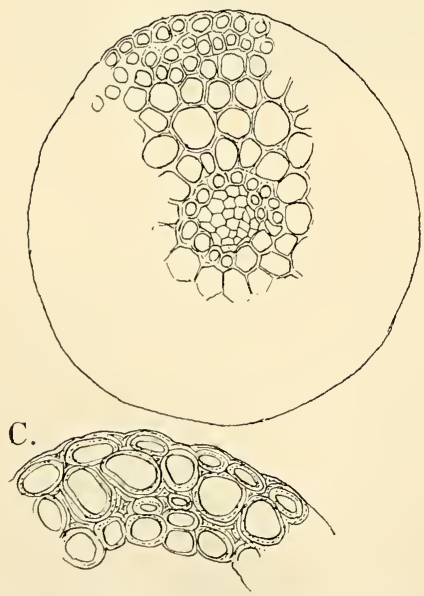

FIG. I02.-Funaria hygrometrica (Sibth.). A, Part of the peristome; $o$, an outer tooth; $i$, one of the inner teeth, $\times 85 ; \mathrm{B}$, section of the seta, $\times 260 ; \mathrm{C}$, cross-section of upper part of calyptra, $\times 525$.

teeth of the peristome are extremely hygroscopic, and probably 
assist in lifting off the operculum as well as removing the spores from the urn. When wet they bend inward, extending into the cavity of the urn. As they dry they straighten out and lift the spores out. The marked hygroscopic movements of the seta also are no doubt connected with the dissemination of the spores.

The calyptra in the Bryineæ is very large and is carried up on the top of the sporogonium in the form of a conspicuous membranaceous cap. As in other forms it is the venter alone that shows secondary growth. In Funaria it increases very much in diameter at the base, where it is widened out like a bell, and far exceeds in diameter the enclosed embryo. Above it is narrow and lies close to the embryo. After a time the embryo grows more rapidly in length than the calyptra, which then is torn away by a circular rent about its base, and is raised on top of the elongating sporogonium. The lower portion remains delicate and nearly colourless, but the upper part has its cells thick-walled and dark brown in colour (Fig. I 2 2, C). Tipping the whole is the persistent dark brown neck of the archegonium.

\section{Classification of the Bryinea}

The simplest of the Bryinex are the cleistocarpous forms or those in which there is no operculum developed, and in consequence the capsule opens irregularly. If Archidium is removed from this group the simplest form known is Ephemerum. Here, from a highly-developed filamentous protonema, are produced the extremely reduced gametophores. According to Muiller, ${ }^{1}$ who has studied the life-history of this genus, both male and female branches arise from the same protonema, and are only distinguishable by the smaller size of the former. The axis of the branch is scarcely at all elongated, and the leaves therefore appear close together. The sexual organs correspond closely in origin and structure to the other Bryinex. The development of the sporogonium in its early phases is also the same, and the differences only appear at a late stage. The separation of endothecium and amphithecium is apparently exactly the same as in other Bryineæ, and from the former is derived the archesporium, 

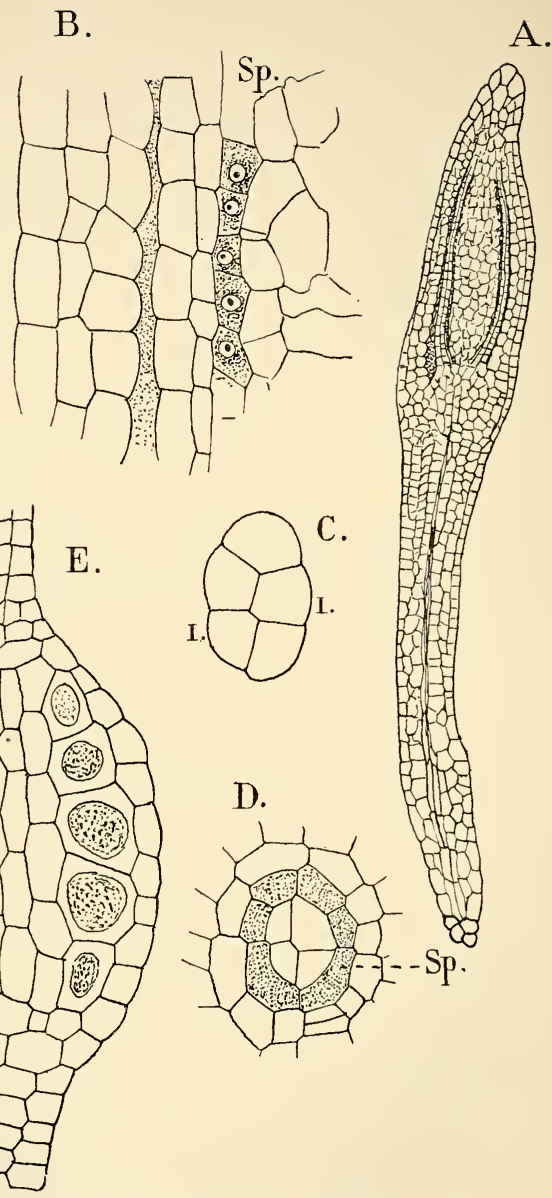

FIG. 103.-A, Longitudinal section of the young sporogonium of Pleuridium subulatum, $\times 80 ; \mathrm{B}$, part of the same, $\times 6 \mathrm{co} ; s p$, archesporium; C, young embryo of Phascum cuspidatum, optical section, $\mathrm{X}_{175} ; \mathrm{D}$, cross-section of an older embryo of the same, $\mathrm{X}_{350} ; s p$, archesporium ; $\mathrm{E}$, longitudinal section of the central part of the young sporogonium of Ephemerum phascoides, $\times 35^{\circ}$; $s p$, archesporium. C, D, after Kienitz-Gerloff; E, after Müller. 
which like that of Funaria has the form of a hollow cylinder through which the columella passes. Between the outer spore-sac and the wall of the sporogonium an intercellular space is also formed, but the separation of the cells is complete, and there are no filaments connecting the spore-sac and the sporogonium wall as in Funaria. The cells of the archesporium are few in number and correspondingly large (Fig. IO3, E), and before the division into the spores takes place all the central tissue of the columella is absorbed, and the spore mother cells occupy the whole central space. Here the division of the spores is completed, and at maturity the whole of the capsule is filled with the large spores, and no trace of the columella remains.

The highest members of the Cleistocarpæ, such as Phascum and Pleuridium (Fig. IO4), approach very closely in structure the stegocarpous Bryineæ. In these the gametophore is much better developed than in Ephemerum, and the protonema not so conspicuous. The leaves also frequently have a welldeveloped midrib which is wanting in the leaves of Ephemerum.

Kienitz-Gerloff ${ }^{1}$ has carefully studied the embryogeny of Phascum cuspidatum, and except in a few

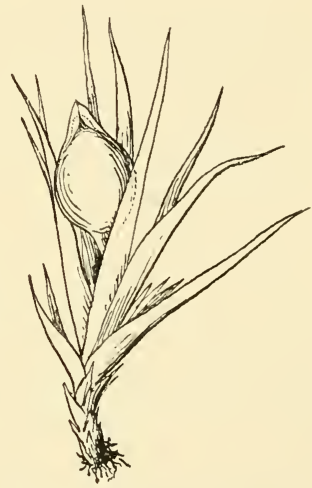

FIG. 104.-Pleuridium subulatum, $\times 20$. minor details it corresponds very closely to that of Funaria, except, of course, as regards the operculum and peristome, which are absent. In Phascum, however, the archesporium is differentiated earlier than in Funaria. In each of the four primary cells of the endothecium, as seen in transverse section, a periclinal wall arises which at once separates the archesporium from the columella (Fig. IO3, D). The outer spore-sac has but two layers of cells, and the capsule wall three, and between them the large lacuna is formed as in Funaria; but in Phascum as in Ephemerum, the separation of the cells is complete. In the seta a slightly-developed central cylinder of conducting tissue is developed, derived, as in Funaria, from the endothecium,

1 Kienitz-Gerloff (2). 
but in Phascum it is much less conspicuous. Pleuridium (Fig. I03, A) in its later stages corresponds exactly to Phascum, except that the capsule is more slender. In both of these genera the seta remains short, but is perfectly evident. Whether the absence of a distinct operculum in the cleistocarpous Mosses is a primitive condition, or whether they are reduced forms, it is impossible to determine positively from a study of their embryogeny.

\section{Bryinea Stegocarpe}

Very much the larger number of Mosses belong to this group, which is primarily distinguished from the foregoing by the presence of an operculum. Of course among the 7000 or more species belonging here there are many differences in structure; but these are mainly of minor importance morphologically, and only the more important differences can be considered here.

As we have already seen, there is great uniformity in the growth of the stem, which, with the single exception of Fissidens, has always a three-sided pyramidal apical cell. In Fissidens this is replaced by a two-sided one, but even here it has been found ${ }^{1}$ that the underground stems have a three-sided initial cell, which is gradually replaced by the two-sided one after the apex of the shoot appears above ground. In Fissidens the leaves are arranged in two rows corresponding to the two sets of segments, and are sharply folded, so that the margins of the leaf are covered over by those of the next older ones, leaving only the apex free. A similar arrangement is found in the genus Bryoziphion (Eustichia), but here there is a three-sided apical cell, and the two-ranked arrangement of the leaves is secondary. The curious genus Schistostega shows also a tworanked arrangement of the leaves of the sterile branches, but here they are placed vertically and the bases connivent, so that the effect of the whole is that of a pinnatifid leaf. The fertile branches, however, have the leaves spirally arranged, and in the sterile ones the three-sided apical cell is found. The leaves, with few exceptions, e.g. Leucobryum, Fontinalis, have a wellmarked midrib, and the lamina is single-layered. Leucobryum (Fig. I07, A) has leaves destitute of a midrib, and made up of

I Goebel (8), p. 37 I. 
two or three layers of cells, large hyaline ones, somewhat as in Sphagmum, and small green cells. The hyaline cells, as in Sphagnum, have round holes in the walls, but no thickenings. The midrib may be narrow, as in Funaria, or it may occupy nearly the whole breadth of the leaf, as in the Polytrichacex, where, owing to the almost complete suppression of the lamina, secondary vertical plates of green cells are formed (Fig. IO7, B).

The one-third divergence of the leaves found in Fontinalis ${ }^{1}$ is replaced in most other genera by a larger divergence. ${ }^{2}$ Thus in Funaria hygrometrica it is $\frac{3}{8}$; in Polytrichum commune $\frac{5}{13}$; in $P$. formosum $\frac{13}{34}$.

As the archegonia are borne upon lateral branches, or upon the main axis, the stegocarpous Bryineæ are frequently divided into two main divisions, the Pleurocarpæ and the Acrocarpæ, which are in turn divided into a number of subdivisions or families. How far the division into acrocarpous and pleurocarpous forms is a natural one may be doubted, as probably the latter is secondary, and it is quite conceivable that different families of pleurocarpous forms may have originated independently from acrocarpous ones.

The simplest of the stegocarpous Mosses, while having the operculum well marked, have no peristome. Thus the genus Gymnostomum has no peristome at all, and in an allied genus, Hymenostomum, it is represented by a thin membrane covering the top of the columella. In nearly related genera, however, e.g. Weisia, a genuine peristome is present.

The Tetraphideæ, represented by the genus Tetraphis (Fig. I05), are interesting as showing the possible origin of the peristome, as well as some other interesting points of structure. Tetraphis pellucida is a small Moss, which at the apex of its vegetative branches bears peculiar receptacles containing multicellular gemmæ of a very characteristic form. The leaves that form the receptacle are smaller than the stem leaves, and closely set so as to form a sort of cup, in which the gemmæ are produced in large numbers. These arise as slender multicellular hairs, the end cell of which enlarges and forms a disc, at first one-layered, but later, by walls parallel to the broad surfaces, becoming thicker in the middle, and lenticular in form. The arrangement of the cells in the young gemmæ looks as if

1 This seems to be strictly the case only in the smaller branches; in the larger axes the leaves are not exactly in three rows. ${ }^{2}$ Goebel (8). 
the growth of the bud was due to a two-sided apical cell (Fig. I0 5, C), but this point was not positively determined. These gemmæ give rise to a protonema of a peculiar form, from which in the usual way the leafy stems develop. The protonemal filaments grow into flat thalloid expansions that recall those of Sphagnum and Andreaa.

The sporogonium of Tetraphis has a peristome of peculiar structure, and not strictly comparable to that of any of the

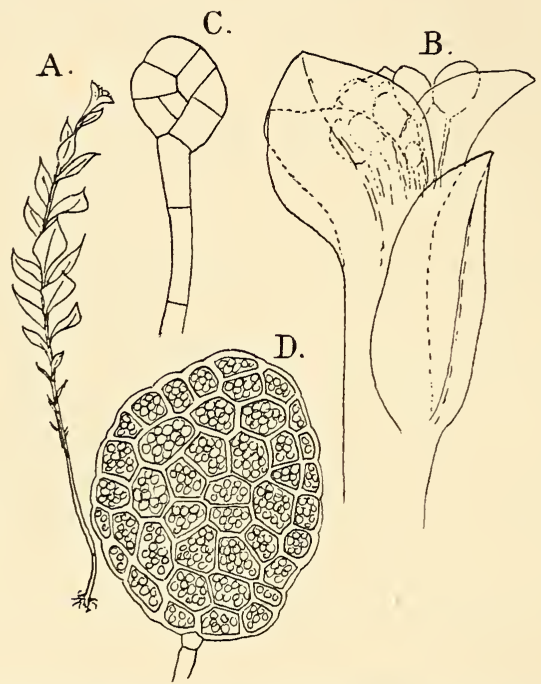

FIG. 105.--Tetraphis pellucida (Hedw.). A, Plant with gemmæ, $\times 6 ; \mathrm{B}$, upper part of the same, $\times 50$; C, young gemma, $\times 600 ; \mathrm{D}$, a fully-developed gemma, $\times 300$.

other Mosses. After the operculum falls off the tissue lying beneath splits into four pointed teeth, which, however, are not, as in Funaria, composed simply of the cell walls, but are masses of tissue.

All of the other higher Bryineæ, with the exception of the Polytrichaceæ, have the peristome of essentially the same structure as that described for Funaria. Sometimes the teeth do not separate but remain as a continuous membrane, i.e. the inner peristome of Buxbaumia, or a perforated membrane, as in Fontinalis (Fig. I06, B). 
The base of the capsule, or apophysis, which Haberlandt ${ }^{1}$
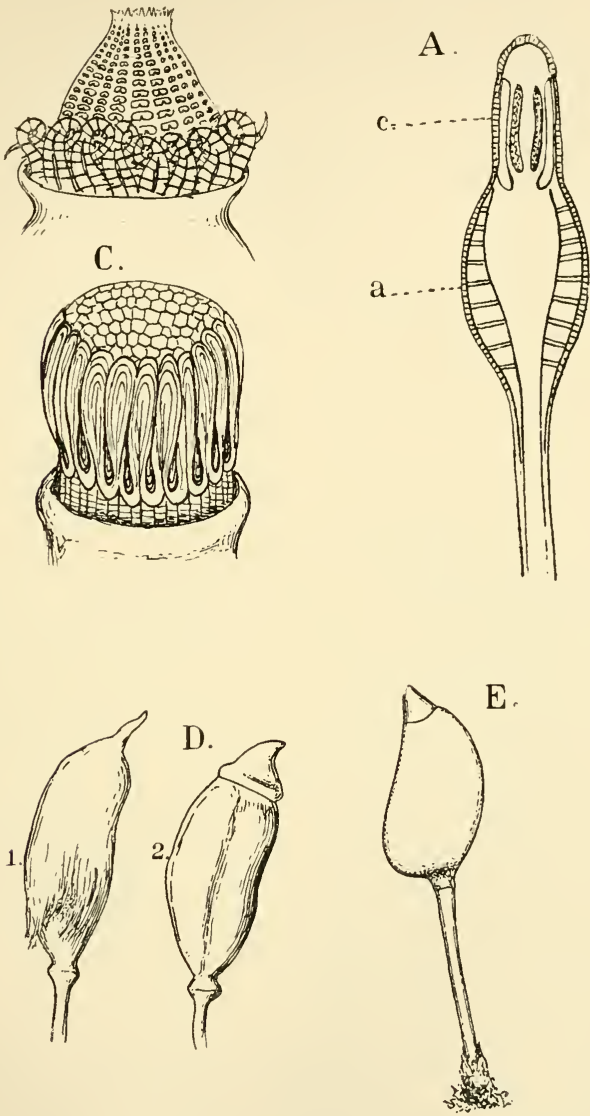

FiG. 106.-A, Splachnum ampullaceum(L.), longitudinal section of the sporogonium(after Haberlandt); $a$, apophysis ; $c$, capsule ; B, peristome of Fontinalis antipyretica (L.) ; C, peristome of Atrichum undulatum (after Schimper); D, sporogonium of Polytrichum commune (L.); I, with the calyptra ; 2, with the calyptra removed; E, Buxbaumia, $\mathrm{x}_{4}$.

has shown to be the principal assimilative part of the sporo-

1 Haberlandt (4). 
gonium, and which alone is provided with stomata, sometimes becomes very large, and in the genus Splachmum ${ }^{1}$ especially forms a largely-developed expanded body, which must be looked upon as a specially-developed assimilating apparatus (Fig. I 06, A).

Undoubtedly the Polytrichaceæ represent the highest stage of development among the Musci. This is true both in regard to the gametophore and the sporogonium. The former reaches in some species, i.e. P. commune, a length of 20 centimetres and sometimes more. The stem is usually angular and the closely-set leaves thick and rigid. The numerous rhizoids are often closely twisted together and form cable-like strands. The structure of the leaves is very characteristic, and differs very much from that of the simpler type found in Funaria. In Polytrichum (Fig. I07, B) the midrib is very broad, and only at the extreme margins of the leaf is the lamina one-layered. Seen in cross-section ${ }^{2}$ the leaf appears somewhat crescentshaped. The cells of the margin of the section, and also a line of cells running through the central part, are comparatively thinwalled, and the latter are empty water-conducting cells similar to the tracheæ in the vascular bundles of the higher plants. Next to these cells on the lower side of the leaf are a number of similar but somewhat smaller cells containing starch, and the rest of the section is made up principally of very thick-walled sclerenchyma. The outer cells contain more or less chlorophyll, but the principal assimilative tissue consists of a series of vertical cell plates or laminx parallel to the long axis of the leaf, and seen in cross-section appear as short vertical rows of four or five cells. These cells contain numerous chloroplasts, and the laminæ cover the whole upper surface of the leaf except the extreme margin and the sheathing part of the base, where they are wanting.

The structure of the stem of $P$. commune is thus described by Goebel." "A transverse section of the stem shows the following structure. In the centre is a cylinder of broad thickwalled cells, with here and there those whose walls have remained thin. The thickened walls show a yellowish colour. Surrounding this cylinder is a ring of several layers of thin-walled narrow cells, which is bounded on the outside by from one to three layers of cells with thin, mostly very dark brown walls. These

${ }^{1}$ Vaizy (3).

${ }^{2}$ Strasburger (10).

${ }^{3}$ Goebel (8), p. 369. 
latter, as well as the cells lying immediately within, are characterised by the starch contained in them, as are the narrow cells of the leaf-traces. Otherwise starch is often completely absent from the stem of Polytrichum and is replaced by oil. The latter is abundant, and probably albuminoids as well, in the thin-walled tissue surrounding the central cylinder. In the latter oil is not so abundant, as its cells for the most part contain only air."

The leaf - traces, or continuation of the central tissue of the midribs of the leaves, bend down into the stem, and finally unite with the axial cylinder of the latter, in a manner quite analogous to that found in the stems of many vascular plants.

Bastit, ${ }^{1}$ who more recently has made a comparative study of the subterranean and aerial stems of $P$. juniperinum, divides the outer tissue of the latter into epidermis, hypoderma, and cortex. In the subterranean stems he finds the construction quite different from that of the leafy
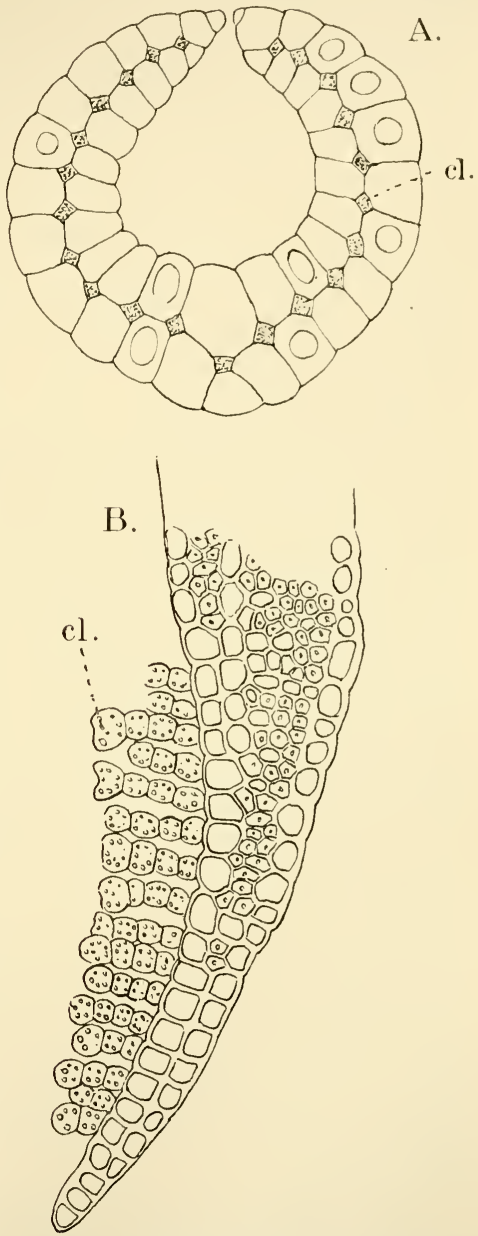

Fig. 107.-A, Transverse section of the leaf of Leuco. bryum; B, similar section of the leaf of Polytrichum commune; $\mathrm{cl}$, chlorophyll-bearing cells (after Goebel).

1 Bastit (I), p. 295. 
branches. The section of the former is triangular, and its epidermis provided with hairs which are absent from the epidermis of the aerial parts. Rudimentary scales, arranged in three rows, are present, and corresponding to these are strands of tissue that represent the leaf-traces of the aerial stems. The central cylinder is much larger relatively than in the leafy branches, and its cross-section is not continuous, but is interrupted by three "pericyclic sectors," composed of cells whose walls are but little thickened. The point of each sector is at the periphery of the medulla, or central cylinder, and the broad end toward the centre. As might be expected, intermediate conditions are found where the rhizome begins to grow upward to form a leafy branch.

The male inflorescence of the Polytrichaceæ is especially conspicuous, as the leaves immediately surrounding the antheridia are different both in form and colour from those of the stem. They are broad and membranaceous, and more or less distinctly reddish in colour. A well-known peculiarity of these forms is the fact that the growth of the stem is not stopped by the formation of antheridia, but after the latter have all been formed the axis resumes its growth and assumes the character of an ordinary leafy branch. This, of course, indicates that, unlike most of the Mosses, the apical cell does not become transformed into an antheridium, and the researches of Hofmeister, ${ }^{1}$ Leitgeb, ${ }^{2}$ and Goebel ${ }^{3}$ have shown that this is the case. The antheridia form groups at the base of each leaf of the inflorescence, and Leitgeb thinks it probable that each group represents a branch, i.e. the inflorescence is a compound structure, and not directly comparable to the simple male inflorescence of Funaria. The sporogonium in Polytrichum has a large intercellular space between the inner spore-sac and columella as well as the one outside the outer spore-sac. In both cases the space is traversed by the conferva-like green filaments found in the other stegocarpous Mosses. The apophysis is well developed, especially in Polytrichum, and the calyptra very large and covered with a dense growth of hairs (Fig. I 06, D).

The structure of the peristome in the Polytrichaceæ is entirely different from that of the other Mosses. It is composed of bundles of thickened fibrous cells arranged in crescent

1 Hofmeister (2).

2 Leitgeb (9).

${ }^{3}$ Goebel (7). 
form, the ends of the crescent pointing up, and united with the adjacent end of the bundle next it. The tops of the teeth thus formed are connected by a layer of cells stretching across the opening like the head of a drum. This membrane is known technically as the "Epiphragm" (Fig. I 06, C).

\section{The Buxbanmiacee}

The last group of Mosses to be considered is the very peculiar one of the Buxbaumiacex. In these Mosses the gametophyte is extraordinarily reduced, although the sporogonium is large and well developed. So simple is the sexual plant, that Goebel ${ }^{1}$ has concluded that these ought to be taken away from the rest of the Mosses, and removed to a distinct order. According to Goebel's account, the antheridia, which are long stalked, are borne directly upon the protonema, and subtended by a single colourless bract. The female branches are also very rudimentary, but less so than the male. On the strength of the extreme simplicity of these, Goebel thinks that Buxbaumia is a primitive form allied to some alga-like progenitor of the Mosses. There are, however, two very strong objections to this. First the sporogonium, which is extremely large, and complicated in structure, and essentially like that of the other stegocarpous Mosses; secondly, Buxbaumia has been shown by Haberlandt ${ }^{2}$ to be distinctly suprophytic in its habits, and the extreme reduction of the assimilative tissue of the gametophyte is quite readily explicable from this cause.

\section{Fossil Muscinea}

The remains of Muscineæ in a fossil condition are exceedingly scanty; so much so indeed as to practically throw no light upon the question of their origin and affinities, as nearly all of the forms discovered belong to the later formations, and are either indentical with living species or closely allied forms. No doubt the great delicacy of the tissues of most of them, especially the Hepaticæ, accounts in great measure for their absence from the earlier geological formations. 


\section{The Affinities of the Musci}

It is perfectly evident that the Mosses as a whole form a very clearly defined class, and that their relationship with other forms is at best a somewhat remote one. Sphagnum, however, certainly shows significant peculiarities that point to a connection between this genus, at least, and the Hepaticæ. It will be remembered that the protonema of Sphagnum is a large flat thallus, and not filamentous, as in most Bryineæ. It is noteworthy, however, that from the margin of this flat thallus later filamentous branches grow out which are apparently identical in structure with the ordinary protonemal filaments of the Bryineæ. In Andreaa similar flat thalloid protonemata occur, but not so largely developed as in Sphagmum, and finally in Tetraphis a similar condition of affairs is met with. As this occurs only among the lower members of the Moss series, the question naturally arises, does this have any phylogenetic meaning? While it is impossible to answer this question positively, it at any rate seems probable that it has a significance, and means that the protonema has been derived from a thalloid form related to some thallose Liverwort, and that by the suppression of the thalloid portion, as the leafy gametophore became more and more prominent, the filamentous branches, which at first were mere appendages of the thallus, finally came to be all that was left of it. The view of Goebel and others that the filamentous form of the protonema is the primitive one, and indicates an origin from alga-like forms, might be maintained if the question were concerned simply with the protonema; but when the structure of the sexual organs, especially the archegonium, is considered, and the development of the sporophyte, the difficulty of homologising these with the corresponding parts in any known Alga is apparent, while on the other hand the resemblance between them and those of the Hepaticæ is obvious.

As to which group of the Hepaticæ comes the nearest to the Mosses, the answer is not doubtful. The remarkable similarity in the development and structure of the sporogonium of Sphagnum and the Anthoceroteæ, leaves no room for doubt that as far as Sphagnum is concerned, the latter come nearest among existing forms to the ancestors of Sphagnum. Of 
course this does not assume a direct connection between Sphagmum and any known form among the Anthocerotex. There are too many essential differences between the two to allow any such assumption: but that the two groups have come from a common stock seems reasonably certain, and the structure of the capsule in Sphagmum points to some form which like Anthoceros had a highly-developed assimilative system. This is indicated by the presence of stomata, which, although functionless, probably were once perfect, and make it likely that with the great increase in the development of the gametophyte the sporophyte has lost to some extent its assimilative functions, which have been assumed by the gametophyte.

Andreaa, both in regard to the gametophyte and the sporophyte, is in many ways intermediate between Sphagnum and the other Mosses. The resemblance in the dehiscence of the sporogonium to that of the Jungermanniacea is probably accidental. It may perhaps be equally well compared to the splitting of the upper part of the capsule into four parts, in Tetraphis, although in the latter it is the inner tissue and not the epidermis which is thus divided.

If this latter suggestion proves to be true, then there would be a direct connection of Andread with the stegocarpous Bryinex, and not through the cleistocarpous forms. These latter would then all have to be considered as degraded forms derived from a stegocarpous type, unless, with Leitgeb, we consider them as a distinct line of development leading up to the higher Bryinex, entirely independent of the Sphagnaceæ, and with Archidium and Ephemerum as the simplest forms. His comparison of these forms with Notothylas, however, cannot be maintained with our present knowledge of that genus, and more evidence is needed before his view can be accepted; but the possibility of some such explanation of the cleistocarpous Bryinea must be borne in mind in trying to assign them their place in the system.

The objections to considering Buxbaumia a primitive form have been already given, and it is not necessary to repeat them. 
THE PTERIDOPHYTA-OPHIOGLOSSACE $Æ$

IN tracing the evolution of the Bryophytes from the lowest to the highest types the gradual increase in the importance of the second generation, the sporophyte, is very manifest. This may or may not be accompanied by a corresponding development of the gametophyte. In the line of development represented by the higher Mosses, in a general way the two have been parallel, and the most highly differentiated gametophyte bears the most complicated sporophyte, as may be seen in Polytrichum, for example; but in the Hepaticæ this is not the case, and much the most highly organised sporophyte here, that of Anthoceros, is produced by a very simple gametophyte.

In this evolution of the sporophyte, it approaches a condition where it is self-supporting, but in no case does it become absolutely so. A special assimilative tissue, it is true, is developed, and in some of the true Mosses, such as Splachmum, this goes so far that a special organ, the apophysis, is formed; but, as we have seen, the sporogonium is dependent for its supply of water and nitrogenous food upon the gametophyte, with which it remains intimately associated, and upon which it lives as a parasite.

In the Pteridophytes the case is different; here by the development of a special organ, the root, the young sporophyte is brought into direct communication with the source of supply of water, and the food materials dissolved in it. In the few cases where true roots are absent their place is taken by other structures that perform their functions. The assimilative activity is restricted to special organs, the leaves, except in a few cases 
where these become much reduced, as in Psilotum or Equisetum. A main axis is present upon which the leaves are borne as appendages, and which continues to form new leaves and roots as long as the sporophyte lives.

The differentiation of these special organs begins while the sporophyte is still very young. The earliest divisions in the embryo correspond closely to those in the embryo of a Bryophyte, but instead of forming simply a capsule, as in all the Bryophytes, there is established more than one growing point, each one forming a distinct organ. In the Ferns there are four of these primary growing points, giving rise respectively to the stem, leaf, root, and foot. The latter is a temporary structure, by which the young sporophyte absorbs food from the gametophyte, but as soon as it becomes independent this gradually withers away, and soon all trace of it is lost.

The originally homogeneous tissues of the embryo become differentiated into the extremely complicated and varied tissues characterising the mature sporophyte. The most characteristic of these are the vascular system of tissues. This is hinted at in the central strand of tissue in the seta of many Mosses, and the columella of the Anthoceroteæ; but in no Bryophyte does it reach the perfect development found in the Ferns and their relations, which are often called on this account the vascular cryptogams.

The gradual reduction in the vegetative parts of the gametophyte, from the large long-lived prothallium of the Marattiacere to the excessively reduced one found in the heterosporous Pteridophytes, has already been referred to in the introductory chapter.

The structure of the sexual organs of the Pteridophytes appears at first sight radically different from that of the Bryophytes, but a careful comparison of the lower forms of the former with some of the Hepaticæ, especially the Anthoceroteæ, shows that the difference is not so great as it at first sight appears. A further discussion of this point must be left, however, until we have considered more in detail the structure of these parts in the different groups of the Pteridophytes, where they are remarkably uniform. In all of them the archegonium has a neck composed of but four rows of peripheral cells, instead of five or six, as in the Bryophytes, and the antheridium, except in the leptosporangiate Ferns, is more or less completely sunk 
in the tissue of the prothallium. The spermatozoids are either biciliate, as in Mosses, or multiciliate, a condition which, so far as is known, does not exist among the Bryophytes.

The formation of spores is very much more subordinated to the vegetative life of the sporophyte than is the case among the most highly organised of the Bryophytes. Indeed it may be many years before any signs of spore formation can be seen. The spores are always born in special organs, sporangia, which are for the most part outgrowths of the leaves, but may in a few cases develop from the stem. In the simplest cases the spores arise from a group of hypodermal cells, generally traceable to a single primary cell. The cell outside of these divides to form a several-layered wall, but the limits of the sporangium are not definite, and it may scarcely project at all above the general surface of the leaf. From this condition found in Ophioglossum, there is a complete series of forms leading to the so-called leptosporangiate type, where the whole sporangium is directly traceable to a single epidermal cell, and where a very regular series of divisions takes place before the archesporium is finally formed.

With very few exceptions all of the existing Pteridophytes fall naturally into three series or classes of very unequal size. The first of these, the Ferns or Filicineæ, is the predominant one at present, and includes at least nine-tenths of all living Pteridophytes. The Equisetineæ are the most poorly represented of the modern groups, and include but a single genus with about twenty-five species. The third class, the Lycopodineæ, is much richer both in genera and species than the Equisetineæ, but much inferior in both to the Filicineæ. The disproportion between these groups was much less marked in the earlier periods in the world's history, as is attested by the very numerous and perfect remains of Pteridophytes occurring especially in the coal-measures. At that time both the Equisetineæ and Lycopodineæ were much better developed both in regard to size and numbers than they are at present.

\section{Class I. Filicinee}

The Filicineæ, as already stated, include by far the greater number of existing Pteridophytes, and are much more extended in range and abundant in numbers than either of the 
other classes. A marked characteristic of all Ficrns is the large size of the leaves, which are also extremely complicated in form in many of them. In a few of these the leaves are simple, i.e. Ophioglossum, Vittaria, Pilularia, but more commonly they are pinnately compound and sometimes of enormous size. The stem varies a good deal in form and may be very short and completely subterranean, as in species of Ophioglossum and Botrychium, or it may be a creeping rhizome, or in some of the large tropical Ferns it is upright, and grows to a height of 8 to 10 metres, or even more.

While some forms of the Ferns are found adapted to almost all situations, most of them are moisture-loving plants, and reach their greatest development in the damp forests of the tropics. A few, e.g. Ceratopteris, Azolla, are genuine aquatics, and still others, e.g. species of Gymnogramme, live where they become absolutely dried up for several months each year. These latter will quickly revive, however, as soon as placed in water, and begin to grow at once. In the tropical and semitropical regions many Ferns are epiphytes, and form a most striking feature of the forest vegetation. With few exceptions the sporophyte is long-lived, but a few species are annual, e.g. Pilularia Americana, Marsilia vestita, and depend entirely upon the spores for carrying the plant through from one season to another. The sporophyte may give rise to others by simply branching in the ordinary way, or special buds may be developed either from the stem or upon the leaves (Cystopteris bulbifera).

Besides the normal production of the gametophyte from the spore, it may arise in various ways directly from the sporophyte (apospory); and conversely the latter may develop as a bud from the gametophyte without the intervention of the sexual organs (apogamy).

The Filicineæ include both eusporangiate and leptosporangiate forms,-indeed the latter occur only here. The former comprise the homosporous orders, Ophioglossaceæ and Marattiaceæ, and the heterosporous order Isoetaceæ, whose systematic position, however, it must be said is still doubtful. The Leptosporangiatæ include the single great homosporous order Filices, and the two heterosporous families, closely related to it, the Salviniaceæ and the Marsiliaceæ. These are usually classed together as a distinct order, the Hydropterides or Rhizocarpeæ. 


\section{The Homosporous Eusporangiate}

The two orders, Ophioglossaceæ and Marattiaceæ, show many evidences of being very ancient forms, and in several respects seem to approach more nearly to the Hepaticæ than any other Pteridophytes. While they are different from each other in many respects, still there is sufficient evidence to indicate that they belong to a common stock to warrant placing them near each other in the system.

\section{The Ophioglossacea}

The gametophyte of the Ophioglossaceæ is still very incompletely known, and only in a few forms. Mettenius ${ }^{1}$ described the older stages of Ophioglossum pedunculosum, and Hofmeister ${ }^{2}$ similar prothallia of Botrychium lunaria, but they were unable, as later observers have been, to procure the earlier conditions. In both cases the prothallia were subterranean and entirely destitute of chlorophyll. In Ophioglossum, however, when it reached the surface of the ground, the part exposed to the light became somewhat flattened and green.

The earliest stages that Mettenius found consisted of a nearly globular tubercle, from which a single conical protuberance grew upward, having a branch that in extreme cases reached a length of as much as two inches (Fig. I08). This branch grows by a single apical cell, and may occasionally branch dichotomously, and always grows towards the light. On reaching the surface of the ground the growth is checked and a flattened expansion is produced whose cells contain chlorophyll. The sexual organs are borne almost exclusively upon the subterranean parts of the branch, and in great numbers. On the weaker prothallia antheridia prevail, on the stronger ones archegonia. The structure and development of these correspond closely with those of the other eusporangiate Pteridophytes. The antheridia are completely sunk in the tissue of the prothallium, and the outer wall is composed of two layers of cells (Fig. I o8, C). The archegonia have a short neck, which projects but little above the surface. The number of canal cells does not seem to have been determined (Fig. I O8, D). 
The prothallium of Botrychium lunaria ${ }^{1}$ is much smaller and does not grow to the surface of the ground. It is oval in form, and consists of a mass of firm tissue, brownish towards the outside and colourless within, where the cells are also larger. Scattered root-hairs grow from the superficial cells, and the prothallia are monœcious. The antheridia, which correspond

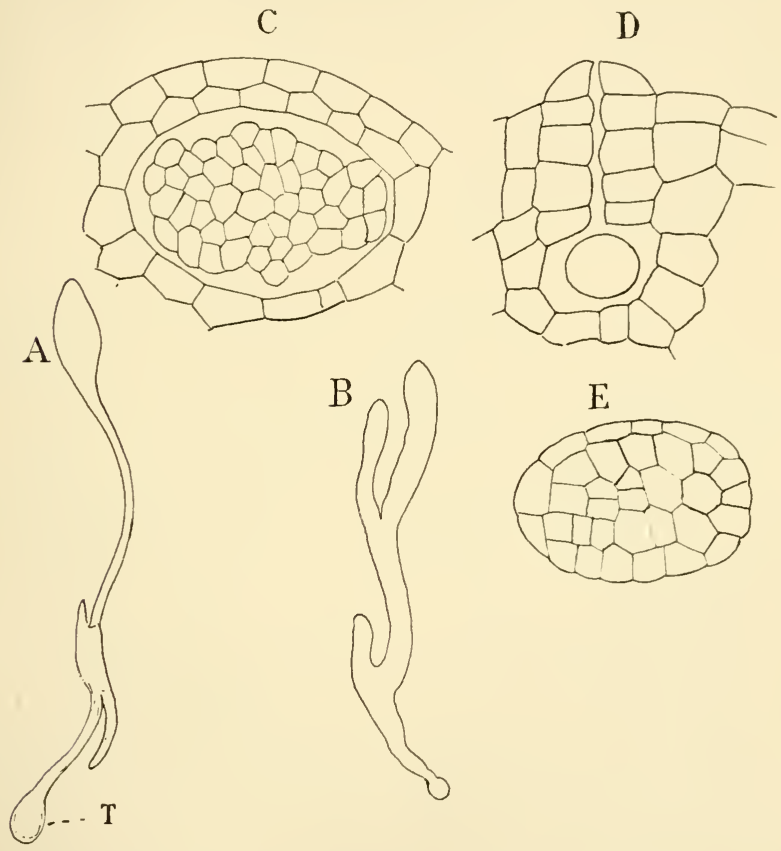

FiG. 108.-Ophioglossum pedunculosum (Desv.). A, B, Prothallia, $\times 2$; T, the primary tubercle; C, antheridium, $\times 200 ; \mathrm{D}$ archegonium; E, a young embryo (after Mettenius).

closely to those of Ophioglossum, are produced principally upon the upper surface, the archegonia below. The latter correspond in structure to those of Ophioglossum, but to judge from Hofmeister's figure the neck is somewhat longer and projects

1 Hofmeister, l.c. 
more above the surface. The spermatozoids are described as similar to those of the Polypodiaceæ, but half as large again.

The writer has succeeded in securing the earliest phases of germination in two other species, viz. Ophioglossum (Ophioderma) pendulum and Botrychium Virginianum, as well as the older prothallia of the latter. The germination in both cases is extremely slow, especially in the former, where a year and a half after the spores were sown the largest prothallia had but

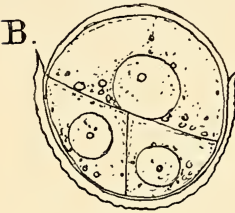
three cells. Probably under natural conditions the growth is more rapid. The spores of both forms show much the same structure. The tetrahedral spores contain granular matter, with numerous oil-drops, and a central large and distinct nucleus. The exospore is colourless, and upon the outside presents a pitted appearance in Ophioglossum, and irregular small tubercles in Botrychium. The perinium or epispore is not clearly distinguishable from the

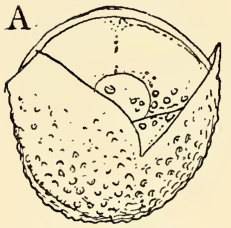

FIG. rog.-Germinating spore of Ophioglossum (Ophioderma) pendulum (I.). A, Surface view; $B$, optical section, $\times 600$. exospore. In both cases chlorophyll is absent in the ripe spore. The first sign of germination is the absorption of water and splitting of the exospore along the three radiating lines on the ventral surface of the spore. The spore enlarges considerably before any divisions occur, but remains globular in form, and no chlorophyll can be detected. In this condition, which was observed within two weeks after the spores were sown in Ophioglossum, it may remain for several months unchanged. The first division wall is usually at right angles to the axis of the spore, and divides it into two nearly equal cells, of which the lower has more of the granular contents than the upper one. The endospore is noticeably thickened where it protrudes through the ruptured exospore. The next wall, in all cases observed, is at right angles to the first, and always in the lower cell, which it divides into equal parts (Figs. I09, I IO). In Botrychium at this stage a few large chloroplasts were seen in both upper and lower cells, but Ophioglossum showed no positive evidence of chlorophyll, although it seemed sometimes as if a faint trace of chlorophyll 
could be detected. As growth proceeds, the oil partially disappears, and the cells become much more transparent than at first. $\quad \mathrm{up}$ to the present writing no further observations have been made, but it is hoped later that some additional information may be obtained on this important point.

In July I 893, at Grosse Ile, Michigan, the writer was fortunate enough to find a number of old prothallia of Botrychium Virginianum. They were all connected with the young sporophyte, and were too old for studying at all completely the

A.
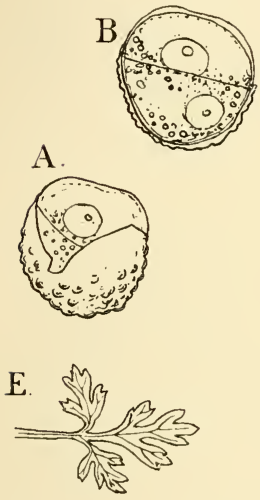

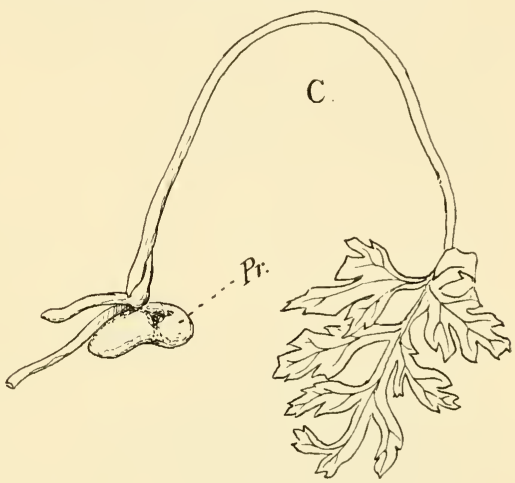

D.

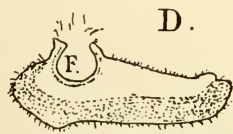

FIG. r10.-Botrychium Virginianum (Sw.). A, B, Germinating spore, $\times 600$; C prothallium (pr), with young sporophyte attached, $\times 2 ; D$, longitudinal section of the prothallium, showing the foot of the embryo $(f), \times_{4} ; \mathrm{E}$, first (?) leaf of a young sporophyte, $\times 2$.

development of the sexual organs and embryo. They resembled closely those of B. lunaria, but were very much larger. They grew at a distance of several centimetres beneath the surface of the ground, in the neighbourhood of a number of large specimens of the mature plant. The prothallium at this stage, like that of B. lunaria, is completely destitute of chlorophyll, and has the form of a slightly flattened tuber, which in the larger ones showed fold-like ridges upon the upper surface. The outer cells were brownish, and short root-hairs grew in large 
numbers from these. The inner tissue was colourless and large-celled, and in the cells of the lower part of this tissue were observed in all cases great numbers of irregular colourless filaments that had all the appearance of an endophytic fungus. Whether this is of the nature of a mycorrhiza remains to be seen, but it is by no means impossible that such should be the case. This lower tissue forms a distinct zone, which in section appears much more opaque than the upper zone, from whose outer cells the sexual organs arise.

The sexual organs were found as a rule only upon the upper side, in which respect it differs from B. lunaria, where the archegonia usually are formed on the lower side. The material was too old to make it possible to tell whether the growth of the prothallium was from a single apical cell or not. All of the archegonia found were old, and it was impossible to follow their development, and the details of the structure of the ripe archegonium could not be made out. A striking point of difference between it and the other forms hitherto investigated is the long neck, which projects quite as much above the prothallium as that of the leptosporangiate Ferns (Fig. I I I, C). In general appearance it closely resembles that of Osmunda, being straight and not curved backward, as in most Ferns. The antheridia may either occur singly, in which case they are sunk in the thallus, or sometimes groups of them occur together upon short branches projecting from the upper surface. In the latter condition the individual antheridia often project somewhat. So far as could be judged from a study of a very small number of young stages, the development corresponds exactly to that in Equisetum or Marattia. The antheridium mother cell probably, as in these, divides first by a wall parallel to its outer surface into two cells, and the inner one divides next by alternate transverse and vertical walls into the mass of sperm cells. In some cases the outer cell divides both by vertical and transverse walls, so that the outer wall of the ripe antheridium is twolayered, as in B. lunaria; but quite as often it remains but one cell thick (Fig. I I I, B), in which respect it resembles Equisetum or Marattia. The spermatozoids were not observed.

In only one case was a young embryo found, and this, so far as could be determined, also resembled in the arrangement of its cells the similar condition in Marattia, but the prepara- 
tion was not a satisfactory one, and the results not conclusive. Although the young plants were so far advanced (Fig. I IO) it was a significant fact that the prothallium still remained alive. A section through the base of the young sporophyte showed the foot, which is extraordinarily large here, and a microscopic examination showed that the peripheral cells of the foot were full of protoplasm, and their nuclei extremely distinct, and the cells were evidently still actively engaged in absorbing food
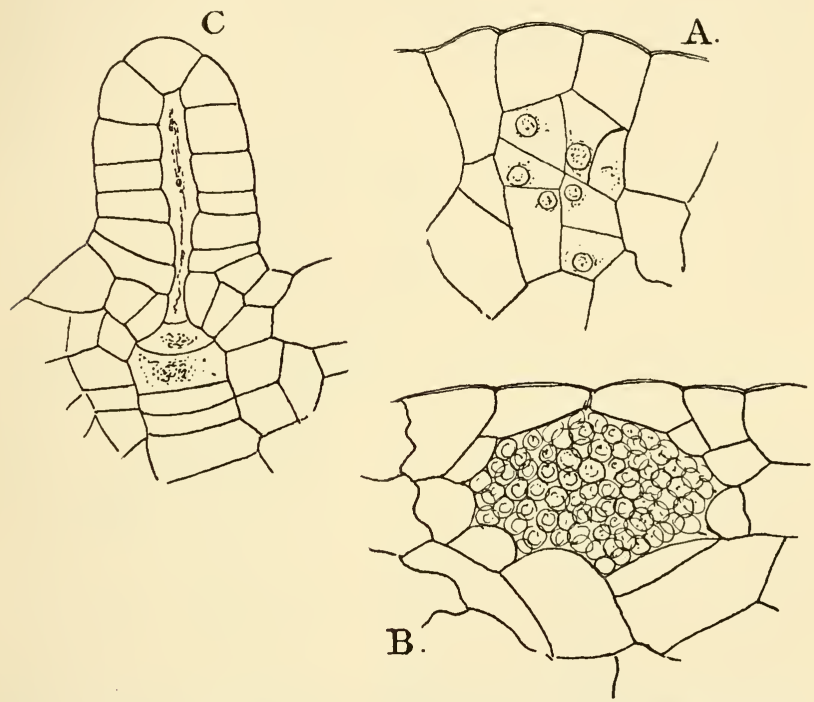

FIG. I11.-Botrychium Viginianum (Sw.). A, Young; B, older antheridium, longitudinal sections. $\mathrm{A}, \times 600 ; \mathrm{B}, \times 300 ; \mathrm{C}$, section of old archegonium, $\times_{300}$.

from the prothallium for the support of the sporophyte. The single leaf in these young plants was not probably the cotyledon, which had apparently disappeared, and is probably of simpler structure.

Hofmeister found that in B. lunaria the first two roots were formed before the first green leaf, and that the first three leaves are scale-like. The fourth leaf is the first to appear above the ground, which it only does the second year, or possibly later. The position of the archegonium in this species 
upon the lower surface, necessitates a bending upward of the growing point of the young sporophyte, which is not the case in B. Virginianum, where the archegonium is above, and the sporophyte grows up vertically from the beginning.

Mettenius' account of the development of the embryo in O. pedunculosum is somewhat more complete. The earliest stage seen by him was already multicellular, and the young embryo had the form of an oval cell mass in which the primary divisions were not recognisable (Fig. I08, E). The upper part, i.e. that next the archegonium neck, grows up at once into the cotyledon, while the opposite part gives rise to the first root. These grow respectively upward and downward, and break through the overlying prothallial cells. Later, at a point between the two, the stem apex is developed. The first leaf here becomes green, and develops a lamina similar to that of the later-formed ones. Usually but one embryo is developed from the prothallium, but occasionally two are formed, especially where the prothallium forks.

Ophioglossum (Ophioderma) pendulum, an epiphyte common in the Eastern tropics, may be taken as a type of the simplest of the Ophioglossaceæ. Its short creeping stem grows upon the trunks of trees, especially tree-ferns, from which the long flaccid leaves hang down. The lamina of the leaf merges insensibly into the stout petiole whose fleshy base forms a sheath about the next younger leaf. Corresponding to each leaf is a thick unbranched root, which penetrates into the crevices of the bark and holds the plant secure. These roots are smooth, and show no trace of rhizoids. The petiole is continued up into the lamina as a very broad and thick midrib, which in the sporiferous leaves (sporophylls) is continued into the peculiar elongated spike which bears the sporangia.

The petiole if cut across shows a number of vascular bundles arranged in a single row, nearly concentric with the periphery of the section. As these enter the lamina they anastomose and form a network with elongated meshes (Fig. I I 4, C) and no free ends. Sections of the spike cut parallel to its broad diameter show a somewhat similar arrangement of the vascular bundles, but here there are free branches extending between the sporangia. The relations of the bundles of the fertile and sterile parts of the leaf are best followed in the 


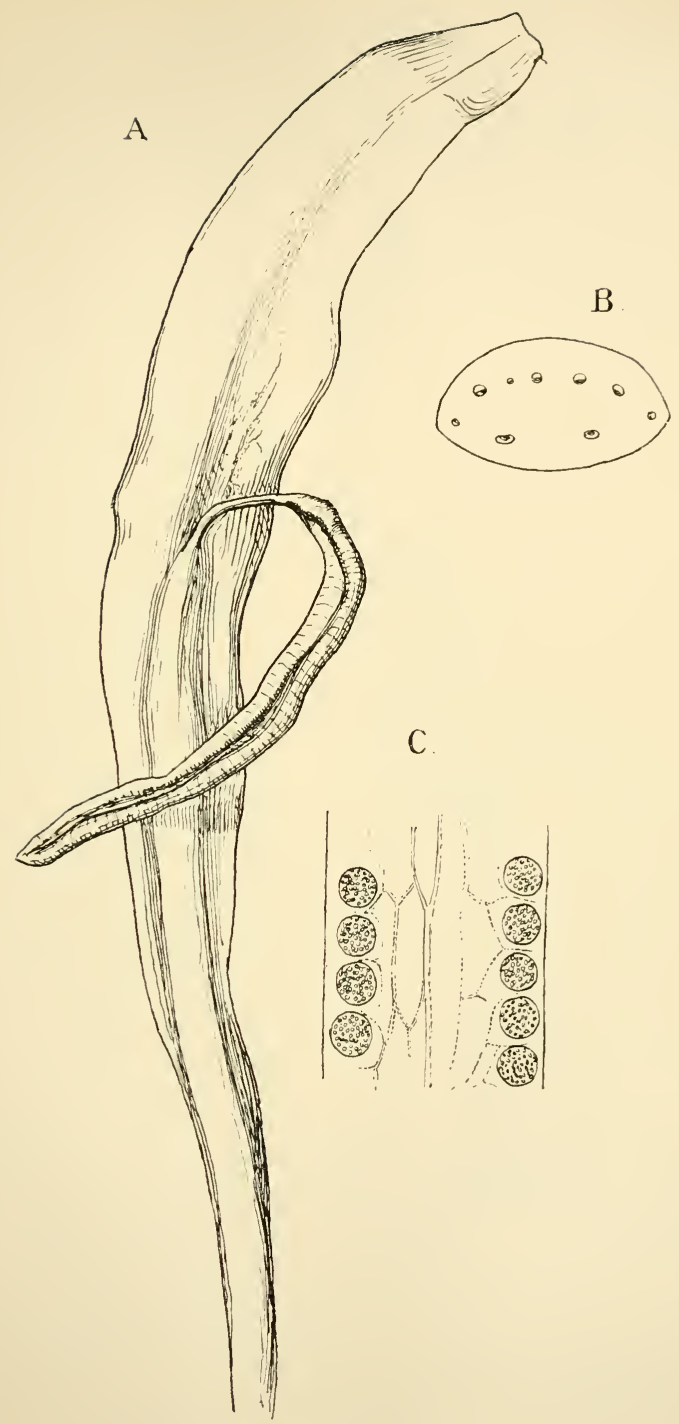

Fig. II2.-Ophioglossum pendulum (L.). A, Leaf with sporangiophore, natural size; B, crosssection of the petiole, $\times 6$; , section of the sporangiophore, parallel to its broad surface $\times 6$. 
smaller species. Prantl ${ }^{1}$ describes it as follows for O. Lusitanicum, and states that it is essentially the same in other species. "The primary bundle given off from the stem branches just after

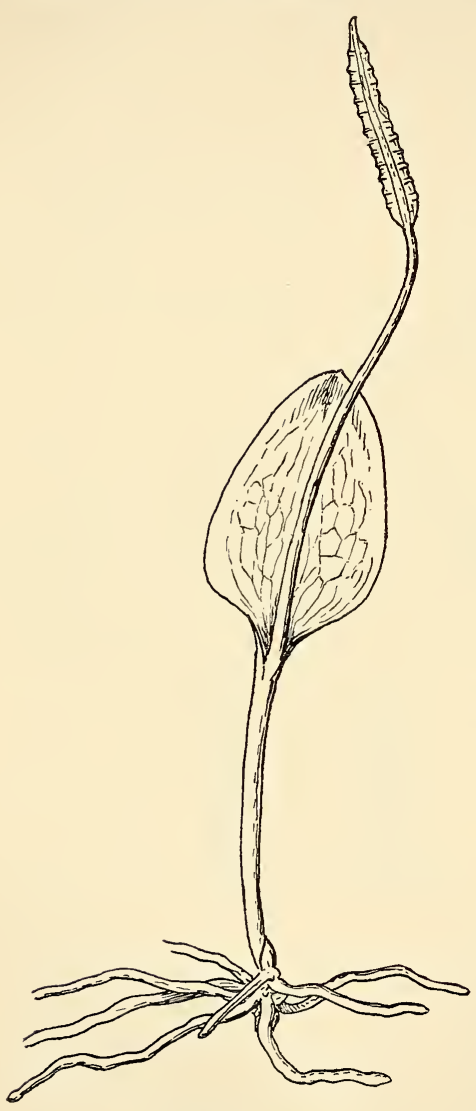

FiG. xi3.-Ophioglossum v'ulgatum (L.), $\times \mathrm{x}$. it enters the petiole. The main bundle gives off two smaller lateral branches right and left. The latter branch again near the base of the sporangiophore, and the upper branches from each unite to form the single bundle that enters the latter."

The sporangia are large cavities sunk in the tissue of the sporophyll, and scarcely projecting at all above the surface, where the position of each one is indicated by a faint transverse furrow which marks the place where it opens. Seen in sections parallel to the flat surface these appear perfectly round, but in transverse section are kidneyshaped (Fig. I 2 I, C).

The apex of the stem forms a blunt cone, which, however, is not visible from the outside. A longitudinal section through the end of the stem shows that it is covered by a sheath composed of several layers of cells, and this encloses a cavity in which are the growing point of the stem and the youngest leaf. The leaves here form much more rapidly than 
in the species of the temperate regions, as the growth continues uninterruptedly throughout the year. The real apex of the stem forms an inclined nearly plane surface, slightly raised in the centre, where the single apical cell is placed (Fig. I I 5, A, B). This cell is by no means conspicuous, and not always readily found, but probably is always present. It has the form of an inverted three-sided pyramid, but the lateral faces are more or less strongly convex, and the apex may be truncate. From the few cases observed it is not possible to say whether in addition to the three sets of lateral segments basal segments are also formed, but it is by no means impossible that such is the case. According to recent investigations of Rostowzew ${ }^{1}$ the apical cell of the stem of Ophioglossum vulgatum shows considerable variation, and may be either a three or four-sided prism, i.e. it apparently also may have the base truncate. Holle's ${ }^{2}$ description agrees with this except that he states that he always found the cell pointed below, not truncate. The segments cut off from the lateral faces are large, and the divisions irregular. They

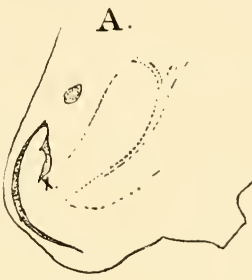

C.

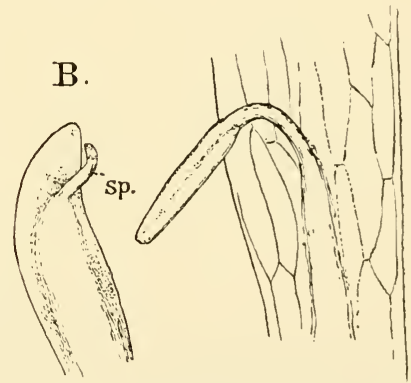

FIG. II4.-Ophioglossum pendulum (L.). A, Median longitudinal section of stem apex, $\mathrm{X}_{4} ; x$, the growing point; $\mathrm{B}$, young sporophyll, $\times 2 ; s p$, the sporangiophore; $\mathrm{C}$, an older leaf, showing the venation, $\times 2$. are apparently formed in very slow succession, and the irregularity of the succeeding divisions in the segments themselves soon makes it impossible to trace their limits. Each segment apparently gives rise to a leaf, but this is impossible to determine with certainty. The first wall in the young segment probably divides it into an inner and outer cell, but the next divisions could not be determined positively. Probably, as in Botrychizm, the outer cell is 
next divided by a vertical wall, perpendicular to the broad faces of the segment, into two cells, in which divisions then take place in both transverse and longitudinal direction without strict regularity.

The stem is mostly made up of thin-walled parenchyma, and the vascular bundles are much less developed than is the case in the underground stem of $O$. vulgatum or Botrychium. The bundles are of the collateral form, i.e. the inner side is occupied by the xylem, the outer by the phloem, and there

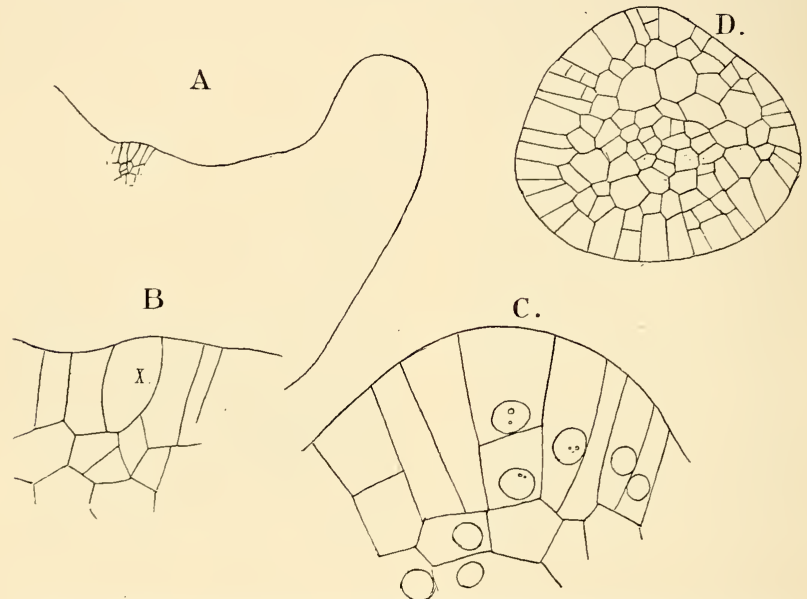

FiG. 115.-Ophioglossum pendulum (L.). A, Longitudinal section of stem apex, $\times 60$; B, the central part of the same section, $X_{1} 80 ; \mathrm{D}$, longitudinal section of very young sporangiophore, $X_{1} 80 ; \mathrm{E}$, cross-section of young sporangiophore, $\times 6$.

is no bundle-sheath developed. The bundles form a very irregular wide-meshed cylinder, not differing essentially from that in 0 . vulgatum.

The young leaf is completely concealed by the sheath formed by the base of the next older one. It is at first a conical protuberance arising close to the stem apex, around which its base gradually grows and forms the sheath about it and the next leaf rudiment. It is probable that here, as in 0 . vulgatum, ${ }^{1}$ the young leaf grows at first by a definite apical 
cell. After the plant has reached a certain age, each leaf gives rise to a sporangial spike, which becomes evident while the leaf is still very small. The first indication of this is a conical outgrowth upon the inner surface of the leaf, about halfway between the apex and base. A longitudinal section of this shows it to be made up of large cells, especially toward the top; but although there was sometimes an appearance that indicated the presence of a single apical cell, this was by no means certain, and if there is such an initial cell, its divisions must be very irregular.

The subsequent growth of the leaf is for a long time mainly from the base, and the young sporangial spike is much nearer the apex in the next stage (Fig. I I 4, B). No distinct petiole has yet developed, but the centre of the young leaf, up to the point of attachment of the spike, is traversed by the thick midrib, above which the lamina is still very small. The young spike now forms a beak-shaped body curving inward and upward, and sections of slightly older stages than the one figured show the first indications of the developing sporangia. Later still the base of the leaf becomes narrowed into the

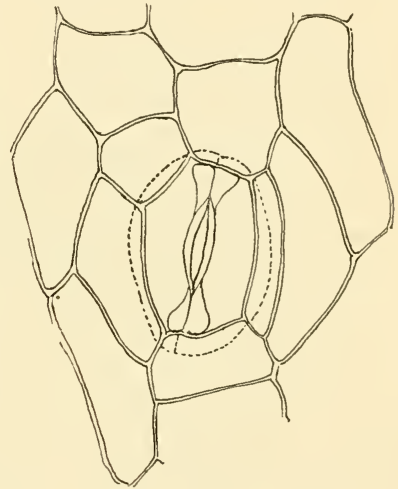

FIG. I I6.-Stoma from the leaf of Ophioglossum pendulum, $\times 260$. petiole, and the spike also becomes divided into the upper sporiferous portion and the short slender pedicel.

The anatomical structure of the leaf is extremely simple. The epidermis is composed of rather thick-walled cells, irregularly polygonal in outline, with large stomata at intervals, about which the cells are arranged concentrically, and frequently with a good deal of regularity. The stomata themselves (Fig. I I 6), seen from above, have an angular outline, but from below are perfectly oval, and cross-sections show that this appearance is due to a partial overarching of the guard cells of the stoma by the surrounding epidermal cells. The upper walls of the guard cells are thickened irregularly, giving them the appearance of 
being folded longitudinally. There is no distinct hypoderma formed, and the bulk of the leaf is made up of a uniform mesophyll composed of nearly globular cells with much chlorophyll, and separated by numerous intercellular spaces. In the petiole the tissues are similar, but more compact, and the walls of the ground tissue are all deeply pitted. The vascular bundles are nearly circular in section and show a compact mass of tracheary tissue (Fig. I I $7, t$ ), surrounded by nearly uniform cells with

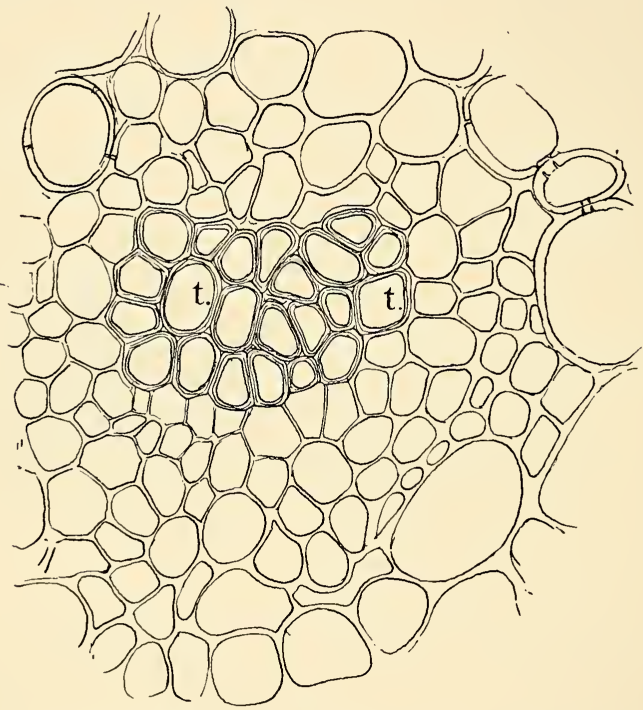

Fig. 117.-Vascular bundle of the petiole of $O$. pendutum, $\times{ }_{260} ; t, t$, the xylem of the bundle.

moderately thick colourless walls. The limits of the bundle are not, as in the higher Ferns, marked by a distinct bundlesheath, but are indicated simply by the somewhat smaller size of the cells of the bundle itself-indeed it is not always easy to say exactly where the ground tissue begins. The xylem is composed of pointed tracheids whose walls are marked with thick reticulate bands. This mass of tracheary tissue is situated near the inner side of the bundle, which like that of the stem is collateral. The rest of the bundle is composed of sieve-tubes 
mingled irregularly with smaller cambiform cells. Whether or not sieve-tubes occur upon the inner side of the bundle could not be positively determined. The sporangiophore has much the same anatomical structure as the rest of the leaf, but stomata are quite absent from its epidermis. In this respect $O$.pendulum differs from $O$. vulgatum and allied species, where stomata are developed upon the sporangiophore as well as upon the rest of the leaf.

\section{The Root}

The roots are formed singly near the bases of the leaves, and are light yellowish brown in colour, and so far as could be
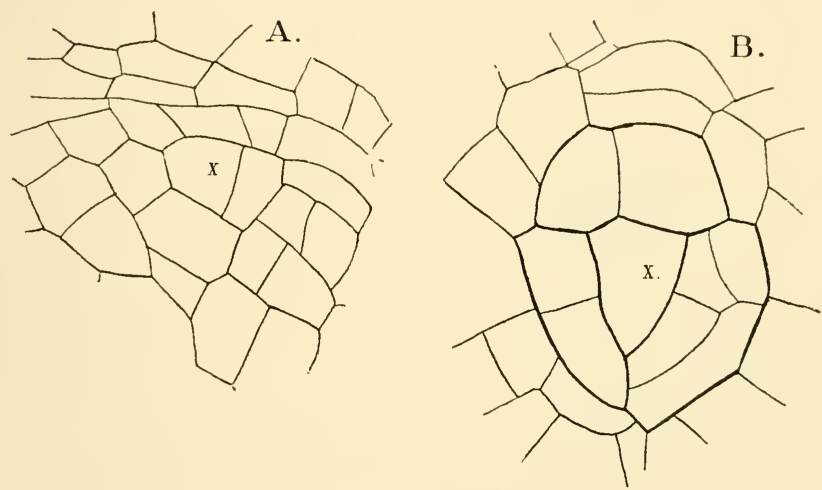

FIG. 1 18. - Ophioglossum pendulum (L.). A, Longitudinal; $B$, transverse sections of the root apex, $\times_{21} 5$.

seen, entirely unbranched. Sections show that here, as in most vascular plants, the growing point of the root is not at the apex, but some distance below and protected by the root-cap. The growth of the root in Ophioglossum can be traced to a single apical cell (Fig. I I 8), which is of large size, and, like that of the stem, approximately pyramidal in form. While the divisions show greater regularity than in the stem, still they are very much less so than in the higher Ferns. Segments are here cut off not only from the lateral faces of the apical cell, but also from its outer face. These outer segments help to form the root-cap, which, however, is not derived exclusively from these, but in part also from the outer cells of the lateral 
segments. Each of the latter is first divided by a nearly vertical wall, perpendicular to its broad faces, into two "sextant cells," but beyond this no regularity could be discovered in the order of division in the segments, and the tissue at the growing point, especially in longitudinal section, presents a very confused arrangement of the cells. A little lower down two regions are discernible, a central cylinder (plerome), whose limits are not very clearly defined, and the periblem or cortex. A definite epidermis is not distinguishable.

The first permanent tissue in the plerome cylinder, which

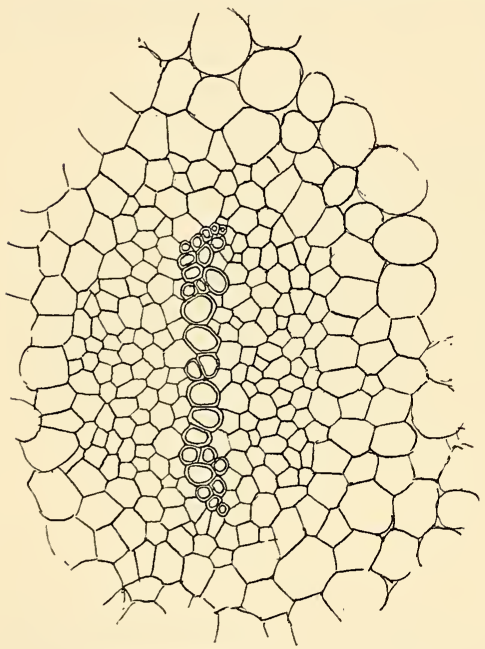
is elliptical in section, arises in the form of small tracheids near the foci of the elliptical section. From here the formation proceeds towards the centre, and in the full-grown root the tracheary tissue forms a continuous band occupying the larger axis of the section, the lastformed tracheids being the largest. On either side of this tracheary plate is a poorly defined mass of phloem, similar to that of the stem and leaf bundles. Here also no bundleFIG. 119. - Vascular bundle of the root of $O$. pendutum, $\times 85$. sheath is present, and the limits of the bundle are not clearly defined. In O.vulgatum the bundle of the root is diarch to begin with, but by the suppression of one of the phloem masses it becomes monarch.

The development of the sporangium has been studied by Goebel ${ }^{1}$ in 0 . vulgatum, and recently by Bower ${ }^{2}$ in this species and in $O$. pendulum. The latter has been carefully examined by the writer, and the results confirm that of the latter investigator, except that it seems possible that the archesporium may

$$
1 \text { Goebel (17), p. } 390 .
$$

2 Bower (14). 
be traced to a single cell, as Gocbel asserts is probably the case in $O$. vulgatum.

A transverse section of the very young sporangiophore is somewhat triangular, the broader side corresponding to the outer surface of the sporangiophore. The cells are very irregular in form, and no differentiation of the tissues is to be observed. Sections of somewhat older stages show in some cases, at least, a large epidermal cell occupying nearly the centre of the shorter sides of the triangular section. This cell has a larger nucleus than its neighbours, and is decidedly broader.

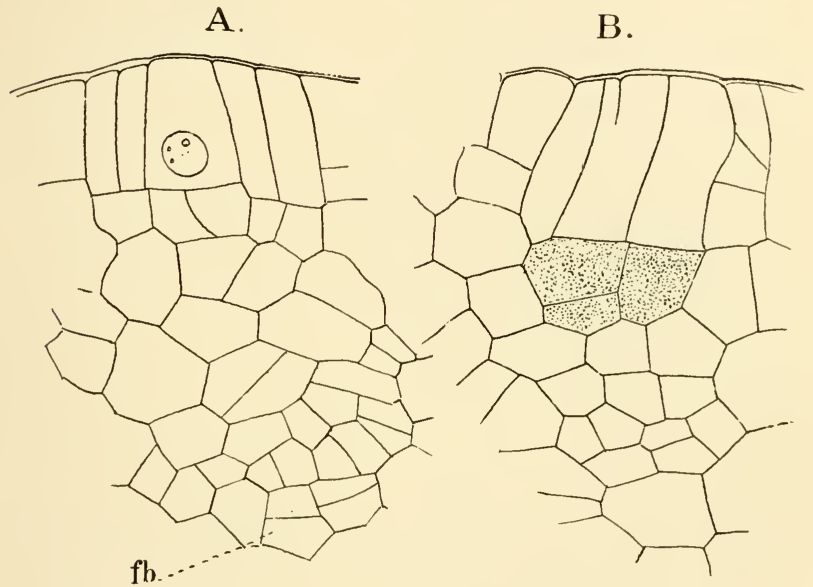

FIG. 120.-A, Very young ; B, older sporangia of $O$. pendulum; transverse sections, $x_{2} 60$.

The next stage was not observed, but a somewhat more advanced one shows a small group of inner cells (shaded in the figure), which appear to have arisen from the primary cell by a transverse wall, although this point is exceedingly difficult to determine on account of the great similarity of all the cells (Fig. I 20). This group of inner cells (or the single one from which they perhaps come) constitutes the archesporium, and by rapid division in all directions forms a large mass of cells whose contents become denser than those of the surrounding ones, between which and these, however, the limits are not very plain. Later, when the number of cells is complete, the difference 
between them and the sterile tissue of the sporangiophore is much more evident.

The cells lying outside of the archesporium divide rapidly both by longitudinal and transverse walls, and form the thick outer wall of the sporangium. In longitudinal sections, two rows of cells may be seen extending from the mass of archesporial cells to the periphery. In these rows the vertical walls have been more numerous than in the adjacent ones, so that

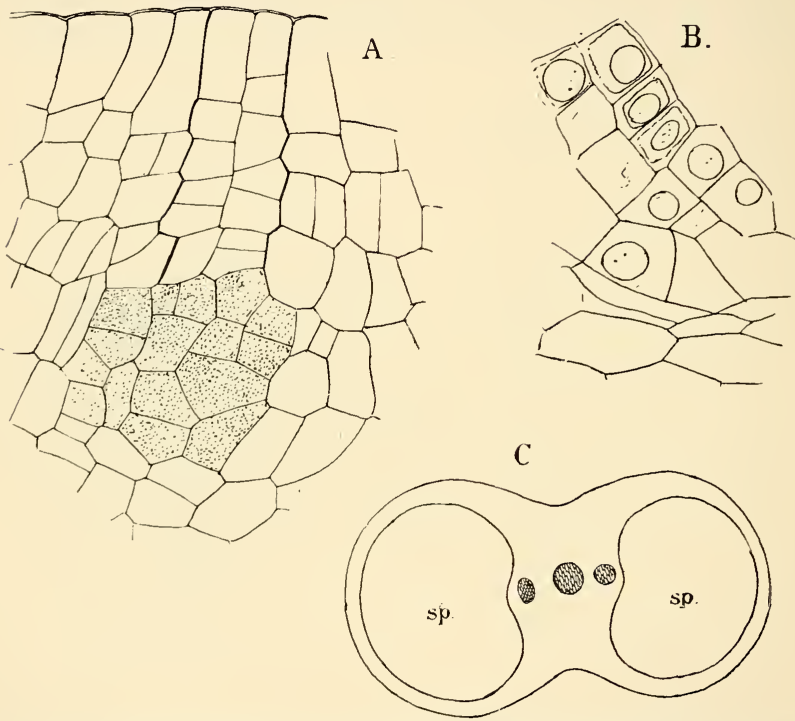

FIG. 121.-Ophioglossum pendulum (L.). A, Young sporangium in longitudinal section, $\times 225$. The archesporial cells are shaded, the double line of cells shows where the sporangium opens; B, part of the sporogenous tissue from an older sporangium, $\times 225 ; \mathrm{C}$, cross-section of a nearly full-grown sporangiophore, $\times 15$.

the number of cells in these rows is greater. It is between these rows of cells that the cleft is formed by which the ripe sporangium opens. The cells of the ground-tissue adjoining the archesporium divide into several layers of narrow cells, which form the "tapetum."

After the full number of cells is reached in the archesporium, their walls become partially disorganised, and the cells round 
off and separate, exactly as in the sporogonium of a Bryophyte, and each cell is, potentially at least, a spore mother cell. Bower ${ }^{1}$ states that only a part of the cells produce spores, and that the rest remain sterile and serve with the disorganised tapetal cells to nourish the growing spores. The final division of the spore mother cells into four spores is identical with that of the Bryophytes.

At maturity the sporangium opens by a cleft, whose position is indicated as we have seen in the younger stages, and as the cells shrink with the drying of the ripe sporangiophore the spores are forced out through this cleft.

Ophioglossum vulgatum and the other terrestrial forms show some points of difference when compared with $O$. pendulum. These grow much more slowly, and longitudinal sections of the upper part of the subterranean stem show several leaves in different stages of development. Each leaf rudiment, as in $O$. pendulum, is covered by a conical sheath, formed at the base of the next older leaf, and these sheaths are open at the top, so that there is direct communication between the outside air and the youngest of these sheaths which encloses, as in the latter species, the youngest leaf rudiment and stem apex. ${ }^{2}$ In these terrestrial forms, also, the sporangiophore is longer stalked, and the lamina of the leaf more clearly separated from the petiole, which is not continued into it. The lamina is relatively broader and the venation more complex, in some species showing also free endings to the ultimate branches. The sporangia, too, project more strongly and are very evident (Fig. I I 3). Branching of the roots occurs occasionally, and according to Rostowzew ${ }^{3}$ may be either spurious or genuine. In the first place an adventive bud, which ordinarily would develop into a stem, develops a single root and then ceases to grow. This root appears to be formed directly from the main root, and as the latter continues to grow the effect is that of a true dichotomy. The latter does occur, but not frequently.

The formation of adventitious buds upon the roots is the principal method of propagation of some species of Ophioglossum, whose prothallia, as we have seen, are apparently very seldom developed. Rostowzew states that these are not developed from the apical cell of the root, but arise from one of the younger segments, and the apical cell is produced from one of
1 Bower (14).
2 Rostowzew (I), p. 451 .
3 Rostowzew, l.c. 
the outer cells of the young segment, but is covered by the root-cap, through which the bud afterwards breaks. The sheath covering the first leaf of the bud is formed from the cortex of the root and the root-cap.

Differing most widely from the other species in general appearance is the curious epiphytic $O$. (Cheiroglossa) palmatum. In this the leaf is dichotomously branched, and instead of a single sporangiophore there are a number arranged in two rows along the sides of the upper part of the petiole and the base of the lamina.

The genus Botrychium includes several exceedingly variable species, the simplest forms, like $B$. simplex (Fig. I $22, \mathrm{~A}, \mathrm{~B}$ ), being very close to Ophioglossum, while leading from these is a series ending in much more complicated types, of which $B$. Virginiamum is a good example. In $B$. simplex the lamina of the leaf is either entirely undivided, as in most species of Ophioglossum, or once pinnatifid. From this there is a complete series to the ample decompound leaf of B. Virginianum. When the other parts of the plant are studied we find that this greater complexity extends to these as well. Thus the sporangiophore is also decompound, and the sporangia entirely free, and showing an approach to that found in such Ferns as Osmunda, and the dichotomous venation of the simpler forms approaches the pinnate type in B. Virginianum. The tissues, especially the vascular bundles, are also more highly differentiated in these species.

Under favourable conditions well-grown plants of $B$. Virginianum reach a height of $50 \mathrm{~cm}$. or more, and the sterile lamina of the leaf, which is triangular in outline, may be 30 to $40 \mathrm{~cm}$. in breadth, and from three to four times pinnate. The texture of the leaf is membranaceous and not fleshy like that of Ophioglossum and most species of Botrychium. The sporangiophore is twice or thrice pinnate. The plant sends up a single leaf each year from the underground stem, which is upright and several centimetres in length in old specimens. The roots are thick and fleshy, and much smaller at the point of insertion. As in Ophioglossum each root corresponds probably to a leaf, but the roots branch frequently, so that the root system is much better developed than in Ophioglossum. The secondary roots of $B$. Virginiamm arise laterally, and in much the same way as those of the higher Ferns. As in the terres- 


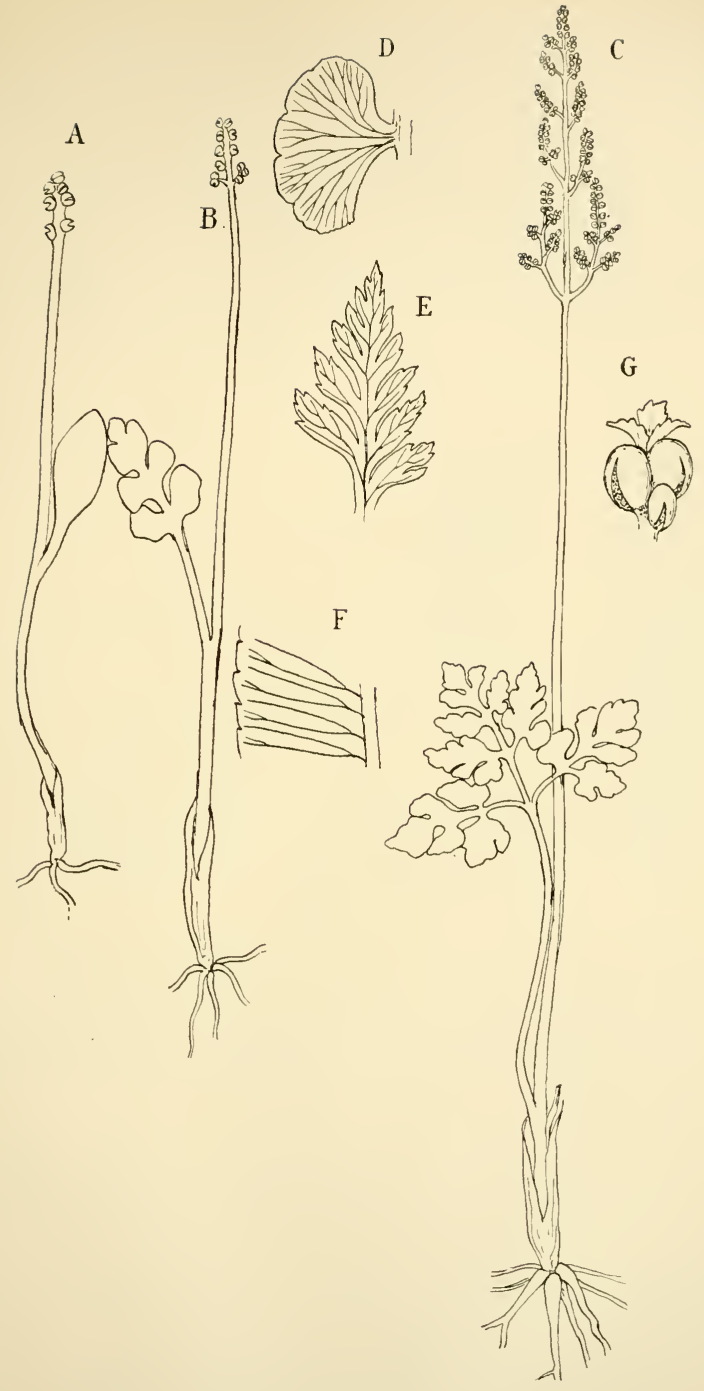

FIG. 122.-A, B, Botrychizm simplex (Hitch), natural size; C, B. ternatum (Sw.), $\times \frac{2}{3} ;$ D, leaf segment of B. lunaria (Sw.); E, leaf segment of B. Virginianum (Sw.), natural size; F, portion of sterile leaf segment of Helminthostachys Zeylanica (Hk.); G, fragment of the sporangiophore of the same enlarged. A, B, C after Luerssen; D, F after Hooker. 
trial species of Ophioglossum, the development of the leaves is very slow.

In most species of Botrychium the relation of the leaf base to the young bud and stem apex is the same as in Ophioglossum, except that the sheath is more obviously formed from the leaf base; but in B. Virginianum the sheath is open on one side, and more resembles a pair of stipules. Fig. I 23, A shows the stem and terminal bud of a plant of this species with all but

B.
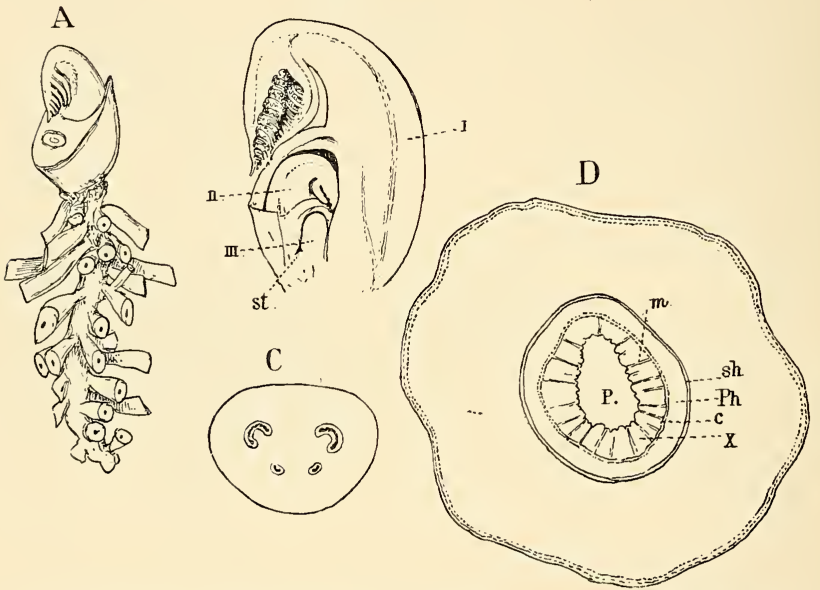

F IG. 123.-Botrychium Virginianum (Sw.). A, Rhizome and terminal bud of a strong plant, the roots and all but the base of the oldest leaf removed, $X_{1} ; \mathrm{B}$, Iongitudinal section of the bud, $\mathrm{X}_{3} ;$ st, the stem apex; I. Il. III., the leaves; C, transverse section of the petiole, $\mathrm{X}_{4} ; \mathrm{D}$, transverse section of the rhizome, $\times$ about $x 6 ; \mathrm{P}$, the pith; $m$, medullary rays; $x$, xylem; $c$, cambium; $p h$, phloem; sh, endodermis.

the base of the leaf of the present year cut away, and B the same with the bud cut open longitudinally. At this stage the parts of the leaf for the next year are well advanced, and the formation of the individual sporangia just begun. The leaf for the second year already shows the sporangiophore clearly evident, and the leaf which is to unfold in three years is evident, but the sporangiophore not yet differentiated. At the base of the youngest leaf is the stem apex. The whole bud is covered in this species with numerous short hairs, which are 
also found in B. ternatum and some other species, but in $B$. simplex and the other simpler species it is perfectly smooth, as in Ophioglossum. The young leaves in B. Virginianum are bent over, and the segments of the leaf are bent inward in a way that recalls the vernation of the true Ferns. The sporangiophore grows out from the inner surface of the lamina, and its branches are directed in the opposite direction from those of the sterile part of the leaf.

The vascular bundles of the stem are much more prominent than in Ophioglossum, and form a hollow cylinder, with small gaps only corresponding to the leaves. This cylinder shows the tissues arranged in a manner that more nearly resembles the structure of the stem in Gymnosperms or normal Dicotyledons than anything else. Surrounding the central pith (Fig. I 23, P) is a ring of woody tissue $(x)$ with radiating medullary rays $(m)$, and outside of this a ring of phloem, separated from the xylem by a zone of cambium (c), so that here alone among the Ferns the bundles are capable of secondary thickening. The whole cylinder is enclosed by a bundle-sheath (endodermis) consisting of a single layer of cells.

The cortical part of the stem is mainly composed of starch-bearing parenchyma, but the outermost layers show a formation of cork, which also is formed in the cortical portions of the roots.

The free surface of the stem apex is very narrow, and the cells about it correspondingly compressed. The apical cell (Fig. I 24, A, B), seen in longitudinal section, is very ${ }^{\circ}$ deep and narrow, but as comparison of cross and longitudinal sections shows, has the characteristic pyramidal form, and here there is no doubt that only lateral segments are cut off from it. Holle's ${ }^{1}$ figure of Botrychium rutefolium closely resembles $B$. Virginianum, and probably the other species will show the same form of apical cell. The divisions are decidedly more regular in the segments of B. Virginianum than in Ophioglossum, and can be more easily followed, although here, too, as the division evidently proceeds very slowly, it is difficult to trace the limits of the segments beyond the first complete set, which in transverse section are sufficiently clear. The first division divides the segment into an inner and an outer cell, 
the former probably being directly the initial for the plerome cylinder. The outer cell by later divisions forms the cortex, and the epidermis which covers the very small exposed surface of the stem apex. Here, as in Ophioglossum, it is impossible to determine exactly the method of origin of the young leaves, one of which probably corresponds to each segment of the apical cell, but as soon as the leaf can be recognised as such it is already a multicellular organ. It grows at first by an apical cell which seems to correspond closely in its growth with that of the stem. From almost the very first (Fig. I 24)
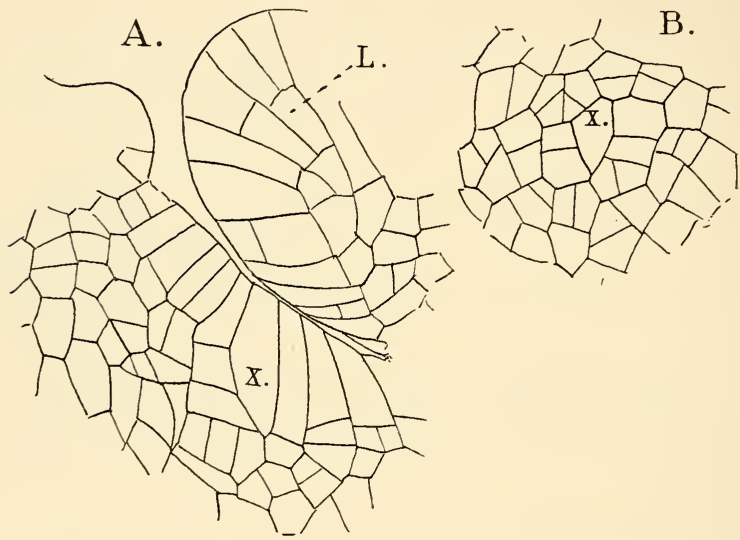

FIG. I24.-Botrychium Virginianum (Sw.). A, Longitudinal section of the stem apex of a young plant, $\times 260 ; \mathrm{B}$, cross-section of a similar specimen; L, the youngest leaf.

the growth of the leaf is stronger on the outer side, and in consequence it bends inward over the stem apex.

The arrangement of the tissues of the fully-developed stem shows, as we have seen, a striking similarity to those in the stems of many Spermaphytes. The xylem of the strictly collateral bundle is made up principally of large prismatic tracheids (Fig. I 25), whose walls are marked with bordered pits not unlike those so characteristic of the Coniferæ, but somewhat intermediate between these and the elongated ones found in most Ferns. The walls between the pits are very much thickened, and the bottoms of 
corresponding pits in the walls of adjacent tracheids are separated by a very delicate membranc. At intervals medullary rays, one cell thick, extend from the pith to the outer limit of the xylem. The cells are elongated radially, and have uniformly thickened walls and granular contents.

The phloem consists of large sieve-tubes and similar but smaller parenchymatous cells. No bast fibres or sclerenchymatous cells are present. The whole cylinder is bounded by a single layer of cells somewhat compressed radially, forming

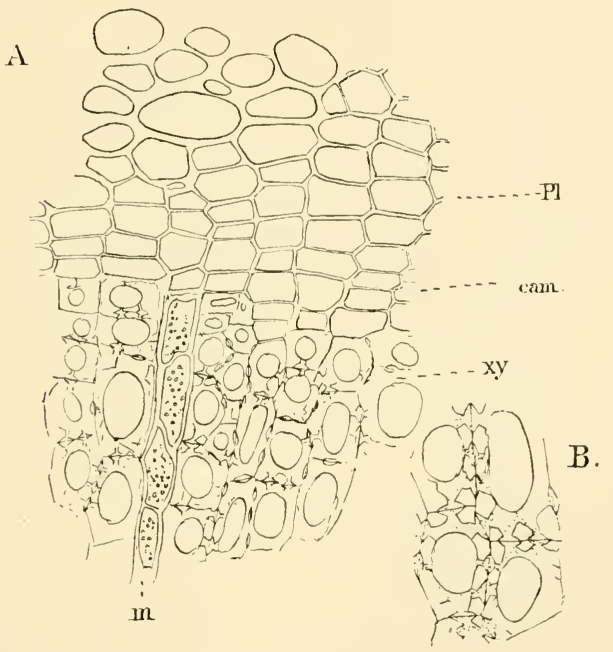

F1G. 125.-A, Part of a cross-section of the stem bundle of B. Iivginianum, $\times 200,-$ lettering as in Fig. 123 ; B, a portion of the tracheary tissue, showing the peculiarly pitted walls, $\times 400$.

the endodermis or bundle-sheath. Between the xylem and phloem is a well-defined layer of cambium by whose growth the thickness of the vascular cylinder is slowly but constantly added to, and as a result there is a secondary growth of the stem strictly comparable to that of the Dicotyledons.

The outer layer of the cortex (the epidermis is quite absent) develops cork, but not from a definite cork cambium. ${ }^{1}$ These cork cells arise by repeated tangential divisions in cells 
near the periphery, and have in consequence the same regular arrangement seen in similar cells of the higher plants.

A cross-section of the petiole of the earliest leaves of the young plant show but a single nearly central vascular bundle, but as the plant grows older the number becomes much larger, and may reach ten. ${ }^{1}$ In leaves of moderate size there are usually about four, and these are arranged symmetrically. The ground tissue is composed mainly of large thin-walled parenchyma and a well-marked epidermis. The fibrovascular
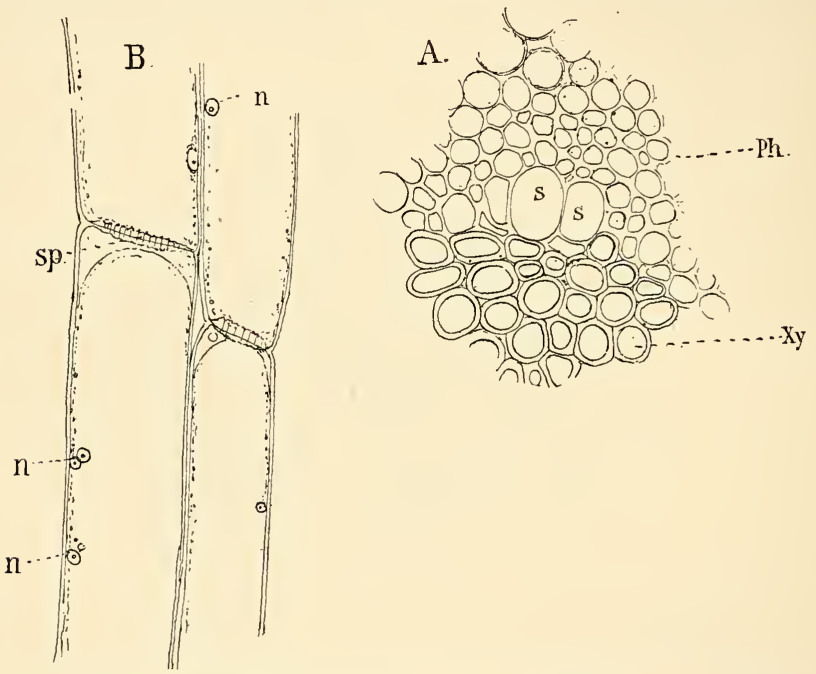

FIG. 126. - Part of a vascular bundle from the petiole of B. Virginianum, $\times 245 ; x y, x y l e m ; p h$, phloem; $s, s$, sieve-tubes; $\mathrm{B}$, two sieve-tubes in longitudinal section, $\times_{490} ; s p$, sieve-plates; $n$, nuclei.

bundles are arranged in two groups, right and left, and where there are four of them the inner ones are the larger, and in cross-section crescent-shaped. The xylem here occupies the middle of the section, and is completely surrounded by the phloem, i.e. the bundle is concentric, like that of the true Ferns. In $B$. lunaria the bundle has the phloem only perfectly developed on its outer side and approaches the collateral form. $B$. ternatum and $B$. lunaria, while having concentric bundles, 
also have the phloem more strongly developed on the outer side. The tracheary tissue is much like that of the stem, but the tracheids are smaller and the walls thinner.

The phloem is composed also of the same elements, large sieve-tubes, arranged in a pretty definite zone next the xylem, and smaller cells of similar appearance, but not showing the multinucleate character or perforated transverse walls of the latter. The sieve-tubes are large (Fig. I 26), and in longitudinal section are seen to consist of rows of wide cells with either horizontal or oblique division walls. The transverse walls separating two members of a sieve-tube are somewhat swollen and show small perforations, which are not always easily demonstrated. According to Janczewski ${ }^{1}$ these pits do not penetrate the membrane between the cells, but Russow's ${ }^{2}$ assumption that there is direct communication between the cells is correct, although difficult to prove. Russow also states that callus is present in the sieve-plates of Botrychium, although poorly developed. According to Janczewski ${ }^{3}$ the pores are not confined to the transverse walls, but may also occur, but much less frequently, in the longitudinal walls. The contents of the sieve-tubes consist of a thin parietal layer of protoplasm in which numerous nuclei are imbedded. Little glistening globules are also found, especially close to the openings of the pores of the sieve-plates.

The lamina of the sterile segment of the leaf is composed of a spongy green mesophyll, more compact on the upper surface. The epidermal cells show the wavy outlines characteristic of the broad leaves of other Ferns, and develop stomata only upon the lower side of the leaf.

\section{The Root}

The roots arise singly at the bases of the leaves, and in older plants branch monopodially. Like those of Ophioglossum they have no root-hairs, but the smooth surface of the younger roots becomes often strongly wrinkled in the older ones. Sections either transverse or longitudinal, through the root tip, when compared with those of Ophioglossum, show a very much greater regularity in the disposition of the cells. This is less marked in B. ternatum, and probably an examination
${ }^{1}$ Janczewski (4).
2 Russow (5).
${ }^{3}$ Janczewski (4), p. 69. 
of such forms as $B$. simplex will show an approximation to the condition found in Ophioglossum, although Holle's ${ }^{1}$ figure of $B$. lunaria shows even greater regularity in the arrangement of the apical meristem than is found in B. Virginianum. A careful examination of this point is much to be desired.

The first wall in the young lateral segment is the sextant wall, as in the higher Ferns, and divides the segment into two cells of unequal depth. The next wall divides the larger of these cells into an inner and an outer one, the former becoming the initial of the central plerome cylinder, the outer one, together with the whole of the smaller semi-segment, giving rise to the
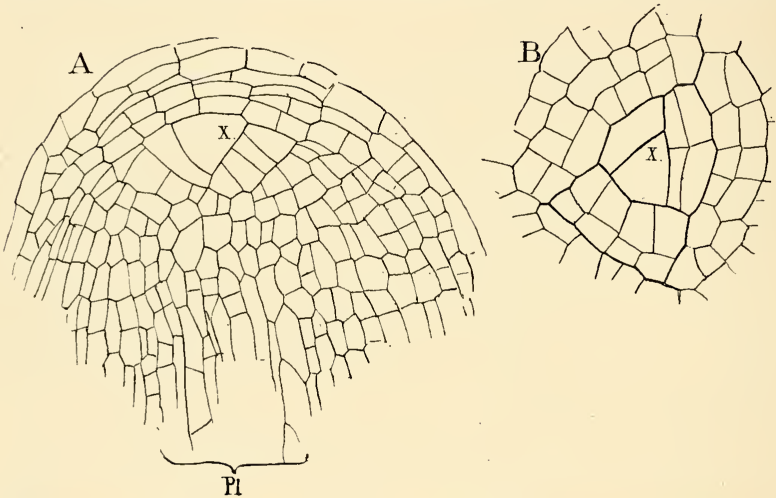

FIG. 127.-Botrychium Virginianum (Sw.). A, Longitudinal; B, transverse sections of the root apex, $\times 200 ; p l$, plerome.

cortex, in which the divisions are very similar to, but somewhat less regular than in Equisetum and the leptosporangiate Ferns. As usual in roots of this type segments are also cut off from the outer face of the apical cell, but I have never seen, either in B. Virginianum or B. ternatum, any indication that the growth of the root-cap was due exclusively to the development of these segments, as Holle states both for $B$. lunaria and Ophioglossum vulgatum. In both species of Botrychium examined by me the growth of the root-cap was evidently due in part to the division of cells in the outer part of the lateral segments, so that in exactly median sections 
there was not the clear separation of the root-cap from the body of the root that is so distinct in Equisetum, for example.

The central fibrovascular cylinder of the root is not provided with a definite endodermis, and its limits are not clearly defined. It varies in the number of xylem and phloem masses, even in the same species. In $B$. Virginianum the larger roots show three or four xylem masses (Fig. I 28 ). $B$. tematum has a usually triarch bundle, while $B$. lunaria is commonly diarch. ${ }^{1}$ The elements both of the xylem and

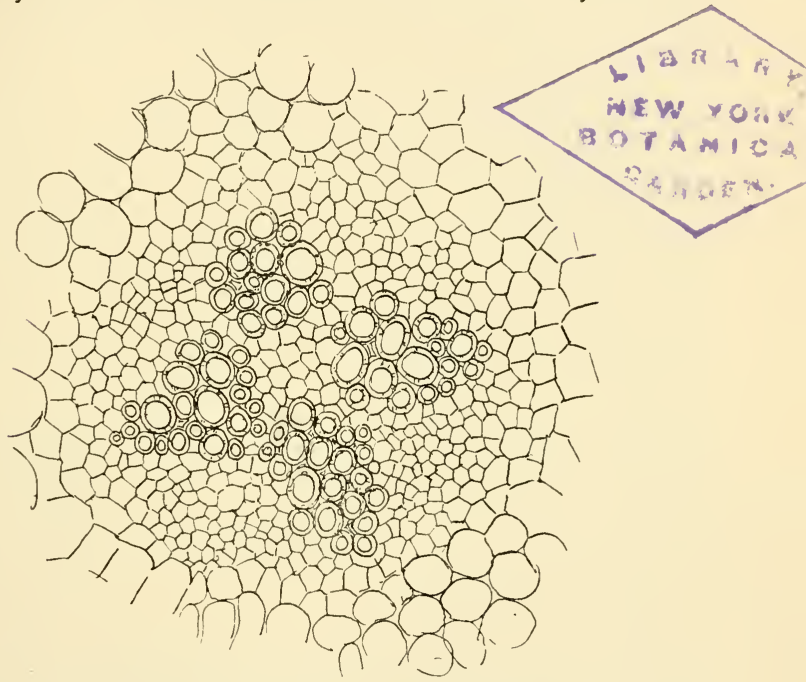

FiG. 128.-Tetrarch vascular bundle of the root of B. Virginianum, $\times 85$.

phloem are much like those in the stem and do not need any special description. The roots increase considerably in diameter as they grow older, but this enlargement does not take place at the base, where the root is noticeably constricted. The enlargement is due entirely to the cortical tissue, and is mainly simply an enlargement of the cells. The diameter of the central cylinder remains the same after it is once formed. In the outer part of the root, as in the stem, there is a development of cork. 


\section{The Sporangium}

In the simplest forms of $B$. simplex the sporangia, which are much larger than those of $B$. Virginianum, form two rows very much as in Ophioglossum; but in all the more complicated forms the sporangiophore branches in much the same way as the sterile part of the leaf, and the ultimate segments become the sporangia. In $B$. Virginianum the development of the individual sporangia begins just about a year previous to their ripening, and if the plants are taken up about the time the spores are shed, the earliest stages may be found. The sporangiophore is at this time thrice pinnate in the larger specimens, and an examination of its ultimate divisions will show the youngest recognisable sporangia. These form slight elevations growing smaller toward the end of the segment (Fig. I 29), and exact median sections show that at the apex of the broadly conical prominence which is the first stage of the young sporangium there is a large pyramidal cell with a truncate apex. Holtzman ${ }^{1}$ thinks the sporangium may be traceable to a single cell, and that the divisions at first are like those in a three-sided apical cell. I was unable to satisfy myself on this point, but the youngest stages found by me in which the sporangial nature of the outgrowths was unmistakable, would not forbid such an interpretation, although there was no doubt that the basal part of the sporangium is derived in part from the surrounding tissue.

From the central cell, by a periclinal wall, an inner cell, the archesporium, is separated from an outer one. The outer cell divides next by cross walls, and this is followed by similar divisions in the inner cells (Fig. I 29). The succeeding divisions in the outer cells are now mainly periclinal, and transform the four cells lying immediately above the archesporium into as many rows of tabular cells. Growth is active in the meantime in the basal part of the sporangium, which projects more and more until it becomes almost spherical. To judge from the somewhat incomplete account given by Goebel ${ }^{2}$ of $B$. lunaria, this species corresponds closely in its early stages to that of $B$. Virginianum. The later divisions in the archesporium do not apparently follow any definite rule, but divi-

1 Holtzman (I).

${ }^{2}$ Goebel (3). 
sions take place in all directions until a very large number of cells is formed. The cells immediately adjoining the sporogenous tissue divide into tabular tapetal cells, as in Ophioglossum. The sporangium shortly before the isolation of the spore mother cells (Fig. I 29, C) is a nearly globular body with a thick, very short stalk. The central part of the upper portion is occupied by the sporogenous tissue surrounded by a massive wall of several layers of cells, of which the inner ones constitute the tapetum. The central cells, as

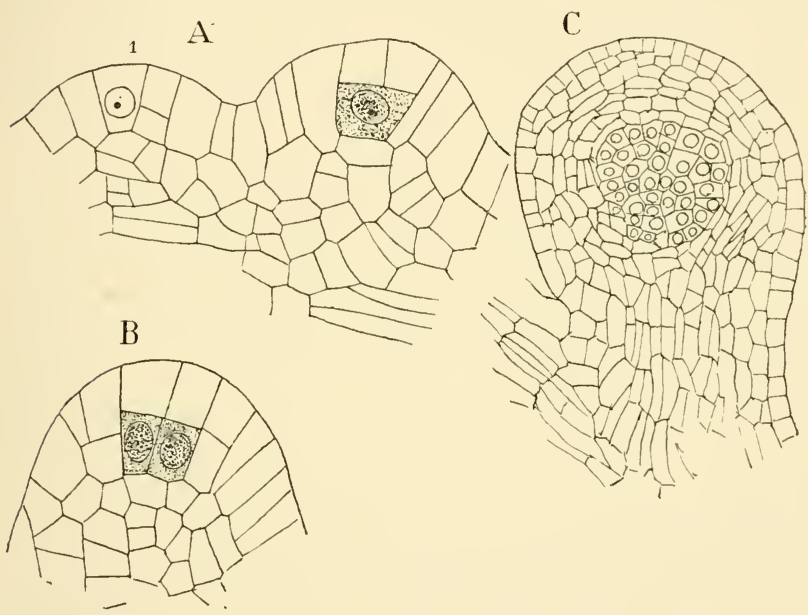

FIG. 129.--Botrychium Virginianum (Sw.). Development of the sporangia. A, I, 2, Very young sporangia ; B, a som what older one, $\times_{4} 80$; C, older sporangium, $\times_{240}$, all median longitudinal sections, the sporogenous cells have the nuclei shown.

usual, have larger nuclei, and more granular contents than the outer ones. The stages between this and the ripe sporangium were not seen, so that it cannot be stated positively whether all the cells of the sporogenous tissue (which seems probable) or only a part of them, as in Ophioglossum, develop spores.

The stalk is traversed by a short vascular bundle, which is first evident about the time that the number of sporogenous cells is complete, and joins directly with the young vascular bundle of the leaf segment (Fig. I 29, C). The ripe sporangium opens by a transverse slit, as in Ophioglossum. 
The presence of fungous filaments in the roots of the Ophioglossaceæ has been repeatedly observed, and has been the subject of recent investigations by Atkinson, ${ }^{1}$ who is inclined to regard them as of the same nature as the mycorrhiza found in connection with the roots of many Dicotyledons, especially Cupuliferæ. Atkinson asserts that he finds them invariably present in all the forms he has examined; but Holle ${ }^{2}$ states that, while they are usually present in Ophioglossum, he has found strong roots entirely free from them, and that in Botrychium rutefolium they were mainly confined to the diarch roots, and that this is connected with a weakening of the growth of the root through the growth of the fungus, by which the triarch bundle of the normal fully-developed root is replaced by the diarch form of the weaker one.

The third genus of the Ophioglossaceæ, Helminthostachys, with the single species $H$. Zeylanica, is in some respects intermediate between the other two, but differs from both in some particulars. The sporophyte, which alone is known, and that very imperfectly, has a creeping fleshy subterranean rhizome, with the insertion of the leaves corresponding to Ophioglossum pendulum. According to Prantl, who has made a somewhat careful study of a plant, the roots do not show any definite relation to the leaves, as Holle claims is the case in the other genera. The plant sends up a single leaf, which may reach a height of 30 to $40 \mathrm{~cm}$. or more, and as in the Ophioglossum vulgatum and $B$. Virginianum, the sporangiophore arises from the base of the sterile division of the leaf. The latter is palmately lobed, and the primary divisions are also divided again. Often the primary divisions are ternately arranged, as in the larger species of Botrychium. The venation is different from that of the other Ophioglossaceæ, and is extremely like that of Angiopteris. Each pinnule is traversed by a strong midrib, from which lateral dichotomously branched veins run to the margin. In regard to the structure of the sheath that encloses the young leaf and stem apex, Helminthostachys resembles Ophioglossum.

Prantl ${ }^{4}$ states that the vascular cylinder of the stem is solid on the lower surface, but on the upper side has the openings corresponding to the leaf insertions. Two primary bundles are formed for each leaf, which fork before they enter the petiole,
1 Atkinson (2).
2 Holle (I).
3 Prantl (7).
4 Prantl, l.c. 
so that there are four bundles at the base of the petiole. Higher up a cross-section shows ten bundles arranged about the periphery, and an inner one, formed by the branching of one of the others upon the upper side. This inner bundle, and those of the upper side of the stalk, furnish the bundles for the sporangiophore.

The sporangiophore is long-stalked and in general appearance intermediate between that of the other genera, but a careful examination shows that it is much more like that of Botrychium. It is pinnately branched, but in an irregular way, and the small branchlets bear crowded oval sporangia, which open longitudinally on the outer side, and not transversely as in the other genera. The tips of the branches, instead of forming sporangia as in Botrychium, develop into green leaflike lobes, which upon the shorter branchlets are often arranged in a rosette of three or four together, with the sporangia close below them (Fig. I 22, D). This at first sight looks as if the sporangia were produced upon the lower side of these, like Equisetum, but a very slight examination shows at once that this is only apparent, and the sporangia are undoubtedly outgrowths of the branches as in Botrychium. The green lobes are seen to be only the vegetative tips of the branches, or perhaps better comparable to such sterile leaf segments as are not uncommon in Osmunda Claytoniana.

Unfortunately the life history is absolutely unknown, and its histology is also too imperfectly known to make it possible at present to determine its exact relation on the one hand to the other Ophioglossaceæ, and on the other to the Marattiaceæ and Filices. 


\section{CHAPTER IX}

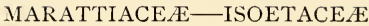

\section{The Marattiacee}

THE Marattiaceæ at the present time include four genera with about twenty-five species, confined exclusively to tropical regions. In a fossil condition they are much more numerous and diversified, and according to Solms-Laubach ${ }^{1}$ comprise the majority of the carboniferous and pre-carboniferous Ferns.

Recently a good deal of attention has been paid to these Ferns, and our knowledge of their life-history and structure is fairly complete. Some of them are Ferns of gigantic size. Thus the stem of Angiopteris evecta is sometimes nearly a metre in height and almost as thick, with leaves 5 to 6 metres in length, and some species of Marattia are almost as large. The other genera, Kaulfussia and Danaa, include only species of small or medium size. While in the structure of the tissues and the character of the sporangia these show resemblances to the Ophioglossaceæ, their general appearance is more like that of the true Ferns, with which they. also agree in the circinate vernation of their leaves. The sporangia are borne upon the lower surface of ordinary leaves, as in most leptosporangiate Ferns, but the sporangia themselves are very different, and are more or less completely united into groups or synangia, which open either by longitudinal slits or, in Danaa, by a terminal pore. The base of the leaf is provided with a pair of fleshy stipules, which possibly correspond to the sheath at the base of the petiole in Botrychium.

\footnotetext{
1 Solms-Laubach (2), p. I 42.
} 


\section{The Gametopliyte}

The germination of the spores and development of the prothallium were first investigated by Luerssen ${ }^{1}$ and Jonkman ${ }^{2}$ in Angiopteris and Marattia, and later by the latter investigator for Kaulfussia. ${ }^{3}$

The spores are of two kinds, bilateral and tetrahedral, but the former are more common. They contain no chlorophyll, but oil is present in drops of varying size, as well as other granular bodies. The nucleus occupies the centre of the spore and is connected with the wall by fine protoplasmic filaments. The wall of the spore is colourless and shows three coats, of which the outer one (perinium) is covered with fine tubercles.

Germination begins within a few days and is first indicated by the development of chlorophyll. This does not, as Jonkman ${ }^{4}$ asserts, first appear in amorphous masses, but very small, faintly-tinted chromatophores appear between the large oildrops, and these rapidly increase in size and depth of colour as germination proceeds, and their number increases by the ordinary division. In the bilateral spores the exospore is burst open above the thickened ventral ridge found in these spores, and the growing endospore slowly protrudes through this. The spore enlarges to several times its original diameter before the first division occurs, and forms a globular cell in which the large chloroplasts are arranged peripherally.

The first division takes place about a month after the spores are sown, and is perpendicular to the longer axis of the cell, dividing it either into two equal parts, or the lower may be much smaller and develop into a root-hair. In the former case each cell next divides by walls at right angles to the first, and the resulting cells are arranged like the quadrants of a circle, and one of these cells becomes the two-sided apical cell from which the young prothallium for a long time grows (Fig. I 30), much as in Aneura. This type of prothallium, according to Jonkman, ${ }^{5}$ is commoner in Marattia than in Angiopteris, where more commonly a cell mass is the first result of germination. This latter is usually derived from the form where a root-hair is developed at first. In this case only the larger of the primary

\footnotetext{
1 Luerssen (5).

2 Jonkman (I).

3 Jonkman (2).

${ }^{4}$ Jonkman, Bot. Zeit. I878, p. 136 .

5 Jonkman, l.c. p. 146.
} 
cells give rise to the prothallium. In the larger cell divisions take place in three directions and transform it into a nearly globular cell mass, terminated by four quadrant cells, one of which usually becomes the apical cell, much as in the flat prothallium. In exceptional cases the first divisions are in one plane and a short filament results.

As soon as the apical cell is established it grows in precisely the same way as the similar cell in the thallus of a

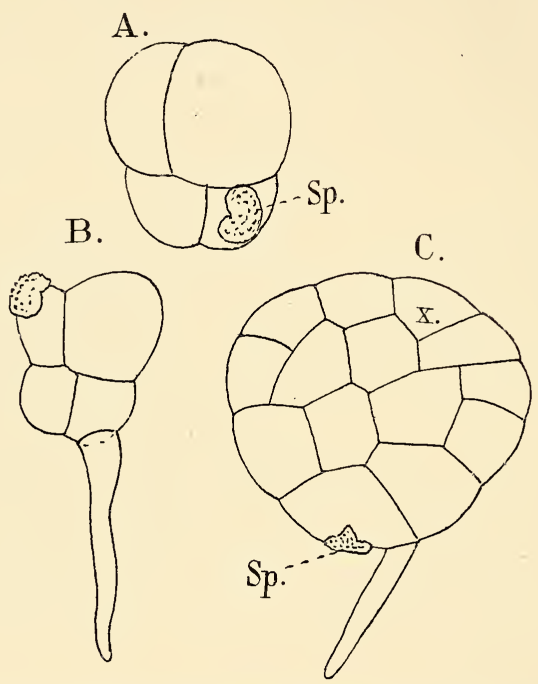

FiG. 130.-Angiopteris evecta (Hoffm). Germination of the spores,-A, $\mathrm{B}, \times_{220} ; \mathrm{C}, \times_{175} ; s p$, spore membrane; $x$, apical cell (after Jonkman).

Liverwort, and produces a thallus of much the same form and structure. As the prothallium grows older, however, a crosswall forms in the apical cell, and this is followed by a longitudinal wall in the outer one, forming two similar cells which, by further longitudinal divisions, may produce a row of marginal initials, and the subsequent growth of the prothallium is due to the divisions and growth of this group of initial cells (Fig. I $3 \mathrm{I}, \mathrm{A}$ ).

At first the prothallium has a spatulate form, but before the 
single apical cell is replaced by the group of marginal initials, the outer cells of the segments grow more rapidly than the inner ones, and the segments project beyond the apical cell, which comes to lie in a depression between the two lobes formed by the outer parts of the segments, and the prothallium assumes the heart-shape found in most homosporous Ferns. The secondary initial cells vary in number with the width of the indentation in which they lie. Seen from the surface they are oblong in shape, but in vertical section are nearly semicircular (Fig. I 3 I, B). Basal segments are cut off by a wall that extends the whole depth of the prothallium, and the segment is then divided by a horizontal wall into a dorsal and ventral cell of nearly equal size. The divisions are more numerous in the ventral than in the dorsal cells of the segment, this difference first being manifest some distance back of the apex. Owing to this, a strongly projecting, nearly hemispherical cushionlike mass of tissue is formed upon the ventral surface. The superficial cells of both sides of the prothallium have a well-marked cuticle. Numerous brown root-hairs, which, like those of the simpler Liverworts, are unicellular
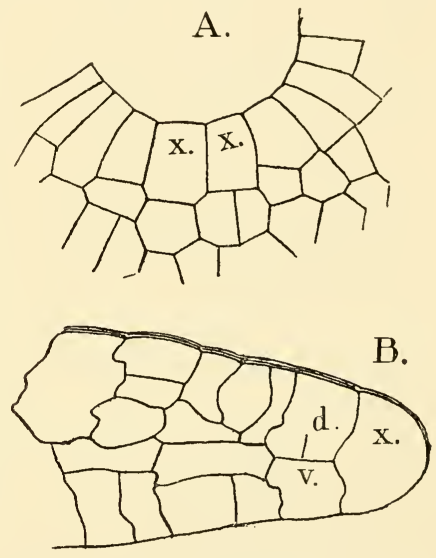

F1G. I31.-NTarattia Douglasiz (Baker). A, Horizontal section of prothallium apex, with two initials, $\times \mp 60$. B, Longitudinal section of a similar growing point ; $d$, dorsal; $v$, ventral segment.

and thin-walled, grow out

from the cells of the lower surface, especially from the broad midrib. The full-grown prothallium in $M$. Douglasii is sometimes a centimetre or more in length (Fig. I32), and tapers from the broad heart-shaped forward end to a narrow base. In Angiopteris ${ }^{1}$ it is more nearly orbicular. In both genera it is dark-green in colour, looking very much like the thallus of Anthoceros lavis, and like this too is thick and fleshy in texture. A broad midrib extends for nearly the whole length 
of the thallus and merges gradually into the wings, which are also several-layered, nearly or quite to the margin.

The very old prothallia sometimes branch dichotomously (Fig. I 32, B, C), and the process is identical with that in the thallose Hepaticæ. The two growing points are separated by a median lobe in the same way, and the midrib with the sexual

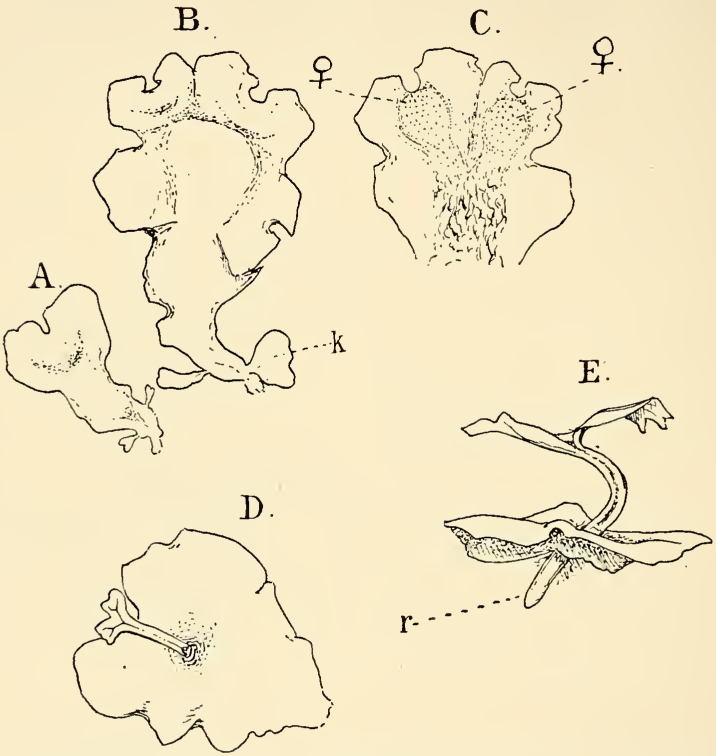

F1G. I32.-Marattia Douglasii (Baker). A, Prothallium about one year old, $\times_{2} ; \mathrm{B}$, the same prothallium about a year later, showing a dichotomy of the growing point; $\mathrm{C}$, the same seen from below, showing two archegonial cushions $(\%)$; D, prothallium with young sporophyte, $\times_{4} ; \mathrm{E}$, a somewhat older one, seen from the side, $\times_{4} ; r$, the primary root.

organs upon it forks with it, exactly as we find, for example, the antheridial receptacle forking in Fimbriaria Californica (Fig. I, A). Besides this form of branching, which is not common, adventitious buds are produced upon the margin of the thallus very frequently. These grow in precisely the same way as the main prothallium, and after a time may become detached and form independent plants; or they may develop sexual organs (mainly antheridia) while still connected with the mother 
plant. The duration of the prothallium is apparently unlimited, so long as it remains unfecundated. The writer kept prothallia of Marattia Douglasii for nearly two years, during which they grew continuously and finally reached a length of over two centimetres. At the end of this time they were growing vigorously, and there was nothing to indicate the slightest decrease in their vitality.

The prothallia are monœecious, although not infrequently the smaller ones bear only antheridia. The latter always appear first, and are mainly found upon the lower side of the midrib, but may also occur upon the upper side. The archegonia are confined to the lower surface of the midrib, and as they turn dark brown if they are not fertilised, they are visible to the naked eye as dark brown specks studding the broad thick midrib. Both antheridia and archegonia resemble closely those of the Ophioglossacer.

The antheridium arises from a single superficial cell which first divides into an inner cell, from which the sperm cells are derived, and an outer cover cell (Fig. I33, A). The latter divides by several curved vertical walls (Figs. E-G) which intersect, and the last wall cuts off a small triangular cell $(o)$, which is thrown off when the antheridium opens, and leaves an opening through which the sperm cells are ejected. The inner cell, by repeated bipartitions, gives rise to a large number of polyhedral sperm cells. Before the full number of these is complete, cells are cut off from the adjacent prothallial cells, which completely enclose the mass of sperm cells. As in other Archegoniates, the nucleus of the sperm cell, after its final division, shows no nucleolus. The first sign of the formation of the spermatozoid that could be detected was an indentation upon one side, followed by a rapid flattening and growth of the whole nucleus. The cytoplasmic prominence which, according to Strasburger, ${ }^{1}$ is the first indication of the formation of the spermatozoid, could not be certainly detected. The main part of the spermatozoid stains strongly with alum-cochineal, and is sharply differentiated against the colourless cytoplasm, and for some time shows the characteristic nuclear structure. The origin of the cilia was not very clearly made out, but probably, as Strasburger claims, they are direct outgrowths of the forward end. The free spermatozoid (Fig. I 33, I) is a flattened band, somewhat blunt

1 Strasburger (II), vol, iv. p. I I6. 
behind and tapering to a fine point in front; attached to a point just back of the apex are several fine cilia. The body shows only about two complete coils.

The youngest archegonia are met with some distance back of the growing point, and apparently any superficial cell is potentially an archegonium mother cell. The latter divides usually into three superimposed cells (Fig. I 34, A), of which the lowest (b) forms the base of the archegonium. From the central one by a

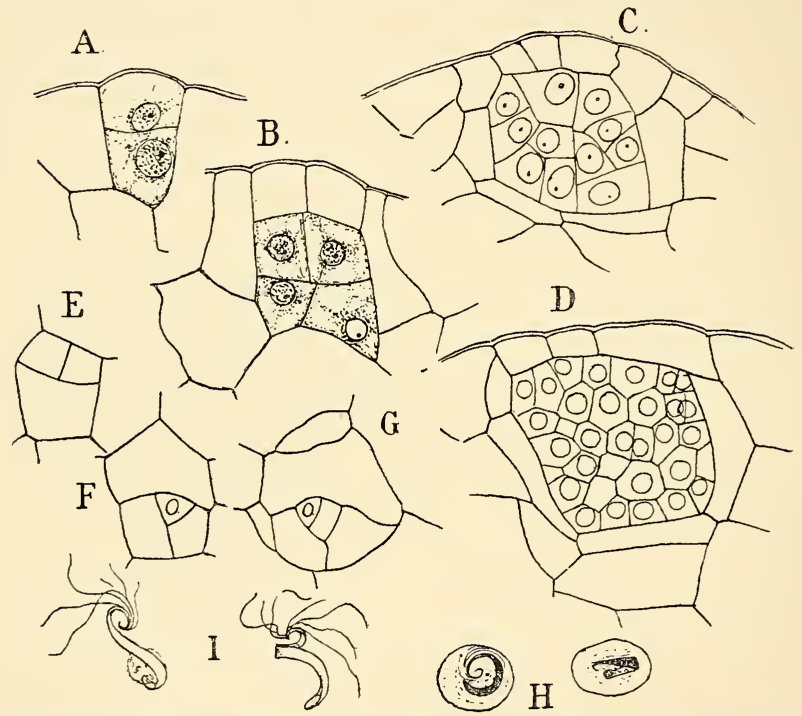

FIG. 133.-Marattia Douglasiz (Baker). Development of the antheridium. A-D, Longitudinal section, $\times_{515}$; E-G, surface views, $\times_{257} ; \mathrm{H}$, ripe sperm cells; I, free spermatozoids, $\times_{1030}$.

transverse division are formed the primary neck canal cell and the central cell. Each of these divides again transversely. In the upper one this division is often incomplete and confined to the nucleus; but in the central cell the division results in the separation of the ventral canal cell from the ovum. Before the separation of the primary neck canal cell from the central cell, the cover cell divides as in the Liverworts into four cells by intersecting vertical walls, and each of these cells by further 
obliquely transwerse walls forms a row of about three cells, and these four rows compose the short neck. The canal cells are very broad and the egg cell small, so that after the archegonium opens it occupies but a small part of the cavity left by the disintegration and expulsion of the canal cells. Before the archegonium is mature, flat cells are cut off from the adjacent prothallial tissue as in the antheridium (Fig. I 34, D). The neck of the ripe archegonium projects but little above the surface of the prothallium, and in this respect recalls both the

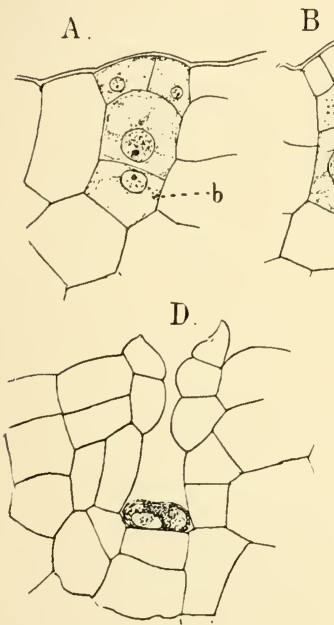

$\mathrm{B}$
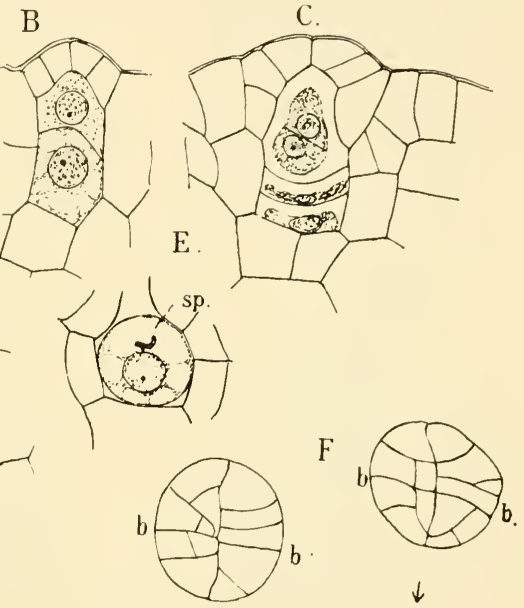

FIG. 134--Marattia Douglasii (Baker). A-D, Development of the archegonium, $\times 450$; E, section of the fertilised egg, showing the spermatozoid $(s p)$ in contact with its nucleus, $\times_{4} 85 ; \mathrm{F}$, successive longitudinal sections of a young embryo, $\times_{225} ; b, b$, the basal wall, the arrow points towards the archegonium.

lower Ophioglossaceæ and the Anthoceroteæ. The ripe ovum is somewhat elliptical, and slightly flattened vertically. Its upper third is colourless and nearly hyaline. This is the "receptive spot," and it is here that the spermatozoid enters. The nucleus is of moderate size, and not rich in chromatin; a small but distinct nucleolus is present. The spermatozoid retains its original form after it first enters the egg, and until it comes in contact with the membrane of the egg nucleus. It afterwards contracts and assumes much the appearance of the 
nucleus of the sperm cell previous to the differentiation of the spermatozoid. The two nuclei then gradually fuse, but all the different stages could not be traced. Before the first division takes place, however, but one nucleus can be seen, and this much resembles the nucleus of the unfertilised egg.

After fertilisation the egg enlarges to several times its original size before dividing. The first (basal) wall is transverse and is followed in each half by two others, the median and octant walls. The nearly globular embryo is thus divided into
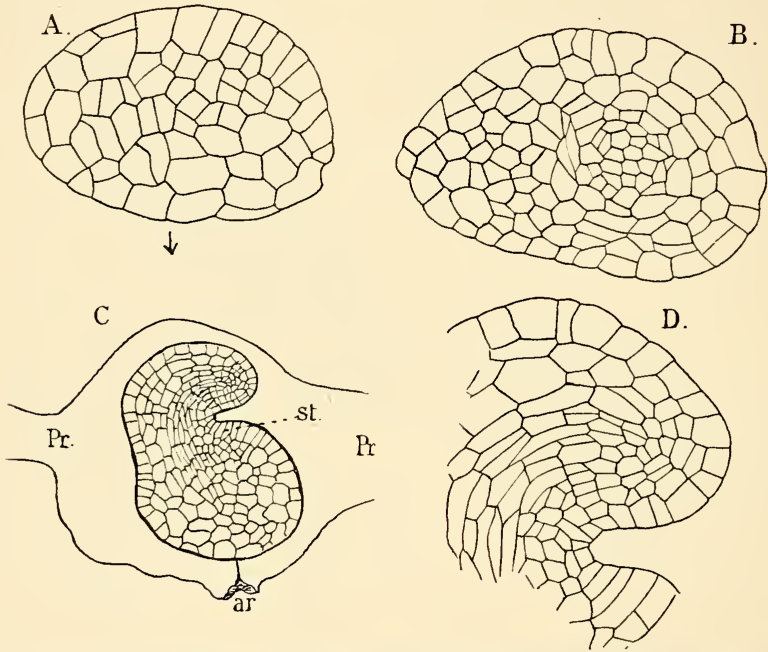

FIG. 135.-Marattia Donglasiz (Baker). Embryogeny. A, Longitudinal; B, transverse sections of embryos, $\times_{215}$; C, vertical section of an older embryo, showing its position in the prothallium, $\times 7_{2} ; s t$, the stem; pr, prothallium; $\mathrm{D}$, upper part of the same embryo, $\times 215$.

eight similar cells, each having the tetrahedral form of a globe octant. The next divisions are not perfectly understood, and evidently are not absolutely uniform in all cases. All the octants at first show nearly uniform growth, and the embryo retains its nearly oval form (Figs. I 34, F, I 35, A). The first division in the octants is essentially the same, and consists in a series of anticlinal walls, before any periclinal walls appear, so that we may say that for a short time each octant has a distinct apical growth, and there are eight growing points. The 
older embryo shows an external differentiation into the first leaf, stem, and root, but the foot is not clearly limitcd at first. The basal wall separates the embryo into two regions, epibasal and hypobasal. From the former the cotyledon and stem apex are derived, from the latter the root and foot.

The cotyledon arises from the anterior pair of epibasal octants, which are in the Marattiaceæ, unlike all the other Ferns, turned away from the archegonium opening. In the earliest stages where the cotyledon is recognisable, no single apical cell could be made out, and later the growth is very largely basal. At first the growth is nearly vertical, but it soon becomes
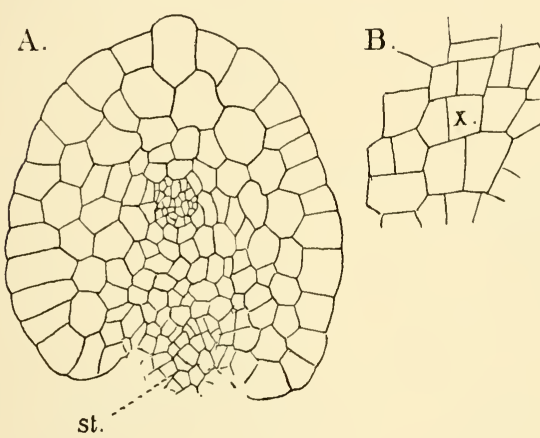

C

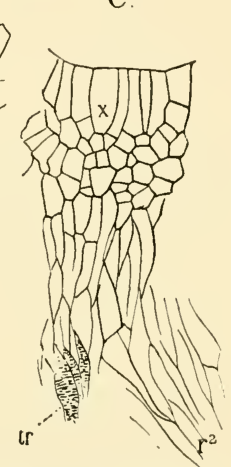

FIG. 136.-Marattia Douglasii (Baker). A, Cross-section of the young sporophyte at the junction of the cotyledon and stem; st, the apical meristem of the stem, $\mathrm{X}_{215} ; \mathrm{B}$, the stem apex of the same, $\times 430 ; \mathrm{C}$, longitudinal section of the stem apex of a plant of about the same age, $\times 215$; tr, the primary tracheary tissue; $r^{2}$, the second root.

stronger upon the outer side, and the leaf rudiment bends inwards. At this stage the different tissues begin to be distinguishable. Somewhat later the tip of the cotyledon becomes flattened, and still later there is a dichotomy of this flattened part which thus forms a fan-shaped lamina (Fig. I 38 ). The first tissue to be recognised is the vascular bundle, which traverses the centre of the petiole and at first consists of uniform thin-walled elongated cells (procambium). This formation of procambium begins in the centre of the embryo and proceeds in three directions, one of the strands going into the cotyledon, one in an almost opposite direction to the primary 
root, and a very much shorter one to the young stem apex, which lies close to the base of the cotyledon. The outer layer of cells of the cotyledon forms a pretty clearly defined epidermis separated from the axial procambium strand by several layers of young ground-tissue cells.

The apex of the young stem is occupied in some cases, at
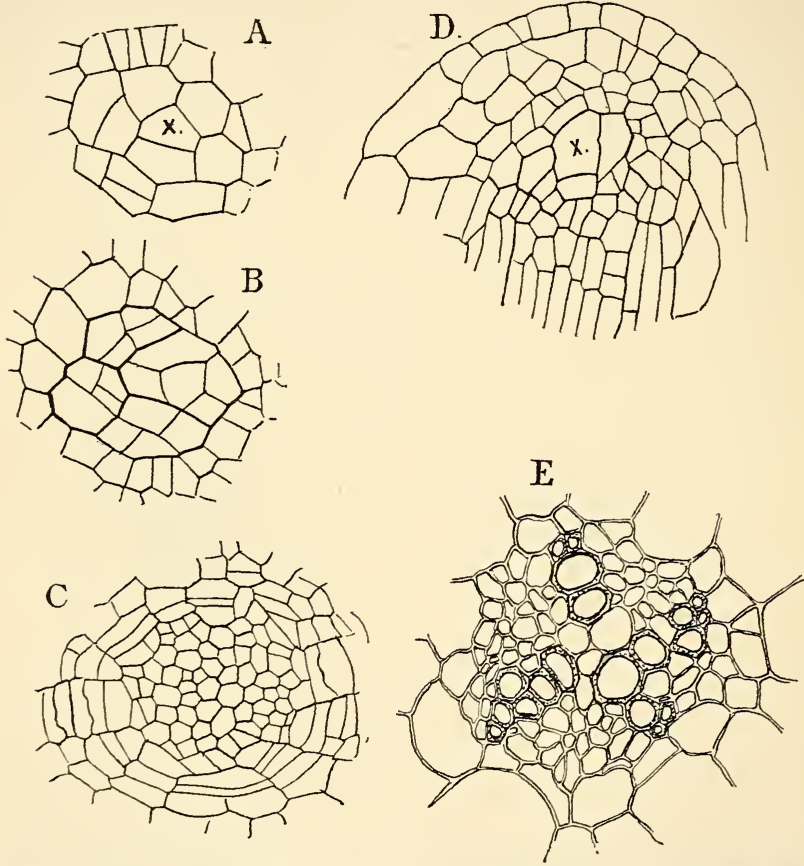

Fig. I37.-Marattia Douglasii (Baker). A, B, C, Three transverse sections of a root from the young sporophyte; A shows the apical cell $(x), \times_{215} ; \mathrm{D}$, longitudinal section of a similar root, $\times_{260}$; $\mathrm{E}$, vascular bundle of the root, $\times 260$.

least, by a single apical cell, which probably is to be traced back directly to one of the original octants of the embryo. Whether this is always the case in the youngest stages cannot be determined until further investigations are made. Farmer ${ }^{1}$ was 
unable to make out a single initial in Angiopteris, which otherwise agrees closely with Marattia.

The study of the root was confined mainly to the older embryos, and although some variation is noticed, it is pretty certain that there is a single apical cell, not unlike that found in the Ophioglossaceæ. Whether this can be traced back to one of the primary hypobasal octants, it is impossible now to say; but Farmer's ${ }^{1}$ statement that in Angiopteris there is at first a three-sided apical cell would point to this. Unfortunately my own preparations of Marattia were too incomplete to decide this point in the latter. In the older root the form of the apical cell was usually a four-sided prism, from all of whose faces segments were cut off, although sometimes an approach to the triangular form found in the Ophioglossaceæ was observed.

The foot is much less prominent than in Botrychium, and in this respect the Marattiaceæ are more like Ophioglossum. ${ }^{2}$ In Marattia all the superficial cells of the central region of the embryo become enlarged and act as absorbent cells for the nourishment of the growing embryo.

As the embryo grows, the surrounding prothallial tissue divides rapidly, and a massive calyptra is formed which completely encloses the young sporophyte for a long time. Owing to the position of the cotyledon and stem, which grow up vertically through the prothallium, a conspicuous elevation is formed upon its upper side, through which the cotyledon finally breaks. A similar elevation is formed by the calyptra upon the lower side, through which the root finally penetrates, but not until after the cotyledon has nearly reached its full development. The prothallium does not die immediately after the young sporophyte becomes independent, but may remain alive for several months afterwards, much as in Botrychium.

The first tracheary tissue arises at the junction of the bundles of the cotyledon, stem, and root. These primary tracheids are short and their walls are marked with reticulate thickenings. From this point the development of the tracheary tissue, as well as the other elements of the bundles, proceeds toward the apices of the young organs. The formation of the secondary tracheids is always centripetal.

Short hairs with cells rich in tannin, and staining strongly

1 Farmer (3), p. 268.

2 Mettenius (2), P1. XXX. 
with Bismarck-brown, occur sparingly upon the leaves and stem of the young sporophyte.

The fully-developed cotyledon has the fan-shaped lamina somewhat lobed, and the two primary veins arising from the forking of the original vascular bundle usually fork once more, so that the venation is strictly dichotomous in character. Farmer ${ }^{1}$ figures the cotyledon of Angiopteris as more spatulate in form, with a distinct midrib, but this is never the case in M. Douglasii. The nearly cylindrical petiole is deeply channeled upon the inner side, and the single axial vascular bundle is almost circular in section. While the crescent-shaped mass of tracheary tissue is completely surrounded by the

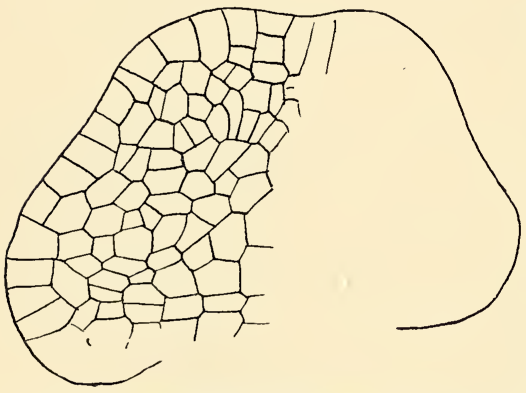

FIG. 138.-Horizontal section of the lamina of the cotyledon of M. Douglasiz, $\times 26$. phloem, the latter is much more strongly developed upon the outer side, and the bundle approaches the collateral form of Ophioglossum. Indeed, if the tannin cells, which are found here, belong to the cortex, as Farmer asserts to be the case in Angiopteris, the bundle would be truly collateral, as these are immediately in contact with the tracheids. The lamina of the cotyledon is similar in structure to that of the later leaves, and differs mainly in the smaller development of the mesophyll. The smaller veins have the xylem reduced to a few (I-3) rows of tracheids upon the upper side of the collateral bundle. Stomata of the ordinary form occur upon the lower side of the leaf.

As the root finally breaks through the calyptra and penetrates into the earth, numerous fine unicellular root-hairs develop from the older parts, but the tip for some distance remains free from them. Owing to the numerous irregularities in the cell divisions, the exact relation of the tissues of the older parts of the root to the segments of the apical cell is 
impossible to determine, and evidently is not always exactly the same. The root-cap is derived mainly from the outer segments of the apical cell, but also to some extent from the outer cells of the lateral segments; and the plerome cylinder, where the base of the apical cell is truncate, is formed mainly from the basal segments, but in part as well from the inner cells of the lateral segments.

The vascular cylinder of the root is usually tetrarch. At four points near the periphery small spiral or annular tracheids appear, and from them the formation of the larger secondary tracheids pro. ceeds toward the centre. The phloem is made up of nearly uniform cells with moderately thick colourless walls. A bundlesheath is not clearly to be made out (Fig. I 37 ).

The cotyledon is destitute of the stipules found in the perfect leaves of the Marattiacex, but they are well developed in the third leaf, where they form two conspicuous appendages clasping the base of the next youngest leaf. The edges of these stipules are somewhat serrate, and the edges of the two meet,
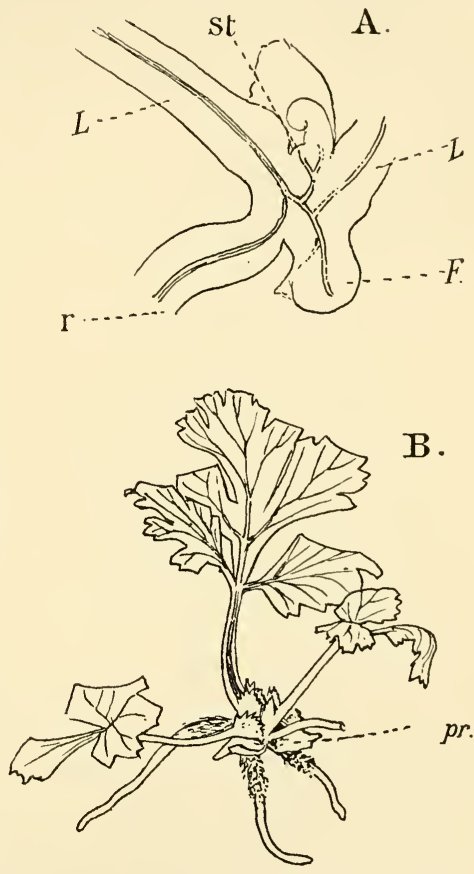

Fig. 139:-Marattia Douglasii(Baker), A, Longitudinal section of the young sporophyte, showing the distribution of the vascular bundles, $\times 6 ; l$, leaves; st, stem apex; $r$, a root; $f$, the foot; $\mathrm{B}$, young sporophyte with the prothallium $(p r)$, still persisting.

much like two bivalve shells. The strictly dichotomous character of the cotyledon is gradually replaced in the later leaves by the pinnate arrangement, both of the divisions of the leaf and the venation. This is brought about in both cases by an unequal dichotomy, by which one branch develops more 
strongly than the other, so that the latter appears lateral. With the assumption of the pinnate form the leaf also develops the wings or appendages upon the axis between the pinnæ. In the fully-developed leaves of the mature sporophyte, the last trace of this is seen in the ultimate branching of the veins, which is always dichotomous.

The second root arises close to the base of the second leaf, and at first there seems to be one root formed at the base of each of the young leaves; in the older sporophyte the roots are more numerous. Holle ${ }^{1}$ states that this is not the case in Marattia, where only one root is formed for each leaf, in Angiopteris two. This, however, requires confirmation in the older plants. As the roots become larger it is no longer
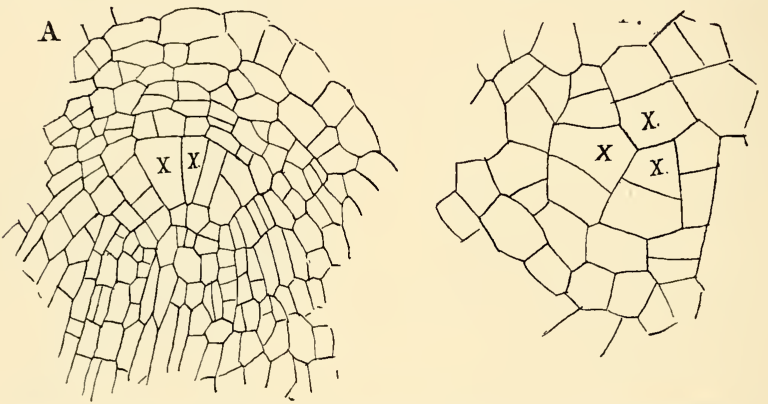

FIG. I40.-A, Longitudinal section; B, transverse section of roots from older sporophyte of M. Douglasii, showing apparently more than one initial cell, $\times 200$.

possible to distinguish certainly a single initial cell. The adjacent segments themselves assume to some extent the function of initials, and thus in place of the single definite apical cell a group of apparently similar initials is formed, which takes its place (Fig. I 40). This seems to be in some degree associated with the increase in size of the roots. ${ }^{2}$

According to Holle ${ }^{3}$ the four-sided apical cell found in the stem of the young sporophyte is retained permanently, but in Angiopteris this is not the case, as in the older sporophyte a single apical cell is not certainly to be made out. Bower ${ }^{4}$

1 Holle (2), p. 2 I 7.

2 It is possible that a single initial may be present even here, but the great similarity of the central group of cells makes this exceedingly difficult to determine. 
comes to the same conclusion as Holle, although in an carlier paper $^{1}$ he attributes a single apical cell to the stem of Angiopteris. The stem in both genera becomes very massive, but its surface is completely covered by the persistent stipules. The arrangement of the bundles is like that of Ophioglossum, and they form a hollow cylinder with distinct meshes corresponding to the position of the leaves. The bundles are,
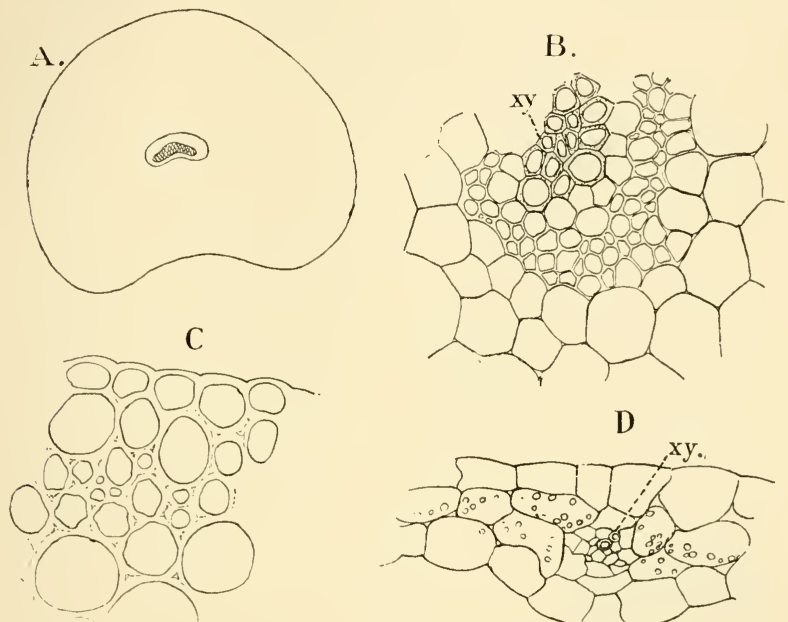

D

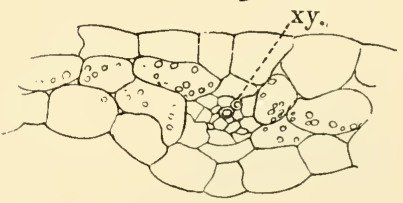

FIG. I4x.-Marattia Douglasii (Baker). A, Cross-section of the ultimate rachis of a fully-developed leaf, $\times_{26}$; B, part of the vascular bundle of the same, $X_{200}$; , collenchyma from the cortex of the same, $\times x_{50} ; \mathrm{D}$, cross-section of the lamina of the cotyledon, $\mathrm{X}_{200} ; x y, x y$ lem.

according to Holle, ${ }^{2}$ concentric, but the phloem more strongly developed upon the outer side.

The thick petioles of the full-grown leaves are traversed by very numerous vascular bundles, which at the base give off branches that supply the thick stipules within which they branch and anastomose to form a network. These bundles in Angiopteris are arranged in several circles, or according to De Vriese and Harting, ${ }^{3}$ the central ones form a spiral. In the rachis of the last divisions of the leaves, howerer, both of

1 Bower (2), p. 579.

2 Holle (2), p. 217.

3 De Vriese (I). 
Marattia and Angiopteris, there is but a single axial bundle, as in the petiole of the cotyledon.

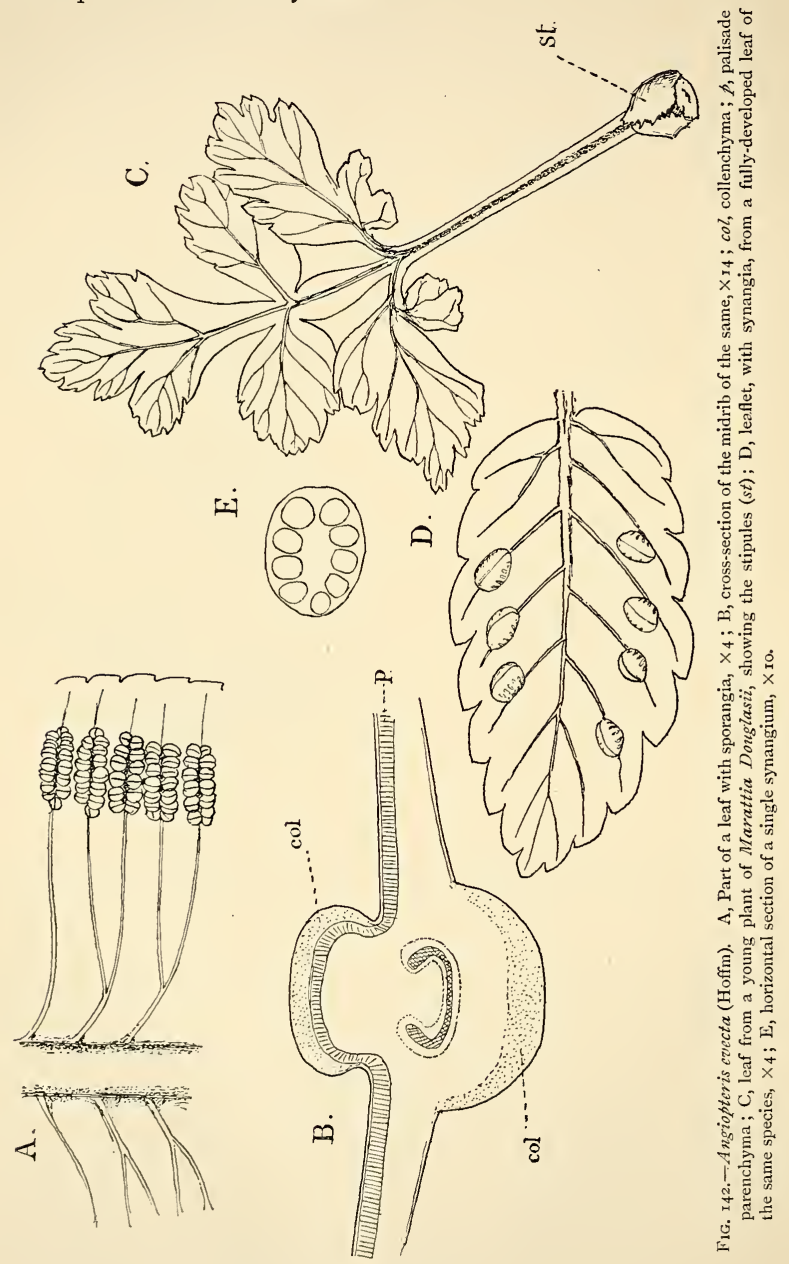

Fig. I 42, B shows a cross-section of a pinnule from a large 
leaf of $A$. evecta, which has much the same structure as that of Marattia. The central vascular bundle is horse-shoe shaped in section, and shows a central mass of large tracheids with reticulate or scalariform markings, surrounded by the phloem made up of very large sieve-tubes much like those of Botrychium, and with these are the ordinary protophloem cells and bast parenchyma. A distinct bundle-sheath is absent, as, according to Holle, ${ }^{1}$ it is from all the bundles in both Marattia and Angiopteris, except those of the larger roots. The bulk of the ground tissue is composed of large parenchyma cells, but on both sides just below the epidermis is a band of colourless cells which resemble exactly the collenchyma of Phanerogams. In the base of the petiole this becomes harder and forms a colourless sclerenchyma, according to Holle, ${ }^{2}$ which in Danaa is replaced by brown sclerenchyma like that of the true Ferns. In the lamina of the leaf in Angiopteris too, the arrangement of the tissues is strikingly like that of the typical Angiosperms. A highly-developed palisade parenchyma occupies the upper part of the leaf beneath the epidermis, which bears stomata only on the lower side of the leaf. The rest of the mesophyll is composed of the spongy green parenchyma found in the other Ferns. The smaller veins both here and in Marattia have collateral bundles.

\section{The Sporangia}

The sporangia of the Marattiacex differ most markedly from the Ophioglossaceæ in being borne on the lower side of the ordinary leaves, and not on special segments. Except in Angiopteris, they form synangia, whose development has only been studied in Marattia. ${ }^{3}$ Luerssen describes the process thus: "In Marattia the first differentiation of the sporangium begins while the young leaf is still rolled up between the stipules of the next older one. The tissue above the fertile vein is more strongly developed than the adjoining parenchyma, and forms an elevated cushion parallel with the vein. This is the receptacle, which develops two parallel ridges, separated by a cleft. These two ridges grow up until they meet, and their edges grow together and completely close the cleft which lies between. In each half there are differentiated the separate

${ }^{1}$ Holle (2), p. 2 I6.
3 Luerssen (7), vol. i. p. 579. 
archesporial groups of cells corresponding to the separate chambers found in the complete synangium." The whole process takes, according to his account, about six months. Luerssen was unable either in Marattia or Angiopteris to trace back the archesporium to a single cell, which Goebel ${ }^{1}$ claims is present in the latter.

In Angiopteris the process begins as in Marattia, but at a period when the leaf is almost completely developed and unfolded. The first indication of the young sorus is the

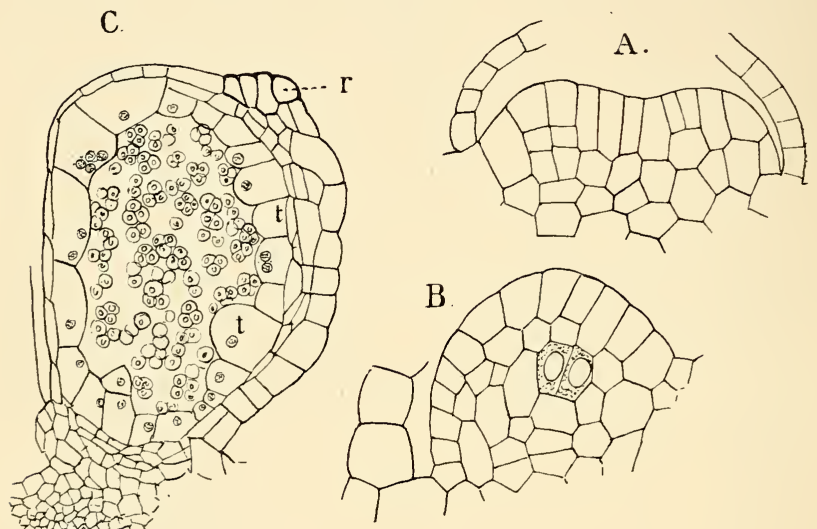

formation of an oblong depression above a young vein, and about the border of this are numerous short hairs, which as a rule are absent from the epidermis of the leaf (Fig. I 43, A). The placenta is formed as in Marattia, but instead of the two parallel ridges that are found in the latter, the young sporangia arise separately, much as in Botrychium. As in the latter too, Goebel states that the archesporium can be traced to a single hypodermal cell in the axis of the young sporangium. This

1 Goebel (3). 
cell divides repeatedly, but apparently without any definite order, and the division of the spores follows in the usual way. From the cells about the archesporium tapetal cells are cut off, but these do not disappear, as Goebel ${ }^{1}$ asserts, but persist until the sporangium is mature. The growth is greater upon the outer side, which is strongly convex, while the inner face is nearly flat.

A section of the nearly full-grown sporangium (Fig. I 43, C) shows that the wall upon the outer side is much thicker, and is composed for the most part of three layers of cells, of which the outer in the ripe sporangium have their outer walls strongly thickened. The top of the sporangium and the inner wall are composed of but one layer of cells (exclusive of the tapetum), which are flat and more delicate than those upon the outer side. Near the top on its outer side is a transverse line of cells with thickened darker walls, which project somewhat above the level of the others. This is the annulus or ring, and resembles closely that of Osmunda. Lining the wall is a layer of very large thin-walled cells which form the tapetum. This in Angiopteris remains intact until the spores are divided. Whether it disappears before the dehiscence of the sporangium was not determined. The contents of these cells, which are very much distended, and evidently actively concerned in the growth of the forming spores, contain very few granules, but are multinucleate in many cases. Whether this condition is due to a coalescence of originally separate cells, or what seems more likely, arises simply from nuclear division in the young tapetal cells, without the formation of cell walls, was not decided. The young spore tetrads, at this time, are embedded in an apparently structureless mucilaginous matter, which stains uniformly with Bismarck-brown. This apparently is secreted by the tapetal cells for the nourishment of the spores.

\section{Classification of Marattiacee}

The living forms are divisible into three families :-

I. Angiopteridex, with the single genus Angiopteris, and probably only one extremely variable species, A. evecta (Hoffm), which occurs throughout the Eastern tropics.

II. Marattieæ, with two genera, Marattia and Kaulfussia. ${ }^{2}$

${ }^{3}$ Goebel (3), IS81, p. 684 .

2 Kaulfussia is sometimes made the type of a separate family. 
The former genus includes seven species ${ }^{1}$ belonging to the tropics of both the old and new world. The latter includes but a single species, belonging to south-eastern Asia. The synangia are scattered over the lower surface of the palmate leaf, and are circular, with a central space into which the separate loculi open by a slit, as in Marattia. Kaulfussia is characterised by very large pores upon the lower side of the leaf. A study of the development of these shows ${ }^{2}$ that at first they are perfectly normal in form, and that the large round opening is a secondary formation, the two guard cells of the young stoma being torn apart, and disappearing almost entirely in the older leaf.

III. The Danæaceæ. The single genus Danæa includes eleven species, according to Hooker, ${ }^{3}$ all confined to the new world. They are Ferns of moderate size, with simple or pinnate leaves, whose venation is like that of Angiopteris. The synangia are long, and frequently extend completely from the midrib to the margin of the leaf. They are like those of Marattia, but open by a terminal pore instead of by a slit. Between the synangia the tissue of the leaf in some species forms an elevated ridge, with the top broader, so that the section is T-shaped.

\section{Fossil Marattiacee}

It has been shown ${ }^{4}$ that the majority of the earlier fossil Ferns belong to this order, and of the living families the Angiopterideæ and Danæaceæ have also representatives in a fossil condition. The Marattieæ and Kaulfussieæ are only known in a living state. Five families, on the other hand, contain only fossil forms, some of which appear to be in certain respects intermediate between the Marattiaceæ and some of the leptosporangiate Ferns. ${ }^{5}$

\section{The Isoetacee}

The systematic position of this extremely isolated group has been long a debated question. Most botanists assign it a place near the Lycopodineæ, but there are serious objections to this, and it seems to the writer that at present the weight of evidence is in favour of placing Isoetes with the eusporangiate

1 Hooker (i).

2 Luerssen (I).

3 Hooker (I).

+ Solms-Laubach (2), p. 143.

5 Solms-Laubach, l.c. p. 148. 
Filicinea, although it must be understood that this is provisional.

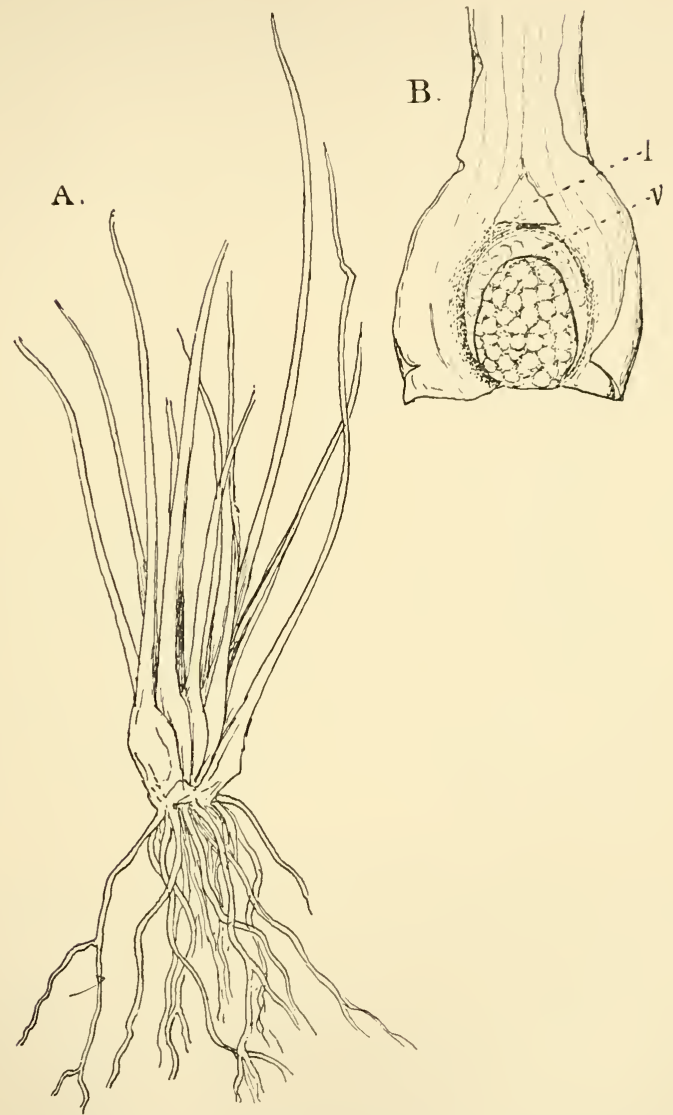

FIG. I44.-A, Plant of Isoetes Bolanderi (Englm), $\times_{\mathbf{I}} ; \mathrm{B}$, base of a leaf with macrosporangium, $\times_{4}$; $l$, ligula; $v$, velum.

Isoetes has been the subject of repeated investigation, Hofmeister ${ }^{1}$ being the first to study its development in detail. 
The sporophyte is in most species either aquatic or amphibious, but a few species are terrestrial. They are very much alike in appearance, having a very short stem whose upper part is completely covered with the overlapping broad bases of the leaves, which themselves are long and rush-like, so that the plant in general appearance might be readily taken for an aquatic Monocotyledon. The roots are numerous and dichotomously branched. The stem grows slowly in diameter, and the older ones show two or three vertical furrows that unite below, and as the stem continues to grow these furrows deepen, so that the old stem is strongly two or three lobed. In the furrows the roots are formed in acropetal succession. The leaves are closely set and expanded at the base (Fig. I44) into a broad sheath, with membranaceous edges. Just above the base of each perfectly-developed leaf is a single very large sporangium, sunk more or less completely in a cavity (fovea), which in most species is covered wholly or in part by a membranaceous indusium (velum), and above the fovea is a scale-like outgrowth of the leaf, the ligula. The spores are of two kinds, borne in separate sporangia. The outer leaves of each cycle produce microspores, the inner ones macrospores, many times larger than the former. The innermost leaves, which are not usually perfectly developed, are sterile, and separate one year's growth from the next. In some of the land forms, e.g. I. hystrix, these sterile leaves are very much reduced, and form spine-like structures.

\section{The Gametophyte}

The germination of the microspores was studied by Hofmeister, ${ }^{1}$ and later by Millardet ${ }^{2}$ and Belajeff, ${ }^{3}$ the later writer differing in some essential particulars from the earlier observers. The two former studied $I$. lacustris, and Belajeff I. setacea and I. Malinverniana, which do not seem to differ, however, from $I$. echinospora, which was investigated by the writer. The microspores of all the species are bilateral, and are small bean-shaped cells with thick but in most species nearly colourless walls. The epispore sometimes has spines upon it, but in I. echinospora var. Braunii the surface of the spore is nearly smooth. In this species the spores begin to ripen in the

\footnotetext{
1 Hofmeister (I), p. 34 I.
}

2 Millardet (I).

3 Belajeff (I). 
early autumn, and continue to do so as long as the conditions permit of growth. The spores are set free by the decay of the sporangium wall, which probably in nature is not completely the case until winter or early spring, which seems to be the natural time for germination. If they are set free artificially, however, they will germinate promptly, especially if this is done late in the autumn or during the winter. Thus spores sown in December produced free spermatozoids in two weeks. The spores do not all germinate with equal promptness, and all
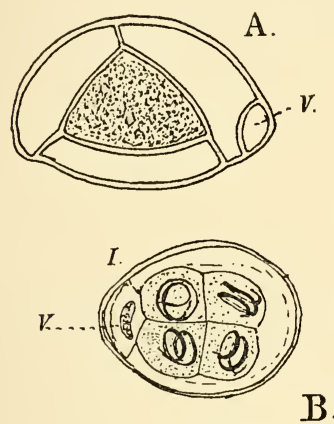

B.
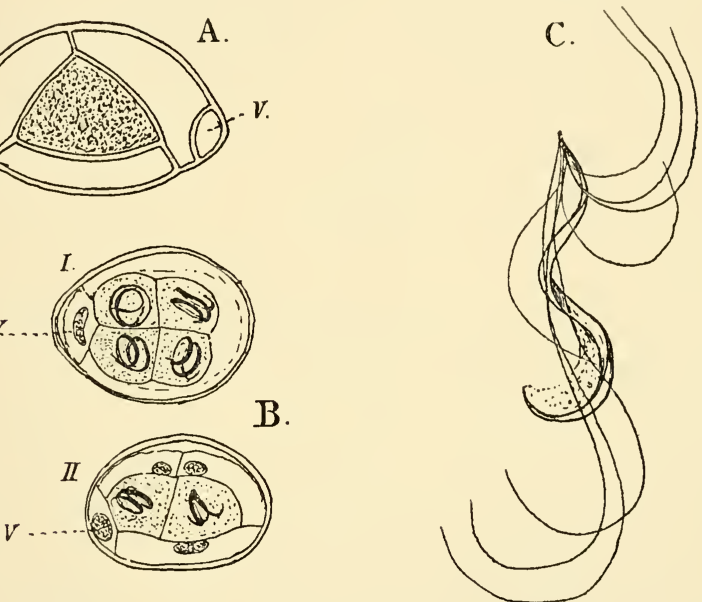

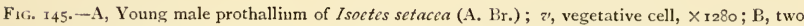
fully-developed male prothallia of 1 . echinospora var. Braunii (Durieu), $\times 1200 ; 1$, horizontal section; II, vertical section; C, spermatozoid of I. Malinverniana, $\mathrm{I}_{4} 8 \mathrm{o} . \mathrm{A}$ and $\mathrm{C}$ after Belajeff.

stages of development may be met with in the same lot. The ripe spore has no chlorophyll, but contains besides the nucleus, albuminous granules, small starch grains, and oil.

The first division wall cuts off a small cell from one end, which undergoes no further development, and represents the vegetative part of the prothallium, which is here absolutely rudimentary. The rest of the spore forms at once the single antheridium. In the latter two, walls are formed so inclined to each other as to include two upper cells and one lower one (Fig. I 45). This latter next divides into two by a vertical 
longitudinal wall, and each of the resulting cells is further divided by a periclinal wall, so that the antheridium consists of four peripheral cells and two central ones. The latter finally divide again, by vertical walls, making four central cells, which become at once the sperm cells. According to Belajeff ${ }^{1}$ the walls of the peripheral cells become dissolved finally, so that the sperm cells float free within the spore cavity. Each sperm cell forms a single coiled spermatozoid, which is more slender than those of Marattia, but like them is multiciliate.

The macrospores are very many times larger than the microspores, and are of the tetrahedral type instead of bilateral. They are nearly globular in form and show plainly the three converging ridges on the ventral surface. If the fresh spore is crushed in water, its contents appear milky, and microscopic examination reveals numerous oil-drops and some starchgranules, mingled with roundish bodies of albuminous nature. The latter absorb water and swell up so that they look like free cells.

The wall of the spore is very thick. The perinium is thick and transparent in appearance, and in the species under consideration provided with short recurved spinules. The interior, in microtome sections, is filled with coarsely granular cytoplasm, which often appears spongy, owing no doubt to the dissolving out of the oil. Scattered through the cytoplasm are round starch-granules with a central hilum. The large nucleus lies in the basal part of the spore. ${ }^{2}$ It is broadly oval in outline, and the cytoplasm immediately about it is nearly free from large granules. Before germination begins there are few chromosomes, and the nucleolus does not stain readily.

After the spores have lain a few days in water, the nucleus increases in size, and then the nucleolus stains very intensely and the chromosomes become more conspicuous. The nucleus divides while still in its original position, and undergoes division in the usual way. A very evident cell plate is formed in the equator of the nuclear figure (Fig. I 46, A), but no cell wall is found, and the result of the division is two large free nuclei. The next youngest stage observed (Fig. I 46, B) had four free nuclei, which now had moved to the ventral side of the spore.

1 Belajeff (1), p. 797.

2 Farmer (Annals of Botany', December I890) states that in $I$. lacustris the nucleus lies near the apex of the spore. 
These are very much smaller than the primary one, but are relatively richer in chromatin. They continue to divide until there are from about thirty to fifty frec nuclei, but as yet no trace of cell division can be seen. Most of the nuclei lic in

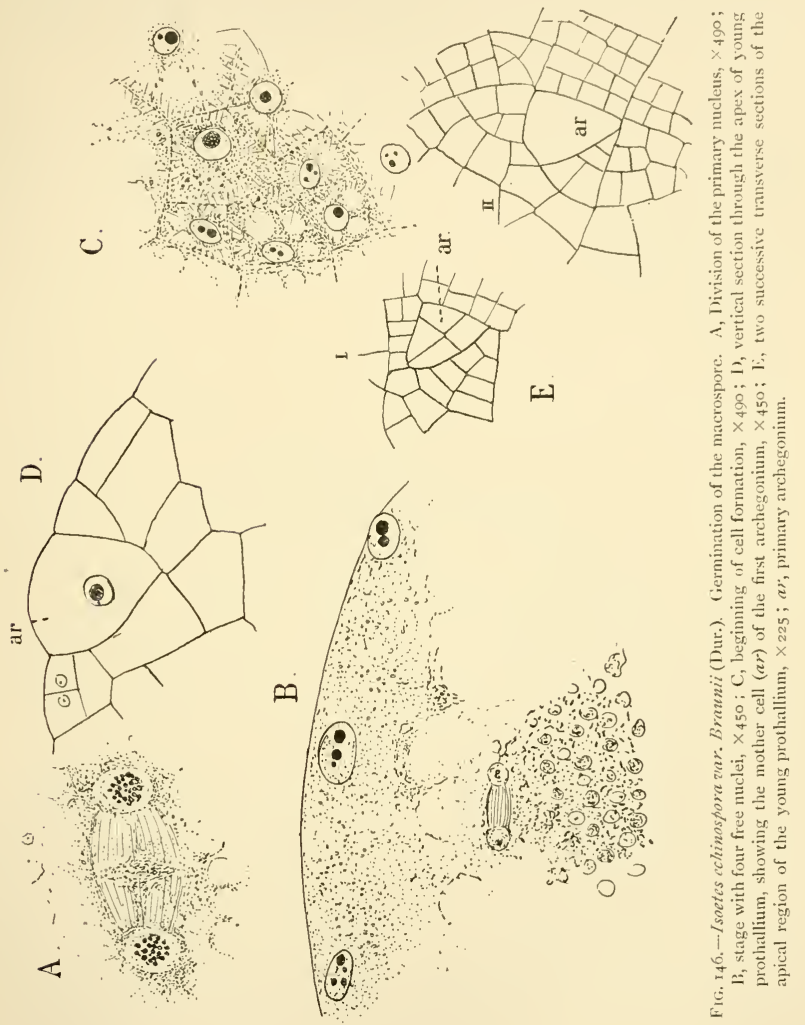

the ventral part of the spore, close to the outer wall, but an occasional one may be detected elsewhere.

Cell division begins at the apex (ventral part) of the spore. At this time the cytoplasm stains more deeply than before, and sometimes extremely delicate threads may be detected, 
radiating from the nuclei and connecting adjacent ones (Fig. I 46, C). The first traces of the division walls appear simultaneously between the nuclei in the form of cell plates composed of minute granules, probably of cellulose, which quickly coalesce and form a continuous membrane. In this way the upper part of the spore becomes transformed into a solid tissue (Fig. I 47).

The cell formation proceeds quickly toward the base of the spore, following the spore wall, so that for a time the central space remains undivided. The whole process recalls most vividly the endospore formation of most Angiosperms. On account of the extremely thin walls and dense contents of the young prothallial cells it is not easy to determine exactly when the whole spore cavity becomes filled up with cellular tissue. Because of the greater number of free nuclei in the upper part of the spore, and their consequent close proximity, the cells are smaller than those in the central and basal parts of the prothallium. Sometimes the transition from this small-celled tissue to the large-celled tissue of the basal part is quite abrupt, and the more noticeable as the upper cells are more transparent; but there was nothing to indicate that this was in any way connected with the early divisions of the primary nucleus, and more often no such sudden transition was seen.

Hofmeister's account of the coalescence of previously separate cells to form the prothallium was obviously based upon incorrect observation, and is not borne out by a study of sections of the germinating spore.

The first archegonium is very early evident, generally before the cell division is complete in the lower part of the spore. It occupies the apex of the prothallium, and the mother cell is distinguished by its large size and dense granular contents. It is simply one of the first-formed cells that soon ceases to divide, and as its neighbours divide rapidly the contrast between them becomes very marked. Whether seen from above or in longitudinal section, it generally is triangular, or nearly so. In the structure of the mature archegonium, Ophioglossum, to judge from Mattenius' somewhat incomplete account, shows strong points of resemblance, as do the Marattiaceae.

The development of the archegonium corresponds almost exactly with that of Marattia, but the basal cell is always 
wanting, and the first transverse wall separates the central cell from the cover cell. The first division in the inner cell is

A
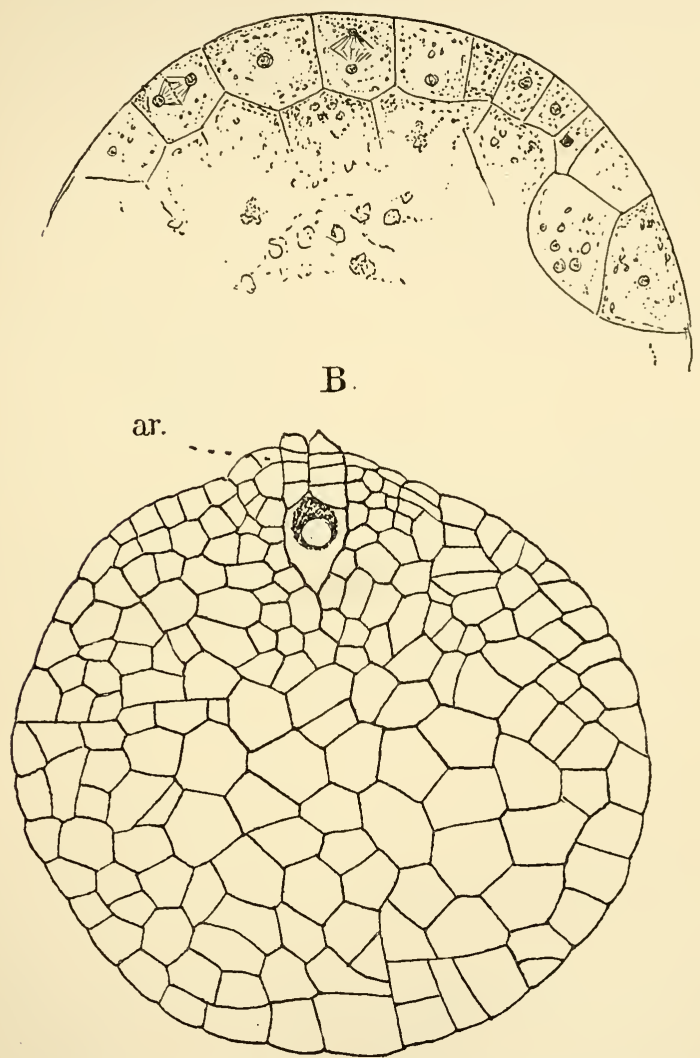

FIG. 147.-Isoetes echinospora var. Braunii (Dur.). A, Longitudinal section through the apex of the female prothallinm, showing the first cell formation, $x_{300} ; \mathrm{B}$, similar section of a prothallium with the divisions completed and the first archegonium (ar) already opened.

parallel with the base of the cover cell, and divides it into the primary canal cell and central cell. The contents of the three 
cells of which the archegonium is now composed are similar, and the nuclei large and distinct. The cover cell next divides into four by transverse walls (Fig. I $46, \mathrm{E}$ ), and from these, as in Maratiia, the four rows of cells of the neck are formed. The number in each row is four in the mature archegonium. The ventral canal cell, which like that of Marattia extends the whole breadth of the central cell, is separated almost simul-
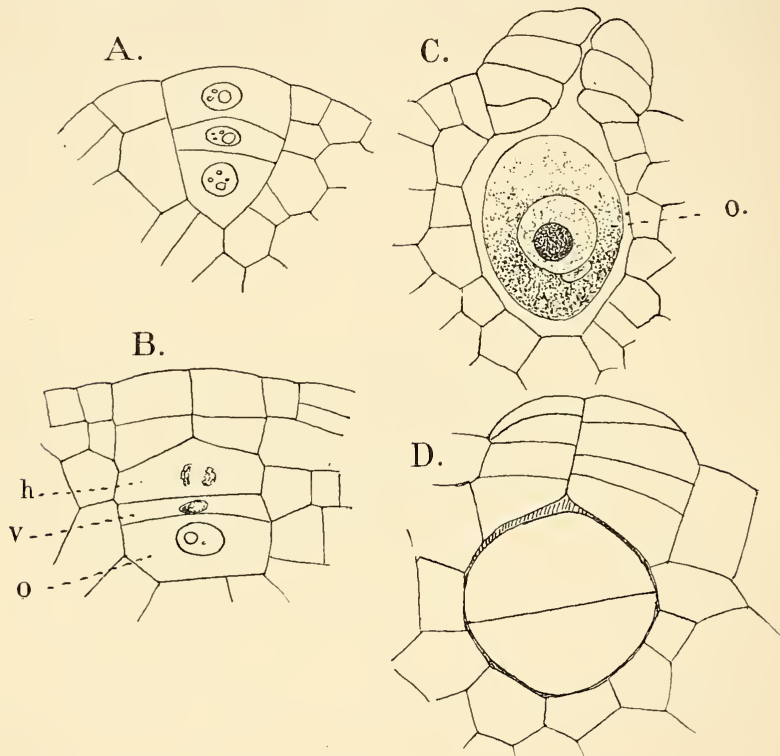

F1G. $1_{4} 8 .-$ Isoetes echinospora var. Braunii (Dur.). Development of the archegonium, $\times 500 ; o$, the egg; $v$, ventral canal cell; $h$, neck canal cell; D shows a two-celled embryo within the archegonium.

taneously with the appearance of the first transverse divisions in the neck cells. The neck canal cell has at first a single nucleus, which later divides, but there is no division wall formed. Although the number of cells in each row of the neck is usually greater than in Marattia, the neck canal cell is shorter and extends but little between the neck cells (Fig. I $48, \mathrm{~B})$.

The egg is very large, round or oval in form, and the 
nucleus contains a large round body (nuclcolus?) that stains very intensely, but otherwise shows little chromatin. The receptive spot is of unusual size, and occupies about one-third of the egg. It is almost hyaline, showing, however, a faint reticulate arrangement of fine granules; the lower portion of the egg is filled with granules that stain strongly.

In I. lacustris, according to Hofmeister, ${ }^{1}$ only one archegonium is formed at first, and if this is fertilised, no others are produced; but in I. echinospora, even before the first archegonium is complete, two others begin to develop and reach maturity shortly after the first, whether the latter is fertilised or not. In case all of these primary archegonia prove abortive, a small number, apparently not more than five or six, may be formed subsequently; but so far as my observations go, the production of archegonia is limited, as is the growth of the prothallium itself. $^{2}$

The development of the prothallium goes on without any increase in size, until the first archegonium is nearly complete, about which time the spore opens along the line of the three ventral ridges, and the upper part of the enclosed prothallium is exposed, but projects but little beyond the opening. In case all the archegonia prove abortive, the prothallium continues to grow until the reserve food material is used up, but then dies, as no chlorophyll is developed in its cells, and only in very rare instances are root-hairs formed.

\section{The Embryo}

Besides the earlier account of Hofmeister, ${ }^{3}$ Kienitz-Gerloff ${ }^{*}$ and Farmer ${ }^{5}$ have made some investigations upon the embryogeny of I. lacustris, which correspond closely, so far as they go, with my own on I. echinospora.

The youngest embryos seen had the first division wall complete (Fig. I $48, \mathrm{D}$ ). This is transverse, but more or less inclined to the axis of the archegonium. The nuclei of the two cells are large and contain several chromatin masses. The second division in the epibasal and hypobasal cells does not

1 Hofmeister (I), p. 340.

" Kienitz-Gerloff (6) states that in old prothallia of $I$. lacustris the number is sometimes twenty to thirty.
${ }^{3}$ Hofneister ( $\mathrm{I}$ ).
4 Kienitz-Gerloff (6).
5 Farmer (2). 
always occur simultaneously, the lower half sometimes dividing before the upper one, and at times the second walls are at right angles instead of in the same plane. Of the quadrants thus formed, the two lower form the foot, and the two upper ones the cotyledon and primary root. The stem apex arises secondarily at a later period, and probably belongs to the same quadrant as the root; but as it does not project at all, and is not certainly recognisable until after the boundaries between the quadrants are no longer evident, this cannot be positively asserted.

Sometimes the quadrants divide into nearly equal octants, but in several young embryos examined, no definite octant walls were present, at least in the upper octants, but whether this is a common occurrence would be difficult to say. The next divisions in the embryo resemble those in Marattia, and as in the latter it may be said that the young members of the embryo grow for a short time from an apical cell, inasmuch as the tetrahedral octants at first have segments cut off parallel with the basal, quadrant, and octant walls, leaving an outer cell (Fig. I 49, A) that still retains its original form; but very soon periclinal walls arise in this cell in each quadrant, and it is no longer recognisable as an apical cell, and from this time the apex of the young member grows from a group of initial cells.

Up to this time the embryo has increased but little in size, and retains the globular or oval form of the egg. It now elongates in the direction of the basal wall, and soon after the cotyledon and primary root become differentiated. The axis of the former coincides with the plane of the basal wall, and it approaches more or less the vertical as the latter is more or less inclined. Occasionally the basal wall is so nearly vertical that the cotyledon grows upright and penetrates the neck of the archegonium at right angles to its ordinary position. At the base of the leaf at this stage a single cell, larger than its neighbours, may often be seen (Fig. I $50, l$ ). This is the mother cell of the ligule, found in all the leaves. This cell projects, and as the leaf grows divides regularly by walls in a manner compared by Hofmeister to the divisions in the gemmæ of Marchantia. It finally forms a scale-like appendage about twelve cells in length by as many in breadth.

Almost coincident with the first appearance of the ligule 
a depression is evident, which separates the bases of the cotyledon and root. The base of the latter, which begins now also to grow in length, projects in the form of a semicircular ridge that grows rapidly and forms a sheath about the ligule and the base of the cotyledon (Fig. I 52,v). The growth of this sheath is marginal, and continues until a deep cleft is formed. A number of cells at the bottom of the latter between the sheath and the leaf base constitute the stem apex. As

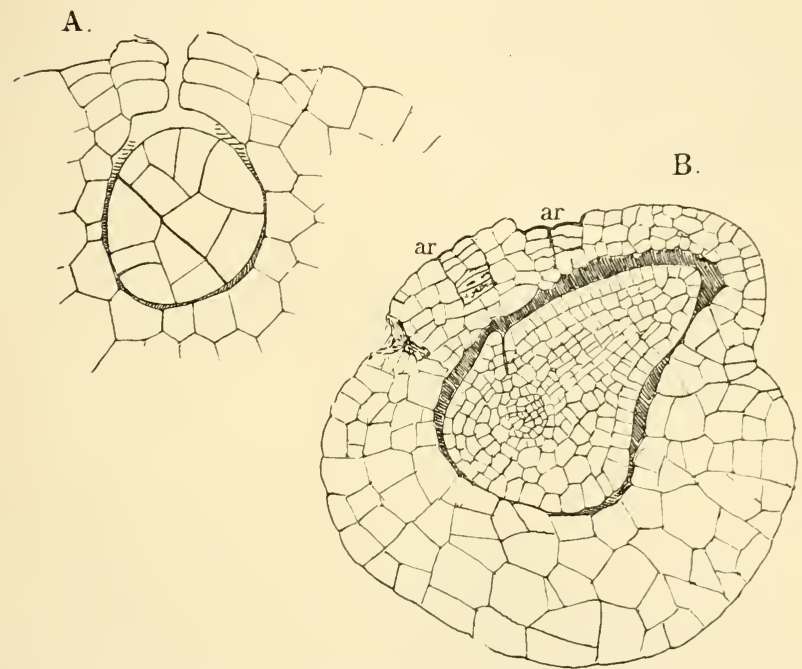

FIG. 149.-A, An embryo of I. echinospora zar. Braunii, with unusually regular divisions, $\times_{450}$; $\mathrm{B}$, a much older one, still enclosed within the prothallium, $\times_{150} ;$ ar, archegonia.

they differ in appearance in no wise from the neighbouring cells, it is quite impossible to say just how many of them properly belong to the stem. So far as can be judged, the origin of the growing point of the stem is strictly secondary, and almost exactly like that of many Monocotyledons. ${ }^{1}$

Longitudinal sections of the embryo, when root and leaf are first clearly recognisable, show that the foot is not clearly defined, as the basal wall early becomes indistinguishable from the displacement due to rapid cell division in the axis of the

${ }^{1}$ See Hanstein's figures of Alisma, for example, in Goebel's Outlines, Fig. 332. 
embryo. It projects but little, and the cells are not noticeably larger than those of the cotyledon and root.

As the cotyledon lengthens it becomes somewhat flattened, and in the later stages its increase in length is due entirely to basal growth. Even in very young embryos a distinct epidermis is evident in the leaf, and about the time that the ligule is formed the first trace of the vascular tissue appears.
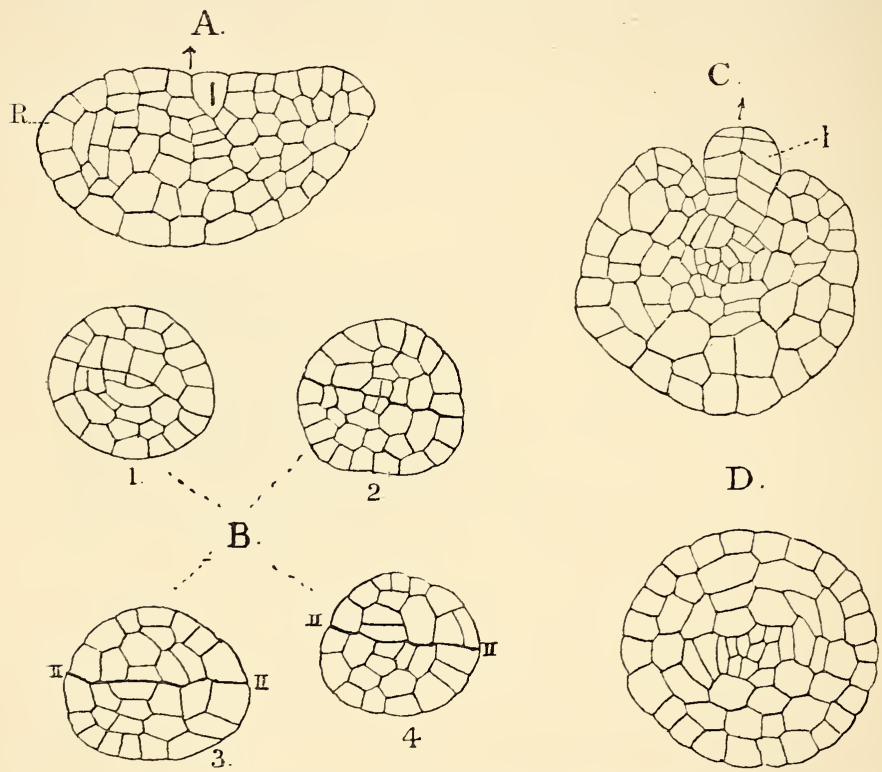

F1G. I50.-Development of the embryo in I. echinostora var. Braunii (Dur.). A, Median longitudinal section of a young embryo; $\mathrm{B}$, four horizontal sections of a younger one ; $\mathrm{C}$, two vertical transverse sections of an older embryo; $l$, the ligula, $\times 300$.

This consists of a bundle of narrow procambium cells, which lie so near the centre of the embryo that it is impossible to assign it certainly to either root or leaf; indeed it sometimes seems to belong to one quadrant, sometimes to the other. From it the development of the axial bundles of cotyledon and root proceeds, and by it they are directly united. The section of the plerome cylinder of the leaf is somewhat elliptical, and 
it does not extend entirely to the end. Its limits are clearly defined from the periblem, in which the divisions are mainly transverse and the cells arranged in regular rows.

The primary xylem consists of small spiral and annular tracheids at the base of the leaf, and from these the formation of similar ones proceeds towards the tip. Their number is small, even in the full-grown leaf, and they are the only
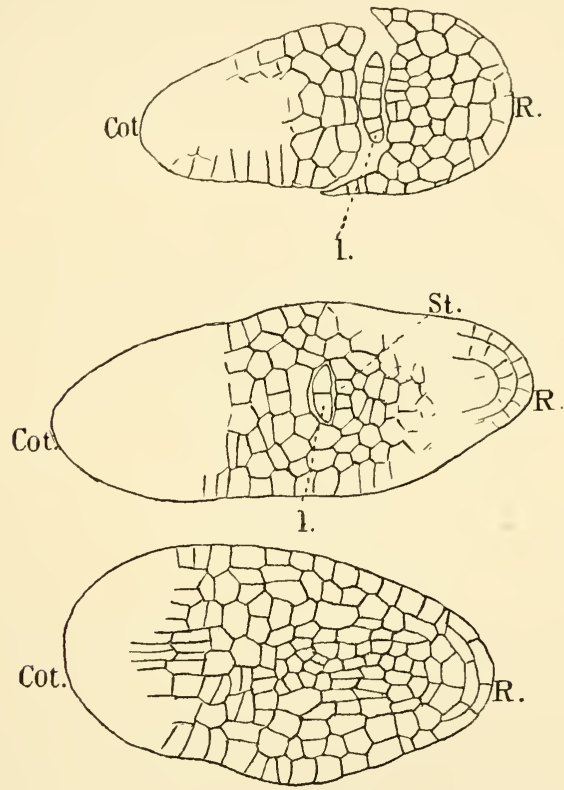

FIG. I5I.- Three successive horizontal sections of a somewhat advanced embryo of 1. echinospora var. Braunii, $\times 260$; R, root ; cot, cotyledon; st, stem ; $l$, ligula.

differentiated elements, the rest of the bundle showing only elongated parenchyma, much like the original procambium cells.

The axis of growth of the primary root usually coincides with that of the cotyledon, but this is not always the case. In the very young root (Fig. I $52, \mathrm{R}$ ) the end is covered with a layer of cells continuous with the epidermis of the rest of the 
embryo. Beneath are two layers of cells concentric with the epidermis. From the inner one arises the initial cell (or cells?) of the plerome, which soon becomes well defined and connected with the primary strand of procambium in the axis of the embryo. It is quite possible that here, as in the older roots, a single initial cell is present in the plerome, but this is not certain. The layer of cells immediately below the primary epidermis is the initial meristem for all the tissues of the root except the plerome. The primary epidermis later divides into two concentric layers which take no further part in the growth of the root except as they join the outer layers of the root-cap.

From the layer above the plerome initial, additions are

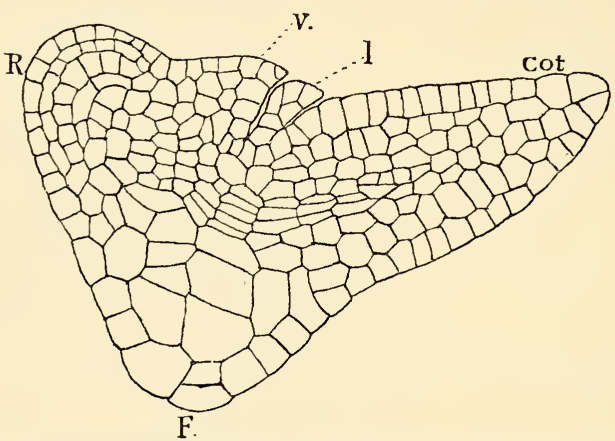

FIG. 152.-Median longitudinal section of an embryo of the same species shortly before the cotyledon breaks through the prothallium; lettering as in the preceding, $x_{3} 00$.

made at regular intervals to the root-cap, and these layers remain one cell thick, so that the stratification is very marked. At the apex of the root there is no separation of dermatogen and periblem, which are first differentiated back of the apex. The primary xylem consists of very delicate spiral tracheids formed at the base of the root at the same time that the first ones appear in the leaf.

The foot increases much in size as the leaf and root develop, and its superficial cells become much enlarged and encroach upon the large cells of the prothallium, whose contents are gradually absorbed by it.

The cotyledon is at first composed of compact tissue, which 
during its rapid elongation separates in places, and forms a system of large intercellular spaces. There are two rows of very large ones, forming two broad air-chambers extending the whole length of the leaf, but which are interrupted at intervals
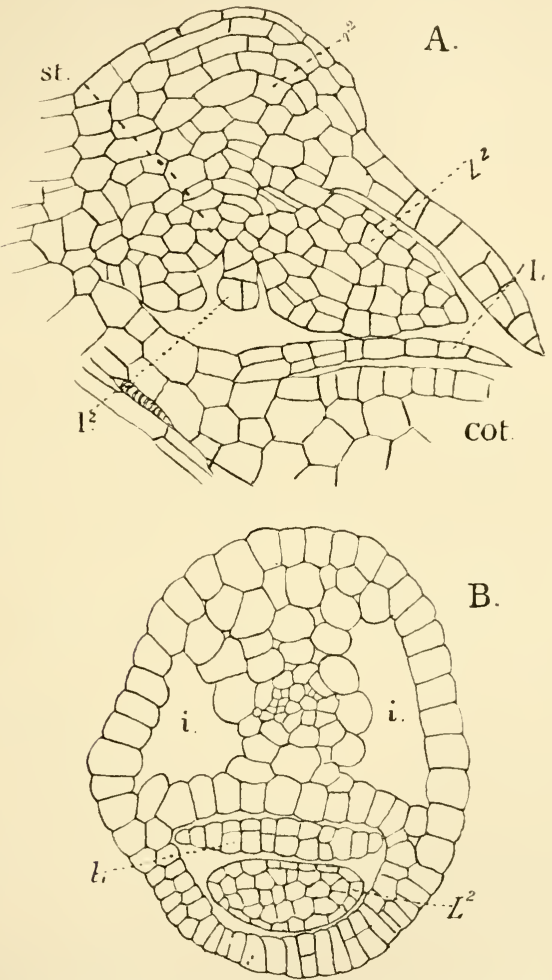

Fig. 153.-A, Median section of a young sporophyte with the second leaf L2 already formed ; $r$. second root; st, stem-apex, $\times{ }_{150} ; \mathrm{B}$, cross-section near the base of the cotyledon, showing the intercellular spaces $i$ and the second leaf $\mathrm{L}^{2}$ surrounded by the sheath $v$ at the base of the coty. ledon $; l$, the ligule of the cotyledon, $\times 300$.

by imperfect partitions composed of single layers of cells. In the root there are similar lacunæ, but they are smaller and less regularly arranged. 
The growing embryo is for a long time covered by the prothallial tissue, which in the upper part continues to grow with it; but finally cotyledon and root break through, the former growing upward, the root bending down and anchoring the young sporophyte in the mud. Owing to the large airspaces the cotyledon is lighter than the water, and always stands vertically, whether the original position was vertical or horizontal. In the latter case the plant appears to be attached laterally to the prothallium, and the stem apex, which when first formed stands almost vertically, now assumes the horizontal position which it has in the older sporophyte.

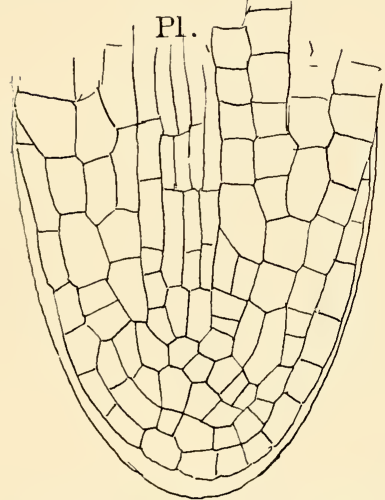

FIG. 154.-Longitudinal section of the second root, $\times 5^{25} ; p l$, plerome.

About the time that the young sporophyte breaks through the prothallium, the second leaf begins to develop. The growing point (Fig. I 53, st) now lies in the groove between the base of the root and the cotyledon, and its nearly flat surface is at right angles to the axis of the latter. The second leaf $\left(\mathrm{L}^{2}\right)$ arises as a slight elevation on the side of the stem directly opposite the cotyledon. From the first it is multicellular, and its growth is entirely like that of the cotyledon, which it otherwise resembles in all respects. Almost as soon as the leaf is evident at all, a strand of procambium cells is formed running from the junction of the cotyledon and first root, and is continued into the second leaf as its plerome.

The second root develops from the base of the second leaf in the immediate vicinity of the common fibrovascular bundle, and is formed about the time that the leaf begins to elongate. A group of cells here begins to multiply actively, and very soon shows a division into the initials of the tissue systems of the young root. From this time the growth proceeds as in the primary root, and it finally breaks through the overlying tissues.

The stem has no vascular bundle apart from the common 
bundle formed from the coalescence of the bases of the bundles from the leaves and roots. In all the later-formed leaves and roots there is but a single axial bundle. In the leaves this is decidedly collateral in form with the poorly-developed xylem upon the inner (upper) side. Except for their larger size, and their having usually four instead of two air-channels, the later leaves resemble in all respects those first formed.

The development of the young plant was not followed beyond the appearance of the third leaf, but it probably in its later history corresponds to I. lacustris. Here, according to Hofmeister, ${ }^{1}$ the opposite arrangement of the leaves continues up to about the eighth, when the $\frac{1}{2}$ divergence is replaced successively by $\frac{1}{3}, \frac{2}{5}, \frac{3}{5}, \frac{5}{13}$, and $\frac{x}{21}$, which is the condition in the fully-developed sporophyte.

\section{The Sporophyte}

The structure of the mature sporophyte has been the subject of repeated investigations, the most recent being those of Farmer, ${ }^{2}$ who has made a most careful examination of the vegetative organs. The thick, very short stem has a central vascular bundle, which as in the young plant is made up of the united leaf-traces, and there is no strictly cauline portion, as Hegelmaier ${ }^{3}$ and Bruchman ${ }^{4}$ assert. This central cylinder is composed of very short tracheids, with spiral and reticulate markings, mixed with similarly-shaped cells with thin walls. Surrounding this xylem-cylinder is a layer of cells, which Farmer calls the "prismatic layer." This, according to Russow, ${ }^{5}$ is continuous with the phloem of the leaf-traces, and he regards it as the phloem of the stem bundle. Outside of this prismatic layer is a zone of meristematic cells, which form the "cambium." The cells of this zone are like those of the cambium of Botrychium or of the Spermaphytes, and like these new cells are formed on both sides; but those formed upon the outside remain parenchymatous and are gradually thrown off with the dead outer cortex, but those upon the inner side develop into the prismatic cells, mingled with which are cells very like the tracheids, except that they retain to some

\footnotetext{
1 Hofmeister (I), p. 354.

${ }^{3}$ Hegelmaier (1).

${ }^{2}$ Farmer (2).

+ Bruchman (1).
}

5 Russow (1), p. 139. 
cxtent their protoplasmic contents. These cells are arranged in more or less well-marked zones, and possibly mark the limits of each year's growth. It will be seen from what has been stated that while a true secondary thickening of the stem occurs in Isoetes, it is quite different from that in Botrychium, which closely resembles the normal thickening of the coniferous or dicotyledonous stem. It has been compared to that found in Yucca or Dracana, and this perhaps is more nearly like it. However, as the development of cambium and secondary thickening have evidently occurred independently in very widely separated groups of plants, it is quite likely that we have here one more instance quite unconnected with the same phenomenon elsewhere.

The leaves, as already stated, differ but little from those of the young plant. The vascular bundle is here somewhat better developed, but remains very simple, with only a few rows of tracheids fully developed. The phloem remains undifferentiated, and no perfect sieve-tubes can be detected. The phloem lies upon the outer side of the xylem, but shows a tendency to extend round toward the upper side. Of the other Filicinex, Ophioglossum comes the nearest to it in the structure of the bundles. The air-channels are four in number in the fullydeveloped leaf, and the diaphragms across them more regular and complete. Instead of being throughout but one cell thick, as in the first leaves, they are thicker at the edges, so that in section they appear biconcave. In the older leaves the broad sheath at the base is much better developed, and the overlapping leaf bases give the whole stem much the appearance of the scaly bulb of many Monocotyledons. In all the terrestrial species, and those that are but partially immersed, the leaves are provided with numerous stomata of the ordinary form; but in some of the submersed species these are partially or entirely wanting. The development of the ligule also varies, being very much greater in the terrestrial species, where it may possibly be an organ of protection for the younger leaves.

Hofmeister ${ }^{1}$ states that in I. lacustris the first sporangia are not developed until the fourth year from the time the young sporophyte is first formed. The sporophylls begin to form in the third year, but it is a year more before the sporangia are

1 Hofmeister (1), p. 364 . 
complete. From this time on, the regular succession of sporophylls and sterile leaves continues.

There has been much disagreement as to the method of growth in the root. The earlier observers attributed to it a single apical cell, not essentially different from that of the true Ferns; this was shown to be incorrect by Bruchman ${ }^{1}$ and KienitzGerloff, ${ }^{2}$ but Farmer ${ }^{3}$ claims that none of these have correctly described the structure of the larger roots, which differs somewhat from that of the earlier ones. According to the latter observer there is always a single initial for the plerome, and above this two layers of meristem, one giving rise to the inner cortex, the other to the outer cortex, as well as to the epidermis and root-cap. The fibrovascular bundle is monarch, like that of Ophioglossum vulgatum, and the phloem becomes differentiated before the xylem elements are evident.

The later roots arise much as the second one does in the young plant, but the rudiment is more deeply seated. The roots are arranged in I. lacustris in four rows, two corresponding to each furrow. ${ }^{4}$ According to Bruchman ${ }^{5}$ the first evidence of a forming root is a single cell of the cortical tissue lying a short distance outside of the leaf-trace. This, however, cannot be looked upon as the apical cell, as it only gives rise to calyptrogen and dermatogen. The periblem and plerome arise from the cells lying immediately below it.

The branching of the roots is a genuine dichotomy, and has also been carefully studied by Bruchman. He states that the process begins by a longitudinal division of the plerome initial, and each of the new initials at once begins to form a separate plerome. The overlying tissues are passive, and their divisions are governed by the growth of the two plerome strands.

\section{The Sporangium}

The development of the sporangium has been very carefully examined by Goebel, ${ }^{6}$ and his results confirmed by later observers. All of the leaves, except the imperfect ones that separate the sporophylls of successive years, bear a single, very large sporangium at the base. From the first it consists of an

1 Bruchman (I), p. 554 .

3 Farmer (2), p. 37.

5 Bruchman (I), p. $55^{\text {S. }}$
2 Kienitz-Gerloff (6).

4 Van Tieghem and Douliot (5).

${ }^{6}$ Goebel (3), Bot. Zeit. I881. 
elongated elevation composed of cells which have divided by periclinal walls. In I. lacustris the sporangium arises mainly from the three outer layers of cells thus formed. The lower part of this cushion-shaped prominence forms the base or stalk, while the archesporium is formed from the hypodermal layer of cells (Fig. I 55, A). Each cell of the archesporium shows an independent growth, and up to this point the development of macro- and micro-sporangia is the same. In the latter each
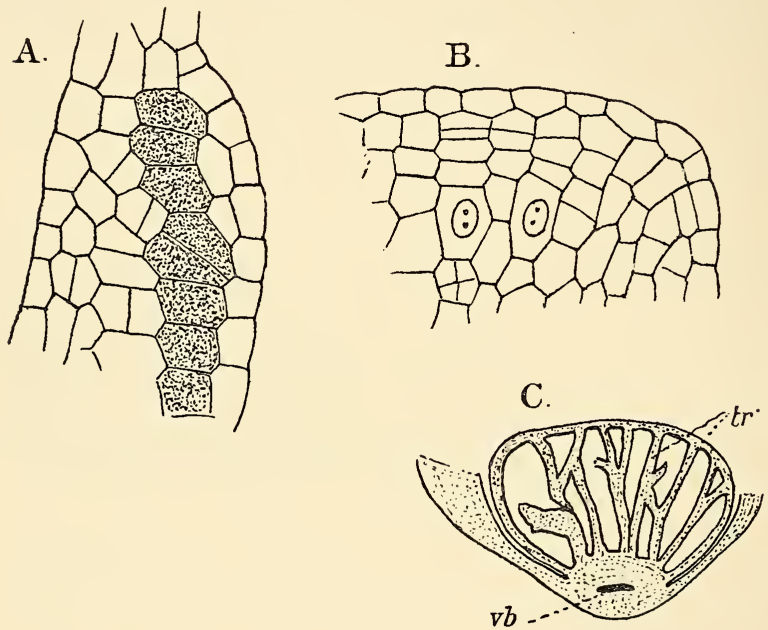

FIG. 155.-Isoetes lacustris (L.). A, Longitudinal section of young microsporangium; B, similar section of macrosporangium. The shaded cells in A, the nucleated ones in B, represent the archesporium (after Goebel); C, transverse section of the sporophyll and microsporangium, $\times 8 ;$ tr, the trabeculæ (after Bower).

archesporial cell divides by a series of tangential walls and at first all appear alike; but soon some of the rows become more transparent and divide less rapidly, so that they form elongated tabular cells. The others divide in all directions and form large masses of cells with abundant protoplasm. These finally form the spore mother cells. The outer cells of both sporogenous and sterile rows form the tapetum. The sporangium at this stage consists of a series of irregular chambers separated by incomplete layers of colourless cells 
(trabecula), and containing the spore mother cells (Fig. I $55, \mathrm{C}$ ). The whole process is not unlike that in the spike of Ophioglossum, especially if Bower's statement is correct that the whole hypodermal layer in Ophioglossum is to be considered as the archesporium. ${ }^{1}$

As the sporangium grows the tissue of the leaf surrounding it grows up on all sides so as to enclose it in the fovea, whose edges extend more or less over the sporangium to form the velum. Goebel calls attention to the analogy of the latter with the integument of an ovule.

The macrosporangium corresponds in its earlier stages exactly to the microsporangium, and the difference between them is first indicated by the fertile archesporial cells in the former only dividing by the walls which form the tapetal cells, and an inner cell of each row becomes at once the macrospore mother cell. This is much larger than the others, and is very conspicuous. Between the fertile rows are the trabeculæ, at first also only one row of cells. As the spore mother cell grows, it encroaches upon, and destroys, the surrounding tapetal cells, and lies in the cavity thus formed. The division into four spores follows in the usual manner.

In the development of the sporangia, especially the formation of the large hypodermal archesporium, and perhaps also the integument, the resemblance to corresponding structures in the Spermaphytes is obvious, and in these respects Isoetes certainly does come nearer the latter than any other living Pteridophyte.

Bower ${ }^{2}$ has recently made a careful study of the sporangium of Lepidodendron and found structures which closely resembled the trabeculæ in that of Isoetes, and is inclined to regard this as an evidence of relationship between the two genera.

In I. lacustris the sporangium is sometimes replaced by a leafy bud which may develop into a perfect plant. ${ }^{3}$

\section{The Affinities of the Eusporangiate Filicinea}

In attempting to discover the affinities of the members of this group, many difficulties are encountered. First, and perhaps most important, is the small number of forms still

1 Bower (14).

2 Bower (15).

3 Goebel, "Ueber Sprossbildung aus Isoetesbläter," Bot. Zeit. I879. 
existing, which probably are merely remnants of groups once much more abundant. This is certainly true of the Marattiaceæ, and presumably is the case with the Ophioglossaceæ and Isoetaceæ as well. In the former order this is amply proven by the geological record; but in the others the fossil forms allied to them are very uncertain, and as yet poorly understood. In the Ophioglossaceæ the series from Ophioglossum through the simpler species of Botrychium to the higher ones, such as B. Virginianum, is complete and unmistakable, but when points of connection between these and other forms are sought, the matter is not so simple.

Our still very incomplete knowledge of the gametophyte of the Ophioglossaceæ makes the comparison doubly difficult. From the development of chlorophyll in the germinating spore of $B$. Virginianum, as well as from analogy with other Ferns, it seems probable at any rate that the subterranean chlorophylless prothallium is a secondary formation, but this cannot be asserted positively until the development is much better known than at present, and its relation to the green prothallium of the Marattiaceæ and the thallus of the Hepaticæ must remain in doubt. The structure of the sexual organs and development of the embryo point to a not very remote connection with the former order, and in some respects also to the Anthoceroteæ.

Ophioglossum beyond question shows the simplest type of sporangium of any of the Pteridophytes, and may be directly compared to a form like Anthoceros. In both cases the archesporium is hypodermal in origin, and is formed without any elevation of the tissue to form separate sporangia. In Anthoceros, alternating with the sporogenous cells, are sterile cells which divide the archesporium into irregular chambers containing the spores. A direct comparison may be drawn between this and the origin of the archesporium in Ophioglossum, except that in the latter the archesporium seems to be discontinuous, and from the first separated into parts corresponding to the separate sporangia. In some species of Ophioglossum, too, the epidermis above the sporangium has stomata as in Anthoceros. A comparison of these remarkable points of similarity in the structure of the sporophyll of Ophioglossum and the sporogonium of Anthoceros, together with the very simple tissues of the former, led the writer ${ }^{1}$ to express the belief that Ophioglossum,

1 Bot. Gazette, Jan. I 890. 
of all living Pteridophytes, scemed to be the nearest to the Bryophytes. Subsequent study of the cusporangiate Ferns has strengthened that belief, and from a comparison of these with Ophioglossum on the one hand and the Anthocerotere on the other, it seems extremely likely that the latter represents more nearly than any other group of living plants the form from which the Pteridophytes have sprung, and that in the series of the Filicince at any rate, Ophioglossum comes nearest to the ancestral form. Of course the possibility of Ophioglossum being a reduced form must be borne in mind, and the saprophytic habit of the prothallium may perhaps point to this ; still, whatever may be its real character, there is little doubt that it is the simplest of the Filiciner.

The resemblances between Ophioglossum and the Anthoceroteæ are not confined to the sporophyte. The sexual organsand this is true of all the eusporangiate Pteridophytes - show some most striking similarities that are very significant. It will be remëmbered that in the Anthoceroter alone among the Bryophytes the sexual organs are completely submerged in the thallus - the antheridia being actually endogenous. It will be further remembered that in the eusporangiate Filicinex a similar condition of things exists.

In all the Hepaticæ the axial row of cells in the archegonium terminates in the cover cell, which by cross-divisions forms the group of stigmatic cells of the neck. In the Anthoceroteæ this terminal group of cells is the only part of the archegonium neck that is free, the lateral neck cells being completely fused with the surrounding tissue. This arises from the archegonium mother cell not projecting at all, but we have seen that in cross-section a similar arrangement of the cells is presented to that found in the young archegonium of other Hepaticæ. In the Filicinex a similar state of affairs exists, but the divisions in the mother cell are, as a rule, not so regular. Still, e.g. Isoetes, it is sometimes easy to see that the mother cell (so-called) of the archegonium is triangular when seen in cross-section, and cut out by intersecting walls in exactly the same way as the axial cell in the Bryophyte archegonium. In short, what is ordinarily called the mother cell of the archegonium in the Ferns is really homologous with the axial cell only of the young archegonium of a Liverwort. A comparison of longitudinal sections of the young archegonium of Marattia, for instance, 
with that of Notothylas, will show this clearly. From this it follows that the four-rowed neck of the Pteridophyte archegonium does not correspond to the six-rowed neck of the Bryophyte archegonium, but only to the group of cells formed from the primary cover cell, and is a further development of this. The relatively long neck of the archegonium in the more specialised forms, e.g. Botrychium Virginianum, and especially the leptosporangiate Ferns, must be regarded as a secondary development connected probably with fertilisation. The shifting of the archegonium to the lower surface of the gametophyte has probably a similar significance. In B. Virginianum, however, the archegonia are borne normally upon the upper side of the thallus, as in the thallose Liverworts.

It is possible that a similar relation exists between the antheridia of the eusporangiate Ferns and that of the Anthoceroteæ. In both cases the formation of the antheridium begins by the division of a superficial cell into a cover cell and a central one. The former divides only by vertical walls in the Marattiacee, but in Ophioglossum and the Anthoceroteæ it becomes two-layered. In the latter the central cell may form a single antheridium, or it may produce a group of antheridia, but in the others it divides at once into a mass of sperm cells. By the suppression of the wall in the antheridium of an Anthoceros where only one antheridium is formed, there would be produced at once an antheridium of the type found in Ophioglossum, and by a further reduction of the division of the cover cell, by which it remains but one cell thick, the type found in Marattia would result.

Such an origin of the antheridium of the Filicineæ is, at any rate, not inconceivable, while not so obvious perhaps as the resemblances in the archegonium, and is simply suggested as a possible solution of a very puzzling problem.

The Marattiaceæ agree closely among themselves, and the structure of the gametophyte is like that of the Ophioglossacex, so far as the latter is known, and also offers most striking resemblances to the Hepaticæ. The long duration of the prothallium here, and its persistence after the sporophyte is independent, as well as the long dependence of the latter upon the gametophyte, are all indications of the low rank of this order. The sporophyte, while showing many points of resemblance to the Ophioglossaceæ, still differs very much 
also, and in general habit as well as the position of the sporangia comes nearer the leptosporangiate Ferns. Of the Ophioglossacex, Helminthostachys on the whole approaches nearest to the Marattiaccæ, so far as the general character of the sporophyte is concerned. The venation of the leaves and dehiscence of the sporangia are very similar to Angiopteris, and the green sterile tips to the sporangial branches hint at a possible beginning of the lamina of the sporophylls in the Marattiacex. However, as the life-history of the plant and its histology are almost unknown as yet, it is not possible to draw any definite conclusion as to its affinities, and the question whether the Marattiacea are connected directly with the Ophioglossacex, or have branched off from the same stock lower down, must remain for the present unanswered; but the similarities in both sporophyte and gametophyte are too numerous to make an entirely independent origin for the two orders at all probable.

In secking a connection with the leptosporangiate Ferns there are two points where this is possible. The higher species of Botryclium show an unmistakable approach to the leptosporangiate type. The archegonium neck projects much more than in the other Eusporangiate, and the vascular bundles in the petiole are truly concentric. The venation of the leaves also becomes that of the typical Ferns. The sporangia are completely free here, and smaller and more delicate, although truly eusporangiate in development. In all these respects there is an approach to Osmunda, unquestionably the lowest of the leptosporangiate series. Helminthostachys too may be almost as well compared to Osmunda as to Angiopteris.

On the other hand, in the circinate vernation of the leaf as well as the histology, in the roots, and in the sporangia, the Marattiaceæ, especially Angiopteris, approach quite as close or closer to the Osmundacex than does Botryclizum or Helminthostachys.

Isoetes differs so much from all other Pteridophytes that it seems almost hopeless to try to assign it its proper position in the series. The reasons for assigning it to the Filicineæ rather than the Lycopodinea, are first the character of the gametophyte and sexual organs, and second the histology of the mature sporophyte. The archegonium resembles very 
closely that of the other eusporangiate Filicineæ, and the spermatozoids are multiciliate, which is never the case in any of the Lycopodineæ, but is universal in the Ferns. The tissues of the sporophyte, especially the vascular bundles, are collateral, and are most like those of Ophioglossum, and the dichotomy of the roots, which was formerly taken as a sign of its relationship with the Lycopods, is now known to occur also in Ophioglossum. The sporangium, too, may perhaps as well be compared to the spike of Ophioglossum as to the single sporangium of Lycofodium or Lepidodendron. It would be rash to assert positively that the trabeculæ correspond to the partitions between the sporangia of Ophioglossum, and that the sporangium is really compound, but this is not inconceivable. The position and origin of the large sporangium of Isoetes are certainly not very unlike those of the sporangiophore of Ophioglossum.

The early stages in the development of the female prothallium certainly resemble those of Selaginella, so far as the "free-cell formation" is concerned; but there is no reason why this may not have arisen independently in the two groups, just as heterospory arose quite independently in all the classes of the Pteridophytes. At present, then, the weight of evidence seems to indicate that Isoetes bears the same relation, but in a much more remote degree, to the lower members of the eusporangiate Filicineæ that Selaginella does to Lycopodium.

As to the affinities of Isoetes with the Spermaphytes, it more nearly resembles them in the formation of the female prothallium than any other Pteridophyte except Selaginella, and the reduction of the antheridium is even greater than there. The embryo resembles very much that of a typical Monocotyledon, and the histology of the fully-developed sporophyte, the leaves with their sheathing bases surrounding the short bulb-like stem, and the structure of the roots, all suggest a possible relation to the Monocotyledons directly rather than through the Gymnosperms.

There is, however, a great interval between the flower of the simplest Angiosperm and the sporophylls of Isoetes, and more evidence must be produced on the side of the former before it can be asserted that this relationship is anything more than apparent. 
We may conclude, then, from the data at our disposal, that the living eusporangiate Filicinex consist of a few remnants of widely divergent branches of a common stock, which formerly was predominant, but has been supplanted by more specialised modern types. From this primitive stock have arisen on the one hand the leptosporangiate Ferns, on the other, through Isoetes, or some similar heterosporous forms, the Angiosperms. 
THE Leptosporangiatæ bear somewhat the same relation to the eusporangiate Ferns that the Mosses do to the Hepaticæ, but the disproportion in numbers is much greater in the former case. While the whole number of living Eusporangiatæ (including Isoetes) is probably considerably less than IOO, the Leptosporangiatæ comprise about 3500 species. In the former the differences between the groups are so great that there is some question as to their near relationship, while all the leptosporangiate Ferns show a most striking similarity in their structure, and except for the presence of heterospory in two families, might all be placed in a single order. Carrying our comparison still further, we may compare the Polypodiaceæ, which far outnumber all the others, with the Bryineæ among the Mosses. Both groups are apparently modern specialised types that have supplanted to a great extent the lower less specialised ones.

The distribution of the leptosporangiate Ferns, too, offers some analogy with the Mosses. While the eusporangiate Ferns are few in number of species, they are for the most part also restricted in numbers of individuals and in their range. The Leptosporangiates, on the other hand, occur in immense numbers, especially in the tropics, where they often form a characteristic feature of the vegetation. This is true to a limited extent in temperate regions also, where occasionally a single species of Fern, e.g. Pteris aquilina, covers large tracts of ground almost to the exclusion of other vegetation. A somewhat prevalent idea that the Ferns of to-day form merely an insignificant remnant of a former vegetation is hardly borne 
out by the facts in the casc. Any one who has seen the wonderful profusion of Ferns in a tropical forest, and the enormous size to which many of them grow, is very quickly disabused of any such notion.

The fossil record is also extremely instructive as bearing on this point. According to Solms-Laubach ${ }^{1}$ there is but one certainly authentic case from the Carboniferous rock which can be regarded certainly as a leptosporangiate form, all of the other sporangia discovered being of the eusporangiate typc. In the later formations the Leptosporangiates increase in number, but according to Luerssen ${ }^{2}$ undoubted Polypodiaceæ are not found before the Tertiary, where a number of living genera are represented. That is, so far as we can judge from the fossil record, the Leptosporangiata, instead of being a leftover type, are essentially a modern one.

Except in the few heterosporous forms there is, on the whole, great uniformity in the prothallium. The most marked exception to this is the wcll-known filamentous protonema-like prothallium of some species of Trichomanes. Except in these, however, the germinating spore, either directly or after forming a short filament, produces normally a flat, heart-shaped prothallium, growing at first by a two-sided apical cell, the prothallium being at first one cell thick, but later producing a similar cushion to that found in Marattia but less prominent, and the wings always remain one cell thick. Upon the lower side of the cushion are produced the archegonia, which have always a projecting neck, sometimes straight, but more commonly bent backward. The antheridia are produced upon the same prothallium as the archegonia in most forms, but a few species of Ferns are dicecious, and usually there are small male prothallia in addition to the large hermaphrodite ones. The antheridia, like the archegonia, always project above the prothallium.

The heterosporous genera, as in Isoetes, produce two sorts of prothallia, but the male prothallium is not so much reduced, and the female is formed by successive cell divisions and not by free cell formation.

The first divisions in the embryo always divide it into regular quadrants, and the young members always grow from a definite apical cell, which, with the possible exception of some

1 Solms-Laubach (2), p. 153 .

2 Luerssen (7), vol. ii. p. 574 . 
of the Osmundaceæ, is also found at the apex of the later roots and always in the stem. In size the sporophyte varies extremely. In some of the smaller Hymenophyllaceæ the creeping stem is not thicker than a common thread, and the fully-developed leaves scarcely a centimetre in length. The other extreme is offered by the giant tree-ferns belonging to the Cyatheaceæ, e.g. Alsophila, Cyathea, Cibotium. The leaves are in most cases compound, and either firm and leathery in texture, or in the delicate Hymenophyllaceæ have the lamina reduced to a single layer of cells, so that in texture it recalls a moss leaf. With the single exception of the Salviniaceæ the leaves are always circinate in the bud. The surface of the stem and leaves is frequently provided with various epidermal outgrowths, scales, and hairs, which show a strong contrast to the mostly glabrous Eusporangiatæ. The vascular bundles are, both in the stem and petioles, of the concentric type with a very distinct endodermis, and in the older parts of both stems and leaves parts of the ground tissue are often changed into thick-walled and dark-coloured sclerenchyma. In the finer veins of the leaf the vascular bundles are reduced in structure and more or less perfectly collateral.

The sporangia are extremely uniform in structure throughout the group. They can be traced back to a single epidermal cell, in most cases developed from the lower side of the unmodified sporophylls, as in the Marattiaceæ. They are always more or less distinctly stalked, and grow for a time from a pyramidal apical cell, whose growth is stopped by the formation of a periclinal wall (Fig. I67). The central tetrahedral cell has first a layer of tapetal cells cut off from it, and the central cell then forms the archesporium. No sterile cells are formed in the archesporium, but all the cells (except in the macrosporangium of the Hydropterides) develop perfect spores. The ripe sporangium is provided, except in the Hydropterides, with an annulus or ring of thickened cells, which assists in its dehiscence, and forms the most characteristic structure of the ripe sporangium.

\section{Non-Sexual Reproduction}

In a few of the Ferns special non-sexual reproductive bodies, buds of different kinds, occur upon the prothallium, which thus 
may have an unlimited growth. Such buds may have the form of ordinary branches, or they are of a special form. Buds of the latter class occur, sometimes in great numbers, in certain Hymenophyllacex, where they are formed upon the margin of the prothallium, to which they are attached by short unicellular pedicels from which they readily become detached. In this way, as well as by the separation of ordinary branches, the prothallia of some species of Hymenophyllum form dense mats several inches in diameter, which look exactly like a delicate Liverwort. A most remarkable case is that of Gymnogramme leptophylla, examined by Goebel. ${ }^{1}$ The prothallium multiplies extensively by buds, some of which form tuber-like resting bodies, by which the prothallium becomes perennial. The sporophyte in this species is annual and dies as soon as the spores ripen. The archegonia are borne on special branches of the prothallium, which penetrate into the ground and lose their chlorophyll. Goebel ${ }^{2}$ suggests what seems very probable, that the subterranean prothallium of the Ophioglossaceæ may be of this nature, and the fact that in Botrychium Virginiamum the germinating spore develops chlorophyll would point to this.

Apogamy, or the development of the sporophyte from the prothallium as a vegetative bud, was first discovered by Farlow ${ }^{3}$ and later investigated by De Bary, ${ }^{4}$ Leitgeb, ${ }^{5}$ and Sadebeck. ${ }^{6}$ It is known at present in Pteris Cretica, Aspidium filix-mas var. cristatum, Aspidium falcatum, Todea Africana, and several others. Sometimes archegonia are produced, or they may be absent from the apogamous prothallium, but antheridia usually are found. When archegonia are present they do not appear to be functional. In Pteris Cretica, where usually no archegonia are developed, the cushion of tissue which ordinarily produces them is formed as usual; but instead of forming archegonia it grows out into a leaf at whose base is formed the stem apex, which soon produces a second leaf. The first root arises endogenously near the base of the primary leaf, and the young plant closely resembles the sporophyte produced in the normal way. Previous to the development of the bud there is formed in the prothallium itself a vascular bundle which is continued into the leaf, but which is entirely absent from normal prothallia.

The opposite state of affairs, where the gametophyte arises
1 Goebel (I).
2 Goebel (IO), p. 245.
3) Farlow (I).
4 De Bary (2).
5 Leitgeb (13).
6 Sadebeck (6), p. 23 I. 
directly from the sporophyte without the intervention of spores, is known in a number of species, and has been especially investigated by Bower. ${ }^{1}$ He found that there were two types of apospory, as he named the phenomenon, one where the prothallium was produced from a sporangium arrested in its normal growth, and by active multiplication of the cells of the stalk and capsule wall formed a flattened structure, which soon showed all the characters of a normal prothallium with sexual organs. In the second case the prothallia grew out directly from the tips of the pinnæ, and there was no trace of sporangia being formed previously. The first observation of these phenomena were made upon two garden varieties, Athyrium filixfomina var. clarissima and Polystichum angulare var. pulcherrimum, but since, Farlow ${ }^{2}$ has discovered the same phenomenon in Pteris aquilina. In the latter the prothallia were always transformed sporangia.

The production of secondary sporophytes as adventitious buds upon the sporophyte is a regular occurrence in some species. Asplenium bulbiferum and Cystopteris bulbifera are familiar examples of such sporophytic budding. In these large numbers of buds are formed which soon develop all the characters of the perfect sporophyte. Very early a definite apical cell is established from which all the other parts are derived. In Camptosaurus rhizophyllus, the "walking fern" of the Eastern United States, a single bud is formed at the tip of the slender leaf which bends over until it takes root. From this terminal bud another leaf grows and roots in the same way.

\section{Classification of the Leptosporangiate}

The Leptosporangiatæ fall into two groups, which may be termed orders, although the two families in the second order (Heterosporeæ) are not closely related to each other, but each has nearer affinities with certain of the homosporous forms.

I. Homosporous forms with large green prothallium, usually in its early stages growing from a single apical cell, more commonly monœcious but sometimes diœcious. Leaves always circinate in vernation. Sporangia with a more or less developed annulus, either borne upon ordinary leaves or on specially 
modified sporophylls. Usually, but not always, each group of sporangia (sorus) covered by a special covering, the indusium.

Order I. Filices.

Family I. Osmundacere.

Family 2. Gleicheniaceæ.

Family 3. Hymenophyllacex.

Family 4. Schizæaceæ.

Family 5. Cyatheaceæ.

Family 6. Polypodiaceæ.

II. Heterosporous forms, either aquatic or amphibious; the prothallia are always diøecious, the female prothallium with chlorophyll and capable of more or less independent growth when not fertilised; male prothallium always without chlorophyll, the vegetative part reduced to one or two cells, besides the antheridium. Leaves either circinate (Marsiliaceæ) or folded (Salviniaceæ); sporangia without an annulus and borne in special "sporocarps," which are either modified branches of ordinary leaves (Marsiliaceæ) or a very highly developed indusium.

Order II. Hydropterides.

Family I. Marsiliaceæ.

Family 2. Salviniacee.

\section{Order I. Filices}

The six families of the Filices form an evidently very natural group, but there has been a good deal of disagreement as to their relative positions. The Osmundaceæ are generally recognised as approaching most nearly the eusporangiate Ferns, and the Gleicheniaceæ come next to these. The Hymenophyllacex are usually considered at the other extreme of the series, but there are a number of reasons why this seems doubtful, and I am inclined to assign them an intermediate position. Their structure and development give evidences of their being a specially modified group adapted to living in very damp situations, and they probably cannot be regarded as connecting any of the other families, but rather as a side branch which has developed in a direction away from the type. They come nearest the Gleicheniaceæ and Osmundaceæ in the structure of the sexual organs, and the sporangium shows points in common 
with the former family. It, however, also resembles that of the Cyatheaceæ as well, and the strongly-developed indusium is much like that of the latter. The Schizæaceæ also may possibly form a side branch from the ascending series which ends in the Polypodiaceæ.

As these latter are the typical modern Ferns, it will be best to trace the development of the plant here before considering the variation found in the other families. The spores of the genus Onoclea are especially suited to studying the germination and development of the prothallium, and we will follow this in O. struthiopteris (Struthiopteris Germanica), the well-known Ostrich Fern.

The large oval spores contain, besides much oil and some starch, numerous small crowded chloroplasts. The three walls of the spore are plainly demonstrable, especially as the brown perinium is often thrown off by the swelling of the spore, and the transparent exospore can then be seen, with the delicate endospore lying close to its inner face. A large nucleus occupies the centre of the spore. Contrary to the statements usually made that spores containing chlorophyll quickly lose their vitality, these will germinate after a year or more, although not so well as those of the same season, but they normally remain from autumn until spring before they germinate. $O$. sensibilis acts in the same way, and spores of other Ferns containing chlorophyll have been germinated after an equally long period.

The spores germinate promptly, varying from two or three days to about a week, depending upon the temperature. The exospore is ruptured irregularly near one end, and through this a short colourless papilla protrudes and is shut off by a transverse wall (Fig. I 56, B). This papilla contains little or no chlorophyll and rapidly lengthens to form the first root-hair, which undergoes no further divisions. The large green cell alone produces the prothallium. The divisions in the prothallial cell vary somewhat, but in the great majority of cases a series of transverse walls is first formed, and the young prothallium (Fig. I 56, C) has the form of a short filament. Sooner or later, in normally-developed prothallia, the terminal cell of the row becomes divided by a longitudinal wall, which may be straight, but more frequently is oblique and followed by another similar wall in the larger of the two cells, meeting it so as to 
include a triangular cell, which is the "two-sided" apical cell of the next phase of the prothallium's growth. The divisions up

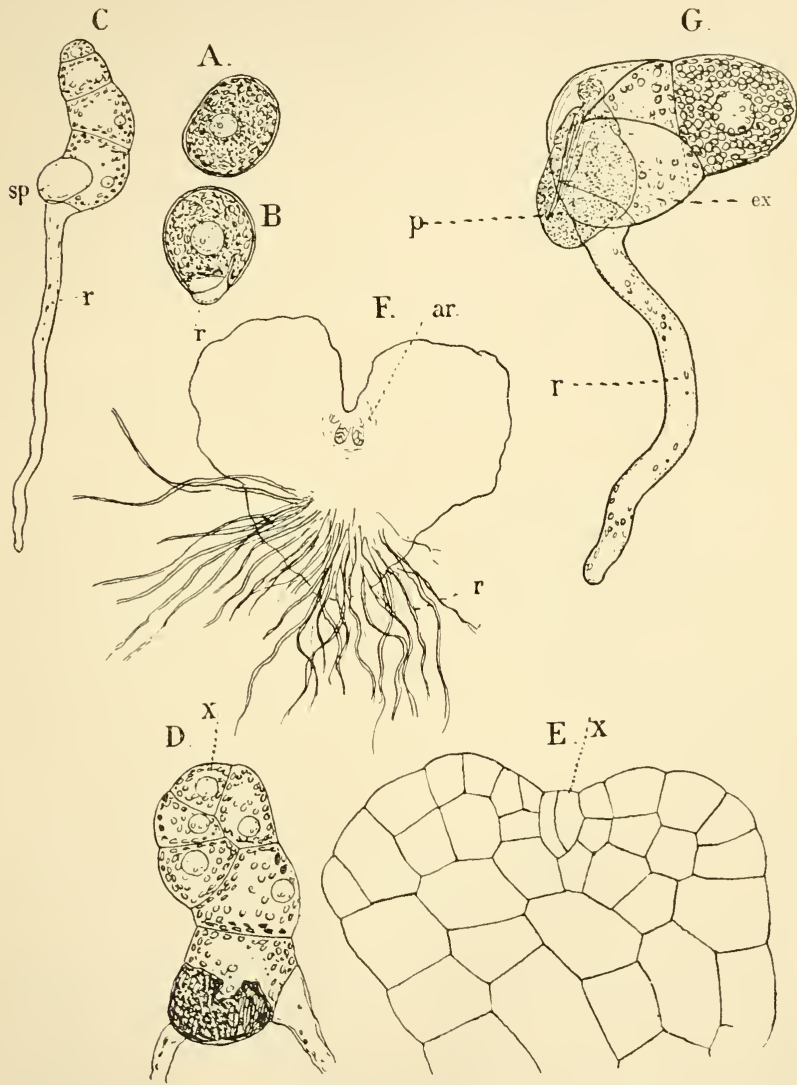

Fig. 156.-Onoclea struthiopteris (Hoffm). A, B, Germinating spores with the perinium removed, $\mathrm{X}_{300} ; \mathrm{C}$, young prothallium, $\times$ roo; $\mathrm{D}, \mathrm{E}$, older prothallia with two-sided apical cell $(x), \mathrm{X}_{300} ; \mathrm{F}$, small female prothallium seen from below, $\mathrm{X}_{25}$; G, very young prothallium with the two outer spore-coats, $\times 300 ; r$, primary rhizoid ; $a r$, archegonia ; $p$, perinium ; $e x$, exospore.

to this point correspond exactly with those of Aneura or Metzgeria, and are also much the same as in Marattia, except 
that here the prothallium only in very rare cases assumes the form of a cell mass at first.

By the regularly alternating segments of the apical cell the young prothallium soon assumes a spatulate form, which becomes heart-shaped by the rapid growth of the outer cells of the young segments, which grow out beyond the apical cell. Sooner or later the single apical cell is replaced by two or more initials formed from it in the same way as in the Marattiaceæ, and from this time on the growth is from a series of marginal initials. This change is connected with the formation of the thickened archegonial cushion, which, so far as I have observed, does not form in Onoclea so long as the single two-sided apical cell is present.

As the prothallium grows new root-hairs grow out from the marginal and ventral cells and fasten the prothallium firmly to the ground. These hairs, colourless when first formed, later become dark brown.

In the genus Onoclea, as well as some other Polypodiaceæ, the prothallia are regularly diœcious, and only a part of them develop the archegonial meristem. The others remain onelayered, and are often of very irregular form, and may be reduced to a short row of a few cells. In Athyrium filixfomina these may even be reduced to a single vegetative cell besides the root-hairs, and an antheridium. Cornu ${ }^{\mathrm{I}}$ records similar reduced prothallia in Aspidium filix-mas. All of the "a-meristic" prothallia, as Prantl ${ }^{2}$ calls them, are males. In the majority of the Polypodiaceæ these occur more or less plentifully, and are often the result of insufficient nutrition; but in Onoclea it is something more than this, as not only the small prothallia are male, but the large ones are exclusively female, and not hermaphrodite, as in most Ferns.

The first antheridia appear within three or four weeks under favourable conditions, and are formed either from marginal or central cells of the prothallium. The very young antheridium is scarcely to be distinguished from a young root-hair. Like it, it arises from a protrusion of the cell which is cut off by a wall, which is usually somewhat oblique. The papilla thus formed enlarges and soon becomes almost hemispherical. It contains a good deal of chlorophyll and a large central nucleus surrounded by dense cytoplasm. The first wall in the young antheridium

1 Cornu (I).

2 Prantl, Flora, I878, p. 499. 
(Fig. I 57, A) is very peculiar. It has usually the form of a funnel, whose upper rim is in contact with the wall of the antheridium cell, and whose base strikes the basal wall of the antheridium. Sometimes this first wall does not reach to the base, in which case it is simply more or less strongly concave, and the basal cell cut off by it from the antheridium is discoid

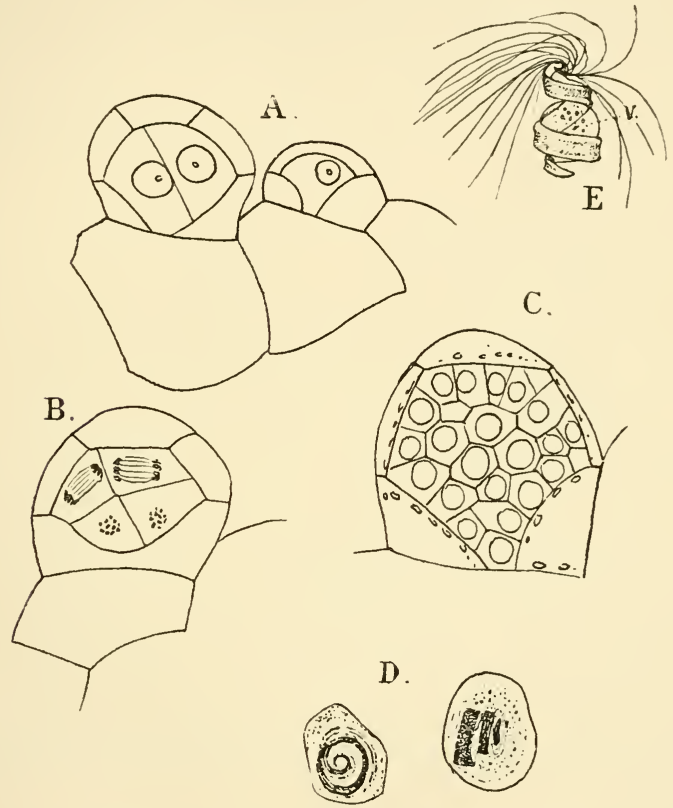

FIG. I57.-Onoclea struthiopteris (Hoffm). Development of the antheridium. A-C, Vertical sections, $\times 600 ; \mathrm{D}$, two nearly ripe sperm cells; E, free spermatozoid, $\times 1200$ (about).

instead of ring-shaped (Fig. 157, B). The second wall is hemispherical, and is nearly concentric with the outer wall of the antheridium. The dome-shaped central cell produces the mother cells of the spermatozoids, and has much more dense contents than the outer cells, but all the chloroplasts remain in the latter. A third wall now forms in the upper peripheral cell, much like the first one in form, and cuts off a cap cell at 
the top. The young antheridium at this stage consists of four cells - a central dome-shaped one surrounded by three others, the two lower ring-shaped, and the terminal one discoid. These outer cells are nearly colourless, and contain very little granular contents, except the small chloroplasts, which are mainly confined to the surface of the inner walls.

The divisions in the central cell are at first very regular. The first one is always exactly vertical, and is followed by a transverse wall in either cell which strikes it at right angles, and next a third set of walls at right angles to both of these, so that whether seen in cross-section or longitudinal section, the central cells are arranged quadrant-wise. Successive bipartitions follow in all the cells until the number may be a hundred or more, but the number is usually much less, about thirty-two being the commonest. The regular arrangement of the sperm cells soon becomes lost, and they form a mass of polyhedral cells with dense granular cytoplasm, and large nuclei. A nucleolus is visible until the last division, after which it can no longer be distinguished; otherwise the nuclei show no peculiarities. The transformation of the nucleus into the body of the spermatozoid proceeds here as in other Ferns that have been examined, but I was unable to satisfy myself that so large a part of the forward end of the spermatozoid is of cytoplasmic origin, as Strasburger ${ }^{1}$ asserts. The fullydeveloped spermatozoid describes about three complete coils within the globular sperm cell, and does not lie coiled in a single plane, as in the Hepaticæ, but in a tapering spiral (Fig. I $57, \mathrm{D})$. The very numerous long cilia are attached at a point a short distance back from the apex, and as Buchtien ${ }^{2}$ showed, cover a limited zone, although hardly so restricted as he figures.

The separation of the sperm cells begins at about the time the development of the spermatozoids commences. The mucilaginous walls stain now very strongly, and in a living state appear thick and silvery-looking. The central lamella of the cell wall, however, remains intact, so that when the spermatozoids are ejected, they are still enclosed in a delicate cell membrane, which swells up as the water is absorbed and finally dissolves completely.- The vesicle derived from the remains of the cytoplasm is very conspicuous here, and the

1 Strasburger (II), vol. iv. P. 115.

${ }^{2}$ Buchtien (1), p. 38 . 
granular contents usually, but not always, show the starch reaction. The body of the free spermatozoid has the form of a flattened band with thickened edges, which tapers to a fine point at the anterior end, but is broader and blunter behind. The peripheral cells of the antheridium become so much compressed by the crowding of the sperm cells that they are scarcely perceptible, but after the antheridium is burst open, the two lower ones become so distended that they nearly fill the central cavity. The opening is effected either by a central rupture of the cover cell, or less commonly by a separation of this from the upper ring cell.
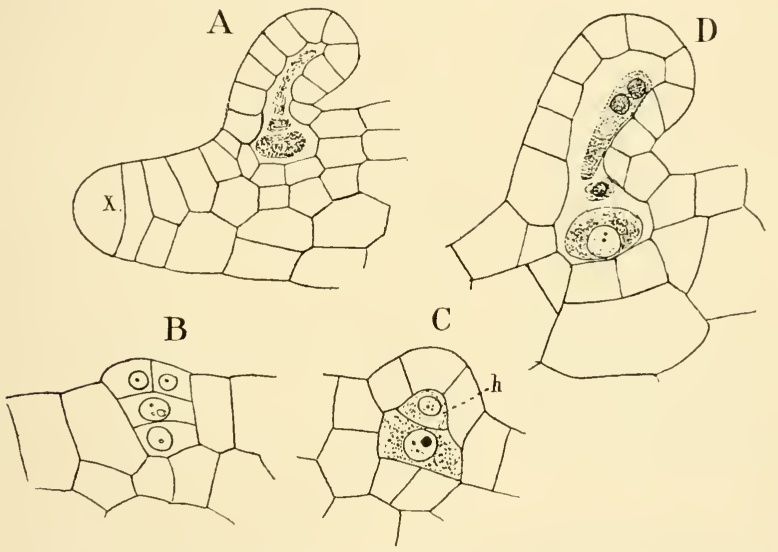

Fig. 158.-Onoclea struthiopteris (Hoffm). A, Longitudinal section of the apex of a female prothallium, showing the apical cell $(x)$ and a nearly ripe archegonium, $\times 215 ; \mathrm{B}-\mathrm{D}$, development of the archegonium ; longitudinal sections, $\times_{430} ;$, neck canal cell.

The development of the archegonium is intimately connected with the apical growth of the large female prothallium. As soon as the single apical cell has been replaced by the marginal initials, the divisions in the latter become very definite. Comparison of cross and longitudinal sections shows that these are much like those of Marattia or, among the Hepaticæ, Dendroceros or Pellia epiphylla. Each initial cell has the form of a semi-disc (Fig. I $58, A$ ), and the growth is both from lateral segments, which mainly go to form the wings of the prothallium, and basal, or inner segments, which produce the projecting arche- 
gonial cushion. If this begins to form very early, it may form a midrib extending nearly the whole length of the prothallium; but usually it does not form until relatively late. Each basal segment of the initial cells divides into a dorsal and ventral cell (semi-segment), the latter the larger of the two, and with much more active growth. The latter alone is concerned in the growth of the projecting cushion. Each ventral semisegment is first divided by a wall parallel with the primary segment wall, and from the anterior of these cells, almost exactly as in Notothylas, the archegonium is developed. It is not possible to make out any definite

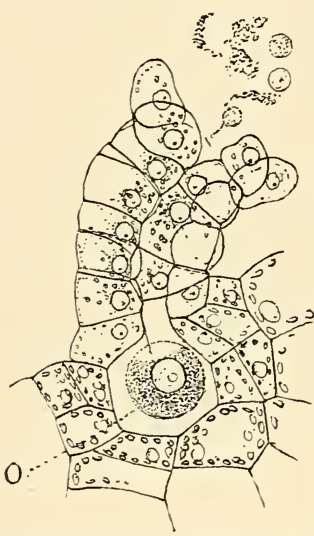

FIG. 159.-Ripe archegonium of 0 . struthiopteris in the act of opening, $\times 300 ; o$, the egg. succession of walls by which the axial cell of the archegonium is cut out, but it soon is recognisable by the granular cytoplasm and large nucleus. As in Marattia, the first transverse wall separates the inner cell from the cap cell, and the inner one then divides into the basal and the central cells. The cover cell divides into the four primary neck cells, and the central cell arching up between these has the pointed apex cut off by a curved wall from the central cell. The primary neck canal cell, so formed, is noticeably smaller than that of Marattia. The neck cells, which in the eusporangiate forms all grow alike, here show a difference, and the two anterior rows develop faster than the posterior ones, so that these rows are longer and the neck is strongly bent backward. In Onoclea there are usually about seven cells in each anterior row and about two less in the posterior ones. The neck cells are almost colourless, with distinct nuclei, and a few small, pale chloroplasts. From the central cell is now cut off the ventral canal cell, which is quite small, and separated from the egg by a strongly concave wall. The nucleus of the neck canal cell always divides, but no division wall is formed, and the two nuclei lie free in the cell. The basal cell divides by cross-walls into four, and with similar cells cut off from the adjacent prothallial tissue forms 
the venter of the ripe archegonium. The disintegration of the division walls of the canal cells, and the partial deliquescence of the inner walls of the neck cells, offer no peculiarities.

When the archegonium opens, the terminal cells diverge widely and the upper ones are often thrown off.

The opening of the scxual organs and the entrance of the spermatozoids may be easily seen by simply allowing the plants to remain slightly dry for a few days until a number of sexual organs are mature. If these are now placed upon the slide of the microscope in a drop of water, in a few minutes the sexual organs will open, and the spermatozoids will be seen to be attracted to the archegonia in large numbers, and with care some of them may be followed into the neck and down to the central cell. The actual entrance of the spermatozoid into the egg has been observed, but is difficult to demonstrate in the living condition. Pfeffer ${ }^{1}$ has shown that the substance which attracts the spermatozoids in the Polypodiacex is malic acid, and that an artificial solution of this, of the proper strength, will act very promptly upon the free spermatozoids of these Ferns.

As soon as the egg is fertilised it develops a membrane, and soon after undergoes its first segmentation. The inner walls of the neck cells almost immediately turn dark brown, and the cells of the ventral part begin to divide actively and form the calyptra, which here, as in the Bryophytes, is formed from the venter alone, and is tipped with the remains of the neck cells.

The position of the archegonium depends largely upon the light. If both sides of the prothallium are about equally illuminated, archegonia will develop from both sides. As soon as an archegonium is fertilised, no new ones form, but it frequently happens that a very large number prove abortive before finally fertilisation is effected.

\section{The Embryo}

The first division wall in all Polypodiaceæ yet investigated is vertical and nearly coincident with the axis of the archegonium. This basal wall (Fig. I60, I) at once divides the embryo into the anterior epibasal half and the posterior

1 Pfeffer (3). 
CHAP.

hypobasal. The former produces the stem and cotyledon, the latter the primary root and foot. The early divisions are extremely regular, and offer a marked contrast to those in the eusporangiate embryo. The second wall is the transverse (quadrant) wall, separating the leaf and stem in the epibasal

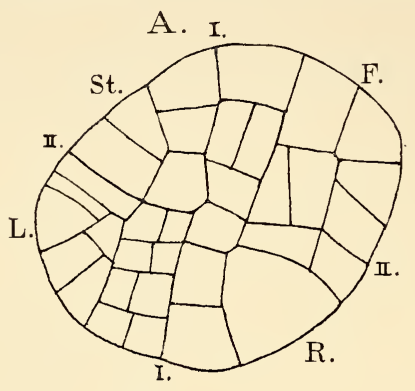

B.
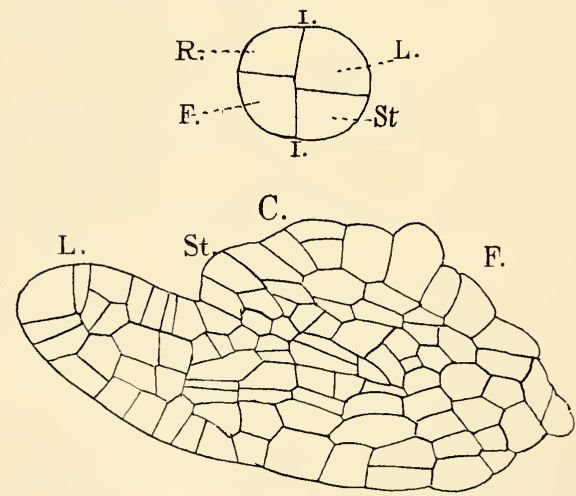

FIG. I60.-A, Median longitudinal section of a young embryo of Adiantum concinnum (H. B. K.) (after Atkinson); B, a four-celled embryo of O. struthiopteris; $\mathrm{C}$, an older embryo of the same in nearly median section, $\times 250 ;$ st, stem; $\mathrm{R}$, primary root ; L, cotyledon; $\mathrm{F}$, foot.

part, and the root and foot in the hypobasal. The next walls are the median or octant walls, but they do not correspond exactly in all the quadrants. While in the cotyledon and stem they are almost exactly median, in the root especially the octant wall diverges often a good deal from the median line, 
and the two resulting octants are unequal in size. The following divisions correspond for a short time in all the octants, but soon show characteristic differences. For a short time each octant shows a definite apical growth, the segments being cut off by walls formed successively parallel to the three primary divisions in the embryo, so that each octant may be said to have a three-sided apical cell. When the octant wall in the root quadrant is decidedly oblique this is not always evident in the smaller octant, and the larger one in this case at once becomes the definitive apical cell of the primary root.

The first of these walls is usually parallel to the basal, the second to the quadrant wall. Sometimes this order is reversed, but never, apparently, is the first wall parallel with the octant wall. Before the third segment is cut off from the octant, each of the two first ones divides by a periclinal wall into an inner and an outer cell. Each octant now consists of five cells, two inner and three outer ones, of which one is the primary octant cell, which still retains its original tetrahedral form. The outer cell of each segment divides by a radial wall, but beyond this the succession in the walls differs. Of the eight original octants, one in each quadrant persists as the apical cell respectively of cotyledon, stem, root, and foot, but in the latter it becomes very early obliterated by the formation of a periclinal wall and further longitudinal divisions, which is the case also with one of the octants in the leaf and root. In the stem both octants persist, one becoming the permanent stem apex, the other forming the apical cell of the second leaf.

\section{The Cotyledon}

Of the two primary octants of the cotyledon, one very early ceases to grow and soon becomes indistinguishable, and the subsequent growth is due almost entirely to the activity of a single octant. The apical cell is at first like that of the other members, tetrahedral, but after about two sets of segments have been cut off from it no more are usually cut off from the side of the apical cell parallel to the basal wall, and the threesided cell thus passes over into a two-sided one with segments cut off alternately right and left. By the suppression of the growth in the sister octant, the apical cell gradually assumes a nearly median position. By the change to the two-sided form 
of the apical cell, the originally conical leaf rudiment becomes flattened, and a little later this is followed by a dichotomy of the growing point and the production of two apical cells like the original one (Fig. I6I, C). The division is first brought about by a nearly central longitudinal division of the apical cell, and on either side of this, by a curved wall running to the outer wall of each cell, two new apical cells, separated by two elongated central cells, result. Each of these new growing points develops one of the lobes of the cotyledon, which undergo one or more bipartitions before the cotyledon breaks through
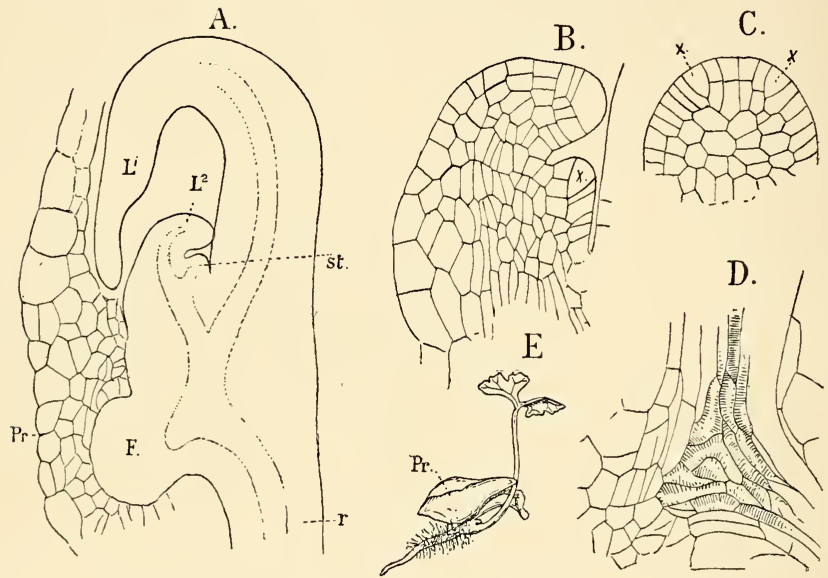

FIG. I $\in \mathrm{I},-$ Onoclea struthiopteris (Hoffin). A, Longitudinal section of young sporophyte still connected with the prothallium $(p r), \times 60 ; \mathrm{B}$, the apex of same, $\times_{180} ; \mathrm{C}$, surface view of the young cotyledon showing the first dichotomy; $\mathrm{D}$, central region of $\mathrm{A}$, showing the primary tracheary tissue, $\times_{1} 80 ; E$, young sporophyte with nearly full-grown cotyledon and primary root, $\times_{3} ;$ st, stem; $\mathrm{L}^{1}$, cotyledon; $\mathrm{L}^{2}$, second leaf; $\mathrm{F}$, foot; $p r$, prothallium.

the prothallium. As in Marattia the growth is much stronger upon the outer side and the leaf strongly curved over. It very early grows beyond the stem apex, and the embryo loses its oval form much earlier than is the case with any of the Eusporangiatæ.

\section{The Stem}

The early segmentation of the stem apex is much the same as in the cotyledon; but later the divisions in the segments are 
somewhat different, and the first wall is a radial one, instead of periclinal. The stem is very short at the time the young sporophyte breaks through the prothallium, and its apex more pointed than is afterwards the case.

\section{The Root}

At first the segmentation of the apical cell of the root is almost exactly like that of the stem, and it is not until sereral lateral segments, usually about two series of them, have been formed that the first periclinal wall, cutting off the first cell of the root-cap, is formed. There is a good deal of difference, however, as to the time this occurs, and there is probably some connection between it and the different period at which the primary root breaks through the calyptra. In most Polypodiacex the root is the first of the organs to penetrate the calyptra, but sometimes in Onoclea it is still short at the time the cotyledon is nearly developed, and in this recalls Marattia, where this is regularly the case. As soon as the first segment of the root-cap is formed, the segmentation of the root is extremely regular, and corresponds essentially to that found in the later roots.

\section{The Foot}

All definite divisions cease very soon in both of the foot octants, and this part of the embryo forms a more or less projecting hemispherical mass of cells, closely appressed to the prothallial cells. As usual in such cases the outer cells are large and distinct.

Shortly before the embryo breaks through the calyptra, which takes place much earlier than in Marattia, the first traces of the vascular bundles are seen as strands of procambium cells occupying the axis of each of the primary organs, and united in the centre, so that the four bundles together form a cross. Of these the one going to the foot is short, and ends blindly within that organ, but the others continue to grow with the elongation of the members to which they belong. The first permanent tissue to be recognised forms, as in Marattia, a bundle of short irregular tracheids at the junction of the young bundles (Fig. I6 I, D). These primary tracheids in Onoclea are scalariform, but the pits are shorter than in the later ones. 
Throughout the life of the sporophyte no vessels are formed, but only tracheids, as in nearly all Ferns. In the cotyledons the tracheids are all spiral, and occupy the centre of the concentric bundle, and from these growth proceeds centrifugally. The elements of the phloem are poorly differentiated, and in this stage no true sieve-tubes could be detected. While a definite bundle-sheath can scarcely be made out, the limits of the bundle are clearly defined. The venation of the cotyledon is dichotomous, corresponding to the dichotomous branching of the lamina.

The bundle of the young stem is solid, and is mainly composed of short and broad scalariform tracheids, but in the centre of the bundle are some small spiral and reticulate ones. The phloem at this stage is not well developed, and does not show perfect sieve-tubes. The bundle sends a branch to the second leaf, but is continued beyond the point of contact, and develops tracheids above the point of union before the first ones are formed in the leaf. In this early stage the bundlesheath is very poorly differentiated in the stem, but becomes better marked as the plant develops.

The primary root is monarch, and the tracheary tissue composed of short pointed tracheids with irregular scalariform markings. These are surrounded by one or two layers of narrow cells with oblique transverse septa. The calyptra is soon penetrated by the cotyledon, which, instead of growing straight up through the prothallium, as it does in Marattia, breaks through upon the ventral side and then bends upward between the lobes in front (Fig. I6I, E). The root bends down and penetrates the earth, and very soon after the prothallium dies. The epidermis of the cotyledon produces small glandular hairs, and that of the root numerous root-hairs.

The second leaf is directly traceable to one of the primary stem octants, and may be either regarded as one of the primary members of the embryo, or as the first segment of the stem. Its development corresponds exactly to that of the cotyledon, as it does in its fully-developed state. The second root arises endogenously, like all the later ones, and its apical cell is formed close to the point of union of the bundles of the leaf and stem, and probably, as in the later roots, is derived from a cell of the endodermis.

The new leaves arise in regular succession from the segments 
of the apical cell of the stem and up to the fifth or sixth, and possibly later the first division of the leaf is dichotomous, and the pinnate form of the later leaves is gradually attained, as in Marattia. As the stem grows its vascular cylinder becomes better developed, and a distinct endodermis becomes evident, and it gradually passes over from the monostelic condition of the young plant to the polystelic form found in the adult. A cross-section of a plant with three fully-developed leaves showed the vascular cylinder to be oval in outline, and consisting of the following parts. A central pith of elongated parenchymatous cells, surrounded by a thick ring of short spiral and reticulate tracheids, outside of which was a zone of phloem, the whole enclosed by a distinct endodermis. The latter is continuous, with the endodermis of the bundles going to the leaves and roots, and the xylem of these also connects with those of the stem bundle. The apex of the stem becomes more and more hidden by the development of scales from the epidermis, which finally completely hide it and form a very efficient protection.

The petioles of the first three leaves have a single axial vascular bundle, but in the fourth, as in all subsequent ones, there are two. They separate very soon after leaving the stem bundle, which is deeply cleft where they issue from it. These bundles are typically concentric in structure, and have a welldeveloped endodermis. The number of roots in the young plant exceeds the leaves. In a plant with the fourth leaf still unfolded, there were six fully-developed roots.

\section{'The Mature Sporophite}

\section{The Stem}

The stem in most of the Polypodiaceæ is either an erect or creeping rhizome which, unlike that of the Eusporangiatæ, often branches freely. These branches are always formed monopodially, and are usually of the same structure as the main axis; but in 0 . struthiopteris great numbers of peculiar stolons are formed that are quite different at first in appearance from the ordinary shoots. The main axis in this species is an upright rhizome about $2 \mathrm{~cm}$. in diameter, but appearing much larger on account of the thick persistent leaf-bases which cover 
it. The stolons arise from the bases of these leaves, apparently as adventitious buds. They may remain dormant for a long time, as very many more of the very small ones are found than those that are fully developed. These finally bend upward, and the scattered scale-like leaves give place to the perfect green ones. The main rhizome is occupied by a central cylinder composed of a network of anastomosing bundles. Inside of this cylinder is a medulla made up of large parenchyma
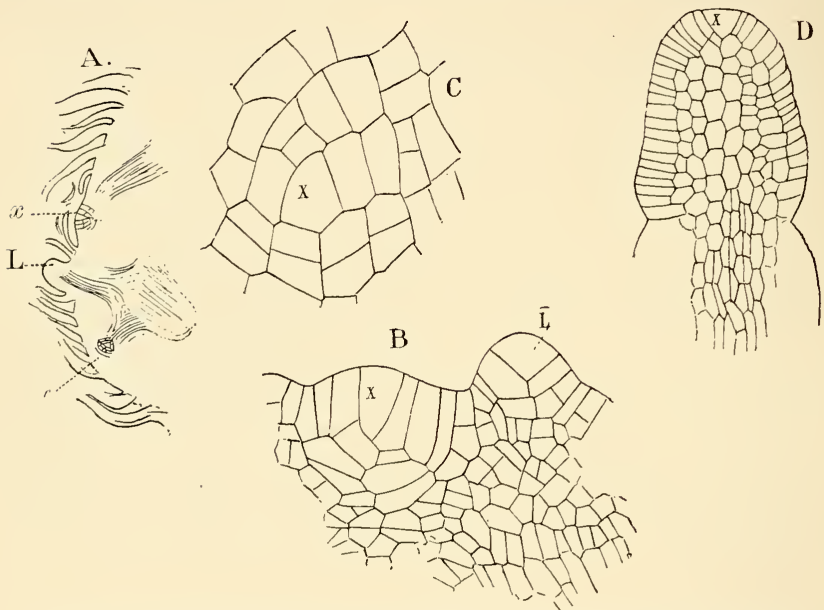

Fig. 162.-A, Vertical longitudinal section of the apex of a rhizome of Adiantum emarginatum (Bory), $\times 25 ; \mathrm{B}$, the central part of the same, $\times 180 ; \mathrm{L}$, a young leaf; $\mathrm{C}$, cross-section of a similar stem apex, $\times_{1} 80 ; D$, apex of a young leaf of Onoclea struthiopteris, showing the apical cell $(x)$.

cells, and communicating with the cortex by means of the foliar gaps, or spaces between the bundles.

Fig. I62, A shows a longitudinal section of the apex of a stem of Adiantum emarginatum, which shows the typical appearance in the Polypodiaceæ. The apex of the stem forms a slight cone, whose centre is occupied by the large initial cell, which is deeper than broad. In cross-section it shows much the same form. Divisions occur, evidently, only at comparatively long intervals, and each segment presumably gives rise to a leaf. The first division in each segment is longitudinal and 
perpendicular to its broad faces. Each of the six semi-segments is then divided into an inner and an outer cell, and the latter again by a longitudinal wall parallel to its inner and outer faces, so that each original segment is divided into two inner cells and four outer ones. From the inner cells the pith and vascular bundles arise, from the outer ones the cortex and epidermis, but after the first divisions there is great irregularity in the succession of the cells. The young vascular bundles can be traced nearly to the apex, and first appear as bundles of procambium cells, which lower down unite and are joined by others from the leaves and roots.

In $O$. struthiopteris characteristic air-chambers are formed in the young medulla at an early period. At certain points the cells become longer and their contents more transparent. These cells divide less rapidly than the surrounding tissue, and large intercellular spaces are formed. The loose cells about these form masses of trichomes, either hairs or scales, which later dry up and leave a large empty space, which may or may not communicate with the exterior through the foliar gaps.

In Onoclea struthiopteris, as in most leptosporangiate Ferns, the outer cortical cells become changed into sclerenchyma. In $O$. struthiopteris the sclerenchyma forms several hypodermal layers, distinctly separated from the inner cortical parenchyma. These sclerenchyma cells are much elongated; their lateral walls are somewhat uneven, and in their younger stages swell up more strongly under the action of potassic hydrate than do the cortical cells. Their walls become thick, are first pale yellow, and later a dark reddish brown. The walls are very markedly striate, and the central lamella distinct. Deep pits extend down to the latter.

The bundles in the stems of the Polypodiaceæ are very uniform in structure. They are usually elliptical in section, and the first tracheary tissue formed is a strand of small spiral or reticulate tracheids at the foci of the bundle. From there the formation of the very large scalariform ones, so characteristic of the leptosporangiate Ferns, proceeds towards the centre of the bundle, where the last-formed ones are situated. The young tracheids have thin walls and abundant protoplasm, but as the wall thickens, the contents gradually disappear, and finally no living protoplasm remains in them. Faint elongated transverse pits become evident, and the spaces between these 
rapidly thicken at the expense of the cell contents until all the protoplasm is used up. The thickened bars between the pits give the characteristic ladder-like appearance to the older tracheid (Fig. I63, B). In cross-section these bars are nearly rhomboidal, and give the familiar beaded appearance to sections of the tracheid wall.

Sieve-tubes of very characteristic form are found in the bundles of all the Polypodiaceæ. In $O$. strutliopteris they

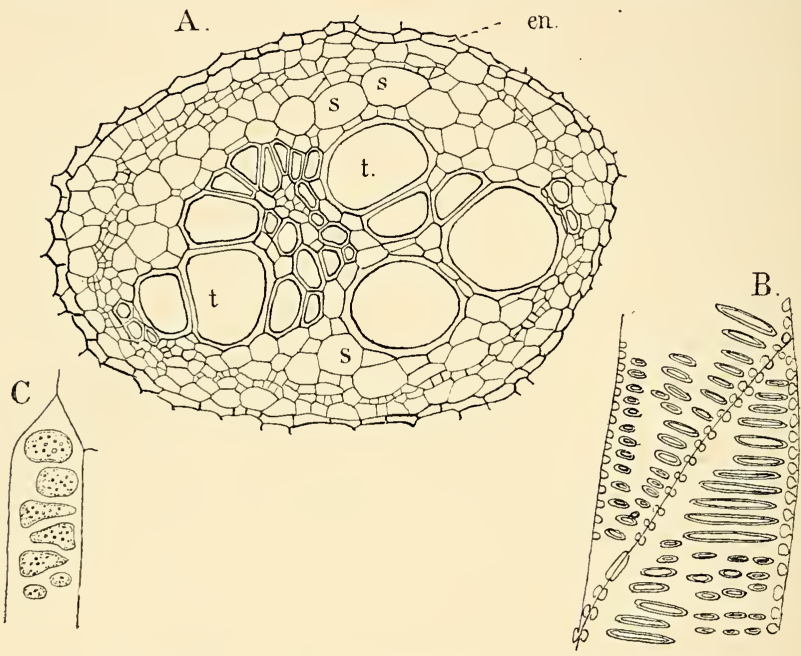

FiG. I63.-A, Vascular bundle from the rhizome of Pteris aguilina (L.); en, endodermis; $s, s$, sievetubes; $t, t$, vessels (after Atkinson); $\mathrm{B}$, longitudinal section of two large scalariform tracheæ of the same species (after Atkinson); $\mathrm{C}$, part of a sieve-tube of Onoclea struthiopteris, $\times 375$.

occupy an irregular area at each end of the bundle. Their differentiation begins shortly after that of the large scalariform tracheids, and in some respects resembles it. The procambium cells from which they arise are uniform in diameter, and have squarer ends than the young tracheids. Their contents are more colourless and finely granular than those of the tracheids, and the nucleus not so evident. Whether the subsequent division of the nucleus takes place before the thickening of the wall begins was not determined. The formation of the sieveplates begins by transverse thickened bars on the lateral walls, 
less regular than in the tracheids, and the bars more or less anastomosing so as to enclose thin areas, the sieve-plates (Fig. I 63, C). These occur all over the lateral walls, as well as the transverse ones. While it could not be positively shown, it is extremely probable that the pores, afterwards formed, penetrate completely the thin membrane of the sieve-plates, and throw the adjacent sieve-tubes into communication.

\section{The Leaf}

While the leaf in a few of the Leptosporangiate is simple, in much the larger number it is compound, either dichotomously branched (Adiantum pedatum) or more commonly pinnately divided. Owing to the great irregularity of the divisions and slow formation of new segments in the stem apex, it is exceedingly difficult to determine positively whether each segment of the stem apex produces a leaf, but this seems probable. The leaf appears as a blunt conical emergence, whose apex is occupied by a single large apical cell, which in nearly all forms examined is wedge-shaped and forms two rows of segments. As the leaf grows it assumes the form of a flattened cone with a broad base, more convex on the outer side, and very soon showing the circinate vernation. The petiole grows much more rapidly than the lamina, which remains small until the close of the season before which it unfolds. In most species of colder climates the development of the leaves is very slow, and may occupy three or four years. The last stage of growth consists merely in an expansion of the leaf, with comparatively little cell division. This latter phase of growth often goes on with great rapidity, in strong contrast to the excessively slow growth during the early stages.

The first wall in the young segment of the apical cell divides it into an inner and an outer cell, and the latter then divides into two by a longitudinal wall, and each of the latter into two more by a transverse wall. Of these five cells, the inner oncs, in the lamina of the leaf, produce the rachis, the outer ones the lamina itself. The outer cells of the segments form the pinnæ. Soon after the separation into lamina and petiole, the development of pinnæ begins in those Ferns which, like $O$. struthiopteris, have pinnate leaves (Fig. I62, D). Their formation is strictly monopodial, and begins by an increase in 
growth in the outer cells of the young segment, which thus form a lobe. The marginal cells divide rapidly by longitudinal walls, so that at first the young pinna does not grow from a single apical cell, but sometimes two of the division walls intersect and an apical cell is formed. Whether this always happens could not be absolutely determined. As each pinna corresponds to a segment of the apical cell of the leaf, it follows that they alternate with each other on opposite sides of the rachis. Where these grow from an apical cell, the divisions follow those in the apex of the leaf. From the inner cells of the segments the rachis of the pinna is developed. The midrib of each lobe of the pinna bears the same relation to it that the rachis does to the pinna itself. The secondary veins arise in acropetal succession, and at first form a strand of procambium reaching from the midrib to the margin. Where dichotomy of the veins occurs, as it so frequently does in their ends, this is connected with a dichotomy of the marginal group of meristematic cells. ${ }^{1}$ Each marginal cell, like the segment of the apical cell of the leaf, divides into an inner and an outer cell. The latter then divides longitudinally, and the dichotomy is thus inaugurated. These secondary marginal cells now repeat the same divisions, and the two diverging rows of inner cells form the beginning of the young veins.

Except the smallest veins, which are collateral, the bundles are typically concentric, and differ only in minor particulars from those in the stem. The ground tissue of the petiole shows much the same structure as that of the rhizome in most Ferns, and usually develops several layers of hypodermal sclerenchymas. In the lamina, the cells of the ground tissue, as the leaf expands, separate and form large intercellular spaces between them. The cells are in many places connected by prolongations or protrusions of the wall. On the upper side, in cases where no stomata are developed, an imperfect palisade parenchyma may form, but in none of the forms examined by me was it nearly so distinct as in Angiopteris. The fullydeveloped epidermal cells are very sinuous in outline, and always contain numerous chloroplasts.

In Onoclea struthiopteris stomata are developed only upon the lower side of the lamina, but sometimes these also are found upon the upper surface as well. Usually, but not always, the

\footnotetext{
${ }^{1}$ Sadebeck (6), p. 27 c.
} 
formation of the young stoma is preceded by the formation of a preliminary cell (Fig. I $64, v$ ), horse-shoe shaped, and cutting off a small cell from one corner of an epidermal cell. A similar wall forms within this small cell, parallel to the first one (Fig. I $64, \mathrm{~B}, s t$ ), and the cell thus separated is the stoma mother cell. A longitudinal wall next divides this, and then splits in the middle to form the pore of the stoma (Fig. I 64, C). This when complete is exactly in structure like that of other vascular
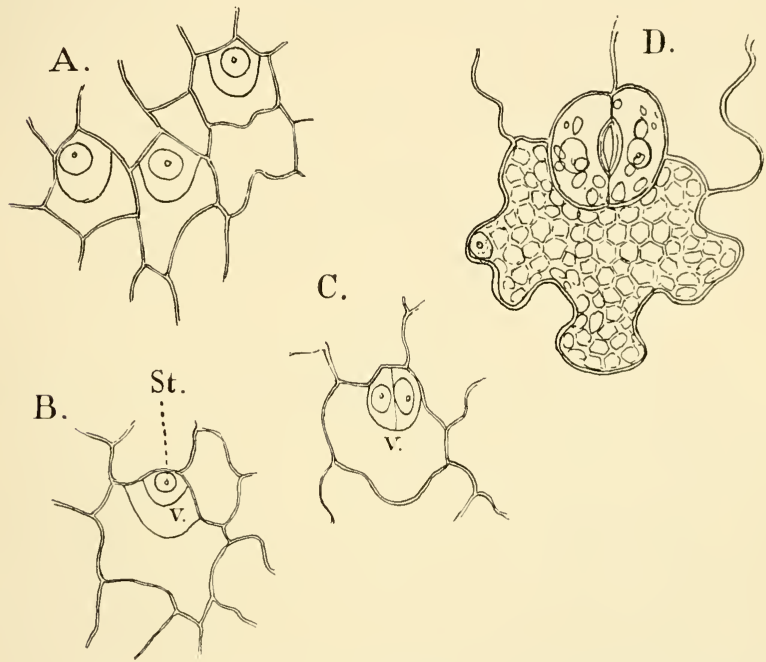

Fig. 164.-Adiantum emarginatum (Bory). Development of the stomata, $\times 525$; $v$, accessory cell ; st, stoma mother cell.

plants, and like them communicates with the air-spaces of the mesophyll. The accessory cell enlarges very much with the expansion of the leaf, and its walls have the same sinuous outline that the other epidermal cells, exhibit. A curious variation of the ordinary form is seen in Aneimia, ${ }^{1}$ where the mother cell of the stoma is cut out by a perfectly circular wall, very much like the funnel-shaped one in the antheridium, and the stoma is apparently free in the centre of an epidermal cell. It seems that this also occurs in Polypodium lingua. ${ }^{2}$

1 De Bary (3), p. 42.

2 De Bary, l.c. 
Most of the Leptosporangiatæ are characterised by numerous epidermal outgrowths, either hairs or scales. These are especially abundant upon the younger parts, and are largely protective. The hairs are either simple or glandular ones. In the latter case the gland is usually a terminal, pear-shaped cell, which secretes mucilaginous matter, or less frequently (Onoclea struthiopteris) this secretion may be resinous. In the common Californian "gold-back" Fern, Gymnogramme triangularis, the yellow powder upon the back of the leaf is a waxy secretion, derived from epidermal hairs. Of similar nature are the large chaffy scales (paleæ) which occur in such numbers upon the bases of the petioles of so many Ferns. This development of hairs, however, is most marked in the large tree-Ferns, Dicksonia, Cibotium, etc., where the young leaves are completely buried in a thick mass of brown wool-like hairs, which are sometimes utilised as a substitute for wool in stuffing mattresses, etc.

\section{The Root}

The roots arise in large numbers in most Ferns, and apparently bear no definite relation to the leaves. The primary ones are first visible very near the apex of the stem (Fig. I62, A, $r$ ), and Van Tieghem, ${ }^{1}$ who has made a very exhaustive study of the subject, states that they always arise from an endodermal cell. This divides into a basal cell and a terminal one, and by the former the young root is directly connected with the xylem of the stem bundle. In the outer cell the three walls defining the pyramidal apical cell now arise, and the latter at once begins its characteristic divisions.

The segmentation in the apex of the roots of the Leptosporangiatæ is exceedingly regular. Corresponding to each set of lateral segments an outer segment forms as well. Van Tieghem ${ }^{2}$ does not apparently recognise the root-cap as distinct from the epidermis, but all other observers consider the rootcap as a distinct structure. The first division wall in the lateral segments is the sextant wall, which is perpendicular to the broad faces of the segment and curves somewhat so as to strike one of the lateral walls a little above the base, and thus makes the two sextant cells of unequal size (Fig. I 65, C). The next wall is transverse and separates an inner from an outer cell, and with 
this divides the plerome from the cortex. After this in the outer of the primary cells there is a separation of an outer from an inner cell, the former giving rise either directly or by a subsequent division to a single layer of cells upon the outside of the root, which is usually regarded as the epidermis, and the inner cells form the cortex. The inner layer of the cortex, which can be traced back almost to the summit, is the endodermis, and its radial walls are peculiarly folded.

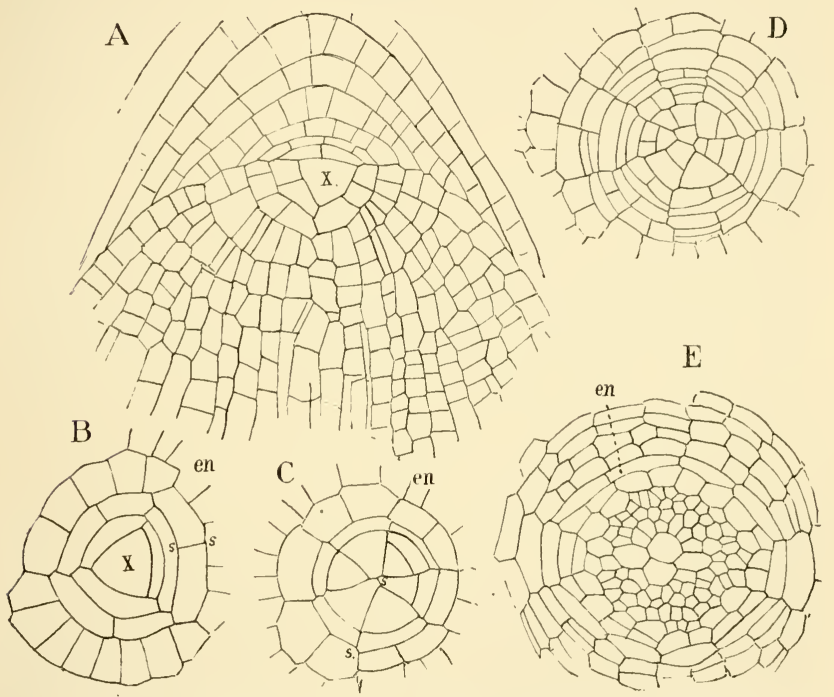

Fig. 165.-Adiantum emarginatum (Bory). A, Longitudinal; B-E, a series of transverse sections of the root, $\times 200 ; x$, apical cell : $s-s$, sextant walls ; $c n$, endodermis.

According to Strasburger, ${ }^{1}$ in Pteris Cretica the cap cells divide only by perpendicular walls, and the older layers of the cap remain but one cell in thickness. Van Tieghem ${ }^{2}$ states, and I have verified this in Adiantum emarginatum and Polypodium falcatum, that with the exception of the firstformed cap cell (or "epidermal segment," to use his terminology), there is, in the central part, always a doubling of the cells

1 Strasburger (10).

2 Van Tieghem (5), p. 532. 
by periclinal walls, so that each layer of the older root-cap is normally double, except sometimes at the extreme edge.

There is very little displacement of the cells for a long time, and cross-sections of the root, made some distance below the summit, still show the limits of the original sextant walls, which form six radiating lines with periclinal walls arranged with great regularity. In the centre the divisions proceed with great rapidity, and the plerome soon shows the elongated narrow procambium cells. In the centre are four much larger cells, which develop later into tracheids, and three of these can be traced back to the central cells of the three larger sextants (Fig. I $65, \mathrm{D}$ ); the fourth arises from the inner cell of one of the smaller ones. This central group of cells marks the position of the plate of tracheary tissue, found later in the root. By this time the parts of the complete root are all indicated. The bundle is bounded externally by the endodermis, whose cells are much elongated transversely, and clearly distinguishable from the pericambium (pericycle), which consists of one or two rows of cells. Inside this is the mass of procambium cells, the large tracheids of the central part of the xylem being very evident. The masses of procambial cells on either side of this central line of cells constitute the young phloem.

The primary tracheids (proto-xylem) arise simultaneously at the foci of the section, and consist of a single line of narrow pointed tracheids, with fine spiral markings, very closely set at first, but later pulled apart somewhat with the increase in length of the root. These are formed a long time before any other permanent tissue elements can be distinguished. Around these primary tracheids are formed a group of similar ones, and from here the formation proceeds towards the central group of large tracheids, which are the last to have their walls thickened and lignified. The large secondary tracheids are scalariform, like those of the stem. The cells of the pericycle remain nearly unchanged, but in the two phloem masses, according to Poirault, ${ }^{1}$ sieve-tubes are always present. These tubes are of two types, with horizontal transverse walls, or inclined ones. The perforations in the sieve-plates were demonstrated, and lateral perforations, either isolated or in groups, also occur. His statement that the sieve-tubes have no nuclei requires further proof. The walls of the sieve-tubes are of cellulose,

1 Poirault (I). 
but in the sieve-plates callus is found. The rest of the phloem is composed of conducting cells, with thin walls and oblique septa. The endodermis becomes dark-coloured and its walls lignified, and when the root dries the vascular cylinder often becomes separated from the ground tissue by the transierse splitting of the endodermal cells.

The secondary roots arise in regular succession in two lines, corresponding to the ends of the xylem plate in the diarch bundle. They themselves generally branch further, and thus very extensive root systems are formed. The origin of the lateral roots of the Ferns has been exhaustively studied by Lachmann, ${ }^{1}$ but their position seems to be of very little importance systematically, and except in a few cases like Osmunda, where two roots regularly arise for each leaf, there is little relation between roots and leaves. In creeping rhizomes they arise either mainly from the ventral side or from all parts indifferently. As yet the only forms in which complete absence of roots is known among the Leptosporangiatæ are Salinina, species of Trichomanes, and Stromatopteris, ${ }^{2}$ one of the Gleicheniaceæ. In all of these, however, there are substitutes either in the form of modified leaves (Salvinia) or root-like rhizomes.

The formation of buds from the roots, such as occur in Ophioglossum, have been also observed in some Leptosporangiatæ. This was first discovered by Sachs in Platycerium IVallichii, and later described by Rostowzew, ${ }^{3}$ and Lachmann ${ }^{4}$ also describes it in Anisogonium Seramporense. In all these cases the apex of the root appears to become transformed directly into the apex of the bud.

\section{The Sporangium}

The development of the sporangium of all the Leptosporangiatæ is much the same, but the position of the sporangia, and the character of the indusium when present, varies much, and will be discussed later as the different families are treated separately.

In the Polypodiaceæ the sporangia, as is well known, arise usually in groups (sori) upon the backs of leaves that differ but little from the ordinary ones. Sometimes, however, e.g. Onoclea, they are very different, the sporangia being produced

\footnotetext{
${ }^{1}$ Lachmann (7). ${ }^{2}$ Poirault (2), p. 147. ${ }^{3}$ Rostowzew (1). ${ }^{4}$ Lachmann (7).
} 
in great numbers, and the lamina of the leaf much contracted. One of the simplest cases is seen in Polypodium. Here the sporangia develop late upon ordinary leaves, and form scattered round sori, bearing, however, a definite relation to the veinsin this case forming above the free end of one of the small veins. Where there are special sporophylls, the development of the sporangia begins before the leaves begin to unfold.

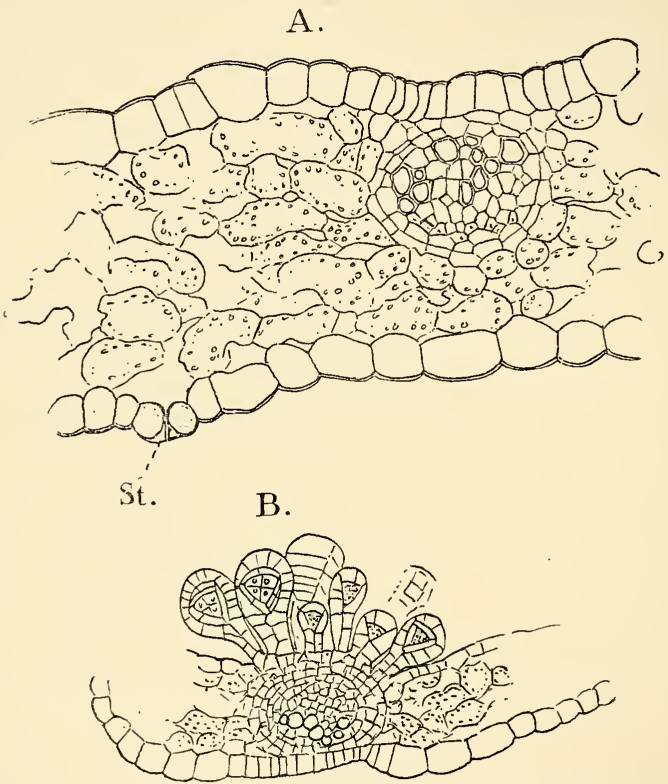

Fig. 166.-Polypodium falcatum (Kellogg). A, Cross-section of a sterile leaf, cutting across one of the smaller veins, $\times 260$; st, section of a stoma; $\mathrm{B}$, similar section of a sporophyll, showing the position of the sorns above the vein, $\times 85$.

In Polypodium (Fig. 167) the first evidence of the formation of sporangia is a series of minute depressions upon the lower side of the leaf, much as occurs in Angiopteris. The bottom of this depression is occupied by a low elevation, the placenta, and upon this the sporangia form in an analogous way, but are not all developed at the same time, so that a single sorus may 
contain nearly all stages of development. The sporangium here can be readily traced back to a single epidermal cell.

The sporangial cell protrudes until it is nearly hemispherical, when it is cut off by a wall level with the surface of the placenta. This basal cell takes no further part in the development of the sporangium, and after a time becomes indistinguishable. The outer cell now divides by a wall, occasionally transverse, but much more commonly strongly inclined (Fig. $167, \mathrm{~A}$ ), and striking the basal wall. This is
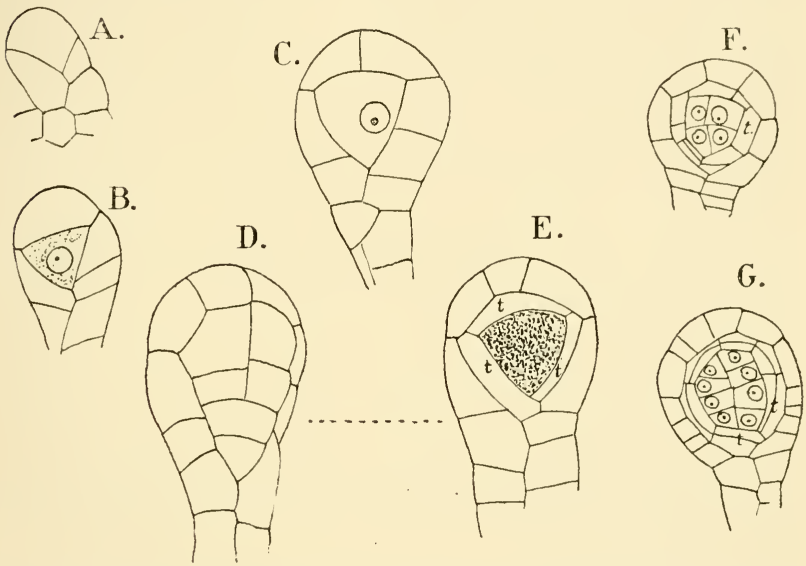

FiG. 167.-Polypodium falcatum (Kellogg). Development of the sporangiun. A-E, from living specimens; F, G, microtome sections; A, B, C, optical sections; D, E, the same sporangium, showing respectively the surface cells and central optical section; $t, t$, tapetum. A-E, $\times 400 ; F$, $\mathrm{G}, \times 200$.

now followed by two others, also inclined, and meeting so as to enclose a pyramidal apical cell, from which a varying number of lateral segments are cut off. These form three rows, corresponding to the three rows of cells found in the stalk, which is not sharply separated from the capsule, as stated by Goebel, ${ }^{1}$ and formed from the lower of two primary cells, but is merged gradually into the capsule, and owes its three-rowed form to a primary and not a secondary division. The upper part of the young sporangium enlarges, so that it becomes 
pear-shaped (Fig. I 67, B), and a periclinal wall is then formed in the apical cell. The cells of the stalk undergo no longitudinal divisions, and it remains permanently composed of three rows.

Kündig ${ }^{1}$ first called attention to the real state of affairs, and since, C. Muiller ${ }^{2}$ has investigated the matter further. The central tetrahedral cell of the young sporangium (archesporium) has cut off from it, by periclinal walls, the primary tapetal cells $(t)$, and in the meantime the wall of the capsule forms repeated radial divisions but no periclinal ones, and, unlike that of the eusporangiate Ferns, always remains single-layered. A surface view of the sporangium at this stage shows the last-formed lateral segment to still retain its triangular form, and the cell divisions in it are very regular. After two or three transverse divisions, a median vertical wall follows, and in each of the resulting cells a transverse wall. Of the two upper cells, one, according to Miiller, ${ }^{3}$ remains undivided, the other divides again by a vertical wall, and the inner of the two cells thus formed by further transverse divisions forms the stomium or mouth of the sporangium.

The cells of the young sporangium contain but little granular contents, and the divisions are very evident. As soon as the archesporium is formed its contents begin to assume a more granular appearance, and become more highly refractive than those of the surrounding cells. The contrast between the archesporial cells and those of the wall increases as the sporangium grows older.

The first division in the central cell begins soon after the separation of the primary tapetal cells. The direction of this first wall is usually transverse, but may be more or less inclined, or even vertical. In each of these cells a wall is formed at right angles to the first-formed, and the quadrant cells are again divided into equal octants. Each of these eight cells divides once more (Fig. I67, G), and the sixteen spore mother cells, found in most Ferns, are complete. In Onoclea struthiopteris I found twelve as the ordinary number, but at what point the division is suppressed was not made out. During the division of the central cells the tapetal cells also divide, first by radial walls only, but later by one set of periclinal walls. This doubling of the tapetum, while it occurs in the majority
1 Kïndig (I).
2 Muiller, C. (2).
${ }^{3}$ Muiller, l.c. 
of Polypodiacex, does not seem to be universal. ${ }^{1}$ The cells of both sporogenous cells and tapetum have dense granular cytoplasm, and large nuclei. Soon after the divisions in the sporogenous complex are completed, the walls of the tapetal cells become broken down, and their contents dispersed through the large central cavity. The sporangium continues to enlarge rapidly after this, and the spore mother cells, still united, float in a large cavity, which in the living sporangium seems to be filled with a structureless mucilaginous fluid, but when fixed and stained is seen to contain the unchanged nuclei of the tapetum, as well as its cytoplasmic contents. Gradually the connection between the sporogenous cells is lost, and the isolated cells, each surrounded by a very delicate membrane, float in the large central cavity. Here they divide into four cells, as usual, and the division may be simultaneous, resulting in tetrahedral spores, or successive (Onoclea), in which case bilateral spores are formed. Strasburger ${ }^{2}$ states that during the division of the spores in Osmunda there is a reduction of the chromosomes to one-half their original number, but whether this also occurs in the other Ferns must be left undecided at present. Stained microtome sections of sporangia during the formation of the spores show that the spore mother cells, and afterwards the spores themselves, are embedded in a granular matter, evidently the product of the disorganised tapetum, and that the nuclei of the latter are collected about them, evidently intimately associated with the growth of the young spores, and in the later stages with the formation of the perinium. The latter is rarely smooth, but shows spines, ridges, and folds of characteristic form in different species.

When chlorophyll is present in the ripe spore it only arises at a late period. In Onoclea struthiopteris, about the time that the perinium begins to form, numerous small colourless granules appear near the nucleus, and with the ripening of the spore these increase rapidly in size and number, and an examination shows that the increase in number is the result of division. These are young plastids, and as they enlarge chlorophyll is formed in them, and they become very much crowded, so that the green colour of the ripe spore is very pronounced.

The further history of the sporangium wall is somewhat complicated. The stomium, as we have seen, arises from a 
special cell of the last-formed lateral segment. The segment on the opposite side (next older but one) shows a quite similar arrangement of cells, and, according to Müller, ${ }^{1}$ the cell corresponding to the stomium by two transverse walls forms the first segment of the annulus. The cells immediately below also divide similarly, and give rise to a second section. The rest of the annulus arises from the upper or cap segment of the sporangium wall, and extends from the stomium over the top of the sporangium, and joins the part of the annulus upon the

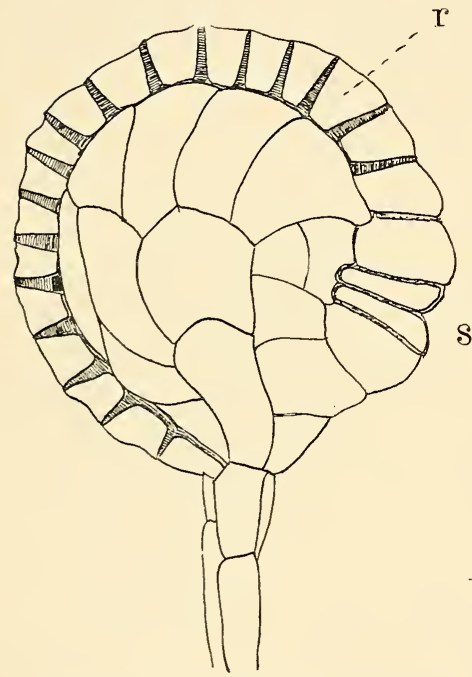

F1G. 168.-Surface view of a nearly ripe sporangium of Polypodium falcatum, $\times \mathrm{I}_{75}$; st, stomium; $r$, annulus.

Atkinson ${ }^{2}$ describes the process thus for the Polypodiaceæ. "While the opening of the stomium between the lip cells is aided by their peculiar form, it seems possible that at maturity the line of union is less firm than between the other cells. The fissure once started proceeds across the lateral walls of the sporangium, usually in a straight line, thus splitting in half the cells of the middle row, their frailty favouring this. The drying of the annulus brings about the unequal tension all the cells are at first alike, but those of the annulus begin to thicken, this being confined to their inner and radial walls, the outer walls remaining thin. In most species the cells of the annulus are the same for the whole extent, but in Polypodium falcatum (Fig. I68), which is figured here, the cells of the annulus immediately above the stomium are larger and thinner-walled. The stomium cells are more extended laterally than the other cells of the annulus, and between them the sporangium opens by a wide horizontal cleft. other side. The walls of 
of its cell walls. During this process it slowly straightens, carrying between the distal portion of the lateral walls of the sporangium, which remain attached to the free extremity, the greater part of the spores. When straight, it continues to evert, and this usually proceeds until the two ends of the annulus nearly or quite meet, when with a sudden snap it throws the spores violently away and returns to nearly its normal position."

Paraphyses, in the form of pointed hairs, often with a glandular terminal cell, sometimes occur with the sporangia. These in some Ferns, e.g. Aspidium filix-mas, are direct outgrowths of the sporangium itself. 


\section{CHAPTER XI}

CLASSIFICATION OF THE HOMOSPOROUS LEPTOSPORANGIATA

\section{Fam. I. Osmundacee ${ }^{1}$}

THE Osmundaceæ, which in many respects form a transition from the eusporangiate to the leptosporangiate Filicineæ, are represented by two genera, Todea, with four species, mostly confined to Australasia, one species only being found in South Africa; Osmunda, with six species, belonging mainly to the temperate and warm temperate regions of the northern hemisphere. The widely distributed species $O$. regalis is found also in South Africa, but otherwise they belong exclusively to the northern hemisphere. Osmunda has the large sporangia borne on very much modified sporophylls, which recall strongly those of Botrychium or Helminthostachys; Todea, while its sporangia are like those of Osmunda, has them borne upon the backs of ordinary leaves.

The development of the gametophyte is completely known in Osmunda, ${ }^{2}$ and somewhat less perfectly in Todea, ${ }^{3}$ which does not, however, seem to differ essentially from Osmunda. In the latter there is considerable difference in the species examined. In all of them the spores contain chlorophyll at maturity, and quickly lose their power of germination. Sown as soon as ripe, they germinate very promptly, and the first division of the spore often takes place within twenty-four hours. The early stages show great variation, even in the same species, and these seem to be often quite independent of external conditions. The ungerminated spore

\footnotetext{
1 Hooker and Baker (I).

${ }^{2}$ Kny (5); Campbell (12).

${ }^{3}$ Luerssen (3).
} 
has an exceedingly delicate endospore, which is difficult to demonstrate, but after the exospore bursts along the three ventral ridges, and the endospore is exposed, it becomes very evident.

The first division takes place after the spore has elongated slightly, and is usually transverse, separating the small root-hair
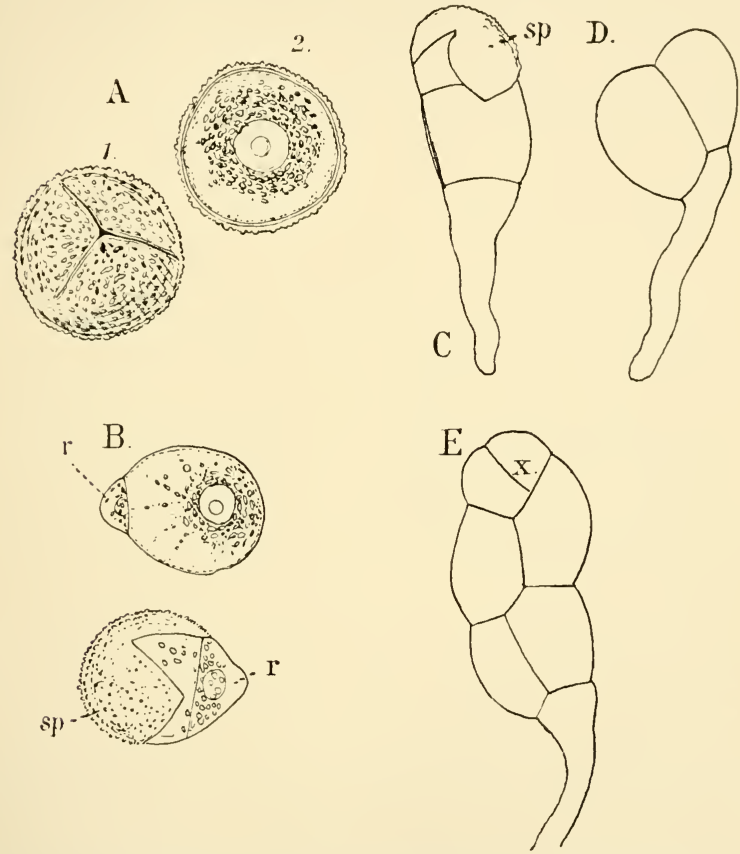

FIG. 16g.-Osmunda Claytoniana (L.). A, Ungerminated spore; I, ventral surface; 2, optical section, $\times_{550}$; $\mathrm{E}$, germinating spores, $\mathrm{X}_{275} ; r$, primary rhizoid; C-E, older stages, $\mathrm{X}_{275} ; s p$, spore membrane; $x$, apical cell.

from the large prothallial cell (Fig. I69, B). The young roothair contains chlorophyll, but not so much as the larger cell. As germination proceeds the chloroplasts separate and increase in size. They are often arranged in lines extending from the large nucleus to the periphery of the cell. As a general thing, 
the growth of the prothallium is exactly opposite to that of the first rhizoid (bi-polar germination), and $\mathrm{Kny}^{1}$ lays a good deal of stress upon this, as distinguishing Osmunda from the Polypodiaceæ ; but it is not at all uncommon for O. Claytoniana, especially, to have the axis of growth of the rhizoid almost or quite at right angles to that of the prothallium, exactly as in the Polypodiaceæ. Where the germination is truly bi-polar the exospore is pushed up with the growing prothallium, and appears like a cap at its apex, but if the root-hair is lateral, the exospore remains at the base.

In $O$. Claytoniana there are usually several transverse walls
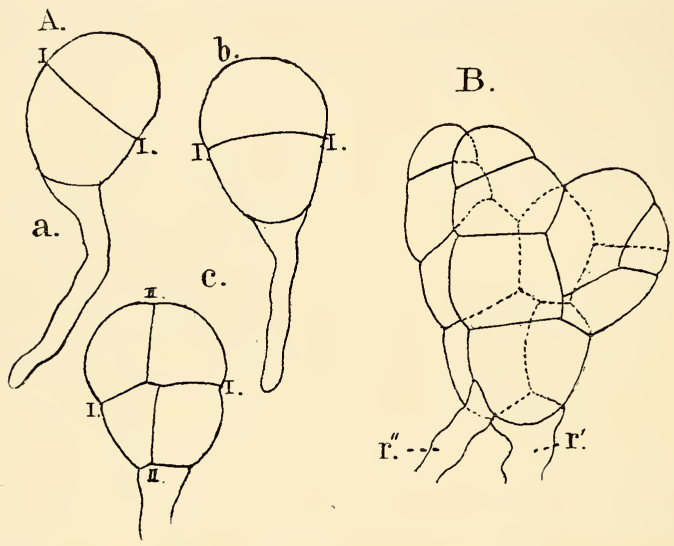

FIG. I70.-Osmznda cinnamomea (L.). A, Young prothallia; B, an older prothallium, $\times 260$.

formed before any longitudinal ones, but in $O$. cinnamomea and 0 . regalis it is quite common to have the first transverse wall followed by a longitudinal wall in each cell, so that the four primary cells are arranged quadrant-wise (Fig. I 7O, A, c). Rarely the first wall in the prothallial cell is longitudinal, as is often the case in Equisetum, and sometimes the first divisions are in three planes, so that a cell mass is formed at once, as so often occurs in the Marattiaceæ. Where a filamentous protonema is formed, a two-sided apical cell is soon established in exactly the same way as in Onoclea. Where 
the four quadrant cells are formed, one of the terminal ones becomes at once the apical cell.

As soon as the apical cell is established, growth proceeds as in Onoclea, and a heart-shaped prothallium is formed. One difference, however, may be noted. Each segment cut off from the apical cell divides first by a transverse wall into an inner and an outer cell, but the inner cell from the first undergoes divisions by horizontal walls, so that a central midrib is formed, very much as in Metzgeria, and the prothallium becomes more elongated than is common in the Polypodiacex. The single two-sided apical cell persists for a long time, but is finally replaced either by a single cell, much like that of Pellia epiphylla, or more commonly by a series of marginal cells, as in the Marattiaceæ or Polypodiaceæ. The subsequent growth of the prothallium is the same as in those forms, but no definite relation could be made out between the archegonia and the segments of the initial cells. Among the Hepaticæ Dendroceros offers almost an exact analogy in the form of the apical cells and the divisions of the segments.

According to Luerssen, ${ }^{1}$ in Todea a distinct apical cell is often wanting, and the growth throughout is due to the activity of several similar initials. His figures, however, hardly bear out his statement, and further information is desirable on this point.

As the prothallia grow older the midrib becomes conspicuous, and projects strongly from the ventral surface. In $O$. cinnamomea and $O$. regalis even at maturity it is very little broader where the archegonia are formed, but in $O$. Claytoniana it forms a cushion in front, much like that of Marattia or the Polypodiaceæ, and in this respect, as well as the form of the apical cells, seems to approach the latter. In this species the prothallium is lighter coloured, and the root-hairs not so dark, while in its dark green colour and fleshy texture $O$. cimnamomea recalls Anthoceros lavis or Marattia.

Where a cell mass is formed at first, this condition is temporary, and an apical cell is established which gives rise to the ordinary flat prothallium. The small male prothallia, which are formed in large numbers, exhibit various irregularities, and quite commonly do not show any definite apical growth, and in O. Claytoniana especially often branch irregularly, or in some 
cases there is a true dichotomy (Fig. I 7 I, A). Slender filamentous prothallia are especially common in this species (Fig. I 72, C), and recall somewhat those of some species of Trichomanes.

The prothallia of the Osmundaceæ often form adventitious buds, much like those of the Marattiaceæ. These secondary

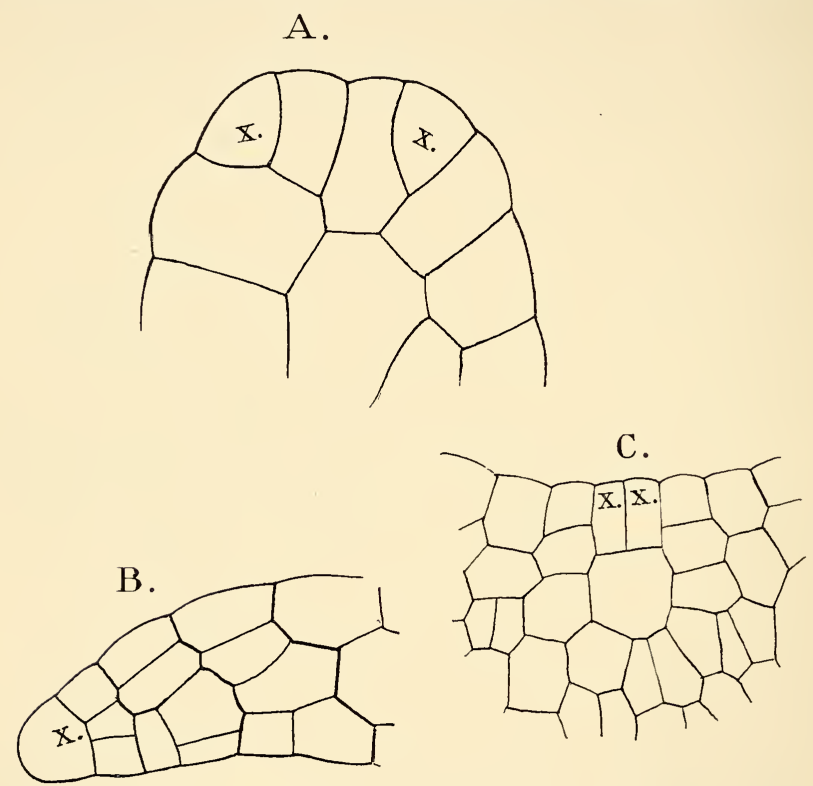

Fig. 17x.-A, Apex of a young prothallium of $O$. Claytoniana, with two similar initials, $x, x, \times_{5} 60$; $\mathrm{B}$, longitudinal section of an advanced prothallium of $O$. cinnamomea, $\times 260 ; \mathrm{C}$, horizontal section of a similar one, showing two initials, $\times 260$.

prothallia (Fig. I 72, B) generally arise from the margin, but may be produced from the ventral surface. An apical cell is usually early established, and the subsequent growth is closely like that of the primary one.

The prothallia are long lived if they remain unfertilised, and Goebel ${ }^{1}$ states that in 0 . regalis they may reach a length of four 
centimetres. He also records a genuine dichotomy of the older prothallia of this species.

\section{The Antheridium}

Under favourable circumstances the first antheridia appear after about a month in O. Claytoniana, and continue to form for

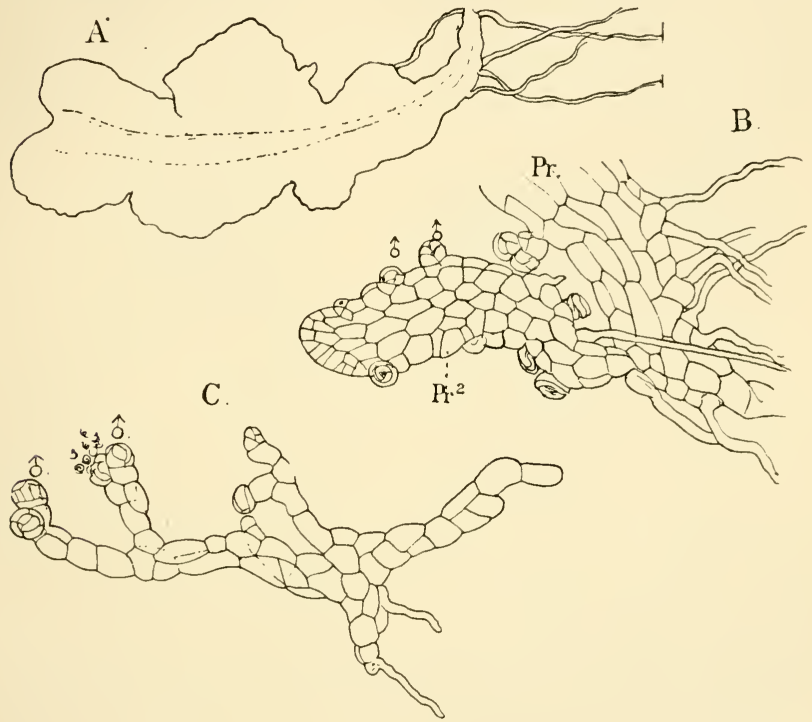

Fig. 172.-A, Prothallium of $O$. Claytoniana, ahout two months old, $x$ about 30 ; B, base of an older prothalliun of the same species with a secondary prothallium $\left(p r^{2}\right)$ growing from it, $\times 80$; $\delta$, antheridia ; $C$, small branching male prothallium of the same species, $\times 75$.

a year or more. In O. cinnamomea they first appeared about two weeks later. While they are almost always present upon the large female prothallia, ${ }^{1}$ numerous exclusively male plants are always met with. These latter are usually irregular in form, and even filamentous, especially when crowded. Upon the latter the antheridia are either terminal or marginal; in the flattened prothallia they occur mainly upon the margin and

1 Luerssen (l.c. p. 449) states that they are often absent from very vigorous prothallia. 
CHAP.

lower surface of the wings. The development corresponds closely in all forms that have been examined, and differs considerably from that of the Polypodiacex.

The mother cell is cut off as usual, but the second wall is not funnel-shaped, but plane and inclined, so that it strikes the basal cell. In the larger of the two cells thus formed a varying number of divisions occur, cutting off a series of lateral segments, much after the fashion of a three-sided apical cell. The segments thus cut off form the basal part of the antheridium, and when the number is large a pedicel may be formed. When the full number of basal segments is complete, a dome-shaped
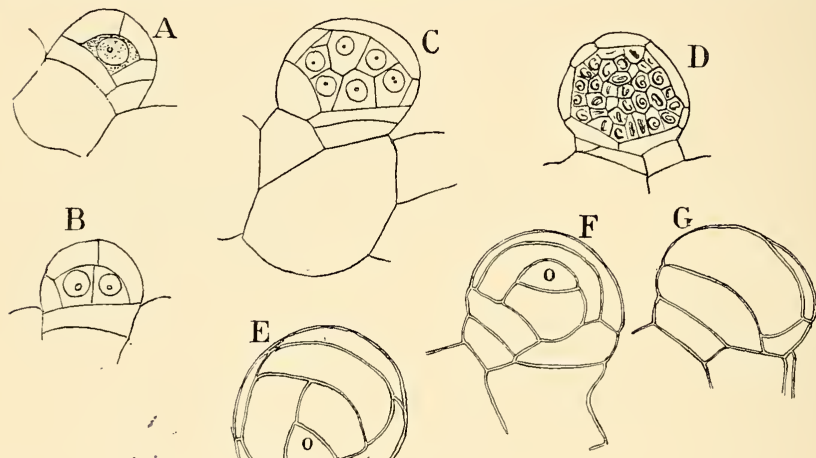

Fig. I73.-A-D, Development of the antheridium of $O$. cinnamomea, in longitudinal section, $\times_{425}$; E, F, G, three surface views of a ripe antheridium of $O$. Claytoniana; $\mathrm{E}$, from above, the others from the side; 0 , opercular cell, $\times 425$.

wall arises in the apical cell, as in the Polypodiaceæ, and the central cell has much the same form (Fig. I73, A). This has no chlorophyll, and as usual the large distinct nucleus is embedded in dense highly refractive cytoplasm. There are next formed in the outer dome-shaped cell two or three walls, running more or less obliquely over the apex; either at the top or at one side the last-formed wall encloses a small cell, which is thrown off when the antheridium opens (Fig. I 73,o). This opercular cell, both in form and position, recalls strongly that found in the Marattiaceæ.

The divisions in the central cell correspond closely to those 
in Onoclea, but the number of sperm cells is larger, being usually $\mathrm{I} 00$ or more. The development is also the same, and will not be entered into here. ${ }^{1}$ After the final division of the sperm cells the nuclei remain slightly flattened in the plane of division, as in the Hepaticæ, and the mature spermatozoids are coiled more flatly than in the Polypodiacere. The free spermatozoid recalls that of Marattia or Equisetum rather than
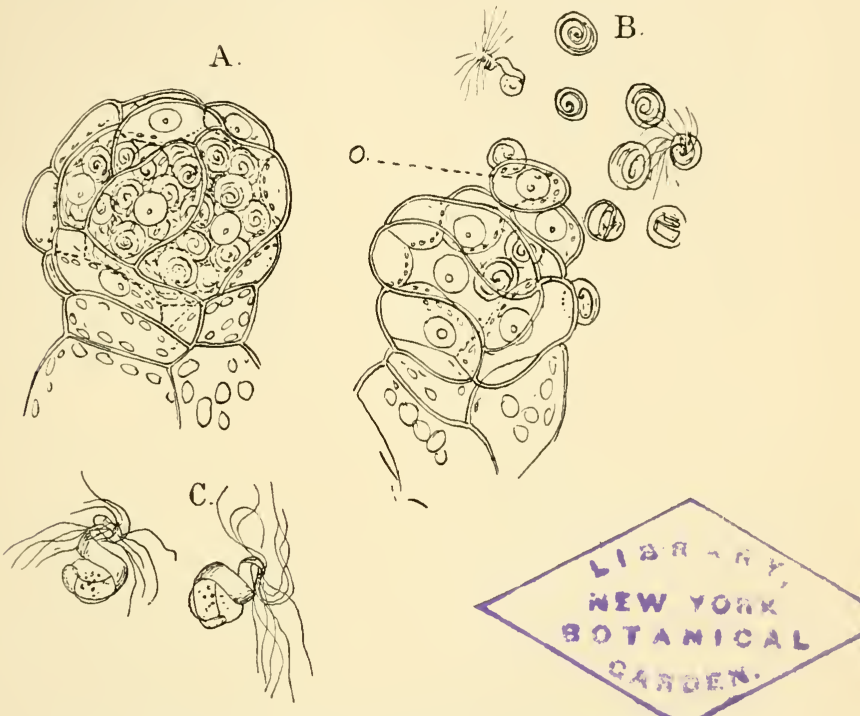

FIG. 174.-A, Ripe antheridium of 0 . Claytoniana, just ready to open; B, the same discharging the sperm cells, $\times 600 ; \mathrm{C}$, two spermatozoids, $\times$ זzoo.

the Polypodiaceæ. There are but about two complete coils, and the hinder one relatively larger than in the latter forms. In swimming there is peculiar undulating movement, suggestive of the spermatozoid of Equisetum.

\section{The Archegonium}

The archegonia are only borne upon the large heart-shaped prothallia, and occupy the sides of the projecting midrib, where,

1 For details see Campbell (12), p. 61. 
if the earlier ones are not fertilised, they may continue to form indefinitely; but no correspondence can be made out between them and the initial cells, and while formed for the most part in acropetal order, new ones may arise among the older ones.

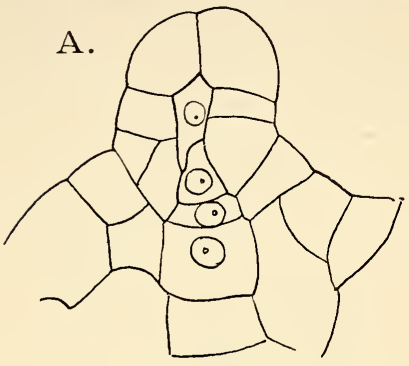

B.

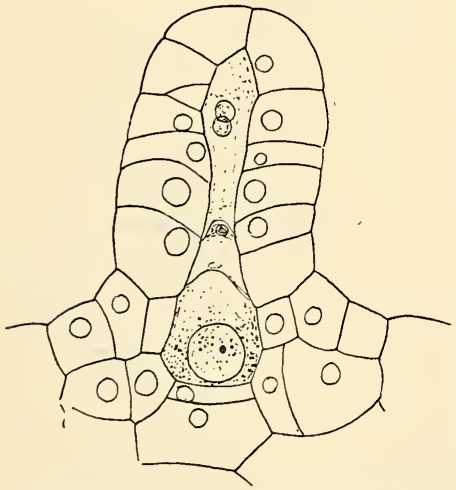

FIG. 175.-A, Young archegonium of $O$. cinnamomea, with the neck canal cell divided by a cell wall; $\mathrm{B}$, a nearly ripe archegonium of the same species, $\times 525$.

small nuclei, and in the living state are almost transparent, with little chlorophyll. Small glistening bodies, apparently of albuminous nature, are often present, and are especially conspicuous in material fixed with chromic acid. Kny and Luerstinguishable from the neighbouring cells, either in size or contents, and cannot always be identified until after the first transverse divisions. The development is much as in the other Ferns, but there are some differences that may be noted. The first transverse division, as in these, separates the cover cell from the inner cell, and the latter may divide into a basal and central cell, but sometimes this division is omitted, and the basal cell is absent. The cover cell divides by the usual cross-walls into the four primary neck cells, which here all develop alike, and the neck remains straight. The complete neck has about six tiers of cells. The separation of the neck and ventral canal cells follows in the usual manner, but occasionally the former may be divided by a transverse cell wall (Fig. I 75 , A), although ordinarily the division is confined to the nucleus. The neck cells have 
sen both speak of the quantity of starch in the axial row of cells in $O$. regalis, but in neither $O$. cinnamomea nor $O$. Claytoniana was this noticeable. As the egg approaches maturity the nucleus becomes large and distinct, and one or two nucleoli are present. The chromosomes are not conspicuous, a condition that we have seen before is not uncommon in the egg nucleus.

A curious appearance was noted several times just before the archegonium seemed about to open, and after the formation of the ventral canal cell. This was the separation from the upper part of the egg of a small body containing what looked like a nucleus. Whether this is something analogous to the "polar body" found in animal ova could not be determined.

When the archegonium opens, the four rows of cells bend strongly outward, and frequently some of the terminal cells become detached. A large receptive spot is present, and the nucleus is smaller than in the younger egg, and contains more chromatin, and usually but a single nucleolus.

\section{Fertilisation}

The horizontal position of the archegonia, as they project from the sides of the midrib, makes it easier to follow the entrance of the spermatozoid than is the case in most Ferns. The spermatozoids collect about the mouth of the freshlyopened archegonium, and soon one finds its way in. With the ciliated end down, it revolves rapidly, not seeming to be much impeded by the mucilage thrown out by the archegonium. Suddenly, with a quick movement, quite unlike the slow wormlike movement seen in most Ferns, it slips through the neck into the central cavity, where its movement is resumed. After about three or four minutes it disappears, and has presumably penetrated the egg. Other spermatozoids may make their way into the central cavity, but only one penetrates the ovum. The lower neck cells now approach, but not enough to prevent the entrance of other spermatozoids. Within a few hours the inner walls of the neck cells begin to show the brown colour that indicates that fertilisation has been accomplished.

The egg quickly secretes a cellulose membrane, which prevents the entrance of the other spermatozoids. The egg nucleus moves towards the receptive spot at the time of 
fertilisation, where the spermatozoid may be seen but little altered in form. It almost at once comes into contact with the female nucleus, and the two then move toward the centre of the ovum. Here the spermatozoid gradually loses its coiled form and contracts until it becomes oblong, and in close contact with the egg nucleus, in some cases looking as if it were actually within it. The process is a slow one, and in one case twenty-four hours after the entrance of the spermatozoid the two nuclei were still recognisable. Finally they are completely fused, and a single nucleus, with usually, perhaps always, two nucleoli is seen. No sign of a separation of the chromosomes of the copulating nuclei was observed.

\section{The Embryo}

The first division of the ovum is the same with respect to the archegonium as in Onoclea, i.e. the basal wall is parallel
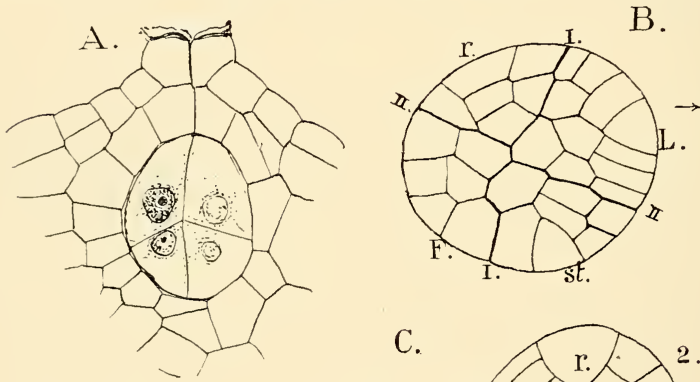

C.

1.
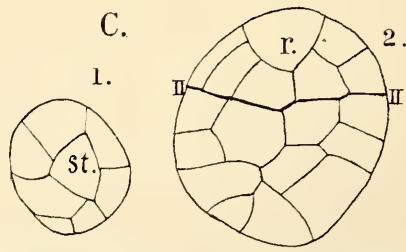

Fig. 176.-A, Vertical section of an eight-celled embryo of 0 . Claytoniana, $\times 260$. Median longitudinal section of an older embryo of the same species, $\times 260 ; C$, two transverse sections of a somewhat younger embryo of $O$. cinnamonea, $\times 260 ; s t$, stem apex; L, cotyledon; $r$, primary root: $F$, foot.

with its axis; but the quadrant wall is also parallel with this instead of transverse, although its position with reference to the axis of the prothallium is the same; so that the embryo- 
quadrants, and the organs derived from them, are situated like those of the polypodiaceous embryo, with reference to the prothallium, but not to the archegonium.

As in Onoclea the primary organs are established by the first two walls, and the next divisions form octants, but there is somewhat less regularity in the later divisions, in which respect Osmunda is intermediate between the Polypodiaceæ and the Eusporangiatæ. As in the former, the two epibasal quadrants form stem and cotyledon, the hypobasal ones, root and foot. At this stage the cells of the young embryo contain but little
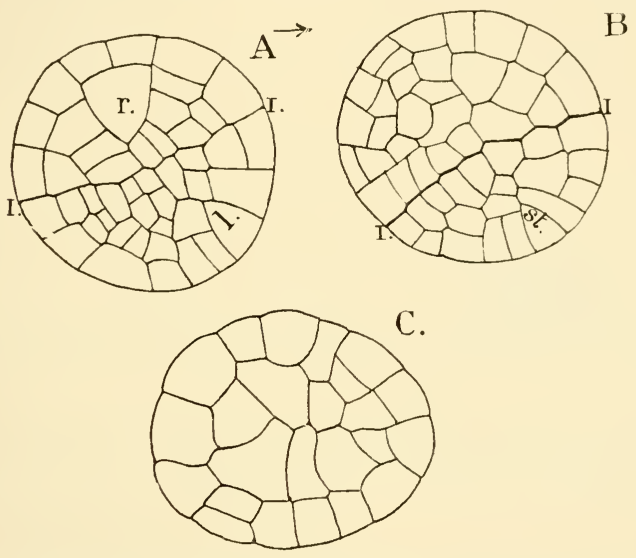

FIG. 177.-Three sections of one embryo of $O$. cinnamomea in which the root $(r)$ is especially well marked, $\times 260$. Lettering as in the last.

granular cytoplasm, and there are large vacuoles. As the embryo grows older the granular cell contents increase in quantity. The subsequent divisions follow very closely those in the embryo of Onoclea, but are less regular, and the embryo retains for a longer time its original nearly globular form.

The direction of growth of the cotyledon is determined in part by the first walls in its primary octants. The outer octant usually becomes at once its apical cell, and if its first segment is formed on the side next the octant wall, this throws the axis of growth very much on to one side, so that the axis of the leaf may be almost at right angles to the median line of 
the embryo. Otherwise it nearly coincides with this. The original three-sided apical cell persists for a long time, and it
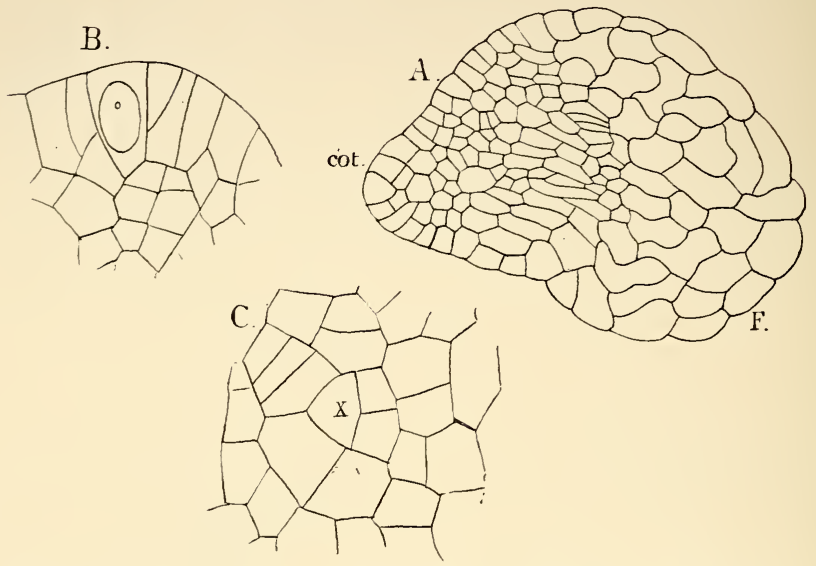

FIG. 178.-A, Horizontal section of an advanced embryo of $O$. Claytoniana, passing through the cotyledon and foot, $\times 230 ; \mathrm{B}$, longitudinal section of the stem apex in a somewhat older embryo of $O$. cinnamomea, $\times 460 ; \mathrm{C}$, transverse section of the apex of the primary root of the same, $\times 460$.

could not be positively shown whether or not it was afterwards replaced by a two-sided one. The further development of the

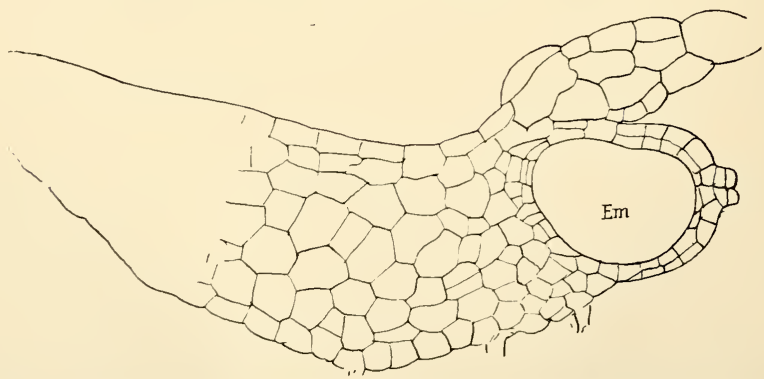

FIG. 179.-Transverse section of a prothallium of 0 . Claytoniana, showing the lateral position of the embryo $(e n t), \times 75$.

cotyledon corresponds almost exactly with Onoclea. It does not break through the calyptra until later, and in this respect 
shows its primitive character. The single vascular bundle of the petiole approaches the collateral type, and is much like that of the cotyledon of Marattia. Stomata of the usual form occur on both sides of the lamina. The development of the stem offers no peculiarities. The apical cell is of the tetrahedral form found in the mature sporophyte.

The root is bulky, and the apical cell relatively small, with large segments, dividing less regularly than in Onoclea, and on the whole approaches most nearly to Botrychium. The form of the apical cell is like that of Onoclea or Botrychium, and is interesting because in the later roots this is replaced by another form, so that this would indicate that the three-sided form found in so many cases is the primitive condition. The vascular bundle is diarch.

The foot is very large, and while formed originally from the upper hypobasal quadrant, it encroaches more or less upon all the others. Very early its cells cease to show any regular order in their divisions, and divide more slowly than the other cells of the embryo, so that they become decidedly larger. The cells lose much of their protoplasm as they increase in size, and serve simply

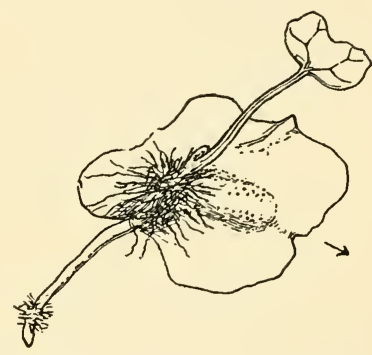

Fig. r8o.-Young sporophyte of $O$. Claytoniana, still attached to the prothallium, $\times 6$. as absorbent organs. They are in close contact with the prothallial cells, and crowd upon them until the foot penetrates deep into the prothallium, whose cells it partially destroys. It is upon the large development of the foot, whose outer cells sometimes are extended into root-like extension like those in Anthoceros, that the young embryo is maintained so long at the expense of the prothallium.

Frequently more than one embryo begins to develop, and sometimes a number of archegonia may be fertilised; but no cases were met with where more than one embryo came to maturity, although it is quite possible that this may occur. 


\section{The Mature Sporophyte}

The growth of the stem in the mature sporophyte is only known in O. regalis. ${ }^{1}$ Here there is usually an apical cell of
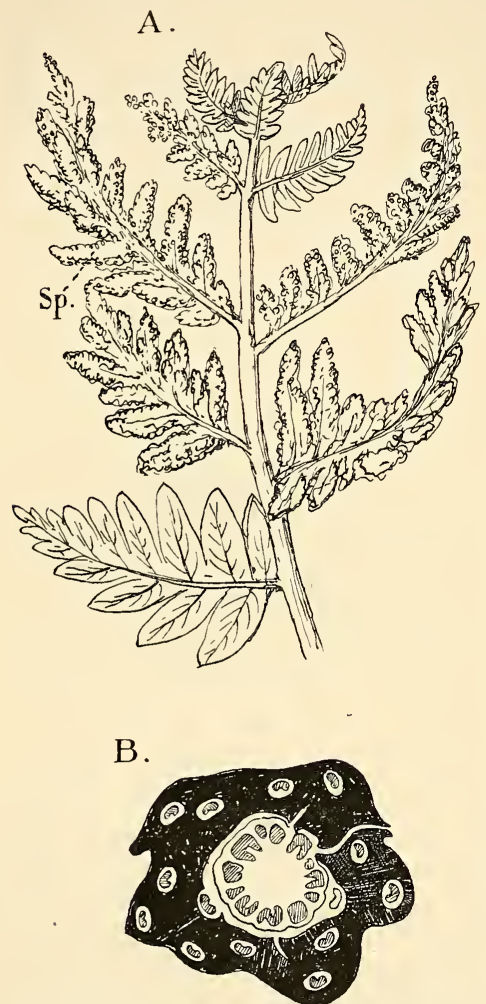

FiG. I8r.-Upper part of a sporophyll of $O$. Claytoniana, $\mathrm{X}_{2} ; s p$, sporangia; $\mathrm{B}$, section of the rhizome of $O$. regalis ( $L$.$) , showing the arrangement of the vascular$ bundles, $\times_{4}$ (after De Bary). bundles and bounded externally by the endodermis. The ground tissue is mainly composed of dark sclerenchyma,

\footnotetext{
${ }^{1}$ Bower (II). ${ }^{2}$ Bower, l.c.
} found in the Ophioglossaceæ or Polypodiaceæ, but Bower ${ }^{2}$ states that sometimesit is impossible to refer the tissues to the division of a single initial cell, and that there are probably in these cases several initials. The growth of the stem is much like that in the other Ferns described, and the structure of the older parts shows much the same arrangement of the tissues as that in the typical Polypodiaceæ. The vascular bundles, however, are very decidedly collateral in structure. A cross-section of the stem (Fig. I $8 \mathrm{I}, \mathrm{B}$ ) shows a circle of horseshoe shaped or wedgeshaped bundles, with the xylem directed inward and bordering directly upon the pith. Between the bundles are layers of parenchyma (medullary rays), and the phloëm forms a continuous band outside the woody

the same type as that 
through which the leaf-traces pass from the axial bundles to the leaves. Each leaf-trace is surrounded by a sheath of colourless cells.

The origin of the leaves is the same as in the Polypodiacex, but the young leaf grows from a three-sided apical cell much like the stem, ${ }^{1}$ and the young leaf is more conical than there. In the very young leaf, according to Bower, one side of the apical cell is always directed toward the stem apex, and never one of the angles. In the presence of a three-sided apical cell, as well as its more cylindrical form, there is an approach to Botrychium. The further development of the leaf is like that of the pinnate leaves of the Marattiacex or Polypodiacex, with which they agree also in the strongly circinate vernation. The leaves are always pinnately divided, and are similar in all the forms, and the type of venation is the same. While in all species of Osmunda and in Todea barbara, the structure of the leaf is quite like that of the Polypodiaceæ, the other species of Todea (Leptopteris) have the lamina of the leaf reduced to two or three layers of cells, and there are no stomata. The texture of the leaves in these forms is filmy, like that of Hymenophyllum.

The petiole is traversed by a single large vascular bundle, which in section is crescent-shaped and in structure concentric, with the elements like those of the Polypodiacer, but the endodermis is not so clearly differentiated, and close to the inner side of the bundle are numerous mucilage cells, recalling the tannin ducts of Angiopteris. A further point of resemblance to the Marattiaceæ is the presence of stipular wings at the base of the petiole. The chaffy scales (palex) so common in the Polypodiacex are quite wanting, but hairs are developed, often in great numbers. Thus in $O$. cimnamomea the young leaves are covered completely with a felted mass of hairs, recalling those in some of the Cyatheacex. Some of these are glandular. The sterile leaves and sporophylls are either very much alike, as in Todea, or the sporophylls may be very different. An extreme case is seen in $O$. cimnamomea, where the whole sporophyll is devoted to the development of sporangia. In this species, as well as $O$. Claytoniana, the sporophylls develop first and form a group in the centre of a circle of sterile leaves. In $O$. cimnamomea the sporophylls

\footnotetext{
1 Bower (I I), p. 332 ; Klein (2), p. 647.
} 
develop no mesophyll, and die as soon as the spores are scattered.

\section{The Roots}

The roots of the mature sporophyte differ very markedly from those of the other Leptosporangiatæ, and have been the subject of numerous investigations, but there still is a good deal of diversity of opinion as to their exact method of growth. Bower ${ }^{1}$ states that in 0 . regalis there may be a single apical
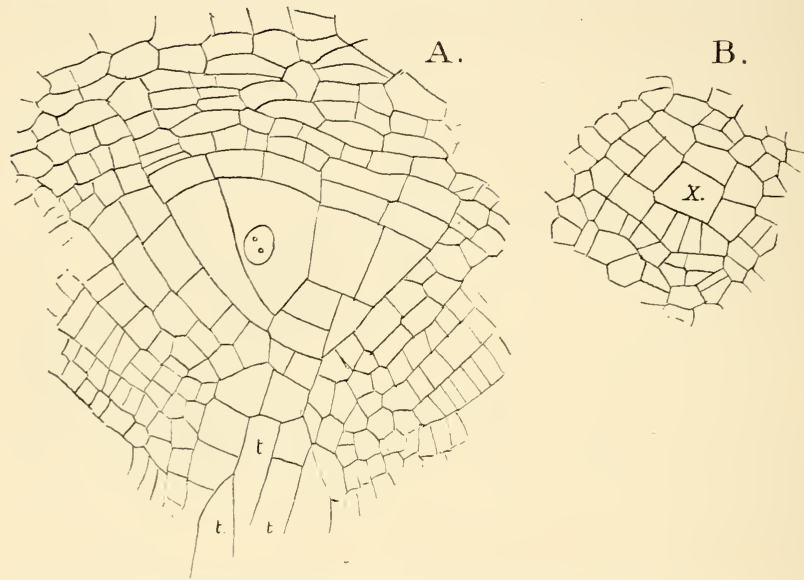

FiG. 182.-A, Longitudinal section through the root apex of $O$. cinnantonica; $t$, young tracheids, $\times 200 ; \mathrm{B}$, cross-section of root apex of $O$. Claytoniana, $\times 200$.

cell, such as exists in the first root of $O$. Claytoniana and $O$. cimnamomea, but that it never shows the regular segmentation of the typical leptosporangiate root, and it may be replaced by two or three similar initials. In Todea barbara he found four similar initials, and in no case a single one, although Van Tieghem and Douliot ${ }^{2}$ ascribe to this species a single threesided apical cell. ${ }^{3}$

Osmunda cimnamomea (Fig. I \&2, A) shows a single very

1 Bower (II), pp. 310, 314.

2 Van Tieghem and Douliot (5), p. 378.

${ }^{3}$ Lachmann (I) asserts, however, that he found a group of initials such as Bower describes. 
large initial, more or less triangular in form when seen in profile, but with the point sometimes truncate. Transverse sections show that it is really a four-sided pyramid. The young segments are very large, and it is possible that these may sometimes assume the rôle of initials. Owing to the slowness and irregularity of cell division it is difficult to trace the limits of the segments beyond the youngest ones. They usually form a spiral, but cases were sometimes encountered where the segments were apparently cut off in pairs from opposite sides of the initial cell. The root-cap arises in part from special segments cut off from the outer face of the apical cell, but also in part from the outer cells of the lateral segments, as in the Eusporangiatæ. The separation of the tissue system
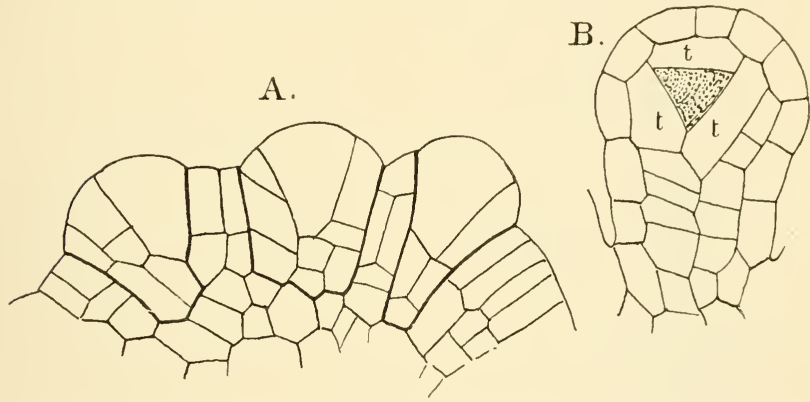

FIG. 183.-Osmunda regalis (L.). A, Section of young sporophyll passing through three very young sporangia; $\mathrm{B}$, longitudinal section of an older sporangium; $t$, the tapetum, $\times 325$ (after Bower).

follows much as in Botrychium. The plerome cylinder is large and oval in section, but with poorly-defined limits, and it is not possible to state positively whether it owes its origin exclusively to the innermost cells of the segments. The large central tracheæ, as in Adiantum, are very early distinguishable. $O$. Claytoniana agrees on the whole with $O$. cinnamomea, but the divisions are much more regular, and it approaches nearer the typical leptosporangiate type, both in the arrangement of the young tissues and the structure of the fully-developed vascular bundle, which closely resembles that of the Polypodiaceæ, and differs from the investigated species of Osmunda and Todea in the better development of the endodermis, and in having the pericycle of but one or two layers. 
CHAP.

The roots arise regularly, two at the base of each leaf, ${ }^{1}$ and their bundles connect with those of the stem near the bottom of the elongated foliar gap in its vascular cylinder.

\section{The Sporangia}

The sporangia in Osmunda are produced upon sporophylls

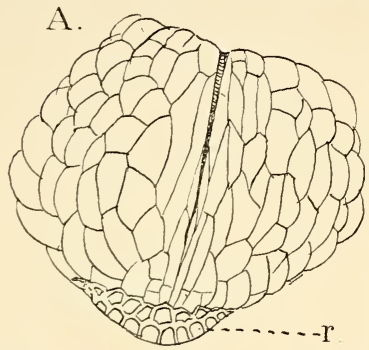
that closely resemble those of Botrychium or Helminthostachys, but in Todea they occur upon the backs of the leaves, as in most Ferns. In structure and development they are intermediate between the true leptosporangiate type and the eusporangiate. So far as they have been investigated they all correspond very closely. The

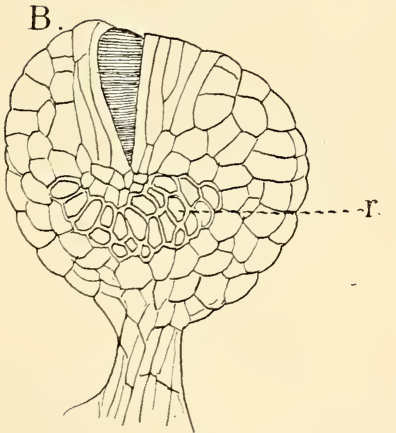

FIG. I84.-A, Apical view ; $\mathrm{B}$, front view of ripe sporangium of $O$. cinnamomea; $r$, annulus, $\times 45$. origin of the sporangia is almost identical with that in Botrychium, and more than one cell may take part in their formation." ${ }^{2}$ Bower says: "In all cases, however, one cell distinctly takes the lead, and this we may call the initial cell (Fig. I 83, A); but the arrangement of its division walls does not, as in the true leptosporangiate Ferns, conform to any strict plan; the initial cells are oblong, seen in vertical section, and the first divisions are longitudinal, so as to meet the basal wall : both in the segment thus cut off and in the central cell, periclinal or sometimes oblique divisions may take place, so that a considerable bulk of tissue is formed, in the projecting apex of which a single large cell occupies a central position." Like Botrychium the archesporium is derived from a single hypodermal cell, which approaches more or less

1 Lachmann (7), p. II 8 .

2 Bower (II), p. 362 ; Goebel (I 7), p. $3^{87}$. 
the tetrahedral form of the true Leptosporangiates, but shows a good deal of variation. As in these the wall of the sporangium is only one-layered, and the tapetum ordinarily two, but occasionally three-layered. The fully-developed sporangium is in shape much like that of Botrychium Virginianum, and has a very short massive stalk. Like Helminthostachys and Angiopteris, it opens by a vertical cleft, and like the latter there is a rudimentary annulus consisting of a group of thickwalled cells (Fig. I $84, r$ ).

\section{The Gleicheniacee}

These comprise about twenty-five species of tropical and sub-tropical Ferns, which may be all placed in two genera ${ }^{1}-$
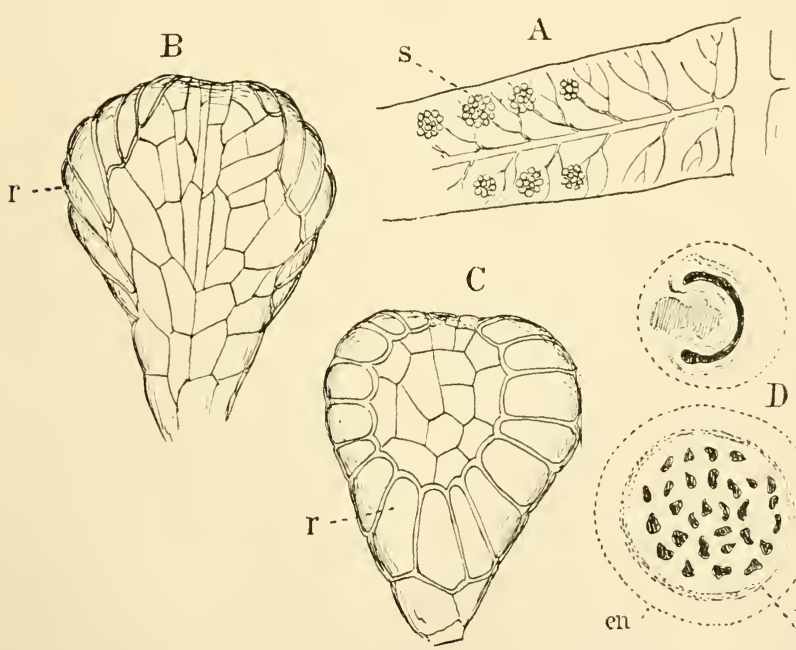

FIG. 185.-A, Pinnule of Glcichenia dichotoma (Willd,), showing the position of the sori $(s), \times_{4} ; \mathrm{B}$, ventral; C, dorsal view of the ripe sporangium, $\times 85 ; \mathrm{D}$, vascular bundles of the petiole and stem of Gleichenia (sp.) (after Poirault). The dark masses represent the xylem masses; ph, phloëm; $c n$, endodermis.

Platyzoma, with a single species $P$. microphyllum, and Gleichenia. The best known is $G$. dichotoma, an extremely common Fern of 
the tropics of the whole world. It has very long leaves, which fork repeatedly, and may be proliferous from the growth of buds developed in the axils of the forked pinnæ.

The development of the prothallium has been studied by Rauwenhoff, ${ }^{1}$ and shows some interesting points in which it is intermediate between the Osmundaceæ and the other Leptosporangiatæ. The spores of Gleichenia are usually tetrahedral, and contain no chlorophyll. When the ripe spores are sown, after a few days the oil-drops become much smaller but more numerous, and the first chloroplasts become evident. The latter increase in number and size, and small starch grains are developed. The exospore is ruptured in from two to three weeks from the time the spore is sown, and the spore contents surrounded by the intine project through the opening. The first wall usually separates the first rhizoid, which, like that of Osmunda, often contains a good deal of chlorophyll, from the larger prothallial cell. As a rule the development of the prothallium corresponds closely to that of the Polypodiaceæ, but it may have a midrib like that of Osmunda. The growth is normally from a twosided apical cell, which is replaced later by marginal initials. A point of resemblance to Osmunda is the abundant production of adventitious shoots, which are formed in numbers upon the margin or from the ventral surface, and may develop into perfectly normal prothallia.

Rauwenhoff's account of the sexual organs is not as complete as might be wished, but is sufficient to show some interesting points of resemblance to the Osmundaceæ. The first wall in the antheridium cuts off a basal cell, and the next wall is somewhat like the funnel-shaped wall in the Polypodiaceæ. The dome-shaped wall next formed is here not so marked, being nearly flat. ${ }^{2}$ No definite cover cell is cut off, but the upper cell appears to divide by a single wall running obliquely over the apex, somewhat as in Osmunda. The divisions in the central cell offer no peculiarities, and the spermatozoids resemble those of other Ferns. The archegonia are formed on the forward part of the midrib, but are not confined to the sides, as in Osmunda. Apparently a basal cell

1 Rauwenhoff (I).

2 Rauwenhoff's statement that the centrai cell of the antheridium contains chlorophyll, to judge from his Fig. 58 , which illustrates this, is based upon a pathological case. The absence of chlorophyll from the central cells of the antheridium is a very constant character in all Archegoniates. 
is not formed, but as to this and the much more important point, the number and character of the canal cells, Rauwenhoff says nothing definite. The neck is long and straight, like that of Osmunde and the Hymenophyllacex.

\section{The Embryo}

To judge from the few rather vague statements made by Rauwenhoff in regard to the embryo, this more nearly resembles the typical leptosporangiate type than it does Osmunda. The primary root has a large and definite three-sided apical cell, and the divisions in the segments are very regular.

Poirault ${ }^{1}$ has recently made a study of the stem of various species of Gleichenia, which differs a good deal from that of Osmunda, and approaches that of the Hymenophyllacer and Schizæaceæ. A single axial bundle traverses the stem, and is separated from the sclerenchymatous cortex by a distinct endodermis. Within the latter is a pericycle of several layers of cells, within which is a continuous zone of phloëm containing large and small sieve-tubes, and phloëm parenchyma. Within the phloëm are also secreting cells. The whole central part of the stem is occupied by bundles of large scalariform tracheids separated by parenchyma (Fig. I $85, D$ ). The single bundle traversing the petiole is much like that of Osmunda, and the lamina of the leaf does not show any peculiarities.

The development of the sporangium is still unknown, but it probably does not differ essentially from that of the Hymenophyllacer, with which it closely agrees in its mature condition. In $G$. dichotoma (Fig. I 85 ) the sporangia form rounded naked sori above the terminal branch of a lateral vein. They are pear-shaped, with a very short stalk, and upon the outer surface is a nearly complete very distinct annulus composed of a single row of large thick-ivalled cells. This is interrupted at the top of the sporangium by three or four narrow thin-walled cells, and starting from this point and extending along the median line of the ventral surface are two rows of narrow cells, between which the sporangium opens.

\footnotetext{
1 Poirault (I), p. I 70.
} 


\section{The Hymenophyllacea}

The Hymenophyllaceæ have been the subject of much discussion on account of the assumption made by all the earlier writers that they were the most primitive of the Pteridophytes. This was based very largely upon the apparent resemblance between the delicate sporophyte of many of them and the leafy gametophore of the Mosses. More recent study of their development, especially the gametophyte, has led to a modification of this view, although it is still held by many botanists. It seems more probable that the peculiarities of both gametophyte and sporophyte are due to the peculiar environment of these plants, which grow only in very moist places, indeed are almost aquatic at times. They are for the most part extremely delicate Ferns, of small size, and with few exceptions are exclusively tropical. Many are epiphytes, and these have the roots very poorly developed or even entirely wanting. The leaves are, with few exceptions, reduced to a single layer of cells, except the veins, which gives them a striking resemblance in texture to the leaves of some of the larger Mosses, e.g. species of Mnium. Hooker ${ }^{1}$ reduces them all to three genera, which, however, are often further divided. Of these Loxsoma is represented by but one species, L. Cunninghamii, a form which seems to be intermediate in general characters between the Cyatheaceæ and the other Hymenophyllacex, but its life history and anatomy are not known. Of the other genera Hooker gives seventy-one species to Hymenophyllum and seventy-eight to Trichomanes. ${ }^{2}$

\section{The Gametopliyte}

The gametophyte is known more or less completely in several species of both Trichomanes and Hymenoplyyllum. The large spores germinate promptly, but their subsequent development is very slow. They contain chlorophyll, and often begin to germinate within the sporangium, where they may often be found divided into three equal cells by walls radiating from the centre (Fig. I86). All of the cells begin to grow out

1 Hooker and Baker (I).

${ }^{2}$ The number of species known now considerably exceeds this. 
into filaments, but usually only one of them derelops into the prothallium, the others dividing only once or twice, and forming
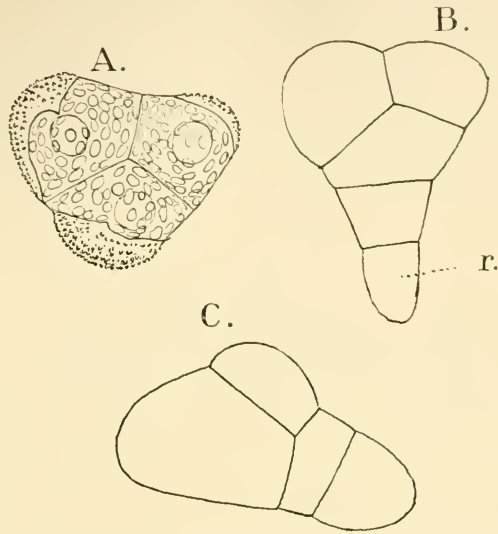

Fig. 186.-Trichomanes Draytonianum (Brack). Germination of the spores, $\times 525$; 1 ; primary rhizoid.

short brown rhizoids. In some species of Trichomanes, e.g. T. pyxidiferum, ${ }^{1}$ the prothallium remains filamentous, and forms a densely branching structure very much like the

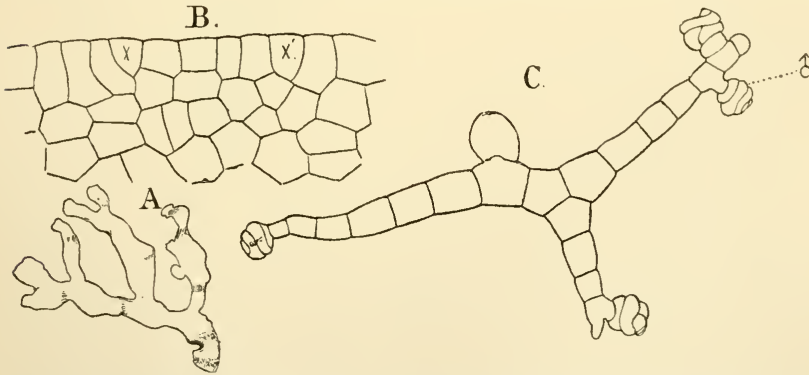

FIG. 187.-Hymenophyllum (sp). A, Large prothallium of the natural size; B, part of the margin of one of the growing branches, showing two similar initial cells, $x_{1} 80 ; \mathrm{C}$, a filamentous male prothallium derived from a bud, $\times 60$.

protonema of some Mosses, but coarser in texture. Other species, however, e.g. T. alatum, produced flattened thalloid 1 Bower (\$). 
prothallia from branches of the filamentous forms, and Hymenophyllum always has a flat hepatic-like prothallium, which in its earlier stages, according to Sadebeck, ${ }^{1}$ always develops a two-sided apical cell, and differs in no wise from that of other Ferns. These prothallia, however, remain single-layered throughout, although they reach an extraordinarily large size, and branch much more freely than those of any other Ferns (Fig. I 87). The root-hairs are always very short and dark-
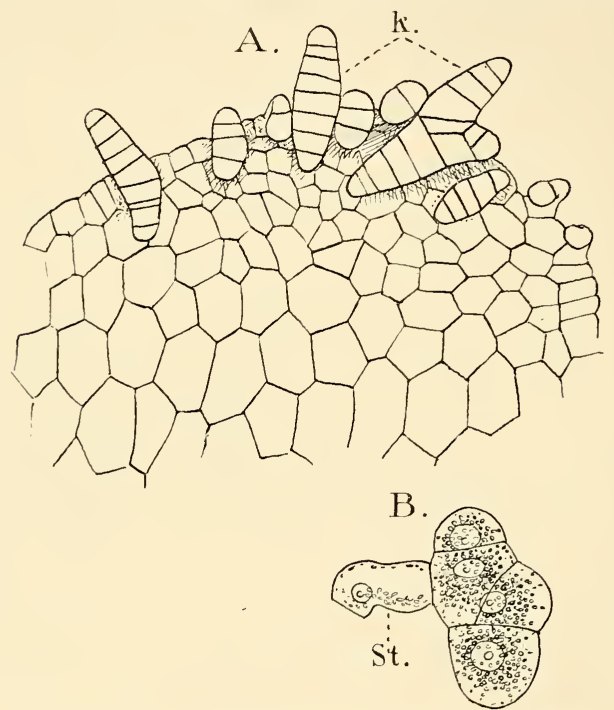

FIG. 188.-Hymenophyllum (sp). Margin of a prothallium with numerous gemmæ $k ; \times 85$; $\mathrm{B}$, a young gemma, $\times_{250}$; st, its stalk.

coloured, and generally occur in groups upon the margin only. The branching of the prothallia is either monopodial or dichotomous, and the latter method may be repeated a number of times. They may live for an indefinite time apparently. The writer has kept prothallia of both Trichomanes and Hymenophyllum for nearly two years, at the end of which time they showed no diminution of vigour.

They form ordinary adventitious shoots, but there are also 
special gemmæ developed in many of them, often in great numbers. In an undetermined species of Hymenophyllum collected in the Hawaiian Islands (Fig. I S8) these gemmx occurred very abundantly upon prothallia that had ceased to form sexual organs. Here a marginal cell grew out and curved upward, and the tip was cut off by a transverse wall from the basal cell. In the terminal cell are next formed a series of vertical walls, which transforms it into a row of cells extended at right angles to the axis of the pedicel. One of the central cells now bulges out laterally, and this papilla is cut off by an oblique wall and forms the beginning of a short lateral branch, so that the fully-developed bud has somewhat the form of a three-rayed star, and in this condition becomes detached and grows into a new prothallium. The prothallia formed in this way often do not develop a flat thallus, but may remain filamentous, and each ray may produce antheridia either terminally or laterally (Fig. I $87, \mathrm{C}$ ). In case a flat thallus is formed, only one or sometimes two of the rays grow out in this form, the other having only a limited growth, and terminating in a short rhizoid. In short, the process is very similar to that in the germinating spores.

\section{The Sexual Organs}

Bower ${ }^{1}$ has investigated the structure of the antheridium in Trichomanes, and Goebel ${ }^{2}$ both Trichomanes and Hymenophyllum. My own study of their development has been confined to an undetermined species of Hymenophyllum from the Hawaiian Islands, but the results of my observations agree entirely with those of other observers. The antheridia arise mainly upon the margin of the prothallium, or upon the ends of the filamentous ones. After the mother cell is cut off, there is usually formed another transverse wall, by which a short pedicel is produced. A funnel-shaped wall does not ever seem to be formed, but the next division walls are more like those in Osmunda, and extend only part way round the circumference of the mother cell. After a varying number of basal cells are thus formed, a dome-shaped wall arises, separating the central

1 Bower (S).

2 Goebel, Ueber epiphytische Farne und Muscineen. Ann. du Jardin botanique de Buitenzorg, vol. vii. 
cell. This wall is not so convex, as is usually the case in the Polypodiaceæ, and in this respect, as well as the form of the wall cells, the antheridium resembles that of Gleichenia. In the Hymenophyllaceæ no cap cell is formed, but as in Osmunda and Gleichenia, the upper cell is divided by walls running over the apex. The divisions in the central cell and the structure of the spermatozoids, so far as these have been studied, correspond with those of the other Leptosporangiatæ.

A single archegonial cushion is not formed, but the archegonia occur in small groups at different points upon the
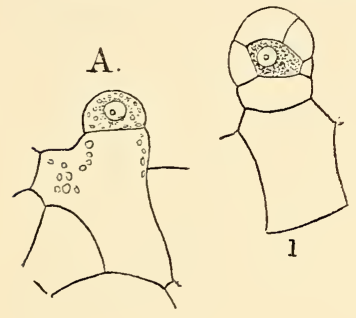

B.

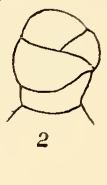

$\mathrm{D}$

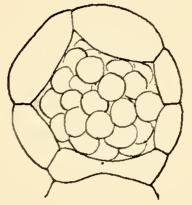

1.

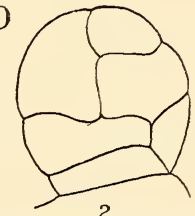

2.
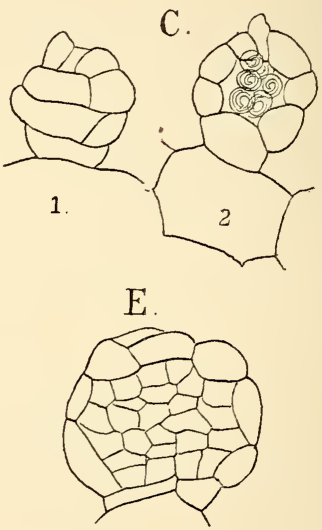

FIG. I89, - Hymenophyllum ( $s p$ ). Development of the antheridium, $x_{2} 60 . A, D$, From living specimens; E, microtome section; $\mathrm{B}_{1}, \mathrm{C}_{2}, \mathrm{D}_{1}$, optical sections; $\mathrm{B}_{2}, \mathrm{C}_{\mathrm{I}}, \mathrm{D}_{2}$, surface view of the same.

margin. Goebel ${ }^{1}$ has shown, however, that these archegonial groups arise first near the growing point of the prothallial branch, and that they are simply separated by the intervention of zones of sterile tissue. At the point where they arise the prothallium becomes more than one cell thick, and in all cases where the development could be certainly followed, the archegonium arose from one of the ventral cells, and never directly from a marginal cell. The details of the development have not been

${ }_{1}$ Goebel, Ueber epiphytische Farne und Muscineen. Ann. du Jardin botanique de Buitenzorg, vol. vii. p. 105. 
followed, and whether there is any division of the neck canal cell is not known. The neck is straight, as in Osmunda and Gleichenia.

In Trichomanes the archegonial meristem (archegoniophore) may be formed as a short branch, directly upon the filamentous prothallium.

The lateral walls of the prothallial cells are in all the forms thicker than is the case in most Ferns, and there are distinct pits in them. In the root-hairs a parasitic fungus is frequently found.
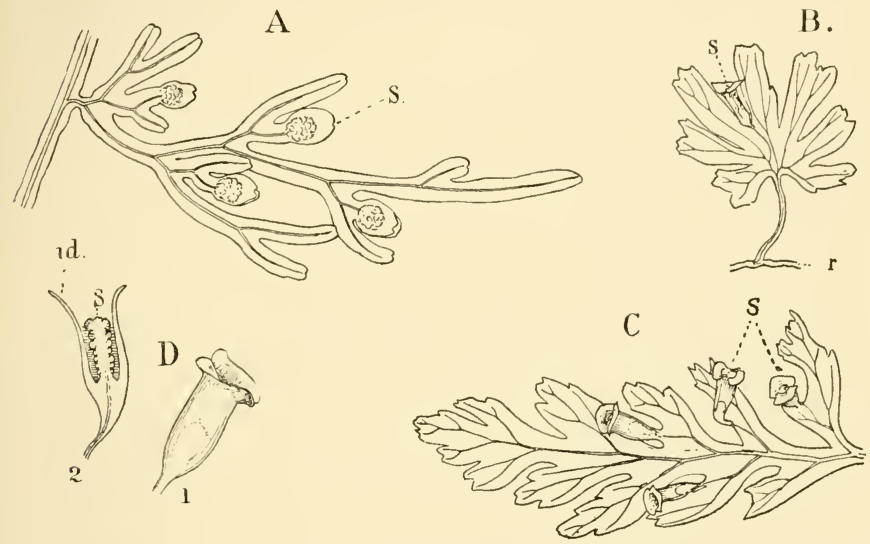

FiG. 19o.-Pinna of the leaf of Hymenophylhum recurum (Gaud.), $\times_{3} ; 1$, part of rhizome $(r)$ and leaf of Trichonzanes parvulum (Poir.), $\times_{3} ; \mathrm{C}$, pinna of the leaf of Trichomanes cyrtotheca (Hilleb.) $\times_{3} ; D_{1}$, trumpet-shaped indusium of the same, $x_{4} ; 2$, section of the indusium (id) with the central sorus, $\times_{5} ; s$, the sorus.

The embryogeny is almost unknown, ${ }^{1}$ but the first divisions and the very young sporophyte correspond closely with those of the other Leptosporangiatx. The cotyledon is simple with a single median vein, and a root is present in all forms yet examined.

\section{The Mature Sporopliyte}

Prantl $^{2}$ has given a very complete account of the structure of the mature sporophyte, and Bower ${ }^{3}$ has added to this by a careful study of the meristems of the different organs. From

1 Janczewski (2).

2 Prantl (I).

3 Bower (II). 
the investigations of the latter it seems that here, as in nearly all other Ferns, the stem apex has the usual three-sided initial cell, but only a small part of the segments give rise to leaves, which are arranged in two ranks. As in Gleichenia, there is a single vascular bundle in the stem, and this, according to Prantl, ${ }^{1}$ is collateral in Hemiphlebium as in Osmunda. The tracheary tissue lies upon the ventral side of the stem, the phloëm on the dorsal side. The pericycle, ${ }^{2}$ which at points shows clearly its common origin with the endodermis, surrounds the whole bundle. The cortex is composed in part of parenchyma, and partly of sclerenchyma. In the sub-genus Hemiphlebium the latter occupies the periphery of the stem, in the others the position is reversed, and it lies next the vascular bundle. In the other forms also the stem bundle is concentric, and corresponds closely with that of Gleichenia.

\section{The Leaf}

The observations on the earliest stages of the leaf are very incomplete, but in some cases at least a two-sided apical cell is present. In those with palmately lobed or entire kidney-shaped leaves, the later growth is marginal, and of the same type found in similar leaves among the Polypodiaceæ. The venation in these forms is exclusively dichotomous, in those with pinnate leaves, e.g. Trichomanes radicans, this is only true of the last formed veins.

With the exception of a very few species, e.g. T. reniforme, $H$. dilatatum, where the mesophyll of the leaves is three to four cells thick, the whole lamina, with the exception of the veins, is single-layered, and of course stomata are completely absent. The form of that leaf is either pinnate, as in the larger species of Trichomanes and Hymenoplyyllum (Fig. I90), reniform ( $T$. reniforme), or palmately divided (T. parvulum, Fig. I90, B). The smaller veins, as in other Ferns, have collateral vascular bundles, and in the smallest ones the xylem may be reduced to a single row of tracheids. The latter may be spiral, reticulated, or scalariform. In the phloëm Prantl could not distinguish any well-marked sieve-tubes, but it was mainly composed of bast

1 Prantl (1), p. 26.

2 Van Tieghem (3) considers the endodermis to be double, and that no true pericycle is present. 
fibres and cambiform cells, and in Hemiphlebium (Trichomanes) Hookeri the phloëm is absent from the very much reduced smaller veins. This is possibly an intermediate condition between the normally developed bundles of the veins of most species and the so-called pseudo-veins, in which there is no tracheary tissue developed, but which in their origin correspond to the ordinary veins. The petiole always has a single vascular bundle, usually of typical concentric structure, but in the section Hemiphlebium Prant ${ }^{1}$ states that it is collateral. The ground tissue of the petiole is largely composed of sclerenchyma like that of the stem.

\section{The Roots}

The development of the roots has been studied only in a very few forms. Bower ${ }^{2}$ states that in $T$. radicans and $H$. demissum it "conforms to the normal type for the root of leptosporangiate Ferns, as described by Nägeli and Leitgeb," but does not go into details, and Prantl $^{3}$ makes an equally brief statement. While lateral roots are completely wanting in the section Hemiphlebium, where their place is taken by leafless branches, in most of the other forms they are developed in considerable numbers. There is, according to Prantl, ${ }^{4}$ great variation in the arrangement of the parts in the vascular cylinder. Thus while all the species of Hymenophyllum have diarch bundles, that of Trichomanes pyxidiferm is monarch, while in one species, T. brachypus, as many as nine primary xylem masses were found. The Marattiacex alone, among the other Ferns, show this great variability.

Trichomes occur, but not so abundantly as in most of the Leptosporangiatæ. They have mostly the form of hairs, which are either temporary (those formed on the margins of the young leaves) of persistent for a longer time, like those that cover the end of the stem apex and bases of the petioles in many species.

\section{The Sporangium}

All of the Hymenophyllacer agree closely in the position of the sporangia, whose development has, however, been studied only in Trichomanes; but from the close correspondence in

\footnotetext{
1 Prantl (I), p. 26.

2 Bower (I I), p. $30 \$$.

3 Prantl (I).

+ Prantl, l.c.
} 
other respects it is not likely that Hymenophyllum differs essentially from the latter. The sorus occupies the free end of a vein, which often continues to grow for a long time in Trichomanes, and forms a long slender placenta or columella, upon which the sporangia arise basipetally. While the receptacle is still very

A

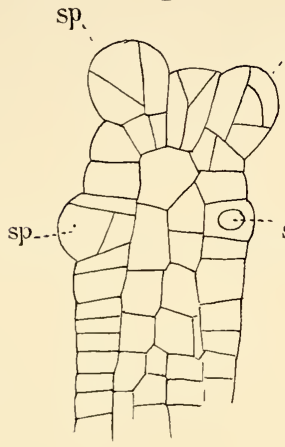

$\mathrm{B}$

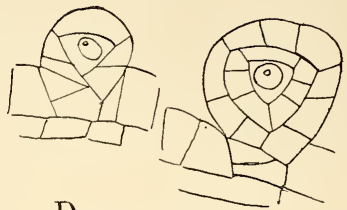

$\mathrm{D}$

$\mathrm{C}$
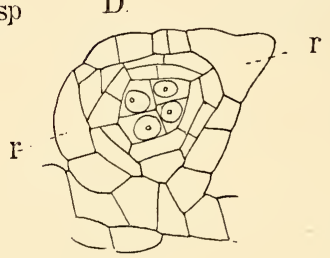

E
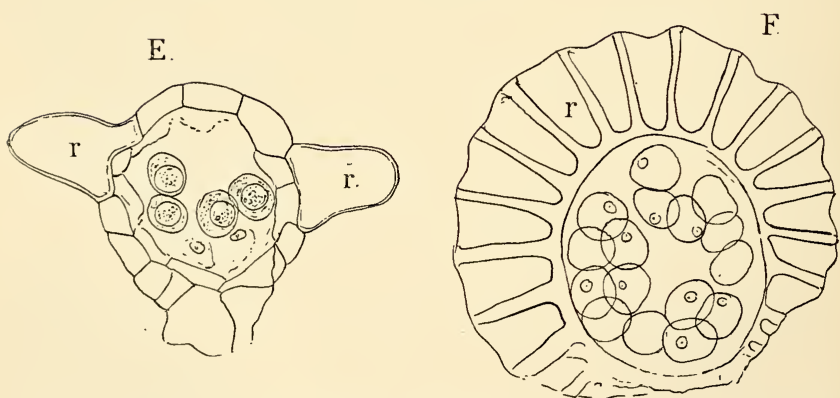

F1G. I9t.-Trichomanes cyrtotheca (Hilleb.). Development of the sporangium, $\times 225$. A, Longitudinal section of very young receptacle with the first sporangia $(s p)$; B-D, successive stages of development seen in longitudinal section; $\mathrm{F}$, horizontal section of nearly ripe sporangium; $r$, the annulus.

young the tissue of the leaf immediately about it forms a ringshaped ridge, which grows up in the form of a cup-shaped indusium, which either remains as a tube (Trichomanes) or is divided into two valves (Hymenopliyllum). Many species of the 
former genus, however, show an intermediate condition, with the margin of the indusium deeply two-lipped.

The first sporangia arise at the top of the placenta (Fig. I 9 I), but the apex itself does not usually develop into a sporangium. After the first sporangia have formed, new ones continue to develop. Near the base of the placenta a zone of meristem is formed, which constantly contributes to its growth, and the young sporangia arise from the surface cells formed from this meristem. The mother cell is very easily distinguished by its larger size and denser contents. About every third cell seems to develop a sporangium, but this probably is not absolutely uniform. The first wall is usually nearly vertical, and cuts off a narrow segment from one side of the mother cell (Fig. I9I, A). This in most cases examined was next followed by a wall almost at right angles, forming a small basal cell. After these preliminary divisions, which form the very short stalk, the next divisions are exactly as in the Polypodiacex, and give rise to the central tetrahedral cell with the four peripheral ones. Prantl ${ }^{1}$ states that the first divisions of the cap cell are also spirally arranged. In T.cyrtotheca (Fig. I9I) the tapetum is massive, and composed throughout of two layers. The archesporium divides into eight cells, whose further history is the same as in other Ferns. The annulus in the Hymenophyllacex is large, and situated much as in Gleichenia. According to Prantl ${ }^{2}$ it arises in part from the cap cell and partly from numbers one and three of the primary peripheral cells. Where the young sporangium is cut longitudinally (Fig. I9I), the annulus cells are at once recognised by their larger size, especially upon the dorsal side. Their radial and inner walls become very thick, and a horizontal section (Fig. I 9 I) shows that the annulus is not complete, but is interrupted on the inner side where the stomium is formed.

\section{Apogamy and Apospory}

Both of these phenomena have been discovered by Bower ${ }^{3}$ to occur not infrequently in Trichomanes, and probably further investigations will reveal other instances. Apogamy was common in $T$. alatum, in which species archegonia were not seen at all, and the origin of the young sporophyte was unmistakably non-sexual. Prothallia, arising directly from the leaf, or from

1 Prantl (1), p. 39.

" Prantl, l.c. p. 40.

3 Bower (\$). 
the sporangial receptacle, were found to be a common phenomenon in the same species.

\section{The Schizaced ${ }^{1}$}

The Schizæaceæ include about sixty species belonging to five genera. The very characteristic sporangia have a terminal annulus, which forms a sort of crown at the apex. Some of them, like Schizca pusilla and Trochopteris elegans, are very small
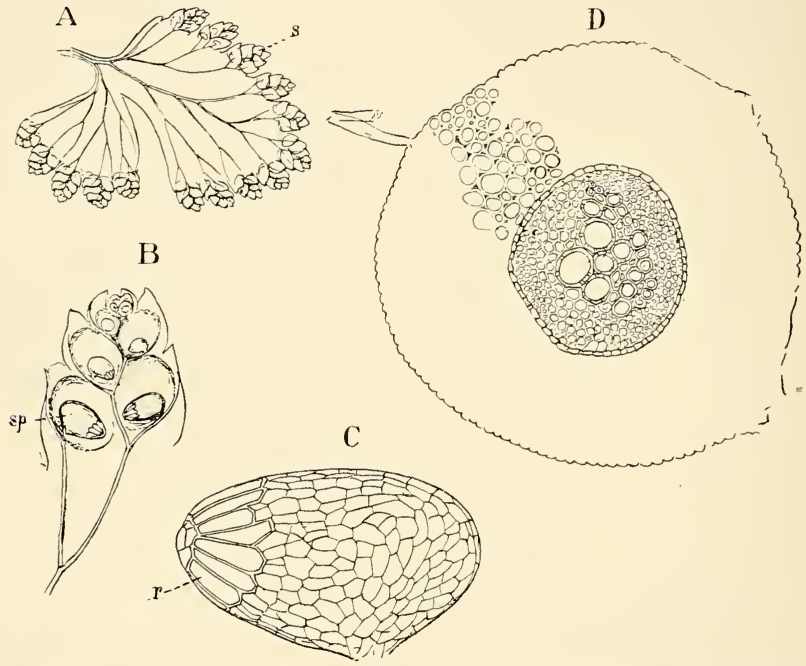

FIG. r92. - Lygodium Japonicum (Sw.). A, Pinnule, $\times_{3} ; s$, the sporangial segments ; B, horizontal section of one of the latter showing the sporangia, $s p, \times_{1_{4}} ; \mathrm{C}$, a single sporangium, showing the terminal annulus $(r), \times 6_{5} ; \mathrm{D}$, cross-section of the petiole, $\times 6_{5}$.

and delicate species; the largest species of Lygodium have fronds 2 or 3 metres in length, but always slender and delicate in texture.

The development of the prothallium corresponds closely to that of the Polypodiaceæ, ${ }^{2}$ but there are one or two peculiarities. The spores are always of the tetrahedral form, and without chlorophyll. The germination follows as in the Polypodiaceæ,

1 Prantl (5).

2 Bauke, Pringsheims Jahrb. f. wiss. Botanik, vol. xi. 
and a filament is first formed, after which the flat prothallium grows for a time by a single apical cell, which is finally replaced by a group of marginal cells. In Aneimia and Mohria the growing point lies on one side, so that the prothallium is not heart-shaped. In Ly'godium, ${ }^{1}$ however, the prothallium has the ordinary form.

The development of the antheridia has been studied by Kny ${ }^{2}$ in Aneimia hirta. The only difference between this and the normal antheridium of the Polypodiacer is that in Aneimia the first wall is always flat instead of funnel-shaped, and the basal cell of the antheridium is therefore disc-shaped. The archegonia appear to correspond exactly with those of the Polypodiaceæ.

The tissues of the sporophyte in Lygodium and Schizaa are much like those of Gleichenia and the Hymenophyllaceæ. As in these the stem is traversed by a single concentric vascular bundle, as well as the petioles. In Aneimia and Moleria the bundles of the stem form a cylindrical network like that of the Polypodiaceæ. The stem bundles are concentric, as are those of the petiole and larger veins in all but Sclizaca, which Prantl ${ }^{3}$ states has collateral bundles throughout, except in the stem. The small veins have collateral bundles as in other Ferns. Sclerenchyma is largely developed, especially in the petioles, where the whole mass of ground tissue in Lygodium (Fig. I 92) is composed of this tissue.

The leaves are pinnate in all the forms except a few species of Schizar. Ly'godium, as is well known, shows a continuous growth at the apex of the leaf, something like Gleichenia, but here the primary apex retains its meristematic condition, and the extremely long and slender axis of the leaf twines about its support like the stem of many climbing plants. The sporophylls are usually smaller than the sterile leaves, or where only portions of the leaf are sporiferous these are much contracted. The anatomy of the leaf corresponds closely with that of the other Ferns. The stomata, which are for the most part confined to the lower side of the leaf, are always arranged in two parallel rows in Schizea, and the peculiar stomata of Aneimia have already been mentioned. The trichomes are for the most part hairs. Only in Mohria do scales occur.

The leaves arise from the upper side of the creeping stem,

1 Bauke, Bot. Zeit. I $\delta 7 \delta$.

${ }^{2}$ Kny (4).

3 Prantl (5), p. 23 
and in Lygodium, Prantl ${ }^{1}$ states that they form but a single row. He also says that the roots are always diarch, like the Polypodiaceæ, but gives no further details of their growth or structure.

\section{The Sporangia}

The development of the sporangia has been carefully investigated by Prantl, $^{2}$ and in origin and arrangement they differ decidedly from the othei Leptosporangiates, but approach most nearly Osmunda, and among the eusporangiate Ferns show a certain likeness to Botrychium. The sporangia arise always in acropetal order from the apex of the terminal segments (sorophore) of the sporophyll, and are strictly lateral in origin, not originating from epidermal cells, but from marginal ones. The young sporangium appears as a lateral outgrowth of the margin, exactly like a young pinna upon the main axis, and the young sorophore has the appearance of a young pinnate leaf, and at this stage recalls strongly the similar one in Botrychium. This is especially marked in Aneimia and Lygodium, less so in Schizea, where the sporangia are smaller, and the mother cells project much more strongly. The early divisions correspond closely with those of the Hymenophyllaceæ, and as there the tapetum is massive and two-layered, and the stalk of the sporangium very short. The wall is derived in major part from the cap cell, which in all the forms becomes much more developed than in any other Ferns, and from it alone the apical annulus is derived. ${ }^{3}$ In Aneimia and Molvia the tissue of the tip of the leaf adjacent to the sporangia grows into a continuous indusium, which pushes them under to the lower side. In Lygodium (Fig. I92) each sporangium very evidently corresponds to a single lobe of the leaf segment, and has a vein corresponding to this. The pocket-like indusium surrounding each sporangium grows up about it much as the indusium of Trichomanes grows up about the whole sorus.

\section{The Cyatheacee}

These are all Ferns of large size, some of them tree-Ferns, Io metres or more in height. They occur in the tropics of

1 Prantl (5).

2 Prantl, l.c.

3 The divisions in the wall are too complicated to be explained without numerous figures. See Prantl's figures, Plates V.-VIII. 
both hemispheres, and some of them, e.g. Dicksonia antarctica, are also found in the extra-tropical regions of the southern hemisphere. They correspond so closely in all respects with the typical Polypodiacex that, except for the slightly different annulus, they might be placed in that family. In some forms, e.g. Alsophila contaminans, the trunk is quite free from roots, and the leaves fall away, leaving very characteristic scars marked by the vascular bundles. In others, like Dicksonia antarctica, the whole trunk is covered with a thick mat of roots, thicker than the trunk itself.

The prothallium is exactly like that of the Polypodiaceæ, so far as it has been studied, ${ }^{1}$ except that in some species of Alsophila there are curious bristle-like hairs upon the upper surface. In the structure of the antheridia the Cyatheaceæ are intermediate in character between the Polypodiacex and the Hymenophyllaceæ. The characteristic funnel-formed primary wall of the former occurs here, but not until one and sometimes two preliminary basal cells are cut off, as in Osmunda or Hymenophyllum. The following divisions correspond exactly with those of the antheridium of the Polypodiaceæ, except that Bauke states that the cap cell, as well as the upper ring cell, may divide again. The dehiscence is effected either by the separation of an opercular cell or by the rupture of the cap cell. The archegonia are like those of the Polypodiacez. In Cyathea medullaris Bauke figures a specimen, however, where the neck canal cell is divided by a membrane. ${ }^{2}$

The first divisions in the embryo correspond with those of the Polypodiacex, but the further development of the young sporophyte is not known.

The position of the sori is that of the typical Polypodiaceæ, and sometimes a decidedly elevated placenta is present. The indusium is either cup-shaped (Cy'athea, Alsophila) or bivalve, e.g. Cibotium (Fig. 193). In the latter the outer valve fits closely over the other like the cover of a box. The sporangia, which are either long or short-stalked, although their development has not been followed, correspond so closely in the mature state to those of the Polypodiacer that there is little doubt that their development is much the same. The annulus is nearly or quite complete, but above the stomium in Cibotium Menziesii the cells of the annulus are broader but thinner-walled

1 Bauke (I).

2 Bauke, l.c. Pl. IX. Fig. S. 
(Fig. I93, C), and Atkinson shows much the same appearance in $C$. Chamissoi. In the former species the stalk is long and composed of three rows of cells, as in typical Polypodiacex. With the sporangia in this species are also numerous long paraphyses (Fig. I 93, D).

The very interesting genus Matonia is represented by the two species $M$. pectinata and $M$. sarmentosa, the latter but recently discovered. Both belong to the Malayan Archipelago,
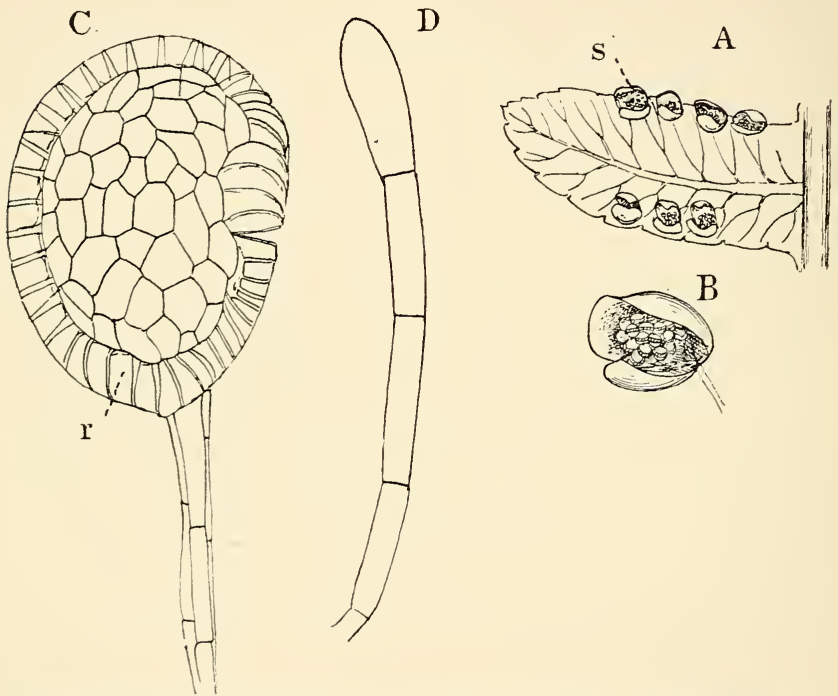

FIG. I93.-Cibotiun Mensiesii (Kaulf). A, Pinnule with the sori $(s), \times_{3} ; \mathrm{B}$, a single sorus showing the two-valved indusium, $\times 9 ; \mathrm{C}$, a single sporangium, $\times 80 ; r$, the annulus; $\mathrm{D}$, a paraphysis, $\times 80$.

and are very restricted in their range. From a study of the latter species Baker ${ }^{1}$ concludes that the genus is the type of a special family intermediate between the Gleicheniaceæ and Cyatheaceæ. The indusium is umbrella-shaped, and firm in texture, and the sporangia are arranged in a circle about its base.

Zeiller, ${ }^{2}$ from a comparison of Matonia with the fossil genus 
Laccopteris, which occurs in early Jurassic beds, concludes that the two genera are very near each other if not identical, and represent the earliest forms of the Cyatheacex, and that Matonia is the last remnant of a group which is now in process of extinction.

\section{The Polypodiacea}

The Polypodiacex may very aptly be compared to the stegocarpous Bryincæ among the Mosses, inasmuch as like that group they give evidence of being the most specialised members of the order to which they belong, and compose a very large majority of the species. Most of them agree closely in their structure, which has been given in detail, and will not be repeated here. With very few exceptions the structure of the prothallium and sexual organs is like that of Onoclea, but one or two variations may be mentioned. In Vittaria, Goebel ${ }^{1}$ has found a type of prothallium recalling that of Hymenophyllum, both in its large size and extensive branching. Its earlier stages show the ordinary development, but it later branches extensively, and, like Hymenophyllum, numerous groups of archegonia are formed upon one prothallium. Bodies resembling the oil bodies of Liverworts are also met with in this genus. The sexual organs closely resemble those of the Polypodiacex, but the antheridia have a well-marked stalk, something like that found often in the Hymenophyllaceæ. Another aberrant genus is Ceratopteris, which differs so much in several respects that it has sometimes been regarded as the type of a separate family. ${ }^{2}$ It is, unlike all other homosporous Ferns, a genuine aquatic, and no doubt this anomalous habit has something to do with its peculiarities, especially the imperfect development of the ring of the sporangium, which, according to Hooker, ${ }^{3}$ is often met with.

The prothallia show some peculiarities as well. Thus, while the early stages are like those of other Polypodiaceæ, the archegonial meristem is developed, not from the apex of the prothallium, but laterally, and quite independent of the original growing point, which is pushed to one side. The antheridia are of the polypodiaceous type, but project less than in the other forms. The sporangia are very large, but correspond in their development with that of the other Polypodiacex:

1 Goebel (9). $\quad 2$ Kny (6).

${ }^{3}$ Hooker (I), p. 174. 
Among the many genera and species aside from these, while there is extraordinary variety, the differences are all of secondary importance, and consist mainly in the form and
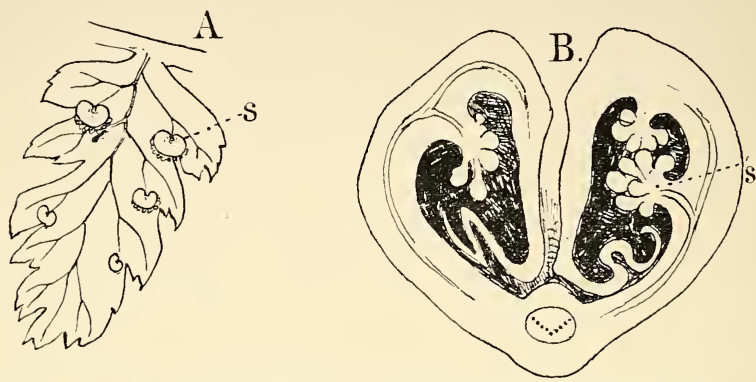

Fig. 194.-A, Pinnule of Aspidium spinulosum (Schw.), showing the sori $(s)$ with kidney-shaped indusium, $\mathrm{X}_{4} ; \mathrm{B}$, cross-section of a pinna from a young sporophyll of Onoclea struthiopteris; $s$, sorus, $\times 40$.

venation of the leaves and the position of the sporangia. The leaves range from the undivided ones of Vittaria or Scolopendrium to the repeatedly divided leaves, usually pinnate, of such forms as Pteris Aquilina. In some tropical epiphytic species,

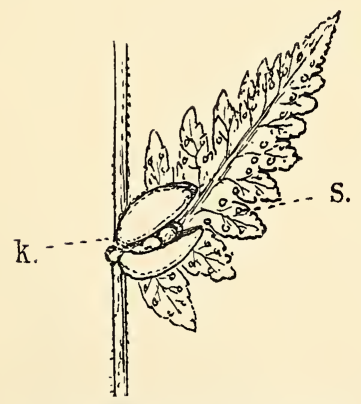

FIG. 195.-Pinna from the leaf of Cystopteris bulbifera (Bernh.), with a bud $(k)$ at the base, $\times_{2} ; s$, the sori (after Atkinson). such as Asplenium nidus, Platycerium, species of Polypodium, the leaves are arranged so that they form receptacles for collecting humus. In the two latter genera these leaves are very much modi-

S. fied, the two forms of leaves being familiar to all botanists in the common Platycerium alcicorne, where the closely overlapping round basal ones are very highly developed. ${ }^{1}$

The sporangia may almost completely cover the backs of the sporophylls, as in Platycerium, or more commonly form definite sori, which may or may not have an indusium. Where

${ }^{1}$ Goebel, Ueber epiphytische Farne und Muscineen. Ann. du Jardin botanique de Buitenzorg, vol. vii. 
the latter is present, it is either formed by the margin of the leaf, as in Adiantum or Pteris, or it may be a special scalelike outgrowth of the lower side of the leaf. In such cases it forms a membraneous covering of characteristic form. Thus in Aspidium (Fig. I94, A) it is kidney-shaped, in Asplenium elongated, and free only along one side. Where, as in Onoclea (Fig. 194, B), the margins of the sporophyll are involute, so as to completely enclose the sori, the indusium is wanting or very rudimentary. 


\section{CHAPTER XII}

LEPTOSPORANGIATE HETEROSPOREA (HIDROPTERIDES) ${ }^{1}$

THE two very distinct families of heterosporous Leptosporangiatæ have obviously but little to do with each other, but, both of them being evidently related to the homosporous forms, they may be placed together for convenience. Each of the two families contains two genera, which in the Marsiliaceæ are closely allied, but in the Salviniaceæ not so evidently so, although possessing many points in common. They are all aquatic or amphibious plants, and the gametophyte, especially in the Marsiliaceæ, is extremely reduced.

\section{Salviniacea}

The two genera, Salvinia and Azolla, contain a number of small floating aquatics which differ very much in the habit of the sporophyte from any of the other Filicineæ, but in the development of the sporangia and the early growth and form of the leaves show affinities with the lower homosporous Leptosporangiatæ, from some of which they are probably derived.

The fully-developed sporophyte is dorsiventral, and the leaves are arranged in two dorsal rows in Azolla, four dorsal and two ventral in Salvinia. The dorsal leaves are broad and overlap, so that they quite conceal the stems. Roots are developed in Azolla, but are quite wanting in Salvinia, where they are replaced physiologically by the dissected ventral leaves (Fig. I96). The sporophyte branches extensively, and these lateral shoots readily separate, and in this way the plants

1 Also known as Rhizocarpex. 
multiply with extraordinary rapidity. The sporangia are enclosed in a globular or oval "sporocarp," which is really an

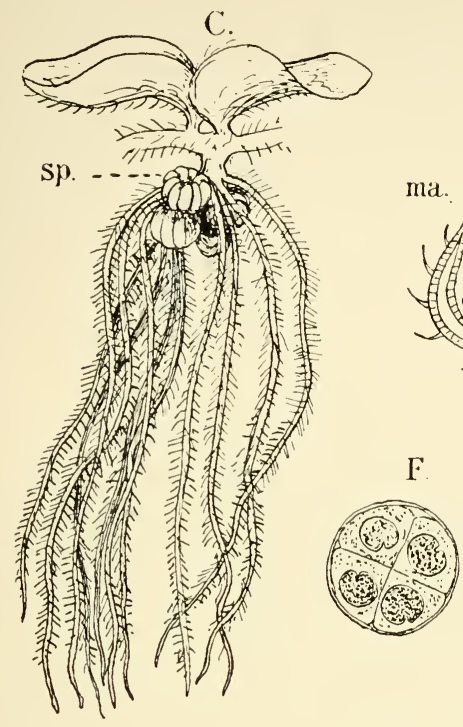

A
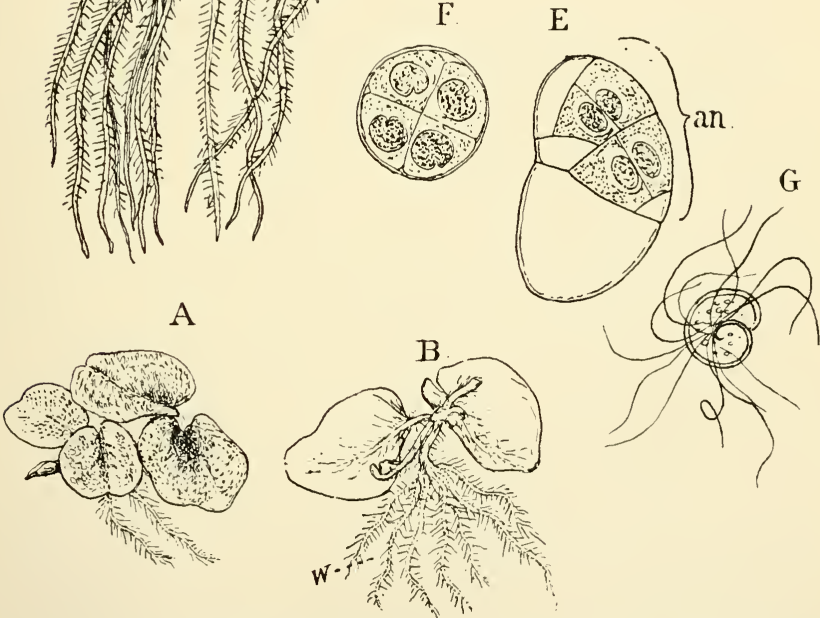

Fig. 196.-Salvinia natans (L.). A, Small plant, $\times 2$, seen from above; B, a similar one from below; $w$, root-like submerged leaf; $\mathrm{C}$, fragment of a fruiting plant, $\mathrm{X}_{2} ; s p$, sporocarps; $\mathrm{D}$, a macrosporangial $(m a)$ and microsporangial $(m i)$ sporocarp in longitudinal section (slightly magnified); E, male prothallium with the single antheridium $(a n)$ from the side, $\times$ I000; F, a similar one seen from above; G, spermatozoid (Figs. C, D after Luerssen).

indusium, much like that of some of the Hymenophyllaceæ and Cyatheaceæ. 


\section{The Gametopliyte}

The first account of the development of the sexual stage of the Salviniaceæ that is in the least degree accurate is Hofmeister's, ${ }^{1}$ who made out some of the most important points in the development of the female prothallium. Pringsheim's ${ }^{2}$ classic memoir on Salvinia added still more, as well as Prantl ${ }^{3}$ and Arcangeli, ${ }^{4}$ but none of these observers were able to follow accurately the earliest divisions in the germinating macrospores. Berggren's ${ }^{5}$ account is the only one on the female prothallium of Azolla, except a paper by the writer, but Belajeff ${ }^{6}$ has given an excellent account of the germination of the microspores.

\section{The Male Prothallium}

The microspores at maturity are embedded firmly in a mass of hardened protoplasm, which in Salvinia fills the whole sporangium, in Azolla is divided into separate masses, "massulæ." The wall of the sporangium in Azolla decays and sets these free in the water, but in Salvinia the wall of the sporangium is still evident when the germination takes place. In the latter the young prothallium grows into a short tube, whose basal part is separated as a large vegetative cell, from whose base later, Belajeff ${ }^{7}$ states, a small cell is cut off. The upper cell becomes the antheridium. In it is first formed in most cases an oblique wall, which Belajeff states is always followed by another similar one, which forms a central sterile cell separating the two groups of sperm cells. This cell, however, did not occur in the specimens studied by me, when the two groups of sperm cells were usually in immediate contact (Fig. I 96, E). From each of the upper cells peripheral cells are cut off, but they do not completely enclose the sperm cells, which are in contact with the outer wall of the antheridium. A cover cell corresponding to that in the ordinary Fern antheridium is more or less conspicuous. Each of the central cells divides by cross-walls into four, and there are thus eight sperm cells in the ripe antheridium. The spermatozoids of Salvinia have about two complete coils, and a smaller number of cilia than is usually the case in the Filicinex (Fig. 196, G).

\footnotetext{
${ }^{1}$ Hofmeister (I), p. $328 . \quad{ }^{2}$ Pringsheim (I). $\quad{ }^{3}$ Prantl (4). ${ }^{4}$ Arcangeli (I).

${ }^{5}$ Berggren (2). ${ }^{6}$ Belajeff (3). 7 Belajeff (3) in Bot. Centralblatt, I892, p. 328.
} 
In Azolla the contents of the ungerminated microspore, whose wall is thin and smooth, contain but little granular matter. The first indication of germination is the rupturing of the exospore along the three radiating ventral ridges, and the protrusion of a small papilla. This is cut off by a transverse wall near the top of the spore cavity, and forms at once the mother cell of the single antheridium (Fig. I 97, C). Belajeff ${ }^{1}$ says the next divisions are nearly parallel and divide the antheridium into three cells, one above the other, and of these
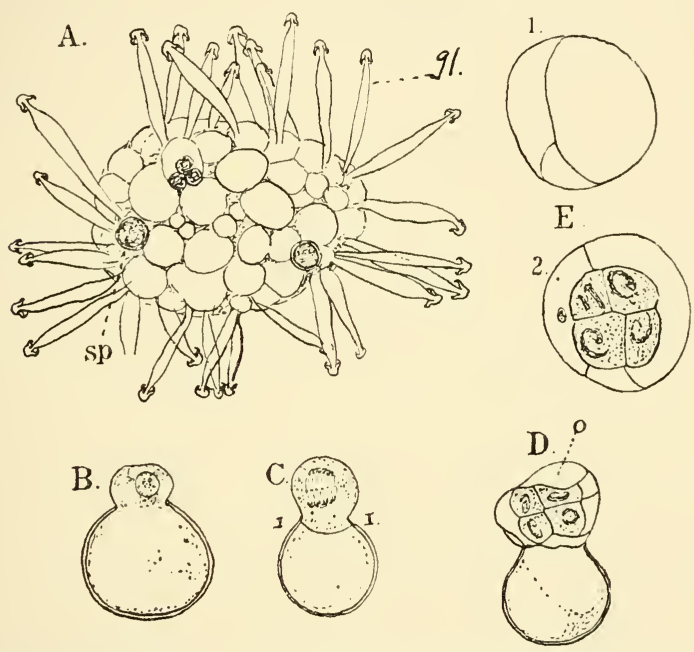

Fig. 197.-Azolla filiculoides (Lam.). A, Massula with enclosed microspores $(s p), \times 250 ; g l$, glochidia; B-D, development of male prothallium and antheridium, $\times 560 ; 0$, opercular cell; $\mathbf{E}$. two cross-sections of a ripe antheridium, $\times 750 ; \mathrm{I}$, the top ; 2 , nearly median section.

only the middle ones divide further. For some reason, which is not quite clear from his account, Belajeff does not regard the whole upper cell as an antheridium, but says that the latter is only formed after five vegetative cells have been cut off. It seems much more in accordance with the structure found in the related homosporous Ferns to regard the whole upper part of the prothallium as the antheridium. In spite of his statement that the development of the male prothallium has little in 
common with the true Filices, his figure of Azolla is extraordinarily like the simple male prothallia that sometimes occur among the Polypodiaceæ. The small cell, cut off subsequently from the basal cell, which he describes, I failed to find in any of my sections, and the conclusion reached after careful study was that but one vegetative cell (the large basal one) is formed, and that the rest of the prothallium is to be regarded as a single terminal antheridium.

The subsequent divisions correspond to Belajeff's account. In the middle cell of the antheridium two nearly vertical walls are formed, which with the top cell (cover cell) completely enclose the central one. The cover cell recalls in form and position the same cell in the antheridium of the Polypodiaceæ, but is formed here previous to the separation of the central cell. In one of the lateral cells a horizontal wall is formed, so that the sperm cells are surrounded by five parietal ones. The central cell now divides by a median vertical wall, and each of the daughter cells twice more, so that eight sperm cells are formed, as in Salvinia. The prothallium remains embedded in the substance of the massula, and the spermatozoids probably escape by the softening of the outer part of the latter. In Salvinia the prothallia project beyond the sporangium wall, and are easily separated.

The antheridiun of the Salviniaceæ does not closely resemble that of any other group. Azolla differs less from the homosporous Ferns in this particular, and shows some resemblance to the Hymenophyllaceæ in the arrangement of the parietal cells. Occasionally a triangular opercular cell occurs in Azolla, which recalls that in Osmunda.

\section{The Female Prothallium}

The macrospores of Azolla filiculoides are borne singly in the sporangia. The spores only germinate after they have been set free by the decay of the indusium, the upper part of which, however, persists as a sort of cap. The decay of the sporangium wall and indusium exposes the curious tuberculate epispore, with its filamentous appendages, which serve to hold the massulæ, which are firmly anchored to them by their peculiar hairs (glochidia) with their hooked tips. This is evidently of advantage by bringing the male and female plants together. 
The macrospores germinate most promptly in the early autumn, and in California, where this species is abundant, this is probably the natural time for germination. As the first stages of germination take place within the completely closed spore, it is difficult to tell precisely just when it begins. So nearly as could be determined, the first division may take place within two or three days, and the whole development be completed within a week.

A section of the ripe spore, still within the sporangium, shows its contents to be nearly uniform, and much like that of Isoetes. The nucleus is here at the apex of the spore cavity and not conspicuous. It is somewhat elongated and stains but little. No nucleolus can be seen.

The first sign of germination is an increase in the size of the nucleus, which becomes nearly globular, and a small nucleolus becomes evident. At the same time the cytoplasm about it becomes free from large granules and indicates the position of the mother cell of the prothallium. This upper part of the spore cavity is now cut off by a nearly straight transverse wall, and this small lenticular cell becomes the prothallium. The granules in its cytoplasm are finer than those in the large basal cell, and the nucleus stains strongly and shows a large nucleolus. The nucleus of the lower cell remains in the upper part, and is much like that of the prothallial cell.

The first division wall in the upper cell is vertical and divides it into two cells of unequal size. In a prothallium having but three cells, the second was also vertical, but in others it looked as if it were horizontal, which Prantl ${ }^{1}$ states is the case in Salvinia. From the upper of the cells formed by the first horizontal wall the first archegonium arises. If the horizontal wall forms early, the primary archegonium is nearly central, but if two vertical walls precede it, its position is nearer the side opposite the first cell cut off. In the few cases where successful cross-sections of the very young prothallium were made, the archegonium mother cell was decidedly triangular, showing that it was formed by three intersecting walls, as in Isoetes. It divides into an outer and inner cell, the latter, as in Isoetes, giving rise at once to egg and canal cells, without the formation of a basal cell.

$\mathrm{Up}$ to this point the exospore remains intact; the central

1 Prantl (4), p. 427. 
cell of the archegonium is only separated from the spore cavity by a single layer of cells, and the young prothallium agrees closely with Prantl's account of the similar stage of Salvinia (Fig. I98, A, B). Berggren's ${ }^{1}$ figures of $A$. Caroliniana, at a stage presumably the same, are too diagrammatic to allow of a satisfactory comparison.

Shortly after the first division in the archegonium a rapid increase takes place in the size of all the cells of the prothallium, by which it expands and ruptures the exospore, which breaks open by three lobes at the top.
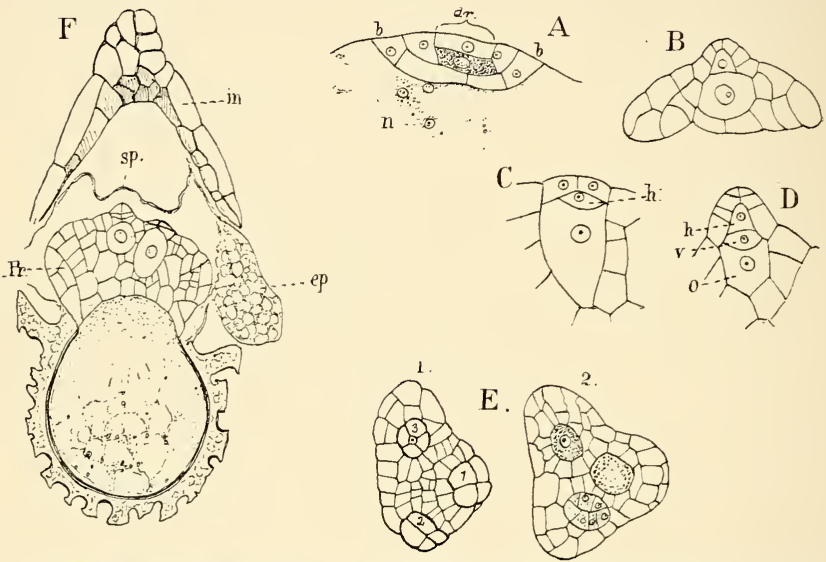

FIG. I98.-Azolla filiculoides (Lam.). A, Longitudinal section through the upper part of the germinating macrospore, $\times 220 ; b, b$, the basal wall of the prothallium; $a r$, young archegonium; $n$, free nuclei; B, similar section of a nearly developed female prothallium, $\times 22.0 ; C, D$, archegonia, $\times_{375} ; h$, neck canal cell ; $v$, ventral canal cell; 0 , egg; E, two transverse sections of a prothallium with the three first archegonia, $\times_{160} ; \mathrm{F}$, median section of a macrospore with large prothallium $(p r), \times 65$; in, indusium; $s p$, remains of sporangium wall; $e p$, perinium.

The most remarkable difference between Azolla and the other Hydropterides is the further development of the lower of the two primary nuclei. In Azolla it undergoes repeated divisions, and the resulting nuclei remain embedded in the protoplasm in close proximity to the lower cells of the prothallium (Fig. I98, A). This nucleated protoplasm is free from the large albuminous granules in the lower part of the spore cavity, and in stained sections presents a finely granular

\footnotetext{
1 Berggren (2), Figs. 7, 9.
} 
appearance, and is evidently concerned with the elaboration of the reserved food materials in the large spore cavity. In exceptional cases indications of the formation of cell walls between these nuclei were seen, but usually they remained quite free. Whether a similar state of affairs exists in Salvinia remains to be seen.

When the first archegonium is ripe, the prothallium is nearly hemispherical, with the originally convex base strongly concave. The central cell of the archegonium is separated by one, sometimes two, layers of cells from the spore cavity, and the neck projects considerably above the surface of the prothallium. The latter now pushes up between the softened episporic mass at the top of the spore, and the archegonium is exposed. In cross-section the prothallium is more or less triangular (Fig. I 98, E), with one angle longer than the others. This longer arm corresponds to the "sterile third" of the prothallium of Salvinia, and represents the first cell cut off from the prothallium mother cell.

If the first archegonium is fertilised, no others are formed; but usually several secondary ones are present. The second archegonium arises close to the primary one; indeed its central cell is generally separated from it only by a single layer of cells. The third forms near the base of the larger lobe (Fig. I98, E). In case all of these prove abortive, others develop between them apparently in no definite order, and to the number of ten or occasionally more. In the older prothallia these later archegonia are sometimes borne in small groups upon elevations between the older ones.

The neck canal cell of the archegonium is formed much earlier than Pringsheim describes in Salvinia, and is cut off from the central cell about the time the first divisions take place in the cover cell. Each row of the neck has four cells, as in Salvinia, and the neck canal cell may have its nucleus divide, as in Isoetes and the homosporous Filicinex. This has not yet been observed in Salvinia.

In Salvinia ${ }^{1}$ the prothallium is large and develops a good deal of chlorophyll. It has a very characteristic appearance; and shows the same triangular form that Azolla does, but from two of the corners long wing-like appendages hang down, and the whole prothallium is saddle-shaped. The side joining the two 
wings is the front, and the primary archegonium occupies the highest point, as in Azolla, and the two secondary ones form a line with it parallel to the forward edge, which develops a meristem and other archegonia in rows parallel to the first ones, in case these fail to be fertilised.

In Azolla the prothallium has but little power of independent existence, and even when unfertilised develops but little chlorophyll. No root-hairs occur (this seems to be true of Salvinia also), and the growtl only proceeds until the materials in the spore are exhausted. To judge from Berggren's figures ${ }^{1}$ A. Caroliniana has a larger prothallium but fewer archegonia than $A$. filiculoides.

\section{The Embryo}

The fertilised ovum, previous to its first division, elongates vertically. The basal wall is usually transverse instead of longitudinal, as in the other Leptosporangiates, although in exceptional cases it may approach this position in Azolla. From the epibasal half in the latter arise, as in the other Leptosporangiatæ, the cotyledon and stem apex; from the hypobasal, foot and root. The quadrant walls do not always arise simultaneously, but as soon as they are formed the primary organs of the embryo are established and are arranged in the same way as in other Ferns. Berggren ${ }^{2}$ asserts that the root does not develop until later, and is derived from the foot; but in sections it is very evident from the first, and corresponds in position exactly with that of other Leptosporangiates.

In all but the stem quadrant the octant walls are exactly median, and this may be true of the latter; but in the stem quadrant the octant wall may make an acute angle with the quadrant wall, and the larger of the two cells then forms at once the two-sided apical cell of the stem, and from now on divides alternately right and left. Where the octant wall is median, it is probable, although this could not be positively proved, that the stem apex forms for a short time three sets of segments instead of two.

In the cotyledon the median octant wall is followed by a vertical wall in each octant, forming two cells that appear respectively triangular and four-sided. The former have larger

1 Berggren (2), Figs. 4-I6.

2 Berggren, l.c. p. 4. 
nuclei and divide for a time after the manner of two-sided apical cells, and perhaps the first division of the leaf quadrant may be of the nature of a true dichotomy, and these cells are the apical cells of the two lobes. In the four-sided cell, the radial and tangential divisions succeed each other with much
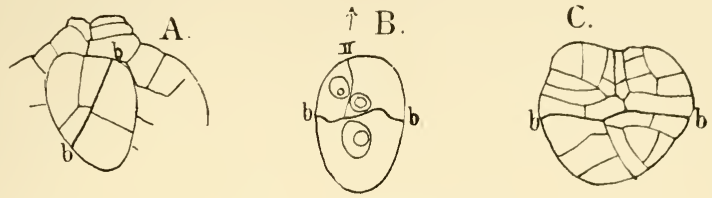
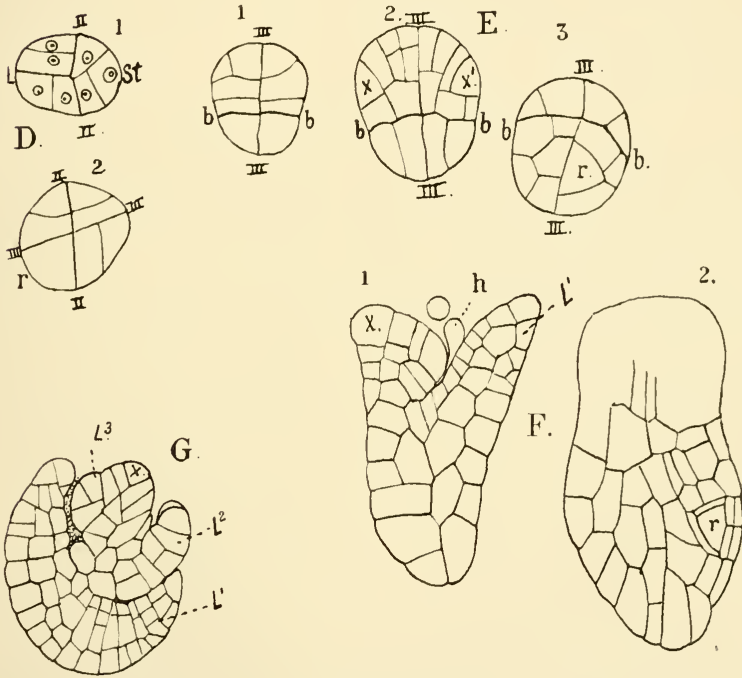

Fig. 199.-Azolla filiculoides (Lam.). Development of the embryo, $\times 350$. A, B, C, Young embryos in median longitudinal section; $\mathrm{D}$, two horizontal sections of a young embryo; $\mathrm{E}$, three transverse sections of a somewhat older one ; $x, x^{\prime}$, initial cells of the cotyledon; $\mathrm{F}$, two longitudinal sections of an advanced embryo; $\mathrm{G}$, horizontal section of an older one, with the rudiments of the second and third leaves; $b, b$, basal wall of the embryo ; st, stem ; $\mathrm{L}^{1}$, cotyledon ; $r$, root ; $h$, hairs ; $x$, apical cell of the stem; $\mathrm{L}^{2}, \mathrm{~L}^{3}$, second and third leaves.

regularity. By the growth of the two initials (Fig. I 99, E, $\left.x, x^{\prime}\right)$ the young cotyledon rapidly grows at its lateral margins and bends forward so as to enclose the stem apex. At the same time the upper marginal cells divide rapidly by oblique 
walls alternately on the inner and outer sides, so that the cotyledon also increases in length, and by this time it is about four cells thick.

As soon as the apical cell of the stem is established, it grows very much as in the mature sporophyte. Each segment divides into a ventral and dorsal half, and each of these into an acroscopic and basiscopic portion. In case the stem octants are equal at first it is not possible to say which is to form the stem apex, but this is determined by the first division in each cell. One of them divides by a vertical wall into equal parts and becomes the second leaf; the other forms the stem apex. If the octants are unequal, the smaller one always forms the leaf. At the base of the cotyledon, between it and the stem, is a group of short hairs (Fig. I 99, F, ll).

The primary root of Azolla arises in exactly the same way as that of the typical homosporous Leptosporangiatæ, except that here the two root octants seem to be always equal in size, and as practically only one of them forms the root, the other dividing irregularly and becoming merged in the foot, the root is more or less decidedly lateral (Fig. I99, E). After one complete set of lateral segments has been formed, the primary cap segment is cut off from the outer face, but, unlike the other Ferns, this is the only one formed. The cap cell divides later by periclinal walls, so that there are two layers of cells covering the apical cell, and these are continuous with the epidermis of the rest of the embryo, and continue to grow at the base, so that a two-layered sheath is formed about the young root. The lateral segments are shallow and arranged very symmetrically, and the divisions correspond to those in the other Ferns.

The divisions in the foot are more regular than is usually the case, and this is especially noticeable in sections cut parallel to the quadrant wall (Fig. I 99, E). The general arrangement of the cells is quite like that of the cotyledon, but the divisions are fewer and the cells larger. Corresponding to the upward growth of the cotyledon, the foot elongates downwards beyond the base of the root, which thus appears as a lateral growth from it, and no doubt led to Berggren's mistake concerning its origin.

Salvinia in its early stages is much like Azolla, but, according to Leitgeb, ${ }^{1}$ the apical cell of the stem is always three-sided at

1 Leitgeb, see Schenk's "Handbuch der Botanik," vol. i. p. 216. 
first, and only later attains its permanent form. The root remains undeveloped, and no later ones are produced, but the first divisions in what corresponds to the root quadrant in Azolla are apparently very similar to those of that plant, and it would perhaps be more correct to say that the primary root remains undeveloped rather than to consider it as completely absent. ${ }^{1}$

The second leaf in the embryo of Azolla arises practically from the first segment of the stem apex, and each subsequent segment also produces a leaf. The early growth in length of the primary root is slow, and it does not become conspicuous until a late stage. The vascular bundles are poorly developed and arise relatively late. No trace of them can be seen until the second leaf is well advanced. Their origin and development correspond to those in other forms described. The tracheary tissue is composed entirely of small spiral tracheids.

The second root arises close to the base of the second leaf, and like all the later ones is of superficial origin. As the cotyledon grows, large intercellular spaces form in it, and the young sporophyte breaks away from the spore or carries the latter with it to the surface of the water. As the embryo breaks through the episporic appendages at the top of the spore, these are forced apart and the cap-shaped summit of the indusium is thrown off. The cotyledon is funnel-shaped, with a cleft on one side, and completely surrounds the stem apex. The root is still conspicuous, and forms only a slight protuberance upon one side of the foot, which looks like a short cylindrical stalk (Fig. 200).

The growth of the first root is limited, and it differs from the later ones by forming peculiar stiff root-hairs. The later roots, except the second, do not seem to bear any definite relation to the succeeding leaves.

A careful examination of the ripe macrosporangium shows a number of colourless small round bodies occupying the space between its upper wall and the indusium. These are the resting cells of a nostoc-like alga-Anabana Azolla,-which is always found associated with this plant. At the same time that the embryo begins to form, these cells become active, assume the characteristic blue-green colour of the growing plant, and divide into short filaments that at first look like short Oscillarice. The cells soon become rounded, and heterocysts are formed. Some of these filaments remain entangled about the stem apex of the 
embryo, while others creep into special cavities which are found in all the leaves except the cotyledon, and here develop into a colony.

The first branch is formed after the plant has developed
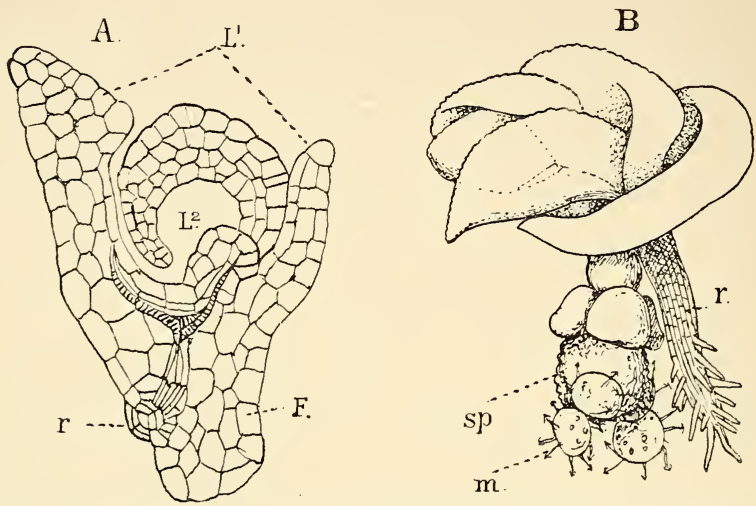

FIG. 200.-Azolla filiculoides (Lam.). Nearly median section of the young sporophyte after it has broken through the prothallium, $\times$ זо०; $\mathrm{B}$, an older plant with the macrospore $(s \not p)$ still attached; $m$, massula attached to the base of the macrospore; $r$, the primary root, $\times 40$.

about eight leaves, but whether its position is constant was not determined.

\section{The Mature Sporophyte}

Strasburger ${ }^{1}$ has investigated very completely the tissues of the mature sporophyte of Azolla, and Pringsheim ${ }^{2}$ has done the same in Salvinia, so that these points are very satisfactorily understood.

The growing point of the stem in Azolla (Fig. 20I, A) is curved upward and backward, in Salvinia (Fig. 203, A) it is nearly horizontal. In both genera there is a two-sided apical cell from which segments arise right and left. Each segment divides into a dorsal and ventral cell, and a transverse section just back of the apex shows four cells arranged like quadrants of a circle. In Azolla the dorsal cells develop the leaves, the ventral ones the branches and roots. Each semi-scgment is 
divided into an acroscopic and basiscopic cell, and these are further divided into a dorsal and lateral cell in the upper ones, into a ventral and lateral one in the lower. The leaves arise from one of the dorsal cells, which may be either acroscopic or basiscopic,

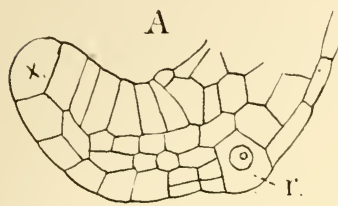

B.
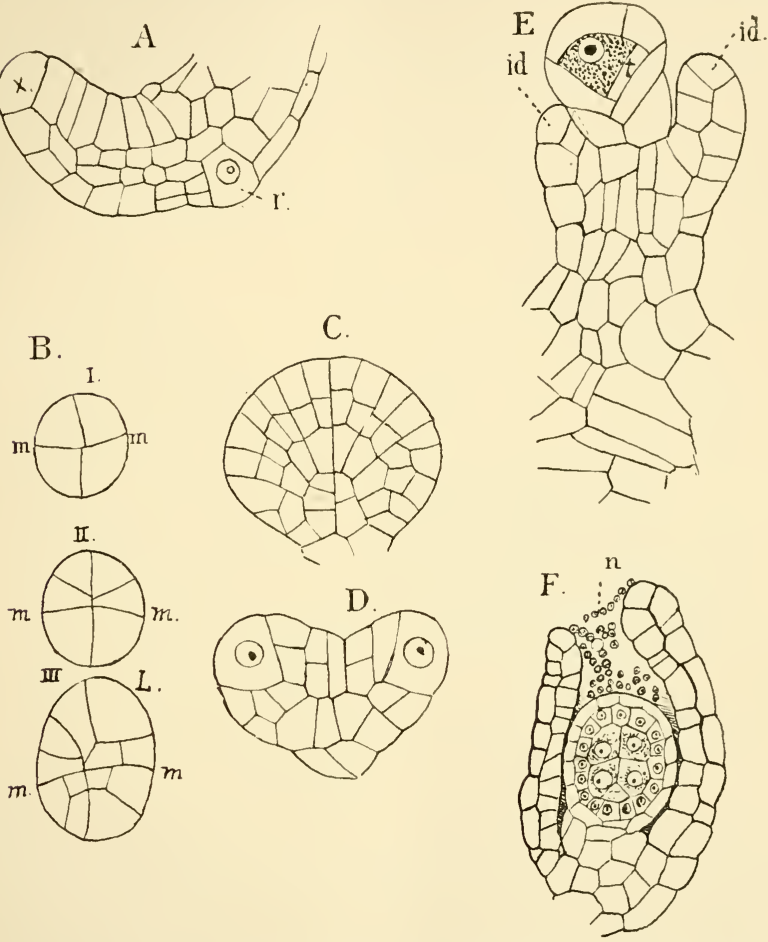

FIG. 20r.-Azolla filiculoides (Lam.). A, Vertical longitudinal section of the stem apex, $\times 600 ; r$, mother cell of a root; $\mathrm{B}$, three successive transverse sections just back of the apex; $m$, the median wall; L, mother cell of a leaf, $\times 600 ; C$, single lobe of a young sterile leaf, $\times 600 ; D$, fertile leaf segments with two very young sporocarp rudiments, $\times 600 ; \mathrm{E}$, longitudinal section of young macrosporangium, showing the young indusium (id), $\times 600 ; t$, first tapetal cell; $\mathrm{F}$, older macrosporangium completely surrounded by the indusium, $\times 35^{\circ} ; n$, Anabana filaments.

but is always constant on the same side of the shoot, so that the two rows of leaves alternate. The lateral buds, which do not seem to appear at definite intervals, arise from one of the 
upper cells of the ventral segment, and alternate with the leaves on the same side of the stem.

The mother cell of a leaf is distinguished by its size and position (Fig. 20I, B, III, L), and the first division wall, as in the cotyledon, divides it into two nearly equal lobes. No trace of an apical cell can be found in the young leaf, and in this respect, as well as the secondary divisions of the stem segments, Azolla differs from Salvinia, where for a long time the young leaves grow, as in most Ferns, by a two-sided apical cell (Fig. 203, A). Each leaf lobe in. Azolla is divided into an inner small cell and an outer larger one, and the latter is then divided by a radial wall. This formation of alternating tangential and radial walls
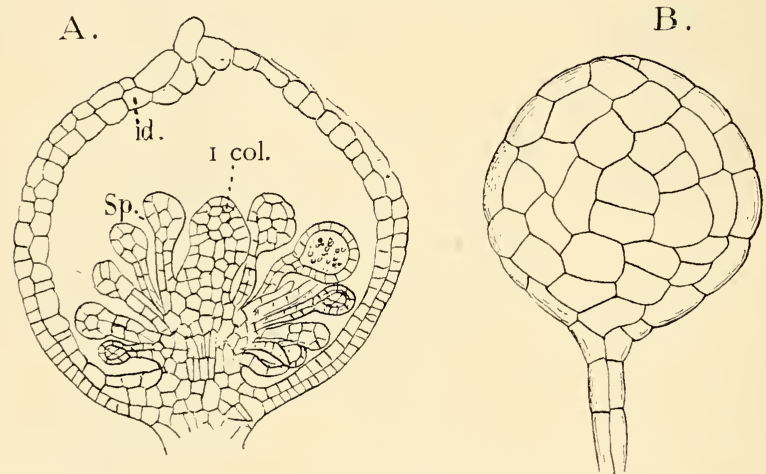

FIG. 202.-A, Young microsporangial sorus of A. filiculoides, $\times 80 ;$ col, columella ; id, indusium; $\mathrm{B}$, nearly ripe microsporangium, $\times 225$.

is repeated with great regularity, and can be traced for a long time. It is not unlike the arrangement of cells figured by Prantl ${ }^{1}$ in some of the Hymenophyllaceæ.

The fully-developed leaves of Azolla are all alike. In A. filiculoides the two lobes are of nearly equal size, the lower or ventral one, which is submersed, somewhat larger, but simpler in structure. The dorsal lobe shows a large cavity near its base (Fig. 204, A), which opens on the inner side by a small pore. On the outer side the epidermal cells are produced into short papillate hairs, which in some species, e.g. A. Caroliniana, are two-celled. Stomata of peculiar form (Fig. 204, B) occur on 
both outer and inner surfaces. The bulk of the leaf is composed of a sort of palisade parenchyma, and the cavity is partly encircled by an extremely rudimentary vascular bundle. The ventral lobe of the leaf is but one cell thick, except in the middle, where there is a line of lacunar mesophyll, traversed by a simple vascular bundle.

In Salvinia the leaves are of two kinds. The dorsal ones are undivided, and traversed by a single vascular bundle. The
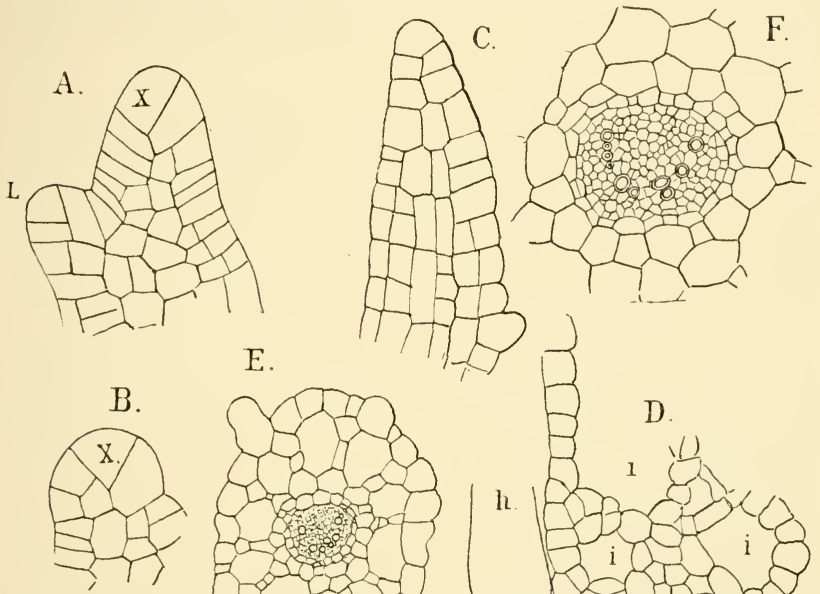

E.
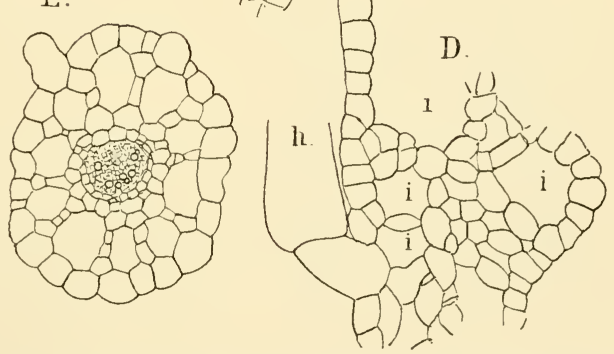

FIG. 203.-Salvinia natans (L.). A, Horizontal section of the stem apex, $\times 450$; L, young leaf; B, a young leaf, showing the apical cell $(x), \times_{450}$; C, longitudinal section of a segment of a ventral leaf, $\times_{450} ; \mathrm{D}$, section of a dorsal leaf; $i$, lacunæ; $h$, hair, $\times 225 ; \mathrm{E}$, cross-section of the stem, $\times 50 ; F$, the vascular bundle, $\times 225$.

mature leaf shows two layers of large air-chambers, separated only by a single layer of cells, whose walls are like those of the epidermis. From both upper and lower surfaces, but especially the former, numerous hairs develop. The ventral leaves are repeatedly divided, and each segment grows by a definite apical cell ; the segments are long and root-like, and covered with numerous long delicate hairs, looking like rhizoids. These submersed 
leaves doubtless replace the roots. The leaves in Salvinia are arranged in alternating whorls of three, corresponding to the nodes, and this arrangement accounts for the six rows of leaves previously referred to.

The mature stem shows a central concentric vascular bundle (Fig. 203, E, F), whose tracheary tissue is somewhat more compact and the tracheæ larger in Azolla. This is surrounded by a definite endodermis and one or two layers of larger parenchyma cells, and radiating from the latter are plates of cells separated by large air-spaces, and connecting the central tissue with the epidermis (Fig. 203, E).

The lateral branches arise in acropetal order, but apparently not always at equal intervals. Their development is a repetition of that of the main axis. Like the branches, the roots in Azolla arise acropetally, and their number is very much less than the leaves. They arise from superficial cells and follow exactly in their development the primary root of the embryo. The inner layer of cells of the sheath, however, in these later roots becomes disorganised, and there is a space between this and the root itself. A single root-cap segment only is formed subsequent to the primary one from which the sheath forms, and this secondary cap segment undergoes division but once by periclinal walls (Fig. 204, C).

\section{The Sporangia}

The sporangia in both genera are contained in a so-called sporocarp, which is really a highly-developed indusium. These sporocarps always arise as outgrowths of the leaves, in Salvinia from the submersed leaves, in Azolla from the ventral lobes. In Salvinia several are formed together (Fig. I96, C), in Azolla two, except in $A$. Nilotica, where there are four. Each sporocarp represents the indusiate sorus of a homosporous Fern.

In Azolla filiculoides these sori arise, as Strasburger ${ }^{1}$ showed, from the ventral lobe of the lowest leaf of a branch. My own observations in regard to the origin differ slightly from his in one respect. Instead of only a portion of the ventral lobe going to form the sori, the whole lobe is devoted to the formation of these, and the involucre which surrounds them is the reduced dorsal lobe of the leaf, and not part of the ventral one. 
The leaf lobe, as soon as its first median division is complete, at once begins to form the sporocarps, each half becoming transferred directly into its initial cell. In this, walls are formed, cutting off three series of segments (Fig. 2OI, D). Next a ring-shaped projection arises about it, and this is the beginning of the indusium (id) or sporocarp, which bears exactly the same relation to the young sorus that it does in Trichomanes, and Salvinia shows the same thing. From this point the two sorts of sporocarps in Azolla differ. In the macrosporic ones the apical cell develops directly into the single sporangium; in

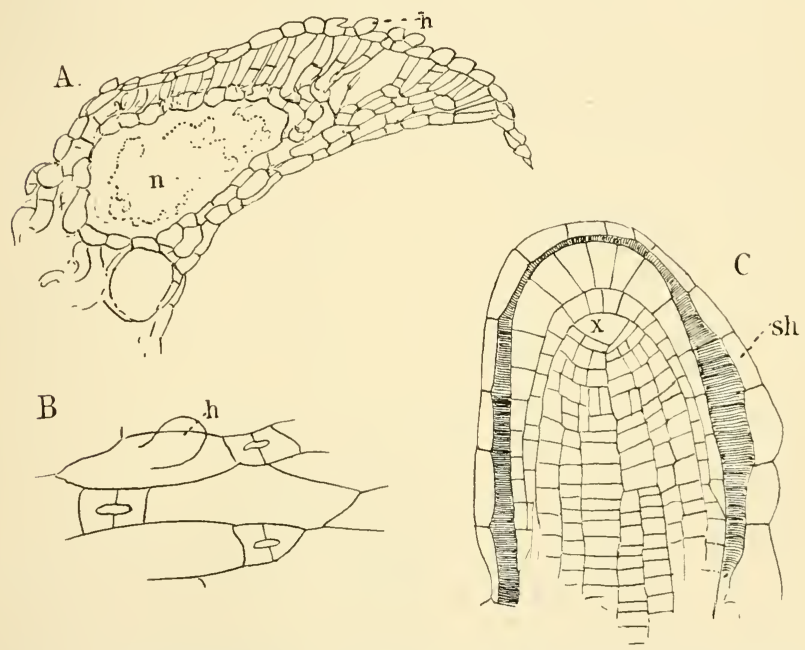

FIG. 204. - Azolla filiculoides (Lam.). A, Longitudinal section of a dorsal lobe of the leaf, $\times$ about $40 ; n$, cavity with colony of Anabana; $h$, unicellular hairs; $\mathrm{B}$, epidernis with stomata, $\times_{150}$ (after Strasburger); C, longitudinal section of young root, $\times 225 ; s h$, root-sheath.

the microsporic ones it forms the columella, from which the microsporangia arise secondarily.

The development of the sporangia follows closely that of the other Leptosporangiatre up to the final development of the spores. The tapetum is composed of but a single layer of cells in Azolla, but in Salvinia it usually becomes double. In both 
genera the wall remains single-layered, and no trace of an annulus can be detected.

In the macrosporangium of Azolla the archesporium produces eight sporogenous cells, the microsporangium sixteen. In Salvinia, according to Jurányi, both sporangia contain sixteen spore mother cells. ${ }^{1}$ Shortly after the divisions are completed in the central cell and tapetum the cell walls of the latter are dissolved, but for a time the sporogenous cells remain together. Finally, they become isolated and round off before the final division into the young spores takes place. In the macrosporangium only one spore finally develops. This is at first, in Azolla, a thin-walled oval cell lying free in the enlarged cavity of the sporangium. Examination shows it to be surrounded by a thick layer of densely granular nucleated protoplasm derived from the tapetum. As the spore grows the surrounding protoplasm and the abortive spores are used by it as it develops, and through their agency the curious episporic appendages of the ripe spore are deposited upon the outside. The spore itself is perfectly globular and surrounded by a firm yellowish exospore, which in section is almost perfectly homogeneous. The epispore covering this shows over most of the spore a series of thick cylindrical papillæ, from the top of which numerous fine threadlike filaments extend. In section the epispore shows two distinct parts, a central spongy-looking mass and an outer more homogeneous part covering all but the tops of the papillæ. At the top of the spore are three episporic masses, composed entirely of the spongy substance and surrounding a central conical mass from whose summit extend numerous fine filaments like those growing from the rest of the epispore. The name "swimming apparatus," which has been applied to this apical mass, is a misnomer, as the ripe sporangium sinks promptly when freed from the plant.

The indusium rapidly grows above the young macrosporangium, or group of microsporangia, and its walls, which become double, converge at the top and finally become completely closed. In the former, before this happens, filaments of Anabana creep in and enter the resting condition. Thus they remain until growth is resumed with the germination of the spore, when the embryo is infected. The upper cells of the indusium become very dark-coloured and hard, and remain after the lower

1 Heinricher (2), however, states that there are but eight, as in Azolla. 
part decays. The wall of the macrosporangium does not
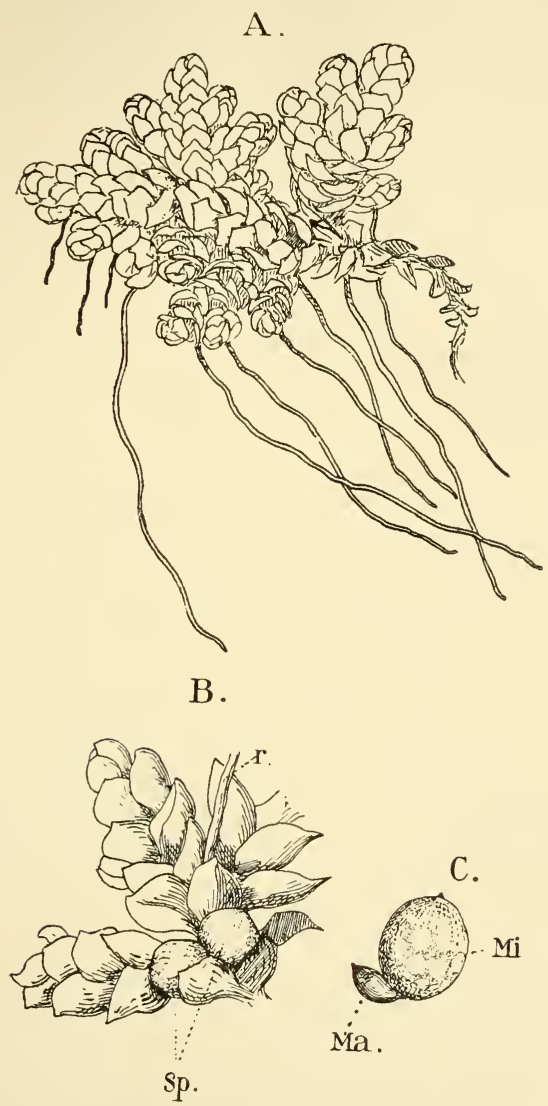

Fig, 205.-A zolla filictuloides (Lam.). A, Mature sporophyte, $\times_{2} ; \mathrm{B}$, lower surface of a branch with two microsporangial sori $(s p), \times 6 ; \mathrm{C}$, macrosporangial ( $m a$ ) and microsporangial ( $m i$ ) sori, $\times$ Io.

become absorbed, as Strasburger ${ }^{1}$ states, but remains intact, though very much compressed, until the spore is ripe. 
In the microsporic sorus, the apex of the placenta does not develop sporangia, but remains as a sort of columella (Fig. 202, A).

The sporocarps of Salvinia are like those of Azolla, but the two layers of cells are separated by a series of longitudinal airspaces which correspond to ridges upon the surface of the sporocarp (Fig. I 96, D).

The microsporangia of Azolla have a long stalk, which is composed of usually two, but sometimes three rows of cells. The sixteen sporogenous cells all develop, so that there are normally sixty-four microspores in each sporangium. These have the exospore thin and smooth, and are included in a kind of common epispore, which here too owes its origin mainly to the tapetal cells. This episporic substance is divided into masses (massulæ), which have the foamy structure of the episporic appendages of the macrospore. This appearance is apparently due to the formation of vacuoles, which make these massulæ look as if composed of cells. The tapetal nuclei are confined to the outside of the massulæ, and can be detected almost up to the time they are fully developed. Finally, upon the outside of the massulæ are formed the curious anchor-like "glochidia" (Fig. I 97, $g l$ ), whose flattened form is due to their formation in the narrow spaces between the massulæ.

In Salvinia the microsporangia arise as branches from sporangiophores which bud out from the columella, so that their number much exceeds that of the macrosporangia, or of the microsporangia of Azolla. There are no separate massulæ, and in the macrosporangium the epispore is much less developed than in Azolla.

\section{The Marsiliacee}

The two genera of the Marsiliacex, Marsilia and Pilularia, are much more closely related than Salvinia and Azolla, and at the same time their resemblance to the homosporous Ferns is closer, and of the two genera Pilularia is evidently the nearer to the latter. The development of both gametophyte and sporophyte in the two corresponds very closely.

The sporangia are borne in "sporocarps," which are morphologically very different from those of the Salviniaceæ, being metamorphosed leaf segments enclosing several sori, and not single sori enclosed simply in an indusium. The spores germinate with extraordinary rapidity, especially in Marsilia, 
and in $M$. Esyptiaca the writer has found a two-celled embryo developed within thirteen hours from the time the ungerminated spores were placed in water.

The sporocarp of Marsilia is a bean-shaped body, which is attached to the petiole of the leaf by a more or less prominent pedicel. It is very hard, and unless opened artificially may remain a long time unchanged, if placed in water; but if a little of the hard shell is cut away, the swelling of the interior mucilaginous tissue quickly forces apart the two halves of the

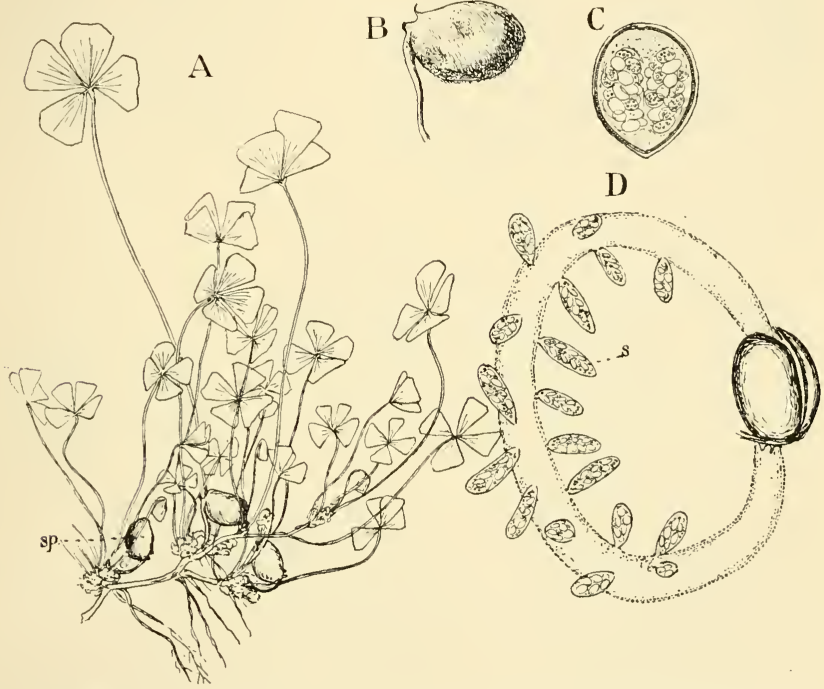

FIG. 206.-Marsilia vestita (Hook and Grev.). A, Fruiting plant of the natural size; sp, sporocarps; $\mathrm{B}$, a single sporocarp, $\mathrm{x}_{4} ; \mathrm{C}$, cross-section of the same, $\mathrm{x}_{5} ; \mathrm{D}$, germinating sporocarp, showing the gelatinous ring by which the sori $(s)$ are carried out, $\times_{3}$.

fruit. As more water is absorbed, this gelatinous inner tissue continues to expand and forms a long worm-shaped body (Fig. $206, D)$, to which are attached a number of sori, each surrounded by a sac-shaped indusium in which the sporangia are closely packed. Macrosporangia and microsporangia occur in the same sorus. The former contain a single large oval white spore, the latter much more numerous small globular ones. The indusium remains intact for several hours, if not injured, 
but finally, with the sporangium wall, is completely dissolved, and the spores set free.

\section{The Microspores and Male Prothallium}

The microspores of $M$. vestita (Fig. 207) are globular cells about $.075 \mathrm{~mm}$. in diameter. The outer wall is colourless and
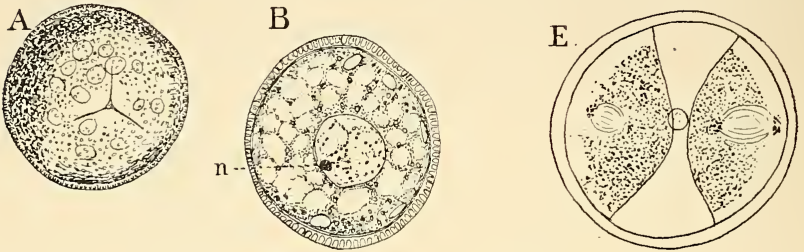

$\mathrm{D}$
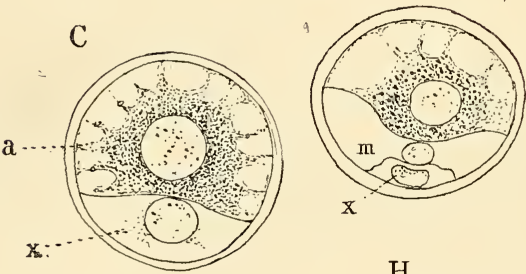

H.
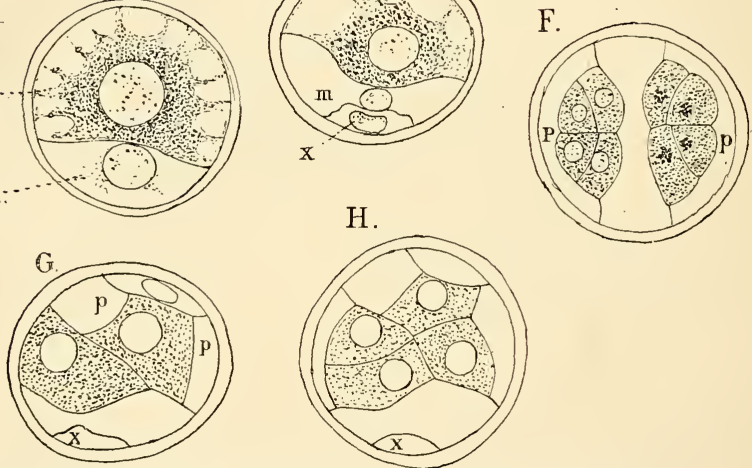

Fig. 207.-Marsilia vestita (Hook and Grev.). Germination of the microspores, $\times 450$; $x$, vegetative prothallial cell; $m$, basal antheridial cell; $p$, peripheral antheridial cells; $A$, an ungerminated spore, ventral aspect; $\mathrm{B}$, section of a similar one-all longitudinal sections except $\mathrm{E}$ and $\mathbf{F}$, which are transverse. In these the two groups of sperm cells are separated by a large sterile cell.

sufficiently transparent to allow the contents to be dimly seen. Lying close to the wall are numerous distinct starch granules, and in the centre the nucleus is vaguely discernible. Sections through the ungerminated spore show that the wall is thick, with an inner cellulose endospore, outside of which are the 
exospore and the epispore or perinium, composed of closely-set prismatic rods. The central nucleus is large and distinct, with usually one or two nucleoli.

The first division takes place at ordinary temperatures, about $2 \mathrm{O}^{3} \mathrm{C}$., within about an hour after the spores are placed in water. Previous to this the nucleus enlarges and moves to one side of the spore, usually the point opposite the apex, and the granular cytoplasm collects near the centre and is connected with the peripheral cytoplasmic zone only by thin strands. The first wall divides the spore into two very unequal cells, the smaller containing but little granular contents, and representing the vegetative part of the prothallium, while the upper becomes the antheridium. In Pilularia there is subsequently cut off a small cell from the vegetative cell, and Belajeff ${ }^{l}$ states that this also is the case in Marsilia, but a careful examination of a great many microtome sections of $M$. vestita has failed to show it in that species. The next division is not always the same, but is usually effected by a wall nearly parallel to the first one, but more or less concave, being in fact the homologue of the first funnel-shaped wall in the antheridium of the Polypodiacex (Fig. $207, \mathrm{D})$. Sometimes the antheridial cell divides at once by an oblique wall into two nearly equal cells, from each of which a group of sperm cells is later cut off. In no case was the central cell cut off by a dome-shaped wall, such as is common in the homosporous Ferns, and also in Pilularia. The formation of this wall is apparently suppressed here, perhaps as the result of the extremely rapid development of the antheridium, and the separation of the sperm cells takes place by walls cut off from the periphery of the two upper cells. A cap cell (Fig. $208, d$ ) is almost always present, as in Pilularia and the Polypodiaceæ.

From the two cells of the middle part of the antheridium a varying number of sterile cells are cut off, which are quite transparent, while the contents of the central cells are very densely granular. Not infrequently the two groups of sperm cells are completely separated by one of these sterile cells (Fig. 207, F), but this is by no means always the case, and does not justify Belajeff's ${ }^{2}$ interpretation of each group representing a separate antheridium. It is simply a more complete separation of the two primitive groups of sperm cells

${ }^{1}$ Belajeff (3), p. 33 .

2 Belajeff, l.c. 
which is indicated by the first vertical wall in the central cell of the antheridium of all Leptosporangiatæ. The divisions in the central cells are very regular, and the sixteen sperm cells in each group are arranged very symmetrically (Fig. 208). The whole number in $M$. vestita is completed in about seven hours from the time germination begins, and the formation of the spermatozoids commences about an hour later and takes about four hours for its completion. The structure of the fully-developed antheridium will be best understood from a comparison of the three different views (Fig. 208, A, B, C). In these figures $x$
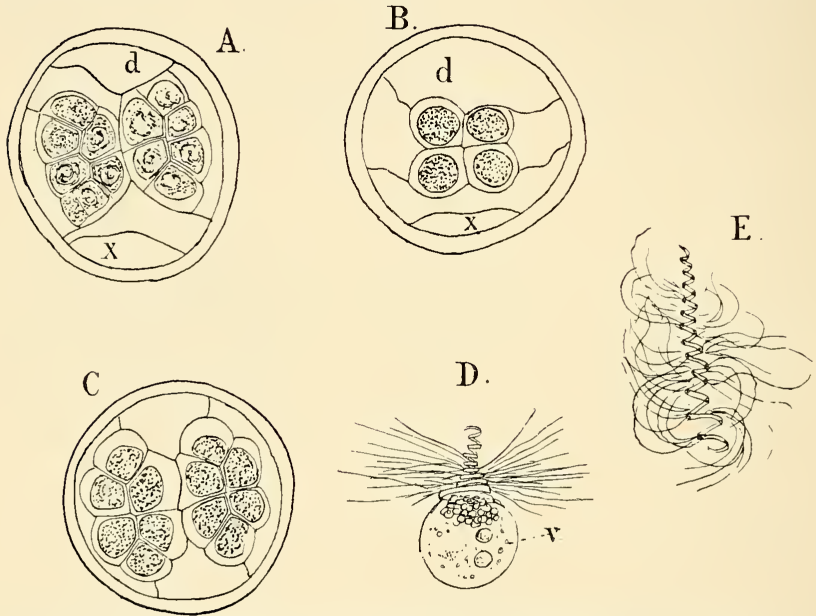

FIG. 208.-A, B, C, Sections made in three planes of the ripe antheridium of Marsilia $z^{\prime e s t i t a, ~} \times 45^{\circ}$; $x$, vegetative prothallial cell $; d$, cover cell of the antheridium; $\mathrm{D}, \mathrm{E}$, spermatozoids, $\times 900 ; v$, the vesicle attached to the large posterior coils.

is the small vegetative cell, $m$ the basal cell of the antheridium, $p$ the lateral wall cells, and $d$ the cover cell. Pilularia approaches much nearer to the Polypodiacex in the structure of the antheridium (Fig. 209). The first funnel-shaped wall is much more frequently extended to the basal wall, and the two groups of sperm cells are much less distinct than in Marsilia.

The spermatozoids of Marsilia are at once distinguished by a great number of coils, sometimes thirteen or fourteen in $M$. vestita. The cilia are very numerous, but are attached only 
to the broad lower coils, the upper narrow ones being quite free from them, and, according to Strasburger, ${ }^{1}$ probably of cytoplasmic nature-unfortunately the development of the spermatozoids in Marsilia is especially difficult to trace. The vesicle attached to the broad lower coils is very conspicuous and contains numerous starch granules as well as albuminous ones. In Pilularia the long upper part of the spermatozoid is absent, and it apparently corresponds only to the

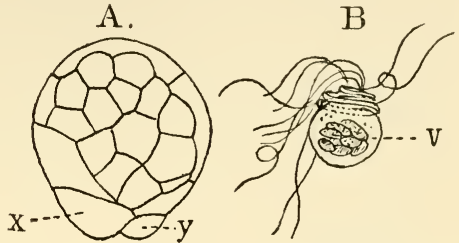

FIG. 209.-Ripe antheridium of Pilularia globulifere (L.), showing the two vegetative prothallial cells $(x, y), \mathrm{X}_{375}$; $\mathrm{B}$, free spermatozoid, showing the large vesicle $\left(\tau^{\prime}\right)$ with the contained starch granules.

few broad basal coils of that of Marsilia, which are of nuclear origin, like the greater part of the body in the spermatozoid of Pilularia.

\section{The Macrospore and Female Prothallium}

The macrospores of the Marsiliaceæ are extremely complex in structure, and are borne singly in the sporangia. In Marsilia vestita they are ellipsoidal cells about $.425 \times .750 \mathrm{~mm}$. in diameter, ivory-white in colour, and covered with a shiny mucilaginous coating. The upper part of the spore has a hemispherical protuberance covered with a brown membrane, and it is the protoplasm within this papilla that forms the prothallium. The apex of the papilla shows the three radiating ridges like those in the microspores, and indicates that, like those, the macrospore is of the radial or tetrahedral type.

Sections of the ungerminated spore (Fig. 2 IO, A) show a structure much like that of the microspore, but more highly developed. A noticeable difference is the segregation of the protoplasm containing the nucleus, which occupies the apical papilla. This is filled with fine granules, but is entirely free from the very large starch grains of the large basal part of the spore. The nucleus is somewhat flattened. A similar arrangement of the spore contents is found in Pilularia, but the apex of the spore does not form a distinct papilla. The epispore is of nearly equal thickness, except at the extreme apex, in

\footnotetext{
1 Strasburger (II), vol. iv, p. I22.
} 
Marsilia, but in Pilularia, especially in $P$. globulifera, the epispore of the upper third is much thicker, and from the outside the spore appears somewhat constricted below this.

Previous to the first division, which in $M$. vestita takes place about two hours after the spores are placed in water, the amount of protoplasm at the apex increases, and the nucleus becomes nearly globular and there is an increase in the amount of chromatin. In Pilularia the first wall is always transverse and separates the mother cell of the prothallium;

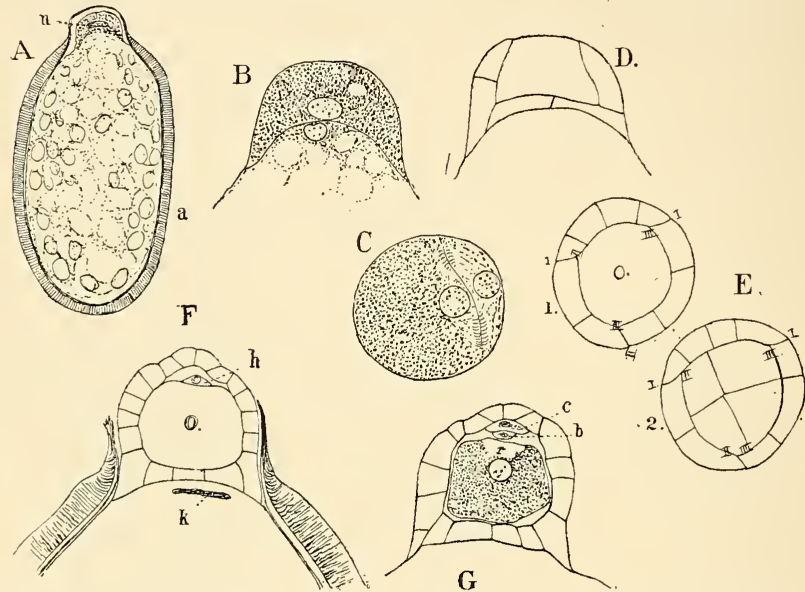

FIG. 210.-Marsilia vestita (Hook and Grev.). Germination of the macrospore; A, Iongitudinal section of the ripe macrospore, $\times 60 ; n$, nucleus; $\mathrm{B}-\mathrm{G}$, successive stages in the development of the female prothallium and archegonium, $\times_{360} ; \mathrm{C}, \mathrm{E}$, transverse sections, the others longitudinal ; $n$, neck canal cell ; $h$, ventral canal cell ; $r$, receptive spot of the egg; $k$, remains of the nucleus of the spore cavity.

but in Marsilia, while this is usually so, occasionally a lateral cell is cut off first from the papilla. In Pilularia the next wall is parallel to this transverse primary wall, and this may also occur in Marsilia, but in the latter more commonly the first lateral cell is first cut off by a vertical wall, and this is followed by two others, which intersect it and include a large central cell (Fig. 2 IO, E), from which a basal cell is subsequently separated. In Pilularia, besides the formation of the basal cell by the second wall, the central cell is, as a rule, cut out by two, 
and not three, walls. The basal cell of the archegonium in Marsilia divides by cross-walls into equal quadrants, and the lateral cells divide both by vertical and horizontal walls before any further divisions take place in the archegonium. This finally divides into the cover cell and inner cell. The neck is very short, especially in Marsilic, and each row has but two cells. These in Pilularia (Fig. 2 I I) are much longer. Both neck and ventral canal cells are very small, especially in Marsilia, and the former has its nucleus undivided. In Marsilia the prothallium grows gradually as the divisions proceed, but in Pilularia (Fig. 2 I I) the young prothallium increases but little in size until the divisions are almost completed, when there is a sudden enlargement. The complete development of the prothallium occupies about twelve to fifteen hours in Marsilia vestita, and in Pilularia globulifera forty to forty-five hours.

The egg in both genera is large, but in Marsilia it is the larger. In both, the receptive spot is evident. The nucleus is unusually small in Marsitio, which otherwise resembles

\section{Pilularia.}

The phenomena of fecundation are very striking in the Marsiliaceæ. The mucilagin-
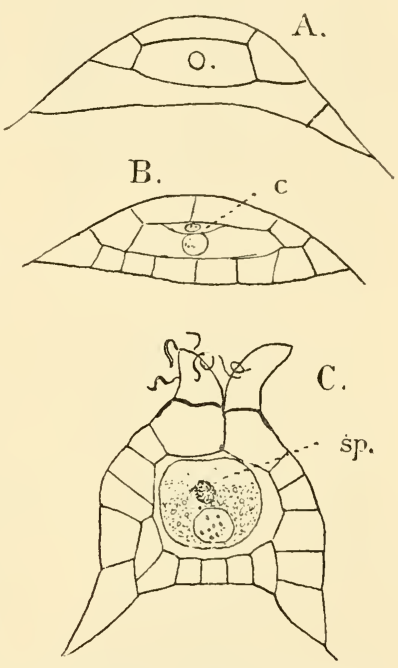

Fig. 2II.-Pilularia globulifera (L.). A, B, Young female prothallia, longitudinal sections, $\times 300 ; c$, neck canal cell; $\mathrm{C}$, section of a recently fertilised archegonium, $x_{3} 00$; $s p$, spermatozoid within the egg.

ous layer about the macrospore attracts and retains the spermatozoids, which collect by hundreds about it. The mucilage above the archegonium forms a deep funnel, which becomes completely filled with the spermatozoids. As these die their bodies become much stretched out, so that they look very different from the active ones, with their closely placed coils. The attractive substance here is not confined to the material sent out from the open archegonium, as the 
spermatozoids collect in equal numbers about those which are still closed, and even about spores that have not germinated at all. Marsilia did not prove a good subject for studying the behaviour of the spermatozoid within the egg, owing to the difficulty of differentiating the spermatozoid after its entrance. Pilularia is better in this respect, and shows that
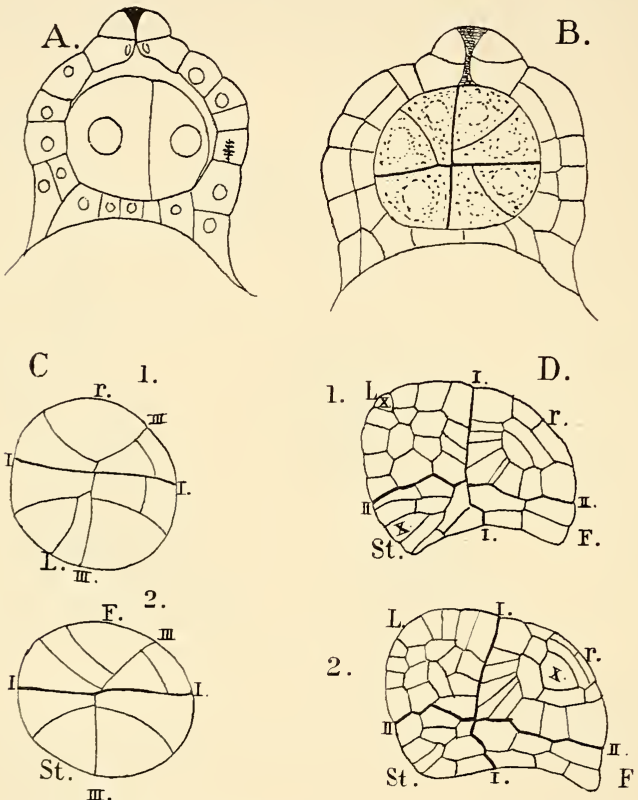

FIG. 212.-Marsilia vestita (Hook and. Grev.). Development of the embryo. A, Longitudinal section of archegonium with two-celled embryo; $\mathrm{B}$, similar section of a later stage; C, two transverse sections of a young embryo; D, two longitudinal sections of an older one; $\mathrm{I}, \mathrm{I}$, the basal wall; L, cotyledon; st, stem; $r$, root ; F, foot. A.C, $\times 525 ; \mathrm{D}, \times 26$ o.

the changes are the same as those described in Marattia and Osmunda.

Coincident with the first divisions in the embryo, each of the lateral cells of the prothallium (venter) divides by a periclinal wall, but the basal layer of cells remains but one cell thick. The prothallium grows with the embryo for some 
time, and in its later stages devclops abundant chlorophyll, and its basal superficial cells grow out into colourless rhizoids. In case the archegonium is not fertilised, the prothallium grows for a long time, and reaches considerable size, but never develops any secondary archegonia. In Pilularia, both prothallium and embryo may develop chlorophyll in perfect darkness. ${ }^{1}$

\section{The Embryo ${ }^{2}$}

The two genera correspond very closely in the development of the embryo, which shows the greatest resemblance to the Polypodiacer. In Marsilia the development of the embryo proceeds very rapidly. The first division of the egg is completed within about an hour after the spermatozoid enters, and in Pilularia after about three hours, as nearly as could be made out. In both the basal wall is vertical and divides the somewhat flattened egg exactly as in Onoclea. The quadrant walls next follow, and then the octant walls, as usual. Of the latter the one in the root quadrant diverges very strongly from the median line (Fig. 2 I 2, C), and that in the foot quadrant is much like it. In the others it is nearly or quite median, and it is impossible to say which of the leaf and stem octants is to form the apical cell of those organs. The relative position of the young organs is exactly the same, both with reference to each other and to the archegonium, as in the Polypodiaceæ.

\section{The Cotyledon}

The cotyledon grows for a time from the regular divisions of one or both of the primary octant cells, but this does not usually continue long, and the subsequent growth is purely basal. The cotyledon is alike in both genera, and is a slender cylindrical leaf tapering to a fine point, where the cells are much elongated and almost colourless. Its growth is at first slow, but at a later period (in Pilularia globulifera about the eighth day) it begins to grow with great rapidity and soon reaches its full size. This is largely due to a simple elongation and expansion of the cells, which are separated in places, and form a series of longitudinal air-channels separated by radiating plates of tissue (Fig. 2 I 3, i). The simple vascular bundle 
traversing the centre is concentric, with a definite endodermis, but the tracheary tissue is very slightly developed. This becomes first visible about the time the leaf breaks through the calyptra.

\section{The Stem}

Of the two octants in the stem quadrant one becomes at once the apical cell of the stem, the other the second leaf, as in other Leptosporangiatæ. The first wall in each octant meets octant and quadrant walls, and cuts off a large cell

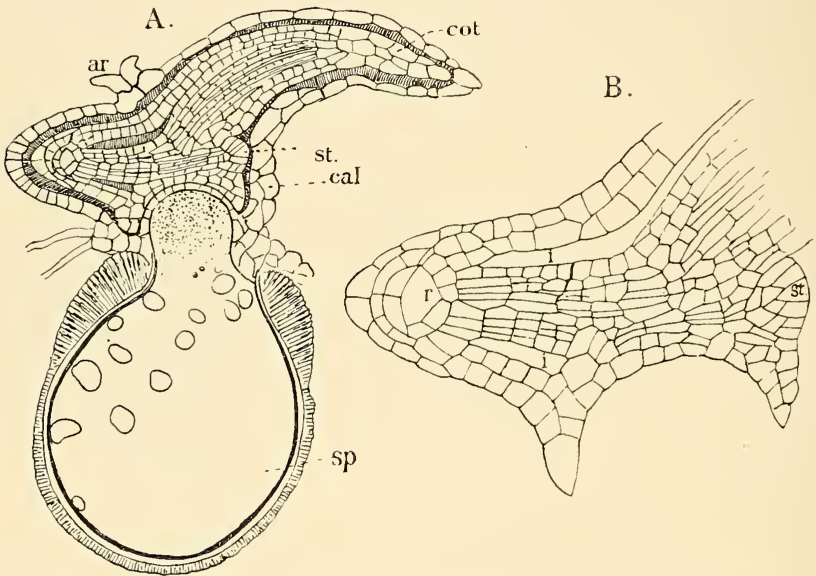

FIG. 2I3.-Longitudinal section of the young sporophyte of Pilularia glahulifera, still enclosed in the calyptra (cal), and attached to the macrospore $(s p), \times 75 ; \mathrm{B}$, the lower part of the same embryo, $\times_{215} ; r$, apical cell of the root ; st, apical cell of the stem; $i$, lacuna.

from each octant, in contact with the foot. Hanstein and Arcangeli regard these as part of the foot, and physiologically they no doubt are to be so considered, but morphologically they are beyond question segments respectively of the stem and second leaf. At first these are not distinguishable from each other, but the divisions in the latter are usually (in Pilularia) less regular, and the apical cell early lost. It may, however, develop a regular three-sided apical cell, like that of the later leaves. The earlier segments of the stem apex are larger than the subsequent ones, and the broadly tetrahedral form of the 
primary octant is reduced to the much narrower form found in the older sporophyte.

\section{The Root}

The first wall in the root quadrant strikes the basal wall at an angle of about $60^{\circ}$, so that the octants are of very unequal size (Fig. 2I2, C), and the larger one, as in other similar cases, becomes at once the initial cell of the root, which in both genera shows the same regular divisions that characterise the Polypodiacex. The segments of the root-cap do not form any periclinal walls, and remain single-layered. The root, like the cotyledon, is traversed by regular air-chambers, and its transverse section resembles very closely that of the leaf. These air-chambers appear while the root is very young, and at a point between the endodermis and the cortex. The latter is at this stage divided into but two cells, the outermost of which by a further tangential division becomes two-layered, the outer forming the epidermis, and the inner by similar divisions three-layered. The two outer layers divide by radial walls, but the inner ones divide only by periclinal walls, and form one-layered lamellæe separating the air-spaces and connecting the endodermis with the outer cortex.

\section{The Foot}

The first divisions in the foot quadrant follow closely those in the root, but this regularity soon ceases, and after the first divisions no definite succession in the walls can be distinguished. The foot remains small, but, as we have seen, the first segments of the lower epibasal octants practically form part of it, and doubtless all the lower cells are concerned in the absorption of food from the spore. The volume of the protoplasm in the spore increases as the prothallium grows, but loses more and more its coarsely granular structure. In both Marsilia and Pilularia the nucleus of the spore cavity soon becomes indistinguishable, and in the former is from the first very small. In Pilularia it is larger, and in the later stages bodies were observed that looked as if they might be secondary "endospermnuclei," like those of $A z o l l a$, but their nature was doubtful.

'The leaves are at first alike in both genera, and the earliest ones do not show any trace of the circinate vernation of the 
later ones. In Pilularia the later leaves are essentially like the cotyledon, but in Marsilia all the later leaves show a distinct lamina. This is at first narrow and undivided, and spatulate in form. In $M$. vestita this is succeeded by five or six similar ones, with constantly-broadening laminæ, which finally divide into two narrow wedge-shaped lobes, and these are then succeeded by others with broader lobes, which finally are replaced by four lobes, the central ones being narrower than the outer ones. All of these early lobed leaves are folded flat, and it is not until about ten or twelve leaves have been formed that finally the leaf attains the form and vernation of the fullydeveloped ones.

The divisions in the stem apex take place slowly, but apparently a complete series of segments is produced in rapid succession, and there is an interval before any more divisions occur, as there is always considerable difference in the ages of any two succeeding sets of segments. The apical cell of Pilularia in cross-section has the form of an isosceles triangle with the shorter face below. Probably each dorsal segment at first gives rise to a leaf, and each ventral one to a root. However, the number of roots exceeds that of the leaves, but the origin of these secondary roots was not further investigated.

\section{The Mature Sporophyte}

In both Marsilia and Pilularia the fully-developed sporophyte is a creeping slender rhizome, showing distinct nodes and internodes. At the nodes are borne the various appendages of the stem, and the elongated internodes are, except for occasional roots, quite destitute of appendages. Leaves and branches arise from the nodes, and in Marsilia are much crowded. The plants are aquatic or amphibious, and the habit of the plant is very different, especially in Marsilia, as it grows completely submerged, or partially or entirely out of water. Some species, like $M$. vestita, which grow where there is a marked dry season, grow in shallow ponds or pools, which dry up as the end of the growing period approaches, and the ripening of the sporocarps takes place after the water has evaporated. In the first case the petioles are extremely long and weak, and the leaf-segments float upon the surface. In the other case the petioles are much shorter and stouter, and the leaves are borne upright. The 
young leaves are circinate, as in the ordinary Ferns, and in

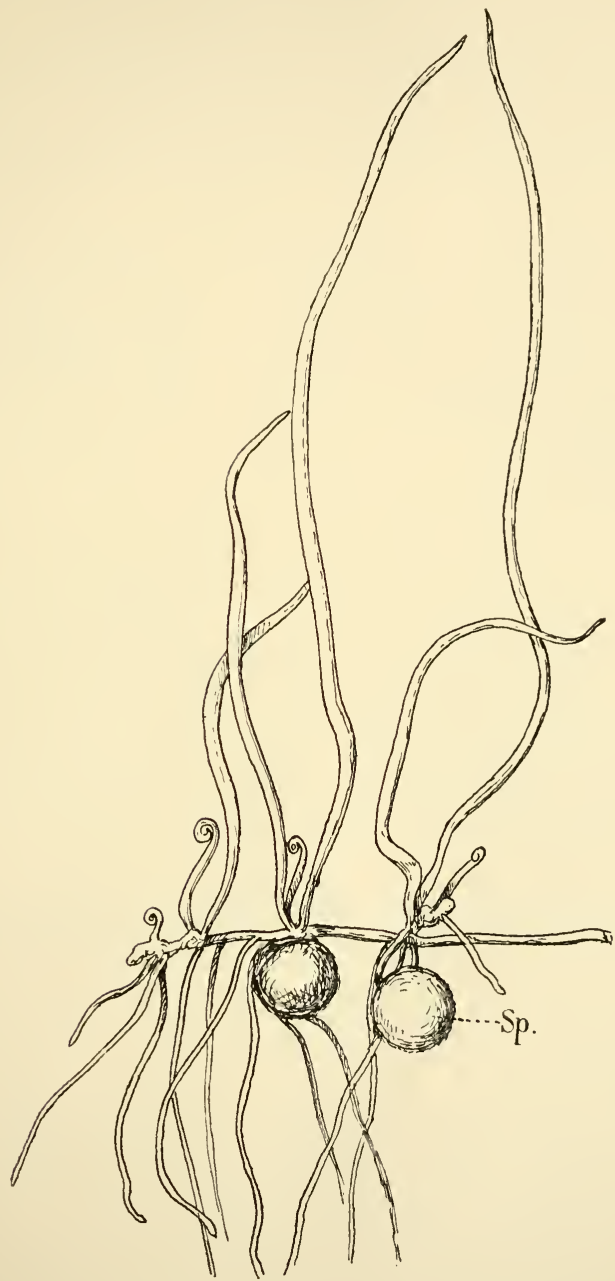

FIG. 214.-Part of a fruiting plant of Pilularia Americana (A. Br.), $\times_{4}$; $s p$, sporocarps. 
Pilularia retain the same structure as the cotyledon. In Marsilia they are always four-lobed. The sporocarps are modified outgrowths of the petiole, which are often formed so near the base as to appear to grow directly from the stem. They often are borne singly, but may occur in considerable numbers-twenty or more in $M$. polycarpa-and are globular in Pilularia, bean-shaped in Marsilia. The growth of the

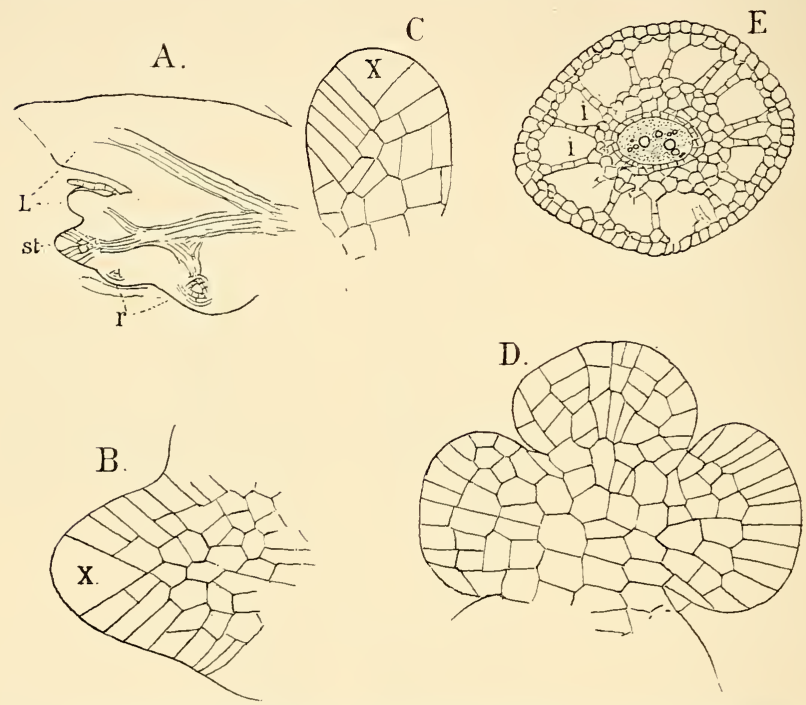

FIG. 215.-Marsilia vestita (Hook and Grev.). A, Vertical longitudinal section of the stem apex, $\times 80$; L, leaves ; st, stem apex; $r$, roots ; B, the stem apex, $\times_{45}$; C, horizontal section of very young leaf, $\times 450 ; D$, similar section of an older one, $\times 450$; E, cross-section of mature stem, $\times 80$.

stem and the origin of the various appendages are the same in both genera.

A longitudinal section of the stem (Fig. 2 I 5, A) shows the decidedly pointed apex occupied by a large and deep apical cell with very regular segmentations. Each segment divides into an inner and an outer cell, the former in all the segments forming the central plerome cylinder, and the outer cells developing the cortex of the stem, and the leaves in the dorsal segments, the roots in the ventral ones. The young leaves are 
separated by distinct intervals or internodes, and apparently all of the dorsal segments do not give rise to leaves, but just what the relation is between the nodes and internodes was not determined. The roots arise in strictly acropetal order from the ventral segments, but their number does not seem to be constant. In Pilularia Americana the number of roots considerably exceeds that of the leaves, as it does in the young sporophyte of $P$. globulifera.

The single axial vascular bundle is truly cauline, and extends considerably beyond the base of the youngest leaf. The later leaves in Pilularia, both in their growth and complete structure, correspond to the primary ones. They grow for a time from a three-sided apical cell, in which respect they differ from Marsilia. The development of the leaf of the latter has been carefully studied by Hanstein in $I$. Drummondii, and $M$. vestita corresponds exactly with that species. A section of the very young leaf (Fig. 2 I 5, C) parallel with the surface shows a large two-sided apical cell. The leaf-rudiment assumes a somewhat spatulate form, and on either side a projecting lobe is formed, the rudiment of one of the lateral segments of the leaf. The apical cell is now divided by a median wall, after which periclinal walls are formed, and from this time the growth of the leaf can no longer be traced to a single initial cell. The first longitudinal wall in the apical cell establishes the two terminal lobes, which at first are not separated (Fig. 2 I 5, D). The establishment of the veins follows exactly as in Ferns with a similar venation, and is strictly dichotomous. The stem branches freely in both genera, and the branches arise close to the apex, and below a young leaf somewhat as in Azolla.

The roots correspond exactly with those of the higher homosporous Ferns. The segmentation of the apical cell follows the same order as in the Polypodiacex. Goebel's figure of $I$. salvatrix ${ }^{1}$ differs somewhat from the account given more recently by Andrews ${ }^{2}$ for $M$. quadrifolia. The latter observer states that there are no periclinal walls in the root-cap segments, which remain throughout one-layered, and that the separation of the plerome takes place earlier than Goebel indicates. Van Tieghem's ${ }^{3}$ account of the root of $M$. Drummondii confirms Andrews' observations upon M.quadrifolia. The bundle of the root is diarch, as in the Polypodiacex, and the lateral roots arise

1 Goebel (10), p. 238.

2 Andrews (1).

3 Van Tieghem (5), p. 535. 
in the same manner. The endodermal cells from which they spring are distinguished from the others by their shorter and broader form, and are very easily recognisable by this as well as from their position. They form two vertical rows exactly opposite the ends of the xylem plate, and the lateral roots therefore are also strictly two-ranked. Narrow lacunæ are formed in the cortical tissue of the root, and the cells surrounding these are connected by regular series of short outgrowths, which connect them in a way that recalls very strongly the connecting tubes between conjugating filaments of Spirogyra, and produce a similar ladder-shaped appearance.

The solid vascular cylinder of the young stem is later usually replaced by a tubular one, but its structure is also concentric, with phloëm completely surrounding the xylem, and has both an inner and outer endodermis. When the plants are completely submerged the ground tissue is mainly parenchyma, but in the terrestrial forms sclerenchyma may be developed in the cortex of the stem and petiole. The latter is always traversed by a single axial bundle, which in the lamina in Marsilia divides repeatedly near the base of the wedge-shaped leaflets into numerous dichotomous branches.

Luerssen ${ }^{1}$ mentions as special reproductive bodies, tubers found in $M$.hirsuta. These are irregular side branches covered with imperfectly-developed leaves, and with the cortical tissue strongly developed and full of starch. These are supposed to survive long periods of drought, and to germinate under favourable conditions. A condition somewhat analogous to this appears in $M$. vestita (Fig. 206, A), but whether these short lateral branches are of this nature was not investigated.

\section{The Sporocarp ${ }^{2}$}

The development is much the same in the two genera, but is most easily followed in the simple sporocarp of Pilularia. In $P$. Americana, the young fruit begins to develop almost as soon as the leaf can be recognised, and while it is still close to the stem apex. Growth is stronger upon the back of the young leaf, and it very early assumes the circinate form. Before this

1 Luerssen (7), p. 6or.

2 Sachs, Text-book, 2nd English edition, p. 455; Goebel (6); Jurányi (2); Russow (I), Meunier (I). 
curvature is very pronounced, however, in the sporophyll, a protuberance arises upon its inner face, a short distance above the base (Fig. 2I6, A). This originates from a single cell, which functions for some time as an apical cell, and causes the young sporocarp to project strongly from the leaf, of which it is simply a branch, somewhat analogous to the spike in Ophioglossum. It has at first the form of a blunt cone, but soon upon the side turned toward the leaf a slight prominence appears (Fig. 2 I6, B, L), and about the same time two similar
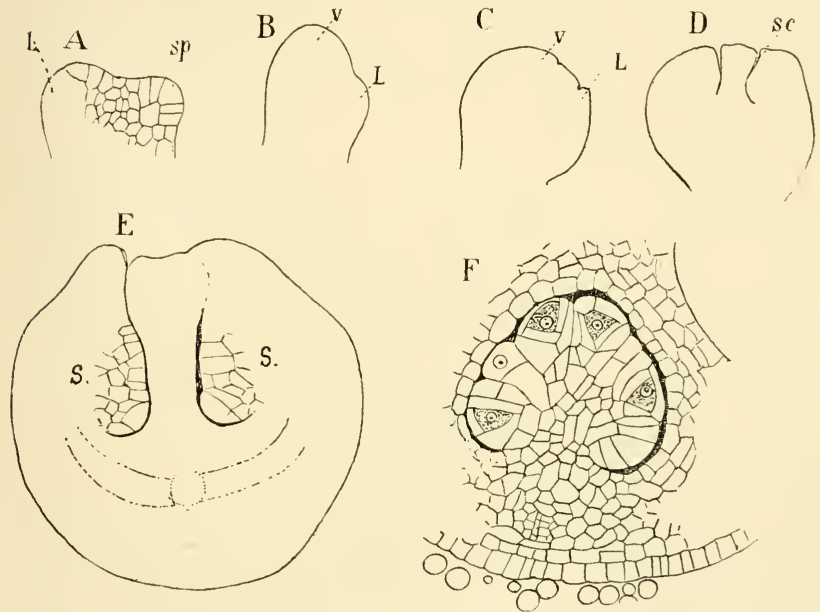

Fig. 216.-Pilularia Americana (A. Br.). Development of the sporocarp. A, Very young sporophyll with sporocarp rudiment $(s p)$, showing a distinct apical cell; B-D, longitudinal sections of young stages, showing the formation of the "sorus canals" $(s c), \times 130$; $z$, the original apex of the young sporocarp; L, secondary lobes or leaflets; E, longitudinal section of an older stage, $\times$ about $130 ; s, s$, young sori ; F, transverse section of an older sorus, $\times 180$.

lateral ones are formed. As in the sterile part of the leaf growth is stronger on the outside, and the young sporocarp bends in toward the leaf, so that the position of fertile and sterile segments is very like that in the young sporophyll of Oplizglossum. The apex of the sporocarp rudiment, together with the three lobes, enclose a slightly depressed area, which becomes the top of the sporocarp. The four prominences (including the original apex of the fertile segment) are beyond 
question to be considered leaflets, which remain confluent except at the top. A little later a slight depression or pit forms at the base of each lobe and the central area at the top. These pits are separated laterally by the coherent edges of the leaflets, which extend to the axis of the sporocarp and are continuous with it. As the young fruit enlarges, the depressions deepen owing to the elongation of both leaflets and the axial tissue, which forms a sort of central columella (Fig. 2 I 6 , D). Thus are formed four deep cavities, separated laterally by the united margins of the leaflets, and corresponding to the much more numerous "canals" described by Russow in the fruit of Marsilia; like these they at first open at the summit by a pore, and a study of longitudinal sections shows clearly their strictly external origin.

Up to the time the cavities begin to form, the young fruit is composed of uniform tissue, but shortly after, the tissue systems become differentiated, and the peduncle of the sporocarp is formed. At this time the vascular bundle of the peduncle can be recognised, and joins that of the sterile segment near its base. The peduncle is much longer in $P$. Americana than in the very similar $P$. globulifera. The circinate coiling of the sterile segment is repeated, though less conspicuously, here, and the body of the sporocarp is bent at right angles to the peduncle.

The cavities rapidly become larger with the expansion of the growing sporocarp, but the space between the inner surface of the lobes and the columella remains narrow, owing to the growth of the sorus, which almost completely fills it from the first. The sorus forms an elongated cushion, extending nearly the whole distance from the apex to the base of the lobe, along the median line of its inner face. In origin and position it corresponds exactly to that of most homosporous Ferns, except that it arises from the upper instead of the lower side of the leaf. The laminæ separating the cavities are composed of about four layers of cells.

The vascular bundle of the peduncle divides into four branches, where it enters the sporocarp, and one branch goes to each lobe, of which it forms the midrib lying below the sorus. From each of these, two smaller branches are given off near the base, following the margin of the lobe (Fig. $2 \mathrm{I} 7, \mathrm{~A})$. By this time the outer epidermal cells begin to 
thicken, the first indication of the hard shell found in the ripe sporocarp.

The development of the sporangia corresponds almost exactly with that of the Polypodiaceæ. The surface cells of the sorus protrude as papillæ, in which the same divisions arise as in other Leptosporangiatæ. The first division wall is usually strongly oblique, but may be transverse. The formation of the archesporium is the same, but the apical growth of the

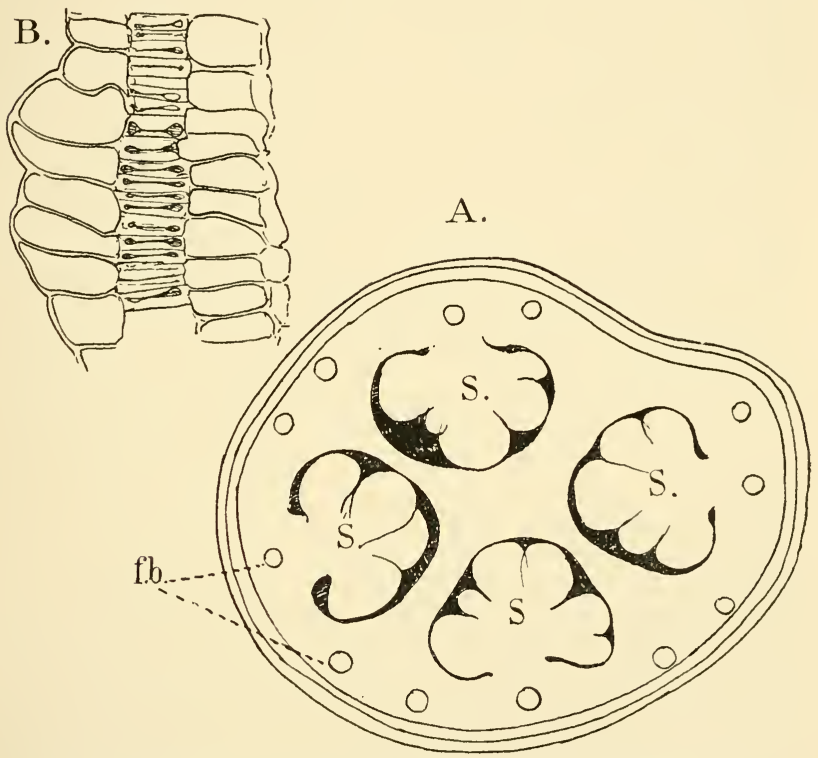

FIG. 217.-Transverse section of an older sporocarp of $P$. Anericana, showing the four sori $(s)$; $f b$, vascular bundles, $\times 8_{5} ; \mathrm{B}$, section of the wall of a nearly ripe sporocarp, $\times 255$.

sporangia is checked sooner in the earlier ones, which have consequently a very short stalk. In the later ones, which arise between the others, the stalk is longer. The first sporangia are formed at the base of the sorus, and their development proceeds toward the apex; but later secondary ones may arise at any point in the sorus.

The tapetum is well developed, and, as in most homosporous 
Ferns, consists of two layers, in some places of three. The number of sporogenous cells is usually eight, but some or all of these may divide again, so that the whole number ranges from eight to sixteen. The dissolution of the tapetum walls and subsequent division of the spores follow precisely as in Azolla. In stained sections the nucleated protoplasm of the tapetal cells is very evident after the walls have disappeared. At this point the difference in the two kinds of sporangia becomes manifest. Those in the lower part of the sorus, i.e. the oldest ones, form the macrosporangia, the upper ones microsporangia. In the latter all the spores mature; in the former, as in Azolla, one spore grows at the expense of the other, and finally fills the sporangium completely. As in Azolla no trace of an annulus is seen, either in the young or fully-developed sporangium. ${ }^{1}$

As the sporocarp ripens, the outer cells become excessively hard, especially the first layer of hypodermal cells (Fig. 2 I 7), whose walls become so thick as to almost obliterate the cell cavity. The second hypodermal layer is also thickened, but not so strongly. At maturity the sporocarp of $P$. Americana forms a globular body about $3 \mathrm{~mm}$. in diameter, covered with hairs, and attached to a long peduncle which bends downward and buries the ripe sporocarp more or less completely in the earth. The statement ${ }^{2}$ that this species has but three chambers is incorrect, and except for the longer pedicel of the fruit, and a slightly thinner epispore in the upper part of the macrospore, it corresponds exactly to $P$. globulifera. The sporocarp splits into four parts, corresponding to the four lobes of the young fruit, and the membranaceous margins of the leaf form a tough indusium surrounding the sporangia. This indusium is not, at least in $P$. globulifera, readily pervious to water, and germination does not begin for a long time after the valves separate, unless the indusium is artificially opened. Except for the number and position of the sori, and the relative position of the two sorts of sporangia, Marsilia agrees exactly with Pilularia. The sorus canals form two longitudinal rows along the sides of the elongated fruit rudiment, which may be compared to a pinnate leaf. In Marsilia, occupying the middle

1 For the details of the development of the macrospore, see Meunier (I), pp. $382-387$.

2 Goebel (Io), p. 240 ; Underwood (4), 2nd ed., p. I27 ; "Botany of California," vol. ii. p. $35^{2}$. 
line of each sorus, is a row of large tetrahedral cells, which form three sets of segments, like any three-sided apical cell. Each of these cells produces a group of sporangia. The terminal one, derived directly from the apical cell, is a macrosporangium; the smaller lateral ones, derived from its earlier segments, the microsporangia.

\section{Fossil Leptosporangiate}

Sporangia of undoubted Leptosporangiatæ are exceedingly rare in the earlier geological formations. Solms-Laubach ${ }^{1}$ cites Hymenophyllites as probably being a genuine leptosporangiate Fern, and Zeiller ${ }^{2}$ describes some isolated sporangia that seem to be much like those of the modern Gleicheniacex. Forms like the Osmundacex have also been described by various writers, but no traces of Cyatheaceæ or Polypodiaceæ have been yet detected in Palæozoic formations. In the Jurassic, undoubted evidences of Gleicheniaceæ, Osmundaceæ, and Schizæaceæ are found, ${ }^{3}$ but the Polypodiaceæ do not seem to have appeared until still later. The existence of the Hydropterides below the Tertiary is doubtful, but in the latter formation occur undoubted remains of the living genera Salvinia, Pilularia, and Marsilia.

\section{Affinities of the Leptosporangiate}

The Osmundaceæ undoubtedly are intermediate between the Eusporangiatæ and Leptosporangiatæ, but with which order of the former their affinities are closest is difficult to say. Among the Ophioglossacex, the larger species of Botrychium and Helminthostachys show apparent close structural similarity; but, on the other hand, in the distinctly circinate leaves and the character of the sporangia, as well as the histology, the Marattiaceæ are certainly quite as nearly related. Apparently all of these forms are generalised types, springing from a common stock, but no two of them directly related.

Among the Leptosporangiatæ themselves the relationships are evidently much closer. A common type of prothallium and sporangium prevails throughout, even in the heterosporous forms. The four families, Osmundaceæ, Gleicheniaceæ, Cyatheaceæ, and

1 Solms-Laubach (2).

2 Zeiller (I); Bower (I2), p. 126.

3 Raciborski (I). 
Polypodiaceæ, form a pretty continuous series, of which the Polypodiaceæ are with very little question the latest and most specialised forms. This is evinced both by the geological record, which, so far as yet examined, shows that they were the latest to appear, and by the fact that at present they greatly outnumber the other Ferns, probably including at least 90 per cent of all living species. The single genus Polypodium has over 400 species, probably as many as all the lower Ferns combined. These facts, together with the specialised character of all the parts, indicate that they are Ferns which have adapted themselves to modern conditions.

The Schizæaceæ and Hymenophyllaceæ do not seem to belong to this main line, but are somewhat peculiar types, apparently belonging near the bottom of the series. The Hymenophyllaceæ, on the whole, approach most nearly the Gleicheniacex, with which they agree in many points, both in the sporophyte and gametophyte, but they also recall the Osmundaceæ, and possibly may form a branch somewhere between the two, but nearer the former. The peculiarities of the gametophyte are probably in large measure the result of environment, and the filamentous prothallium of some species of Trichomanes is beyond question a secondary and not a primary condition, and the prothallium is typically like that of the other Leptosporangiatæ.

The nearest affinities of the Schizæaceæ seem to be with the Osmundacex, but in the structure and arrangement of their vascular bundles they are more like the Gleicheniaceæ.

Of the two families of the Hydropterides, the Salviniacex show several points of resemblance to the Hymenophyllaceæ. The development of the leaves is strikingly like those of Hymenophyllaceæ, with reniform or palmate leaves, and the structure of the sori almost identical. The absence of secondary roots in Salvinia is suggestive also of the similar absence in some species of Trichomanes. The two-sided apical cell of the stem is, however, different from that of the few Hymenophyllacex examined, which all possess the pyramidal initial, but possibly further examination may show forms with an initial cell similar to that of Azolla or Salvinia.

The Marsiliaceæ in all respects, except their heterospory, conform closely to the type of the higher families, and may be assumed to be derived directly from the Polypodiacex, or forms 
much like them. The curious Ceratopteris suggests a possible connecting form. This strictly aquatic Fern has the large sporangia with the annulus sometimes incomplete, and the sporophylls modified into pod-like structures which suggest a possible homology with the "fruit" of the Marsiliacex. The form of the early leaves, too, suggests those of Marsilia. The two genera of the Marsiliacere are evidently very closely related, and of these Pilularia approaches nearer the homosporous Ferns. The accompanying diagram shows the relationship assumed here.

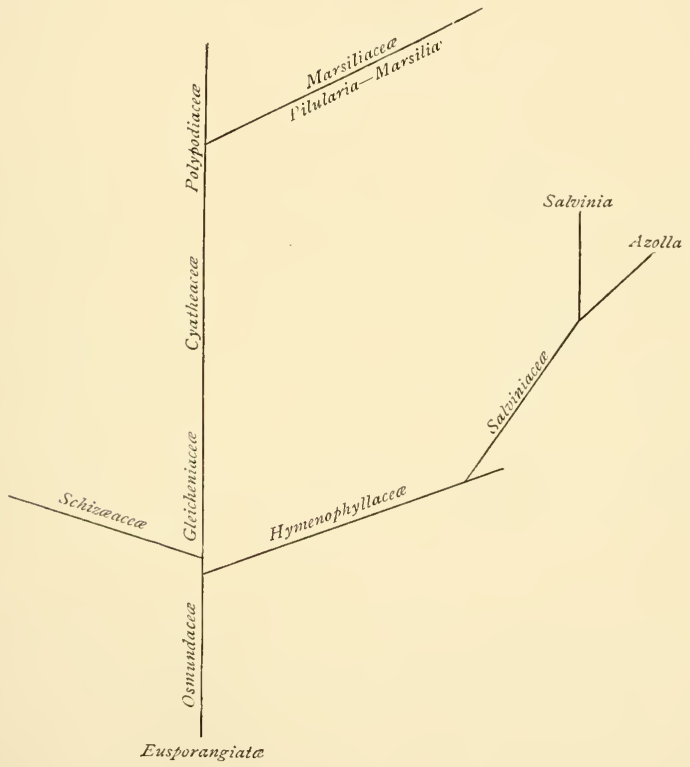




\section{CHAPTER XIII}

\section{EQUISETINEÆ}

ALL of the living representatives of the second class of the Pteridophytes may without hesitation be referred to the single genus Equisetum, with about twenty-five species, some of which, e.g. E. arvense, are almost cosmopolitan. In the largest species, E. giganteum, the stems reach a height of Io metres or more, but are slender, not more than 2 to $3 \mathrm{~cm}$. in diameter, and supported by the surrounding trees and bushes. The smallest species is E. scirpoides (Fig. 242, B), whose slender stems are seldom more than I 5 to $20 \mathrm{~cm}$. in length, and often one millimetre or less in dianeter. In spite of these differences in size, the structure is remarkably uniform, both in gametophyte and sporophyte. The following account is based mainly upon a study of E. telmateia, ${ }^{1}$ but applies to the other species that have been studied.

\section{The Prothallium}

The ripe spore of Equisetum is globular and shows no trace of the ventral ridges usually evident in tetrahedral spores. Four distinct membranes surround it, the inner one (intine) being exceedingly delicate, but with care showing the cellulose reaction. ${ }^{2}$ Outside of this are the exospore and the elaters, between which lies another layer, "Mittelhaut" of Strasburger," belonging to the exospore. The well-known elaters (Fig. 2 I 8 , A) form two strips attached in the middle and terminating in spoon-shaped appendages. The elaters are usually more or less spirally twisted, and when dry show faint oblique striations,

\footnotetext{
1 E. maximum.

2 Buchtien (I).
}

3 Strasburger, "Bau und Wachsthum der Zellhäute," p. 199. 
except on the expanded ends. They are extremely hygroscopic, and respond instantly to any changes in the moisture of the atmosphere. A careful study of the dehiscence of the sporangium shows that as it dries the expansion of the elaters assists very materially in opening it, and their function is something more than that of keeping the spores together, as has been asserted. ${ }^{1}$ The striation of the elaters is merely the result of wrinkling by drying, and when moistened this disappears completely. The elaters show the cellulose reaction except upon the upper surface, which is cuticularised.

The spores contain much chlorophyll, which in the dry spores appears amorphous and gives them a dark olive-green colour. So soon as the spore is moistened, however, it increases
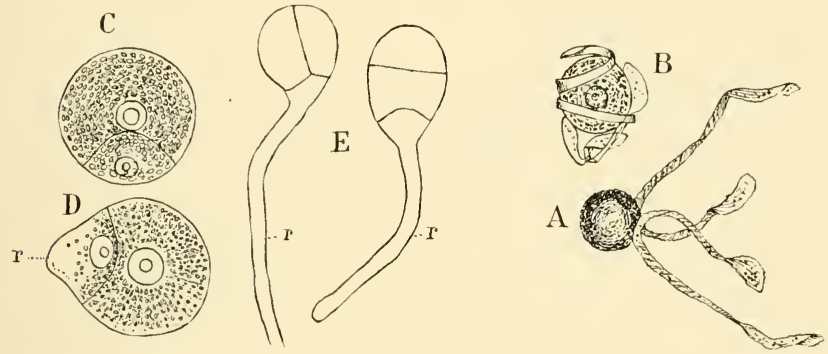

FIG. 218.-In this and all the following figures of Equisetum, the drawings were made from E. telmateia (Ehrh.), (E. maximum, Lam.), unless otherwise indicated. A, ripe dry spore with expanded elaters, $\times \mathbf{1} 80 ; \mathrm{B}$, a similar spore placed in water, $\times \mathbf{1} 80 ; \mathrm{C}, \mathrm{D}$, germinating spores, $\times 360 ; \mathrm{E}$, older stages of germination, $\times 180 ; 1$, primary rhizoid.

in diameter by about one-half through the absorption of water, and the numerous small round chloroplasts then become very evident. The nucleus is large, and occupies the centre of the spore. After a short time the elaters and the outer layer of the exospore are thrown off, and probably the rest of the exospore, as no trace of this can be seen in the young prothallium.

The spores quickly lose their power of germination, and should be sown as soon as they are discharged. If this is done germination begins almost at once, and within ten to twelve hours the first division wall may be completed. The chloroplasts rapidly multiply by division and often show a distinct

1 Buchtien (I), p. I5. 
radiae arrangement, extending in lines from the nucleus to the periphery. The first division may occur before the spore has changed form, and in this case (Fig. 2 I 8, C) a small cell is cut off by a strongly curved wall. Both cells contain chlorophyll, but the nucleus of the smaller cell is smaller than the other. In other spores there is first an elongation, as in Osmunda, and the smaller end, which like that has some chlorophyll, but not so much relatively as the larger, is cut off, and forms the first rhizoid, and within twenty-four hours, under suitable conditions, this may reach a length considerably exceeding the diameter
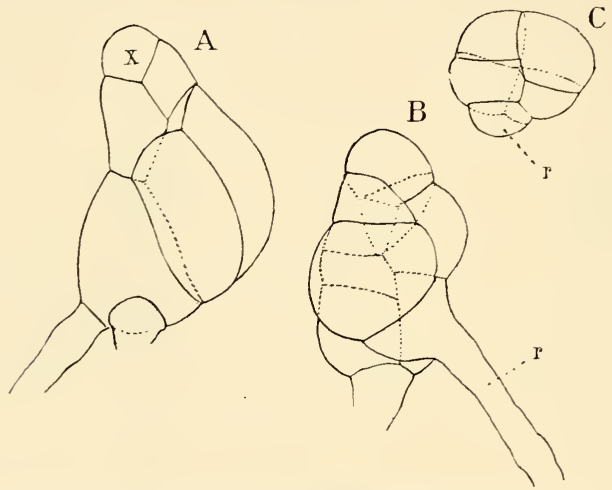

FIG. 219.-Young prothallia of Equisetum, showing the variation in form, $\times 180$. In A there is apparently a definite initial cell; $r$, rhizoid.

of the spore. Sadebeck ${ }^{1}$ showed and Buchtien ${ }^{2}$ confirmed this, that the first root-hair is positively heliotropic.

The first divisions in the prothallial cell are extremely various, in this recalling the behaviour of the eusporangiate Filicineæ and the Osmundaceæ. The first wall may be either vertical or transverse (Fig. 2 I8), and sometimes, but not often, there are several transverse walls, and a short filament is formed. More commonly the first transverse wall is followed by a vertical wall in one or both cells. In case the first wall is vertical it not infrequently happens that the two cells, by repeated transverse divisions, form two parallel rows of cells, which may diverge, so that the young prothallium becomes two- 
lobed. In a number of cases a two-sided apical cell was seen (Fig. 2 I 9), but its growth is very limited. Finally, a cell-mass occasionally is the first product of germination. As a not infrequent occurrence may be mentioned also the suppression of the first rhizoid (Fig. $219, \mathrm{C}$ ). The development for some time is so varied that it is impossible to give any rule for it, but generally the prothallium at this stage, like that of the leptosporangiate Ferns, consists of but one layer of cells, and does not show a midrib. These prothallia also do not have a definite apical growth, and are usually more or less branched. Often, however, the prothallium while still small has a some-
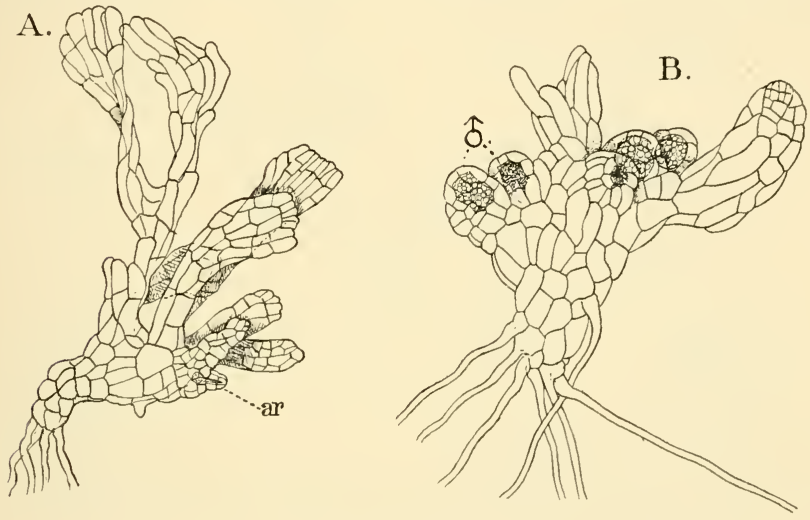

FIG. 220.-A, Female prothallium with the first archegonium $(a r), \times 70 ; \mathrm{B}$, male prothallium, $\times 70$.

what cylindrical body composed of several layers of cells, and in these the root-hairs are mainly confined to the base. The chloroplasts which these at first contain are gradually changed into leucoplasts, and may be completed absorbed. ${ }^{1}$

\section{The Sexual Organs}

The prothallia of Equisetum are usually diœecious, and, as is usual in such cases, the males are smaller and the antheridia develop first. The latter generally appear in about a month. In $E$. telmateia there is not so much difference in the appear- 
ance and size of the male and female plants, and they are not always distinguishable by the naked eye. While in this species, as in others, the antheridia may form at the ends of the prothallial branches, they also may be formed upon a meristem quite like the archegonia, and are usually in this species in groups, so that longitudinal sections show antheridia of very different ages, all evidently derived from the activity of the meristem (Fig. 22 I). The development shows a close resemblance to that of the eusporangiate Ferns, and in connection with the other points in the growth of the gametophyte and sexual organs, suggest a nearer connection of these two groups than is usually admitted. Here, as in the

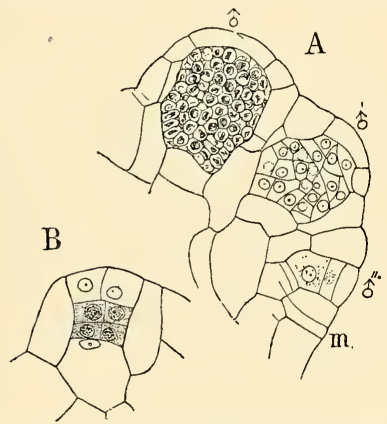

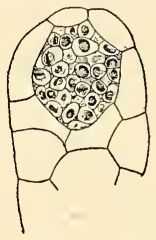

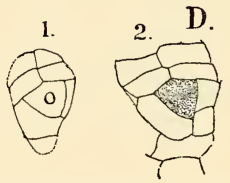

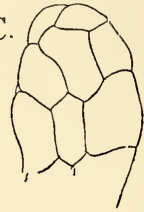

D.

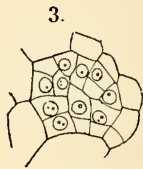

FIG. 221. -Development of the antheridium, $\times$ Igo. A, Longitudinal section through the antheridial meristem showing antheridia of different ages; B, longitudinal section of young antheridium, $\times 375$; C, two sections of a terminal, single antheridium, nearly ripe, $\times$ rgo; $D$, three transverse sections of young antheridium, $\times$ I90; 0 , opercular cell.

eusporangiate Ferns, the antheridium mother cell is divided into an inner and an outer cell, of which the inner one forms at once the sperm cells. When the antheridium arises at the end of a filament, the divisions in the terminal cell are very much like those in Osmunda. In the mother cell three intersecting walls enclose a tetrahedral cell, which then has the cover cell cut off by a periclinal wall. In both forms of antheridium the subsequent history is the same. The central cell divides first by a transverse wall, followed by vertical walls in each cell, and subsequently by numerous divisions which show no definite arrangement (Fig. $22 \mathrm{I}, \mathrm{C}$ ), and produce a very large number of sperm cells. In the cover cell only radial walls are formed, and 
it thus remains single-layered, as in Marattia and Osmunda. There is often a triangular opercular cell (Fig. $22 \mathrm{I}, \mathrm{D}, o$ ), recalling the similar cell in these forms.

\section{Development of the Spermatosoids}

The large size of the spermatozoids of Equisetum makes them especially suitable for the study of their development, and this was traced with some care in E. telmateia. The material

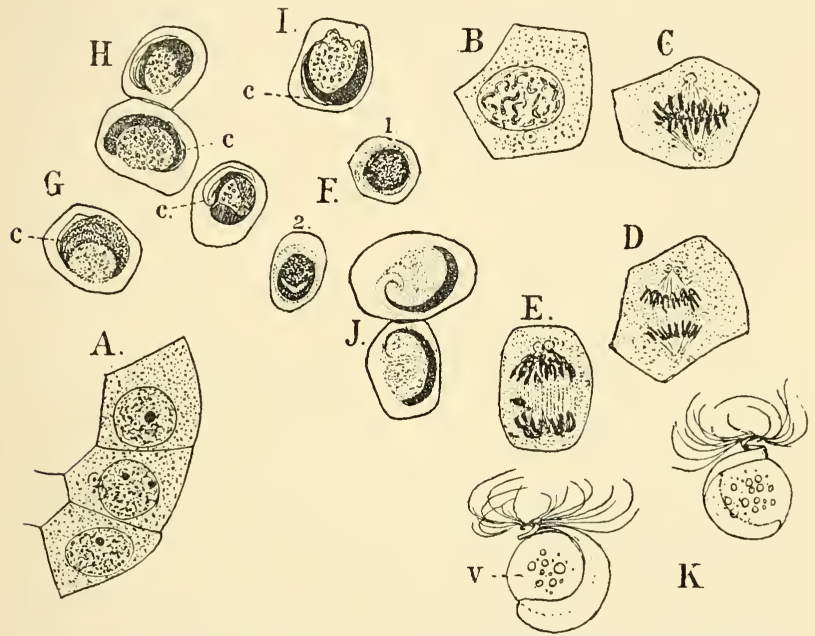

FIG. 222. - Development of the spermatozoids, $\times$ rooo. A, Three of the central cells of an antheridium before the final division; B-E, final nuclear divisions in the spernı cells; F-J, development of the spermatozoid from the nucleus of the sperm cell ; $c$, the cilia; $\mathrm{K}$, two free spermatozoids; $z$, the vesicle.

used was fixed with I per cent chromic acid, stained with alumcochineal, and microtome sections were then examined in Canada balsam. The nuclei of the sperm cells previous to their final division are globular and show one, sometimes two, small but distinct nucleoli, and numerous chromosomes. In exceptional cases the two "directive spheres" could also be seen. Previous to the final division the latter take their place on opposite sides of the now somewhat flattened nucleus, whose nucleolus cannot be distinguished and whose nuclear segments are very distinct, 
short, curved bodies. Their number could not with certainty be determined. The nucleus passes through the various karyokinetic phases, and the directive spheres occupy the poles of the nucleus spindle when at a later period they divide so that each daughter nucleus has two of them. After the daughter nuclei have assumed the resting condition these can no longer be distinguished, and what their fate is must for the present remain undecided. The resting nuclei, as in other cases, show no nucleolus. Fig. 222, F to J, shows the earliest stage in the differentiation of the spermatozoid, and this corresponds exactly with what I have observed in various Ferns, and differs somewhat from Buchtien's figures of corresponding stages. The nucleus, which is not noticeably lateral in position, shows a narrow cleft upon one side. Seen in profile (Fig. 222, F, I), one side projects somewhat more than the other, and becomes the anterior end, which later becomes thinner than the posterior part. I was unable to see that this forward part behaved differently with regard to the nuclear stain employed from the hinder part, nor could I satisfy myself of the presence of the cytoplasmic anterior prominence which Strasburger $^{1}$ figures in the Ferns. Staining with the mixture of fuchsin and iodine-green, recommended by Strasburger, gave indifferent results, both in the younger stages and the free spermatozoids. In microtome sections, where the spermatozoids were very strongly stained and the cytoplasm almost colourless, the nuclear structure was unmistakable nearly to the extremity. It is not impossible that the extreme forward end may be cytoplasmic; but if so, it forms but a very insignificant part of the fully-developed spermatozoid. The cilia (Fig. 222, C) are evident long before the spermatozoid has attained its full length, and are shorter at first than later on. There seems little doubt that they are direct outgrowths of the forward end, and lie close to the convex surface of the body, so that they are easily overlooked.

The body rapidly elongates and becomes quite homogeneous, but this does not occur until a comparatively late stage. The nucleus is here somewhat flattened to begin with, and the coils of the spermatozoid lie nearly in the same plane and resemble a good deal those of Marattia, except that they are larger. The protoplasm enclosed within the coils is con-

1 Strasburger (I I), vol. iv. Pl. III. Figs. 26, 27. 
spicuously granular, and forms the large vesicle attached to the posterior coils of the free spermatozoid. The mucilaginous change in the walls of the sperm cells begins about the same time as the differentiation of the spermatozoids.

The free spermatozoids consist of from two to three complete coils, of which the forward one or two are very much smaller than the very large and broad hinder one, which encloses the vesicle. The cilia are much like those of the Fern spermatozoid, but somewhat shorter. The cover cells of the ripe antheridium are forced apart by the swelling of the mucilage from the disorganised walls of the sperm cells, which are forced out of the opening into the water, where the rcmaining wall of the sperm cell is dissolved and the spermatozoid set free. When in motion a peculiar undulation of the large posterior coil is conspicuous, a phenomenon which has also been observed in the quite similar spermatozoids of Osmunda.

\section{The Archegonium}

The young female prothallium is always a cylindrical mass of cells with a series of thin lateral lobes. After the archegonia begin to form and a definite apical meristem is established, the formation of these lobes is almost exactly like the similar ones in young plants of Anthoceros fusiformis. The exact relation of the growing point in the older prothallium to the primary one could not be made out. In the former this arises, according to Buchtien, ${ }^{1}$ upon the under side of the prothallium, without any apparent relation to the primary growing point. This much is certain, that just before the first archegonium appears, there is formed a cushion not unlike that of the Ferns. In the youngest condition this in profile (Fig. 223, A) shows an evident apical cell (probably one of several), not unlike that of the Ferns ; but the great difficulty of obtaining accurate sections through it made it impossible to follow exactly its further development. This much can be stated confidently, however, that at the time when the first archegonia are produced, the structure of the prothallium is essentially that of Osmunda or Marattia, and consists of a central massive midrib and a onecelled lamina, which is not continuous, but composed of separate lobes. A similar condition exists in Osmunda, where

1 Buchtien (I). 
in the older prothallia similar but much shorter and broader lobes arise alternately from either side of the growing apex.

The development of the archegonium is intimately associated with the formation of the lobes. The archegonium mother cell is formed close to the base of the young lobe upon the ventral side. By subsequent growth of the tissue between it and the apical meristem, it is subsequently forced to the upper side, but its origin is ventral, as in the Ferns. The lobe at whose base it is borne grows for some time by a

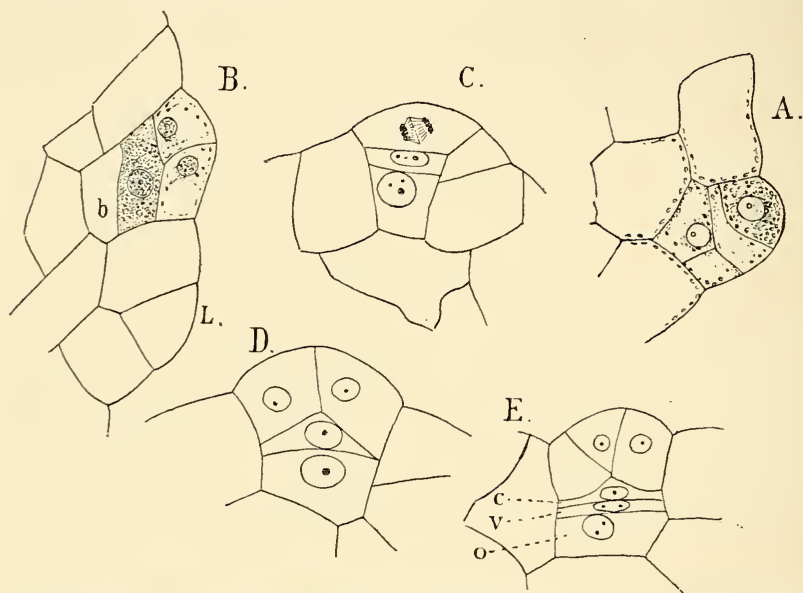

FIG. 223.-Development of the archegonium. A, Optical section of the very young archegonial meristem, $\times 225$; B-E, longitudinal sections of young archegonia, $\times 450 ; c$, neck canal cell; $v$, ventral canal cell; $o$, egg.

definite apical cell, which is very evident in horizontal sections (Fig. 224, C).

The development of the archegonium most nearly resembles that of the eusporangiate Ferns. Usually, but not always, no basal cell is formed, and the first division in the inner cell separates the neck canal cell from the central cell. Both neck and ventral canal cells (Fig. 223, E) equal in breadth the central cell, and in this respect are most like the Marattiaceæ. The neck canal cell later grows up between the neck cells, but there is usually a space between its summit and the terminal neck cells, which here are much longer than the others. It 
subsequently divides by a transverse wall, as may happen in the Marattiacex and occasionally in Osmunda, but whether this always takes place is not certain (Fig. 224, A). The four rows of neck cells are all alike, and consist ordinarily of three cells each, the terminal ones being very long, and when the archegonium opens bending back strongly, but not becoming detached. The central cell is surrounded by a single layer of

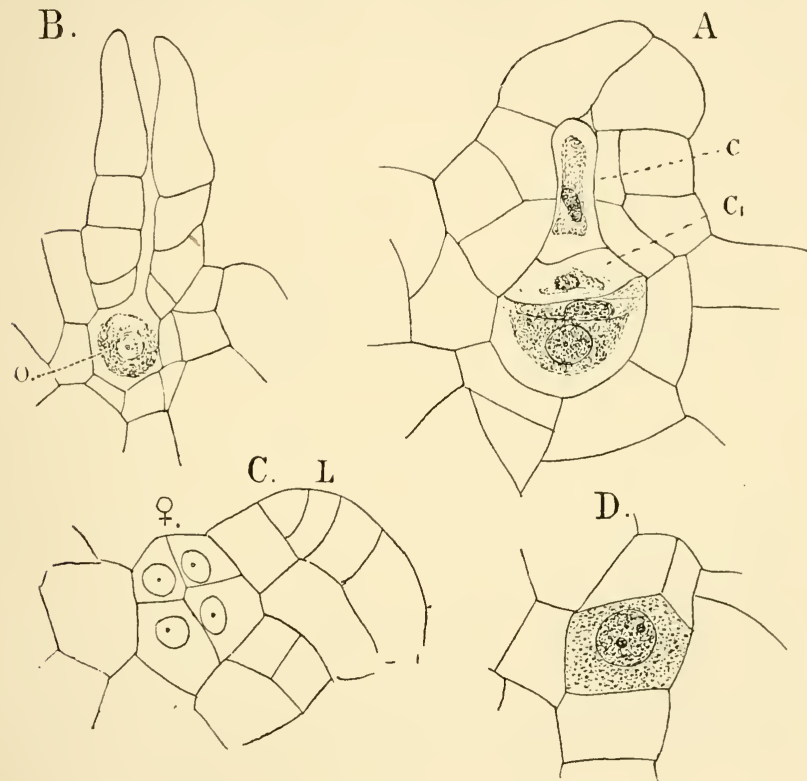

FIG. 224. - A, Longitudinal section of nearly ripe archegonium, with two neck canal cells $\left(c, c_{1}\right), \times 550$ : $\mathrm{B}$, section of an open archegonium, $\times 275 ; \mathrm{C}, \mathrm{D}$, two cross-sections of a young archegonium; L, the lobe at the base of which the archegonium is formed, $\times 550$.

tabular cells cut off from the adjacent prothallium tissue, but these divisions may extend to the lower neck cells (Fig. 224, A). The egg is globular and shows no peculiarities of structure. Buchtien's ${ }^{1}$ account of the further development of the meristem, as well as his figures, point to something very much like a repeated dichotomy of the growing point ; a further investigation

1 Buchtien (I), p. 24. 
of the exact origin of the primary meristem and its relation to the secondary ones found in the branches is much to be desired.

Each archegonium stands between two lobes, the one from whose base it has itself developed, and the next younger one. As these lobes in vigorous prothallia grow to a large size, and branch, this gives the prothallium an extremely irregular outline, recalling very much that of Anthoceros punctatus or $A$. fusiformis. These branching lobes are not to be confounded with the branches of the prothallium body due to the dichotomy of the archegonial meristem. These latter are always short, and project but little compared to the secondary branching lobes produced from them. The entrance of the spermatozoids and the changes subsequent to fertilisation seem to be exactly the same as in Ferns.

The prothallia are normally diøecious, but this is not exclusively the case. To a certain extent the external conditions influence the production of males or females, as in the Ferns, and unfavourable conditions of nutrition tend to increase the proportion of the former.

According to Hofmeister ${ }^{1}$ the number of archegonia upon vigorous prothallia varies from twenty to thirty. His statement that this exceeds the number of antheridia in the larger male prothallia is not confirmed by Buchtien, ${ }^{2}$ who found as many as $\mathrm{I} 2 \mathrm{O}$ of the latter in some cases.

Usually more than one archegonium is fertilised, Hofmeister having found as many as seven embryos upon a single prothallium. He does not state how many of these develop. The embryo corresponds closely to that of the Ferns, and has been carefully described by Sadebeck. ${ }^{3}$

\section{The Embryo}

The fertilised egg grows until it completely fills the ventral cavity, and its granular contents become more separated, and the nucleus is decidedly larger than before fertilisation. The lower neck cells approach and apparently become grown together, and as the divisions in the lower neck cells here contribute to the calyptra, the young embryo becomes more

1 Hofmeister (I), p. 301 .

2 Buchtien (I), p. 22.

"Sadebeck ; Pringsheim's "Jahrb. für wiss. Botanik," I878. 
deeply sunken in the prothallial tissue than is common in the Ferns. The basal wall is transverse, as in the Marattiacex, and the formation of the quadrants takes place as usual. The position of the quadrant walls is, however, sometimes slightly different, being often decidedly inclined in both epibasal and hypobasal halves (Fig. $225, \mathrm{E}$ ). In the former the larger of the two primary cells is the initial for the stem, and its large size, compared to the leaf quadrant, already points to the greater development of the stem in the sporophyte compared

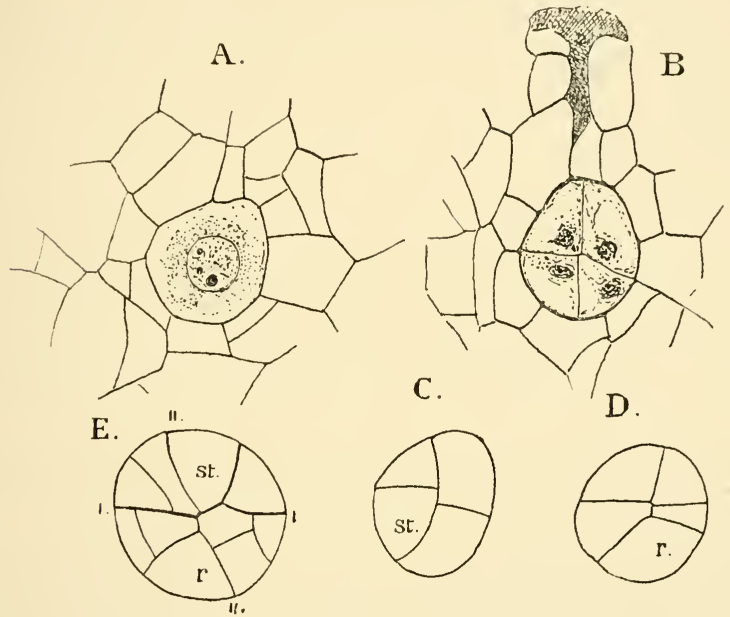

FIG. 225. -A, Longitudinal section of the venter of a recently fertilised archegonium, $\times 300$; $\mathrm{B}$, a similar section of an archegonium with the young embryo; C, D, two transverse sections of a somewhat older embryo, $\times 300 ;$ st, apical cell of the stem; $r$, apical cell of the root; $\mathrm{E}$, longitudinal section of an older embryo, $\times 300 ; \mathrm{I}, \mathrm{I}$, the basal wall.

to the leaves. Of the hypobasal quadrants the larger becomes at once the root, whose axis is coincident with that of the stem. The first two divisions in the stem quadrant establish the definitive apical cell, which occupies nearly the centre of the epibasal part of the embryo, and is surrounded by a circle of four cells, two of which belong to the leaf quadrant (Fig. 225, C), and two are segments of the stem quadrant, the first one corresponding morphologically to the second leaf of the Fern embryo. This circle of cells forms the first sheath about the 
stem of the young sporophyte. After one set of lateral segments has been cut off from the root quadrant, the primary cap cell is formed as in the Ferns. Unlike the latter, the divisions in the stem apex proceed rapidly, and it soon projects in the centre of the embryo as a broad conical prominence, terminating in the large tetrahedral apical cell.

The three parts of which the primary leaf-sheath is composed remain distinct and form the three teeth (Fig. 226, C), which grow rapidly until they are about on a level with the apex of the stem. This growth is mainly due to the activity of the marginal cells. The root grows less actively at first than either stem or leaves, and at the time the latter is nearly fully developed forms but a small protuberance at the base of the embryo (Fig. 226, C). The foot at this time is not conspicuous, but later enlarges more. Its cells are in close contact with the prothallial cells. The root now grows rapidly downward, penetrating through the prothallium until it reaches the ground. The stem apex next rapidly elongates and grows upward through the calyptra. The embryo thus perforates the prothallium both above and below, as in Marattia, although owing to the position of the archegonium in the former the relation of the embryo to the latter is not the same.

Hofmeister states ${ }^{1}$ that the vascular bundles are not formed until after the primary organs have broken through the prothallium, but this point needs further examination.

The development of the primary axis, unlike that of the Filicineæ, is limited, and it ceases growing after producing ten to fifteen sheaths, which, like the first one, are three-toothed. ${ }^{2}$ The stem remains very slender, but shows the marked division into nodes and internodes found in the later ones. This primary stem has irregular lacunæ in the cortex, but does not show the cavity so conspicuous in the central part of the older plant, and in E. telmateia, according to Buchtien, ${ }^{3}$ this is quite solid. In this species he figures four vascular bundles, whose xylem is relatively much better developed than in the later stems. The bundles, like all of those in the stem and leaves, are collateral, and the whole group is surrounded by a wellmarked endodermis. From the base of this primary shoot a

1 Hofmeister (1), p. 303.

2 Buchtien states that in $E$. variegatum they are only two-toothed.

3 Buchtien (I), Fig. I I9. 
second stronger one grows. Hofmeister ${ }^{1}$ states that the bud is an adventitious one, arising endogenously, but it is much more likely that it is an axillary one, like all the later buds, and formed in the axis of the cotyledon. This point does not appear to have been examined by either Sadebeck or Buchtien. This second shoot is much more vigorous, and its leaf-sheaths have four teeth. From the base of this others arise in the same way and in rapid succession. Sometimes the third, or one or more of the later formed basal shoots, bends downward and penetrates the earth, producing the first of the characteristic rhizomes. The first of these have also four-toothed sheaths, but the branches produced from them gradually assume the characters of the fully-developed shoots, some of which ultimately bear sporangia. The first shoots of the sporophyte, even in such species as later branch very freely, produce only an occasional branch, which breaks through the base of the sheath. Whether in these early stems a bud is formed normally at the base of each tooth does not appear to have been investigated. Numerous roots are found at the nodes of these rhizomes, which probably originate, as in the acrial stems, from the bases of the buds in the axil of the sheath.

\section{The Mature Sporophyte}

On comparing the sporophyte of Equisetum with that of most Ferns, the greatest contrast is in the relative importance of stem and leaves. The stem in all the Equisetinex is extraordinarily developed, while the leaves are rudimentary, in strong contrast to their great size and complexity in many Ferns. All species of Equisetum produce a more or less developed underground rhizome, which often grows to a great length and ramifies extensively. This, like the aerial branches developed from it, shows a regular series of nodes and internodes. The latter are marked by longitudinal furrows, and about each node is a sheath whose summit is continued into a number of teeth, varying with the size of the stem. Corresponding to each tooth of the sheath there is developed an axillary bud, which may either at once develop into a shoot, subterranean or aerial, or these buds may remain dormant for an indefinite period, being capable of growing, however, under favourable 
conditions. The surface of the rhizome in E. telmateia, especially at the nodes, is covered with a dense dark-brown felt of matted hairs, and a whorl of roots occurs at each node, corresponding in number to the number of axillary buds, from whose bases the roots really grow. Sometimes the buds become changed into tubers (Fig. 227), which are especially common in E. telmateia and E. arvense. These tubes are protected by a hard brown sclerenchymatous rind, within which is a mass of starchy parenchyma, traversed by the slender
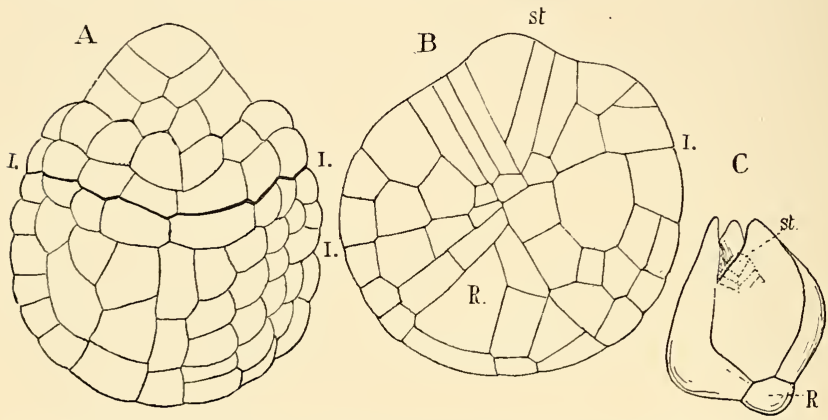

FIG. 226.-A, An advanced embryo of $E$. arvense (L.), surface view, $\times_{3} 60 ; \mathrm{B}$, optical section of a similar stage of $E$. palustre (L.), $\times 360 ;$ C, older embryo of E. arvense (L.), $\times 160 ; s t$, stem; R, root (all the figures after Sadebeck).

vascular bundles. In some cases these buds form in chains and are then seen to be the swollen internodes of short branches.

The aerial stems are of two kinds, sporiferous and sterile. In one group the only difference between the two is that the former bear at the apex the sporangial strobilus; in the second, of which E. telmateia is an example, the sporiferous branches are almost entirely destitute of chlorophyll and quite unbranched, while the green sterile shoots are extensively branched. In such forms the fertile shoots die as soon as the spores are shed, and usually appear before the green shoots are developed. 


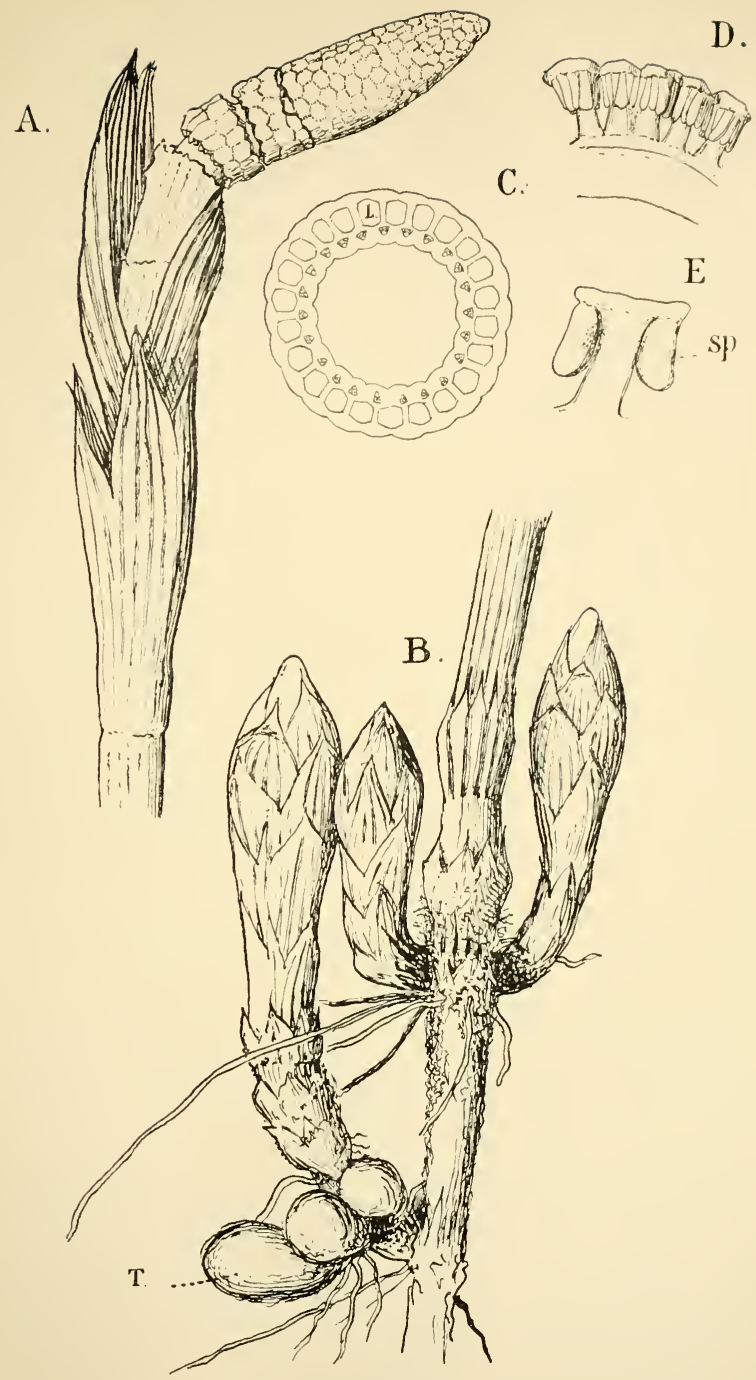

Fig. 227.-A, Upper part of a fertile shoot of E. telmateia, $\times 1$; B, lower part of a vegetative shoot, with young branches for the next season's growth, $X_{I} ; \mathrm{T}$, tubers; $\mathrm{C}$, cross-section of an internode of the fertile shoot, $\times_{4} ; \mathrm{L}$, cortical lacunæ; D, sporangiophores, $\times_{4} ; \mathrm{E}$, median section of a single sporangiophore, $\times 6 ; s p$, sporangia. 


\section{The Stem ${ }^{1}$}

A longitudinal section of one of the numerous subterranean buds (Fig. 228) shows that the conical apex of the stem is occupied by a large pyramidal cell whose segmentation is exceedingly regular. The youngest of the foliar sheaths is separated from the apex by several segments, but below, the next older sheath is very close to it, and the internode, which in the older stem is so conspicuous, is scarcely perceptible. The closely-set sheaths grow very rapidly, so that all but the youngest ones extend beyond the stem apex, which is thus

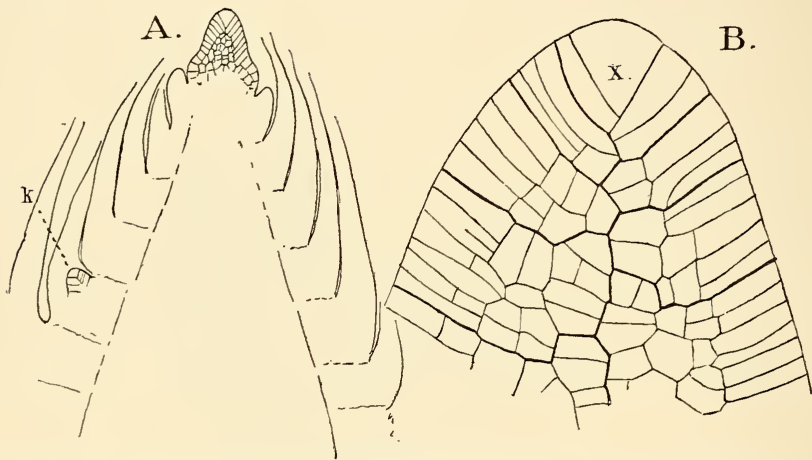

FIG. 228.-A, Median section of a strong subterranean (vegetative) bud, $\times_{30} ; k$, lateral bud; $\mathrm{B}$, the apex of the same section, $\times 200$.

very completely protected. They form a compact, manylayered covering about it, presenting very much the appearance of the leaf-buds of many Spermaphytes. The apical cell shows the usual three series of lateral segments. These are arranged in three rows, but owing to a slight displacement in the younger ones, the teeth of the sheaths alternate. Each cycle of three segments comes to lie practically in the same plane, and constitutes a disc which later forms a node and internode of the stem. Each segment is first divided by a wall nearly parallel to the wall by which it was cut off from the apical cell, into two overlying cells. The upper cells or semi-segments give rise to the nodes, the lower to the internodes.

1 Rees (2); Sachs, see Goebel (I0), p. 26 I ; Janczewski (3). 
The next walls are like the sextant walls in the roots of the Ferns, and a cross-section just below the apex presents exactly the same appearance. Each cell now divides by walls, apparently not always in the same order, parallel with the primary and lateral walls, and very soon there are periclinal divisions by which an inner cell is cut off from each segment cell that extends to the centre. This primary group of central cells is the pith, which later in the internodes is usually torn apart and destroyed, leaving the large central hollow met with in all the larger species of Equisetum. From the outer cells are developed the leaves, the vascular bundles, and cortex.

The annular leaf-sheaths begin as outgrowths of the superficial nodal cells of each cycle of segments, and these form a circular ridge or cushion running round the base of the apical cone. The summit of this ridge is occupied by a row of marginal cells, which are the initial cells, and from which segments are cut off alternately upon the inner and outer sides (Fig. 233, A). The growth is stronger at certain points, which, according to Rees, ${ }^{1}$ have a definite relation to the early divisions. Thus in E. scirpoides the teeth are always three, and correspond to the primary nodal cells; in E. arvense there are six or seven, in the first case corresponding to the sextant cells, in the latter to the sextant cells plus the first division in one of them. In the large species, like E. telmateia, it is difficult to trace any such relation. In most forms, by subsequent dichotomy of some or all of the primary teeth, others are formed, so that the number in the fully-developed sheath exceeds that first formed. As soon as the young sheath begins to project, a section through one of the teeth shows that it is divided into an upper and lower tier of cells, the apical cell terminating the upper one. This division no doubt corresponds to the first horizontal division in the outer nodal cell from which the leaf-tooth originally comes. In one a little older (Fig. 233, B), in this upper tier of cells a line of cells occupying the axis is evident $(f b)$, extending from the base of the leaf nearly to the summit, and growing at its outer end by the addition of cells derived from the inner part of the youngest upper segments of the terminal cell of the leaf. ${ }^{2}$ This is the beginning of the single vascular bundle found in each leaf.

1 Rees (2), p. 228.

2 Each tooth is here regarded as a leaf, the sheath as a circle of confluent leaves. 
Shortly after this first indication of the vascular bundle of the leaf can be seen, the cells of the cortex immediately outside the central pith begin to divide rapidly by longitudinal walls and form

A.

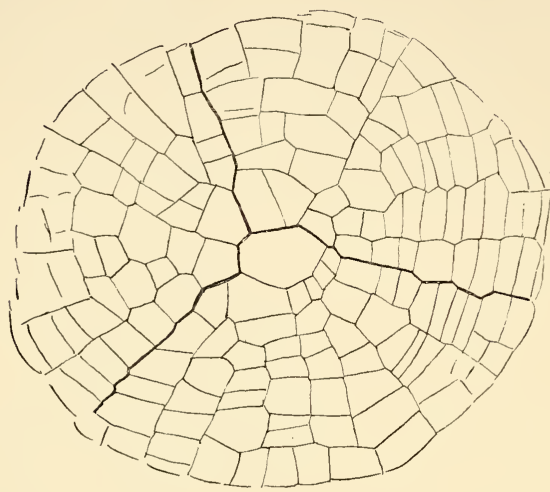

B.

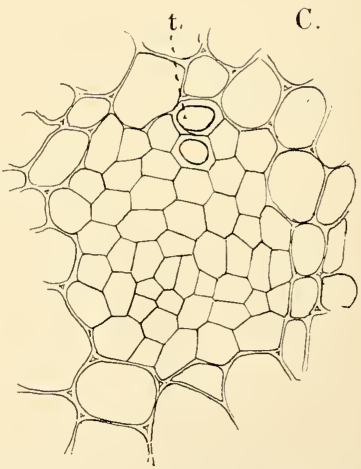

FIG. 229.-Transverse section of a young vegetative shoot just below the apex, $\times 260$; B, outer part of a section lower down, $\times_{260}$; pr, procambial zone; $\mathrm{C}$, young vascular bundle, $\times 520 ; t$, primary tracheids.

a zone of cambiform cells completely surrounding the medulla. In the primary central row of cells in the leaves similar divisions occur, and a very evident procambium cylinder is formed, bending 
in and joining the procambium zone of the cortex. At the point of junction the cells are shorter and broader, and the cortical cells lying outside are also much broader, so that the cortical procambium is very conspicuous. If cross-sections are examined about this time, in the procambium zone are found a number of groups of cells where the divisions are more rapid, and the resulting cells narrower than the surrounding ones. These are the separate vascular bundles, and are continuous with those in the leaves (Fig. 230). The first permanent tissue consists of one or two small annular tracheids upon the

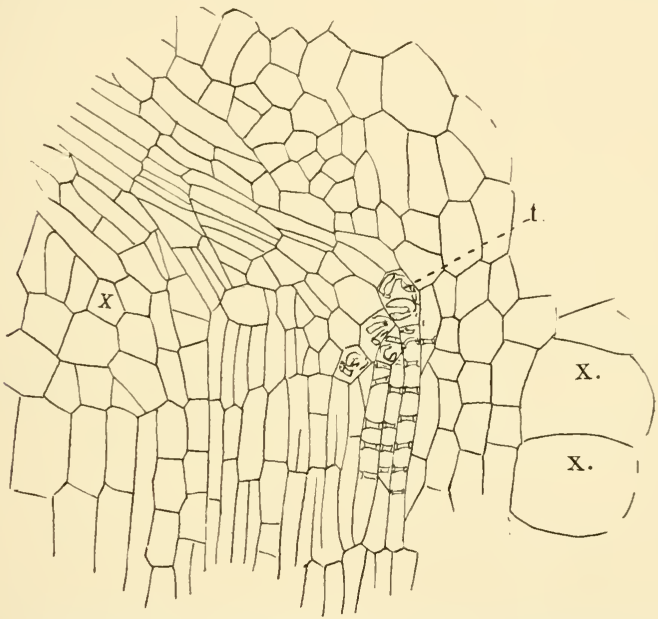

FIG. 230.-Longitudinal section of the young stem, showing the junction of the foliar and internodal bundles; $t r$, the primary tracheids; $x, x$, tannin-hearing cells.

inner side of the bundle (Fig. 229, C). These are followed by several others. They first form in the internodal part of the bundle and only later in the foliar portion. The nodal tracheids joining the xylem of the foliar and internodal bundles are very irregular short cells with annular thickenings upon their walls. Later two small groups of larger spiral tracheæ are formed at the sides of the xylem, but the greater part remains but little changed. By this time, in E. telmateia, numbers of cells with peculiar contents are noticed scattered through the pith and cortex (Fig. 230). The contents of 
these are dense, and stain deeply, indicating the presence of mucilaginous matter, and probably tannin, their appearance and behaviour being very much like the tannin cells of Angiopteris or Marattia.

In the older parts of the section the nodal cells remain short, while the internodal cells elongate very much and separate the nodes with their attached foliar sheaths. With this growth is associated the formation of the characteristic lacunæ. In all the large species the growth of the medullary cells very soon ceases to keep up with the expansion of the stem, and they are torn apart and almost completely disappear, leaving a great central cavity in each internode separated from the neighbouring ones by a thin diaphragm,-all that is left of the medulla in the fully-developed stem. The leaves of successive sheaths alternate, and a study of the course of the vascular bundles shows that at each node the alternating bundles of successive internodes are connected by short branches. Corresponding to the vascular bundles are ridges upon the surface of the internodes and foliar sheaths, due to greater growth at these points, as a result of which a regular series of cortical lacunæ (vallecular canals) is formed, alternating with them (Fig. 227, C), and lying just outside of the cortical zone containing the vascular bundles. In some of the small species of Equisetum, as in the primary shoot, the central lacuna is absent.

A cross-section of the fully-developed stem of E. telmateia (Fig. 227, C) shows this very regular arrangement of the vascular bundles and lacunæ. In addition to the large cortical ones, each vascular bundle has, on the inner side, a large airspace, which like the other is formed by the tearing apart of the tissues of the bundle. In this way the primary tracheids are torn apart and often destroyed, so that all that remains of them are the isolated thickened rings adhering to the sides of the canal. The bundle is strictly collateral in structure, and very much resembles that of many grasses and other simple Monocotyledons. The phloëm is composed of sieve-tubes, which, according to Russow, ${ }^{1}$ have only horizontal sieve-plates, and no lateral ones as in the Ferns. These are mingled with cambiform cells. In the species in question there is in addition a zone of bast fibres, at the outer limit of the phloëm.

Surrounding the whole circle of bundles in E. telmateia, 
E. aroense, and several other species, there is a common endodermis (Fig. 23I, en). In others the arrangement is different. ${ }^{1}$ Thus in E. limosum, each separate bundle has its own endodermis; in E. hiemale there is a common inner as well as an outer endodermis in the aerial stems, while the bundles of the rhizome are like those of E. limosum. Inside the endodermis lies the single pericyclc.

All the cortical cells are separated by small intercellular spaces, which are very conspicuous in the soft tissue of the fertile stems of E. telmateia and E. arvense. In all of the

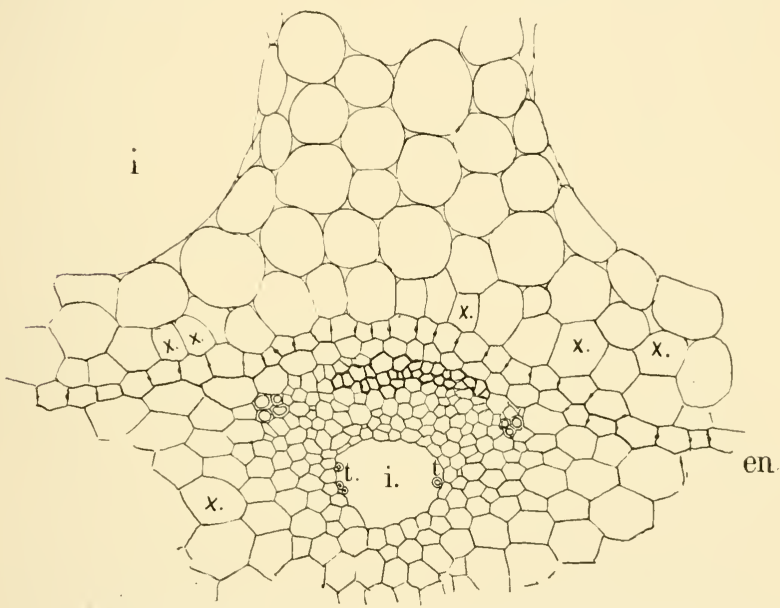

FIG. 231.-Transverse section of the vascular bundle of a fully-developed vegetative shoot, $\times 75 ; i, i$, lacun $x ; x, x$, tannin cells ; $t, t$, remains of the primary tracheids; $c n$, endodermis.

internodes of the main axes of $E$. telmateia chlorophyll is absent, but in most species the principal assimilative tissue is situated here. It consists usually of isolated masses of transversely extended green cells separated by strands of colourless sclerenchymatous fibres, which form the ridges so prominent upon the internodes and foliar sheaths. Seen in cross-section the masses of green cells are concave outwardly and lie beneath the grooves between the ridges. In secondary branches

1 Pfitzer (I), p. 292 : Van Tieghem (6), p. 365. 
the amount of this tissue is much greater and the lacunæ less conspicuous, or indeed even wanting.

The epidermis, as is well known, contains great quantities of silex, which gives it its very rough and harsh surface. This is deposited either uniformly, as is usually the case in the lateral cell walls, or in tubercular masses. Upon the inner surface of the guard cells of the stomata it forms regular transverse bars (Fig. 232). Upon the outer walls of the epidermal cells the masses form either isolated bead-like projections or these are more or less completely confluent.

The stomata are peculiar in structure, and their development was first correctly described by Strasburger. ${ }^{I}$ In E. telmateia these only occur usually upon the foliar sheaths, but in species with green internodes they are found principally upon the sides of the furrows over the green hypodermal tissue. ${ }^{2}$ Before the stoma proper is formed, the cell divides twice by longitudinal walls (Fig. 232), and the original cell is thus divided into a central one (the real stoma mother cell) and two narrow lateral accessory cells. The central cell now divides again, and the division wall splits in the centre as usual. A cross-section of the young stoma (Fig. 232, D) shows that the walls by which the accessory cells are cut off are inclined, so that the stoma cell is broader at the bottom than at the top, and as development proceeds the accessory cells completely overarch the stoma, and in the older ones look as if they had arisen by horizontal divisions in the primary guard cells. The accessory cells show the same tuberculate silicious nodules upon their outer walls as the other epidermal cells, and upon the inner face of the real guard cells only are formed the regular bars. Stomata are quite absent from the rhizome, and also from the colourless fertile branches of E. telmateia. Compared with the aerial stems, the rhizome shows a smaller number of vascular bundles, and a corresponding reduction in the number of the lacunæ.

Until the researches of Janczewski ${ }^{3}$ and Famintzin ${ }^{4}$ it was supposed that the lateral branches arose endogenously. Their researches, however, showed conclusively that this was

1 Strasburger (I).

2 Miss E. A. Southworth (I) found that in E. arvense they occur upon the ridges, and upon the fertile as well as the sterile shoots.

${ }^{3}$ Janczewski (3).

4 Famintzin (I). 

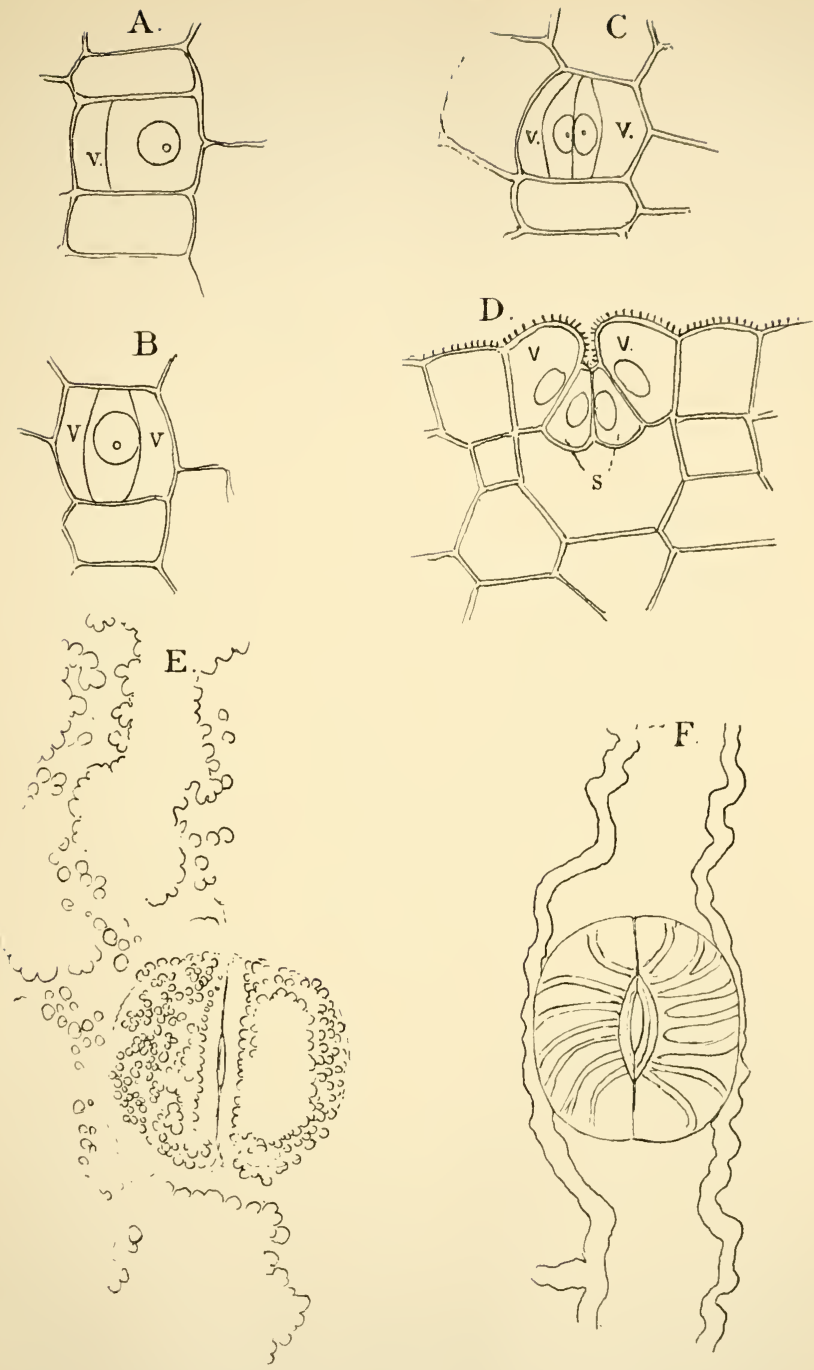

FIG. 232.-Development of the stomata. A.C, Surface views of very young stomata of E. telntateia, $\times 600 ; \mathrm{D}$, section of an older stoma of E. limosum, $\times 700$ (after Strasburger); E, outer surface of a complete stoma of E. telmateia, showing the silicious nodules upon the epidermal cells; F, inner side of the same, showing the silicious bars upon the inner walls of the guard cells; $z, \tau^{\prime}$, accessory cells ; $s$, guard cells. 
not the case, but that the origin was exogenous. In most species these are produced abundantly, and a bud is formed in the axil of each leaf, although it frequently happens that some of them do not develop fully. In E. telmateia they do not form at all, as a rule, upon the colourless sporiferous shoots, but are regularly formed from all but the lowest nodes of the sterile stems. In E. scirpoides they are absent from all the aerial stems, but whether rudiments of them are formed does not seem to have been investigated.

Their development may be readily traced in a series of
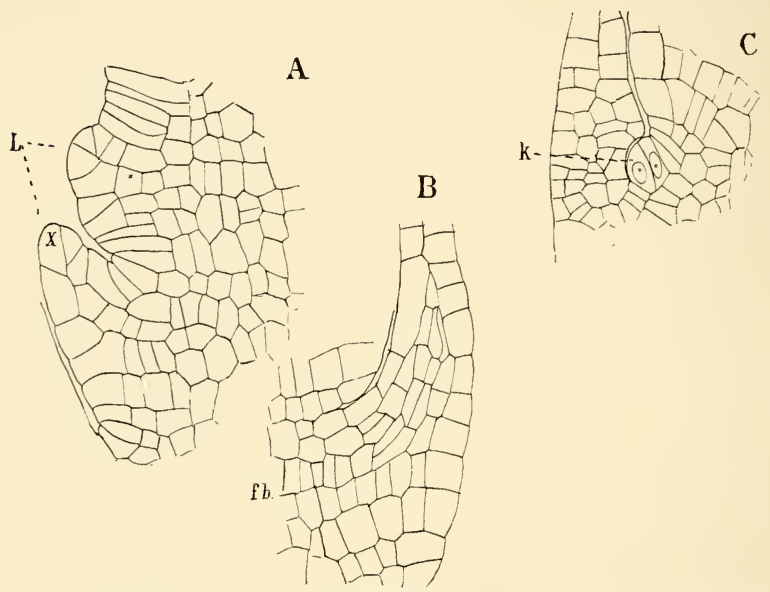

FIG. 233.-Longitudinal section of a young vegetative shoot, showing two young leaves (L.), $\times 200$; $\mathrm{B}$, section passing through the hase of a somewhat older leaf; $f b$, vascular bundle; $C$, section passing through a young bud $(k)$.

median longitudinal sections through a vigorous sterile stem of $E$. telmateia or $E$. arvense before it appears above ground. The young bud (Fig. 233, C) originates from a single epidermal cell just above the insertion of the leaf. This cell enlarges and is easily recognisable. In it are formed three intersecting walls cutting out the apical cell, which at first is somewhat irregular, but soon assumes its definite form, and the subsequent growth of the branch resembles in all essential points that of the main shoot. Very early the cells of the leaf-base immediately above the young bud grow around it like a sheath, and 
finally become grown together with the epidermal cells of the axis above the bud, which thus lies in a completely closed cavity. As the bud grows it gradually destroys the tissuc surrounding the cavity, and finally breaks through the base of the leaf, appearing from the outside as if it had developed from below and not from the axil of the leaf. In most species these

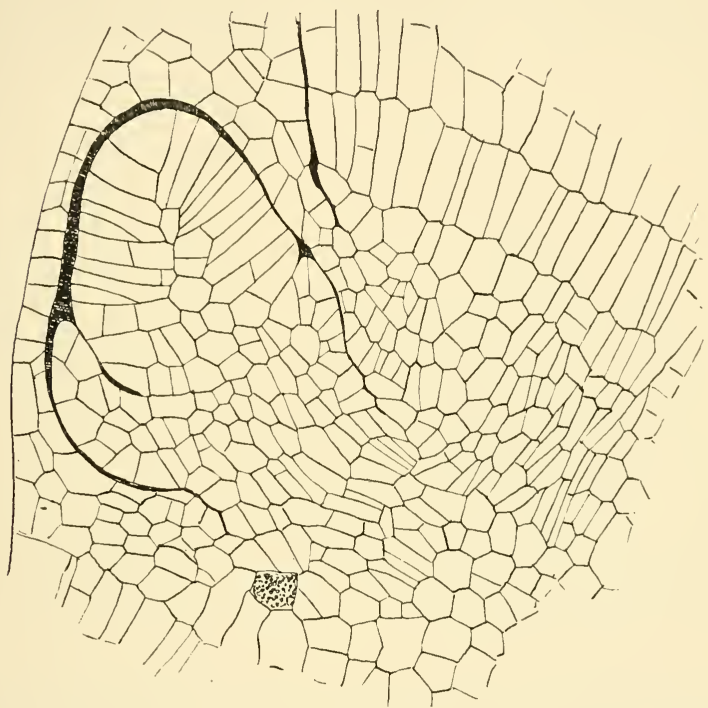

FIG. 234.-Section of a lateral bud, enclosed within the sheath formed by the leaf-base, $\times{ }_{175}$.

branches remain simple, but in E. sylvaticum and E. giganteum the secondary branches also ramify.

\section{The Roots}

The formation of the roots is intimately connected with that of the lateral buds. Each bud normally produces a single root below the first foliar sheath, which in the buds derived from the rhizome all develop, whether the buds themselves grow further or not. According to Janczewski, certain of these rhizogenic buds of the rhizome produce several roots, but the 
buds remain otherwise undeveloped. In the aerial stems the roots remain normally undeveloped, but may often be stimulated into growth by keeping the stem moist and dark.

Van Tieghem ${ }^{1}$ describes the roots of $E$. palustre as being exogenous, and says they can be traced to a definite cell of one of the young segments. Janczewski, ${ }^{2}$ however, was unable to recognise the young root until the first foliar sheath was well developed, and in E. telmateia I could see no trace of the root in still older buds, and they were apparently always of
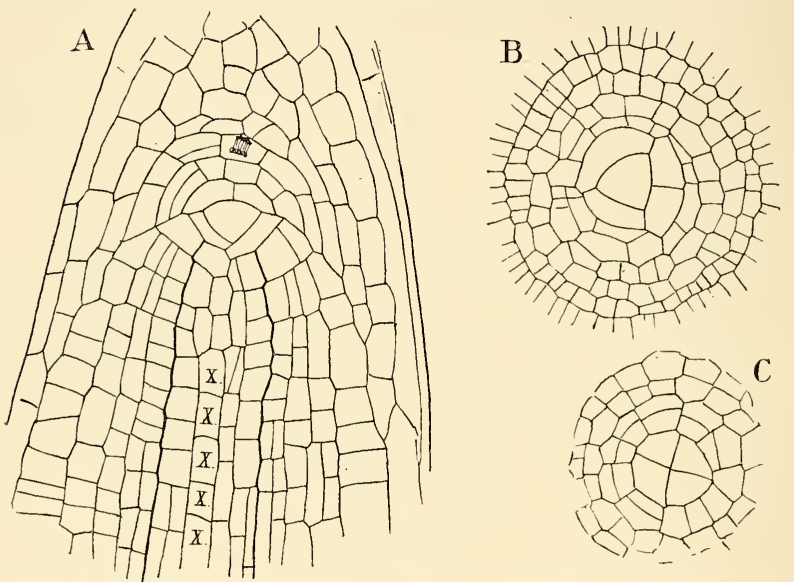

Fig. 235.-A, Longitudinal section of the root apex, $\mathrm{X}_{200} ; x, x$, the large central vessels of the vascular bundle; $\mathrm{B}, \mathrm{C}$, two transverse sections passing through the apex, $\times 200$. In $\mathrm{C}$ is shown the first divisions of the cap cell.

endogenous origin, although this point was not closely investigated.

The structure of the apical meristem is much like that of the leptosporangiate Ferns, the main difference being the greater development of the root-cap, in which periclinal walls are frequent, so that the older layers, especially in the middle, are several cells thick, and not clearly limited.

After the sextant walls are formed, each semi-segment is divided at once into an inner and an outer cell, the former 
giving rise directly to the plerome. The next division (secn in longitudinal section) separates the epidermis initials from the cortex. A cross-section of the young plerome immediately after the first divisions have taken place (Fig. 236, A) shows that the three primary cells are of unequal size, and that the two smaller ones divide first. From the larger one, the first periclinal wall separates a central cell, which occupies almost exactly the middle of the section, and this stands immediately above the corresponding one in the older segments, so that in longitudinal sections these form a very conspicuous axial row of cells $(x, x)$, which together constitute the single large vessel which occupies the centre of the older bundle.
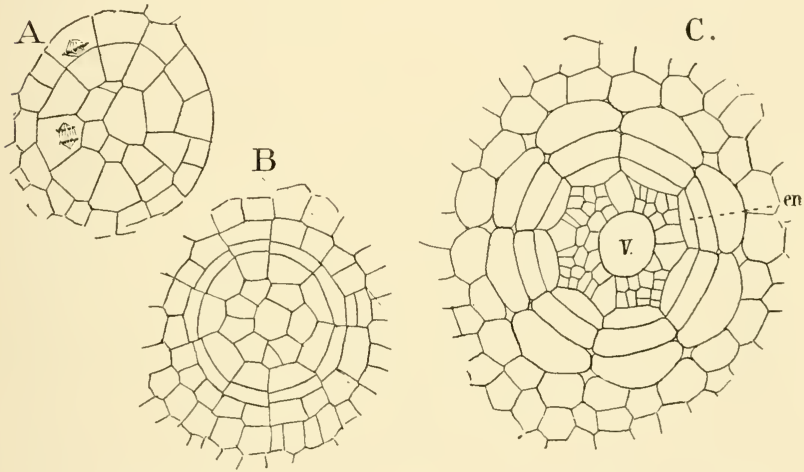

FIG. 236. - Three transverse sections of the young root, $\times 200 ; e n$, endodermis; $v$, central vessel.

The endodermis becomes separated by this time, and a little lower down divides by periclinal walls into the two layers found in the completely developed root. The tissues of the central part of the young root are very regularly disposed (Fig. 236, $\mathrm{B}, \mathrm{C})$. In the centre is the large vessel already described, around which are arranged at first a single row of usually six or eight cells (Fig. 236, B). By these first divisions the separation of the xylem and phloëm of the bundle is complete. If there are six of these primary cells the bundle will be triarch, if eight, tetrarch. In somewhat older sections of a tetrarch bundle (Fig. 236, C) four of the primary cells are still recognisable and have divided but little. These form the four groups 
of tracheids of the older bundle. The intermediate cells divide much more rapidly and constitute the phloëm. The number of endodermal cells in a cross-section corresponds generally to the number of xylem and phloëm masses. The peripheral groups of tracheæ early develop spiral thickenings upon their walls, and sometimes there is but a single row of tracheæ in each xylem mass. Each of the three phloëm masses of E. variegatum has three narrow sieve-tubes in contact with the inner endodermis surrounded by thin-walled cambiform cells. The thickenings upon the walls of the large central vessel form only at a late period.

Intercellular spaces arise at the angles of the outer endodermal cell, and similar ones also between the outer cells of the cortex, which becomes very spongy in the older roots. Numerous brown root-hairs, like those upon the rhizome, cover the surface of the root. A pericycle is quite absent, and the secondary roots arise from the inner endodermis in direct contact with the tracheids. The latter, as will be seen from the figure, lie between two endodermal cells, and the young root lies therefore not directly opposite, but to one side of the corresponding xylem mass. The young roots may arise from either of these endodermal cells, and consequently there is formed a double row of rootlets corresponding to each xylem mass of the bundle. Shortly after the rootlet is formed, the endodermal cell outside it divides by a tangential wall, and this develops into a double layer of cells completely enclosing the young rootlet. ${ }^{1}$ A similar "digestive pouch" is formed, according to Van Tieghem, in the roots of many Ferns, but is in these derived from the cortex outside the endodermis. The double endodermis of the bundle of the older root shows the characteristic foldings of the radial walls only upon the outer cells.

Cormack ${ }^{2}$ has recently published a paper showing that in E. maximum (telmateia) there is a slight secondary increase in thickness in the nodes of the stem, due to the presence of a genuine cambium, not unlike that in the stem of Botrychium.

\section{The Sporangia}

In all species of Equisetum the sporangia are formed upon the under side of peltate sporophylls arranged in closely-set 
circles about the upper part of the axis of the fertile shoots (Figs. 227, 242). A section through the apcx of the young shoot shows much the same structure as a sterile one, but the apical cell is smaller and the leaves do not arise so near the summit. Circular foliar sheaths are formed in the same way, but the lcaves form rounded elevations, either entirely separated or but slightly joined (Fig. 237). These are at first nearly hemispherical, but soon become constricted at the base, and about the same time the first trace of the sporangia can be seen. A section of the young sporophyll

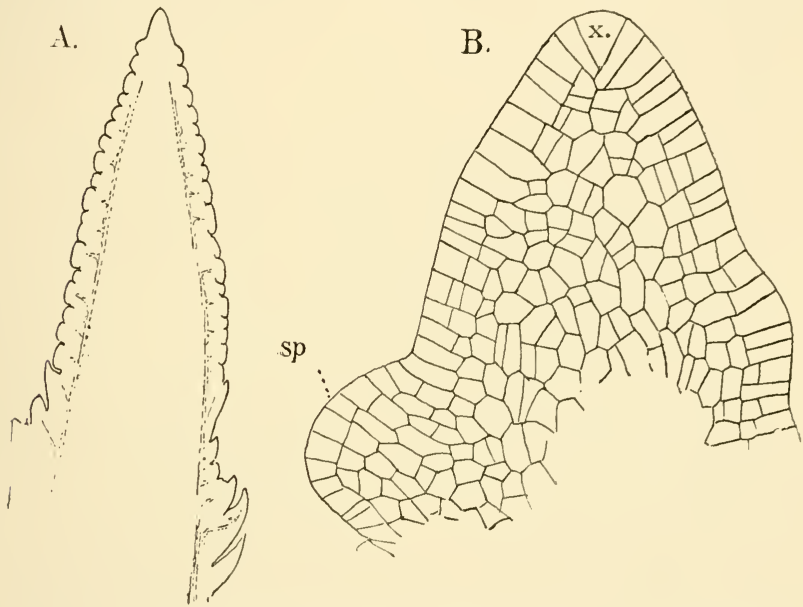

FIG. 237.-A, Longitudinal section of the apex of a young fertile shoot, $\times_{16}$; B, apex of the same, $\times 160 ; s p$, young sporangiophore; $x$, apical cell.

shows that the centre of the prominence already has formed the young plerome which, as in the ordinary leaves, joins that of the internode beneath. Just above the base a cell may sometimes be detected, which is larger than its fellows, and has a larger nucleus. From a comparison with slightly older stages there is no doubt that this is the sporangium mother cell, or more correctly the axial sporangial cell, as the adjacent tissue also takes part in its further growth. This axial cell now becomes separated into an inner and outer cell, as in Botrychium. The outer cell divides again. The innermost 
cell of the axial row is the archesporium, and gives rise to the sporogenous cells by repeated divisions, at first at right angles to each other, later in all directions. Bower ${ }^{1}$ thinks that all the sporogenous cells are not to be traced back to the single archesporial cell, but that the inner of the two cover cells also takes part in spore-formation. The exact limits of the archesporium are difficult to follow, as the contents of the sporogenous cells are not strikingly different from the inner tapetal ones. These are derived from the cells adjacent to the axial

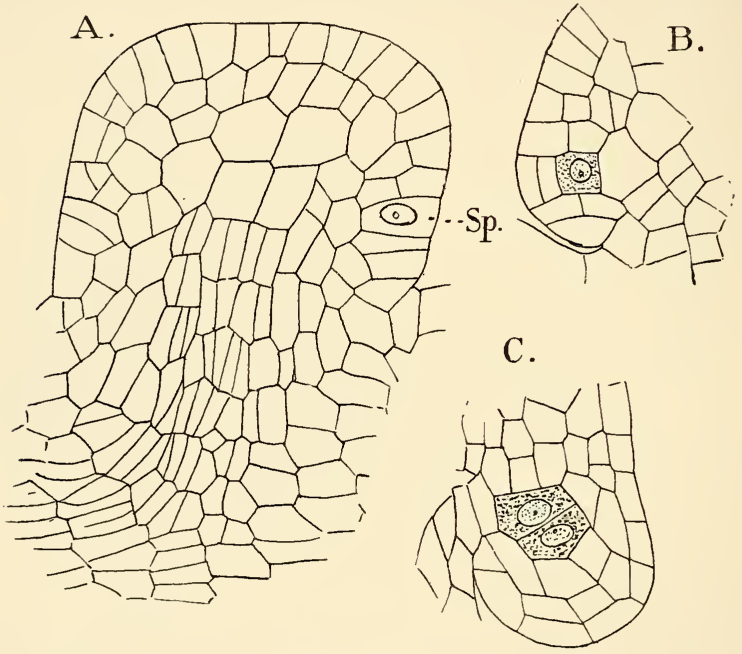

FIG. 238.-A, Longitudinal section of young sporangiophore, showing the primary sporangial cell $(s p)_{r}$ $\times 260 ; B, C$, longitudinal sections of young sporangia, $\times 260$. The archesporial cells are shaded.

row, and from the cells of the latter just outside the archesporium. The wall of the sporangium is mainly formed from the cells adjacent to the axial row of cells. All the cells grow and divide rapidly, so that the sporangium soon projects strongly from the margin of the sporophyll, whose upper part becomes broad and flattened, while the stalk increases but little in diameter. The wall of the sporangium at first is three or four cells thick. Finally it is reduced to but a single complete 
layer by the absorption of the others, but the remains of a second layer can be made out in stained sections of the ripe sporangium (Fig. 24 I, E). The vascular bundles of the sporophyll branch, one branch running to each sporangium.

Of the two species studied by Bower, E. arvense and $E$. limosum, the latter showed more slender and strongly projecting sporangia, but otherwise they were alike. E. telmateia has even more massive sporangia than $E$. arvense. The sporophylls form a regular cone at the apex of the fertile branch, and are arranged in regular whorls, which vary in number in

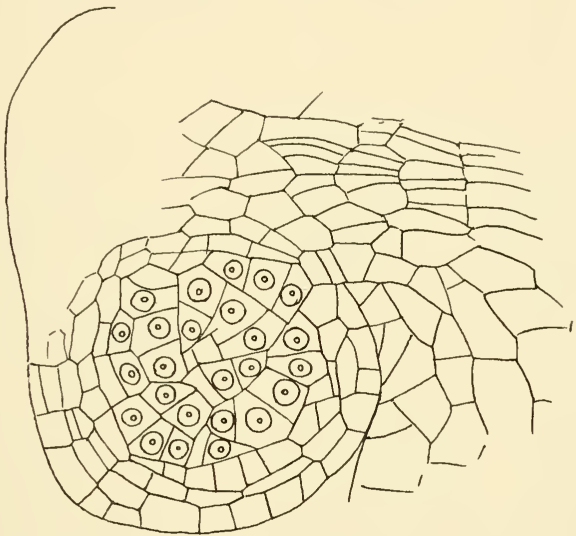

FIG. 239. - Longitudinal section of an older sporangium, $\times_{2} 60$. The nuclei are shown in the archesporial cells.

proportion to the size of the cone. The top of the sporophyll is always polygonal in outline, owing to the lateral pressure of its neighbours, and very often they are regularly hexagonal, but this bears no relation to the number of sporangia, which usually exceed in number the angles of the sporophyll.

\section{Development of the Spores}

The development of the spores in Equisetum, while agreeing in many respects with that of the eusporangiate Ferns, shows some peculiarities that are noteworthy, and as this offers one of the best cases for studying spore-formation, it was 
somewhat carefully followed in E. telmateia. After the complete number of cells has been formed in the archesporium, and before the tapetal cells are broken down, the sporogenous cells are divided into groups which begin to separate from each other. With the enlargement of the sporangium and the breaking down of the inner tapetal cells these masses become isolated, and are very easily removed from the sporangium (Fig. 240, A). They usually consist of four cells, which in water swell up somewhat. In a fresh condition they appear quite colourless, but the cytoplasm is densely granular. The nucleus is very large and appears quite transparent with one or two distinct nucleoli. In material treated with osmic acid, what appeared to be the centrospheres were seen, but not very clearly. In microtome sections of about the same age (Fig. $240, \mathrm{~B})$ the numerous rod-shaped chromosomes were very evident, but their number could not be determined. The nucleolus is conspicuous, and on one side, in a slight depression in the nuclear membrane, are the two centrospheres. These latter were not always perfectly evident, but are probably always present. The radiating lines about them were not seen. Before the final division takes place, the sporogenous cells become completely rounded off, and are embedded in a mass of nucleated protoplasm (Fig. 24 I, A) derived from the tapetal cells, but also in part from some of the archesporial cells which do not develop into spores. ${ }^{1}$

Fig. 240 shows the successive stages in the process. During the division of the primary nucleus there is an evident cell plate formed (Fig. 240, E), but no division wall. The period at which the centrospheres divide could not be made out, but by the time the division is complete each nucleus is provided with two, which are decidedly smaller than the primary ones. During this first division there is probably a reduction in the number of the chromosomes, as in Osmunda. At any rate the number is evidently much smaller during the metaphases of the second nuclear divisions (Fig. 240, F). The second divisions are the same as the primary one, and the planes of the two nuclear spindles may either be parallel or at right angles (Fig. 240, F). In either case the resulting nuclei arrange themselves at equal distances from the centre of the cell, and the connecting filaments are formed between them.

1 Bower (15), p. 500. 
In the connecting spindles is formed between each pair of
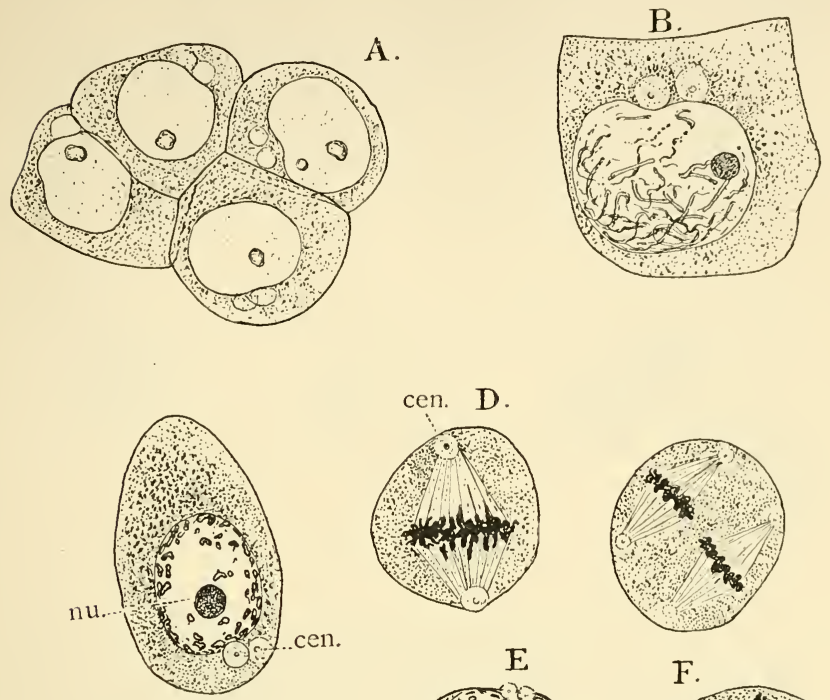

cen. D.

C.
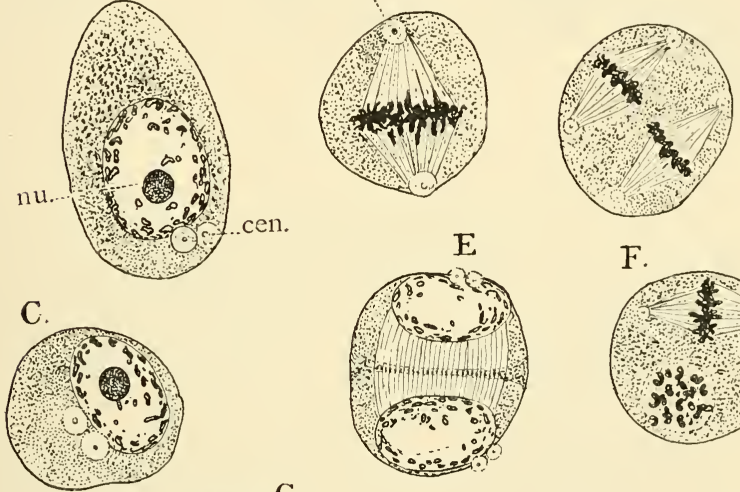

F.

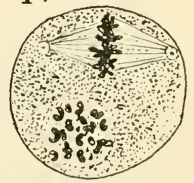

G.
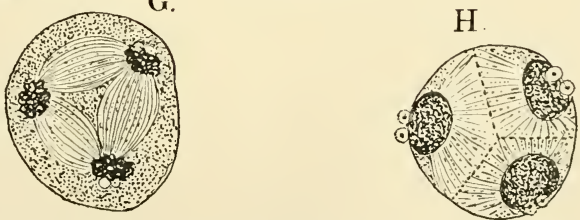

FiG. 24c.-Development of the spores. A, Group of four sporogenous cells, $\times 600 ; \mathrm{B}$, section of a single sporogenous cell, just before the first division of the nucleus, $\times 1200 ; D-H$, successive stages in the division of the nuclei, $\times 1200 ; c e n$, centrospheres; $n u$, nucleolus.

nuclei a cell plate, which here soon develops into a definite cellulose membrane, and the spores separate completely. 
The young spore has at first a very delicate cellulose membrane, which thickens, and later has separated from the outside the "middle layer" (Fig. 24I, B, m), which in spores placed in water lifts itself in folds from the underlying exospore. The outer perinium seems to be unquestionably formed through the agency of the nucleated protoplasm, in which the young spores lie. It is at first a uniform membrane, closely applied to the middle coat, but when placed in water it swells up and
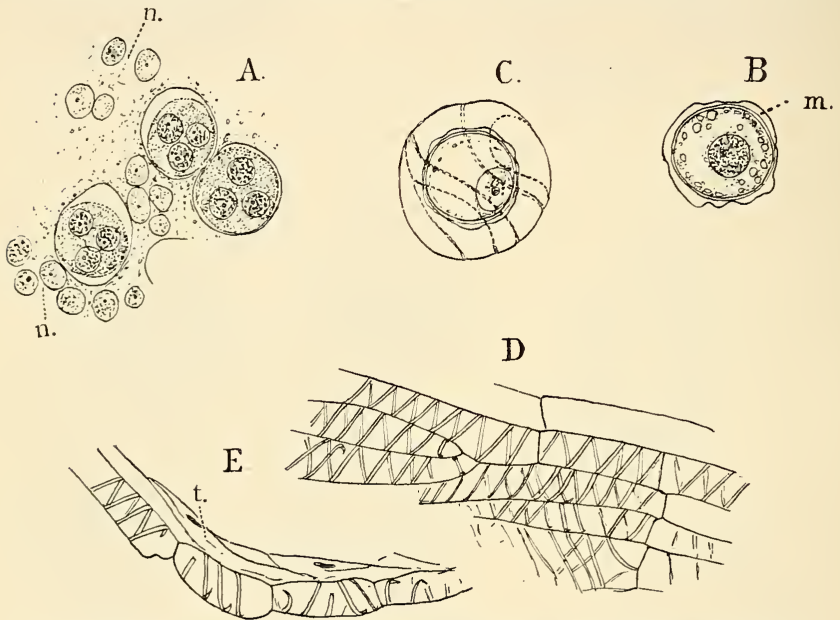

FIG. 241.-A, Group of sporogenous cells, just before the final division into the spores, embedded in the nucleated protoplasm formed from the disintegrated tapetum, and sterile archesporial cells, $\times 500 ; \mathrm{B}$, optical section of young spore, showing the three membranes; $m$, the middle lamella, $\times 500 ; \mathrm{C}$, an oIder spore, showing the splitting of the outermost coat to form the elaters, $\times 500$; $\mathrm{D}$, surface view of the dorsal cells of the wall of a ripe sporangium, $\times_{150} ; \mathrm{E}$, section of the wall, showing the remains of the inner layers of cells $(t), \times 250$.

separates completely from the exospore, or remains attached to it at one point only, which marks the point of attachment of the elaters in the ripe spores. The elaters arise from the epispore by its splitting spirally into four bands (Fig. 24 I, C), due apparently to thickening along these bands, leaving thin places between, which are finally absorbed. The outside of the elaters becomes cuticularised. The ripe spores contain numerous chloroplasts, which only are evident in the latest stages of development. In $E$. arvense the formation of the 
sporangia begins nearly a year before the spores are shed, and they are completely developed during the preceding autumn. The growth of the fertile branch and the scattering of the spores take place very soon after growth begins in the spring. Whether in cold climates E. telmateia behaves the same way I cannot state; but in California, where growth continues all the winter, the development of the sporangia is gradual, and the fertile stems grow up and scatter the spores as soon as they are ripe. The ripe sporangia are oblong sacs, whose wall is composed for the most part of a single layer of elongated cells, marked with spiral thickened bands upon the dorsal surface and rings upon the ventral cells, where the longitudinal slit by which the sporangium opens is placed (Fig. 24I, D, E). The internodes in the strobilus are very little developed, but as the spores ripen there is a slight elongation, by which the sporophylls are separated.

\section{Classification}

Milde ${ }^{1}$ divides the genus into two, Equisetum (Equiseta phanopora), in which the accessory cells of the stoma are on a level with the surface of the epidermis; and Hippochate (E. cryptopora), in which the stomata are sunk in depressions of the epidermis. In the former group are two divisions, those which, like $E$. arvense and $E$. telmateia, have the fertile and sterile branches different, and those where they are alike, e.g. E. limosum (Fig. 242, A). In the former group some species, e.g. E. pratense, have the fertile stems at first colourless, but afterwards forming chlorophyll and developing branches. In Hippochate, which includes among American species E. hiemale, E. robustum, E. variegatum and E. scirpoides (Fig. 272, B), the aerial branches are all similar and often are quite unbranched. The foliar sheaths show considerable variation. In the fertile stems of $E$. telmateia (Fig. 227) they are extremely large and the ribs very prominent, but the separate leaves are not all distinct at the apex, but the sheath splits into a few very deeply cleft pointed lobes. In the sterile shoots, however, and in all the stems of most species, the teeth are very distinct and the foliar sheath much shorter. The number of teeth varies from three in 


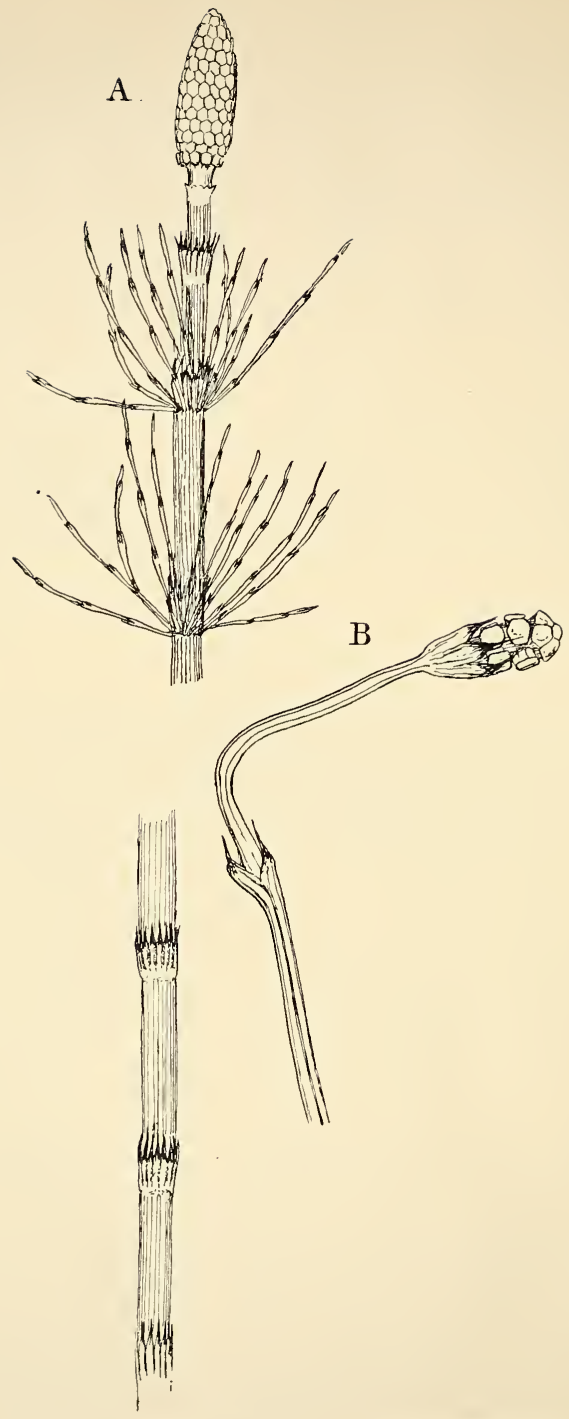

FIG. 242.-A, Equisetum limosum (L.), $\times \frac{1}{2} ; \mathrm{B}$, E. scirpoides (Michx.), $\times 2$. 
E. scirpoides, to thirty to forty, or even more, in E. telmateia and E. robustum.

\section{Fossil Equisetinea}

To this class are usually assigned two groups of fossil plants, one belonging to the Equisetacex, and represented by the genus Equisetites, which evidently was very close to the genus Equisetum, if not identical with it. The other group, the Calamarieæ, differed in some respects from the living forms, and there is much diversity of opinion about their real affinities. The best known members of this order are the Calamiteæ, whose anatomical structure is well known. Cormack ${ }^{1}$ has recently made a comparison of the structure of these with Equisetum, and comes to the conclusion that the type of structure is essentially the same. The general points of difference are the completely separate leaves of the Calamites, the frequent absence of diaphragms at the nodes, and the marked secondary thickening of the vascular bundles. Cormack has shown that a slight thickening of the same character occurs in the nodes of E. maximum, and in the Calamiteæ this thickening seems to begin in the nodes and to extend later to the internodes. Cormack concludes that all the Calamiteæ possessed this secondary thickening of the stem. The two groups Annularieæ and Asterophylliteæ, which have slender stems with regular whorls of leaves at the nodes, have been found to be to some extent, at least the smaller branches, of indubitable Calamiteæ; but it is questionable whether this is always so. ${ }^{2}$

The most important remains of this group are the fossils known under the name Calamostachys. These are cone-shaped structures, whose close affinity with Equisetum is beyond question. The whorls of sporophylls, which are peltate, like those of Equisetum, and bear four sporangia upon the lower surfaces, are separated by alternating whorls of sterile leaves. Through the kindness of Dr. D. H. Scott ${ }^{3}$ I have had an opportunity of examining a beautiful series of sections of $C$. Binneyana. The structure of the axis and sporangia correspond in the closest manner to those of Equisetum, but a most interesting difference is the fact that this genus was heterosporous. Macrosporangia and microsporangia occurred in the same strobilus, but the difference in the size of the

\footnotetext{
${ }^{1}$ Cormack (1). $\quad{ }^{2}$ Solms-Laubach (2), p. 323. $\quad{ }^{3}$ Scott and Williamson (I).
} 
spores is much less than in the living heterosporous Filicineæ or Lycopodineæ.

The Calamarieæ are all very ancient types. The first certain remains of them occur in the Upper Devonian, and they disappear before the Trias. ${ }^{1}$

\section{Affinities of the Equisetinea}

The Equisetineæ, as will be seen from the account of the fossil forms, are a very ancient group, and their relation to the other Pteridophytes somewhat problematical. The modern forms being so restricted in number and type, offer but partial means of comparison; still a comparison of these with the simpler Filicineæ does indicate some affinity between the two groups, although, as might be expected, a very remote one. Van Tieghem ${ }^{2}$ has shown that the structure and arrangement of the vascular bundles in the stem of Ophioglossum and Equisetum have much in common, and a careful study of the development of the bundles in the young sporophyte of the latter may perhaps show still further resemblances. As we have seen, the prothallium is not essentially different in Equisetum and the eusporangiate Ferns, and the spermatozoids are closely like those of the latter, and not at all like those of the Lycopodineæ. This latter point I believe to be one of great importance.

If the Equisetineæ do come from a common stock with the Ferns, they must have branched off at a very remote period, long before the latter had become completely differentiated. The very different importance relatively of the stem and leaves in the two groups points to this, as well as the extremely dissimilar character of the sporophylls. The genus Equisetum is evidently but a reduced remnant of a once predominant type of plants which has been crowded out by the more specialised Ferns and Spermaphytes. The presence of heterospory is interesting, but from what we know at present it never developed to the same extent as in the other groups of Pteridophytes. 


\section{CHAPTER XIV}

\section{LYCOPODINEA}

THE Lycopodineæ, though far exceeding in number the species of Equisetum, are inferior in number to the Ferns. Baker ${ }^{1}$ enumerates 432 species, of which 334 belong to one genus, Selaginella, while another, Lycopodium, has 94. Like the Equisetinex they are abundant in a fossil condition, and it is very evident that these ancient forms were, many of them, enormously larger than their living representatives, and more complicated in structure. The living species are mainly tropical in their range, but Lycopodium has a number of species common in northern countries, and a few species of Selaginella, e.g. S. mpestris, have a wider range; but the great majority of the species are found only in the moist forests of the tropics. The gametophyte of the homosporous forms is known only in Lycopodium, and this only within a comparatively short time. Our knowledge of it is based mainly upon the important researches of Treub, ${ }^{2}$ but these have been added to by Goebel ${ }^{3}$ in the case of $L$. inundatum. The gametophyte in its earliest condition, so far as is certainly known, develops chlorophyll, and this condition may be permanent, e.g. L. cernum, but other forms have a chlorophylless prothallium, and are saprophytic in habit, like Ophioglossum. The germination of these forms is at present unknown.

The sporophyte has the axis strongly developed, and the leaves, though usually numerous, are simple in structure and generally small. The genera are all homosporous except Selaginella, which is very markedly heterosporous, and has the

1 Baker (2).

2 Treub (2).

${ }^{3}$ Goebel (18). 


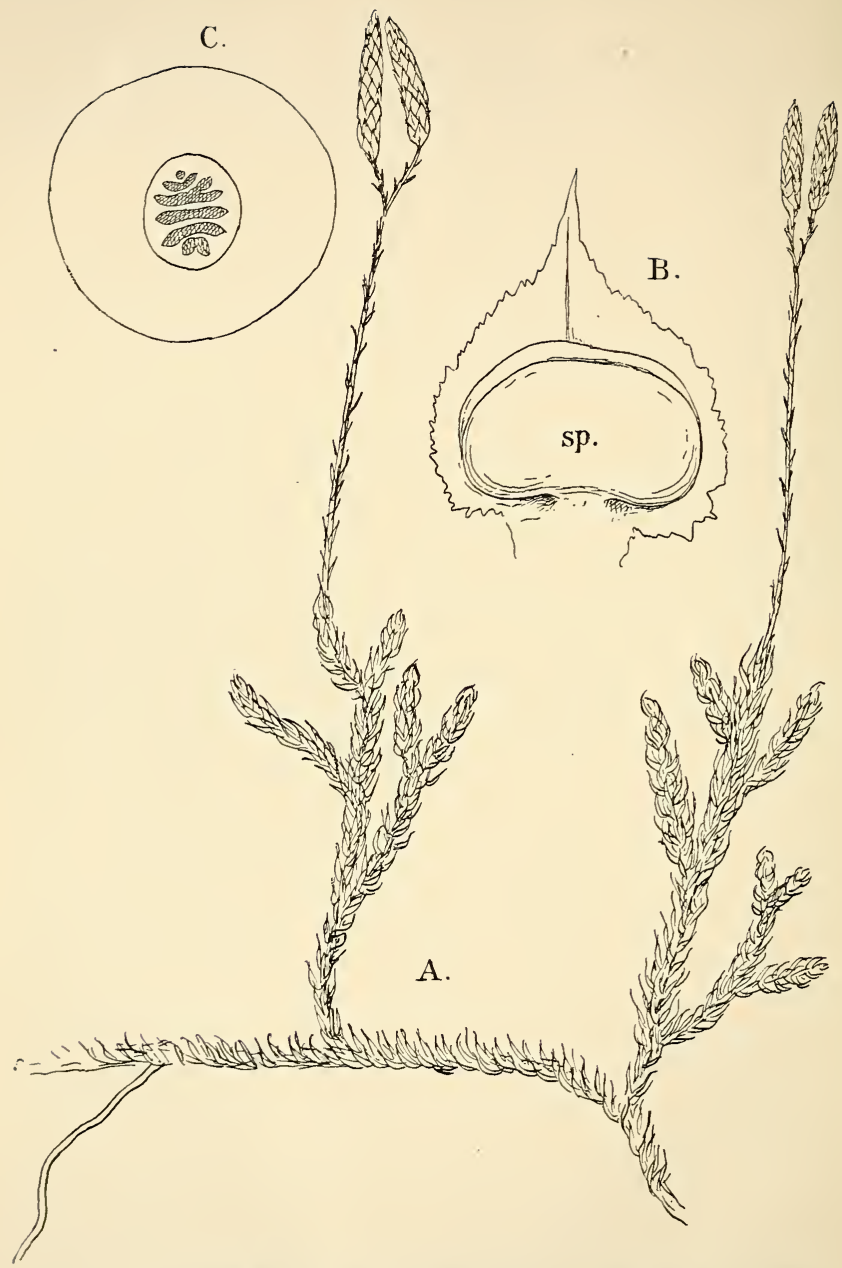

F1G. 243.-Part of a fruiting plant of Lycopodium clavatum (L.), $\times \frac{t}{5} ; \mathrm{B}$, sporophyll, with sporangium $(s p)$ of $L$. dendroideum $($ (Michx.), $\times 12 ; \mathrm{C}$, cross-section near the base of an aerial shoot of $L$. dendroideum, $\times 12$. 
gametophyte very much reduced and projecting but little beyond the spore wall.

\section{Classjfication}

\section{A. Homosporea}

I. Roots always present; sporangia alike, simple, in the axils of more or less modified leaves, which may form a distinct strobilus, or may be but little different from the ordinary ones both in form and position ; prothallia either green or colourless, monœcious.

\section{ORDER I. LYCOPODIACEAE}

\section{Genera 2.-( I ) Lycopodium; (2) Phylloglossum}

II. Roots absent; vegetative leaves much reduced (Psilotum) or well developed; sporophylls petiolate, bilobed; sporangia plurilocular; gametophyte unknown.

\section{ORDER II. PSILOTACEAE}

\section{Genera 2.-(I) Psilotum ; (2) Tmesipteris \\ B. Heterosporea}

Characters those of Order I., but spores always of two kinds.

\section{ORDER III. SELAGINELLEAE}

\section{Genus I. Selaginella}

\section{The Lycopodiacea}

The Lycopodiaceæ include the two genera Lycopodium and Phylloglossum, the latter with a single species, $P$. Dmumondii. The gametophyte is known in a number of species of Lycopodium, but as yet is quite unknown in Phylloglossum. The first investigator who succeeded in obtaining the germination of the spores was De Bary, ${ }^{1}$ who studied the earliest stages in the germination of $L$. inundatum, but was unable to obtain the later ones. About fifteen years later Fankhauser found the old 
prothallia of L. annotinum, ${ }^{1}$ but our principal knowledge of the prothallium and embryo is due to the labours of Treub, ${ }^{2}$ who has most thoroughly examined several tropical species of Lycopodium. Goebel ${ }^{3}$ succeeded in finding a number of prothallia of $L$. inundatum which corresponds very closely to $L$. cermum, the first species examined by Treub.

The germination of the spores is much like that of the homosporous eusporangiate Ferns. The tetrahedral spores contain no chlorophyll, but this develops before the first division wall is formed. This may be either vertical or horizontal, or more or less inclined. The two primary cells are nearly equal in size, but one of them appears to normally remain undivided. The other enlarges and becomes divided by an oblique wall (Fig. 244, A), and functions for some time as an apical cell, from which segments are cut off alternately right and left. Usually each segment is then divided by a periclinal wall into a central and a peripheral cell. $U_{p}$ to this point the germination of L. cernum corresponds exactly with De Bary's observations upon L. inundatum. The ovoid body formed at first Treub calls the "primary tubercle," and this does not develop directly into the complete prothallium, but the apical cell ceases to form two rows of segments and elongates so as to produce a filament in which for a time only transverse walls are formed (Fig. 244, B). The base of this filamentous appendage, however, later develops longitudinal walls and forms a thickened cylindrical mass, which is the beginning of the prothallium body. Sometimes, but not usually, a second filamentous outgrowth is formed from the primary tubercle, which may produce a second prothallial body.

The growth of the prothallium proper does not seem to show a definite meristem, but at the summit are produced a number of leaf-like lobes which seem to arise in acropetal succession, and the growth may be considered, in a general way at least, as apical. The individual lobes are usually two cells thick, and like those of Equisetum show a definite twosided apical cell. This apical growth later disappears and all trace of it is lost in the older lobes. Root-hairs are produced only in small numbers from the cylindrical prothallium body, and are usually entirely absent from the primary tubercle, whose peripheral cells are always occupied by an endophytic fungus
1 Fankhauser (I).
2 Treub, M. (2).
${ }^{3}$ Goebel (18). 
which Treub refers probably to the genus Pythium. We have secn that similar fungus mycelia occur in the chlorophylless prothallium of Botryclizm, and Gocbel found the same in $L$. imundatum. While in the primary tubercle the fungus occupies the lumen of the cells, as it penetrates into the body of the prothallium it confines itself mainly to the intercellular spaces, where its growth causes more or less displacement of the cells. It does not, however, seem to penetrate into the meristematic tissues at the summit.

The fully-grown prothallium of $L$. cermum is a small upright cylindrical body, seldom, apparently, exceeding about two $\mathrm{mm}$. in height. The base is more or less completely buried in the ground, and contains but little chlorophyll. The summit is surrounded by the lobes already spoken of, and these have somewhat the appearance of leaves crowning a short stem. The whole structure of the prothallium recalls in some respects that of Equisetum, and like that resembles the young plants of Anthoceros fusiformis or $A$. punctatus.

Besides the type of prothallium found in L. cernum with which $L$. inundatum closely agrees, Treub has also studied the very different prothallium of L. phlegmaria, and others of similar habit. These are only known in their mature condition, in which they are saprophytes, growing in the outer decayed layers of bark upon the trunks of trees. In this condition they are extremely slender branched structures, totally different from those of $L$. cermunm, both in form and in the complete absence of chlorophyll. Like the prothallia of many Hymenophyllaceæ, they multiply by special gemmæ and apparently may live for a long time. Like those of L. cermum they are always infected by an endophytic fungus.

A third type of prothallium is that of L. annotimum, which is also destitute of chlorophyll in its adult condition, but is compact in form, more like that of Botrychium. Unfortunately in this species, as well as the Phlegmaria type, the germination of the spores is unknown, and it is still doubtful whether chlorophyll is developed at first, as in L. cermumm.

\section{The Sexual Organs}

The prothallia of all the forms investigated are monœcious, and the sexual organs not arranged in any definite order. 
The sexual organs of all investigated species of Lycopodium are very similar, and closely resemble those of the eusporangiate Ferns and Equisetum. As in these forms the antheridium mother cell divides first by a periclinal wall into an outer and inner cell, the latter giving rise immediately to the sperm cells. In the outer cell the divisions are much like those in Marattia, but the opercular cell does not become detached as in these, but is broken through as in the Polypodiaceæ. In L. phlegmaria the outer wall is often in places double, as not unfrequently is the
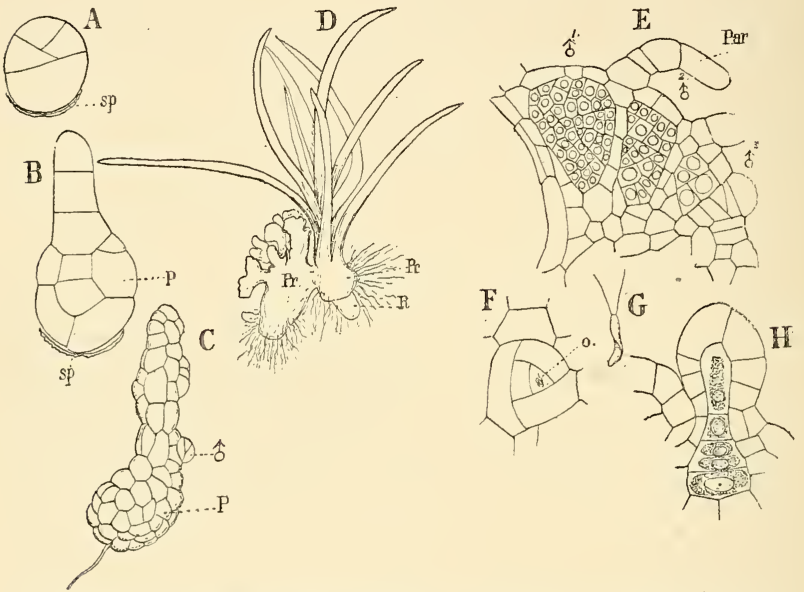

Fig. 244.-A, B, Very young prothallia of Lycopodium cemum (L.). A, X250; B, X200. P, Primary tubercle; $C$, an older prothallium of the same species with the first antheridium ( $\delta$ ), $\times 75 ; \mathrm{D}$, a fully-developed prothallium $(p r)$ with the young sporophyte attached, $\times 12$; pc, protocorm; R, primary root; $\mathrm{E}$, section through an antheridial branch of the prothallium of $L$. phleg. maria (L.), showing antheridia ( $\delta$ ) in different stages of development; par, a paraphysis, $\times 180$; $\mathrm{F}$, surface view of the top of an antheridium of the same species; 0 , opercular cell, $\times 180 ; \mathrm{G}$, a spermatozoid, $\times_{4}$ 10; $H$, section of the archegonium of the same species, $\times 180$ (all the figures after Treub).

case in the Ophioglosseæ. The spermatozoids are almost straight oblong bodies with two cilia, like those of the Bryophytes (Fig. 244, G). The vesicle, which usually remains attached to the spermatozoids of most Archegoniates, here is almost always free, and often remains within the sperm cell after the escape of the spermatozoids.

The archegonium in its development corresponds essentially with that of the other Pteridophytes. The basal cell appears 
to be always wanting, as is usually the case in Equisetum, and $\mathrm{a} \cdot$ definite layer of cells surrounding the venter is also not usually evident. L. phlegmaria is especially noteworthy on account of the large number of canal cells, which range in number from three to five. Treub also states that the nucleus of each canal cell may divide again, so that in regard to the number of canal cells L. phlegmaria, of all Pteridophytes, approaches most closely to the Bryophytes. Another peculiarity of this species is the presence of numerous paraphyses among the sexual organs, in which respect it also offers an analogy with many Bryophytes.

\section{The Embryo ${ }^{1}$}

Treub has traced the development of the embryo in $L$. phlegmaria through all its stages, and has shown that $L$. cernum corresponds closely to it, and Goebel's ${ }^{2}$ investigations upon $L$. inundatum show that this species does not differ essentially from the others. The first division in the embryo is transverse, and of the two primary cells the one next the archegonium remains undivided, or divides once by a transverse wall and forms the suspensor, which is characteristic of all investigated Lycopodinex, while the lower cell alone gives rise to the embryo proper. In the embryonal cell the first wall is a somewhat oblique transverse one, which divides it into unequal cells. In the larger of these a wall forms at right angles to the primary wall (Fig. 245, A), and this is soon followed in the smaller cell by a similar one, so that the embryo is divided into quadrants. Of these the two lower form the foot, while of the upper ones in L. phlegmaria, the one formed from the larger of the two primary cells (moitié convexe of Treub) produces the cotyledon, the other the stem apex. The primary root, which in Lycopodium arises very late, originates from the same quadrant as the cotyledon.

In L. cernum while the early divisions correspond exactly with those of L. phlegmaria, the further development of the embryo shows some noteworthy differences. As in that species, the two lower quadrants form the foot, which here remains completely buried within the prothallium. From the upper part of the embryo is next developed what Treub calls

$$
1 \text { Treub (2). } 2 \text { Goebel (IS). }
$$


CHAP.

the "protocorm." This is a tuber-like organ (Fig. 244, D, pc), from which the leaves and stem apex are subsequently developed. The cotyledon arises from the summit of the
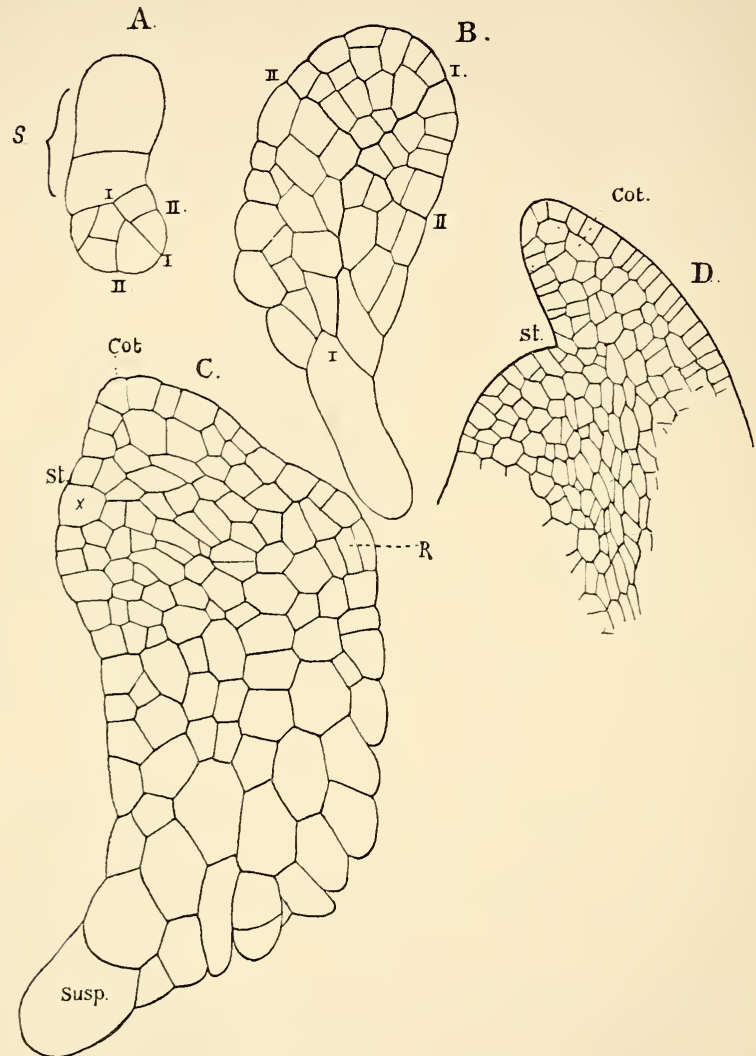

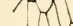

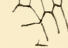

Fig. 245.-Embryogeny of Lycopodium phlegmaria (L.) (after Treub). st, Stem ; cot, cotyledon ; susp, suspensor. A, $\times_{315} ; \mathrm{B}, \times_{235} ; \mathrm{C}, \times_{235} ; \mathrm{D}, \times_{175}$.

protocorm, and is followed by a number of secondary leaves which form successively from a group of meristematic cells, which usually develop into the permanent apex of the stem. 
About the time that the stem apex becomes recognisable as such, the first root appears as a surface outgrowth of the protocorm, and strictly cxogenous in origin. Not infrequently the end of the primary root gives rise to a tubercle similar to the protocorm.

An interesting case was seen by Trcub, where, apparently by a longitudinal division of the young embryo, two embryos were formed, much as is normally the case in some Gymnosperms.

On comparing the two types of cmbryo found in $L$. plulegmaria and L. cernum, the main differences are the almost complete absence of the protocorm and greater development of the suspensor in the former. L.inundatum, as might be expected, corresponds closely in the structure of the young sporophyte with L. cernuum.

Corresponding with the late appearance of the roots is the late development of the vascular bundles, which, according to Treub, are often quite absent from the cotyledon and even occasionally from the second leaf. The protocorm of $L$. cermum and $L$. inundatum Treub regards as the remains of a primitive structure originally possessed by the Pteridophytes, which replaced the definite leafy axis found in the more specialised existing forms.

\section{The Sporopliyte}

In all species of Lycopodium the sporophyte possesses an extensively branched stem, which may be upright, as in $L$. cernumm, or extensively creeping, as in L. clavatum and other species, where the main axis is a more or less completely subterranean rhizome with upright secondary branches. In the Tropics some species are epiphytes. The leaves are always simple, and of small size. Each leaf has a single median vascular bundle, which does not extend to the apex. The arrangement of the leaves is usually spiral, and they are uniformly distributed about the stem, and all alike; but in a few species, e.g. L. complanatum, they are of two kinds and arranged in four rows, as in most species of Selaginella. The branching of the stem is either dichotomous or monopodial. The roots, which are borne in acropetal succession (Bruchmann found also in $L$. inundatum adventive roots), branch dichotom- 
ously, like those of Isoetes. The sporangia are borne singly, in the axils of the sporophylls, which may differ scarcely at all from the ordinary leaves (L. selago, L. lucidulum), (Fig. 248), or the sporophylls are different in form and size from the other leaves and form distinct strobili, which are often borne at the end of almost leafless branches (Fig. 243).

None of the investigated species of Lycopodium show a definite initial cell at the apex of the stem, and Treub ${ }^{1}$ was

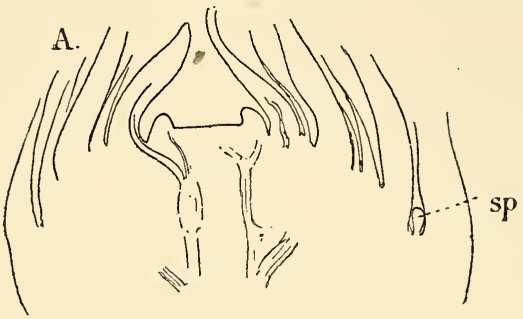

B.

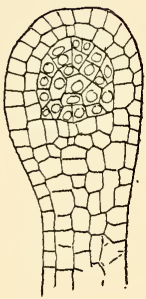

FIG. 246.-Longitudinal section of the stem apex of Lycopodium lucidulum (Michx.), $\times 3$ o. sp, Young sporangium ; $B$, longitudinal section of the young sporangium of the same species, $\times 215$.

unable to determine positively whether such a one exists in the embryo. In L. phlegmaria ${ }^{2}$ he describes and figures embryos, where a single prismatic apical cell is apparently present, but in others the presence of such a cell was doubtful, and in $L$. cernum in no case did he find any evidence of a single initial.

The vegetative cone of the mature sporophyte is usually broad (Fig. 246) and only slightly convex. Its centre is occupied by a group of similar initial cells, which in L. selago, 
according to Strasburger, ${ }^{1}$ usually show two initials in longitudinal section (Fig. 247, i). From these initials are cut off lateral segments which, by further periclinal and anticlinal walls, produce the epidermis and cortex, and secondarily the leaves. Periclinal walls also are formed from time to time in the initial cells, by which basal segments are cut off, which produce the large central plerome cylinder.

The leaves arise as conical outgrowths near the stem apex, and owe their origin to the three or four outer cell layers of the growing point. The separation of the epidermis does not occur
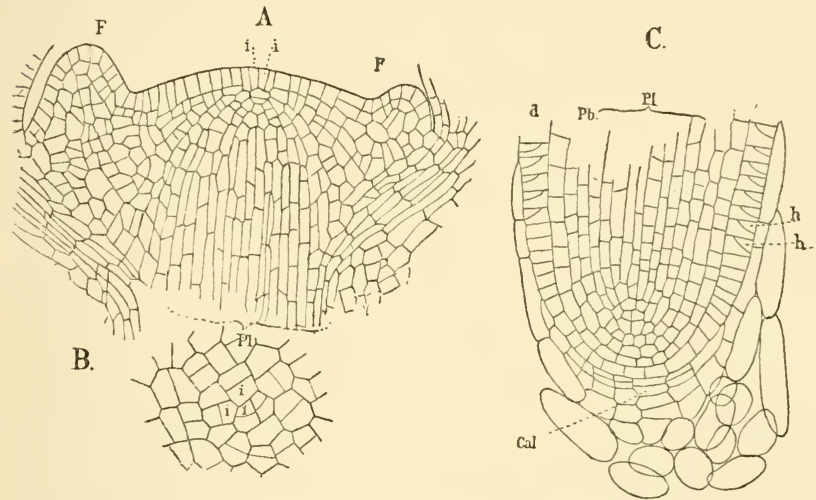

Fig. 247.-Lycopodium selago (L.). A, Longitudinal section of the stem apex, $\times$ rzo; $f, f$, young leaves; $i$, $i$, initial ceils; $p l$, plerome; $\mathrm{B}$, surface view of the stem apex, showing the group of initial cells, $\times 260 ; \mathrm{C}$, longitudinal section of the root-tip; $d$, dermatogen; $p b$, periblem; $p l$, plerome : cal, calyptrogen; $h, h$, root-hair initials, $\times$ I20 (all the figures after Strasburger).

until the leaf has formed a conspicuous conical protuberance. The differentiation of the procambium in the young leaf begins early, and the strand joins the central procambial cylinder of the stem, which, however, is quite independent of the leaftraces. Each young leaf-trace joins an older one at the point of junction with the stem cylinder, and thus the complete stem possesses two systems of vascular bundles, the strictly cauline central cylinder, and the system of common bundles formed by the united leaf-traces.

The first elements of the vascular bundles to become 
recognisable are spiral tracheids, both in the stem and leaves, and these are followed in the former by the much wider scalariform tracheids that occupy the central part of the tracheary plates in the fully-developed bundles.

The fully-developed central cylinder of the stem ${ }^{1}$ is undoubtedly to be considered as a group of confluent vascular bundles or as gamostelic. The oval or nearly circular crosssection (Fig. 243, C) is sharply separated from the surrounding ground tissue by a clearly-marked endodermis, within which is a pericycle which may be only one cell thick, but is usually several-layered. According to Strasburger ${ }^{2}$ this pericycle does not properly belong to the central cylinder, but is of cortical origin. The cutinised band ("radial folding") of the endodermal cells is only observable in the younger stages, as later the whole wall of the endodermal cells becomes cutinised. ${ }^{3}$ This cutinisation extends also through a number of the succeeding cortical layers. The rest of the cortical region is in most species occupied by elongated sclerenchyma cells, with no intercellular spaces.

The central vascular cylinder contains, as is well known, alternating, usually transversely placed, tracheary plates, alternating with phloëm masses, and surrounding these a varying amount of parenchyma. In upright species the tracheary plates are often more or less completely confluent, and in cross-section have a somewhat star-shaped outline. In the dorsiventral stems the tracheary plates are quite separate and perfectly transverse in position. Their outer angles are occupied by the small primary spiral or annular tracheids, from which the centripetal formation of the large scalariform elements proceeds exactly as in the leptosporangiate Ferns. The mass of tracheary tissue is compact, and contains no parenchymatous elements. According to Strasburger ${ }^{4}$ the oblique end walls of the large tracheids show the same elongated pits as the lateral walls, but in no cases could any communication between adjacent tracheids be demonstrated. Each tracheary mass is surrounded by a single layer of parenchyma, whose inner cell walls show bordered pits, like those of the adjacent tracheids.

1 Russow (I), p. I28; De Bary (3), p. 28I ; Strasburger (I I), vol. iii. p. 458.

2 Strasburger, l.c. p. 460.

3 Strasburger, l.c.; Van Tieghem (5), p. 553.

4 Strasburger, l.c. p. 459. 
The phloèm masses are, in the arrangement and development of the parts, very like the xylem, and the formation of the sieve-tubes begins at the outer angles and proceeds centripetally. The fully-developed sieve-tubes appear almost empty, and the small sieve-plates are poorly developed and difficult to demonstrate.

Where the branching is monopodial, the young branches arise laterally close to the growing point, but without any relation to the leaves. Where, however, as in L. selago, ${ }^{1}$ there is a genuine dichotomy, it is inaugurated by an increase in the number of initial cells, which is then followed by a forking of the apex of the plerome cylinder, and the two resulting branches are exactly alike. Intermediate conditions between a perfect dichotomy and true monopodial branching occur. In these there is a true dichotomy, but one branch is stronger than the other, and continues as the main axis, while the weaker one is pushed to one side and looks like a lateral shoot. Bruchmann ${ }^{2}$ has described certain "pseudo-adventive" buds, which are young branches arrested in their development at a very early stage, which may later develop. Strasburger ${ }^{3}$ has found adventive buds in $L$. aloifolium, $L$. verticillatum, $L$. taxifolium, and $L$. reflexum, which possibly may be of the same nature.

\section{The Leaf}

The leaves of all species of Lycopodium are relatively small, and are usually lanceolate in outline with broad sessile base. The margins of the leaves are often serrate, and in all cases the leaf is traversed by a simple midrib, which, as already stated, does not reach to the apex. Their arrangement varies, even in the same species, and upon the same shoot. Thus in $L$. alpinum ${ }^{4}$ the leaves are regularly arranged in pairs which arise simultaneously; in L. selago they are usually in true whorls of four or five. The latter, however, often shows a spiral arrangement of the leaves, with a divergence of twoninths, less often two-sevenths.

The structure of the vascular bundle of the leaf is simple..$^{5}$ It is concentric in structure, with the central part composed of a small number of spiral and annular tracheids, with the

\footnotetext{
${ }^{1}$ Strasburger (10), p. $242 . \quad{ }^{2}$ Luerssen (7), vol. vii. p. 627. ${ }^{3}$ Strasburger (7).

${ }^{4}$ Hegelmaier (I), p. SI 5 . $\quad{ }_{5}^{5}$ Strasburger (II), vol. iii. p. 46 I.
} 
peripheral portion made up of parenchyma, with a circle of scattered narrow sieve-tubes. A definite endodermis cannot be demonstrated. In the species with the leaves all alike both surfaces bear stomata, but in those with decussate leaves the greater part of the upper surface is destitute of them.

\section{The Root}

The roots of Lycopodium arise, as in other Pteridophytes, in acropetal succession, but with no relation to the position of the other organs. According to Bruchmann adventive roots may arise in L. inundatum, but they have not been observed in other forms. L. selago ${ }^{1}$ may serve to show the characters of the root in the genus. The meristem of the apex is clearly differentiated into the initials of the different primary tissues (Fig. 247, C). The dermatogen (d) completely covers the apex of the growing point as a single layer. The periblem $(p b)$ is three cells thick; the plerome ( $p l)$ terminates in a group of special initials. As in the stem, the plerome alone forms the central cylinder, the periblem giving rise only to the cortex, and the structure of the mature root corresponds closely to that of the stem, except for the presence of the root-cap, which has its own initial group of cells (calyptrogen, cal). From the older dermatogen cells are derived, by special walls, the mother cells of the root-hairs $(h)$.

Van Tieghem ${ }^{2}$ states that the secondary roots arise from the pericycle instead of from the endodermis, as in other Pteridophytes, but Strasburger claims that the so-called pericycle of Lycopodium is really cortical, and does not belong properly to the central cylinder, so that this difference is only apparent. The endodermis itself is not readily recognisable on account of the complete cutinisation of the walls.

The origin of the root-hairs is somewhat peculiar. From the base of each dermatogen cell a wedge-shaped cell is cut off (Fig. 247, C, $h$ ), and this afterwards is divided into two similar cells, each of which grows out into a unicellular hair. Thus the root-hairs are found in pairs.

The roots always normally branch dichotomously, as in Isoetes, and the successive divisions usually are in planes at right angles to each other. As in Isoetes, the process is in-

\footnotetext{
${ }^{1}$ Strasburger (10), p. $259 . \quad 2$ Van Tieghem (5), p. 553.
} 
augurated by a broadening of the apex of the root, which is followed by a forking of the plerome and a subsequent division of the other histogenic tissues.

The structure of the mature root $^{1}$ in $L$. clavatum, $L$. alpinum, and most species examined, is much like the stem. The hexarch to decarch fibrovascular cylinder is radial in structure, the xylem plates often united at the centre, so that in cross-section they present a more or less regular stellate form. In L. selago and L. inundatum, according to Russow, ${ }^{2}$ the xylem is diarch and the two masses united into a single one, which is crescent-shaped in section, with the phloëm occupying the space between the extremities. As in the stem the primary tracheids are narrow annular and spiral ones, and the large secondary ones scalariform.

\section{Gemme}

Special bulblets or gemmæ are formed regularly in a number of species of Lycopodium, and have been the subject of several special investigations. ${ }^{3} \quad$ These in L. lucidulum (Fig. 248, A. k) are flattened, heart-shaped structures composed of several thickened fleshy leaves, and formed apparently in the axils of somewhat modified stem
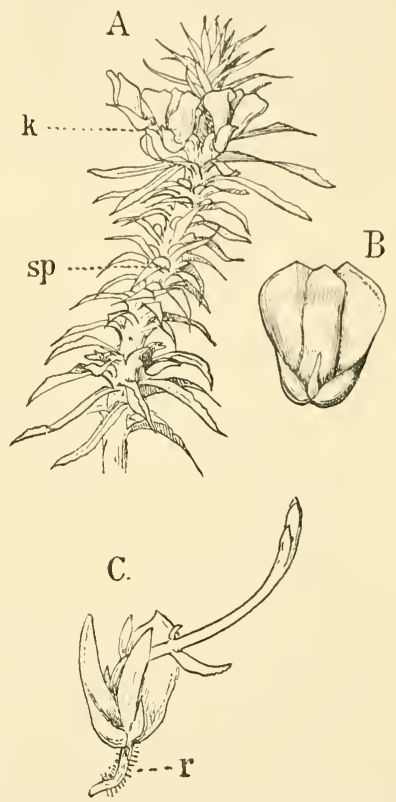

Fig. 248.-A, End of a shoot of Lycopodium lucidulum (Michx.), with gemma $(k)$ and sporangia $(s p), \times 2 ; \mathrm{B}$, a single bulblet, $\times_{4} ; \mathrm{C}$, germinating bulblet of $L$. selago (after Cramer), $\times_{4} ; r$, the primary root. leaves, from which they readily separate when fully grown. The axillary origin of the bulblets is only apparent ; they are really, so far as can be determined, similar in origin to the ordinary

1 Russow (1), p. 150; Van Tieghem, "Récherches sur la symmetrie de la structure dans les Plantes vasculaires" (Ann. Sc. nat., ser. 5, No. xiii.).
2 Russow (I).
${ }^{3}$ Hegelmaier (1); Strasburger (7); Cramer (1). 
branches, and formed without any relation to the leaves. Before the bulblet becomes detached, the rudiment of a root can be made out at the base, and as soon as it falls off and comes in contact with the earth the root begins to grow and fastens the bulblet to the ground (Fig. 248, C). The axis of the bulblet, which at first is very short, rapidly elongates, and the leaves formed up it have the characters of the ordinary ones. As the leafy axis develops the fleshy leaves of the bulblet lose their chlorophyil completely and finally decay.

Hegelmaier ${ }^{1}$ describes mucilage ducts in the stem and leaves of $L$. inundatum and some other species, which are not unlike those found in Angiopteris.

\section{The Sporangia}

The most recent and accurate account of the structure and development of the sporangia of the Lycopodineæ is that given by Professor Bower in his recent memoir upon this subject. ${ }^{2}$ His investigations include a number of species of Lycopodium, and the following account is taken mainly from his memoir. The results of his investigations show that there is much more variety shown than was before supposed, both in the form of the sporangium itself and in the mode of origin and number of the archesporial cells.

In L. selago the sporangium originates upon the upper surface of the sporophyll close to its base, and in radial section the young sporangium appears to originate from a single cell ; but this is really only one of a transverse row of cells, all of which participate in its formation. Each cell of this primary row divides first into a large central cell (Fig. 249, C, x) and (in radial section) two peripheral ones. The central cell next by successive periclinals forms a row of three cells, of which the middle one is the archesporium, which, judging only from radial sections, seems to consist only of a single cell ; but comparing with the radial section a tangential one, it is seen that the archesporium really consists of a row of similar cells (Fig. 249, F). The growth in the upper part of the sporangium is stronger than below, so that a distinct, although short stalk is formed. The archesporial cells rapidly divide, but show little

1 Hegelmaier ( $\mathbf{I})$.

2 Bower (15) ; also Goebel (3), Bot. Zeit. I8So, p. 56I ; Sadebeck (6), p. $3 \mathbf{1} 3$. 


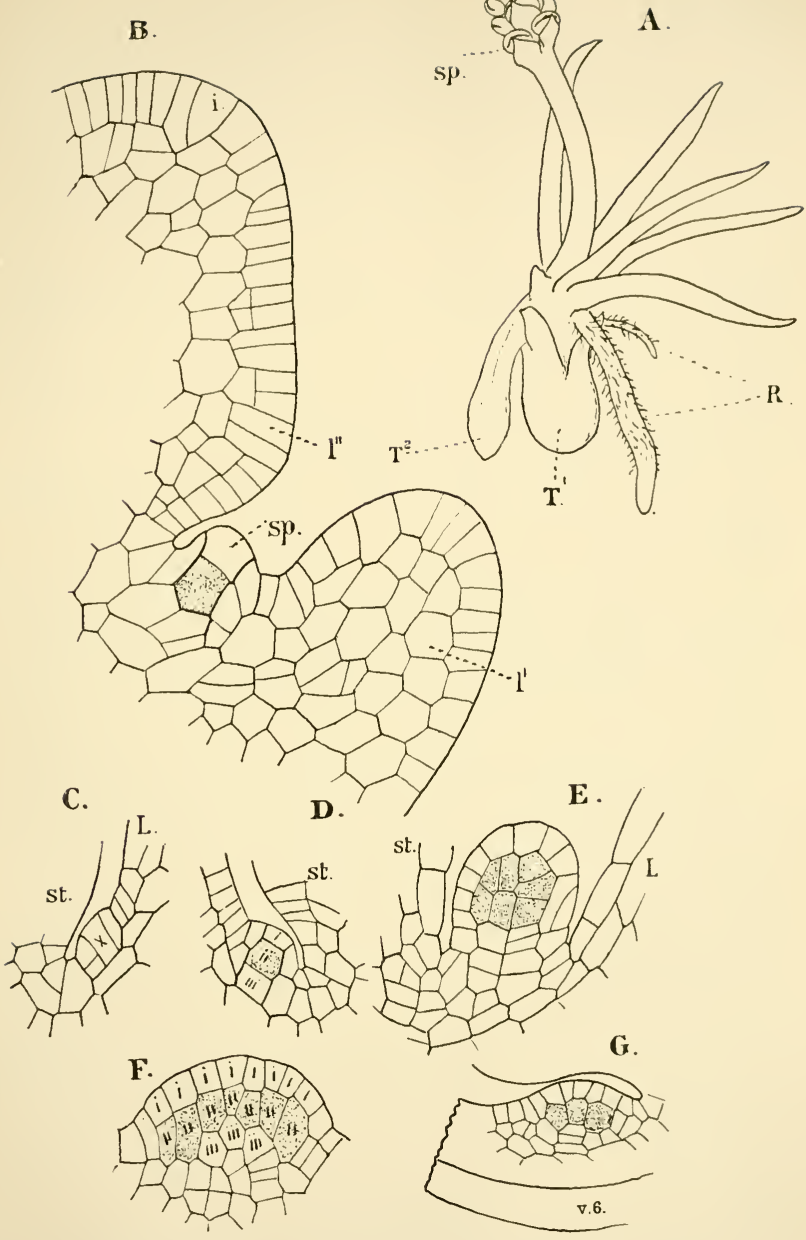

Fig. 249.-A, Plant of Pliylloglossum Drummondii (Kunze), xabout 3 (after Bertrand). sp, Sporangia ; $\mathrm{R}$, roots ; $\mathrm{T}^{1}$, protocorm ; $\mathrm{T}^{2}$, secondary protocorm ; $\mathrm{B}$, longitudinal section of the young strobilus of the same, showing the initial cell $(i)$, young leaves $\left(l^{\prime}, l^{\prime \prime}\right)$, and young sporangium $(s p)$, $\times 240$; C-E, young sporangia of Lycopodium selago, radial sections, $\times 225 ; \mathrm{F}$, tangential section of the same; G, radial section of young sporangium of $L$. clavatum (Figs. B-G after Bower). 
regularity in the divisions. All of the resulting cells separate and produce four spores in the usual manner. The wall of the mature sporangium consists regularly of three layers of cells, of which the innermost is the tapetum. The tapetum bounding the lower part of the archesporium is derived from the cushionlike group of cells below it, to which Bower gives the name "sub-archesporial pad." The tapetum does not, apparently, become disorganised, as in most Ferns and Equisetum, but remains as part of the sporangium wall. The fully-grown sporangium, as in all species of Lycopodium, is kidney-shaped.

Among the numerous other species investigated by Professor Bower, $L$. clavatum represents the type most widely removed from L. selago. The differences between the two are summarised by Professor Bower ${ }^{1}$ as follows.

" $\mathrm{I}$. The sporangium is similar in position and in general form to that of $L$. selago, but its body is more strongly curved.

" 2. The archesporium here consists of three rows of cells, each row being composed of a large number (about twelve) of cells; thus the extent of the archesporium is much greater than in L. selago, occasional additions to it seem to be made by cells cut off periclinally from the superficial cell at an early stage.

" 3. The tapetum is similar in origin to that in L. selago.

" 4 . The sub-archesporial pad is much more developed, and is at times extended as processes of tissue which penetrate the sporogenous mass for a short distance.

" 5. The stalk of the sporangium is much shorter and thicker than in L. selago.

“6. Arrested sporangia are frequently present, and may be found either at the base or apex of the strobilus.

"7. L. inundatum may be looked upon as an intermediate link between the type of sporangium of L. selago and that of L. clavatum, both as regards form of the sporangium and complexity of the archesporium."

\section{Phylloglossum}

The other genus of the Lycopodiacex contains but the single species $P$. Drummondii, from Australia. This curious and 
interesting little plant has been carcfully investigated by Bower ${ }^{1}$ and Bertrand, ${ }^{2}$ and the former regards it as the most primitive in structure of all the living Pteridophytes. Unfortunatcly the gametophyte is almost entirely unknown, ${ }^{3}$ but the structure and development of the sporophyte have been carefully studied by the above writers.

The sporophyte resembles in an extraordinary degree the young sporophyte of Lycopodium, especially $L$. cermum. It grows from a small tubercle (protocorm), which is regarded as homologous with the same structure in the embryo of Lycopodium. This protocorm in small plants produces only sterile leaves - from four to seven - and a small number of roots, often only a single one. In more vigorous plants a smaller number of sterile leaves is formed, but the apex of the protocorm grows into an elongated axis, bearing a single small strobilus at the apex (Fig. 249, A). The structure of the latter is essentially as in Lycopodium. The roots are produced exogenously, as in the Lycopodium embryo, and are in structure much the same. All of the tissues are very simple, and none of the organs show a single apical cell, except possibly the apex of the strobilus, where such a single initial seems to be sometimes present (Fig. 249, B, i). At the end of the growing season a new protocorm is formed. This arises directly from the apex of the old one, where no strobilus is developed, but in the latter case grows out upon a sort of peduncle from near the base of one of the leaves. The development of the sporangia is essentially the same as in L. selago (Fig. 249, B).

The anatomy of the vegetative organs has been carefully studied by Bertrand, ${ }^{4}$ and corresponds closely to that of Lycopodium, but the tissues are simpler. In the axis which bears the strobilus there are about six xylem masses arranged in a circle, but there is no definite endodermis limiting the central cylinder. The root-bundle is diarch.

Bertrand ${ }^{5}$ states that M. L. Crié found that the spores germinated readily, and produced a colourless prothallium like that of the Ophioglosseæ, both in form and in the structure of the sexual organs, but that the spermatozoids are biciliate.

1 Bower (5).

2 Bertrand (3).

3 The observations of Crié, quoted by Bertrand, were not accessible to the writer.

${ }^{4}$ Bertrand (3).

${ }^{5}$ Bertrand, l.c. No. 34, pp. 22 I, 222. 
These observations have not yet, however, been confirmed by other observers.

The differences between Phylloglossum and Lycopodium do not seem sufficient to warrant the establishment of a separate family, the Phylloglosseæ, as Bertrand proposes.

\section{The Psilotacee}

The Psilotaceæ include the two evidently related genera Psilotum and Tmesipteris, the former with two species, ${ }^{1}$ the latter with but a single one. All the species are tropical or sub-tropical, Psilotum being found in all the warmer parts of the world; but Tmesipteris is confined to Australia, New Zealand, and parts of Polynesia. The prothallium is quite unknown in both genera, but the development and anatomy of the sporophyte of both are now pretty well known. The sporophyte, ${ }^{2}$ which in its mature condition is quite destitute of roots, grows either upon earth rich in humus (Psilotum triquetrum), and is evidently more or less saprophytic, or it may be an epiphyte. Tmesipteris grows upon the trunks of tree-Ferns, and Bertrand states that it is a true parasite, which, however, like Viscum or Phorodendron, has not entirely lost its chlorophyll. The plant always consists of two parts, a lower portion consisting of branched root-like rhizomes, which take the place of roots, and aerial green branches which ramify dichotomously. The branching is especially marked in Psilotum, much less so in Tmesipteris. The leaves are small and scale-like in Psilotum, larger and lanceolate in Tmesipteris. The sporangia (or synangia) are bilocular in the latter, trilocular in Psilotum, and in both cases borne upon a small bilobed sporophyll.

The development of the sporophyte has been carefully studied by Solms-Laubach, ${ }^{3}$ who discovered that it multiplied rapidly by means of small gemmæ (Fig. $25 \mathrm{I}, k$ ) produced in great numbers upon the subterranean shoots. These buds or bulblets are small oval bodies, but one cell in thickness, and showing usually a definite two-sided apical cell. Their cells are filled with starch, and they sometimes remain a long time

${ }^{1}$ Baker (2). $\quad{ }^{2}$ Bertrand (I, 2); Solms-Laubach (1); Bower (15).

3 Solms-Laubach (I). 
dormant. These buds may produce others, but usually from each one is produced one, or sometimes more, elongated shoots, which develop into subterranean branches like those from which the bud was originally produced. The young plant

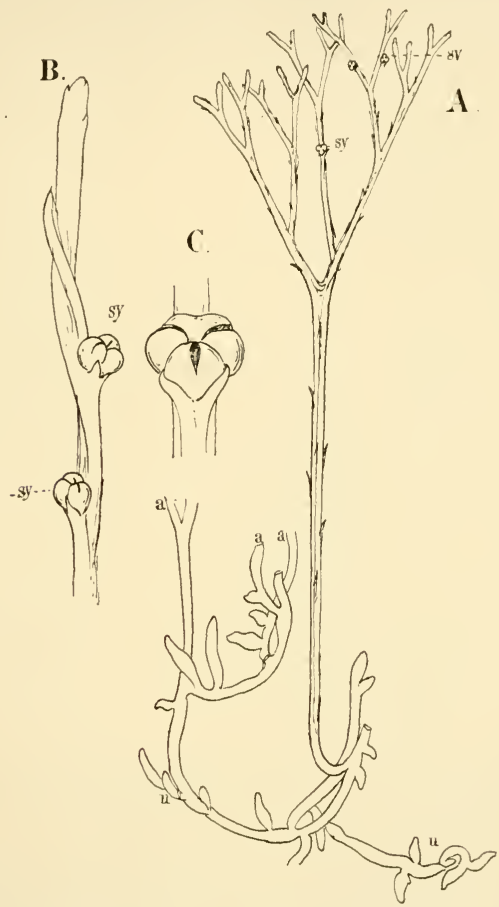

FIG. 250.-Part of a vigorous plant of Psilotum triquetrum (Sw.), about $\frac{1}{3} . \quad u$, $u$, Subterranean shoots; $a, a$, the bases of aerial branches; $s y$, synangia; $\mathrm{B}$, branch with two mature synangia, slightly enlarged; C, a single opened synangium, showing the two lobes of the sporopbyll below it (after Bertrand).

arising from the gemma is at first composed of uniform parenchyma, but in the later formed portions a simple vascular bundle is finally developed. No definite apical cell can be detected in the earlier stages, but later each branch of the rhizome shows a pyramidal initial cell, much like that in the 
Ferns, but less regular in its divisions, and it is not possible to trace back all the tissues with certainty to this single cell. The branching is a true dichotomy, but is not brought about by the division of the original apical cell, but this becomes obliterated previous to the formation of the two branches, and two new initial cells are formed quite independently of it. ${ }^{1}$

The tissues are very simple. In the subterranean stems the bulk of a section is composed of parenchyma, while the

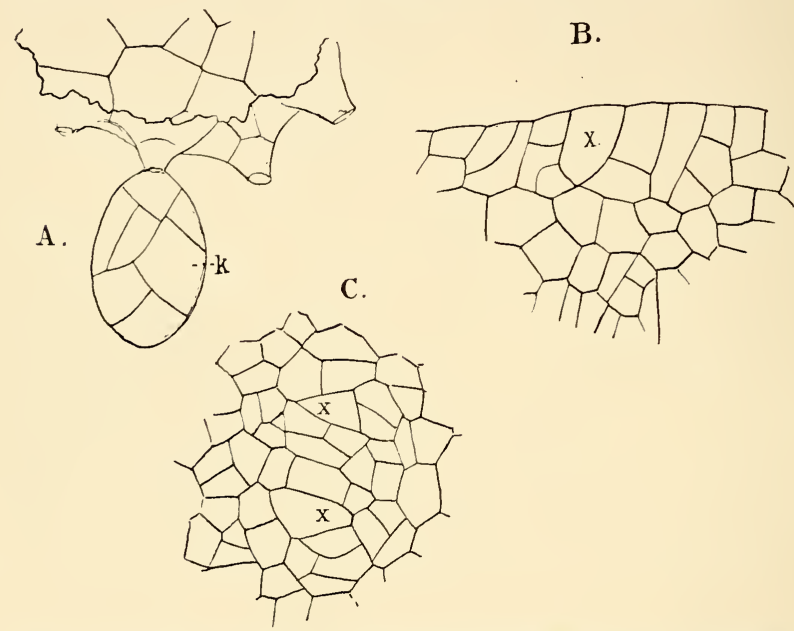

FIG. 251.-Psilotum triquetrum (Sw.). A, Fragment of a subterranean shoot with a young gemma

$(k), \times_{120} ; \mathrm{B}$, longitudinal section of the apex of a subterranean shoot, $\times_{185} ; \mathrm{C}$, transverse section of the apex of a subterranean shoot in the act of forking; $x, x$, the apical cells of the two branches, $X_{185}$ (all figures after Solms-Laubach).

vascular bundle is very similar to that of the roots of the Ferns. The bundle is diarch, and the two xylem masses are confluent at the centre. In the aerial shoots the cross-section of the vascular cylinder shows a central mass of thick-walled lignified cells about which the triarch to octarch xylem forms a continuous ring. ${ }^{2}$ The phloëm is poorly developed, and the xylem is mainly composed of small thin-walled scalariform tracheids. In Psilotum the leaves have no vascular bundle, in Tmesipteris a single bundle traverses the leaf, as in Lycopodium. 


\section{The Sporangia}

There has been much disagreement as to the morphological nature of the sporangiophores of the Psilotacex. The two chief views are the following. ${ }^{1} \quad$ (I) That the whole sporangio-

A.

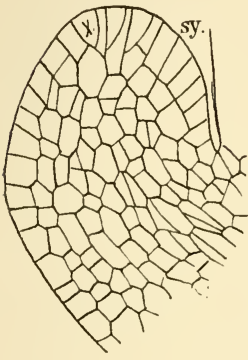

B.

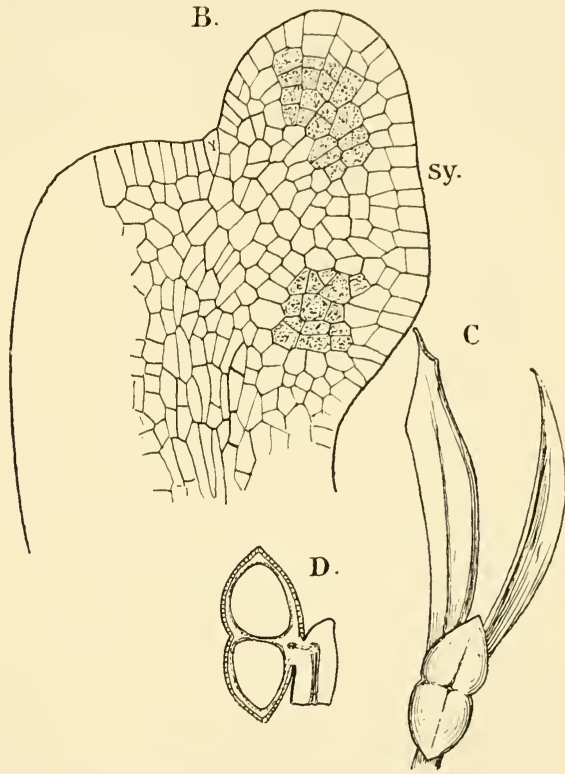

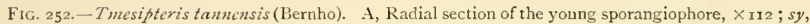
the young synangium; $\mathrm{B}$, similar section of an older sporangiophore, $\times_{112}$. The archesporial cells are shaded. C, Fully-developed synangium, showing its position between the two lobes of the sporophyll, $\times_{3} ; \mathrm{D}$, a longitudinal section of the synangium, showing the two loculi (all the figures after Bower).

phore is a single foliar member; (2) that it is a reduced axis bearing a terminal synangium and two leaves. The recent very careful researches of Bower upon the origin of the sporangiophore and synangium confirm the former view. He describes the development in Tmesipteris as follows. "The apical cone of the plant is very variable in bulk... In the

1 Bower (15), p. 541. 
large as well as the small specimens a single initial is usually present, but its segmentation does not appear to be strictly regular, and it is difficult to refer the whole meristem to the activity of one parent cell. .. . When a leaf or sporangiophore is about to be formed, certain of the superficial cells increase in size, and undergo both periclinal and anticlinal divisions so as to form a massive outgrowth, the summit of which is occupied, as seen in radial section, by a single larger cell of a wedge-like or prismatic form. . . . In these early stages I find it impossible to say whether the part in question will be a vegetative leaf or a sporangiophore, and even when older it is still a matter of uncertainty. . . . Those which are to develop as sporangiophores soon show an increase in thickness, while they grow less in length; an excrescence of the adaxial surface soon becomes apparent (Fig. 252, A, sy), in which the superficial cells are chiefly involved. . . . The superficial cells at first form a rather regular series, which may be compared with the cells which give rise to the sporangia in Lycopodium clavatum, or in Isoetes: they undergo more or less regular divisions, which, however, I have been unable to follow in detail: a band of tissue some four or more layers in depth is thus produced. About this period certain masses of cells assume the characters of a sporogenous tissue: but though they can be recognised as such by the character of the cells, it is extremely difficult to define the actual limits of these sporogenous masses."

In Tmesipteris there are normally two masses of sporogenous tissue corresponding to the two loculi in the mature synangium; in Psilotum, which correspond closely with Tmesipteris in other respects, there are three. Whether additions are made to the sporogenous tissue from cells outside the original archesporium was not determined with certainty, but Professor Bower thinks it not improbable. In Psilotum the young archesporium is more clearly defined than in Tmesipteris, and it seems not unlikely that each sporogenous mass is referable to the division of a single primary archesporial cell. In both genera some of the sporogenous cells do not develop spores, but simply serve for the nourishment of the others, as in Equisetum.

The fully-developed synangium has the outer walls of the loculi composed of a single superficial layer of large cells, beneath which are several layers of smaller ones (Fig. 252, D). 
The cells composing the septa are narrow tabular ones, with firm woody walls marked by numerous pits. Occasionally the septum is partially absent and the loculi are thus thrown more or less completely into communication. The spores are usually of the bilateral form, like the microspores of Isoetes, but may also be of the tetrahedral type.

Bower regards the whole synangium as homologous with the single sporangium of Lycopodium, and also calls attention to its resemblance to the sporangium of Lepidodendron, with which the Psilotacex also show remarkable resemblances in the structure of the stem.

\section{The Selaginellea}

Unlike the Filicineæ, the heterosporous Lycopodineæ outnumber very much the homosporous forms, but all of the former may be reduced to a single genus, Selaginella, which contains nearly three hundred and fifty species, and, except for the presence of heterospory, approaches closely the genus Lycopodium, to which it is clearly not very distantly related. The great majority of the species of Selaginella belong to the Tropics, and form a characteristic feature of the forest vegetation of those regions. A few belong to the more temperate parts of Europe and America, and a small number, e.g. $S$. rupestris, S. lepidophylla, grow in dry situations.

\section{The Gametophyte}

Hofmeister ${ }^{1}$ included Selaginella among the other Pteridophytes he studied, but he was unable to make out the earlier stages of development of the prothallium. Later Millardet ${ }^{2}$ and Pfeffer ${ }^{3}$ made further investigations upon the same subject, and added much to Hofmeister's account, but were also unable to determine the earliest phases of germination. Belajeff ${ }^{4}$ has since given a clear account of the germination of the microspores, but up to the present time the exact method of formation of the female prothallium has remained doubtful. Recently a further contribution has been made to the subject by Heinsen, ${ }^{5}$ which, however, adds but little to our previous knowledge. The

${ }^{1}$ Hofmeister (I). ${ }^{2}$ Millardet (I). $\quad{ }^{3}$ Pfeffer, W. (I).
4 Belajeff (I).
5 E. Heinsen (I). 
account of the female prothallium given here is based upon the writer's observations upon S. Kraussiana, made from microtome sections of spores treated with chromic acid and embedded in paraffin.

\section{The Microspores and Male Prothallium}

The microspores of all species of Selaginella are small and of the tetrahedral type. According to Belajeff ${ }^{1}$ they may show either a distinct perinium, or the latter is not clearly

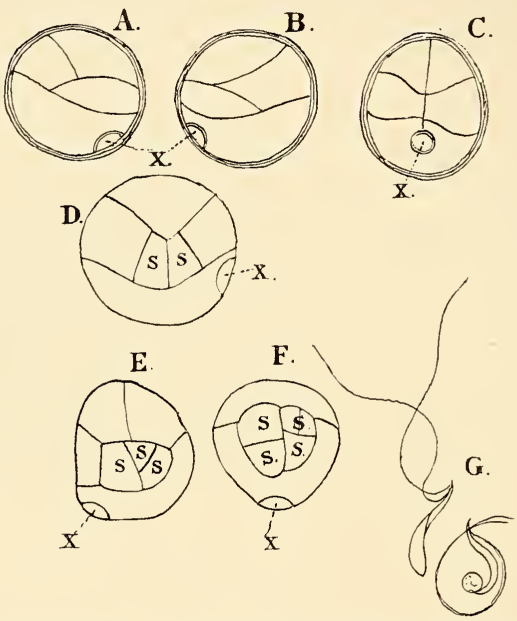

Fig. 253.-A, B, C, Three views of the young antheridium of Selaginella Kraussiana (A. Br.), $\times_{450}$; $\mathrm{D}$, an older stage of the same, $\times 480 ; \mathrm{E}, \mathrm{F}$, two views of an older antheridium of $S$. stolonifira, $\times 480 ; \mathrm{G}$, spermatozoids of S. cuspidata (Sk.), $\times_{1170} ; x$, vegetative prothallial cell ; $s$, central cells (after Belajeff).

separated from the exospore. The spores contain no chlorophyll, but much oil as well as solid granular contents. At the time that the spores are shed each one has already divided into two very unequal cells, a very small lenticular cell (Fig. 253,x) and a much larger one which, as in Isoetes, becomes the single antheridium.

The first wall in the antheridium divides it into two equal cells, each of which then divides into two others, a basal and 
an apical cell. The latter divides twice more, forming three segments, so that the young antheridium at this stage consists of eight cells arranged in two symmetrical groups. Of the three segments formed in each apical cell, the first and sometimes the second form periclinal walls, so that a central cell (or two cells) is formed in each half of the antheridium, not unlike what obtains in Marsilia, and the young antheridium consists now of two (or four) central cells and eight peripheral ones. Belajeff states that the cell walls do not show the cellulose reaction, and that they are later absorbed. Where there are four primary central cells, these by further divisions produce a single cell-complex, which, after the disintegration of the peripheral cell walls, floats free in the cavity of the spore. Where but two primary central cells are formed, each produces a separate hemispherical cell mass. Belajeff does not state the number of sperm cells formed. The spermatozoids (Fig. 253, G) are extremely small and closely resemble those of many Bryophytes, as well as Lycopodium. Like these they are always biciliate.

\section{The Macrospore and Female Prothallium}

The formation of the female prothallium begins while the spore is still within the sporangium, and long before it has reached its full size. The earliest division of the primary nucleus was not seen, but it is undoubtedly much the same as in Isoetes, with which Selaginella closely agrees in the development of the prothallium. The young macrospore is quite transparent, and in the living condition is colourless and shows plainly the single large globular nucleus. The youngest stage, of which successful preparations were made, is shown in Fig. 254, B. The spore here had reached about half its final diameter, and was remarkable for the very small amount of protoplasm it contained. This formed a very thin layer close to the wall, much as in the embryo-sac of the Spermaphytes. In this protoplasmic layer were embedded a number of somewhat flattened nuclei, but as yet there was no trace of cell division. The central cavity appeared absolutely empty, and doubtless in the living spore is filled with a watery fluid. The relation of the nuclei to the primary nucleus could not be traced, but in all probability it is the same as in Isoetes. In 
somewhat older stages (Fig. 254, A) the nuclei were more nearly globular in outline, and were more numerous at the apex of

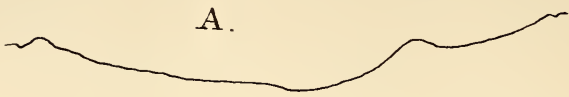

per.

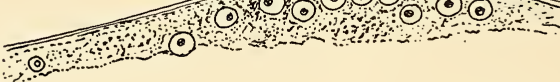

๑

B.
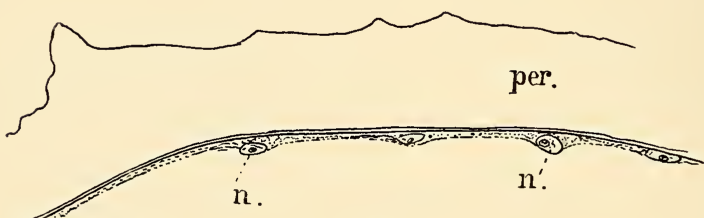

Sp.

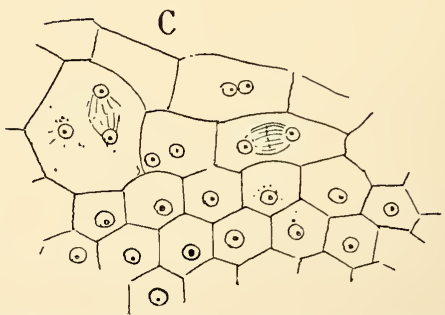

FiG. 254.-Selaginella Kraussiana (A. Br.). A, Section of the upper part of a macrospore still within the sporangium, shortly before the first cell-formation, $\times_{525} ; \mathrm{B}$, a somewhat earlier stage, showing the very thin protoplasmic layer lining the wall, with the free nuclei $(n), \times 525 ; \mathrm{C}$, transverse section through the apex of the macrospore, showing the first cell-formation, $\times 570$.

the spore, where the protoplasmic layer lining the wall was also noticeably thicker. Shortly after this the first cell division 
occurs, and this takes place in a manner identical with that found in Isoetes, or in the endosperm-formation of most Spermaphytes. Fig. 254 , C shows a cross-section of the apex of the spore shortly after the first cell walls are complete. The extremely regular hexagonal form of the cells toward the centre of the prothallium is very noticeable. At the margin, and below, the cells are larger, and often contain several nuclei.

The cell-formation does not extend at this stage to the base of the spore, as in Isoetes, but is confined to the apex, where a definite cellular body is formed. This is three-laycred

B.

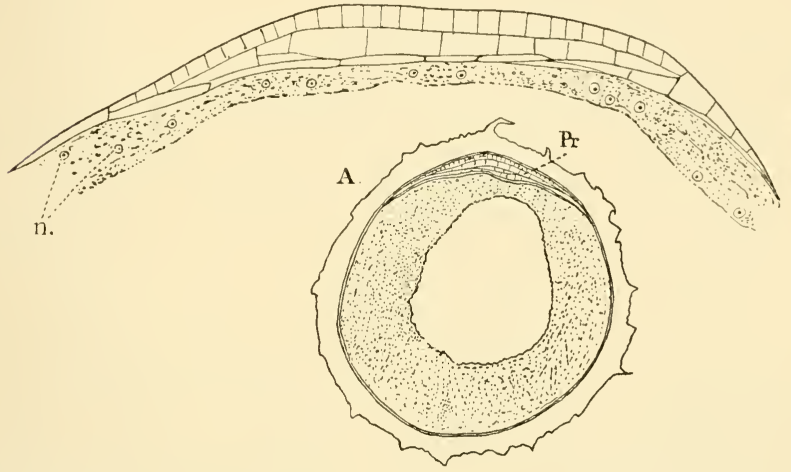

Fig. 255.-Selaginella Kraussiana (A. Br.). A, Longitudinal section of a nearly ripe macrospore, with the primary prothallium $(\phi r)$ complete, but still showing a large vacuole in the centre of the spore, $\times 6_{5} ; \mathrm{B}$, similar section of a younger stage, before the diaphragm has been differentiated, $\times 400 ; n$, nuclei.

in the middle, but at the margins but one cell in thickness. The lower cells have the walls which are in contact with the spore-cavity much thickened at a later stage, and thus is formed the diaphragm which is so conspicuous in most species, and which led Pfeffer to suppose that the first division in the young prothallium was by a cell wall which separated the prothallium proper from the lower part of the spore, in which later the "secondary endosperm" is formed.

Scattered through the protoplasm of the spore-cavity are numerous very small nuclei. The protoplasmic layer becomes rapidly thicker (Fig. $255, \mathrm{~A}$ ), and finally completely fills the 
cavity of the spore. The thickenings upon the outer sporecoat are very evident even before the primary nucleus divides, and they increase rapidly in size, as the spore develops. A very casual examination suffices to show that the tapetal cells of the sporangium here play a most important part, not only in the development of the spore-coat, but also in the growth of the prothallium. The rapid increase in the amount of protoplasm in the spore during the growth of the prothallium, as well as the growth of the spore itself, can only be accounted

A.

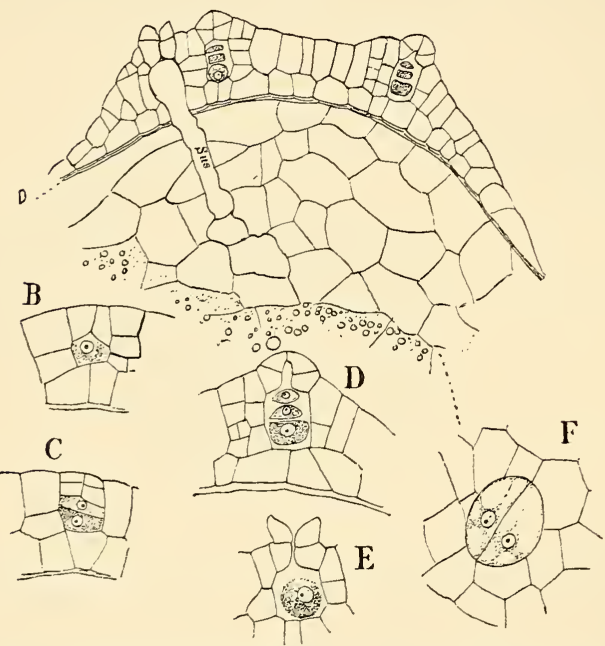

G

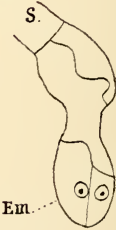

FIG. 256.-Selaginella Kraussiana (A. Br.). A, Nearly median section of a fully-developed female prothallium, showing the diaphragm $(d), \times 180$. One of the archegonia has been fertilised, and the suspensor (sus) has penetrated through the diaphragm into the tissue below it ; B-E, development of the archegonium, $\times_{3} 60 ; \mathrm{F}$, two-celled embryo, belonging to the suspensor shown in $\mathrm{A}$, $\times{ }_{3} 60 ; \mathrm{G}$, end of a suspensor with two-celled embryo $(\mathrm{em}), \times_{3} 60$.

for by the activity of these cells, which are in close contact with the spore, and show every evidence of being active cells, through whose agency the materials are conveyed to the spore for its further development.

The first archegonia begin to form shortly before the spores are shed, and soon after, the exospore splits along the three ventral ridges and exposes the central part of the prothallium. 
This, like that of Isoetes, is quite destitute of chlorophyll, and is entirely dependent upon the food materials in the spore for its further development. About this time also begins the cellformation in the part of the spore below the diaphragm (Fig. 256). This is simply a continuation of the same process by which the apical tissue was developed, but the cells are larger and more irregular.

The archegonia are produced in considerable numbers, and apparently in no definite order. Their development corresponds with that of Lycopodium, but the neck is very short, like that of the Marsiliaceæ, each row of neck cells having but two cells. No basal cell is formed, and the central cell is separated from the diaphragm only by a singlc layer of cells. The neck canal cell (Fig. 256) is broad, like that of Isoetes, but the nucleus does not, apparently, divide again. The egg (Fig. 256, E) shows a distinct receptive spot, and the nucleus is clearly defined. At this stage the diaphragm is very evident and much thickened, so that the archegonial tissue of the prothallium is very sharply separated from the nutritive tissue below.

\section{The Embryo}

The first division in the fertilised ovum is transverse, and as in Lycopodium the cell next the archegonium neck becomes the suspensor. This in Selaginella is much more developed, however, and grows at first more actively than the lower cell from which the embryo proper arises. The upper part of the suspensor enlarges somewhat, and forms a bulbous body, which completely fills the venter of the archegonium. The suspensor grows rapidly downward, penetrating the diaphragm and pushing the young embryo down into the mass of food cells which occupy the space below it. The suspensor is very irregular in form, and undergoes several divisions (Fig. 256, G).

The first division in the embryo proper is almost vertical (Fig. 256, F), and divides it into nearly equal parts. Beyond this the early stages of the embryo were not followed by the writer, but to judge from the later stages, they correspond to those of S. Martensii, which has been most carefully studied by Pfeffer, ${ }^{1}$ and the substance of which may be given as follows. After the first wall is formed in the embryo, there arises in 
one of the cells a second, somewhat curved one, which strikes the primary wall about half-way up. The cell thus cut off, seen in longitudinal section, is triangular, and is the apical cell of the stem (Fig. 257, A). The two other cells (leafsegments) now undergo division by a vertical wall, which divides each into equal parts, and each of these pairs of cells develops into a cotyledon. The apex of the young cotyledon is occupied by a row of marginal cells in which divisions are formed, like those in the apical cell of the stem, and in longi-
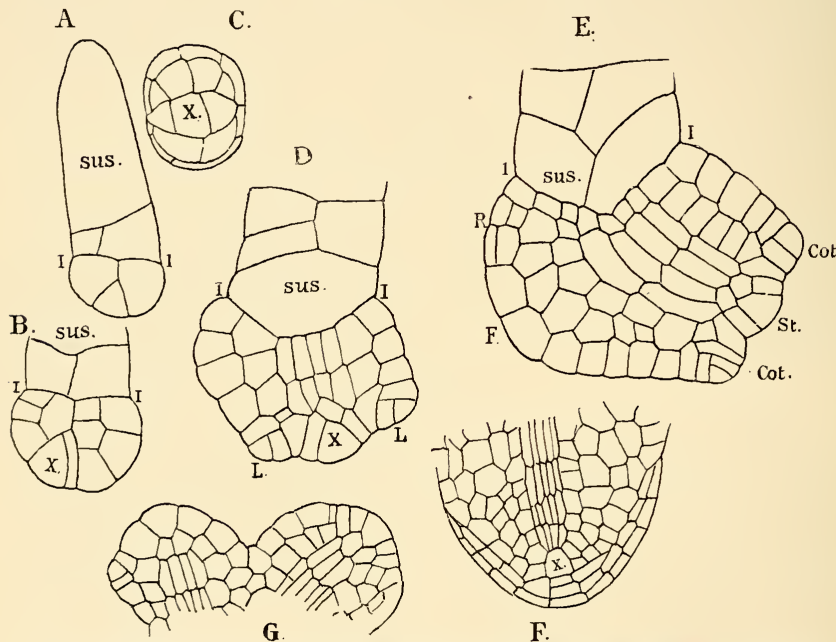

FIG. 257.-Selaginella Martensii (Spr.). Development of the embryo (after Pfeffer). A, B, D, E, Successive stages in Iongitudinal section, $\mathrm{X}_{340} ; \mathrm{C}$, apical view of a young embryo with four-sided apical cell $(x), \times_{340} ; \mathrm{F}$, Iongitudinal section of the primary root, $\times_{205} ; \mathrm{G}$, apex of the young sporophyte, showing the first dichotomy, $\times 340$.

tudinal section the apex of the cotyledon seems to have a single apical cell, much like the stem (Fig. 257, E). From the larger of the leaf-segments, by a more active growth of the cells next the suspensor, the foot is formed, and by its growth the stem apex is pushed to one side, and its axis becomes almost at right angles to that of the suspensor. Each cotyledon develops upon its inner side, near the base, an appendage, the ligula (Fig. 258, l), which is a constant character of all the later leaves. 
The primary root, as in Lycopodium, forms late, and no trace of it can be seen until the other parts are evident. It arises in the larger leaf-segment, close to the suspensor, and therefore is separated from the cotyledon by the foot. The root-cap arises from a superficial cell, which divides carly by both periclinal and anticlinal walls, and thus becomes two-layered. From a cell immediately below is derived the single apical cell to which the subsequent growth of the root is due. The further divisions in the primary root were not followed.

The axes of the stem and root soon develop a strand of procambium which is continuous in the two, but to judge from Pfeffer's figures, the cotyledons do not develop their vascular bundles until later. The early growth in length of the root is mainly intercalary, as the divisions in the apical cell for some time are not very rapid, and for a long time the root-cap consists only of the two original layers.

With the growth of the embryo the cell-formation in the lower part of the spore continues until it is filled with a continuous large-celled tissue, the con-

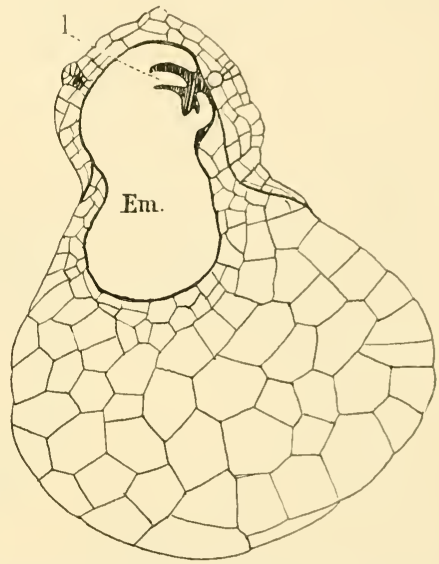

FiG. 258.-Longitudinal section of a fully-developed prothallium of $S$. Kranssiana, with an advanced embryo $(\mathrm{cm}), \times 77 ; l$, ligula. tents of whose cells are much less granular than the undivided regions of the spore, and as the embryo develops the foot crowds more and more upon them until it nearly fills the spore-cavity.

On comparing Pfeffer's account of S. Martensii with my own observations upon S. Kraussiana, the main differences consist first in the smaller development in the latter of the primary prothallium, i.e. the prothallial tissue formed before the spores are shed, the archegonia being only separated from the diaphragm by a single layer of cells instead of by three or four, as in S. Martensii. L. apus, which was also examined by 
the writer, is intermediate in this respect between the two. A second difference is the later period at which the cell division in the lower part of the prothallium is completed in S. Kraussiana. In this species, too, no root-hairs were seen, while Pfeffer observed them in S. Martensii. Finally, in the latter the suspensor is much shorter and straighter than in $S$. Kraussiana.

In S. Martensii, almost as soon as the cotyledons are
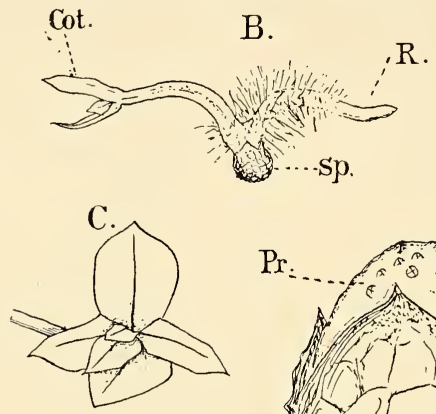

A.
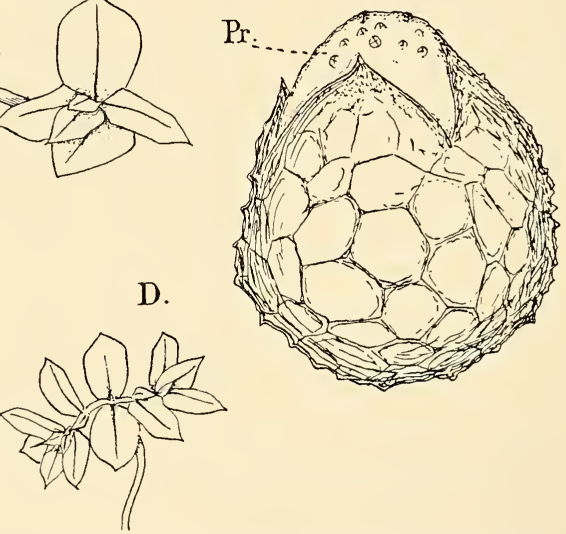

Fig. 259.-Selaginella Kraussiana (A. Br.). A, Macrospore with the prothallium (pr), $\times 50$; B, young sporophyte still attached to the spore $(s p p), \times 8$; cot, cotyledons; $\mathrm{R}$, root ; C, upper part of an older stage, $\times 6 ; \mathrm{D}$, a still older one showing the first dichotomy, $\times_{4}$

established, the two-sided apical cell of the stem is replaced by a four-sided one, from which are then produced two similar ones by the formation of a median wall, and a true dichotomy of the primary axis thus takes place at once, the two new branches growing out at right angles to the cotyledon. While this may also occur in S. Kraussiana (Fig. 259, D), it is not always the case, and frequently the young plant remains 
unbranched until it has reached a length of a centimetrc or more, and has produced numcrous leaves.

\section{The Sporopliyte}

The sporophyte of Selaginella closely resembles that of Lycopodium, and, as in that genus, the leaves may be arranged radially, or the stem may be dorsiventral with the leaves in four rows; the latter is much the commoner arrangement, however, but $S$. rupestris may be mentioned as a familiar example of the homophyllous type. In many species there is

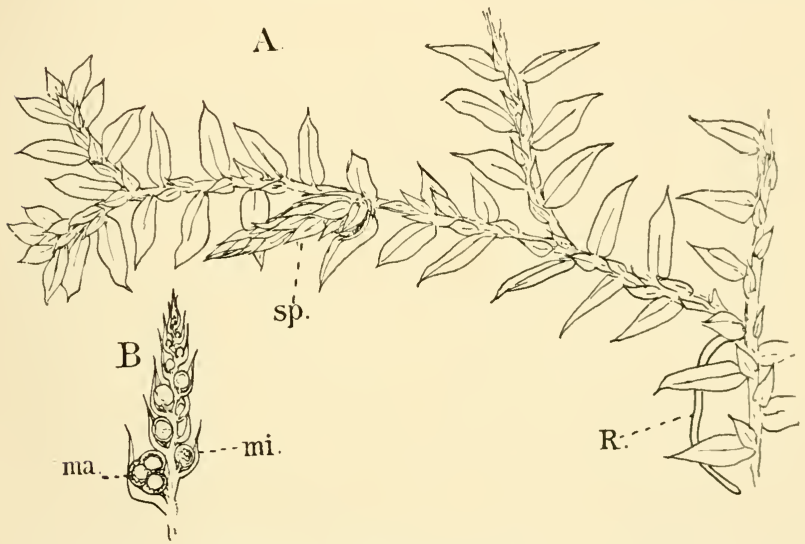

F1G. 260.-A, Part of a fruiting plant of Selaginella Kranssiana, $\mathrm{x}_{3} ; s p$, sporangial strobilus; $\mathrm{R}$, young rhizophore; $\mathrm{B}$, longitudinal section of the strobilus, $\mathrm{x}_{5} ; m a$, macrosporangium; $m i$, microsporangium.

a creeping stem from which upright branches grow, much as in many species of Lycopodium, but in others there is no clear distinction between these parts. The roots may arise directly from the ordinary branches, but in many species, e.g. S. Kraussiana, they are borne at the end of peculiar leafless branches or rhizophores (Fig. 263, A). These, like the stem, show an apparently regular dichotomous branching, which, howerer, is really monopodial. The leaves, like those of Lycopodium, are small, more or less lanceolate in outline, and with a single median vein. In the dorsiventral shoots the leaves are 
arranged in four rows, two lateral ones, composed of large leaves, and two dorsal rows of smaller ones (Fig. 260). In the homophyllous forms the sporophylls differ but little in appearance from the ordinary leaves, but in the heterophyllous ones they, are smaller than the other leaves, and always arranged spirally about the axis, forming a strobilus much like that of Lycopodium, but usually less conspicuous. Commonly the lowest or oldest sporangium is the macrosporangium, and contains four spores; the younger ones, which may continue to form for a long time, are always microsporangia, and are very similar in appearance to those of Lycopodium.

\section{The Stem}

The apex of the stem has the form of a cone, whose summit, in most species examined, is occupied by a single apical cell. This, in S. Kraussiana (Fig. 26I), is of the "twosided" type, and segments are regularly cut off only from the lateral faces. From inner cells of the segments are derived the two vascular bundles (steles), which are found in the fullydeveloped stem, but their limits are difficult to trace in the small-celled meristem at the apex. In other species there is great variation in the character of the apical meristem. Thus in S. Martensii, according to Treub, the apical cell of the older shoots may be either a two-sided one, like that of $S$. Kraussiana, or it may be tetrahedral, like that of Equisetum and most Ferns. In the younger branches, however, a foursided cell, like that Pfeffer describes for the embryo previous to the first forking of the stem, is always present, but is later replaced by the two-sided or tetrahedral form. Strasburger ${ }^{2}$ found in S. Wallichii regularly two apical cells, and several species, e.g. S. arborescens, S. spinosa, show the same type of apical growth as Lycopodium.

Sections of the stem apex, parallel to the plane of the leaves, frequently show the formation of the branches (Fig. 26I, B). It is quite evident that the branch arises as a lateral outgrowth of the stem apex, which retains its original central position for some time. The apical cell of the branch is not established until the latter is very evident. By the rapid growth of the branch it may very early force the main axis

1 Treub (1).

2 Strasburger ( 7$)$. 
to one side, and thus produce the appearance of a true dichotomy, but this does not always occur.

The leaves arise much in the same way that the branches do, but do not develop a single apical cell. The growth is much the same as in the first leaves of the cmbryo, and as in these the early growth is due mainly to a row of marginal

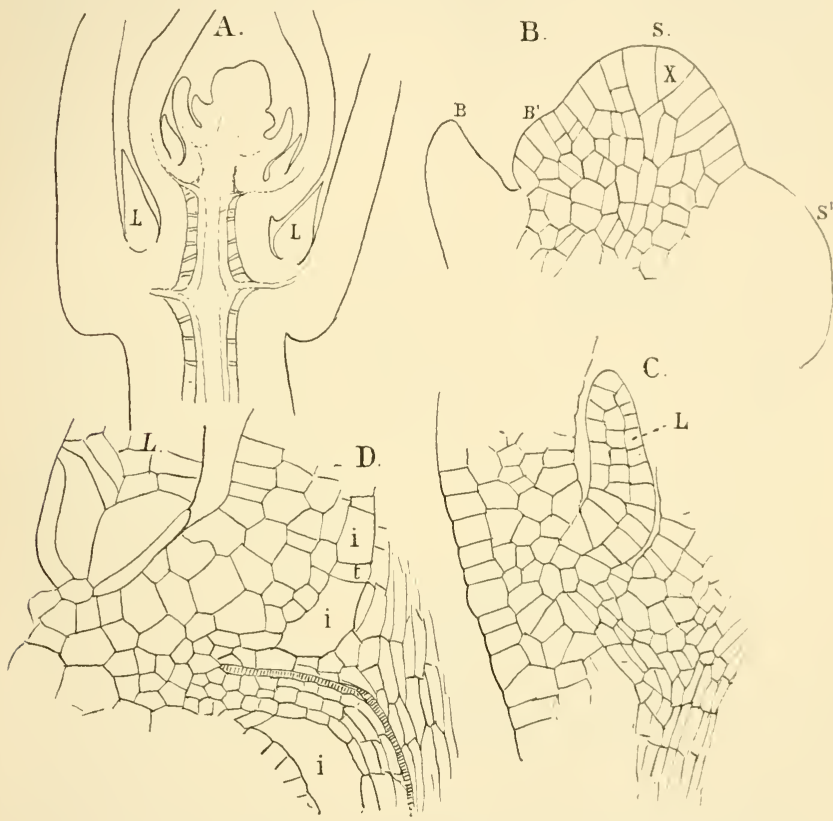

Fig. 261.-Selaginelia Kraussiana (A. Br.). Horizontal section of the apex of the stem, $\times 77 ; \mathrm{B}$, the apical meristem of the same, $\times_{450} ; s$, the apex of the main axis; $s^{\prime}$, a young lateral branch : $\mathrm{B}, \mathrm{B}$, young leaves; L, ligula of the leaf ; C, D, longitudinal sections of the base of older leaves. $\times 450 ; i, i$, lacuna surrounding the vascular bundles of the stem ; $t$, one of the trabecula.

initial cells from which segments are cut off alternately above and below.

If we examine a longitudinal section of the stem a short distance below the apex (Fig. 26I, A), we find a regular intercellular space formed between the central cylinder (or cylinders), which completely surrounds it, and becomes very 
conspicuous as the section is examined lower down. The formation of this lacuna is similar to that in the capsule of the Bryineæ, and, as there, the central mass of tissue is connected by rows of cells with the outer tissue. These rows of cells (trabeculæ) are at first composed of but a single cell, but later by tangential walls become slender filaments by which the vascular cylinders are suspended in the large lacuna which

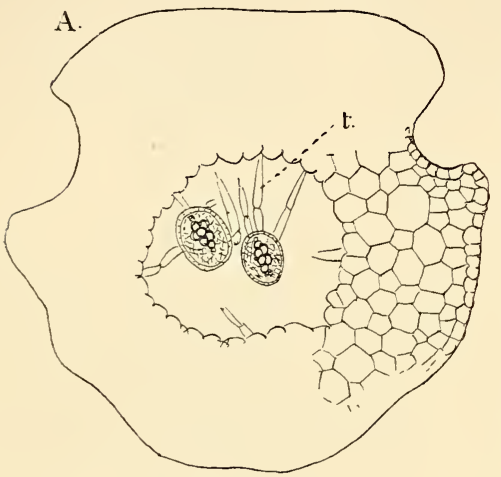
occupies the centre of the stem (Fig. 262, $t$ ). According to Strasburger ${ }^{1}$ both the trabeculæ, which are usually regarded as endodermal, and the pericycle, are of cortical origin.

The fully-developed bundle in S. Kraussiana (Fig. 262, B) shows a pericycle composed of a single layer of rather large cells, within which lies the phloëm, which

B.

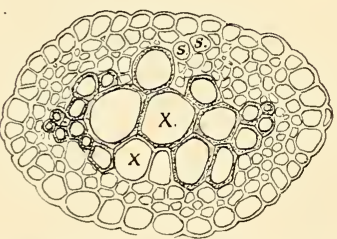

FIG. 262.-Cross-section of a fully-developed stem of $S$. Kraussiana, showing the two vascular bundles suspended in the large central lacuna by means of the trabeculæ $(t), \times_{75} ; \mathrm{B}$, a single vascular bundle, $\times 450 ; x, x$, scalariform tracheids; $s, s$, sieve-tubes. completely surrounds the xylem, as in the Ferns. The sieve-tubes in this species form a single circle just inside the pericycle, but according to Gibson $^{2}$ are absent opposite the protoxylem. He states that there is but a single group of protoxylem elements here, but my own observations lead me to think that there are two, as Russow affirms is the case. The origin of the protoxylem was not traced, but the appearance of the mature bundle in the specimens examined (Fig. 263, B) points to this conclusion. The protoxylem is made up of small spiral and annular tracheids, the metaxylem (secondary wood) of larger scalari- 
form elements, as in Lycopodium. The sieve-tubes have delicate walls and numerous, but poorly developed, sieve-plates upon their lateral walls.

While in the main the anatomical characters are essentially the same in all species examined, there are a number of differences to be noted. ${ }^{1}$ Thus the stem may be monostelic (S. Martensii), bistelic (S. Kraussiana), polystelic (S. lavigata). In the former species the presence of silica in the inner cortex has been demonstrated by Strasburger, and Gibson ${ }^{2}$ has shown the same thing in other species. In this species, too, besides the simple trabecula found in S. Kraussiana,

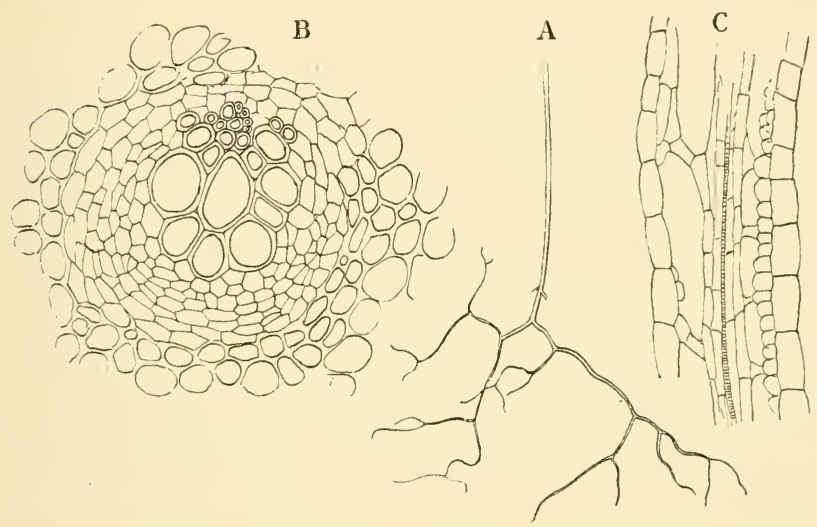

Fig. 263.-A, Rhizophore, with roots of S. Kranssiana, $\times 1 \frac{1}{2} ; \mathrm{B}$, cross-section of the vascular bundle of a root, $\times 430 ; C$, median longitudinal section of the leaf, $\times 215$.

others occur in which the outer cells undergo divisions in more than one plane, and form a group of cells with which the endodermal cell is articulated. In all species examined these cells show more or less marked cutinisation. The number of protoxylems in most species is two, but there may be accessory ones.

The cortex is composed in most species of delicate parenchyma, with few or no intercellular spaces, and most of the cells contain chlorophyll. In species like S. lepidophylla, which grow in dry localities, the cortical cells are sclerenchymatous,

$$
1 \text { Gibson (2), p. 176. } 2 \text { Gibson (1). }
$$


with deeply-pitted walls. In the creeping stems, even in polystelic species, there is but a single stele, which gradually passes over into the separate steles of the upright stems.

The leaves show a single very simple concentric bundle, similar to those of the stem, but less developed. The leaftraces, as in Lycopodium, join the central vascular cylinder (Fig. 26I, C). The leaf always develops a ligula just above the base. This (Fig. 26I, L) is a tongue-shaped organ, which cannot be traced back to a single cell. The basal cells are larger than the others, and it is much constricted at the point where it joins the leaf.

\section{The Roots}

The roots in S. Kraussiand are borne upon the special leafless branches or rhizophores, which in structure are much like the stem. Previous to the formation of the first roots upon the rhizophore, ${ }^{1}$ the apical cell is obliterated and replaced by a group of initial cells. The apical cells of the (usually two) roots formed arise secondarily, and quite independently of each other, from cells lying below the surface, and covered with one or two layers of cells. These cells soon assume a tetrahedral form, and become the apical cells of the primary roots. The branching of the roots, like that of the stem, is really monopodial, although apparently a true dichotomy.

The vascular bundle of the root is monarch (Fig. 263, B), and does not show a distinct endodermis. The phloëm surrounds the xylem completely, but apparently sieve-tubes are not developed opposite the protoxylem. The elements of the bundle are in structure like those of the stem-bundles.

\section{The Chloroplasts}

The chloroplasts of Selaginella are peculiar, on account of their large size and small numbers. A careful study has been made of these by Haberlandt, ${ }^{2}$ who found that in each of the meristematic cells of the stem apex a single plastid was present. This in the assimilative cells of the leaves either remains undivided (S. Martensii), or it may become more or less completely divided into two (S. Kraussiana). In S. Willdenowii 
there may be as many as eight. In the cortical parenchyma of the stem the chloroplasts are apparently of the ordinary form, but a careful examination shows that they are all connected, and are directly referable to the divisions of the primary plastid in the young cell. In all cases the nucleus is in contact with the chloroplast or group of chloroplasts (Fig. 264). The character of the chloroplasts here has its nearest analogy in Anthoceros, where occasionally a division of the chloroplasts
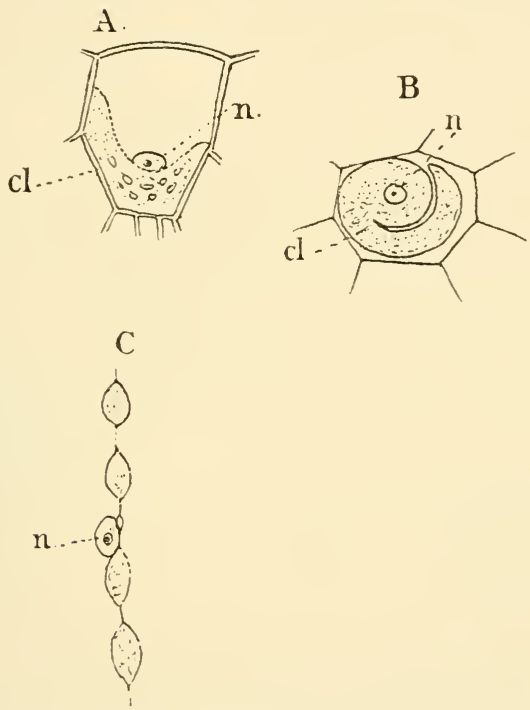

FIG. $264 .-\mathrm{A}, \mathrm{B}, \mathrm{Cells}$ of the mesophyll of Selaginella .1Fartensii, showing the single chloroplast ( $\mathrm{cl}$ ) and the nucleus $(n)$; $\mathrm{C}$, chain of connected oval chloroplasts from the inner cortex of the stem of S. Kraussiana, $\times 6_{4} \mathrm{c}$ (after Haberlandt).

is met with, especially in the elongated cells of the sporogonium.

\section{The Sporangia}

The development of the sporangia is much like that of Lycopodium, and has been studied by Goebel ${ }^{1}$ and Bower in S. spinosa, and by the latter in S. Martensii also. In $S$.

\footnotetext{
1 Goebel (16), p. 388 ; Bower (15).
} 
Kraussiana (Fig. 265, A) a radial section of the young sporangium shows a very regular arrangement of the cells, with a single central archesporial cell (the nucleated cell of the figure). This evidently has arisen from a hypodermal cell of the central row, and from it is already cut off by a periclinal, an outer cell. The whole closely resembles Goebel's figures of S. spinosa. A comparison with older stages indicates that from this central cell alone the sporogenous cells are produced, as in Lycopodium selago. The outer row of cells does not divide by periclinal walls, and from the first forms an extremely
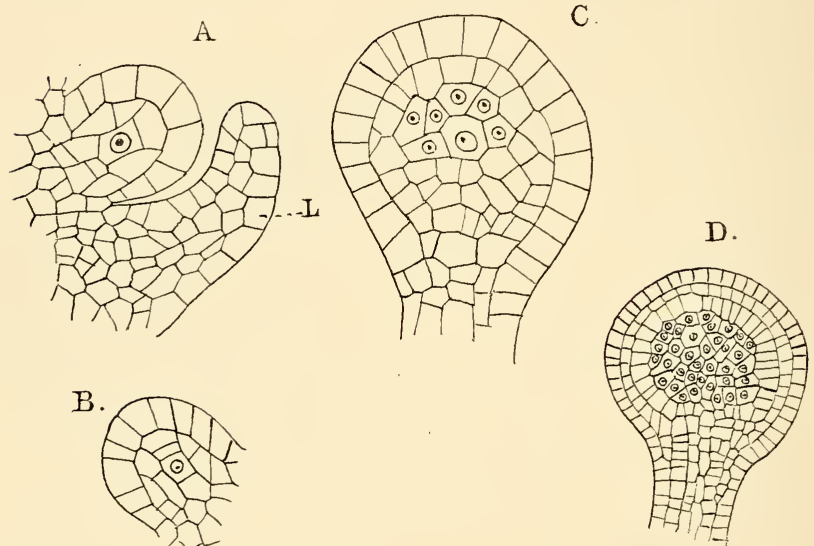

Fig. 265.-Selaginella Kraussiana (A. Br.). Development of the microsporangium, radial sections. A.C, $\times 500 ; D, \times 235$. The nuclei of the archesporial cells are shown. L, The leaf subtending the sporangium.

distinct layer. The first cell cut off from the archesporium divides again by a periclinal wall (Fig. $265, \mathrm{~B}$ ), and the inner cell forms probably the first tapetal cell, although in some cases it looks as if this cell took part in the formation of spores. The archesporium undergoes repeated divisions to form the sporogenous tissue, and finally the layer of cells between these and the primary wall divides by periclinal walls to form the tapetum, which here remains intact until the spores are nearly or quite mature. The formation of the stalk is the same as in Lycopodium. 
Bower $^{1}$ thinks it probable that in $S$. spinosa and $S$. Martensii the sporogenous tissue cannot be traced back always to a single cell (in radial section), and has also shown that when tangential sections are examined, as in Lycopodium, the archesporium always is a row of cells.

In all species of Selaginella yet examined, the sporangium is not of foliar origin, but originates from the axis above the insertion of the leaf by which it is subtended.

As in Lycopodium the tapetal cells do not become dis-
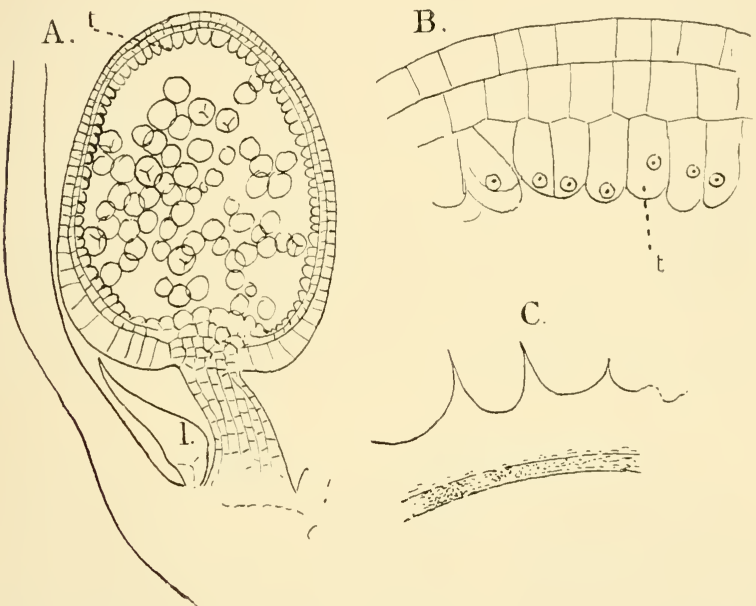

FIG. 266.-Selaginella Kraussiana (A. 1r.). A, Radial section of a nearly ripe microsporangium, $\times$ Ioo; $l$, ligula of the subtending leaf; $t$, tapetum; $\mathrm{B}$, section of young macrosporangium (about half grown), showing the papillate tapetal cells $(t), \times 600 ; \mathrm{C}$, section of the wall of a young macrospore from the same sporangium, $\times 600$.

organised, but remain intact as the inner layer of cells of the three-layered sporangium wall. They form an epithelium-like layer of papillate cells, distinguished by their dense granular contents, and it is evident that they are actively concerned in the elaboration of nutriment for the growth of the young spores (Fig. 266).

As in the other heterosporous Pteridophytes, the two sorts of sporangia are alike in their earlier stages, and this in Sele 
ginella continues up to the time of the final division of the spore mother cells, each of which divides into four tetrahedral spores. These in the microsporangium all develop, but in the macrosporangium only one of the tetrads reaches maturity. The tetrad of macrospores fills the sporangium completely, and with their growth the sporangium itself becomes four-lobed, and very much larger than the microsporangia. The cells of the wall remain green and fresh up to the time that the macrospores are ripe, and sections show that the tapetal cells are in close contact with the wall of the spores. The episporic ridges are very evident before the spore has reached half its final diameter, and sections of the spore wall at this time (Fig. 266, C) show the spine-like section of the surface ridges. The wall rapidly increases in thickness as the spores grow, and this increase is evidently due almost entirely to the activity of the tapetal cells, as the spore at this stage contains very little protoplasm. The first nuclear division in the macrospore takes place when the spore is about half-grown, and by the time it has reached its full size the cell divisions in the apical region are complete and the archegonia have begun to form.

The ripe sporangium, as in Lycopodium, opens by a vertical slit.

\section{The Affinities of the Lycopodinea}

Among the living Lycopodineæ there are two well-marked series, one including the Lycopodiaceæ and Selaginelleæ, the other the Psilotaceæ. In the first, beginning with Phylloglossum, the series is continued through the different forms of Lycopodium to the Selaginellex. The relation of the Psilotaceæ to this series is doubtful, and must remain so until the sexual generation of the former is known. The probable saprophytic or parasitic life of these plants makes it impossible to determine just how far their simple structure is a primitive character rather than a case of degradation.

Of the first series, it seems probable that of the forms whose life history is known, the type of $L$. cernuum represents the most primitive form of the gametophyte. It is reasonable to suppose that in all these forms the prothallium was green, and that the saprophytic prothallia, like those of L. phlegmaria and $L$. annotinum, are of secondary origin. The prothallium, of the type of $L$. cernum, may be directly connected with 
Liverworts like Anthoceros, and resembles them also in the small biciliate spermatozoids, in which latter respect all the Lycopodiner yet examined agree. This latter point is perhaps the strongest reason for assuming that the Lycopods represent a distinct line of development, derived directly from the Bryophytes, and not immediately related to either of the other series of Pteridophytes. The character of the archegonium, as well as the long dependence of the embryo upon the prothallium and the late appearance of the primary root, point to the genus Lycopodium as a very primitive type, even more closely related to the Bryophytes than are the eusporangiate Ferns. Phylloglossum, at least so far as the sporophyte is concerned, is the simplest living Pteridophyte; whether the structure of the gametophyte will bear this out, future investigation must determine.

The close relation of Selaginella to Lycopodium is sufficiently obvious. It is, however, interesting to note that Selaginella seems to have retained certain characters that are apparently primitive. These are the presence of a definite apical cell in the stem and root of most species, and the peculiar chloroplasts, which are especially interesting as a possible survival of the type found in so many Confervacex, e.g. Coleochate, from which it is quite likely that the whole archegoniate series has descended. This form of chloroplast occurs elsewhere among the Archegoniatæ only in the Anthoceroteæ.

In the characters of the sporangium and the early development of the prothallium, Selaginella undoubtedly shows the closest affinity to the Spermaphytes, especially the Gymnosperms, of any Pteridophyte. The strobiloid arrangement of the sporophylls and the position of the sporangia are directly comparable to the strobilus of the Coniferæ. The wall of the sporangium is here not only morphologically, but physiologically comparable to the nucellus of the ovule, and, as there, the macrospore grows, not at the expense of the disorganised sporogenous cells and tapetum alone, but is nourished directly from the sporophyte through the agency of the cells of the sporangium stalk and wall, until the development of the enclosed prothallium is far advanced. The latter, both in its development while still within the sporangium, as well as in all the details of its formation, shows the closest resemblance to the corresponding stages in the Conifers. The formation of a 
"primary" and "secondary" prothallium is, as we have seen, only apparent, and the diaphragm in the prothallium of Selaginella is not a true cell wall, marking a primary division of the spore contents, but only a secondary thickening of the lower walls of certain cells, indicating a temporary cessation in the process of cell-formation. It is by no means improbable that this cell-formation may sometimes go on uninterruptedly, in which case no diaphragm would be formed, and, as in Isoetes, there would be no distinct line of demarcation between the archegonial tissue at the apex and the large-celled nutritive tissue below.

The presence of a suspensor in all investigated Lycopodineæ is a character which distinguishes them at once from the other Pteridophytes, and has its closest analogy again among the Conifers.

\section{Fossil Lycopodinea ${ }^{1}$}

Many fossil remains of plants undoubtedly belonging to the Lycopodineæ are met with, especially in the Coal-measures, where the Lepidodendreæ were especially well developed. Of homosporous forms, it seems pretty certain that the fossils described under the name Lycopodites are related to the living genus Lycopodium, and certain fossils from the Coal-measures have even been referred to the latter genus, some of these being homophyllous, others heterophyllous. Solms-Laubach thinks it somewhat doubtful whether the plants described by various writers, and belonging to older formations, really are Lycopodineæ.

In regard to the Psilotacex he says: "The statements respecting fossil remains of the family Psilotacea are few and uncertain, nor is this surprising in such simple and slightly differentiated forms. If Psilotites . . . does really belong to this group, a point which I am unable to determine from the figures, we should be able to follow the type as far down as the period of the Coal-measures."

The genus Psilophyton, which has been found as far back as the Upper Silurian, is regarded by Dawson ${ }^{2}$ as related to the Psilotaceæ, but there seems some question about the accuracy of his conclusions.

The well-known group of the Lepidodendreæ is one of the

1 Solms-Laubach (2).

2 Solms-Laubach (I), p. 190. 
most characteristic ones of the Coal-measures, where their remains occur in enormous quantities. While evidently related to the modern Lycopodinex, they were different in some respects, especially the gigantic size of some species, which reached tree-like proportions. The leaves were deciduous, and in falling off left the characteristic rhombic leaf-cushions exposed. The structure of the stem ${ }^{2}$ is not unlike that of Lycopodium, and shows a central bundle-strand surrounded by a massive cortex, through which pass the leaf-traces. In some cases the increase in thickness of the stem was due mainly to the cortex, but specimens have been found in which there was an undoubted secondary thickening of the vascular bundles, quite similar to those in Gymnosperms.

The sporangia have been preserved with wonderful perfection in a few cases, and their structure is well known. ${ }^{2}$ In position they correspond to those of Lycopodium, but were heterosporous, somewhat like Selaginella, but usually the macrospores were much more numerous. These sporangial strobili of Lepidodendron were first described under the name Lepidostrobus. Bower, ${ }^{3}$ who has recently carefully examined their structure, states that the cavity of the large sporangium is divided by incomplete trabeculæ, somewhat as in Isoetes.

Probably related to the Lepidodendreæ are other large lycopodinous forms occurring in the same geological formations, and grouped together under the name Sigillariex. They show similar markings upon the surface of the stems, but their structure and fructification are much less perfectly known than is the case with the Lepidodendreæ, with which, however, they seem to agree in the main.

The genus Stigmaria has been conclusively shown to be nothing but the roots or rhizomes of Lepidodendrex or Sigillarieæ.

The Lepidodendrea have been traced as far back as the Lower Devonian, ${ }^{4}$ but the Sigillarieæ are not known certainly below the Coal-measures, and both groups disappear before the end of the Carboniferous period.

1 Solms-Laubach (I), p. 215.

3 Bower, l.c. p. 527.
2 Bower (15).

4 Solms-Laubach (2), p. 194 


\section{SUMMARY AND CONCLUSIONS}

\section{The Interrelationships of the Archegoniate}

IT is pretty generally conceded that the origin of the whole archegoniate series is to be sought somewhere among the green Algæ, and that on the whole Coleochate is, perhaps, the form which is nearest to the simplest Muscineæ. While the Characeæ, as we have seen, approach the latter more nearly in the structure of the sexual organs, yet the character of the vegetative parts is so different from that of any of the Muscineæ, and the sporophyte is so simple, that any close relationship of the two groups is hardly probable. At best, the connection between any known Alga and the Muscineæ is a very remote one.

From a study of the facts presented in the foregoing pages, the conclusion has been reached that the Hepaticæ are not only the most primitive of the existing Archegoniatæ, but are also the forms from which all the other groups have descended. When, however, the question arises as to which of the existing groups of Liverworts is the most primitive, the matter is not so easy to settle. Thus while Riccia undoubtedly has the most primitive sporophyte, the gametophyte shows a much higher degree of differentiation than is found in most anacrogynous Jungermanniaceæ and the Anthoceroteæ. The latter group, while retaining an extremely simple type of gametophyte, has the sporophyte developed beyond that of any other Bryophyte.

It will be remembered that in the germination of most thalloid Liverworts (and occasionally in the foliose forms as well) the occurrence of a single two-sided apical cell is quite general, although this may be absent from the fully-developed 
gametophyte. This suggests the possibility of a derivation of all of them from some type in which this two-sided apical cell was permanent. Aneura and Metzgeria, among living genera, have retained this condition, and in this respect are possibly to be considered as representing the simplest type of the thallus. The peculiar gemmæ of the former, which may properly be compared to the zoospores of Coleochate, strengthen this view.

Starting from this primitive type, we have endeavoured to show that development proceeded along three lines-the Marchantiaceæ, the Jungermanniaceæ, and the Anthoceroteæ. In the first one the differentiation consists mainly in the specialisation of the tissues, while the gametophyte retains its strictly thallose character; in the Jungermanniacex it is rather in the direction of the development of appendicular organs, while the tissues remain nearly uniform. In both of these groups the sporogonium is comparatively simple, in strong contrast to the Anthoceroteæ. Whether the peculiar chloroplasts of the latter are of secondary origin, or have been inherited directly from ancestors like Coleochate, where the same form occurs, it is not possible to determine. The great preponderance of the foliose Liverworts indicates that they are comparatively modern types, which have adapted themselves to present conditions, and show no indications of being connected directly with any higher forms.

Just as the simplest Jungermanniaceæ may have served as a starting-point for the three main lines of development in the Liverworts, so the Anthocerotex show evidences of being the ancestors of two other lines, the Mosses and the Pteridophytes. Whether the former class constitutes a continuous series, beginning with Sphagnum, or whether the Sphagnacex and the higher Mosses represent two branches from a common stock, it seems extremely likely that the thalloid protonema is the primitive condition derived from some Liverwort-like form allied to Anthoceros, and that the alga-like protonema of the higher Mosses is a secondary development from it.

In tracing the gradual evolution of the sporophyte among the Muscineæ we have seen how, starting with the simple sporogonium of Riccia, which, physiologically, is only a sporefruit and quite incapable of independent growth, it gradually becomes more and more independent by the development of a special system of assimilative tissues, which reaches its extreme 
in Anthoceros. It is true that the sporogonium always remains to some extent parasitic upon the gametophyte, but this parasitism is very slight in Anthoceros, where the formation of a root would make the sporogonium quite self-supporting. This increase in the vegetative tissues of the sporophyte is at the expense of the sporogenous tissue, which becomes more and more subordinated to the assimilative and conductive tissue of the sporogonium, as is seen in the Bryineæ among the Mosses, and in Anthoceros.

In most of the Liverworts the sterile tissues of the sporogonium are mainly concerned with the protection and dissemination of the spores. Only the foot, usually, can be properly considered as an organ concerned in the nourishment of the growing embryo. The seta, capsule wall, and elaters are merely adaptations for facilitating the dispersal of the ripe spores. In all of these, except the Anthocerotex, the whole of the central tissue of the capsule constitutes the archesporium, all of whose cells are devoted to the formation of spores or elaters. In the Anthoceroteæ, however, the origin of the archesporium is quite different, and it arises not from the central cells, but by a secondary division of the parietal ones. As yet there is no clear evidence of a direct connection with either of the other series of the Hepaticæ, and it is a question whether the Anthoceroteæ ought not to form a group co-ordinate with all the other Liverworts on the one hand, and the Mosses on the other. It is possible that the axial bundle of sterile cells found in the capsule of Pellia and Aneura may be homologous with the columella of the Anthoceroteæ, and the latter therefore to be considered as derived directly from some simple form among the anacrogynous Jungermanniaceæ; but as the sporogonium in all the Anthoceroteæ that have been thoroughly investigated shows absolutely the same type of structure, and in no case a secondary formation of the columella, this is hardly probable. In the higher Anthoceroteæ, also, the wall of the capsule, instead of simply serving for the protection of the spores, becomes a massive spongy green tissue communicating with the atmosphere by means of perfectly-developed stomata of exactly the same type as those of the vascular plants. This similarity in the assimilative system, together with the basal growth of the sporophyte and the central strand of conductive tissue, has of course suggested a relationship with the vascular 
plants. Indeed the sporogonium of Anthoceros is much more like a small Ophioglossum, for example, than it is like the sporogonium of Riccia.

The Mosses, like the foliose Liverworts, seem to represent a modern, extremely specialised type, with no direct connection with higher forms. Undoubtedly related to the Anthocerotex through Splagnum, their further development has diverged farther and farther away from the other Archegoniatæ, until in the Bryineæ both gametophyte and sporophyte have little in common with them.

The three classes of the Pteridophytes, while they differ strongly in the form of the sporophyte, are yet so much alike in the essential characters of the sexual generation, as to make it inconceivable that they can have originated from very widely separated ancestors. The more closely the gametophyte is studied in all of them, the more evident becomes the strong resemblance to the Anthocerotex, whose sporogonium has always been recognised as the nearest approach to the sporophyte of the vascular Archegoniates. This is notably the case when we consider the structure and development of the sexual organs, which in the Anthocerotex differ so remarkably from those of the other Muscineæ. Whether the submersion of the archegonia and antheridia in the thallus is the result of the cohesion of an envelope, such as is formed about these in Spharocarpus or Riccia, it is impossible to say, as there is no trace of any such process in the development of the sexual organs in any of the investigated species.

The probable homology of the four-rowed neck of the archegonium of the Pteridophytes with the cover cells only of the Liverwort archegonium, has already been discussed at length in a preceding chapter. It is quite possible that a similar correspondence may exist between the antheridium in the lower Pteridophytes and the Anthocerotex. It will be remembered that in the latter the single antheridium, or group of antheridia, arises from the inner of two cells formed from the division of a superficial cell of the thallus, and that the inner cell may either give rise to a single antheridium, or more commonly, by repeated longitudinal divisions, a group of antheridial mother cells is formed. The whole process is strikingly different from the development of the superficial 
antheridia in the other groups of Liverworts. In all of the homosporous Pteridophytes except the leptosporangiate Ferns, however, the first division in the antheridial cell is exactly as in the Anthocerotex; but instead of the inner cell developing into a distinct antheridium, the whole of it is devoted to the formation of sperm cells. It seems not improbable that this type of antheridium may have been derived from that of the Anthoceroteæ by the suppression of the parietal cells of the antheridium.

Aside from the forms without chlorophyll, which are probably all secondary, the Pteridophytes show three types of gametophyte. The first, represented by most homosporous Ferns, is the familiar heart-shaped prothallium, which strongly recalls the simpler anacrogynous Jungermanniaceæ or Dendroceros; the second is the lobed prothallium of Equisetum and Lycopodium cernum, which resembles most nearly among the Hepaticæ such forms as Anthoceros fusiformis; finally, in some species of Trichomanes there occur the branched filamentous prothallia, which some authors look upon as an indication of direct relationship with forms intermediate between Algæ and Muscineæ. As other species have the same type of prothallium as the other Ferns, and this is always true of the closely related genus Hymenophyllum, this view is open to question.

As far as the form and growth of the prothallium are concerned, all forms could be traced back to the Anthoceroteæ; the Fern type to forms like Dendroceros or Anthoceros lavis, the Equisetum and Lycopodium type more resembling $A$. fusiformis. The difference in the character of the chromatophores is a very important one, and at present must forbid the assumption of any immediate connection between the Anthoceroteæ and existing Pteridophytes. Whether the occasional appearance of very large plate-like chromatophores in the prothallium of Osmunda cimnamomea is a reversion to a primitive condition retained in the Anthoceroteæ, it is, of course, impossible to say, but it is not inconceivable, especially as the same thing is found again normally in the sporophyte of Selaginella.

In the Anthocerotex the origin of the archesporium is different from that of the other Hepaticæ, being hypodermal, as in the lower Pteridophytes. The columella is in position 
similar to the primary vascular bundles in the embryo of the Pteridophytes, and in all probability is to be regarded as its homologue. This central strand of conducting tissue, together with the massive assimilative tissue system of the larger species of Anthoceros, would make the sporogonium independent of the gametophyte, were a root or some similar structure present by which it could be connected with the earth. The alternation of sporogenous and sterile cells in the archesporium, by which the latter is divided into imperfect chambers containing the spores, is, perhaps, the first indication of the separate sporangia of the Pteridophytes. The most striking difference, then, between the sporogonium of Anthoceros and the sporophyte of the simpler Pteridophytes, such as Ophioglossum and Phylloglossum, aside from the absence of roots, which are, physiologically, replaced by the massive foot, is the absence of a definite axis with its lateral appendages (leaves) and sporangia. In Anthoceros the assimilative tissue forms a uniform layer over the whole upper portion of the sporophyte, instead of being restricted mainly to the special organs of assimilation or leaves, and the archesporium is continuous instead of being divided into definite sporangia.

Many attempts have been made to explain the origin of the leafy axis of the sporophyte of the vascular Archegoniates from the Bryophyte sporogonium. The latest theory is that of Professor Bower, ${ }^{1}$ who has brought forward much important evidence to show that the simpler strobiloid Pteridophytes, especially Phylloglossum, are the primitive forms from which the others have sprung. His conclusions are based largely upon a comparison of Phylloglossum with the embryonic condition of Lycopodium, where the long dependence of the embryo upon the prothallium, the rudimentary vascular bundles, and the late appearance of the root are very striking, and certainly indicate a very low rank for these forms in the pteridophytic series. Another evidence of the close relation of the Lycopodinex to the Bryophytes is the character of the spermatozoids, which closely resemble those of the Liverworts, both in their small size and the two cilia. Professor Bower's theory as to the origin of the sporophytes is that these arose "by a process of eruption from a hitherto smooth surface." In this way he conceives that the smooth cylindrical sporo- 
gonium became transformed into a structure directly comparable to the strobilus of Phylloglossum. The sterile leaves, as well as the root, are supposed to be outgrowths of the protocorm, which latter is directly comparable to the massive foot in Anthoceros, whose upper limit is the meristematic zone of cells at the base of the capsule. Bower summarises his conclusions as follows : ${ }^{1}$ " The chief points which have been recognised thus far, and are believed to have been the important factors in advance, are: (I) sterilisation of potential sporogenous tissue ; (2) formation of septa; (3) relegation of the spore-producing cells to a superficial position; and (4) eruption of outgrowths (sporangiophores) on which the sporangia are supported."

Professor Bower's explanation of the origin of the Lycopodineæ is certainly the most satisfactory that has yet been given, and we may accept without much question his conclusion, that Phylloglossum is on the whole the simplest known Pteridophyte; but his further conclusion that the Ferns are also probably reducible to a strobiloid type is by no means convincing.

The conclusion reached by the author, after considerable study of the subject, is that in the Ferns, and probably also the Equisetinex, we have to deal with entirely distinct lines of development. That is, while all three groups of the existing Pteridophytes may be traced back to a common stock, closely allied to the Anthoceroteæ, the three lines became differentiated at a very early period, and the differences are so great that it is difficult to see how any one of them could have been derived directly from either of the others. In the Lycopodineæ and Equisetineæ the axis is developed much more strongly than the leaves, and the sporophylls are usually aggregated into a more or less definite strobilus. The origin of the strobilus in the Equisetineæ may have been similar to that in Lycopodium; but the sporangia themselves, as well as the structure of the tissues and the prothallium, are more like those of the Ferns, and make it extremely improbable that the strobilus is homologous with that of the Lycopodinex. In the very definite apical growth of the stem and root, as well as in the structure and arrangement of the vascular bundles, Equisetum approaches much more nearly the condition found in Ophioglossum than that of the Lycopodineæ; and the large multiciliate spermatozoids, and the early divisions of the embryo, are also suggestive 
of the Ferns rather than of the Lycopods. Of course the fact that our knowledge of the Equisetinea is mainly based upon the single genus Equisetum, makes it unsafe to lay too much stress upon conclusions drawn from a study of this single type. However, such of the fossil forms as show unmistakable evidence of belonging to the Equisetinex, conform closely in their structure, so far as it is known, to the living types.

In the Filicinea the development of the leaves is usually much greater than in either of the other classes, and the origin of the sporophyll is probably different. Bower considers the sporophyll of Oplioglossum, for example, as the homologue of a single sporophyll of Lycopodium, and the whole sporangial spike as equivalent to a single sporangium. With this view the author feels that he cannot agree, and it seems more likely that the origin of the Fern-type of sporophyte was quite different from that of the Lycopodinex, and that there is nothing among the Ferns comparable to the strobilus of the latter.

If we could imagine the meristem at the base of the sporogonium of Anthoceros to produce a lateral flattened appendage or leaf, and the foot to develop into a root penetrating the thallus into the earth, we should have a structure not very unlike a small Ophioglossum. In this case the sporangial spike would represent, not a single sporangium of Phylloglossum, but the whole strobilus, and the sterile segment of the leaf would then be comparable rather to the sterile leaves (protophylls) than to a single sporophyll.

While the Lycopodinex correspond closely to the Bryophytes in the form of the spermatozoids, these in the other Pteridophytes are large and multiciliate. Whether these peculiarities have arisen independently in the Filicinex and Equisetinex, or whether they are inherited from some common ancestor, there is no means of deciding. None of the Muscinex, so far as is known, depart from the biciliate type, but among Algæ, Edogonium offers a similar exception to the usual biciliate form.

The Lycopodiaceæ and Selaginelleæ constitute a sufficiently direct series, but the exact affinity of the Psilotacer to these is by no means clear. Our complete ignorance of the sexual stage of the latter, as well as their parasitic habit, makes it impossible to judge just how far their simple structure is primary and how much is due to reduction. 
The reasons for regarding the eusporangiate Ferns as the lowest of the Filicineæ have been already given at length, but may be summarised as follows: (I) The structure of the gametophyte and sexual organs corresponds more nearly to that of the Liverworts than do those of the Leptosporangiatæ, and the prothallium is larger and longer lived than in the latter; (2) the embryo remains much longer dependent upon the gametophyte, and the latter may live for a long time after the sporophyte becomes independent; (3) the differentiation of the organs and tissues of the embryo takes place later than in the Leptosporangiates, and the tissues of the mature sporophyte are also simpler than in most of the latter; (4) the sporangia of the Eusporangiatæ, especially Ophioglossum, are of a much less specialised type than in the typical leptosporangiate Ferns, and approximate more nearly the condition found in Anthoceros; (5) the small number of species of the Eusporangiatæ, but the wide divergence of type shown, especially by the two groups of the Ophioglossaceæ and Marattiaceæ, indicate that these are remnants of formerly more predominant forms. Finally, the strong evidence of the geological record that the Eusporangiatæ were the prevailing types in the earlier formations, and have been supplanted by the more specialised Leptosporangiatæ in more recent times, is reasonably conclusive.

The homosporous Leptosporangiatæ constitute a pretty continuous series, beginning with the Osmundaceæ, by which they join directly to the Eusporangiatæ, and ending with the Polypodiaceæ. From this stock the two heterosporous families, the Marsiliaceæ and Salviniaceæ, have branched off independently of one another.

The systematic position of Isoetes is very difficult to settle, but on the whole its affinities appear to be with the lower Eusporangiatæ.

The development of heterospory in the different groups of the Pteridophytes is of especial interest, from its bearing upon the question of the origin of the Spermaphytes. That heterospory arose in a number of widely remote groups is unquestionable. While among the living Pteridophytes it is confined to the Ferns and Lycopods, the very perfect fossil remains of Calamostachys show that heterospory was also developed in the Equisetineæ, although apparently the differ- 
ence between the two sorts of spores was less marked than obtains in the other two classes. In the leptosporangiate families, the Marsiliacere and Salviniacce, although there is great reduction in the size of the prothallium, its development is essentially the same as in their homosporous relatives, and the female prothallium, if unfertilised, usually develops chlorophyll, and is capable of independent growth; but in the Isoetacex and Sclaginellex the formation of the female prothallium is much more like that in the Spermaphytes, and makes it extremely likely that from some such forms the latter have been derived.

The microsporangia of the Spermaphytes do not differ essentially from those of the heterosporous Pteridophytes, and the microspores (pollen spores) are shed before germination. The macrospore (embryo-sac), however, is retained within the macrosporangium (ovule), where it remains during the whole period of germination. Among the Pteridophytes Selaginella approaches this condition, as the macrospore is retained within the sporangium until germination is far advanced. The integument of the ovule is, with very little question, homologous with the indusium. The young macrosporangium of Azolla is extraordinarily like a developing ovule, and the closely investing indusium has all the appearance of an ovular integument. The velum of Isoetes is possibly of the same nature.

The development of heterospory in several unrelated groups of Pteridophytes at once suggests the possibility of a multiple origin for the Spermaphytes. The radical differences between Gymnosperms and Angiosperms, and the absence of any truly intermediate forms, make it extremely probable that these two great divisions have originated independently of one another, probably from different stocks, and it is by no means unlikely that the same may be said of the Cycads, Conifers, and Gnetaceæ.

Except for their siphonogamic fertilisation, the Gymnosperms really are much nearer the Pteridophytes than they are to the Angiosperms. As both the pollen tube and the seedformation are but further developments of heterospory, it is quite conceivable that these might have arisen independently more than once. The close resemblance between the Conifers and the Lycopods, especially Selaginelia, probably points to a real relationship. The strobiloid arrangement of the sporophylls, as well as the development of the prothallium and 
embryo, are extraordinarily similar, and it is not unreasonable to suppose that this is something more than accidental. Whether the Cycads belong to the same stock, or, as has been frequently suggested, are more nearly allied to the Filicineæ, further investigation must decide.

The Angiosperms are in all probability all members of a common developmental series, but just what is their relation to one another and to the other vascular plants is not so evident. It is usually held that they have been derived from the Gymnosperms through the Gnetaceæ, but it has also been suggested that one or both of the divisions may have originated directly from the Pteridophytes. Attention has been called more than once to the close resemblance between the embryos of the Filicineæ and those of typical Monocotyledons, and this is especially the case in Isoetes, where, in addition; the structure of the mature sporophyte is much like that of the Monocotyledons. It is possible that the surrounding of the sporangium by the base of the sporophyll may be the first indication of the ovary of the Angiosperms, but as this applies to the microsporangia as well, much stress cannot be laid upon it. It is quite as easy to trace back the embryosac of the Angiosperms to the macrospore of Isoetes as to the embryo-sac of the Gymnosperms ; and when the great similarity between the sporophyte of the former and the Monocotyledons is considered, the probability of the origin of the latter from aquatic or semi-aquatic ancestors resembling Isoetes is certainly considerable.

The essential similarity in the structure of the embryo-sac in all Angiosperms yet examined (except Casuarina), as well as the structure of the flower, makes it almost inconceivable that the two branches, Monocotyledons and Dicotyledons, could have arisen from different stocks. Strasburger's suggestion that the Dicotyledons were derived directly from the Gymnosperms, and that the Monocotyledons are a reduced branch of the former, is open to objections both on morphological and palæontological grounds, and we believe that the evidence we have at present points to the Monocotyledons as the more primitive of the two divisions of the Angiosperms, from which later the Dicotyledons branched off. If, as we have assumed, Isoetes has its affinities with the lower eusporangiate Ferns, the Angiosperms would be connected directly with them 
through Isoetes, and the Eusporangiate would bear somewhat the same relation to the Angiosperms and Leptosporangiatre that the Anthocerotere do to the Musci on the one hand, and the Pteridophytes on the other.

To summarise briefly: the conclusion reached is that the Spermaphytes represent not one single line of development, but at least two, and perhaps more, entirely independent ones, having their origin from widely separated stocks. The Gymnosperms (at least the Conifers) are probably direct descendants of some group of Lycopods allied to the Selaginelleæ, while the origin of the Angiosperms is to be looked for among the eusporangiate Filicinex.

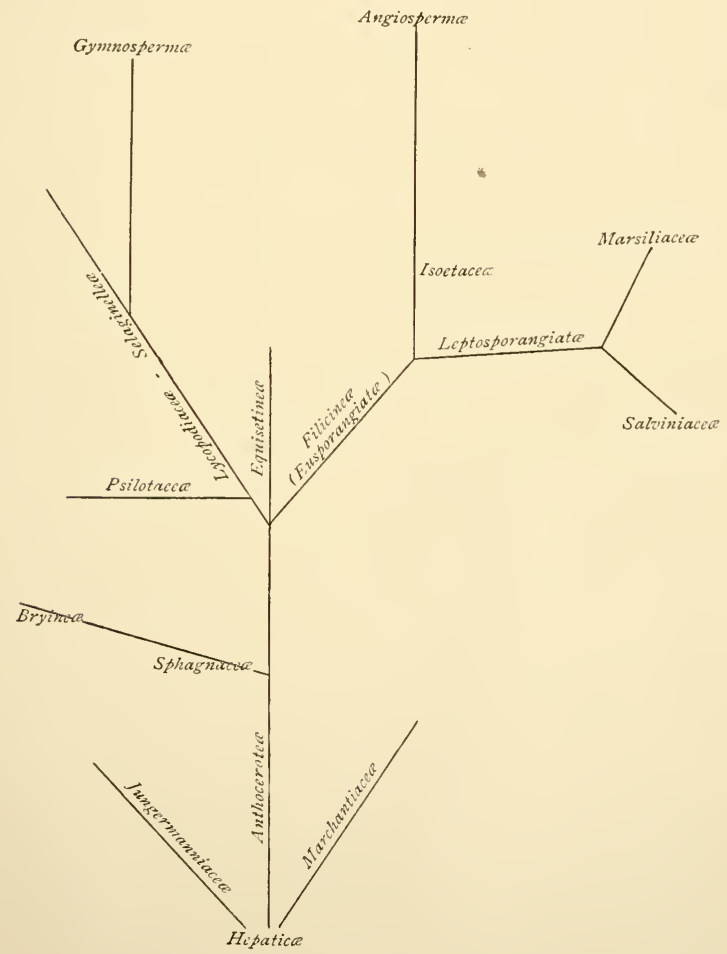





\section{B I B LI OGRA PHY}

Aввот, JAMEs-Scalariform ducts in Prothalli. Quarterly Journal of Microscopical sicience, I874, p. 401.

Ambronx, H. - Ueber Poren in den Aussenwänden der Epidermiscellen. Pringsheims Jahrb. fur wiss. Botanik, xiv. p. 105, I 884.

ANDREWs, W. M.-Apical growth of the roots in Marsilia quadrifolia and Equisetum arvense. Botanical Gazette, xr. 1890.

ArCaxgeli, G.--I. Studii sul Lycopodium selago. Livorno, I874.

2. Sulla Pilularia e Salizina. Nuovo Giornale Botanico Italiano, vol. viii. p. 320,1876 .

ARCHER, JANES-Prothalli with scalariform ducts. Q.J.M.S., I 875 .

Askenasy, E.-Waclisthum der Fruchtstiele von Pellia Epiphylla. Bot. Zeit., IS74, p. 237 .

Atkinson, G. F.--1. The extent of the annulus and the function of the different parts of the sporangium of Ferns. Bulletin of the Torrey Botanical Club, xx., I893.

2. Symbiosis in the Ophioglossacer, Ilid. p. 356 .

3. The Biology of Ferns. Macmillan and Co., 1894.

BAKER, J. G.-I. (and Hooker, Sir J.). Synopsis Filicum. London, I874.

2. Handbook of the Fern Allies, 1887.

3. Summary of New Ferns discovered or described since I874. Oxford, I 892.

BARNES, C. R.-Artificial keys to the genera and species of Mosses. Trans. Wisconsin Acad, of Sciences, Arts, and Letters, viii., ISgo.

Bastit, E.-Comparaison entre le rhizome et la tige feuillée des Mousses. Bul. de la Soc. bot. de France, xxxvi. p. 295, 1889.

BaUke, H. - I. Entwickelungsgeschichte des Prothalliums bei den Cyatheaceen. Pringsheims Jahrb. der wiss. Botanik, vol. x., 1876 .

2. Das Prothallium von Platycerium grande. Bot. Zeit., I879, p. 433.

3. Einige Bemerkungen uiber das Prothallium von Salvinia natans. Flora, 1879.

4. Aus dem botanischen Nachlass von H. Bauke. Bot. Zeit. (Beilag.), IS8o.

BEck, G.-Einige Bemerkungen iiber den Vorkeim von Lycopodium. Oesterreichische botanische Zeitschrift, I8So, p. 34I.

Belajeff, W.-I. Die Antheridien und Spermatozoiden der heterosporen Lycopodineen. Bot. Zeit., IS85, p. 793.

2. Ueber Bau und Entwickelung der Spermatozoiden der Gefässkryptogamen. Ber. der deutschen bot. Gesellschaft, is88.

3. The male prothallium of the Hydropterides (Russian). Olessa, 1890. Reported in Botanisches Centralblatt, I892, No. 24.

4. Ueber Bau und Entwickelung der Spermatozoiden der Pflanzen. Flora, I894. 
Bennett, A. W. : Murray, George.-Handbook of Cryptogamic Botany. London, I889.

Berggrex, S.--I. Entwickelung und Bau des Proembryo von Diphyscium und Edopodium. Botaniska Notiser af Nordstedt, 1873, p. 109.

2. Om Azollas prothallium och Embryo. Lund's Univer. Arsskrift, vol. xvi.

3. Apogamie in Notochlæna. Botaniska Notiser, 1888, Bot. Centralblatt, vol. xxxv. p. 18 3, 1888 .

Berthold, G.-Studien iiber Protoplasmamechanik. Leipzig, I 886.

Bertrand, C. E.-I. Recherches sur les Tmésipteridées. Arch. bot. du Nord de la France, 1882.

2. Le Type Tmésipteridée. Bull. de la Soc. bot. de France, xxx., 1882, p. 157.

3. Phylloglossum Drummondii. Archives botaniques du Nord de la France, 1885 , Nos. 30-33; also 1886, No. 34 .

Blasius, W.-Ueber die americanische "Auferstehungspflanze" (Selaginella lepidophylla, Spr.) Jahresb. d. Ver. f. Naturw. zu Braunschweig, I879, I88o. Bot. Centralblatt, 1880, p. 966.

Bower, F. O.-1. Note on the gemme of Aulacomnium palustre. Journal of Lin. Soc., xx., No. 131, 1884 .

2. Comparative Morphology of the leaf of the Vascular Cryptogams and Gymnosperms. Proc. of the Roy. Soc., xxxvii., No. 232. Phil. Trans., I884, p. 565.

3. Preliminary note on the apex of the root and leaf in Osmunda and Todea, Proc. Roy. Soc., xxxvi., No. 231.

4. Apex of the root in Osmunda and Todea. Q. J. Mic. Sci., new series, No. 25, p. 75 .

5. Phylloglossum Drummondii. Royal Soc. Phil. Transactions, 1885, Part II, p. 665 .

6. Apospory and allied phenomena. Trans. of the Linnæan Soc. Second series, Bot., vol. ii. Part 14, I887.

7. Preliminary note on the formation of gemmæ in Trichomanes alatum. Ann. of Botany, vol. i., 1887 .

8. On some normal and abnormal developments of the Öophyte in Trichomanes. Ann. of Botany, ז888.

9. Antithetic as distinct from homologous alternation of generations in plants. Annals of Botany, Aug. I 890 .

Io. Attempts to induce aposporous development in Ferns. Annals of Botany, 1889.

II. The comparative examination of the Meristems of Ferns as a phylogenetic study. Annals of Botany, vol. iii. No. 11, Aug. I889.

12. Is the Eusporangiate or the Leptosporangiate the more primitive type of Fern? Annals of Botany, vol. v. No. I8, April i891.

13. On the structure of Lepidostrobus Brownii (Sch.). Annals of Botany, vol. vii., 1893.

14. Studies in the Morphology of spore-producing members. Preliminary statement of the Lycopodinex and Ophioglossacer. Proc. Royal Society, I891, vol. 1. p. 265 .

15. Studies in the Morphology of spore-producing niembers. Equisetineæ and Lycopodineæ. Roy. Soc. Phil. Trans, vol. clxxxv., I894, p. 473.

I6. A Theory of the Strobilus in Archegoniate Plants. Ann. of Bot., vol. viii., Sept. I 894 .

Braun, A.-Blattstellung und Verzweigung bei Selaginella und Lycopodium. Sitzber. des botanischen Vereins der Prov. Brandenburg, 1874, p. 60.

Breeves, J.-On the derelopment of the stem and leaves of Physiotizun giganteum. Journal of Botany, xxxii., I894, p. 33 . 
BRUCHMAxi, 11.-1. Wurzeln von Isoetes und Lycopodium. Jenaische Zeitschrift firr Naturwissenschaften, 1874 .

2. Die vegetativen Verhältnisse der Selaginelleen. Giebel's Zeitschrift für die gesammten Naturwissenscliaften, I 877.

3. Ueber einige Ergebnisse der Untersuchungen die Vegetationsorgane von Selaginella spinulosa, A. Br. betreffend. Zeitschrift fur Naturwisse, Halle, fourth series, Bd. iii. p. 356 .

4. Das Prothallium von Lycopodium. Bot. Centralblatt, vol. xxi. p. 23, I8S5.

De Bary, A.-I. Sur la germination des Lycopodes. Ann. des Sci. naturelles, ser. 4 , vol. ix., I 858 .

2. Ueber Apogame Farne und die Erscheinung der Apogamie im Allgemeinen. Bot. Zeit., I 878 .

3. Comparative Anatomy of the regetative organs of the Phanerogams and Ferns. (English Edition.) Oxford, ISS4.

Buchtien, O. - Entwickelungsgeschichte des Prothallium von Equisetum. Bibliotheca botanica, vol. viii., Cassel, I887.

BüNGER, E.-Beiträge zur Anatomie der Laubmooskapsel. Botanisches Centralblatt, vol. xlii., 189o, p. 193.

Burck, W.-I. Das Prothallium von Aneimia. Bot. Zeit., 1875, No. 30.

2. Sur la développement du prothalle d'Aneimia comparé a celui des autres fougères. Archives Néërlandaises des Sciences exactes et naturelles, ix.

Büsgex, M.-Untersuchungen über normale und abnormale Marsilienfruichten. Flora, vol. xlviii. p. 169.

Campbell, D. H. - I. The structure and development of the Ostrich Fern. Mem. Boston Society of Natural History, I887.

2. Zur Entwickelungsgeschichte der Spermatozoiden. Berichte der deutsch. bot. Gesellschaft, 1887 , p. 125 .

3. The development of Pilularia globulifera(L.). Annals of Botany, vol. ii., ISSS, p. 233.

4. Einige Notizen uiber die Keimung von Marsilia Egyptiaca. Ber. der deutschen bot. Gesellschaft, I888, viii.

5. The systematic position of the Rhizocarpex. Bulletin of the Torrey Bot. Club, Oct. I 888 . 1890.

6. A study of the apical growth of the prothallium of Ferns. Ibid., vol. xriii. No. 3,

7. On the affinities of the Filicinere. Bot. Gazette, January I 890.

8. Die ersten Keimungsstadien der Macrospore von Isoetes echinospora (Durieu). Berichte der deutsch. bot. Geselischaft, i\$90, Heft 3.

9. Notes on the apical growth in the roots of Osmunda and Botrychium. Botanical Gazette, February I89I.

Io. Contributions to the Life History of lsoetes. Annals of Botany, rol. v, August IS9I.

I I On the relationships of the Archegoniatie. Botanical Gazette, December I 89 I.

12. On the Prothallium and Embryo of Osmunda Claytoniana (L.), and O. Cinnamomea (L.). Annals of Botany, vol. vi., April I\$92.

13. On the Prothallium and Embryo of Marsilia restita. Proceedings of the California Acad. of Sciences, April IS92.

14. The development of the sporocarp of Pilularia Americana. Bul. Torrey Bot. Club, April 1893 .

15. On the development of Azolla filiculoides (Lam.). Annals of Botany, vol. vii., June $1 \$ 93$.

16. Observations on the development of Marattia Douglasii (Baker). Annals of Botany, vol. viii., March I 894 . 
Celakovsky, L.-Untersuchungen tiber die Homologien der generativen Produkte der Fruchtblätter bei den Phanerogamen und Gefässkryptogamen. Pringsheims Jahrb. für wiss. Botanik, xiv,, p. 29I, I884.

Comber, H.-Morphology of Selaginella. Nature, 1877 .

Cormack, B. G.-On a cambial development in Equisetum. Annals of Botany, vol. vii., 1893 , p. 63 .

CorNu, M. - Note on two-celled male prothallia of Nephrodium filix-mas. Bull. de la Soc. bot. de France, t. xxi., p. I6r.

Crayer, C.- I. Ueber Lycopodizm selago. Pflanzenphysiologische Untersuchungen von Carl Nägeli und Carl Cramer, vol. iii., p. Io.

2. Vorläufige Mittheilung über geschlechtloses. Fortpflanzen des Farn-prothalliums, namentlich mittels Conidien resp. Gemmen, Bot. Centralb., I88o, p. 476.

DANGEARD, P. A.-I. Essai sur l'anatomie des cryptogames vasculaires. Le Botaniste, first series, 1889 , p. 211 .

2. Mémoire sur la morphologie et l'anatomie des Tmésipteris. Le Botaniste, second series, I89I.

Davenport, G. E.-Vernation in Botrychizm. Bulletin of the Torrey Botanical Club, viii., I 88 I.

De Vriese, W. H. : and HAkTiNg, P.-Monographie des Marattiacées, I853.

Dutailly, G.-Sur l'interpretation des différentes parties de l'embryon de Salvinia. Comptes rendues des séances de la Soc. botanique de Lyon, I88I.

Duval-Jouve, J.-Histoire naturelle des Equisetum de France. Paris, I864.

Eaton, D. C. - I. Ferns of North America. Coloured plates by J. H. Emerton and C. E. Faxon.

2. Vascular Acrogens. In Botany of California, vol. ii., Boston, I88o.

EkstRAND, E. V.-Brutknospenbildung bei den foliosen Lebermoose. Botaniska Notiser af Nordstedt, 1879 , No. 2.

Evans, A. W.-1. An arrangement of the genera of the Hepaticæ. Trans. Conn. Acad. viii., p. 262, 1892 .

2. A provisional list of the Hepaticæ of the Hawaiian Islands. Ibid., p. 253.

Famintzis, A.-Knospenbildung bei Equisetum. Mélanges biologiques tirés du bulletin de l'Académie impériale de St. Pétersbourg, t. ix., I876.

Fankhauser, J. - Ueber den Vorkeim von Lycopodium. Bot. Zeit., I873.

FARLOW, W. G.-I. Ueber ungeschlechtliche Erzeugung von Keimpflanzen auf Farn-prothallien. Bot. Zeit., 1874, p. I80; also Quarterly Journal of Mic. Science, I874, July.

2. Apospory in Pteris aquilina. Annals of Botany, I889, p. $38 \mathrm{r}$.

Farmer, J. Bretland-I. On Isoetes lacustris. Proc. Royal Soc., vol. xlv., I889.

2. On Isoetes lacustris. Annals of Bctany, vol. v., December I89o.

3. The Embryogeny of Angiopteris evecta (Hoffm.). Ann. of Bot., vi., I892, p. $26_{5}$.

4. Studies in Hepaticæ. On Pallavicinia decipiens (Mitten.). Ann. of Botany. March I 894 .

5. Studies in Hepaticæ. Ann. of Botany, June $\mathbf{1} 894$.

FelliNer, Ferd. - Ueber die Keimung der Sporen von Riccia glauca. Jabresber. der Akad. des naturwiss. Vereins in Graz, I875.

FIRTSCH, G.-Ueber einige mechanische Einrichtungen im anatomischen Bau von Polytrichum juniperinum. Berichte der deutschen botanischen Gesellschaft, Bd. i., p. 83 , I 883 .

GARDNER, W. : and TOKUTARO, ITO.-On the structure of the mucilage-secreting cell of Blechmum occidentale (L.), and Osmunda regalis (L.). Ann. of Botany, i., August 1887. 
Gerarb, R.-Recherches sur le passage de la racine à la tige. Ann. des Sciences naturelles. Sixth series, t. xi., 188 r.

Ginson, R. J. HARVEY-I. On the silicious deposit in certain species of Selaginella. Ann. liot, vol. vii., I $\mathrm{S}_{3}$.

2. Contributions towards a knowledge of the anatomy of the genus Selaginella. Ibid., June $\mathrm{I} S 94$.

3. Note on the diagnostic characters of the subgenera and species of Selaginella,

Spr. Transactions Biol. Soc., Liverpool, vol. viii., I 894 .

Giesenhagen, C.-Die Hymenophyllaceen. Flora, vol. xlviii., p. 4 II.

Giltay, E.-Ueber eine eigenthimliche Form des Stereoms bei gewissen Farne. Bot. Zeit., 1882, p. 694.

GöbrLer, E.-Die Schutzvorichtungen am Stammscheitel der Farne. Flora, lxix., 1886, p. 45 I.

Goebel, K.-1. Das Irothallim von Gymnogramme leptophylla. Bot. Zeit., 1877 .

2. Wachsthum von Metzgeria und Aneura. Arbeiten des bot. Instituts, Würzburg, Bd. ii. p. 285 .

3. Beiträge zur vergleichenden Entwickelıngsgeschichte der Sporangien. Bot. Zeit. I8So, I88I.

4. Zur Embryologie der Archegoniaten. Arbeiten des bot. Instituts in Wiirzburg, Bd. ii., p. 437 .

5. Zur vergleichenden Anatomie der Marchantiaceen. Ibid., p. 529.

6. Beiträge zur vergleichenden Entwickelungsgeschichte der Sporangien. Pilularia globulifera. Bot. Zeit., I 882 .

7. Ueber die Antheridienstände von Polytrichum. Flora, ISS2, p. 323.

8. Die Muscineen. Schenks Handbuch der Botanik, vol. ii., 1882.

9. Zur Keimungsgeschichte einiger Farne. Annales du Jardin botanique de Buitenzorg, vol. vii., IS87.

I0. Outlines of special Morphology and Classification. (Translation of the German Edition.) Oxford, Clarendon Press, I887. 1886 .

12. Ueber die Jugendstände der Pflanzen. Flora, I889.

13. Norphologische und biologische Studien. Ann. du Jardin botanique de Buitenzorg, vol, ix., 1891 .

14. Archegoniatenstudien. Flora, Ergänzungsband, I892, p. 92. Also Flora, 1 893 , p. 82.

15. On the simplest form of Moss. Ann. of Botany, December I\$92.

16. Vergleichende Entwickelungsgeschichte der Pflanzenorgane. Schenks Handbuch der Botanik, vol. iii., I884.

17. Das Prothallium von Lycopodium inundatum. Bot. Zeit., 1887, p. 161.

Gotтsche, C. M.-I. Anatomisch-physiologische Untersuchungen iiber Haplomitrium Hookeri. Acta Acad. Caes. Leopold. Car. Nat., vol. xx.

2. Uebersicht und kritische Würdigung der Leistungen in der Hepaticologie. Bot. Zeit. (Supplement), $\mathrm{r}_{5} 8$.

GraY, A.-Manual of the Botany of the Northern United States, 6th edit, New York, i 890 .

GRönlaND.-Mémoire sur la germination de quelques Hépatiques. Ann. des Sci. nat., series iv., t. I.

Guignard, Léox.-I. Déreloppement et constitution des anthérozoides. Rérue générale de botanique, $1 \$ 89$, t. i. liv. I-4.

2. Sur les anthérozoides des Marsiliacées et Equisetacées. Bul. de la Soc. bot. de France, xxxvi. 
3. Sur la constitution du noyau sexuel chez les végétaux. Comptes rendus, Paris, I891, I I Mai.

Haberlandt, G.-I. Vergleichende Anatomie des assimilatorischen Gewebesystems der Pflanzen. Pringsheims Jahrb. für wiss. Bot., xiii., I88I.

2. Ueber die physiologische Function des Centralstranges im Laubmoosstämmchens. Ber. der deutschen bot. Gesellschaft, Bd. i., I $88_{3}$, p. 263.

3. Ueber Wasserleitung im Laubmoosstämmchen. Ibid., Bd. ii., I 884 , p. 467 .

4. Beiträge zur Anatomie und Physiologie der Laubmoosen. Pringsheims Jahrb. fiir wiss. Botanik, Bd. xvii., I886, Heft 3 .

5. Das Assimilationssystem der Laubmoosen. Flora, 1886, No. 3.

6. Ueber Collaterale Gefässbündel im Laube der Farne. Sitzb. der k. Akad. der Wiss. Wien, lxxxiv., I Abt. I88I, also Bot. Zeit., I882, p. 2 I 7.

7. Ueber das Assimilationssystem. Ber. der deutschen bot. Gesellschaft, iv. p. 206, I 886 .

8. Zur Kenntniss des Spaltöffnungsapparat. Flora, I887, p. 97.

9. Die Chlorophyllkörper der Selaginelleen. Flora, 1888, p. 291.

Hansel, V.-I. Keimung von Preissia commutata. Sitzungsberichte der kais. Akademie der Wissenschaften, I876, I. Abtheilung.

Hanstern, J.-I. Pilulariæe globuliferæe generatio cum Marsilia comparata. Bonn, I 866 .

2. Befruchtung und Entwickelung der Gattung Marsilia. Pringsheims Jahrbiicher für wiss. Botanik, iv. p. 197, I866.

Hegelmaier. - Zur Morphologie der Gattung Lycopodium. Bot. Zeit., I875.

Heinricher, E.-I. Die jüngsten Stadien der Adventivknospen an der Wedelspreite von Asplenium bulbiferum. Sitzber. der kais. Akad. der Wissenschaften, Wien, lxxxiv., I Abt., I88I, p. I 15.

2. Die näheren Vorgänge bei der Sporenbildung der Salvinia natans verglichen der ibbrigen Rhizocarpeen. Sitzber. der k. Akad., Wien, lxxxvii., I Abt., I882, p. 494.

Heinsen, E.-Die Makrosporen und weibliches Prothallium von Selaginella. Flora, I894.

Hildebrand, F.-Brutkörper von Bryum annotinum. Flora, I874.

HobkiRk, C. P.-On some points in the development of Osmunda regalis. Journal of Botany, xi., I 882 , p. 97 .

Hofmeister, IV.-I. The Higher Cryptogamia. Ray Society, I862. This contains a translation of the "Vergleichende Untersuchungen," as well as the later papers upon the Archegoniatre.

2. Die Antheridienstände der Polytrichaceen. Bot. Zeit., I870.

Holle, J. G.-I. Ueber Bau und Entwicklung der Vegetationsorgane der Ophioglosseen. Bot. Zeit., I875, No. I5.

2. Vegetationsorgane der Marattiaceen. Bot. Zeit., I876.

Holtzvan, C. L.-On the apical growth of the stem, and the development of the sporangium of Botrychium Virginianum. Bot. Gazette, I892.

Hooker, Sir J. : and Baker, J. G.-Synopsis Filicum. London, I874.

Hy, F.-I. De la structure de la tige des mousses de la famille des Polytrichacées. Bull. de la Soc. bot. de France, t. xxvii., I880.

2. Recherches sur l'archégone et le développement du fruit des Muscinées. Ann. des Sciences Naturelles, series 6, No. I8.

JANCZEwsKi, ED. de-I. Vergleichende Untersuchungen über die Entwickelungsgeschichte des Archegoniums. Bot. Zeit., I872, p. 4I8.

2. (und Rostafinski, J.).-Wote sur le prothalle de l'Hymenophyllum Tunbridgense. Mém. de la Soc. nationale des Sciences naturelles de Cherbourg, 1875, t. xix.

3. Recherches sur le développement des bourgeons dans les prêles. Mém. de la Soc. nationale des Sciences naturelles de Cherbourg, t. xx., I 876. 
4. Etudes comparées sur les tubes cribreux. Ann, des Sici. Nat., sixth series, t. xiv. Jonkmax. H. F.-I. La génération sexuée des Marattiacées. Arch. Néerlandaises, etc., t. xw. p. 199. Also in Bot. Zeit., 1878 .

2. Over de Keimung van Kaulfussia resculifolia. Archives Néerlandaises, etc. third series, 1879 .

JukáNYI, L.-I. Ueber die Entwicklung der Sporangien und Sporen von Salvinia natans, Berlin, $1 \$_{73}$.

2. Ueber die Gestaltung der Frucht bei I'ilularia globulifera. Bot. Centralb. I SSO, P. 201.

Karsten, G.-Beiträge zur Kenntniss von Fegatella conica. Botanische Zeitung, ${ }_{1} S_{7} 7$.

Kiexitz-Gerloff, F.-I. Vergleichende Untersuchungen über die Entwickelungsgeschichte des Lebermoossporogons. Bot. Zeit., IS74, IS75.

2. Untersuchungen iiber die Entwickelungsgeschichte der Laubmooskapsel. Bot. Zeit., I 878 .

3. Entwickelung des Embryos von Pteris serrulata. Ibid.

4. Morphologische Bedeutung der Laubmooskapsel in Vergleich zur Lebermoosfrucht. Sitzungsberichte der Gesellschaft. naturf. Freunde, Berlin, i $\$ 76$.

5. Genetische Zusammenhang von Moose und Gefässkryptogamen. Botanische Zeitung, 1876 .

6. Ueber Wachsthum und Zelltheilung in der Entwickelung des Embryos von Isoetes lacustris. Bot. Zeit., I8SI, p. $76 \mathbf{I}$.

7. Ueber die Bedeutung der Paraphysen im Anschluss an H. Leitgeb's " Wasserausscheidung an den Archegonienstande von Corsinia." Botanische Zeitung, ISS6, p. 24 S.

Kifer, J.-Sprossung an den Inflorescenzstielen von Marchantia polymorpha. Botanisches Centralblatt, ISSI.

KLEIN, L.-I. Bau und Verzweigung einiger dorsiventralgebauter Polypodiaceen. Nova Acta d. K. Carol. Akad. d. Naturwiss., Bd. xlii,, No. 7, ISSi. Bot. Zeit., I $8 \mathrm{~S}_{2}, \mathrm{p} .9 \mathrm{II}$.

2. Vergleichende Untersuchungen iiber Organbildung und Wachsthum am Vegetationspunkte dorsiventraler Farne. Bot. Zeit., ISS4, p. 577.

$\mathrm{KNY}$, L. - I. Beiträge zur Entwickelungsgeschichte der laubigen Lebermoosen. Pringsheims Jahrb. fuir wiss. Botanik, iv., I \$65-66.

2. Ueber Bau und Entwickelung der Riccien. Ibid., v., p. 364.

3. Entwickelung des Vorkeims der Polypodiaceen und Schizaaceen. Sitzber. d. Gesellschaft. naturf. Freund., Berlin, I 868.

4. Ueber Bau und Entwickelung des Farnantheridiums. Monatsber. d. Berlin. Akad., I869.

5. Beiträge zur Entwickelungsgeschichte der Farnkräuter. I. Osmunda regalis. Pringsh. Jahrb. f. wiss. Bot., viii., I\$ 72.

6. Entwickelung der Parkeriaceen dargestellt an Ceratopteris thalictroides. Nova Acta der Kais. Leop. Carol. deutschen Akad. der Naturforschern, Bd, xxxrii., No. 4, IS75.

7. Treppengefässe in Farnprothallien. Sitzber. des bot. Vereins der Prov. Brandenburg, i $\$ 74$, p. 7 I.

S. Durchwachsung an dem Wurzelhaare zweier Marchantiaceen. Sitzber, des bot. Vereins der Prov. Brandenburg, Jahrgang 2I, I\$79, p. 2.

9. Entwickelung von Aspidium, filix-mas., I Theil. Berlin, IS95.

KRUCH, O.-I. Appunti sullo sviluppo degli organi sessuali e sulla fecondazione delle Riella Clausonis. Malpighia, vol. iv., p. 403 ; Genoa, IS9o, IS9I.

2. Istologia ed istogenia del fascio conduttore delle foglie di Isoetes. Malpighia, An. iv., $\mathbf{1} 890$, p. 56. 
KüHs, R.-I. Zur Entwickelungsgeschichte der Andreæaceen. Schenk und Luerssen, Mitthl. aus dem Gesammtgebiete d. Botanik, vol. i.

2. Untersuchungen itber die Anatomie der Marattiaceen und anderen Gefässkryptogamen. Flora, is8g.

3. Ueber den anatomischen Bau von Danæa. Flora, I890, p. I47.

K ̈̈xDIG, J.-Beiträge zur Entwickelungsgeschichte des Polypodiaceensporangiums. Hedwigia, I888, Heft 7 , p. I.

Kunze, G. - Phylloglossum. Bot. Zeit., 1843 .

Lachuans, P. - I. De l'accroissement terminale de la racine de Todea harbara. Bul. de la Soc. botanique de Lyon, 1884, p. 42.

2. Sur l'origine des racines chez les fougères. Bul. de la Soc. bot. de France, xxx.

3. Sur le système libéro-ligneux des fougères. Ibid., p. 35, I884. 1886.

4. Recherches anatomiques sur les Davallia. Bul. de la Soc. botanique de Lyon,

5. Sur la structure de la racine des Hyménophyllacées. Ibid., I 886.

6. Structure et croissance de la racine des fougères, et l'origine des radicelles. Bul. de la Soc. bot. de Lyon, 1887 .

7. Insertion des Racines. Ann. de la Soc. bot. Lyon, I889.

Leclerc du SABLox.-I. Sur le sporogone des Hépatiques et le rôle des élatères. Bulletin de la Soc. botanique de France, t. xxxii. pt. I.

2. Sur la développement du sporogone de Frullania dilatata. Bul. de la Soc. bot. de France, ser. ii. t. vii. pt. 4 .

3. Recherches sur la développement du sporogone des Hépatiques. Ann. des Sci. naturelles, ser. vii. t. ii. 1885 .

4. Recherches sur le dissémination des spores chez les cryptogames vasculaires. Ann. des Sci. naturelles, ser. vii. t. ii. p. 5 .

5. Sur les anthérozoides du Cheilanthes hirta. Bul. de la Soc. bot. de France, I 888 , p. 238 .

6. Reviviscence de Selaginella lepidophylla. Ibid.

7. Sur l'endoderme de la tige des Selaginelles. Journal de Botanique, I $\$ 89$, p. 207.

8. Recherches anatomiques sur la formation de la tige des fougères. Annales des Sci. naturelles, ser. vii. t. xi.

9. Sur les tubercules des Equisetacées. Revue générale de Botanique, t. ix., I 892 , p. 97.

Leitgeb, Hubert. - I. Wachsthum des Stämmchens von Fontinalis und Sphagnum. Sitzb. d. Akad. d. Wissenschaften, vol. lvii., Wien, 1868.

2. Entwickelung der Antheridien bei Fontinalis antipyretica. Sitzber. der k. Akad. d. Wiss., Wien, 1868 .

3. Ueber Schistostega. Mittheilung des naturwiss. Vereines, Graz, I874.

4. Zur Kenntniss des Wachsthums von Fissidens. Sitzungsberichte der kaiserlichen Akademie der Naturwissenschaften, Wien, 1874, Bd. lix., p. 20.

5. Verzweigte Moossporangien. Naturwissenschaftliche Verein für Steiermark, 1876.

6. Ueber Zoöpsis. Naturwissenschaftliche Verein für Steiermark, I 876 .

7. Untersuchungen iiber die Lebernoose, I874-1882, 6 volumes. Vol. i., Blasia pusilla; vol. ii., Die foliosen Jungermannieen; vol. iii., Die frondosen Jungermannieen; vol. iv., Die Ricceen; vol. v., Die Anthoceroteen; vol. vi., Die Marchantieen.

8. Das Sporogon von Archidium. Sitzber. der kais. Akad. der Wiss., Wien, I879 (November).

9. Ueber Bilateralität der Prothallien. Flora, 1879.

Io. Die Antheridienstände der Laubmoose. Flora, I882, No. 30. 
II. Ueber Bau und Entwickelung einiger sporen. Ber. der deutsch. bot. Giesellschaft, Bd. i., p. $247, \mathbf{I} S S_{3}$.

12. Ueber Bau und Lntwickelung der sporenhäute und deren Verhalten bei der Keimung. Graz, ISS4.

13. Wasserauscheidung an den Archegonienstande von Corsinia. Flora, ISS5, 1. 327 .

I4. Sprossbildung an apogamischen Farnprothallien. Ber. der deutschen bot. Gesellschaft, iii., p. 169, $18 \$ 5$.

15. Die Stellung der Fruchtsäcke bei den geocalycen Jungermannieen. Sitzber. der kais. Akad, der Wissenschaften, Wien, Bd. lxxxiii., I Abt., I 887.

Lesquereux, L.: and James, T. P.-Manual of the Mlosses of North America. Boston, $\mathrm{ISS}_{4}$.

LiMipricht, G.-I. Ueber Tiipfelbildung bei Laubnıosen. Schlesische botanische Gesellschaft, $1 \mathrm{SS}_{4}$, p. $2 \mathrm{Sg}$.

2. Ueber die Porenbildung in der Stengelrinde von Sphagnum. Ibid., IS85, p. 199.

Luerssen, C.-I. Spaltoffnungen von Kaulfussia. Bot. Zeit., I 873 , No. 40.

2. Dickenwachsthum innerer Parenchymzellen der Marattiaceen. Botanische Zeitung, I 873 , No. 41 .

3. Zur Keinungsgeschichte der Osmundaceen, vorziiglich der Gattung Todea. Mittheilungen aus dem Gesammtgebiete der Botanik, Schenk und Luerssen, Bd. I, p. 460.

4. Ueber Farnsporangien. Ibid., Bd. ii., p. I.

5. Ueber die Entwickelungsgeschichte des Marattiaceenvorkeims. Bot. Zeit., I 875 , No. 32.

6. Intercellularverdickungen im Grundgewebe der Farne. Bot. Zeit., I 875 , No. 43 .

7. Handbuch der systematischen Botanik. Bd. i., Kryptogamen. Leipzig, IS79.

8. Die Farnpflanzen oder Gefässbiindelkryptogamen (Rabenhorst-KryptogamenFlora). Leipzig, $188_{4}-1889$.

Mathuschek, Franz. - Die Adventivknospen an den Wedeln von Cy'stopteris bullifera. Oesterreichische botanische Zeitschrift, IS94, p. I2I.

Mettexius, Georg.-I. Beiträge zur Kenntniss der Rhizocarpeen. Frankfurt am Iain, I846.

2. Filices Hort. bot. Lips., I 856 .

3. Ueber Phylloglossum. Bot. Zeit., I867.

Meuxier, Alph.-La Pilulaire. Étude anatomico-génétique du sporocarpe chez la Pilularia globulifera-La Cellule, iv. IS87, p. 325.

Merex, F. J. F.-Beiträge zur Kenntniss der Azollen. Acta Acad. Cæs. Leop. Carol. Nat. Cur., I $\$_{3} 6$.

Milde, J.-I. Monographia Equisetorum. Nova Acta Acad. Leopold. Carol., xxxii., I 867 .

2. Monographia generis Osmundæ. Verhandl. d. zool.-bot. Gesell., Wien, I869.

3. Monographia Botrychiorum. Ibid.

Millardet, A.-Le prothallium male des cryptogames vasculaires. Strassburg, 1869.

Monteverde, N. A. - Ueber krystallinische Ablagerungen bei Marattia. Arbeiten der St. Petersburg Naturforscher-Gesellschaft, ISS6.

Morin, F.-Anatomie comparée et expérimentale de la Famille des Muscinées. Botanisches Centralblatt, I894, Bd. lviii., No. IS.

Motrier, D. M.-I. Notes on the apical growth of Liverworts. Bot. Gazette, IS9I, p. I4I. 
2. Contributions to the Life-History of Notothylas, Ann. of Bot., Dec. I894.

Müller, Hermaxx.-Sporenvorkeim und Zweigvorkeime der Laubmoose. Arbeiten des botanischen Instituts zu Würzburg, Bd. i., p. 475.

Müller, N. J. C.-I. Das Wachsthum des Vegetationspunktes ron Pflanzen mit decussirter Blattstellung. Pringsh. Jahrb. f. wiss. Botanik, v., p. 247, I 866-67.

2. Die Entwickelungsgeschichte der Kapsel von Ephemerum. Pringsh. Jahrb. für wiss. Bot., ri., p. 237, I867-68.

Müller, Carl-I. Ueber den Bau der Commissuren der Equisetumscheiden. Pringsheims Jahrb. für wiss. Botanik, xix., I888.

2. Zur Kenntniss der Entwickelungsgeschichte des Polypodiaceen-Sporangiums. Berichte der deutsch. botan. Gesellschaft, vol. xi. I893, p. 54.

Nawaschin, S. - Was sind eigentlich die sogenannten Microsporen der Torfmoosen? Bot. Centralblatt, vol. xliii,, I89o, p. 289.

Newcosib, F. C. - Spore dissemination of Equisetum. Botanical Gazette, I 888.

Pedersen, R. - Entwickelungsgeschichte des Polypodiaceenvorkeims. Mittheilungen aus dem Gesammtgebiete der Botanik. Schenk und Luerssen, Bd. ii., I875, p. I30.

Pfeffer, W.-I. Die Entwickelung des Keimes der Gattung Selaginella. Botanische Abhandlungen, etc., herausgegeben von Dr. Johannes Hanstein. Bonn, I87.

2. Die Oelkörper der Lebermoose. Flora, I874.

3. Locomotorische Richtungsbewegungen durch chemische Reize. Untersuch. aus dem bot. Institute zu Tübingen, Bd. i., I 884 , p. 363 .

Pfitzer-Ueber die Schutzscheide. Pringsh. Jahrb. f. wiss. Bot., vi., p. 292, I867-68.

Piccose, A.-Notizie e osservazioni sopra l'Isoetes Durieui. Nuovo Giornale Botanico Italiano, vol. viii., I876.

Poirault, G.-I. Recherches d'histogénie végétale. Développement des tissus dans les organes végétifs des cryptogames vasculaires. Mém. de l'Acad. imp. des sciences de St. Pétersbourg, ser. vii. t. xxxvii., I89o.

2. Recherches anatomiques sur les cryptogames vasculaires. Ann. des Sciences naturelles, ser. vii., t. xviii., I 894 .

Ротохı́́, H.-I. Anatomie der Lenticellen der Marattiaceen. Jahrb. des bot. Gartens, Berlin, I881, p. 307 .

2. Ueber den Bau der Leitbiindel der Polypodiaceen und über den Begriff des Leitbündels bei den Gefässkryptogamen. Sitzber. des Vereins für Naturwiss. der Prov. Brandenburg, I882.

Praxtl, K.-I. Die Hymenophyllaceen, Leipzig, I875. Untersuchungen zur Morphologie der Gefässcryptogamen, vol. i.

2. Morphologische Studien. Flora, I875, No. 34.

3. Sporangienentwickelung einiger Farne. Bot. Zeit., I877, No. 4.

4. Zur Entwickelungsgeschichte des Prothalliums von Salvinia natans. Bot. Zeit., I879, p. 425 .

5. Die Schizæaceen. Untersuchungen zur Morphologie der Gefässkryptogamen, vol. ii., Leipzig, I88I.

6. Die Farngattungen Cryptogramme und Pellæa. Engler's botanisches Jahrbuch, ii. p. 403 .

7. Helminthostachys Zeylanica in ihre Beziehung zu Ophioglossum und Botrychium. Ber. der deutsch. bot. Gesellschaft, $188_{3}$, p. 155 .

8. Systematisches Uebersicht der Ophioglosseen. Ibid., p. 348.

9. Beitrag zur Systematik der Ophioglosseen. Jahrbuch des bot. Gartens, Berlin, I884, p. 297 . 
Io. Die Mechanik des Rings am Farnsporangium. Ber, der deutschen botanischen Gesellschaft, iv. p. 42, 1886 .

I'Ringsheim, N.-I. Zur Morphologie der Salvinia natans. I'ringsh. Jahrb. fiir wiss. Botanik, iii., 1863 .

2. Vegetative Sprossung der Moosfrüchte. Monatsbericht der königlichen Akademie der Wissenschaften zu Berlin, 1876.

3. Sprossung der Moosfrucht und Generationswechsel der Thallophyten. Pringsheins Jahrbiicher fuir wiss. Botanik, Bd. xii., I879-81.

RACIBORSK1, M.-Ueber die Osmundaceen und Schizæaceen der Jura-formation. Engler, Jahrbuch fiir Systematik- P'flanzengeschichte und Pflanzengeographie, xiii., 1891.

Rauwenhoff, N. IV. P.-I. Einiges uber die ersten Keimungserscheinungen der Kryptogamensporen, Bot. Zeit., I879.

2. La génération sexuée des Gleichéniacées. Archives Néerlandaises des Sciences exactes et naturelles, t. xxiv. p. 157, IS9o.

ReEss, M.-I. Zur Entwickelungsgeschichte des Polypodiaceen-Sporangiums. Pringsh. Jahrb. für wiss. Botanik, vol. v., p. 217 , I\$66-67.

2. Zur Entwickelungsgeschichte der Stammspitze von Equisetum. Pringsh. Jahrbiicher fiir wiss. Botanik, vi., p. 209, 1867-68.

RöLı, J.-Ueber die Veränderlichkeit der Stengelblätter bei den Torfmoosen. Bot. Centralblatt, xli. p. 241, ISgo.

Rostowzew, S.-I. Beiträge zur Kenntniss der Gefässkryptogamen. I. Umbildung von Wurzeln in Sprosse. Flora, I89o, p. 155.

2. Recherches sur IOphioglossum vulgatum. Botanisches Centralblatt, I., p. 364,1892 .

3. Die Entwickelungsgeschichte und die Keinung der Adventivknospem bei Cystopteris bulbifera. Ber. der deutschen bot. Gesellschaft, I894, No. I2, p. 45.

Roze, E.-Observations sur le prothalle des Fougères. Bull. de la Soc. bot. de France, xxviii., I88I, p. 135 .

Russow, E.-I. Vergleichende Untersuchungen, betreffend die Histiologie der vegetativen und sporenbildenden Organe und die Entwickelung der Sporen der Leitbündelkryptogamen. Mém. de l'Acad. imp. des Sciences de St. Pétersbourg, ser. 7 , vol. xix., 1872 .

2. Betrachtungen itber das Leitbundel und Grundgewebe aus vergleichend morphologischem und physiologischem Gesichtspunkte. Dorpat, $\mathbf{I} S_{75}$.

3. Ueber die Verbreitung der Callusplatten bei den Gefasspflanzen. Bot. Zeit., I88 I, p. 724 . 167.

4. Développement des tubes cribreux. Ann. des Sci. naturelles, ser. 6, xiv., p.

5. Zur Anatomie resp. Physiologie und vergleichenden Anatomie der Torfmoosen. Dorpat, 1887 .

SAdebeck, R.-I. Ueber die Marchantiaceen. Verhandlungen des botanischen Vereins der Prov. Brandenburg, 1873 .

2. Wachsthum der Farnwedel. Sitzber. des bot. Vereins der Prov. Branden. burg, Jahrgang 15, p. 116.

3. Ueber Asplenium adulterinum. Bot. Zeit., I873, p. 422.

4. Die Entwickelung des Farnblatters, Berlin, I874.

5. Wachsthumsverhältnisse von Osmunda regalis. Bot. Zeit., I875, No. 39.

6. Der Embryo von Equisetum. Bot. Zeit., 1877, No. 3. Also Pringsheims Jahrb. für wiss. Botanik, xi., 1878 .

7. Die Gefásskryptogamen. Schenk's Handbuch der Botanik, vol. i., I882.

SATTER, A.-I. Beiträge zur Entwickelungsgeschichte des Lebermoosantheridiums. Sitzber, der kais. Akad. der Wissenschaften, Wien, Abt. I, July I882. 
2. Zur Kenntniss der Antheridienstände einiger Laubmoose. Ber. der deutschen bot. Gesellschaft, vol. ii., I884, p. 13.

Schiffner, V.-Hepaticæ. In Engler und Prantl, Die naturlichen Pflanzenfamilien, Nos. 91, 92, I893.

Schimper, A. F. W.-Ueber Bau und Lebensweise der Epiphyten West Indiens. Bot. Centralblatt, xvii., I884.

Schimper, PH. W.- Versuch einer Entwickelungsgeschichte der Terfmoose (Sphagnum) und einer Monographie der in Europa vorkommenden Arten dieser Gattung. Stuttgart, 1858 .

Sснмidt, J.-Neue Beiträge zur Mechanik der Farnsporangien. Flora, I887.

Schrenk, J.-The dehiscence of Fern-sporangia. Bulletin of the Torrey Botanical Club, xiii., 1886 .

SchoтtläNder, P.-Beiträge zur Kenntniss des Zellkerns und der Sexualcellen bei Kryptogamen. Cohn's Beiträge zur Biologie der Pflanzen; Bd. vi., I892, p. 267.

Schulze, H.-Ein Beitrag zur Kenntniss der vegetativen Vermehrung der Laubmoosen. Bot. Centralblatt, Bd. xxxi., 1887, p. 382.

Solms-Laubach, H. Graf zu.-1. Der Aufbau des Stockes von Psilotum triquetrum und dessen Entwickelung aus der Brutknospe. Ann. du Jardin botanique de Buitenzorg, vol. iv., I884.

2. Fossil Botany. Oxford, Clarendon Press, I891.

Sonntag, P.-Ueber Dauer des Scheitelwachsthums und Entwickelungsgeschichte des Blattes. Pringsheims Jahrb. für wiss. Botanik, xviii., p. 236.

Southworth, EfFie A.-Structure, development, and distribution of the stomata of Equisetum arvense. American Naturalist, xvii., October I884.

SPRUCE, R.-I. The Morphology of the leaf of Fissidens. Journal of Botany, vol. x., p. 980 .

2. Hepaticæ of the Amazon and of the Andes of Peru and Ecuador. Trans. Bot. Soc., Edinburgh, vol. xv.

Stahl, E.-I. Künstlich hervorrufene Protonemabildung. Hallesche Bot. Zeitung, 1876 , No. 44 .

2. Ueber den Einfluss des Lichteinfalls auf die Theilung der Equisetensporen. Bot. Zeit., 1885, p. 750.

Sterns, E. E.-Bulblets of Lycopodium lucidulum. Bulletin of the Torrey Botanical Club, I888.

Strasburger, E.--I. Ein Beitrag zur Entwickelungsgeschichte der Spaltöffnungen. Pringsh. Jahrb. f. wissen. Bot., v., p. 297, 1866-67.

2. Die Geschlechtsorgane und die Befruchtung bei Marchantia polymorpha. Pringsh. Jahrb. f. w. Bot. vii. p. 409.

3. Die Befruchtung bei den Farnkräutern. Ibid., p. 390.

4. Die Befruchtung bei den Coniferen. Jena, 1869.

5. Die Coniferen und Gnetaceen. Jena, 1872.

6. Ueber Azolla. Jena, I873.

7. Einige Bemerkungen über Lycopodiaceen. Bot. Zeit., I873.

8. Die Angiospermen und die Gymnospermen. Jena, $\mathbf{I} \$ 79$.

9. Zellbildung und Zelltheilung, third edition, Jena, ı88॰.

I0. Das botanische Practicum, second edition, Jena, I887.

1 1. Histologische Beiträge, 5 vols., I888-1 893 .

12. The periodic reduction of chromosomes in living organisms. Ann. of Bot., September I894.

Terletzki, P.-Anatomie der Vegetationsorgane von Struthiopteris Germanica, und Pteris aquilina. Pringsheims Jahrbücher für wissensch. Botanik, xv., p. 452, I 884 .

Thistleton-Dyer, W. F.-Morphology of Selaginella. Nature, 1877 . 
Thомж, K.-Die Blattstiele der Farne. Pringsheims Jahrb. für wiss. Botanik, xvii., p. 99 , I 886 .

Treub, M. - I. Recherches sur les organes de végétation de Selaginella Martensii spr. Musée botanique de Leide, t. ii.

2. Études sur les Lycopodiacées. Annales du Jardin botanique de Buitenzorg. Vols. iv. v. vii. viii., ISS4-IS9o.

Uxderwood, L. M.-I. Hepatice. In Gray, Manual of Botany of North Eastern United States, sixth edition, IS9o.

2. Preliminary list of Pacific Coast Hepatice. Zoe, I89I, p. 36I.

3. Index Ilepaticarum, part I. Bibliography. Memoirs of the Torrey Botanical Club. Vol. iv., No. I, I $\$ 93$.

4. Our native Ferns and their Allies. Fourth edition, New York, I $\$ 94$.

5. The Evolution of the Hepatice. Bot. Gazette, September IS94.

VAIZEY, J. ReYNolds. - I. On the anatomy and derelopment of the sporogonium of the Mosses. Journal of the Linn. Society, IS88, vol. xxiv., No. I67.

2. Transpiration in the sporogonium of Mosses. Annals of Botany, vol. 1, 1887.

3. On the morphology of the sporophyte of Splachmum luteum. Annals of Botany, v., No. xvii., I $\$ 90$.

4. Preliminary note on the root of Equisetum. Annals of Botany, ii. I888, p. 123. Vax Tieghesi, Ph.-I. Sur quelques points de l'anatomie des cryptogames vasculaires. Bull. de la Soc. bot. de France, xxv., I $\$ 8_{3}$, p. 169.

2. (et Douliot). Sur la Polystélie. Ann. des Sci. naturelles, ser. 7, 1886, No. 3, p. 275 .

3. Sur le dédoublement de l'endodermis dans les cryptogames vasculaires. Journal de Botanique, ISSS, p. 404 .

4. Sur la limite du cylindre centrale et de l'écorce dans les cryptogames vasculaires. Journal de Botanique, I888, p. 369.

5. (et DULIOT). Recherches comparatives sur l'origine des membres endogènes dans les plantes vasculaires. Ann. des Sc. naturelles, ser. 7, No. viii.

6. Remarques sur la structure de la tige des prêles. Journal de Botanique, IS9o, p. 365 .

7. Remarques sur la structure de la tige des Ophioglossées. Ibid., p. 405.

8. Traité de Botanique, second edition, Paris, IS92.

Vines, S. H.-I. On the homologies of the suspensor. Q. J. Mic. Sci., IS77.

2. The systematic position of Isoetes. Annals of Botany, ii., I8S8, p. 117.

Yö́nting, H.-Ueber die Regeneration der Marchantiaceen. Pringsheims Jahrb. fiir wiss. Bot., Bd. xvi., Heft 3, $1 S_{5}$.

VoIght, A.-Vergleichende Anatomie der Marchantiaceen. Botanische Zeitung, I $\$ 79$.

Vouk, F.-I. Das Sporogonium von Orthotrichum. Sitzungsber. der kais. Akad. der Wissenschaften, Wien, I\$76, I Abtheilung, Mai-heft.

2. Die Entwickelung des Embryos von Asplenium Shepherdii. Sitzber. der kais. Akad. der Naturwissenschaften, Wien, Bd. 1xxvi., July I $\$ 77$.

Waldner, M.-1. Entwickelung des Antheridium von Anthoceros. Sitzber. der k. Akad. der Wiss., Wien, I877, Bd. 1xxv., Mai-heft.

2. Die Entwickelung der Sporogone von Andrexa und Sphagnum. Leipzig, I887.

Willialison, W. C.: and ScotT, D. H.-Further observations on the Organisation of the Fossil Plants of the Coal-Measures, Roy. Soc. Phil. Trans., vol. clxxxv. IS94.

Wojexowıć. - Beiträge zur Morphologie, Anatomie und Biologie der Selaginella lepidophylla. Inaugural Dissertation, Breslau, I89o.

ZaCHARIAS, E.-I. Ueber die Spermatozoiden. Bot. Zeit., ISSI.

2. Ueber den Nucleolus. Bot. Zeit., I8S5, p. 289 . 
3. Beiträge zur Kenntniss des Zellkerns in den sexuellen Zellen, Bot. Zeit., 1887.

Zeiller.-I. Affinités du genre Laccopteris. Bull. de la Soc. bot. de France, I 885, p. $2 \mathrm{I}$.

2. Le Bassin Houiller et Permien d'Autun et D'Epinac. Paris, I8go.

Zimierman, A.-I. Scheitelzellen an den Adventivknospen einiger Farne. Bot. Centralblatt, 188I, p. 175 .

2. Ueber die Einwirkung des Lichtes auf dem Marchantieenthallus. Arbeiten des bot. Instituts in Wuirzburg, Bd. ii., Heft iv. 


\section{NDEX}

ACROCARP.モ (Bryineæ), 209

Adiantum, 355, 377

emarginatum, 329; apex of stem, 322 ; stomata, 327. Figs. I62, 164, I 65

pedatum, 325

Algre, I, 2, 50S, 512, 515 ; zoospores, 9

green, $14, S_{2}, 150,509$

Alsophila, 304, 373

contaminans, 373

Amblystegium, I $8_{3}, \mathbf{1} \$_{4}, \mathrm{I} \$_{5}, \mathbf{1} S 6$

riparium, var. fluitans, $\mathrm{I} \$ 2$; branches, I $S_{5}$; leaf, I $S_{3}$. Figs. 86,87

Anabrena azollie, 389,396

Andreæa, $153,157,172,175,176,177$, I 7 S, ISS, I92, 194, 20I, 210 , 216,217 ; growth of stem and leaves, I73 ; protonema, 174; pseudopodium, I72 ; sexual organs, I75; sporogonium, I76; spores, 174

crassinerva. Fig. $S_{3}$.

petrophila, 173. Figs. $S_{2}, S_{3}$

rupestris, 173

Andreæaceæ, $152,157,158,172$

Aneimia, 371 I, 372 ; stomata, 327

hirta, 37 I

Anelatereæ, 95

Aneura, 9, I4, I5, 16, 7 I, S2, 83, 92, I03, IOS, I1 5, I 25, 149, I 50, 255, 509, 510 ; embryo, 87 ; gemmæ, $2,8_{3}$

multifida, 82, 93 ; gemmæ, 9, 12. Fig. 36

palmata, 89

pinguis, 89. Fig. 36

pinnatifida, $S_{4}$; antheridium, $S_{5}$; archegonium, 86. Figs. 34, 35, 38
Angiopteris, 252, 255, 257, 265, 266, $268,269,270,271,272,273,274$ $299,326,332,353,357$

evecta, $254,27 \mathrm{I}, 273$ : anatomy of leaf, 269-271 ; germination, 255; prothallium, 257 ; sporangia, 272. Figs. I $30,142,143$

Angiopteridex, 273,274

Angiosperms, 280, 301, 517, 5IS, 5 IS

Anisogonium Seramporense, $33 \mathrm{I}$

Annularier, 459

Anthoceros, I4 19,52 , II 4, II6, I + I, $\mathrm{I}_{43}, \mathrm{I}_{4} 8, \mathrm{I}_{5} 6, \mathrm{I}_{7} \mathrm{O}, \mathrm{I}_{7} 8,202,2 \mathrm{I} \mathrm{S}$, 296, 29S, 351, 501, 505, 509, 510 , 511, 513,514, 515, 516; apical growth, I19: chloroplasts, I20 ; elaters, I34; embryo, 127 ; gametophyte, II 7 ; mucilage-clefts, I I9; spores, development of, I 33 ; sporogonium, dehiscence, 136 ; stomata, 135

lævis, II 7 , I $35,136,257,5$ I 2 ; antheridium, 122 ; archegonium, 125. Figs. 6o, 61, 62, 64, 65

fusiformis, I 1 7, I I 9, I 22, I 26, I 34 , I 36, I 40, 429, 432, 465, 5 I 2 ; apical growth, II9; germination, 136 ; infection with nostoc, 138 . Figs. 55, 56, 57, 58, 59, 63, 66, 67,74

punctatus, II 7

Vincentianus, 123

Anthoceroter, 10, I4, 15, 19, 21, 22, 107, 1 14, 150, 216, 219, 26r, 296, $297,298,505,508,509,510,511$, 512 ; antheridium, I0, I6, II5; archegonium, I0 ; archesporium, I 6 ; chloroplasts, I 15 ; mucilageslits, I 5 , I I 5 ; sexual organs, I I5; sporogonium, I I 5 , I I 6 
Apogamy, 22 I, 305, 369

Apospory, 221, 306, 369

Archegoniatæ, I, 8; alternation of generations, 2 ; antheridium, I ; archegonium, I; archesporium, 5 ; fertilisation, 2 ; gametophore, 2 ; gametophyte, $2,3,4,5$; interrelationships, 508 ; protonema, 2 ; spores, 4,5 ; sporophyte, $3,4,5$

Archegonium, I

Archespermæ (see also Gymnosperm, I, 7)

Archidium, I 53, 158, 177, 178, 205, 217 ; sporogonium, 178

Ravenelii. Fig. 84

Aspidium, 377

filix-mas, 3 Io

filix-mas var. cristatum, apogamy, 305

filix - mas var. falcatum, apogamy, 305

spinulosum. Fig. 194

Asplenium, 377

bulbiferum, 306

filix-fœmina, 310,377

filix-foemina var. clarissimum, apospory, 306

nidus, 376

Asterophylliteæ, 459

Astroporæ, 58

Athyrium (see Asplenium)

Atrichum, I 56

undulatum, I53. Figs. 9 I, 106

Azolla, 7, 378, 380, 381, 382, 384, 386, $388,389,390,392,394,395,396$, $398,409,418,420,421,5$ I 7

Caroliniana, 384, 386, 392

filiculoides, 382, 386, 392, 394 ; antheridium, $38 \mathrm{I}$; archegonium, $383, \quad 385$; cotyledon, 387,389 ; embryo, 386 ; germination of macrospore, 382 ; of microspores, $38 \mathrm{~S}$; leaves, 392 ; macrosporangium, 396; massulæe, microsporangium, 398; primary root, 388 ; second root, 389 ; sporocarp, 394 ; stem apex, 390. Figs. 196, 197, 198, 199, 200, 201, 202, 204, 205

Nilotica, 394

Blasia, 9, I 2, I4, 71, 94, 95 ; gemmæ, 73,94, I 50 ; leaves, 14 pusilla. Fig. 38

Boschia, 42, 68 ; sporogonium, 58

Botrychium, 22I, 23I, 240, 252, 253, $254,265,271,272,292,296$, 299, 338, 35 I, 353, 355, 356, 357, $372,419,451,465$

Iunaria, $223,225,248,250$; gameto- phyte, 222 ; root of young plant, 227. Fig. 122

B. rutæelium, 252

simplex, 240, 243, 248, 250. Fig. I 22

ternatum, 243, 247, 248, 249. Fig. I 22

Virginianum, 227, 228, 240, 296, 298, 305,357 ; anatomy of stem apex, 242 ; cambium, 245; germination, 224 ; growth of stem, 243 ; leaf, 240 ; root, 247 ; sieve-tubes, 247 ; sporangia, 250 ; vascular bundles, $243,246,249$. Figs. I IO, 123 , I $24,125,126,127,128,129$

Bryaceæ, I 52 , I 57,510

Bryinex, I 58, I80, 208, 302, 498, 5 I I ; apical growth, I 82 ; buds, I8I; classification, 205; germination, I 80 ; protonema, I8o

Bryophyte, Bryophyta (see also Muscine $), 3,4,8,508,5^{1} 3,5^{1} 5$

Buxbaumia, 8, $152,154,155,158,210$, 215,217 . Fig. 106

Buxbaumiaceæ, 2 I 5

Calamarie.e, 459,460

Calamites, 459

Calamitex, 459

Calamostachys, 459, $5^{16}$

Calobryum, I2, 7 I, 95

Camptosaurus rhizophyllus, 306

Casuarina, 5 I 8

Cephalozia bicuspidata (see Jungermannia bicuspidata)

Ceratopteris, 375, 42 I

Chara, I 68

Characeæ, I, So, 508

Chiloscyphus, Io 8

combinatus. Fig. 54

Cibotium, 304, 328, 373

Chamissoi, 374

Menziesii, 373. Fig. 193

Cleistocarpæ (Bryineæ), 205, 207

Clevea, development of carpocephalum, 55. Fig. 18

Climacium, I 55, r 86 Americanum, Fig. 75

Codoniex, 95

Coleochrete, I 4, I I 5, 505, 508, 509

Cololejeunea Goebelii, I 12 . Fig. 52

Confervaceæ, $5 \circ 5$

Conifers, 505, 506, 517, 519

Conocephalus, 14, 20, 22, 42, I39; air chambers, 42, 43 ; germination, 47

conicus, mucilage-ducts, 44 . Fig. I 
Corsinia, 42, 47, 68; sporogonium, 58. Fig. 20 marchantioides. Fig. 20

Corsiniex, $21,47,67,69$

Cronisia paradoxa, 4 I

Cupulifere, 252

Cyathea, 304, 373 medullaris, 373

Cyatheacex, 304, 307, 308, 372, 374, $375,419,421$; embryo, 373; prothallium, 373 ; sexual organs, 373 ; sporangium, 373

Cyathodium, 68

Cycads, 5i 7, 5 I 8

Cystopteris bulbifera, 22I, 306. Fig. I95

DANAA, 254, 27 I 274

Danreacer, 274

Darlingtonia, I I I

Dendroceros, I I 4 , I 35 , I $38, I_{44}, I_{4} S$, 3I3, 341, 512; elaters, I 39; gemma, I 39 ; germination, I 39 ; sexual organs, I 39 ; thallus, I $3 \mathrm{~S}$ cichoraceus, I 38 , I 39

Javanicus, I 38 , I 39 . Figs. 55, 74

Diatoms, 122

Dicksonia, 328

antarctica, 373

Dicotyledons, 245, 5 I 8

Draciena, 292

Dumortiera, 22, 23, 42; structure of thallus, 49

irrigua, 49

trichocephala, 49

\section{Elatere.モ, 95}

Ephemerum, I 55, I80, 205, 207, 217 ; sporogonium, 205

phascoides. Fig. 103

Epigonianthex, I I 3

Equisetum, 5, 226, 248, 249, 422, 425, $427,46 \mathrm{I}, 464,465,466,478$, $484,496,512,514,515$; archegonium, 429; assimilative tissue, 442 ; buds, 445 ; cotyledon, 434 ; embryo, 432; epidermis, 444; rhizome, 435 ; roots, 447 ; spores, 423 ; sporophyte, 435 ; stomata, 444

arvense, 422, 436, 439, 443, 446, $453,456,457$. Fig. 226

giganteum, 422,447

hiemale, 457

limosum, 443, 453, 457. Figs. 232, 242

maximum (see E. telmateia), 457
E. palustre, 448 . Figr. 226

pratense, 457

robustum, 457,459

scirpoides, 422, 439, 446, 459. Fig. 242

sylvaticum, 447

telmateia, $422,425,427,434,436$, $439,44 \mathrm{I}, 442,443,444,446,448$, $453,454,457,459$; antheridium, 425,426 ; archegonium, 429; cambium, 457 ; embryo, 432 ; endodermis, 443 ; epidermis, 444 ; germination, 423 ; lacunæ, 434,442 ; leaves, 439, 457 ; prothallium, 424, 425 ; roots, 447,450 ; spermatozoids, 427 ; sporangia, 450 ; spores, $423,453,456$; stem apex, 432 ; stomata, 444; tannin cells, 442 ; tubers, 436 ; vascular bundles, 442 , 449. Figs. $218,219,220,221$, $222,223,224,225,227,228,229$, $230,231,232,233,234,235,236$, $237,238,239,240,241$

variegatum, 450,457

Equisetacere, 6, 459; E. cryptopora, 457 ; E. phanopora, 457

Equisetiner, 220, 422, 515, 516,519 ; affinities, 460 ; classification, 457 ; fossil, 459

Equisetites, 459

Eurynchium prælongum, I 52

Eusporangiatæe (Filicineæ), 222, 298, $304,307,32 \mathrm{I}, 33 \mathrm{~S}, 4 \mathrm{I} 9,42 \mathrm{I}, 426$, $430,453,460,464,466,5$ I 6,5 I 8 , 519 ; affinities of, 295

Fegatella (see Conocephalus)

Ferns (see also Filicinex), 13, 220, 46 I

Tree-ferns, 304,328

Filices, 22I, 307 ; leaf, structure of, 325 ; roots, 328 ; sporangia, $33 \mathrm{I}$; trichomes, 428

Filicinere (see also Ferns), 220, 460, 5 I 5 , 5 I 8,5 I9

Fimbriaria, I6, I9, 42, 48, 64, 70; carpocephalum, 55 ; perianth, 64 . Fig. 14

Californica, 24, 5o, 55, 59, 258; antheridium, 5o, 5I ; breathingpores, $48,57,58$; development of the thallus, 47,48 ; germination, 64,65 ; spores and elaters, 63,64 . Figs. I, 10, 13, I 5, 19, 20, 24, 27 Fissidens, I 53, 208

Fontinalis, 8 , I 52, I 55, 186, I 87 , I 92 , 209 ; peristome, 210

antipyretica, apical growth, IS2. Fig. I 06 
Fossombronia, 14, 71, 73, 94, 138, 150 longiseta. Figs. 37,38

Frullania dilatata, embryo, 106, 107. Fig. 50

Funaria, 184, I85, 209, 214

hygronetrica, I 52, 157, I82, 209 ; annulus, 201 ; antheridium, I 88 ; archegonium, I9I ; calyptra, 205; capsule, I98; embryo, I94; epidermis, 201 ; lacunæe, I98; paraphyses, I9I, I93; peristome, 20I, 204 ; rhizoids, I86 ; seta, 198; spermatozoids, I9I ; sporogonium, 197, 198; stomata, 202. Figs. $85,88,89,90,91,92,93,94,95$, $96,97,98,99$, I00, Iо1, I02

GLEICHENIA, 357, 358,359,364, 365, $366,369,371$; embryo, 359 ; prothallium, 358 ; sexual organs, 358 ; sporangia, 359 ; structure of stem, 359

dichotoma, 357,358 . Fig. I 85

Gleicheniaceæ, 307, 357, 374, 419, 420, $42 \mathrm{I}$

Gnetaceæ, 517, 5 I 8

Gold-back fern (see Gymnogramme triangularis)

Grimaldia, 55, 59, 64

Gymnogramme leptophylla, 305

triangularis, 328

Gymnosperms, I, 300, 469, 505, 507, $517,518,519$

Gymnostomum, 209

HAPLOMITRIUI, I 2, 7 I, 95, 96, I 50

Haplomitriex, 73, 95

Helminthostachys, 252, 299, 338, 356, 357,419

Zeylanica, 252. Fig. 122

Hemiphlebium, 366, 367

Hookeri, 367

Hepaticæ (see also Liverworts), 8, 9, I 3 , 297, 341, 508, 510, 512, 519; calyptra, I2 ; classification, 21 ; dehiscence of sporogonium, 19; elaters, I 2 ; germination, germ-tube, 20; interrelationships of, I49; spores, 19, 20

Heterospory, Io

Hippochæte, 457

Hydropterides, 22 I, 304, 307, 378, 384 , 419,420

Hymenophyllum, 305, 353, 360, 362, $363,366,367,368,373,375,512$; antheridium, 363; archegonium, 364 ; gemmæ, 362,363 ; leaf, 366 ; prothallium, 360 ; root, 367 . Figs. I 87, I 88, I 89

H. demissum, 367

dilatatum, 366

recurvum. Fig. 190

Hymenophyllaceæ, 304, 305, 307, 360, $367,371,372,375,379,382,392$, 420,421 ; embryo, 365 ; gametophyte, 360 ; leaf, 366 ; sporangium, 367 ; sexual organs, 363 ; stem, 366 ; trichomes, 367

Hymenophyllites, 4I9

Hymenostomum, 209

Hypenantron (see Fimbriaria)

Hypnum, 153

IsOetes, 274, 275, 292, 300, 302, 383 , $385,484,485,487,491,506,507$, 516, 517, 518, 519; embryo, 283; gametophyte, 276 ; leaf, 292 ; root, 293 ; sporangium, 293; secondary growth of stem, 29I; stem apex, 285 ; vascular bundles, 286,288 , 290, 29I, 292, 293

echinospora var. Braunii ; antheridium, 277; archegonium, 280: cotyledon, 284,286 ; embryo, 283 ; foot of embryo, 285,288 ; germination, 278 ; macrospore, 278 ; primary root, 284 ; spermatozoids, 278 . Figs. $145,146,147,148$, I 49,150 , I 5 I, I $52,153,154$

hystrix, 276

lacustris, 276, 283, 291, 292, 293, 294, 295; budding of sporophylls, 295; development of roots, 293. Fig. 155

Malinverniana, 276. Fig. 145

setacea, 276. Fig 145

Isoetacer, 221, 254, 274

\section{JUBULOIDEÆ, I I 3}

Jungermannia, 109

bicuspidata, 103,107

Jungermanniaceæ, I2, I 4, I 5, I6, I9, $21,47,64,71,73$, 114, 136, 147, 150, 509 ; antheridium, 72 ; archegonium, I 5 ; classification, 96 ; dehiscence of sporogonium, 73 ; gemmæ, 73, I I 2

Acrogynæ, 73, 94, 96; amphigastria, 96 ; branching, 96, 98 ; classification, I I 3 ; leaves, I I I

Anacrogynæ, 73, 74, 82, 94, I49, $508,510,512$; apical growth, 89; calyptra, 93; classification, 95 ; embryo, 87; sexual organs, 84,89 
KAULFUSSIA, 254, 255, 273, 274 esculifolia, 274

Kaulfussiex, 274

Kinoplasm, I 7

\section{LACCOPTERIS, 375}

Lejeunia, IoS, I 10 metzgeriopsis, I IO, I I 2. Fig. 52 serpyllifolia. Fig. $5 \mathrm{I}$

Lepidodendron, 295, 300, 485, 507

Lepidodendrex, 506, 507

Lepidostrobus, 507

Leptopteris, 353

Leptosporangiatie (Filicinea), $22 \mathrm{I}, 3 \mathrm{OI}$. $302,325,328,331,338,354,367$, 417, 516, 519; affinities of, 419; buds, 33 I ; classification, 306 ; embryo, 303; fossil L., 419 ; L. heterosporee, 378 ; L. homosporea, 302 , $38 S$; non-sexual reproduction, 304 ; sporangia, 304 . $33 \mathrm{I}$; trichomes, 328

Leptothecee, 95

Lellcobryum, 208. Fig. 107

Liverworts (see also Hepatice), 2, 6, 8, I $3,297,298,505,508,509,5$ Io, 5 I I, 5I2, 5I6; apical growth, I 5 ; secreting cells, I4; sexual organs, I 5

Lophocolea, Io8

Loxsoma, 360

Cunninghamii, 360

Lunularia, 44, 58, 64 ; genme, 24, 44, 45

Lycopodium, 300, 461, 463, 464, 466, $469,470,473,474,475,476,478$, $479,480,482,485,49 \mathrm{I}, 493,495$. $496,499,500,501,502,503,504$, $505,506,507,513,514,515$; embryo, 467 ; gametophyte, 464 ; gemmx, 473,475 ; leaf, 468 , 47 I, 473; protocorm, 468; root, 469,474 ; root-hairs, 474 ; sexual organs, 465 ; spermatozoids, 466 ; sporophyte, 469; sporangium, 476 ; stem, 470,473 ; vascular bundles, $469,47 \mathrm{I}, 472,473,475$

aloifolium, 473

alpinum, 473,475

annotinum, 464, 465, 504; prothallium, 465

cernuum, $464,465,467,469,470$, 504 , 512 ; embryo, 467 ; prothallium, 464. Fig. 244

clavatum, $469,475,478,4 S_{4}$. Figs. 243,249

complanatum, 469

dendroideum. Fig. 243
L. inundatum, $461,463,464,465,467$, $469,474,476$; germination, 464 ; mucilage ducts, 476 ; prothallium, 465 ; root, 469

lucidulum, 470, 475 ; gemmx, 475 . Figs. 246,248

phlegnaria, $465,466,467,469,470$, 504 ; embryo, 467 ; paraphyses, 467 ; prothallium, 465 ; sexual organs, 466, 467. Figs. 244, 245

reflexum, 473

selago, $470,473,474,475,476,478$, 502 ; gemme, 475 ; root, 474 ; sporangium, 476 ; stem apex, 470 .

Figs. 247, 24S, 249

taxifolium, 473

verticillatum, 473

Lycopodinex, 220, 274, 300, $46 \mathrm{I}, 4 \mathrm{~S}_{5}$, $506,514,515,519$; affinities of, 504 ; classification, 463 ; fossil L., 506

Lycopodiacex, 463, 504, 5 I 5, 519

Lycopodites, 506

Lygodium, 370, 37 I, 372

Japonicum. Fig. 192

MARATTIA, 226, 255, 265, 268, 270, $27 \mathrm{I}, 272,273,274,27 \mathrm{~S}, 2 \mathrm{So}, 2 \mathrm{~S} 2$, $284,297,298,303,309,3$ I 3 , 3 I , 3I9, 320, 32I, 34I, 345, 35 I, 427 , 428,466

Douglasii, 257, 259, 266 ; antheridium, 259 ; archegonium, 260 ; cotyledon, 266 ; embryo, 262 ; fertilisation, 26I ; foot of embryo, 265 ; germination, 255 ; primary root, 265 ; prothallium, 255 ; second root, 26S; spermatozoids, 259 ; stem apex, 264; tannin cells, 266 ; vascular bundles, 266, 267. Figs. I 3 I, I 32, I 33, I 34, I 35, I 36, I $37, I_{3} 8, I_{39}, 1_{40}, I_{4}$ I, I 42

Marattiace:e, 6, 2 I 9, 22 I, 222, 254,263 , 2So, 296, 298, 299, 304, 310, 340, $341,342,344,353,516$; classification of, 273 ; fossil M., 274 ; sporangium, 27 I

Marattiea, 273,274

Marchantia, I 2, I 4, I 6, 44, 49, 5 I, $59,64,67,68,69,70,73,95$, I 3,284 ; antheridial receptacle, 52 ; carpocephalum, 57 ; egg, 54 ; gemme, 45 ; pores, 58

polymorpha, 24; antheridium, 50 ; carpocephalum, 57; gemmæe, 45, 46; sporogonium, 64. Figs. I I, I 2 geminata, 52 
Marchantiaceæ, 2, 8, 9, I 4, I 5, I 9, 2 I, 22, 68, 71, 72, 73, 76, 79, 80, 82, $88,90,93,114,117,149,150$, I 5 I, 509; branching, 46 ; diagnosis of M., 2 I ; growth of thallus, 24 ; oil bodies, 44 ; résumé of M., 69 ; rhizoids, 22 ; sexual receptacles, 47 ; sporophyte, 24

Marchantiex, 22, 42, 63, 67; air chambers, 22, 42, 48 ; branching, 46 ; classification, 67 ; elaters, 22, 47 ; pores, 22, 42 ; rhizoids, 42 ; spores, 47 ; sporogonium, 22, 47 ; ventral lamellæ, 48

Marsilia, 5, 398, 399, 40 I, 402, 403, $404,405,406,407,409,410,412$, 4I 3, 4I 4, 4 I6, 4 I 8,4 I 9, 42 I, 487; cotyledon, 407 ; foot, 409 ; leaf, $4 \mathrm{I} 3$; root, 409, 4I3; stem, $4 \mathrm{IO}$, 4 I 2 ; sporocarp, 399 ; vascular bundles, 4 I 3, 4 I 4

Egyptiaca, 399

Drummondii, 4 I 3

hirsuta, 4 I 4

polycarpa, 4 I 2

quadrifolia, $4 \mathrm{I} 3$

salvatrix, 4 I 3

vestita, 22 I, 400, 40I, 402, 403, 404, $405,410,413,414$; antheridium, 401 ; archegonium, 404, 405 ; en1bryo, 407 ; germination, 40I, 404 ; macrospore, 403; microspore, 400; spermatozoids, 402 ; stem apex, 412. Figs. 206, 207, 208, 210 , 2 I 2,2 I 5

Marsiliaceæ, 7, $221,307,378,398,403$, $405,420,42 \mathrm{I}, 49 \mathrm{I}, 5 \mathrm{I} 6,5 \mathrm{I} 7$; fertilisation, 405 ; sporocarp, development of, 4 I 4

Mastigobryum, branching of, I I 2. Fis. 53

Matonia, 374, 375

pectinata, 374

sarmentosa, 374

Metzgeria, I4, $7 \mathrm{I}, 82,84$, I 8 , I Io, I I 5, 309, 34 I, 509 ; apical growth, 82 ; branching, $8_{3}$; embryo, 87 , 88 ; sexual organs, 84 ; thallus, 82

furcata, 84,87

pubescens. Fig. 33

Metzgeriacer, 73

Metzgerieæ, 95

Mnium, I 53, 360

Mohria, 37 I, 372

Monocotyledons, 276, 285, 292, 300, 442,5 I 8

Mörlia (see Pallavicinia)
Mosses (see also Musci), 2, 9, I I, I 2, I 3, I 52, 302, 360, 509, 5 I0, 5 I I ; antheridium, 156 ; archegonium, I 56 ; dehiscence of capsule, I 57 ; gemmæ, I 54 ; leaf, I 54 ; non-sexual reproduction, I 54; protonema, I 53 ; rhizoids, I 54 ; sporogonium, I 57 ; stem, I 54 ; stomata, I 57

Musci (see also Mosses), 8, I 52, 519 ; affinities of, 2 I6 ; calyptra, I 3 ; columella, I 3 ; operculum, I 3

Muscineæ (see also Bryophyta), 8, 508, 509,512 ; antheridium, IO ; archegonium, Io ; asexual reproduction, 9 ; classification, I 2 ; dehiscence of sexual organs, I I ; fossil M., 2 I 5 ; gametophore, 9 ; origin of sexual organs, I I ; paraphyses, I I ; perichætium, I I ; protonema, 9 ; sporophyte, I 2

Nostoc, 95, I1 5, I1 7, I 19, I 22, I38, I 39

Notothylas, I 9, I I 4, I I 5, I I 6, I 40, I 50, I 5 I, I70, 17 I, I78, 217 ; archegonium, I40; antheridium, I40; embryo, 14 I ; thallus, I40

melanospora, I 47

orbicularis, I I 6, I 22, I 40, I 42, I 47. Figs. 55, 68, 69, 70, 71, 72, 73, 74

valvata (see $\mathrm{N}$. orbicularis)

\section{Enogonium, 515}

Onoclea, 308, 310, 314, 319, 335, 340, $34 \mathrm{I}, 345,348,349,35 \mathrm{I}, 377$

sensibilis, 308

struthiopteris, 308, 32 I, 323, 324, 325, $326,328,334,335$; air chambers of rhizome, 323 ; antheridium, 310 ; apical growth of prothallium, 313 ; archegonium, 313 ; cotyledon, 317 , 320 ; embryo, 315 ; fertilisation, 315 ; foot of embryo, 319 ; germination of spores, 308 ; leaf, $320,32 \mathrm{I}$, 325 ; prothallium, 3 IO, $3 \mathrm{I} 3$; root, 319, 321 ; sclerenchyma, 323 ; spermatozoids, 3I2, 3I3; spores, $308, \quad 335$; stem, 3I $8, \quad 32 \mathrm{I}$; stomata, 326 ; vascular bundles, $319,320,321,322,323,324$. Figs. I 56, I $57,1_{58}, 159,160$, I 61, I62, I63, 194

Ophioderma (see Ophioglossum pendulum)

Ophioglossum, 4, 220, 235, 240, 242, $243,244,247,24 \mathrm{~S}, 25 \mathrm{O}, 25 \mathrm{I}, 252$, 
$265,266,269,2$ So, 292, 295, 296, $297,298,300,4$ I 5, 460, 46I, 5 II, 5I3, 5I4, 5I5, 5I6; adventive buds, 239

O. Lusitanicum, 230

palmatum, 240

pedunculosum, embryo, $22 \mathrm{~S}$; gametophyte, 222; sexual organs, 222. Fig. 108

pendulum, 224, 228, 235, 236, 239 ; anatomy of leaf, 233 : germination, 224 ; root, 235,236 ; sporangiophore, 233 ; sporangia, 236 ; stem apex, 230 ; vascular bundles, 232, 234. Figs. I O9, I I 2, I I 4, I I 5 , I I 6, I I 7, I I 8 , I I 9, I 20, 12 I

vulgatum, $23 \mathrm{I}, 232,235,236,237$, 239, 293. Fig. I I 3

Ophioglossacex, 2 I $8,221,222,259$, $26 \mathrm{I}, 265,27 \mathrm{I}, 296,299,305,4 \mathrm{I} 9$, 466,516 ; symbiosis of, 252

Oscillaria, 122

Osmunda, 5, 226, 273, 299, 331, 335, $338,340,353,355,356,358,359$, $363,364,365,366,372,373,406$, 426,427 ; antheridium, 343 ; archegonium, 345 ; budding of prothallium, 342 ; cotyledon, 349,350 ; embryo, 348, 351 ; fertilisation, 347 ; foot of embryo, $35 \mathrm{I}$; leaf, 353 ; root, 35I, 354; spermatozoids, 345

cinnamomea, $340,341,343,347,353$, $354,355,512$; hairs, 353 ; root, 354 ; sporophylls, 353. Figs. I70, I 7 I $, 173,175,176,177,178,182$, I $8_{4}$

Claytoniana, 340, 341, 343, 347, 353, 354,355 . Figs. I69, I 7 I, 172 , I 73, I 74, I 76, I 78, I 79, I So, I 8 I regalis, $33 \mathrm{~S}, 340,342,347,352,354$; apical growth, 352 ; vascular bundles of stem, 352. Figs. $18_{1}, 18_{3}$

Osmundacere, $304,307,338,342,419$, 420, 42I, 5 I6 ; germination, 339 ; prothallium, 34I ; sporangium, 356 ; spores, $33 \mathrm{~S}$

Ostrich Fern, 308

Oxymitra (see Tessalina)

PALlaviciNiA, I 4, I 5, 89, 92, 93 ; perianth, 93, I I 9

cylindrica, apical cell, $89 . \quad$ Figs. 38 , 39

decipiens, spore division, 93

Pellia, 9, 20, 72, 102, 103, I 39, I 47, I 50, I 74, 510; antheridium, 92 ; embryo, 92 ; germination, 94; spermatozuids, 17, 92

P. epiphylla, 94, 139, 313, 341 ; apical cell, S9; archegonium, S9; growth of seta, 93 ; spermatozoids, 17 ; sporogonium, 92 ; spores, 94 . Fig. 39

calycina, S9, 94

Phanerogams (see also Spermaphytes), 271

Phascum, 207, 208

cuspidatum, 207. Fig. $\mathrm{IO}_{3}$

Phascacere, I 53, I 58 , I 80

Phoradendron, 480

Phylloglossum, 463, 478, 480, 504, $505,513,514,515$; anatomy of vegetative organs, 479 ; protocorm, 479 ; sporangium, 479 ; sporophyte, 479

Drummondii, 463, 478 . Fig. 249

Phylloglossea, 4 So

Pilularia, 22 I, 40I, 402, 403, 404, 405, $406,407,408,409,410,412,413$, 4I 4, 4IS, 4I9, 42I; embryo, 407; fertilisation, 406 ; sporophyte, 410

Americana, 22I, 4I3, 414, 4I6, 4 IS ; development of sporocarp, $4 \mathbf{I} 4$; sporangium, 417. Figs. 214,216 , 217

globulifera, 404, 405, 406, 4 I3, 4 I6, $4 \mathrm{IS}$; antheridium, 402 ; cotyledon, 406 ; macrospore and female prothallium, 403; spermatozoids, 403: stem apex, 408, 410 . Figs. 209, 2 I I, 2 I 3

Plagiochasma, female receptacle, 55

Platycerium, 376

alcicorne, 376

Wallichii, 33 I

Platyzoma, 357

microphyllum, 357

Pleuridium, 207, 208

subulatum. Figs. I03, 104

Pleurocarpe (Bryinere), 208

Polypodium, 332, 376, 420

falcatum, 329,336 ; development of sporangium, 332-336. Figs. I66, I 67, I 68

lingua, 327

Polypodiacex, 302, 307, 308, 310,315 , $321,323,324,331,336,340,341$, $344,345,349,352,353,355,358$, $366,370,371,372,373,375,402$, $407,413,417,419,420,421$, 516 ; embryo, 315 ; gametophyte, $308,309,310$; leaf, 3 I 7, 325; paraphyses, 337 ; root, $319,328,331$; sexual organs, 310,3 I $, 312,313$, 
3I4, 315 ; sporangium, 332 ; stem, 318,321 ; stomata, 326 ; vascular bundles, 320, 323, 326, 330

Polystichum angulare var. pulcherrimum, apospory of, 306

Polytrichum, 1 54, I 56, 2 I S ; leaf, 2 I 2 ; stem, 212 ; sporogonium, 2 I 4 commune, 209. Figs. I06, I07 formosum, 209

juniperinum, 2 I 3

Polytrichaceæ, I 55, I 57, 209, 2 I O, 2 I 2 ; male flower, 2 I 4

Porella, 96, 99, I00, I02, I03, I07, I08, I68; amphigastria, antheridium, 9S, 99, I00 ; apical growth, 97 ; archegonium, IO2 ; branches, 98 ; embryo, I03; leaves, 96 ; spermatozoids, 100 ; sporogonium, IO4; spores and elaters, 104

Bolanderi, 96. Figs. 4I, 42, 44, 45, $46,47,48,49$

platyphylla, 96

Preissia, 14, 59, 68; sclerenchyma, I4, 44

commutata, 44 ; archegonium, 52

Protocephalozia, 73

ephemeroides, I09

Psilophyton, 506

Psilotites, 506

Psilotum, 463, 48o, 482, 484 ; gemmæ, 480 ; sporangium, 484 ; sporophyte, 480

triquetrum, $48 \mathrm{So}$ Figs. 250, $25 \mathrm{I}$

Psilotaceæ, 463, 480, 504, 506, 5 I 5 , 519 ; affinities, 504; fossil P., 506 ; sporophyte, 480 ; sporangium, 483

Pteridophytes, 3, 4, 6, 218, 297, 298, 299, 300, 422, 460, 467, 474, 479, $485,505,506,5 \mathrm{II}, 5 \mathrm{I} 2,5 \mathrm{I} 3$, 514, 516, 517, 518, 519 ; embryo, 3 ; heterospory, 7,516 ; prothallium, 4, 7; sexual organs, 219 ; sporangium, 4, 220 ; sporophyte, 3,4 ; vascular bundles, 4

Pteris aquilina, 302, 306, 376; apospory, 306. Fig. I 63

Cretica, 305, 329

Ptilidioider, I 13

RADULA, I04, I07, I 74 ; germination, IOS

complanata. Figs. 50, 5 I

Reboulia, 42 ; carpocephalum, 55

hemispherica. Fig. I8

Rhizocarpex (see Hydropterides)

Rhyncostegium murale, I 52

Riccardia (see Aneura)

Riccia, I 2, I 4, I 5, I 6, 22, 40, 4 I, 46,
$47,48,50,52,67,69,75,79,80$, I I 7 , I 49, 508, 509, 511 ; adventive buds, 28; air chambers, 27 ; antheridium, 32 ; archegonium, 29, 30 ; archesporium, 35 ; branching, 28 ; calyptra, 37 ; embryo, 34 ; epidermis, 27 ; growth of thallus, 25 ; root hairs, 28 ; spermatozoids, 33 ; spore division, 35,36 ; sporogonium, I8; tissues, 29 ; ventral lamellæ, 27

R. Bischoffii, 27, 30, 3I

crystallina, 28

fluitans, 25, 28, 40

glauca, 25, 27, 29, 32, 37. Figs. I, 2, 3, 4, 5, 6

hirta, 24, 29, 30, 65 ; development of spores, 36 ; germination, 37 . Figs. $4,5,6,7,8,9$

natans (see Ricciocarpus)

Ricciaceæ, I 8, 19, 22, 25, 42, 68, 74; classification, 40; diagnosis, 2 I ; sexual organs, 29

Ricciocarpus, $8,40,43,48,68$; structure of thallus, 40

natans, 40 ; ventral scales, 27

Riella, 8, I 2, I 4, 7 I, 72, 80, 82, 95

helicophylla, 81 . Fig. 32

Parisii, 8 I

Riellex, 72

SALVINIA, 331, 378, 380, 382, 384, $3^{85}, 386,388,390,392,393,394$, $395,396,398,419,420,421$

natans, antheridium, 380 ; archegonium, 386 ; branching of sporophyte, 394 ; embryo, $3 \$ 8$; leaves, 393 ; microspore, 380 ; prothallium, 3So, 385 ; spermatozoids, 380 ; sporangia, 394, 398; sporocarp, 379, 398; sporophyte, 390 ; stem apex, 390 ; vascular bundles, 394. Figs. I 96,203

Salviniaceæ, 221, 304, 307, 378, 380, $420,42 \mathrm{I}, 5 \mathrm{I} 6,5 \mathrm{I} 7$

Scapanioideæ, I I 3

Schistostega, 208

Schizæa, 371,372

pusilla, 370

Schizæaceæ, 307, 308, 370, 420 ; gametophyte, 370 ; leaf, $37 \mathrm{I}$; root, 372 ; sexual organs, $37 \mathbf{I}$; sporangium, 372 ; stem, $37 \mathrm{I}$; trichomes, 371 ; vascular bundles, $37 \mathrm{I}$

Scolopendrium, 376

Selaginella, 7, I I 5, 300, 46 I, 463, 485 , $486,487,49 \mathrm{I}, 495,500,503,505$, 
506, 507, 512, 517 ; antheridium, 486,487 ; archegonium, 490, 491 ; branching, 494, 496 ; chloroplasts, 500 ; cotyledons, 492, 494; embryo, 49I ; female prothallium, $4 S_{7}$; leaves, 495 ; macrospore, macrosporangium, 7 ; male prothallium, 486 ; microsporangium, 501 ; rhizophore, 495; roots, 493, 500 ; spermatozoids, $4 \mathrm{~S} 7$ : sporophyte, 495 ; stem apex, 496 ; vascular bundles, $49 \mathrm{~S}$, 500

S. apus, 493

arborescens, 496

Kraussiana, 486, 493, 494, 495, 496, $498,499,500,502$; anatomy of stem, 496, 497, 498, 499 ; development of female prothallium, $4 \mathrm{~S}_{7}$, 488, 489, 490, 49I; root, 500; sporophyte, 495 ; sporangia, $50 \mathrm{O}$; vascular bundles, 498, 500. Figs. $253,254,255,256,25 \mathrm{~S}, 259$, $260,261,262,263,264,265$, 266

lovigata, 499

lepidophylla, 485,499

Martensii, 491, 493, 494, 496, 499, 500, 501, 503 ; embryo, 491, 492. Figs. 257,264

rupestris, $461,49_{5}, 495$

spinosa, 501

IVallichii, 496

Vildenowii, 500

Selaginellex, $46_{3}, 48_{5}, 504,515,519$

Sigillariere, 507

Spermaphytes, 4, 154, 244, 295, 300, $460,489,505,516,517,519$; embryo sac, 7 ; ovule, 7 ; seed, 7

Sphzerocarpus, I5, $16,18,72,74,81$, $82,89,95,141,149,150,151$, 511 ; antheridium, 79 , So ; apical growth, 75 ; archegonium, 75,76 ; embryo, 76, 77, 78 ; germination, So; spermatozoids, So ; sporogonium and spores, 78 ; ventral hairs, 75

Michelii (see $\mathrm{S}$. terrestris)

terrestris, 74

terrestris var. Californicus. Figs. 28 , $29,30,31$

Sphagnum, 5, I 52, 153 , I 54, I 56, I 58 , $175,176,177,180 ; 182,183,186$, I 89, 191, 192, 194, 201, 209, 210 , 216, 217 , 509, 511 ; amphithecium, 170 ; antheridium, I66; apical growth, I60 ; archesporium, I 7 I ; archegonium, 168 ; branching, 158 , 165 ; embryo, 170 ; endothecium,
I70; gametophore, I60 ; gernination, 159; leaves, development of, I62; phyllotaxis, I 59 ; protonema, 160; pseudopodium, I 57, I72; rhizoids, I 59, I60 : spermatozoids, I68; spores, I7I ; sporogonium, I 70 ; stem, tissues of, 164 ; vaginula, I 72

S. acutifolium, I70. Figs. 79, So, 8I

cymbifolium, I65. Figs. $77,78,79$

Sphagnacex, I 47, I 53, I 57, I 58, I 72, 217,509

Spirogyra, 64, 414

Splachnum, 2 I 2, 2 IS

ampullaceum. Fig. 106

Steetzia (see Pallavicinia)

Stegocarpe (Bryiner), 205

Stephaninoider, I 13

Stigeoclonium, I I 5

Stigmaria, 507

Stromatopteris, $33 \mathbf{I}$

Struthiopteris Germanica (see Onoclea Struthiopteris)

TARGIONIA, 42, 46, 48, 52, 53, 57, 59, $67,68,93, \mathbf{1} 17$

hypophylla, 24; antheridium, 51 ; archegonium, 52, 53, 54; archesporium, 6o; egg, 54; embryo, 59,60 ; elaters, 64 ; germination, 64 ; sporogonium, 61 . Figs. I, 16, I $7,21,22,25,26$

Michelii (see T. hypophylla)

Targioniea, $67,68,69$

Tessalina, 42, 68, 69

pyramidata, structure of thallus, $4 \mathrm{I}$

Tetraphis, IO, I 53, I 8 I, 209, 2 I 6, 217 pellucida, 154, 209 ; gemmie, 209 Fig. 105

Tetraphidex, 209

Thallocarpus, 95

Thuidium, I 53, I 86

Tmesipteris, $46_{3}, 4 \mathrm{So}_{4} \mathrm{~S}_{2}, 4 \mathrm{~S}_{3},{ }_{4} \mathrm{~S}_{4}$; sporangiophore, $4 \mathrm{~S}_{3}, 4 \mathrm{~S}_{4}$

Tannensis. Fig. 252

Todea, 338, 341, 353, 355, $35^{6}$

Africana, apogamy of, 305

barbara, 353 , 354 ; root apex, 354

Treubia, 95, 96, I 50

insignis, 94

Trichomanes, $303,342,360,361,362$, $363,365,366,367,368,369,395$, 420,512 ; antheridium, 363 ; archegoniophore, archegonium, 365 ; germination, 360 ; indusium, 368 ; leaf, 366 ; placenta, 368 ; prothallium, 361 ; root, 367 ; sporangium, 367 
T. alatum, 36I, 369; apogamy and apospory, 369 brachypus, 367

cyrtotheca, 369 ; development of sporangium, 368, 369. Figs. 190, I 9 I Draytonianum. Fig. I 86 pyxidiferum, $36 \mathbf{I}, 3^{67}$ radicans, $366,3^{67}$ reniforme, 366

Trigonanthere, I 13

Trochopteris elegans, 370
VAscular cryptogams (see Pteridophytes)

Viscum, 480

Vittaria, 221, 375, 376

WaLkixg Fern (see Camptosaurus)

Webera nutans, I 52

Weisia, I 52

YUCCA, 292 



\section{QK505. C3 3 York Botanical Gorden Library}

Campbeil, Douglas $\mathrm{H} /$ The structure \& deve 


\section{(6)}

